DANMARKS GEOLOGISKE UNDERSøGELSE

II. RAKKKE. NR. 79

GEOLOGICAL SURVEY OF DENMARK. II. SERIES. NO. 79

\title{
Molluscan Assemblages from the Marine Middle Miocene of South Jutland and their Environments
}

\author{
By \\ Theodor Sorgenfrei \\ Vol. I \\ Dansk sammendrag: \\ Molluskselskaber fra det marine Mellem Miocæn \\ i Syd- og Sønderjylland og deres miljø
}

I kommission hos

C. A. REITZELS FORLAG (JøRGEN SANDAL)

KØBENHAVN 1958 
With 76 plates

Med 76 tavler 
DANMARKS GEOLOGISKE UNDERSØGELSE

II. RAKKE. NR. 79

Geological Survey of Denmark. II. Series. No. 79

\title{
Molluscan Assemblages from the Marine Middle Miocene of South Jutland and their Environments
}

\author{
By \\ Theodor Sorgenfrei
}

Vol. I

Dansk sammendray:

Molluskselskaber fra det marine Mellem Miocæn i Syd-og Sønderjylland og deres miljø

I kommission hos

C. A. REITZELS FORLAG (JøRGEN SANDAL)

KØBENHAVN 1958 
With 76 plates

Med 76 tavler 


\section{PREFACE}

The studies which have resulted in the present paper were initiated several years ago when Dr. H. ÖDUM collected the first fossiliferous samples at the Toftlund well. The original intention was to give a traditional description of the fossils of the Toftlund sequence. However, fascinated by the beautiful shells, I decided to draw illustrations to accompany the descriptions of the species, and then. as samples from other wells were obtained, I gradually became aware of the possibilities offered for a thorough paleobiological analysis. Plans for the paper became accordingly more and more pretentious.

I have tried to demonstrate the biological significance of the fossil material, and then to evaluate the effect on biostratigraphy. During this study I discovered that data on the ecology of mollusca are widely scattered in the literature. The chapter on the environmental relations of recent mollusca was therefore included in order to give a brief, but coherent account of biological data of importance in biostratigraphy.

The geological sciences are in a stage of rapid evolution, due particularly to increasing use of the exact sciences as auxiliaries, and to the development of new quantitative methods. Naturally this implies the abandonment or improvement of old methods. One example is the development of electric logging techniques which have, as local correlation tools of sometimes very great accuracy, outweighed biostratigraphy in subsurface geology. We are certainly still in an early stage of this development of quantitative geological procedures which may reduce the practical significance of biostratigraphy. Also absolute age determinations will undoubtedly in time replace other applications of paleobiology. However, it is still possible to improve biostratigraphic methods. At present this can best be done by considering biostratigraphy as applied biology, and by developing quantitative methods for the treatment of fossil faunas.

In presenting this work to a scientific public I wish to emphasize the importance of the support I have received during the years of study.

The Carlsberg Foundation furnished funds for a trip to Holland and Belgium in 1947, when I had excellent opportunities to study the collections of Miocene fossils at the Geologische Stichting at Haarlem and Heerlen, and at the Musé Royale d'Historre Naturelle in Bruxelles. I gratefully remember the late professor Dr. J. H. F. UMBgRove who arranged may stay in Holland, where I also received much help from the Director of the Geologische Stichting Dr.A.A.Thiadens and from Dr.J.H.van Voorthuysen. Dr. Maxime GLIBERT assisted me in various ways while I was working i Bruxelles.

In 1951 at the Hofmuseum in Vienna I studied the collections of Miocene shells, which were kindly placed at my disposal by dr. Rudolf Sieber.

I want to acknowledge my debt to Professor Dr. E. S. Deevey, Yale University, who assisted me by reading and discussing the chapter on ecology 
while he worked at the Geological Survey of Denmark in 1954. Statistical matters were discussed with Arne Jensen Ph. D. of the University of Copenhagen, to whom I also want to express appreciation for his reading the chapter on correlation procedure.

Throughout my study I have profited from valuable discussions with my Danish colleagues. Without diminishing the importance of any of them I would like to emphasize the kind interest shown by State geologist V. Nordmann, PH.D. who has always been anxious to contribute from his vast knowledge of the Mollusca. Professor G. Thorson, PH.D. has furnished me material of recent Mollusca and made valuable suggestions regarding the literature on their biology. It has been a great pleasure currently to discuss the discoveries with Leif Banke Rasmussen, M. Sc. and to benefit from his extensive knowledge of Tertiary faunas.

I am grateful to the Director of the Geological Survey of Denmark, H. ÖDum, Рн.D. for his interest and support and for his patience despite the progressive extension of the work.

A very important help has been furnished by Mrs. Käte Hansen who has typed the entire manuscript, and by Mrs. Rigmor Borg and Miss Inger PeterSEN who have drafted the diagrams and maps.

Lastly I would like to thank Peter H. BaAdsgaArd, who has read and corrected the manuscript. However carefully corrections are made, it is probably never possible to remove an individual's peculiarities completely from a manuscript. Mr. BAADSGAARD has in fact tried to retain such peculiarities in my manuscript, although in an acceptable version, and I am therefore really responsible for the contents.

The English manuscript was completed December 1956.

Virum, September 19, 1957.

Theodor Sorgenfrei. 


\section{CONTENTS}

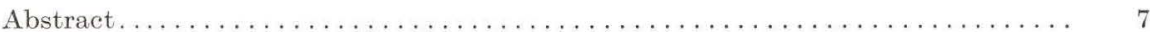

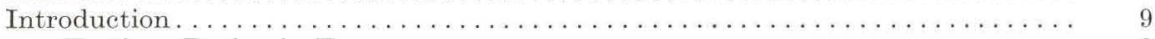

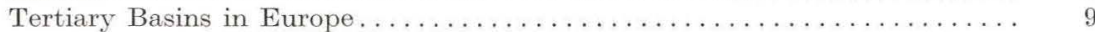

The Subdivision of the Tertiary System in Europe . . . . . . . . . . . . 10

The Subdivision of the Miocene Series in Europe................. 11

Critical Remarks to Time-Stratigraphic Classification of the Miocene....... 15

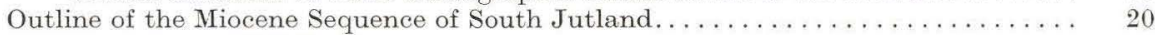

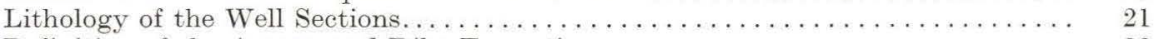

Definition of the Arnum and Ribe Formations..................... 28

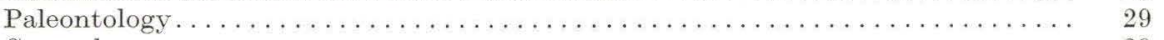

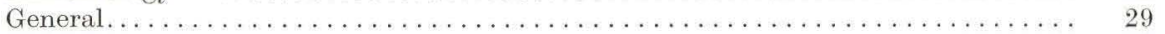

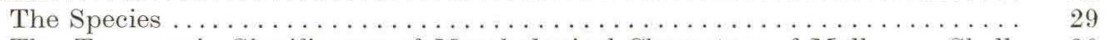

The Taxonomic Significance of Morphological Characters of Molluscan Shells 30

Remarks on Taxonomic Subdivision........................ 32

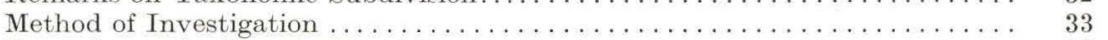

Remarks on the Description of Species ..................... 36

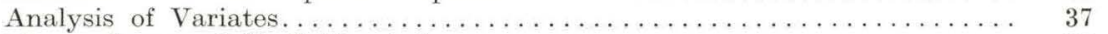

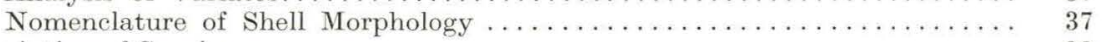

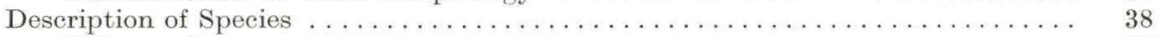

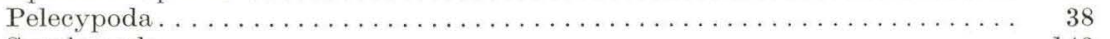

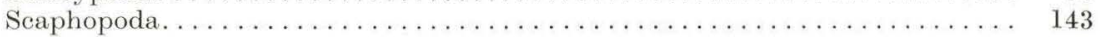

Gastropoda. . . . . . . . . . . . . . . . . . 147

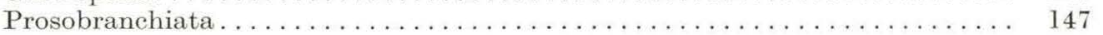

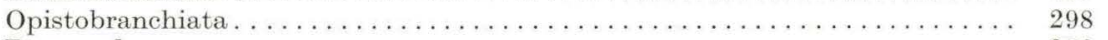

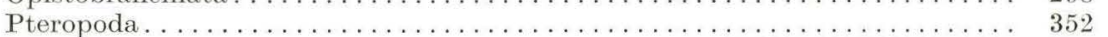

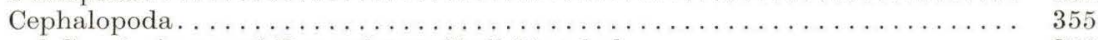

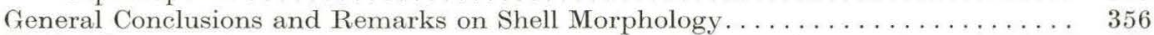

Marine Pelecypoda and Gastropoda in Relation to their Environment . . . . . . . 358

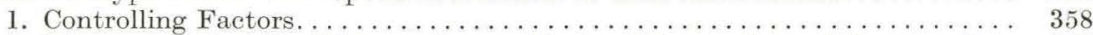

2. Features of the Life History of some Marine Pelecypoda and Gastropoda. . 360

A. Animal Growth and Variation of some Shell Properties........... 360

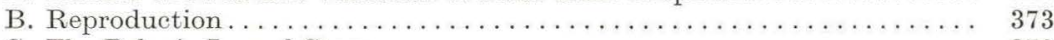

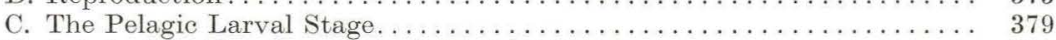

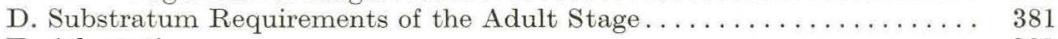

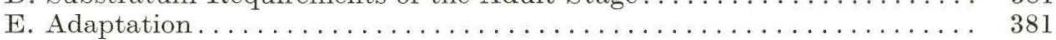

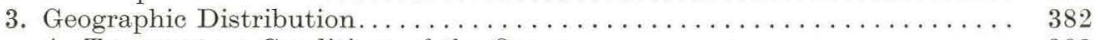

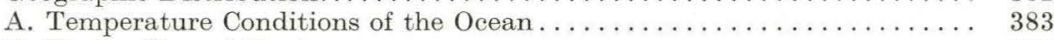

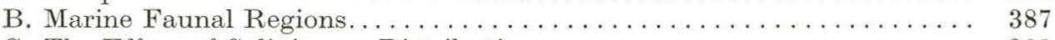

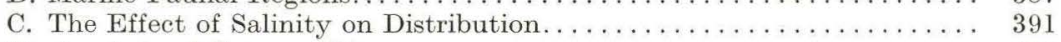

4. Marine Animal Communities...................... 401

The Age of the Mollusean Assemblages of the Arnum Formation . . . . . . . . . 403

Remarks on Correlation Procedure....................... 403

The Biostratigraphic Record of the Miocene of the North Sea Basin....... 405

Correlation of the Assemblages of the Arnum Formation with known Mollusean

Faunas of the North Sea Basin. . . . . . . . . . . . . . . . . . . 407

Analysis of the Fauna and its Development . . . . . . . . . . . . . . . 409

Remarks on the Sedimentation of Molluscan Shells . . . . . . . . . . 409

The Significance of the Fossil Molluscan Assemblages of the Arnum Formation 409

The Faunal Development ........................... 410 
The Evidence of the Abundant Species

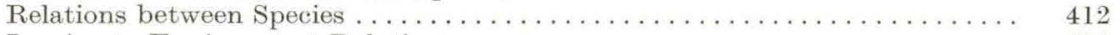

Inanimate Environment Relations . . . . . . . . . . . . . . . . . . . . . . . 414

Classification of the Molluscan Assemblages of the Arnum Formation . . . . . 415

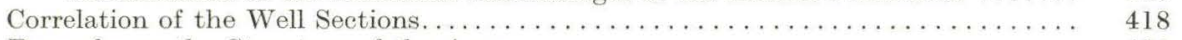

Remarks on the Structure of the Area . . . . . . . . . . . . . . . . . . . . . 421

Table 14. Stratigraphic and Geographic Distribution of the Molluscan Species

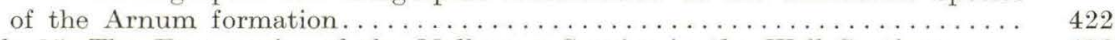

Table 15. The Frequencies of the Molluscan Species in the Well Sections..... 436

Table 16. The Frequencies of Abundant Molluscan Species in the Well Sections 460

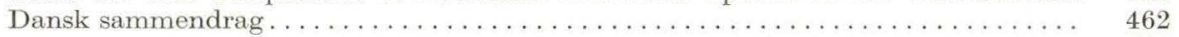

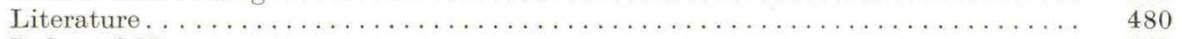

Index of Names . . . . . . . . . . . . . . . . . . . . . . . . . . . . . . . 492

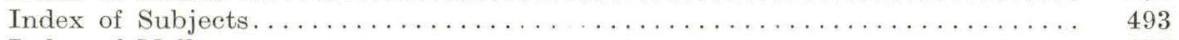

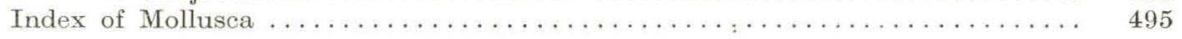




\section{ABSTRACT}

This is a study of the fossil record of marine Miocene beds in South Jutland, Denmark. The beds have been defined as the Arnum formation and referred to the middle Miocene Hemmoor stage as known in Northwest Germany. The object of the work is to increase knowledge of the Danish Miocene and to contribute data on the development of the North Sea Basin during Miocene time.

The introduction deals with the history of Tertiary stratigraphy in Europe and some related problems. Discrepancies and uncertainties regarding the correlation and dating of beds in the separate basins have been particularly emphasized. It is often possible to trace disagreements to the acceptance of unsound fossil evidence. Therefore it is concluded that the lithologic and fossil records of the individual basins should be known in much greater detail before adequate inferences as to the contemporaneity of particular beds can be made. It is also suggested that guide fossils should only be designated when statistically justified.

The chapters on the South Jutland Miocene contain an outline of the geographic distribution of the formations, a lithologic description of the water well sections from which the fossil material was derived, and definitions of the Arnum formation (marine) and the underlying Ribe formation (non-marine). The following formations are now recognized in the Miocene sequence of South Jutland:

\begin{tabular}{|c|c|}
\hline & \\
\hline s. & Miocene \\
\hline ion & Miocene \\
\hline ntinghoved form & early Miocene \\
\hline
\end{tabular}

The chapters on paleontology consist of a description of the molluscan fauna of the Arnum formation, a discussion of the environmental relationships of recent mollusca, and a section on biostratigraphy and paleobiology.

The description of species follows a rigid pattern. The intention being to include as many pertinent facts as possible while using a minimum of technical terms. The variation of shell properties is illustrated by diagrams in a few species, and in some families genetic features have been particularly discussed. The chapter is terminated by a short review and some conclusions regarding the significance of shell morphology.

The chapter on environmental relationships of recent mollusca includes discussion of the effects of inanimate environments on shell morphology and the distribution of mollusca. It is maintained that the reaction of recent mollusca to variations in their environment should be known in greater detail in order to provide a sound basis for biostratigraphic conclusions depending on the evidence of fossil mollusca. 
A discussion of the commonly adopted correlation procedures initiates the chapters dealing with biostratigraphy and paleobiology. It is shown that the "percentage" method by which faunas are correlated on the basis of percentages of species in common should be regarded with much criticism. New correlation formulae, in which are included the total numbers of species in the faunas involved are suggested. It is shown by these formulae and other evidence that the fauna of the Arnum formation in its entirety is apparently in better agreement with the Reinbek and Hemmoor faunas of Germany than with any other fauna of the North Sea Basin.

The paleobiological analysis of the fauna of the Arnum formation is based on: the biology of living species; the actual frequencies of the mollusca in the different drilled sections; and the environmental relationships of recent mollusca. It is inferred that a decrease in salinity took place during deposition of the formation. The faunules of the different fossiliferous levels are shown to be derivatives of one community: the A porrhais alata-Nassa sp. sp. community which inhabited relatively shallow waters of the middle Miocene North Sea Basin.

In conclusion some comments are made on the correlation of the well sections as supported by paleobiology. The Nassa cimbrica and N. Fuchsi zones are defined, and the different elevations of correlated levels in the drilled sections are related to structural displacements. 


\section{INTRODUCTION}

Various stratigraphic classifications have been used in the subdivision of Tertiary deposits in Europe. Any stratigraphic treatment of Tertiary beds in Europe should, therefore, properly start with a definition of the stratigraphic subdivisions approved by the author.

In the present treatise it was also deemed necessary to outline some trends in the historical development of some prevailing classifications, and their hybrids, in order to illustrate particular problems which have influenced the author's attitude concerning stratigraphic method in general, and with particular reference to the Miocene of the North Sea Basin.

\section{Tertiary Basins in Europe}

Many of the problems of European Tertiary stratigraphy may be related to the separation of the sedimentary basins, the local development of fossil faunas, and resulting correlation difficulties.

The sedimentary areas may be naturally grouped in the following way:

1. The North Sea Basin and adjacent marine areas in north Central Europe, including parts of England, northern France, Belgium, Holland, Denmark, northern Germany and Poland.

2. The marginal basins on the Atlantic coast line, including the Aquitanian and Loire Basins in western and southwestern France, and the Guadalquivir Basin in Spain.

3. The Mediterranean Basin and the Vienna Basin.

4. The basins west and north of the Alps, including the Rhone Valley Basin in southern France, and the Molasse Basin extending through Switzerland, Southern Germany and northern Austria.

The Mediterranean sub-basins may have had extensive intercommunication, as well as connections with the Alpine basins. Sea connections between the Mediterranean Basin and the Atlantic Ocean may have existed occasionally in the Guadalquivir region and in North Africa (GIGNoux 1950).

The North Sea Basin may have had a broad connection with the North Atlantic between Scandinavia and Scotland during the greater part if not all of the Tertiary, while a southwestern connection with the Ocean may have existed only at intervals (GRIPP 1916, Kautsky 1925, Gignoux 1950, Wells 1951.) Some writers have assumed temporary sea connections between the North Sea Basin and the Mediterranean Basin over Germany and Poland during the Oligocene and Miocene (see for instance Kautsky 1925, Sorgenfrei 1940). 


\section{The Subdivision of the Tertiary System in Europe}

The study of the Tertiary deposits in Europe was, as is well known, initiated by Cuvier and Brongniart by their paper of 1811 on the "Mineralogical Geography of the Surroundings of Paris", although the term Tertiary (terziarie, terza formazione) was first introduced by BRосcH (1814, 1, p. 52). The deposits of the Vienna Basin were studied in the following years by Prevost (1820), the Tertiary of Northern Italy by BrocchI (1814) and BRongNIART (1823), and the deposits of the Aquitanian Basin by Basterot (1825).

The molluscan faunas of the known Tertiary deposits of Europe were studied by Deshayes $(1830,1831)$ who compared the fossil faunas with the fauna of the recent seas. Deshayes finally referred the Tertiary deposits to three major stratigraphic groups, according to whether the number of recent species amounted to $3 \%, 18 \%$ or $47 \%$ of the entire fossil fauna. The formations of the first group were considered to be oldest, and a successively younger age was assumed for the two other divisions in accordance with the increased proportion of recent species.

The deposits of the Paris Basin, the London Basin, and parts of the Tertiary deposits in Belgium were referred to the oldest group. The deposits of the Aquitanian and Loire Basins, and beds near Torino in northern Italy and near Montpellier in southern France were included in the intermediate group together with the deposits of the Vienna Basin. The youngest subdivision comprised the Subapennine formation of Italy and Sicily, the Crag of England, etc.

In 1833 LyelL applied the subdivision proposed by Deshayes in his "Principles of Geology" and suggested the terms Eocene, Miocene, and Pliocene for the Tertiary epochs corresponding to the stratigraphic divisions established by DeshaYes. In a convincing manner he brought forward geological arguments supporting the stratigraphic classification evidenced by the fossils. It is of interest in the present case to note LYELL's proposals for further stratigraphic subdivision as appears from the following quotation (Principles of Geology vol. III. p. 57. 1833):

"If intermediate formations shall hereafter be found between the Eocene and Miocene, and between those of the last period and the Pliocene, we may still find an appropriate place for all, by forming subdivisions on the same principle as that which has determined us to separate the lower from the upper Pliocene groups. Thus, for example, we might have three divisions of the Eocene epoch, - the older, middle, and newer, and three similar subdivisions both of the Miocene and Pliocene epochs. In that case, the formations of the middle period must be considered as the types from which the assemblage of organic remains in the groups immediately antecedent or subsequent will diverge."

The definition of the boundary between the Eocene and the Miocene soon appeared to be a source of disagreements. DuMONT (1851) referred the Laekenien and the Tongrien of Belgium to the upper Eocene, and the question whether the superimposed Rupelien should be referred to the upper Eocene or to the lower Miocene was kept open. In the following year LyELL (1852) placed the boundary between the middle Eocene and the upper Eocene between the Laekenien and Tongrien and referred the Rupelien to the upper Eocene. On the other hand D'OrBigny (1852) placed the Tongrien and Rupelien at the base of his étage falunien which included typical Miocene formations in its upper part. BEYRICH (1853) united the Tongrien and the Rupelien in one group and thus 
followed LyeLL to a certain extent, but he disagreed with LyELL concerning the allocation to the Eocene and referred the divisions to the lower Miocene.

In 1854 BEYRICH finally proposed to include the Tongrien and the Rupelien in a new stratigraphic unit which was also to include later deposits as defined in the Cassel area in central Germany. He suggested the name Oligocene for this division, which was given a rank equal to that of the Eocene and Miocene.

A consequence of BEYRICH's viewpoints was, that only the Boldérien, as defined by Dumont, remained as a Miocene formation in Belgium. The Tertiary beds known at Bersenbrück, Celle, Lüneburg, Reinbek, Sylt and Gühlitz in northwestern Germany were also approved as Miocene deposits in the restricted sense.

\section{The Subdivision of the Miocene Series in Europe}

The first approach to a subdivision of the deposits assigned to the re-defined Miocene in the North Sea Basin appeared in 1856, when BEYRICH published his geologic map of the Tertiary of Northern Germany. Fossiliferous boulders known as Holsteiner Gestein commonly found in the Glacial Drift of eastern Holstein and Sleswick were assumed to be of intermediate age between the upper Oligocene Sternberger Gestein of Mecklenburg and the "argillaceous" Miocene beds known from the area around the lower River Elbe.

BEYRICH inferred that the boulders of the Holsteiner Gestein were concretions derived from unknown, sandy deposits in the subsurface of eastern Holstein and Sleswick. The hypothetical source deposits were correlated with the Boldérien in Belgium and with the Grund sands in the Vienna Basin on the faunal evidence of the Holsteiner Gestein. These source deposits were assumed to constitute the lower part of the Miocene sequence, while the "argillaceous" beds on the lower Elbe, in western Sleswick and Holstein, and at Bocholt, Dingden, Winterswijk, etc. were assigned to the upper part of the Miocene sequence which was correlated with the Vienna Tegel.

The increase of knowledge on the Tertiary deposits in Europe and their fossil faunas revealed the impossibility of a strict subdivision of the Tertiary on the basis af Deshayes' method. This was partly because several of Deshayes' "recent" species in the Tertiary appeared to be extinct, and others which were assumed to be extinct were found to have survived. The tendency to generalize local stratigraphic developments and subdivisions, to extend local terminologies over wide areas, and to amalgamate concepts of time and rock surely retarded stratigraphic progress. The situation was well illustrated by MAYER (-EyMar) who discussed the multitude of nomenclature in Tertiary stratigraphy in 1857 and wrote: "So sieht es denn gegenwärtig in der Geologie der Tertiär-Gebilde nicht bloss für den Anfänger, sondern auch für den Fachmann sehr konfus aus, und wir Geologen laufen bald Gefahr, bei Anlass der Klassifikation der TertiärGebilde ein kleines Muster einer Sprachverwirrung zu erleben."

MAYER-EyMar tried as is well known to remove some of the difficulties by establishing a new classification of the Tertiary deposits in which he partly used old well defined formation names and partly suggested new ones, in an attempt to create a consistent nomenclature. His ideas concerning the correlation of the 
European Tertiary are shown on a comprehensive correlation chart in his paper 1857. Of particular interest in the present survey is his subdivision of the Miocene into the Aquitanien, Mayencien, Helvétien and Tortonien stages. He correlated part of the Aquitanian with the Oligocene as defined by BEYRICH.

MAYER-EyMAR states that he used in his correlation and classification "the methods of stratigraphy and the general paleontological rules", and he concludes that individual species known from the Tertiary of the Mediterranean region may be absent in contemporaneous deposits of the northern areas in Europe, but present in previous deposits in these areas. This is inferred on the basis of the following four premises: 1 . The differences in temperature of the recent North Sea and the Mediterranean and the corresponding differences of the faunas. 2. The decline of temperature in Europe during the Tertiary from a subtropical level to the present level. 3. The separation of the northern marine area from the Mediterranean during the Tertiary. 4. The recent southerly distribution of surviving species compared with their distribution during the Tertiary.

The advance of knowledge on the stratigraphy of the North Sea Basin was rather slow. Between 1856 and 1861 several papers by O. SEMPER on the mollusca of the German Miocene appeared, and in 1872 and 1882 von KoEnen published his treatise on the Gastropoda, Cephalopoda, and Pteropoda of the same area. Also Gotтsche's paper on the Reinbek fauna (1878) deserves mention, although practically no stratigraphic conclusions were drawn.

The first paper on the mollusca of Miocene deposits in Denmark, by Mørch, appeared in 1874. However, it only included a list of fossils and a few descriptions of new species.

In 1886 von KoEnen made a correlation of the Oligocene and Miocene deposits of Germany and Belgium. By his subdivision of the Miocene of these areas into lower, middle, and upper parts, the type of classification suggested by LyeLL was re-introduced, only covering other formation units. The "Glimmerton" was referred to the upper Miocene; the bulk of the Holsteiner Gestein, the deposits at Reinbek, as well as the Anversien and Bolderien were referred to the middle Miocene, whereas only the fossiliferous boulders from Brothener Ufer near Lübeck were mentioned as representatives of the lower Miocene. The subdivision was obviously based on paleontological evidence and not on new stratigraphic data.

Von KoEneN's subdivision was not agreed to by GoTTSCHE (1887) who was of the opinion that the majority of the boulders of the Holsteiner Gestein were contemporaneous. Only a few types of boulders similar to those of the deposits at Bokup and Reinbek might be separated as a somewhat younger group. Gotтsche explained in his paper that he was unable to decide whether the typical Holsteiner Gestein should be classified as lower or middle Miocene on account of the scattered literature on the Aquitanian and Vienna Bassins. He also stated that it was impossible for him to obtain a clear picture of the faunas of the individual members and stages of the Miocene deposits of these areas.

GotTsCHE's investigations indicated that the fauna of the Holsteiner Gestein included many species which were also known from the Oligocene, and that $42 \%$ of the species survived in the Pliocene. Of the Glimmerton fauna still more species, viz. $56 \%$, survived in the Pliocene. According to GotTsche it was therefore reasonable to assume the fauna of the Holsteiner Gestein to be older than the upper Miocene Glimmerton. 
It is convenient now to discuss the development of knowledge of Miocene stratigraphy in the Aquitanian Basin and the Mediterranean Basin.

In 1892 Depéret went to Switzerland, Southern Germany, Austria and Italy to study the Miocene deposits, correlation of the Miocene of the Rhone Valley being his object. The results of his studies are presented in papers from 1892 and 1893. In the first paper he suggested the name Burdigalien for the Langhien of Mayer-Eymar, a substitute for the original Mayencien of MayerEymar, and defined the Bordelais in the Aquitanian Basin as the type area of the Burdigalien. In 1893 DEPERET published a revised classification of the Miocene as follows:

\begin{tabular}{|c|c|}
\hline \multirow[t]{2}{*}{ Upper Miocene } & Pontien \\
\hline & Sarmatien \\
\hline Middle Miocene & Tortonien \\
\hline & Burdigalien \\
\hline Oli & Aquitanien \\
\hline
\end{tabular}

The stratigraphic subdivision was mainly based on faunal evidence, both marine fossils and mammalian remains from non marine deposits being considered. Some stratigraphic arguments were, however, also set forth. The reason why the Aquitanien was referred to the upper Oligocene was the fact that the mammals of this stage displayed close relationships with the mammalian fauna of the Oligocene. As is well known, however, other authors prefer to refer the Aquitanien to the Miocene on account of the Miocene affinities of the marine faunas.

Lack of good exposures was the greatest obstacle to detailed study of Miocene stratigraphy in the North Sea Basin lowlands of northwestern Europe. However, the increase of drilling activity resulting from the search for water, gas, oil, etc., which was initiated at the end of the 19th century, gradually resulted in the accumulation of valuable data on the Miocene.

In 1907 Ravn published well sections drilled at Viborg and Varde in North Jutland, Denmark. The Viborg well pierced the Miocene and Oligocene sequences and was stopped in Eocene clay, while the Varde well stopped in the Miocene. Several fossiliferous beds were reported from the Varde section while only a single fossil bed was encountered in the Viborg well. The fossils were determined by RAVN (1907) and their stratigraphic ranges were listed, but unfortunately without exact reference to source of information or type localities. If one compares the stratigraphic ranges as indicated by the synonyms cited by RAVN with the ranges listed in RAvN's description, several inconsistencies appear. RAvN apparently favoured a middle Miocene age for the fauna of the Holsteiner Gestein accepting Gotтsche's $(1887,1901)$ relatively vague considerations as a definite statement of that age, since he arrived at the conclusion that all Miocene faunas in Denmark older than the upper Miocene Mica Clay were of middle Miocene age.

A number of papers on the stratigraphy of the Miocene deposits of the Hamburg region, Germany, appeared during the period 1912 to 1927: GRIPP (1912, 
1914, 1915, 1920), Kautsky (1925), and КосH (1912, 1920, 1927). Through the combined efforts of these authors the following subdivision of the Miocene sequence in the Hamburg area was achieved (KоCH 1927):

\begin{tabular}{|c|c|c|c|}
\hline $\mathrm{Age}$ & Formation & Environment & Thickness \\
\hline Upper Miocene & Glimmerton & marine & $\begin{array}{l}\text { mean } 100 \mathrm{~m} . \\
\max .250 \mathrm{~m} .\end{array}$ \\
\hline Middle Miocene & $\begin{array}{l}\text { Reinbek formation } \\
\text { Upper Brown-coal } \\
\text { sand } \\
\text { Hemmoor formation } \\
\text { Hamburg clay }\end{array}$ & $\begin{array}{l}\text { marine } \\
\text { partly non } \\
\quad \text { marine } \\
\text { marine } \\
\text { marine }\end{array}$ & $\begin{array}{l}8-25 \mathrm{~m} . \\
\text { about } 70 \mathrm{~m} . \\
27 \mathrm{~m} . \\
0-58 \mathrm{~m} .\end{array}$ \\
\hline Lower Miocene & $\begin{array}{l}\text { Lower Brown-coal } \\
\text { sands } \\
\text { Vierlande formation }\end{array}$ & $\begin{array}{l}\text { partly non } \\
\text { marine } \\
\text { marine }\end{array}$ & $\begin{array}{l}20-40 \mathrm{~m} . \\
(\max .100+\mathrm{m} .) \\
14-60 \mathrm{~m} .\end{array}$ \\
\hline
\end{tabular}

The Hamburg Miocene sequence is the most complete and most thoroughly studied Miocene succession in the North Sea Basin known at present. The subdivision given above may however be considered a local subdivision which has not yet been correlated in detail with the deposits of other Miocene basins. The first attempt at correlation was made by GRIPP (1915) who paralleled a suggested older group of the Holsteiner Gestein with the Aquitanien, and the fossiliferous beds of Reinbek, Hemmoor etc., with the Helvétien. The Lower Brown-coal sands were consequently referred to the Burdigalien. KAUTSKY (1925) referred the Hemmoor fauna to the Helvétien, but disagreed with GRIPP concerning the Aquitanien age of the Vierlande formation, which was compared with the Burdigalien.

A remarkable advance was the recognition by GRIPP (1922) that the formation boundary between the Glimmerton and the Limonitsandstein in the coast section of Morsum Kliff is identical with the Miocene-Pliocene boundary.

The molluscan fauna of the Limonitsandstein above the Glimmerton substantiated the time relationships of the Limonitsandstein with the Pliocene Crag of England. A tooth of Hipparion gracile KAUP found on the beach, was shown to be derived from the Glimmerton beneath the Limonitsandstein, and was assumed to be strong evidence for a Pontian age of the Glimmerton in Morsum Kliff.

Not all the Glimmerton was, however, referred to the Pontien. GripP (1915 p. 39) had previously shown that the lowermost part of the Glimmerton in the Hamburg region contained a Cardita, which was originally determined as Cardita jouanneti, but later recognized as a new variety, C. laevicosta, var. weingärtneriana (GRIPP 1940). A Tortonian age was inferred from the presence of this species, and it was concluded that the Glimmerton of NW Germany was equivalent to part of the Tortonien, the entire Sarmatien, and part of the Pontien in southern Europe.

Several exploration wells were drilled in southern and eastern Holland from 1903 to 1916 in the search for coal and other mineral resources. The Miocene 
was encountered and penetrated in a number of wells. The sequence appeared to include marine representatives of the Hemmoor, Reinbek-Dingden and Glimmerton stages. A series of non-marine deposits found in a marginal position in the sedimentary area may be contemporaneous with parts of the marine stages. The stratigraphy has been elucidated mainly by VAN WATERschoot van der Gracht $(1913,1916)$, Molengraaf (1913), and Ten Dam and Reinhold (1942).

The Miocene deposits of southern Holland are situated in the embayment between the Ardennes and the Rhine Mountains which has also been termed the Gulf of the Lower Rhine, referring to the paleogeographic conditions during the Tertiary. The Miocene deposits of Belgiu m may be considered as belonging to the same general area. Conditions in Belgium are very similar to Holland although the stratigraphy is less well known. According to TAVERnIER (1943) and Glibert $(1945,1952)$ the Belgian Miocene may be correlated and subdivided in the following way:

$\begin{array}{lll}\begin{array}{l}\text { Age } \\ \text { Tortonian }\end{array} & \begin{array}{l}\text { Formation } \\ \text { Horizon of Edegem } \\ \text { or Anversien }\end{array} & \begin{array}{l}\text { Environment } \\ \text { marine }\end{array} \\ \left.\begin{array}{lll}\text { Upper Helvetian } & \begin{array}{c}\text { Black Lignite sands } \\ \text { (continental Boldérien) }\end{array} & \text { non marine } \\ \text { Middle Helvetian } & \begin{array}{c}\text { Horizon of Houthaelen } \\ \text { Lower Helvetian }\end{array} & \begin{array}{c}\text { Horizon of Bolderberg } \\ \text { or Boldérien }\end{array}\end{array}\right\} \text { marine }\end{array}$

The sequence displays obvious similarities with the development of the upper part of the Miocene in the Hamburg area. Tavernier has consequently correlated the Belgian and German successions as follows:

$\begin{array}{ll}\text { Belgium } & \text { Germany } \\ \text { Anversien } & \text { Dingden-Reinbek stage } \\ \text { Continental Boldérien } & \text { Upper Brown-coal sands } \\ \text { Marine Boldérien } & \text { Hemmoor stage }\end{array}$

The marine Boldérien rests on pre-Miocene rocks, and true lower Miocene deposits are thus apparently absent in Belgium as in Holland.

\section{Critical Remarks to Time-Stratigraphic Classification of the Miocene.}

The history of Miocene stratigraphy in Europe demonstrates a continuous approach to a generalized time-stratigraphic classification, as indicated by the previous discussion. However, since several authors obviously do not realize the deficiencies of the generally used classification a few critical remarks on this topic will be made. Following is the classification to be discussed: 
TIME-STRATIGRAPHIC CLASSIFICATION OF THE MIOCENE AND ADJACENT STAGES

$\begin{array}{llll}\text { Epoch } & \text { Stage } & \begin{array}{l}\text { Environments } \\ \text { of type section } \\ \text { marine }\end{array} & \text { Type area } \\ \text { Lower Pliocene } & \begin{array}{l}\text { Plaisancien } \\ \text { Upper Miocene }\end{array} & \begin{array}{l}\text { Pontien } \\ \begin{array}{l}\text { Sarmatien } \\ \text { Tortonien }\end{array}\end{array} & \begin{array}{l}\text { brackish } \\ \text { brackish } \\ \text { marine }\end{array} \\ \text { Middle Miocene } & \begin{array}{l}\text { Helvétien } \\ \text { Burdigalien } \\ \text { Aquitanien } \\ \text { Chattien }\end{array} & \begin{array}{l}\text { marine-brackish } \\ \text { marine } \\ \text { marine-brackish } \\ \text { marine }\end{array} & \begin{array}{l}\text { Southeastern } \\ \text { Europe } \\ \text { Tortona, northern } \\ \text { Italy }\end{array} \\ \text { Upper Oligocene } & \begin{array}{l}\text { Switzerland } \\ \text { Southwestern } \\ \text { France } \\ \text { Central Germany }\end{array}\end{array}$

A serious difficulty in erecting a time-stratigraphic classification arises from the fact that most areas have incomplete stratigraphic sequences. The quality of a classification therefore depends primarily on the careful definition and demarcation of type sections and type areas, on the possibility of exactly correlating scattered formation units in individual areas, and on the possibility of correlating type areas with nearby and remote areas.

With this in mind the classification above will be briefly commented on.

The type area of the Aquitanien and Burdigalien of southwestern France is described by GIGNoux (1950, p. 622) in the following terms: " $1^{\circ}$ Le Golfe de l'Aquitaine. a) Les Rivage N.-Les mers miocènes ne semblent pas avoir dépassé vers le NE le cours de la Garonne, et tous les gisement se trouvent sur la rive gauche (fig. 98): les affleurements sont très isolés, limités au fond de quelques ravins entaillant la couverture de dépôts récents: les faciès sont presque uniformement de sables à débris de coquilles, ou "faluns de l'Aquitaine"; de sorte que la stratigraphie est très ingrate; par contre, la richesse en fossiles est telle qu'on a choisi là les types des étages Aquitanien et Burdigalien."

This statement may be compared with another quotation from a paper by Magne and Vigneau (1948) dealing with the fauna and stratigraphy of the well known deposits at Saubrigues and Saint-Jean-de-Marsaeq further to the south (loc.cit. p. 293):

"Dans les conclusions de la Conchologie néogénique de l'Aquitaine (t. VI 1932 , p. 505) Peyrot place les gisements de Saubrigues et de Saint-Jean-deMarsacq (Landes) dans le Tortonien, en leur attribuant un facies abyssal.

De l'étude conjuguée des Mollusques et des Bryozoaires de ces deux niveaux, dont il serait trop long de donner ici la liste complète, nous avons été amenées à admettre: $1^{\circ}$ qu'ils sont d'âge burdigalien, $2^{\circ}$ que leur profondeur n'excède pas un centaine de m."

Statements of this kind leave the impression of an unsettled stratigraphic situation in the type area of the Aquitanien and Burdigalien thereby rendering correlation on the basis of fossil evidence a rather difficult task.-

The type area of the Helvetien is situated beween Fribourg and Bregenz in Switzerland. Several European deposits have been referred to the Helvetian 
stage. The method of reference may be best illustrated by the following, eited from Rutsch (1929, p. 7):

"Wenn heute in Frankreich, Norddeutschland, Italien, Oesterreich, ja selbst im aussereuropäischen Neogen eine Schichtserie als Helvetien bezeichnet wird, möchte man annehmen, diese Altersfestlegung sei das Resultat einer Korrelation der Fauna oder Flora der betreffenden Schichten mit dem palaeontologisch genau definierten Typus der Stufe in der Schweiz. Dies ist jedoch nicht der Fall. .... Tatsächlich behält man den Namen Helvetien nur aus Gründen der Priorität bei und verwendet als Vergleichsbasis Faunen des ausländischen Miocäns wie diejenige von Pont-Levoy, Savigne usw. im Loirebecken oder diejenige von Salles und la Sime in der Aquitaine, in der Annahme, diese Faunen seien mit dem Typ des Helvetien in der Schweiz gleichaltrig".

Of particular interest is the conclusion arrived at by RUTSCH concerning the correlation of the Helvétien of the type area with the deposits of the Aquitanian Basin. His considerations are based on the study of the molluscan fauna. (loc. cit. p. 68):

"Würde man unsere Fauna n ur mit der Aquitaine parallelisieren, so müsste man sie eher ins Burdigalien stellen ...... sie (ist) auf alle Fälle etwas älter als die Fauna von Salles, als deren Korrelat sie bis jetzt stets angesehen wurde. Sie repräsentiert nur den tieferen Teil des Untervindobonien."

The situation is no less confusing in other areas as may appear from Rutsch's summary of viewpoints concerning the Aquitaniano, Langhiano, and Elveziano stages in northern Italy which originally were thought to cover the Aquitanien, the Burdigalien and the Helvétien respectively. Quoting Schaffer and Prever, Rutsch states that all deposits formerly classified as Aquitaniano, and part of the Elveziano should be correlated with the Burdigalien of southwestern France.

No comments should at present be made on the Tortoniano which includes argillaceous deposits on the northern slope of the Appenines at Tortona with a molluscan fauna similar to that of the "Tegel" at Baden in the Vienna Basin. (Schaffer 1927). It is identical with the Tortonien.

The Miocene deposits of Austria were, as is well known, originally divided into two parts: the first and the second Mediterraneanstages. A third unit between these two was discovered later and named the Grund beds. In 1927 SCHAFFER assumed the correlations with deposits outside Austria to be sufficiently exact to warrant abandonment of the local stratigraphic nomenclature in favour of time-stratigraphic terms. Burdigalien, Helvétien, and Tortonien were proposed to replace the 1. st Mediterranean stage, the Grund beds, and the 2.nd Mediterranean stage respectively (Schaffer 1927).

The stratigraphic problems of the Miocene of the Vienna Basin were, however, not settled by means of this very simple procedure, as may be demonstrated by the following, written by JANOSCHEK (1951 p. 548): "Die Einreihung der marinen mittelmiozänen Ablagerungen des Inneralpinen Wiener Beckens und der angrenzenden Räume in die helvetische oder tortonische Stufe ist für die Klärung des stratigraphischen und tektonischen Aufbaues der obgenannten Gebiete von grosser Bedeutung. Leider ist aber eine genaue Altersbestimmung eines diesbezüglichen Schichtgliedes auf Grund seines Fauneninhaltes sehr schwierig und erfordert eine eingehende Bearbeitung der einzelnen Formen. ..... Von den Mollusken sind nur verhältnismässig wenige Arten für eine dieser beiden Stufen leitend, wärend die Hauptmasse derselben in beiden Abteilungen des Miozäns vorkommen". 
The Sarmatian and Pontian formations of southeastern Europe were laid down in vast brackish inland seas extending from the Vienna Basin over Hungary and Roumania to southern Russia and the Aralo-Caspian region. The local development of the faunas of the different sub-basins of this region renders correlation with deposits of other areas solely on fossil evidence nearly impossible. It has been mentioned above (p. 12) that the occasional occurrence of remains of mammals like Hipparion in relation to both marine and non marine deposits of remote areas may be utilized for correlation purposes. Since much importance has been attached to the significance of Hipparion as a guide fossil it should be emphasized that remains of Hipparion have been recorded from Tortonian beds of the Lyon area and Provence (SE France), from Sarmatian beds in southern Germany and from Pontian deposits near Istanboul in Turkey (GIGNoux 1950, p. 602). The presence of Hipparion may therefore not be indicative of Pontian age as previously assumed by GRIPP (1933) and WIRTz (1949)*).

Having thus completed an outline of the entangled literature on Tertiary stratigraphy, and the obscurities involved, one is left with the general impression that confusion reigns. It is admittedly difficult to isolate one single reason for the confusion. There are obviously different reasons which are related to the stratigraphic methods applied. These methods deserve, therefore, to be examined, and those applied to critical problems will be briefly mentioned.

The most critical point in stratigraphic research is substantiated by the correlation of separated or subsurface sections over wide distances. In the disentanglement of the problems of the Tertiary deposits in Europe the steps in correlation do not deviate from common procedure which may be characterized by the following three stages:

1. Most workers search for "guide fossils", which implies the concept of the guide fossil, i.e. a species with universal distribution and restricted vertical range. A supposed guide fossil is usually treated as a safe correlation tool.

2. When guide fossils are absent, or the fossil faunas involved do not display pronounced similarities, the next step is an estimate of the relative age of the deposits on the basis of the fossil species included in the beds.

3. Final correlation is mainly based on the assemblage of species, and a bed is generally correlated with the one outside the area with which it has the highest percentage of species of its own stock in common.

The application of this method invariably involves misconceptions and exaggerations concerning the significance of the fossil evidence, as illustrated by the following:

a. The announcement of a guide fossil is very seldom founded on statistics from a sufficient number of sections, and the significance of the postulated guide fossil is thus often rather limited.

b. The presence or absence of a species is not only a function of time. Paleoenvironments may play a more important part in controlling the distribution of species.

*) It may thus be inadvisable to refer part of the Glimmerton as exposed in the Morsum Kliff to the Pliocene. The faunal evidence is rather poor, and it would be very impractical to define an important boundary like the Miocene-Pliocene boundary in the middle of the Glimmerton. The author would therefore suggest defining the boundary at the top of the Glimmerton and refering the Limonitsandstein to the Pliocene as proposed by GRIPP in 1922. 
c. There seems to be a tendency to neglect environments as controlling factors proportionally with increase in the distance between the deposits to be correlated. This may partly be due to the inaccessibility of pertinent data on the sequences in foreign areas.

d. The generally adopted "percentage-correlation" method as mentioned above (3) may result in remarkable errors as pointed out by the present author in 1940. It may serve as an example that $52 \%$ of the species of the recent marine molluscan fauna off Norway also occur in the Mediterranean, while these species only compose $25 \%$ of the much greater Mediterranean fauna. A rich fauna is thus much more impressive than a poor one (see also p. 403).

e. The number of species included in a faunal assemblage, either fossil or recent, may be considered as one of the replies of the animal world to environments. Another reply is the number of individuals of the species present.

f. A general review of biostratigraphical literature reveals that with few exceptions statistics on the abundance of species are generally kept in very vague terms, such as "abundant", "rare", "common", etc., or otherwise quite neglected.

g. The neglect of statistical data on fossil faunas and the lack of exact information on the corresponding sediments may have hampered the recognition of the environmental relations of fossil species and animal communities. It has consequently been impossible clearly to discriminate between the effect of environmental factors and the time factor upon the faunas.

Reviewing our knowledge of the Miocene deposits of Europe, it may be stated that in some respects it is very limited, and much correlation work has obviously been carried out at a premature stage. Future progress must therefore be based on a thorough record of the sedimentary history and faunal evolution of the individual basins, using as clear definitions and descriptions of the local formation units as possible. The study of drilled sections will no doubt yield some of the most useful pertinent data if pursued in the right way.

The following account of well sections including Miocene deposits from South Jutland and the molluscan faunas encountered may be considered an unpretending contribution to knowledge concerning the geologic history of a small part of the Miocene North Sea Basin in accordance with these points of view. 


\section{OUTLINE OF THE MIOCENE SEQUENCE OF SOUTH JUTLAND}

Practically all of South Jutland is covered by glacial drift deposits. PreQuaternary beds are only exposed in a few brickyards in the northwestern part of the area, where the upper Miocene Gram clay is exploited at Gram and Esbjerg.

Numerous records of wells drilled for water and other purposes in South Jutland are kept in the files of the Geological Survey. They reveal that the entire area of South Jutland may be underlaid by Tertiary deposits, presumably of Miocene age. The oldest deposits are to be found on the east coast where Oligocene deposits probably occur locally under the glacial deposits. Marine lower Miocene beds follow upon the Upper Oligocene clay farther to the west, as illustrated by the Langbrogaard and Sønderborg wells (H. ØDum 1935).

Except for the wells around Sønderborg, no wells located on the east coast have encountered fossiliferous Miocene beds. Dark, non calcareous, argillaceous mica silts and mica clays, and gray or light gray mica sands, quartz sands, and quartz gravels are commonly encountered beneath the Quaternary beds.

Highly fossiliferous beds of undoubtedly Miocene age have been encountered at intervals in the area west of a line running from Flensburg to Gram. The fossil assemblages which will be treated in the following originate from a number of wells drilled for water in the northwestern part of this area.

The upper Miocene Mica Clay also termed the Astarte clay or the Gram formation may be correlated with the Glimmerton of Northwestern Germany as shown by Ravn (1907) and Banke Rasmussen (1956). The fossils from this formation collected at Gram are treated in RASMUSSEN's paper.

The Gram formation is preserved in restricted areas west of the FlensburgGram line, the Quaternary glaciers possibly being responsible for its absence elsewhere, since glacial erosion was locally effective to considerable depths.

The regional distribution of the Miocene deposits in South Jutland, as outlined, is the final result of depositional processes, potential pre- and postsedimentary structural displacements, and erosion of the area during the Quaternary. The area is located on the southwestern flank of the Falster-Fyn Uplift (SorgENfrei 1945, 1951). Its affinity with this regional structure is to be seen for instance by the trend of the eastern formation boundary of the Gram formation and by the Upper Miocene coastline as suggested by BANKE Rasmussen (1956, p. 118). 


\section{LITHOLOGY OF WELL SECTIONS}

The two methods used in drilling the wells to be treated in the following are relatively simple. In both methods steel casing is successively twisted into the ground by hand. In the method called 'Flush Drilling' by Danish drillers, a string of drill pipe is washed down inside the casing, and ditch samples may be collected continuously or at intervals from the circulation at the outlet of the casing by means of a bucket or screen. The other method, called 'Dry Drilling', differs from the former in that the drilled rock fragments are removed by means of a bailer. The bailer samples are of a somewhat better quality than the ditch samples obtained by flush drilling. In both cases, however, the samples may be of a relatively high standard compared with the ditch samples obtained by rotary drilling, due to the steady sinking of the casing during drilling operations in order to avoid cavings.

The following well logs and sample descriptions include explicit descriptions of the Miocene deposits. A set of glass tubes containing standard grain sizes was used for estimating the average grain size of the samples in millimetres. The size limits are shown in parenthesis. The size of the samples was generally $200-240 \mathrm{~cm}^{3}$ which is the volume of the boxes delivered to the drillers by the Geological Survey for sampling. In two cases much bigger samples of fossils were, however, collected on the well site (file no. 131.12. b. Bramminge 70-80 m. file no. 150. 9. b. Toftlund $75-100 \mathrm{~m}$.).

The samples were sieved in order to separate the fossils which are described in the chapters on paleontology.

Not all wells in South Jutland from which samples of fossiliferous Miocene deposits have been obtained by the Geological Survey of Denmark have been included in the present account. However, the sample material represent a collection of wells from which more reliable samples have been obtained, and which therefore best suit the author's purpose of an analysis of the fossil assemblages of the Miocene in South Jutland, both on a qualitative and a quantitative basis.

The well locations are shown on the map fig. 1 and 2, and graphic logs of the wells are shown on fig. 2 .

\section{Glejbjerg.}

Chr. Ottosen's farm. Well drilled 1940.

Casing: $\quad 4^{\prime \prime}$ to bottom of hole.

Samples: Bailer samples, collected by the driller.

Driller: D. Husted, Vejen.

$\begin{array}{ccl}\text { Elevation } & \text { Depth } & \text { Log: } \\ +25 \mathrm{~m} . & 0-8 \mathrm{~m} . & \text { Dug well. } \\ +17- & 8-18- & \text { "Marl" (no samples) probably Quaternary moraine de- } \\ +7- & 18-55- & \begin{array}{c}\text { Micasits. } \\ \text { argilt and fine Mica sand }(0.06-0.2 \mathrm{~mm} .) \text {, gray: } \\ \end{array}\end{array}$




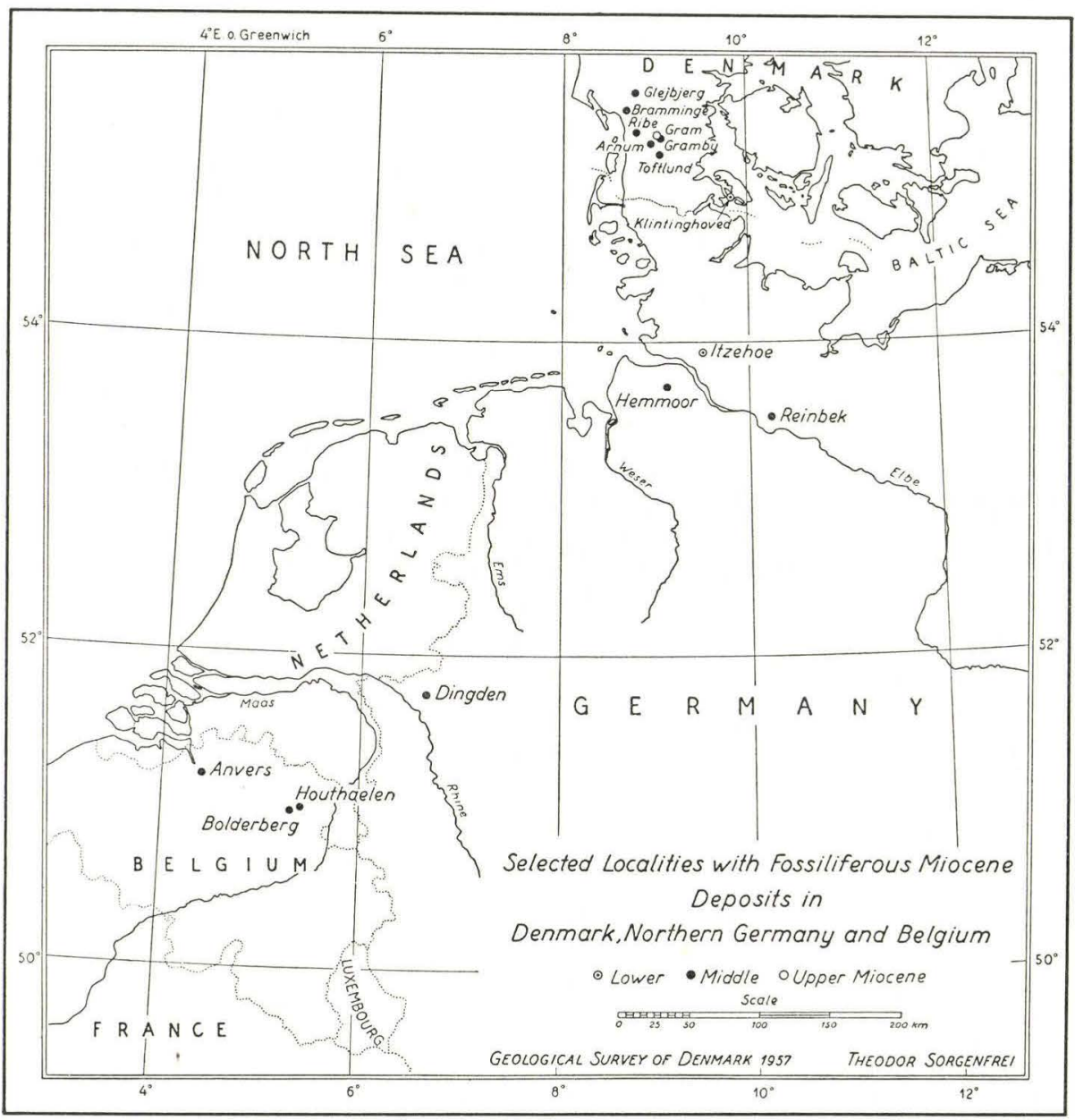

Fig. 1.

$\begin{array}{cc}\text { Elevation } & \text { Depth } \\ +7 \mathrm{~m} . & 18 \mathrm{~m} . \\ +2- & 23- \\ -0- & 25- \\ -7- & 32- \\ -10- & 35- \\ -13- & 38- \\ -17- & 42- \\ -23- & 48- \\ 27- & 52-\end{array}$

\section{Sample description:}

Mica silt, light gray, argillaceous, calcareous.

Mica silt, gray, fossiliferous.

Mica sand, fine (0.06-0.1), argillaceous, slightly darker gray than above with spherical siltstone concretions (diameter $15-25 \mathrm{~mm}$.). Fossiliferous.

Mica sand, fine (0.06-0.2), light gray with greenish tinge, much fossils.

Mica clay, silty, light gray, slightly calcareous.

Mica sand, fine (0.06-0.1), light gray with darker argillaceous lumps, fossiliferous.

Mica sand, fine $(0.06-0.1)$, light gray with greenish tinge, fossiliferous.

Mica clay, dark gray, silty, with some fossil fragments.

Mica sand, fine (0.06-0.1), argillaceous, greenish gray, occasional fossils. 


$\begin{array}{lc}\text { Elevation } & \text { Depth } \\ -28 \mathrm{~m} . & 53 \mathrm{~m} . \\ -28.5 \mathrm{~m} . & 53.5 \mathrm{~m} . \\ -28.75- & 53.75- \\ -29 \mathrm{~m} . & 54 \mathrm{~m} . \\ -30- & 55-\end{array}$

Mica sand, fine (0.06-0.1), argillaceous, greenish gray, with much fossils.

Mica sand, fine (0.06-0.2), much fossils, (main part of sample consists of fossils)

Mica sand, fine (0.06-0.2), and lumps of siltstone concretions, dark gray. Fragments of very thick-shelled pelecypoda, and numerous fossils that are well preserved.

Mica sand, fine (0.06-0.1), argillaceous, dark greenish gray, with large shell fragments and smaller fossils.

Mica sand, fine (0.06-0.1), argillaceous, dark gray, richly fossiliferous.

\section{Bramminge.}

D.G.U. file no. 131. 12. b.

Bramminge waterworks. Trial bore 1932 .

Casing: $4 \frac{1}{2} 2^{\prime \prime}$ to $40 \mathrm{~m}$., $3^{\prime \prime}$ to $80 \mathrm{~m}$. Flush Drilling.

Samples: Ditch samples collected by the director of the waterworks, Mr. O. Christensen; additional sample of fossils from $70-80 \mathrm{~m}$. collected by Sigurd Hansen, Ph.D.

Driller unknown, well log reported by Mr. O. Christensen.

$\begin{array}{rr}\text { Elevation } & \text { Depth } \\ +14 \mathrm{~m} . & 0-12 \mathrm{~m} . \\ +2- & 12-47- \\ -33- & 47-55- \\ -41- & 55-130-\end{array}$

\begin{tabular}{|c|c|c|}
\hline+ & - & $12-15$ \\
\hline-1 & - & $15-20$ \\
\hline-6 & - & $20-25$ \\
\hline-11 & - & $25-30$ \\
\hline-16 & - & $30-32$ \\
\hline-18 & - & $32-35$ \\
\hline-21 & - & $35-40$ \\
\hline-26 & - & $40-47$ \\
\hline-33 & - & $47-51$ \\
\hline-37 & - & $51-55$ \\
\hline-41 & - & $55-60$ \\
\hline-46 & - & $60-65$ \\
\hline-51 & - & $65-70$ \\
\hline-56 & - & $70-80$ \\
\hline-66 & - & 80 \\
\hline & - & $115-120$ \\
\hline-111 & - & $125-130$ \\
\hline
\end{tabular}

\section{Sample description:}

Mica sand, fine (0.06-0.1 mm.), light gray.

Mica sand, fine (0.06-0.2), light gray.

Mica sand, fine (0.06-0.1), light gray.

Mica sand, fine (0.02-0.1), silty, light gray.

Mica sand, fine, light gray, contaminated with Quaternary sand.

Mica sand, fine, brownish gray, contaminated with Quaternary sand.

Mica clay, silty, grayish brown, with indeterminable small shell fragments.

Mica clay as at 47-51 m., single fragment of Nassa cimbrica observed.

Mica sand, fine (0.06-0.1), light "lead gray", non calcareous to slightly calcareous.

Mica sand, fine, silty $(0.002-0.1)$, grayish brown, highly fossiliferous (additional large washed sample of shells) some allochtonous lignite. The fossils are mainly thick-shelled and are partly rolled.

Claystone concretion, calcareous, fossiliferous.

Mica sand, fine (0.06-0.1), brownish gray, with occasional thin indeterminable shell fragments.

Miea sand, fine (0.06-0.1) very light (yellowish) gray, no fossils observed. 
Ribe.

D.G.U. file no. 140. 42.

Ribe waterworks. Trial bore at Tange 1948 .

Casing: $\quad 8^{\prime \prime}$ to $29.5 \mathrm{~m} ., 6^{\prime \prime}$ to $91.2 \mathrm{~m}$., $4^{\prime \prime}$ to $140 \mathrm{~m}$. (partly Flush Drilling).

Samples: Ditch and bailer samples.

Driller: A. Høנfeldt, Herning.

\begin{tabular}{|c|c|c|c|c|}
\hline \multicolumn{2}{|c|}{ Elevation } & \multicolumn{2}{|l|}{ Depth } & og: \\
\hline $\begin{array}{r}+3 \mathrm{~m} \\
-110\end{array}$ & & $\begin{array}{l}0-113 \mathrm{~m} . \\
113-114=\end{array}$ & & $\begin{array}{l}\text { Quaternary deposits. } \\
\text { Mica sand, silty ( } 0.02-0.1 \mathrm{~mm} .) \text {, argillaceous, brownish } \\
\text { black, fossiliferous. }\end{array}$ \\
\hline$-111-$ & & $114-117-$ & & $\begin{array}{l}\text { Mica sand, fine (0.06-0.15), slightly argillaceous, gray, } \\
\text { fossiliferous. }\end{array}$ \\
\hline$-114-$ & & $117-120$ & & $\begin{array}{l}\text { Mica silt (0.02-0.06), argillaceous, light gray, fossili- } \\
\text { ferous. }\end{array}$ \\
\hline$-117-$ & & $120-121-$ & & $\begin{array}{l}\text { Mica sand, silty }(0.02-0.1) \text {, argillaceous, gray, fossili- } \\
\text { ferous. }\end{array}$ \\
\hline$-118-$ & & $121-122-$ & & Mica silt (0.02-0.06), gray, fossiliferous. \\
\hline-119. & & $122-123-$ & & Mica sand, silty $(0.02-0.1)$, darker gray, fossiliferous. \\
\hline-120 - & & $123-124-$ & & Mica sand, fine $(0.06-0.1)$, gray, fossiliferous. \\
\hline-121. & & $124-125$ & & Mica sand, fine, silty $(0.02-0.1)$, gray, fossiliferous. \\
\hline$-122-$ & & $125-125.6 \mathrm{~m}$ & & Mica sand, fine $(0.06-0.1)$, light gray. \\
\hline-122.6 & & $125.6-126.5$ & & $\begin{array}{l}50 \% \text { Mica sand, fine (abt. } 0.1-0.2 \text { ), dark gray, and } \\
50 \% \text { quartz gravel ( } 2-15 \text { ) of well rounded and } \\
\text { polished grains and pebbles. }\end{array}$ \\
\hline$-123,5$ & - & $126.5-131.5$ & - & $\begin{array}{l}\text { Mica sand, fine (0.06-0.2), light gray, with occasional } \\
\text { coarser quartz grains (about } 2 \mathrm{~mm} \text {.) }\end{array}$ \\
\hline-128.5 & - & $131.5-133$ & - & $\begin{array}{l}90 \% \text { Mica sand, fine }(0.06-0.2) \text {, light gray, and } 10 \% \\
\text { quartz and quartzite gravel (max. grain size } \\
\text { abt. } 25 \mathrm{~mm} \text {.). }\end{array}$ \\
\hline-130 & - & $133-140$ & - & $\begin{array}{l}\text { Mica sand silty }(0.02-0.1) \text { and Mica clay, with occa- } \\
\text { sional coarser quartz grains, light gray. }\end{array}$ \\
\hline
\end{tabular}

\section{Sample description:}

\begin{tabular}{|c|c|c|c|c|}
\hline $110 \mathrm{~m}$. & & 13 & $\mathrm{~m}$. & $\begin{array}{l}\text { Mic a sand, silty }(0.02-0.1) \text {, argillaceous, brownish black, } \\
\text { fossiliferous. }\end{array}$ \\
\hline $111-$ & & 14 & -115 & \\
\hline- & & & -116 & ea sand, fine $(0.06-0.15)$, argillaceous, gray, fossili- \\
\hline & - & & -117 & ferol \\
\hline . & - & & $-118-$ & \\
\hline & - & 18 & -119 & a silt (0.02-0.06) argillaceous, light gray, \\
\hline & - & 9 & -120 & fero \\
\hline 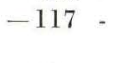 & - & 0 & $-121-$ & $\begin{array}{l}\text { ica sand, } \\
\text { darker gr }\end{array}$ \\
\hline $118-$ & - & & $-122-$ & ica silt \\
\hline 11 & - & & -1 & ay, $\mathrm{f}$ \\
\hline $120-$ & - & & $-124-$ & ica $\mathrm{s}$. \\
\hline $121-$ & - & 24 & $-125-$ & Mica sand and silt $(0.0$ \\
\hline - & & 25 & $-125.6 \mathrm{n}$ & Mica sand, fine $(0.06-0.1)$, \\
\hline & m. & 12 & & $\begin{array}{l}50 \% \text { of Mica sand, fine (about } 0.1 \\
50 \% \text { of quartz and quartz gra }\end{array}$ \\
\hline & - & & & Mica sa \\
\hline & - & & & \\
\hline 1. & - & & -13 & $\begin{array}{l}\text { Mica sand, fine }(0.06-0.2) \text {, light gray. Coarse quartz } \\
\text { grains more abundant. }\end{array}$ \\
\hline-128.5 & - & 13 & $5-133 \mathrm{~m}$. & $\begin{array}{l}(0.06-0.2) \text {, light gray with } 10 \% \text { of } \\
\mathrm{tz} \text { and quartzite grains (max. size: }\end{array}$ \\
\hline 130 & - & 133 & -134 & $\begin{array}{l}(0.02-0.1) \text {, light gray, occasional } \\
\text { rtz grains. }\end{array}$ \\
\hline & & & -135 & 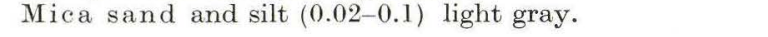 \\
\hline
\end{tabular}


Östergaard dairy. Trial bore 1948.

Casing: 6" to $74 \mathrm{~m}$., $4 \frac{1}{1} 2^{\prime \prime}$ to $128 \mathrm{~m}$.

Samples: Bailer samples (collected by the writer).

Driller: D. Husted, Vejen.

\begin{tabular}{|c|c|c|c|}
\hline \multicolumn{3}{|c|}{ Elevation } & Deptr \\
\hline$a b$ & +5 & $0 \mathrm{~m}$. & 0 -abt. 45 \\
\hline+ & 5 & $\mathrm{~m}$. & $45-57$ \\
\hline - & 7 & - & $57-62$ \\
\hline - & 12 & - & $62-77.9$ \\
\hline- & 27.9 & - & $77.9-81.9$ \\
\hline- & 31.9 & - & $81.9-82.2$ \\
\hline - & 32.2 & - & $82.2-82.7$ \\
\hline - & 32.7 & - & $82.7-83.8$ \\
\hline & 33.8 & - & $83.8-84.7$ \\
\hline - & 34.7 & - & $84.7-87.2$ \\
\hline 一 & 37.2 & - & $87.2-90.4$ \\
\hline- & 40.4 & - & $90.4-92.7$ \\
\hline - & 42.7 & - & $92.7-109.3$ \\
\hline - & 59.3 & - & $109.3-110.9$ \\
\hline - & 60.9 & - & $110.9-121.5$ \\
\hline - & 71.5 & - & $121.5-122.0$ \\
\hline - & 72.0 & - & $122.0-124.8$ \\
\hline - & 74.8 & - & $124.8-128$ \\
\hline
\end{tabular}

Elevation Depth

\section{Log:}

probably Quaternary (no samples).

Clay dark (no samples).

Sand and gravel (no samples).

Mica silt, gray, argillaceous (no samples).

Mica clay, dark gray, silty, non-calcareous, with some pyrite grains.

Lignite and Mica clay, dark gray, silty, non-calcareous.

Mica sand, fine $(0.1-0.2 \mathrm{~mm}$.), light gray with clay ironstone concretions, fossiliferous.

Clay ironstone and Mica clay, dark brown to almost black, fossiliferous.

Mica sand, fine $(0.06-0.2)$, gray, glauconitic, non calcareous.

Sandstone, sideritic, brownish green, fossiliferous.

Mica sand and silt $(0.02-0.1)$, argillaceous, slightly pyritic, non-calcareous.

Sandstone, sideritic, fossiliferous (fossils partly dissol. ved) and Mica sand, fine, dark brownish gray.

Mica sand, fine $(0.06-0.2)$, light gray, with shell fragments.

Sandstone, pyritic, dark gray, fossiliferous.

Mica sand and silt (0.02-0.1), greenish gray, pyritic, fossiliferous (fragments).

Mica silt, dark gray, occasional quartz grains (1-2) and shell fragments (concretions obviously occur; driller reports "stony formation").

Mica sand, fine $(0.06-0.1)$, dark gray, occasional 1-2 $\mathrm{mm}$. quartz grains and small shell fragments.

Mica clay, silty, dark grayish brown to almost black, occasional small shell fragments.

\section{Sample description:}

(The samples were collected by the writer on the well site on October 26, 1948 while the well was being drilled. The inserted samples below, which were arranged in accordance with depth by the driller were unlabelled. They were identified by the driller and related to the labelled samples as indicated. The labelled samples were considered representative or characteristic of the individual intervals by the driller. The fossils from these samples have been examined).

- $27.9 \mathrm{~m}$. $\quad 77.86-78.56 \mathrm{~m}$. Mica clay, dark gray, silty with some pyrite grains, non calcareous.

- 28.6 - 78.56-81.86 - Mica clay, dark gray, silty, non calcareous.

"Sample above the lignite": mainly clay ironstone concretions, dark, non calcareous, pyritic; lumps of Mica silt, light gray, calcareous, and occasional fossils.

- 31.9 - 81.86- 82.16 - Mica clay and Lignite. Mica clay: dark gray, silty. Small piece of greenish gray clay shale. All components non calcareous.

"Sample below the lignite": mainly Mica elay, dark brown to black, silty, fossiliferous, and clay ironstone concretions, brownish green. 
Elevation

$-32.2 \mathrm{~m}$.

$-32.7-$

-32.7 -

$-33.8$

$-34.7$

$-37.2$

$-40.4$

$-40.4$

$-42.7-$

$-59.3$

Depth

$82.16-82.66 \mathrm{~m}$. Mica sand, fine $(0.1-0.2 \mathrm{~mm}$.), light gray with a lump of brownish-green clay ironstone, fossiliferous.

82.66-83.76 - Clay ironstone, brownish green, fossiliferous.

82.66- 83.76 - Mica sand, fine (0.06-0.2), fossiliferous (ditch sample).

"Above sample at $83.76-84.66 \mathrm{~m} . "$ : Mica clay, dark brown to almost black, silty with occasional shell fragments, and a piece of greenish clay ironstone.

83.76-84.66 - Mica sand, fine (0.06-0.2), gray, non calcareous, glauconitic.

84.66- 87.16 - Sandstone, sideritic, brownish green, fossiliferous some pyrites.

87.16-90.42 - Mica sand, fine, silty (0.02-0.1), slightly pyritic, argillaceous, non calcareous.

90.42- 92.72 - Sandstone, sideritic, fossiliferous, (fossils partly dissolved) and Mica sand, fine, brownish gray.

90.42-92.72 - Mica silt, dark brown to almost black, argillaceous, with coarse quartz grains (1-2), fossiliferous.

92.72-109.29 - Mica sand, fine (0.06-0.2), light gray with occasional shell fragments (well preserved left valve of Tellina fallax at $106 \mathrm{~m}$.).

109.29-110.86 - Sandstone concretion, pyritic, dark gray, fossiliferous, and clay ironstone, brownish green, fossiliferous. "Below sample at 109.29-110.86 m." Mica sand, fine (0.06-0.1), gray, fossiliferous, and lumps of Mica silt, dark gray to almost black, and pyritic sandstone concretion.

- 60.9 - 110.86-121.51 - Mica sand, silty $(0.02-0.1)$, pyritic, greenish gray, fossiliferous (fragments).

- 71.5 - 121.51-122.01 - Mica silt, dark gray, occasional quartz grains (1-2), and shell fragments.

- 72.0 - 122.01-124.78 - Mica sand, fine (0.06-0.1), dark gray, occasional coarser quartz grains (1-2), and small shell fragments.

- 74.8 - 124.78-126.98 - Mica clay, silty, dark grayish brown, oceasional pyrite grains.

$-77-$

126.98 - Mica clay, silty, dark brown to almost black, occasional small shell fragments.

Arnum.

D.G.U. file no. 150.13 .

Arnum waterworks. Well drilled 1935.

Casing: $\quad 6^{\prime \prime}$ to $82 \mathrm{~m} ., 3^{\prime \prime}$ to $106 \mathrm{~m}$. Flush Drilling.

Samples: Ditch samples, collected by the driller.

Driller: K. Fr. Sснмпт, Christiansfeld.

$\begin{array}{lc}\text { Elevation } & \text { Depth } \\ +28 \mathrm{~m} . & 0 \text {-abt. } 28 \mathrm{~m} . \\ \pm 0- & 28-40 \mathrm{~m} . \\ -12- & 40-53- \\ -25- & 53-83- \\ -55- & 83-94- \\ -66- & 94-97- \\ -69- & 97-107-\end{array}$

\section{(Log and) Sample description:}

Quaternary deposits.

sample of Mica sand (about $40 \%$ ) and silt (0.02-0.2 $\mathrm{mm}$.) and (about $60 \%$ ) quartz gravel (1-3), fossiliferous (Gram formation).

Mica clay, silty, brownish black.

Mica sand and silt (0.02-0.06), argillaceous, brownish gray, fossiliferous (small fossils).

Mica sand, silty (0.02-0.06), argillaceous, fossiliferous (large fossils).

Mica clay, dark grayish brown, with occasional thinshelled fossil fragments.

Mica sand, fine $(0.06-0.1)$, with occasional thin-shelled fossil fragments.

(The ditch samples were considered representative of the indicated intervals by the driller). 
Arnum.

D.G.U. file no. $150.25 . \mathrm{b}$.

Arnum waterworks. Well drilled 1953.

Casing: 6". Flush Drilling.

Samples: Ditch samples to $95 \mathrm{~m}$., bailer samples from $95-107.5 \mathrm{~m}$.

\begin{tabular}{|c|c|c|c|c|}
\hline \multicolumn{2}{|c|}{ Elevation } & \multicolumn{2}{|c|}{ Depth } & og : \\
\hline+28 & m. & $0-24.4 \mathrm{r}$ & & Quaternary deposits. \\
\hline 3.6 & - & $24.4-52.5$ & - & $\begin{array}{l}\text { Mica clay, silty, dark gray, fossiliferous. (Gram for- } \\
\text { mation to about } 40 \mathrm{~m} \text {.). }\end{array}$ \\
\hline-24.5 & - & $52.5-62.7$ & - & Mica sand and silt $(0.02-0.1)$, argillaceous. \\
\hline-34.7 & - & $62.7-62.9$ & - & $\begin{array}{l}\text { Mica sand, fine, silty }(0.02-0.2) \text {, argillaceous, greenish } \\
\text { gray, with small fossils. }\end{array}$ \\
\hline-34.9 & - & $62.9-95$ & - & Mica elay and sand alternating each $10-20 \mathrm{~cm}$. \\
\hline-67 & - & $95-95.3$ & - & $\begin{array}{l}\text { Mica sand, fine (0.06-0.2), slightly argillaceous, gray, } \\
\text { with large fossils. }\end{array}$ \\
\hline-67.3 & - & $95.3-101$ & - & Mica sand and clay. \\
\hline-73 & - & $101-104$ & - & $\begin{array}{l}\text { Mica sand, fine }(0.06-0.1) \text {, gray, with occasional thin- } \\
\text { shelled fossils. }\end{array}$ \\
\hline-76 & - & $104 \quad-104.3$ & - & Mica sand, fine $(0.06-0.1)$, gray, fossiliferous. \\
\hline-76.3 & - & $104.3-107.5$ & - & Mica sand, fine $(0.06-0.1)$, occasional thin-shelled fossils. \\
\hline-79.5 & - & 107.5 & - & Lignite. \\
\hline
\end{tabular}

\section{Sample description:}

$+\quad 3.5 \mathrm{~m}$.

$24.50 \mathrm{~m}$. Mica clay, gray, silty, single valve of Astarte Reimersi.

$-24.5-$

$52.50-62.70$

Mica sand, fine, silty $(0.02-0.1)$, argillaceous.

- 34.7 - $62.70-62.90-$

$-42-$

70

Mica sand, fine, silty $(0.02-0.2)$, greenish-gray; fossiliferous (small fossils).

$-67-95-95.30-$

$-73-101-104 \quad-$

$-76-104-104.3$

$-76.3-104.3-107.3$

$-79.5-\quad 107.5$

Mica clay, silty, brownish black, occasional fossil fragments, thin-shelled.

Mica sand, fine (0.06-0.2), slightly argillaceous, gray, fossiliferous, (large fossils).

Mica sand, fine (0.06-0.1), gray, with oceasional thinshelled fossil fragments.

Mica sand, fine (0.06-0.1), gray, fossiliferous (thinshelled fossils).

Mica sand, fine (0.06-0.1), gray, occasional thin-shelled fossil fragments.

Lignite.

Toftlund.

D.G.U. file no. 150. 9. b.

Potato flour mill. Trial bore 1935.

Casing: 6". Flush Drilling.

Samples: Ditch samples, collected by the driller and H. ÖDum, Ph. D.

Driller: P. Husted, Kolding.

Elevation

$+33 \mathrm{~m}$.

$-42-$

Depth

0 -abt. $75 \mathrm{~m}$.

$75-100$

$-47-$

-67 .

-72 .

-77 .

$-82$
80 .

100-105-

$105-110$ -

$110-115$ -

115 -

\section{Log and Sample description:}

$\mathrm{S}$ and, argillaceous (no samples), probably mainly moraine deposits of the Quaternary.

Mica sand, fine $(0.06-0.2 \mathrm{~mm}$.), gray, fossiliferous, relatively thin-shelled fossils. Large sample of fossils washed out on well site by $\mathrm{H}$. ÖDur.

Mica sand, fine (0.06-0.2), gray, some fossils.

Mica sand, fine $(0.06-0.2)$, gray, fossiliferous.

Mica sand, fine (washed sample of fossils), fossiliferous.

Mica sand, fine, silty $(0.02-0.1)$, gray, fossiliferous.

Mica sand, fossiliferous (mainly fossils).

(The ditch samples were considered representative of the indicated intervals by the driller). 


\section{DEFINITION OF THE ARNUM AND RIBE FORMATIONS}

Leif Banke Rasmussen (1956) has recently superseded the term "Astarte clay" in the upper Miocene of South Jutland by defining the Gram formation as the clays and silts exposed in the clay pit at Gram Brickworks. The base of the Gram formations is found at a depth of $36 \mathrm{~m}$ at Gram, where it is underlain by quartz sands and gravels.

The Arnum well file no. 150. 25. b. encountered the Gram formation at a depth of $24.4 \mathrm{~m}$., as proved by the presence of a single specimen of Astarte Reimersi. The base of this formation was probably encountered at about $40 \mathrm{~m}$. at Arnum. The fossiliferous silts and sands interbedded with clay below this depth, from about 40 to $107 \mathrm{~m}$. in well no. 150 . 13., and from about 40 to 107.5 m. in well no. 150. 25. b. are herby defined as the Arnum formation.

It will be shown in the discussion at the end of this paper that the assemblages from the fossiliferous sands and silts in the Glejbjerg, Bramminge, Ribe, Gramby, and Toftlund sections are so closely related with the Arnum fauna that there is no doubt about the correctness of referring these sections to the Arnum formation.

The Arnum formation has been penetrated at Ribe, where the upper part was obviously stripped off by the inland ice of the Quaternary. The base of the Arnum formation is found at $125.6 \mathrm{~m}$. depth in the Ribe sequence. The nonfossiliferous sands and gravels below this level are hereafter termed the Ribe formation. This sedimentary unit is undoubtedly limnic-fluviatile.

It is of interest to note that the Arnum and Ribe formations have been encountered in the Arnum no. 1 deep test as shown p. 419. The Arnum formation covers the interval from about $50 \mathrm{~m}$. to about $144.5 \mathrm{~m}$., and its thickness is accordingly about $95 \mathrm{~m}$. The underlying quartz sands and gravels referred to the Ribe formation and penetrated at about $191.7 \mathrm{~m}$. are about $47 \mathrm{~m}$. thick. 

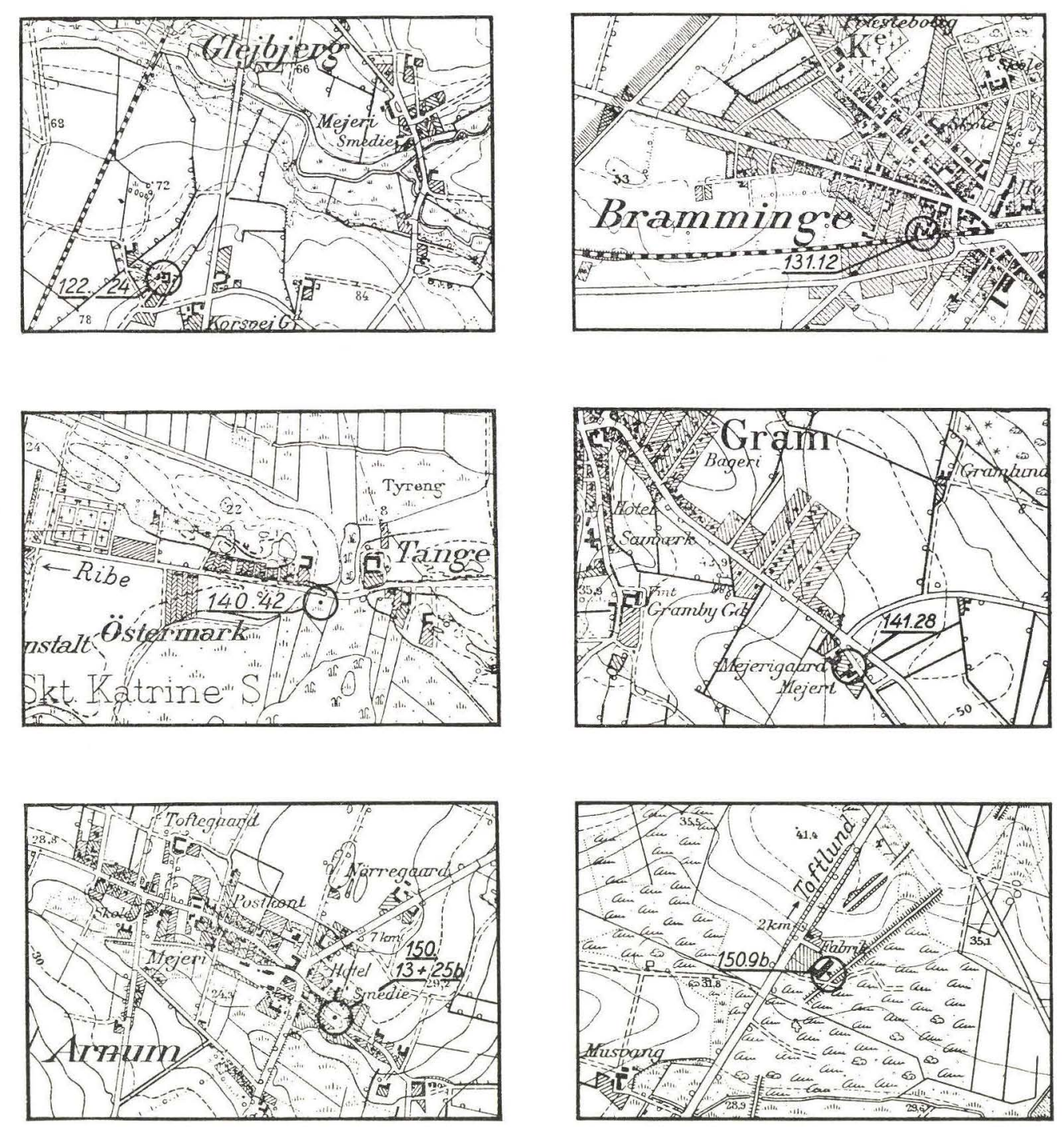

Location maps 1:20 000

$\begin{array}{lll}\text { Well no. } & \text { Location } & \text { Map sheet no. } \\ 122.24 & \text { Gleibjerg } & \text { M. } 3305 \\ 131.12 & \text { Bramminge } & \text { M. } 3404 \\ 140.42 & \text { Ribe } & \text { M. } 3705 \& \text { M. } 3605 \\ 141.28 & \text { Gramby } & \text { M. } 3707 \\ 110.13+25 \text { b } & \text { Arnum } & \text { M. } 306 \\ 150.9 \mathrm{~b} & \text { Toftlund } & \text { M. } 3907 \\ \text { Authorized by the Geodetic } & \text { Institute of Denmark. }\end{array}$

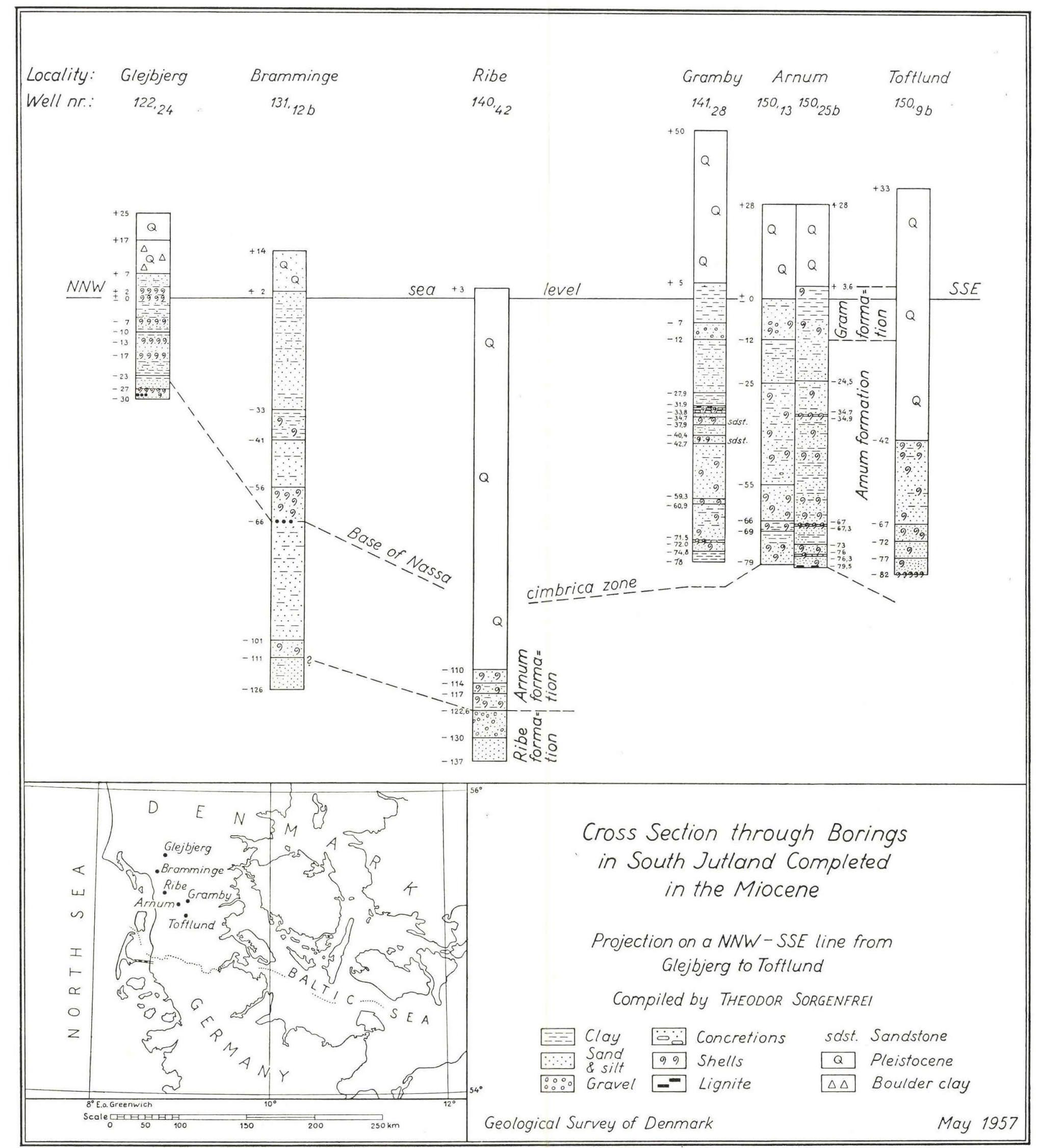




\title{
PALEONTOLOGY
}

\section{General}

\author{
The Species.
}

The definition and delimitation of the species concept has caused many difficulties. Morphological difference, failure to interbreed, infertility of offspring, and ecological, geographical and genetic distinctness are criteria applied in the delimitation of recent species as pointed out by HuXLEY (1940, p. 11). He also stressed that none of the criteria mentioned is singly decisive.

The goal of taxonomy is twofold; partly to attain practical subdivision of the vast mass of organisms, and partly to create a natural classification of organisms which should reflect "evolution at work" (HuXLEY 1940, p. 2, 25).

When dealing with living organisms the taxonomic approach may cover both the descriptive and experimental methods applicable to taxonomy. The paleontologist on the other hand is restricted to the field of morphology in his endeavour to subdivide fossil organisms into genetic units comparable with the units established by the neontologist.

The fundamental difference in approach is doubtless responsible for numerous cases of incompatibility of species of living and fossil organisms. In paleontology it is furthermore important to recognize the fact that species of different families or orders may be of different significance, and that the concept of the species varies from author to author.

Among definitions of a "paleontological" species, the one proposed by Arkell \& Moy-Thomas (1940, p. 395) that in paleontology the species can be thought of as "a practical and convenient unit by which fossils are distinguished" should be particularly noted. This definition implies that distinct morphological differences should be recognized in a collection of fossils before the fossils can be subdivided into "paleontological species". In other words: different species-names presuppose significant differences of morphological characters in the fossils referred to, and: fossils which can not be distinguished by essential morkhological features should be included in one species.

Although paleontology has thus to follow its own lines of approach towards a systematic subdivision of fossil organisms it should simultaneously always strive to follow the taxonomic system adopted by neontology as closely as possible. This statement may possibly appear superfluous since the majority of discussions concerning fossil species or genera, their affinities, validities, etc. do not at all reflect any indication of uncertainty regarding the identity of species in neontology and paleontology. Nevertheless, the statement is put forward here with a dual intention: to call attention to the fact that the "paleontological species" is less objective than the "neontological species" and to emphasize that full identity may hardly ever be obtained. 
In this connection it may be useful here to stress the decreasing degree of objectivity of the taxonomic categories superior to the species: the genus, the family, etc. (HuxLey 1940, p. 3.)

\section{The Taxonomic Significance of Morphological Characters of Molluscan Shells.}

Students of taxonomy generally aim at a "natural classification" which attempts to reflect evolution, as pointed out above. The classification which gives the most reasonable picture of a consistent evolution from primitive to complex organic structures in outlining phylogenetic lineages is generally adopted without hesitation. Evolution presupposes continuity and the adaptability of the living organism, as well as variation in most morphological qualities. In spite of these facts it is generally postulated that some morphological features are better evidence of evolution than others, and such features are consequently considered to be of greater "taxonomic significance".

There is no reason to diminish the importance of the phylogenetic approach in taxonomy. However, it should be borne in mind that there is a tendency to exaggerate the significance of single qualities in this as in other branches of biology.

Proceeding to the systematic subdivision of pelecypoda and gastropoda: The shell features of the adult have been ascribed paramount importance in spite of the fact that little is known about the evidence of shell structure and sculpture concerning the evolutionary stage of the animal in general, and about the influence of environments on shell features in particular (see p. 358). The reasons for the development of different shell structures and sculptures is after all rather obscure in the majority of species.

The part of the shell commonly referred to as the prodissoconch in pelecypoda and the protoconch in gastropoda attracted the attention of paleontologists rather early, while the corresponding stages of the living animal were first studied later (OdHner 1914, Lebour 1932-1938, Thorson 1935, 1936, 1946, Barker Jørgensen 1946, Lemche 1948 and others). Opinions concerning the taxonomic significance of the juvenile part of the shell have differed greatly. Some authors have ascribed genetic significance to the protoconch of the gastropoda (Grabau 1902, Hedley 1903, 1907, 1922, Iredale 1910, 1911, Finlay 1931, Powell 1942), others would only agree as to the specific value of its features (Sмiтh 1907, DaLl 1924), while some have completely rejected its phylogenetic significance (Kesteven 1912, LeMCHe 1948).

It is conceivable that the protoconch attracted the interest of students in view of its often very characteristic and minute features, and attempts were made to use these features as a taxonomic tool. The arguments which were brought forward against the application of protoconch features in phylogenetic and taxonomic studies are, however, of considerable interest. From Lemche's paper (1948 p. 26) the following should be cited: "... there may be some reason to warn against using the larval shells for phylogenetical purposes. Structures so extremely sensitive to ecological (zoogeographical) factors may perhaps be used in palaeontology for determining some of the physical factors in different parts of the oceans of past times, but probably they can tell us nothing about which species are to be regarded as the oldest. Similarly, it is probably hazardous to rely e.g. on the presence or absence of larval shells for taxonomic purposes such as the division into genera or the like. Similarity in ecology does not 
necessarily imply close taxonomic relationship". ... (p. 27): “... the larval shell (of the tectibranchs) may be used in solving ecological problems, but it is without phylogenetical significance".

During the last twenty years data on the larval stage of mollusca have been obtained through extensive studies, particularly by LEBOUR and Thorson. It has for instance been recognized that a big sinistral protoconch in Pyramidellid species evidences a pelagic larval stage, while species in which the protoconch is concealed by the initial adult whorl have a benthonic larval stage (Thorson, 1947, p. 199). Studies by Thorson (1946), Lemche (1948) and others have furthermore shown that the protoconch may in some species attain an abnormally large size, if for instance the pelagic stage is extended beyond the normal period due to stay in deep water where the larva is unable to get into contact with the bottom. (see also p. 00).

The ecological significance of some protoconch features is thus undeniable, and the greatest care should, of course, be exercised, if it is attempted to employ the features concerned in systematic classification. This admission need however not result in the complete rejection of all the protoconch features as aids in taxonomic research in favour of other morphological features such as those of the adult shell, the radula, and various soft parts of the animal whose environmental adaptations are fairly little known. Our lack of knowledge concerning the ecological and environmental dependence of the last-named features should not give them prevalence in systematic research! (see also p. 360) We may well ultimately arrive at the opinion that the obviousness of the environmental significance of particular protoconch characters is in fact advantageous in taxonomic research. It should be possible to exclude these "environment indicators" from phylogenetic considerations and then concentrate effort on the taxonomic evidence of the remaining features of the juvenile shell.

The following descriptions of species from the Miocene of South Jutland show that it is still possible to find hitherto undescribed or unknown morphological peculiarities both in fossil and recent species, and both in the juvenile and adult part of the shell (Pecten opercularis, Corbula gibba, Turridae etc.).

Considerable progress must be made in the field of molluscan shell morphology before every possibility of improvement has been exhausted and before the taxonomic significance of shell morphology is completely known. The author accordingly favours the opinion that extensive studies of every part of the molluscan shell should hold a prominent place in the search for evidence of evolutionary trends.

Our limited knowledge concerning the significance of many protoconch features makes a final decision as to the phylogenetic significance of the protoconch unwarranted at present. It may well be possible, as maintained by Iredale (1911, p. 320), Finlay (1931, p. 9) and VAn Voorthuysen (1945, p. 535 ), that the protoconch may turn out to be a very useful object for phylogenetic studies.

In this connection it is very interesting to recall the latest progress achieved with regard to the systematical relationships just of the Pyramidellidae mentioned above. Through the studies on anatomy by Fretter \& Graham (1949) and on spermiogenesis by Franzén (1955) it has now been proved that the Pyramidellidae are Opistobranchs as suggested by the sinistral structure of the protoconch. This shows that the structure of the protoconch but not the lenght of the protoconch helicocone is of "phylogenetic significance" in this family.

Concluding this paragraph I would like to quote the following statement 
by Thorpe (1940, p. 342), which summarizes and supplements the above standpoints:

"It should hardly be necessary to stress the fact that although many species are distinguished by more or less sharply defined structural characters in the adult, they are in fact equally characterized by biological and physiological peculiarities at every stage in the life history" ... "the present methods of taxonomic investigation often fail to separate groups which biologically and ecologically are clearly distinct, and which on every biological ground would be classified as distinct species. In some cases the difficulties encountered by systematists may be due to lack of precision in the examination of structural characters".

No part or stage of the molluscan animal or its shell should, therefore, be excluded from an evaluation which has the specific or phylogenetic range of the animal as its objective.

\section{Remarks on Taxonomic Subdivision.}

Any systematic subdivision of the mollusca as of any other group of animals has its own peculiar features and its particular deficiencies. The mass of data in the literature concerning mollusca is furthermore so vast that a really critical evaluation of the interminable number of genera and species is clearly beyond the power of a single scientist. There are admittedly a number of textbooks which have resulted from the study of an immensely voluminous literature. However, in many cases the authors could obviously not have been able to control statements set forth by earlier authors, since arguments for the taxonomic decisions arrived at are very often lacking. Naturally, this does not prove lack of verification, as shortage of space in the textbooks may for instance be responsible for the absence of premises. However, it can be suggested that incomplete definitions given by authors of species, inaccessibility of type material, etc., may in some cases be the real reason for insufficient substantiation. Hence it follows that genera, subgenera, species, etc., may have been approved more or less arbitrarily.

On account of the omnipresent risk of erratic taxonomic judgements in the textbooks on mollusca the writer finally decided mainly to regard the taxonomic systems at hand as practical means of characterization. The writer has generally used binary nomenclature and avoided to refer the species to subgenus with a few exceptions. The omission of the subgenus name agrees with my point of view that evidence is insufficient for splitting the genera into consistently defined subgenera in a great many instances. It should further be added that in my opinion the scientific and practical use of the subgenus name is mostly rather obscure.

The taxonomy suggested by THIELE in his "Handbuch der systematischen Weichtierkunde" (1931-35) was largely followed. The "Essais de Paléoconchologie Comparée" by Cossmann, the "Paläozoologie" by Wenz (1938-43), "Tertiary Faunas" by A. Morley Davies (1934-35) and other textbooks were, however, also currently consulted.

Many of THIELE's decisions appear as postulates and are thus incontrollable, but it is assumed that the wide experience of this author in the field of mollusea may have restricted misinterpretations to a practical minimum. The writer's disagreements with THIELE's viewpoints are mentioned in the following description of the mollusca where it was deemed advisable. 


\section{Method of Investigation.}

It was originally planned to treat the fossil material from the borings in the ordinary way, including descriptions of the species, illustrations of more significant forms, and a generalized rough estimate of the abundance of the individual species in the samples. Work was started on the samples from the Toftlund well (file no. 150. 9. b.) and the first Arnum well (150. 13). These samples were washed on a sieve of about $0.1 \mathrm{~mm}$. mesh, and afterwards they were divided into different "grain sizes" for practical sorting by sieving on $10.5,5.2,2.6$, and $1.7 \mathrm{~mm}$ meshes. Well preserved shells of the common species and all specimens of rare species contained in the sieved sections were afterwards sorted out.

When fossil material was obtained later from the other wells listed, it appeared that the fossil assemblages from the different wells were of similar aspects, but it was simultaneously recognized that there were marked differences as to the abundance of the species. This observation was the impulse which initiated the quantitative investigation of the entire material. The object of the statistical treatment of the fossils was primarily to get numerical expressions for the abundance of the species in the different samples for biostratigraphic purposes, but secondarily a paleoecologic approach was intended.

The countings of the fossils were carried out as follows: any pelecypod valve or part of it with preserved umbo was defined as one half individual, and any gastropod shell or part of it which included the protoconch was counted as one individual. Single determinable fragments of rare species were, however, also defined as individuals even if they did not fulfill the above requirements as to presence of the juvenile part of the shell, provided they were the only representatives of the fossils concerned.

The protoconch is very often absent in shells of A porrhais alata, and generally also in Turritellid shells. The fragility of the juvenile part of the shell in these species may be the main reason to the absence of the protoconch, since it is relatively scarce even in the small grain sizes of the samples. If all shells without a protoconch referred to these species had to be disregarded the species would obviously be underrated in the statistical balance. It was finally decided to consider shells with preserved protoconch, and also shells without protoconch, but including the first adult whorls, as individuals. All other fragments were disregarded in the countings.

Counting the fossils of the clay-ironstone concretions presented a particular problem. The concretions were repeatedly boiled and cooled in an oversaturated solution of Glauber's salt (WICHER 1942). By this process the concretions were gradually broken due to the formation of salt crystals in cavities and fissures of the rock, and the fossils were in most cases detached*). Counting could then proceed like in the other samples.

In the material from Bramminge and Toftlund the original samples were divided into sections as mentioned above, and well preserved fossils were sorted out in a relatively arbitrary way. When it was decided to work the samples statistically the percentages of the fossils had to be determined in each of the sieved sections. Only weighed fractions of the sections were counted since

*) The method which was developed by Wicher for microfossil purposes is not recommended in general for detaching megafossils from indurated rock since the fossils are also often broken. 
counting all the material would have been too laborious a task, and unnecessary from a statistical point of view.

The calculated total numbers of specimens of each species in all the sections of each sample were added the number of specimens previously sorted out. The figures thus obtained indicated the total number of specimens contained in the entire sample concerned, and the percentage of the individual species could finally be calculated easily. The sample from Arnum 150.25 b., 62.7-62.9 m. was treated in a similar way, but no fossils were sorted out before sectioning.

Below is an account of the number of specimens which have been counted or sorted out from the individual samples.

\section{Outline of Number of specimens sorted or counted.}

\begin{tabular}{|c|c|c|c|}
\hline File no. & Location & Depth & $\begin{array}{l}\text { Number of } \\
\text { specimens }\end{array}$ \\
\hline \multirow[t]{12}{*}{122.24} & Glejbjerg. & $23 \mathrm{~m}$. & 643 \\
\hline & Standard samples of & $25-$ & 559 \\
\hline & about 240 cubic $\mathrm{cm}$. & $32-$ & 391 \\
\hline & All fossils investigated & $38-$ & 77 \\
\hline & & $42-$ & 118 \\
\hline & & $48-$ & 6 \\
\hline & & $52-$ & 30 \\
\hline & & 53 & 139 \\
\hline & & $53.5-$ & 821 \\
\hline & & $53.75-$ & 336 \\
\hline & & $54-$ & 31 \\
\hline & & $55 \cdot$ & 315 \\
\hline \multirow[t]{8}{*}{ 131. 12. b. } & Bramminge & \multirow[t]{2}{*}{$70-80 \mathrm{~m}}$. & \\
\hline & Originally sorted & & 8727 \\
\hline & Above $5.2 \mathrm{~mm} .642 .3 \mathrm{~g}$. & & 2105 \\
\hline & $\begin{array}{ll}5.2-2.6 & 3497 \\
\text { investigated } & 1198.6\end{array}$ & & 3634 \\
\hline & $2.6-1.7 \mathrm{~mm} .1753 .5$ & & 5004 \\
\hline & investigated 229.3 & & 696 \\
\hline & $1.7-0.5 \mathrm{~mm} .1128 .2$ & & \\
\hline & investigated 112.6 - & & 666 \\
\hline \multirow[t]{12}{*}{140.42 . } & Ribe & $113-114 \mathrm{~m}$. & 59 \\
\hline & Standard samples. & $114-115$ & 9 \\
\hline & All fossils investigated. & $115-116$ & 7 \\
\hline & & $116-117$ & 1 \\
\hline & & $117-118$ & 4 \\
\hline & & $118-119$ & 1 \\
\hline & & $119-120$ & 4 \\
\hline & & $120-121$ & 2 \\
\hline & & $121-122$ & 3 \\
\hline & & $122-123$ & 4 \\
\hline & & $123-124$ & 8 \\
\hline & & $124-125$ & 19 \\
\hline
\end{tabular}

Sum total 43 391 77 
File no. Location

Depth

141.28.

Gramby

Standard samples.

All fossils investigated.

$81.86-82.16 \mathrm{~m}$

$82.16-82.66$ -

$82.66-83.76$ -

$84.66-87.16$ -

$90.42-92.72-$

92.72-109.29

109.29-110.86 -

$110.86-121.51$.

Number of

specimens

Sum

total

5109

150.9. b. Toftlund

*)Original sample abt. $3100 \mathrm{~g}$.

$5.2-2.6 \mathrm{~mm}$. $\quad 772.3 \mathrm{~g}$. sorted 269.5 -

$2.6-1.7 \mathrm{~mm} . \quad 908.4$. sorted 104.8 -

$1.7-0.5 \mathrm{~mm} .1309 .8$ sorted 86.2 -

$75-100 \mathrm{~m}$.

$\begin{array}{r}3880 \\ 5756 \\ 6712 \\ 12153 \\ \hline\end{array}$

28501

$100-105 \mathrm{~m}$

Above $0.5 \mathrm{~mm}$. abt. $100 \mathrm{~g}$. $105-110$

$695 \mathrm{I}$

13022

Above $0.5 \mathrm{~mm}$. abt. 325 -

110-115 -

4226

115.

1474

54174

150. 13. Arnum

Standard samples.

All fossils investigated.

$\begin{array}{lr}28-40 \mathrm{~m} & 161 \\ 53-83- & 5449 \\ 83-94- & 162\end{array}$

150. 25. b. Arnum

Standard samples.

Original: $\quad 70.65 \mathrm{~g} . \quad 62.7-62.9 \mathrm{~m}$.

investigated: 2.62 -

Above $0.5 \mathrm{~mm} .45 .03$.

investigated: 4.73 -

Above $0.5 \mathrm{~mm}$.

investigated for

rare species only 45.03 .

$0.5-0.33 \mathrm{~mm}, \quad 23.0$.

investigated: $\quad 4.75$.

Original: $77.09 \mathrm{~g}$.

Above $0.33 \mathrm{~mm}$. $66.42 \mathrm{~g}$.

Above $0.33 \mathrm{~mm} .1 .27$ -

Above $0.33 \mathrm{~mm} .34 .36$ -

Above $0.33 \mathrm{~mm} .2 .62$ -

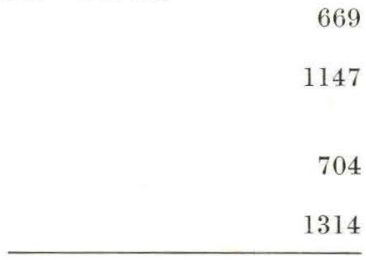

$95-95.3 \mathrm{~m}$.

101-104.3 m.

104.3-107.5 m.

$107.5 \mathrm{~m}$.
3834

1311

74

529

139

*) The sample sections were weighted after some fossils had been sorted out, and the estimated weight of the sorted fossils was added. 

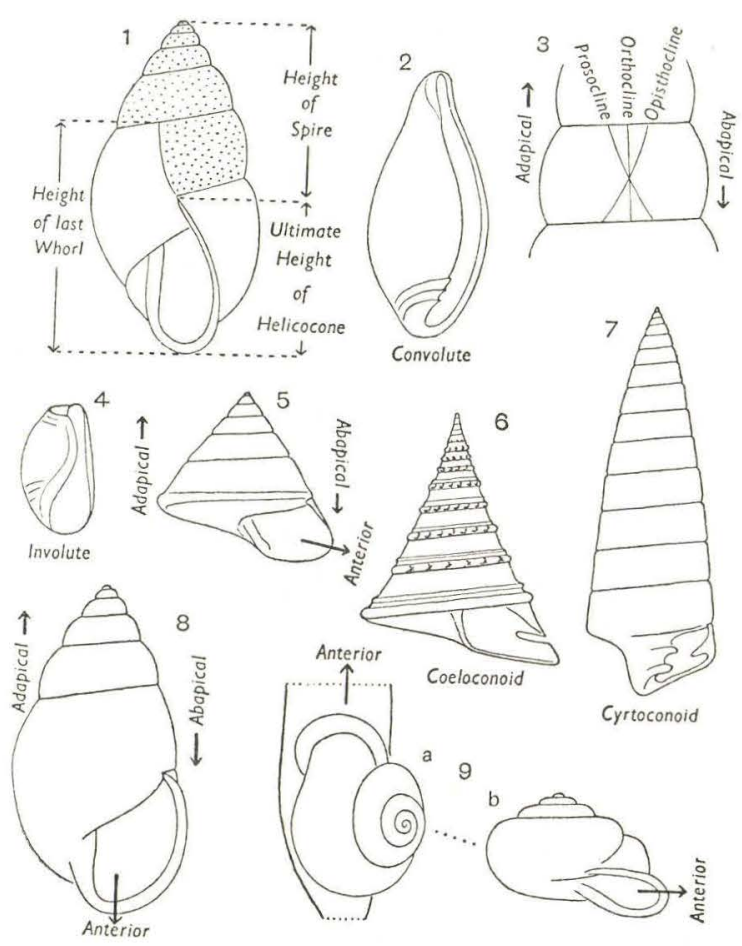

Cyrtoconoid
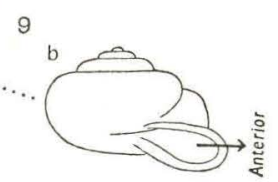

Fig. 3.

EXPLANATION OF FIGURES ( $\frac{2}{3}$ OF NATURAL SIZE UNLESS STATED)

1. Amphidromus, viewed with aperture facing obliquely (at about $45^{\circ}$ ) to line of vision; showing full extent of spire (dotted) and boundary between spire and last whorl. 2. Actaeonella laevis D'ORBIGNY, a convolute shell (after D'ORBIGNY, $\times \frac{1}{3}$ ). 3. Illustrating terms applicable to inclination of collabral lines and to directions parallel with axis. 4. Bulla, an involute shell. 5. Calliostoma, showing anterior, abapical and adapical directions. 6. Pleurotomaria luciensis D'ORBIGNy, a coeloconoid shell (after D'ORBIGNY, $\times \frac{1}{8}$ ). 7 . Nerinea requieniana D'ORBIGNY, a eyrtoconoid shell (after D'ORBIGNY, $\times \frac{1}{3}$ ). 8. Amphidromus, anterior and abapical directions coinciding. 9. Helix, showing anterior direction; (a) shell poised on crawling head-foot mass, (b) apertural view. (From Cox 1955).

If the number of species is compared with the size of the samples and the grain size of the sieved fossil samples it appears that the bulk of the fossils is of small size. Relatively large shells are found only in the Glejbjerg well from 53 to $55 \mathrm{~m}$., in the Bramminge well from 70 to $80 \mathrm{~m}$., in the Arnum wells from 83 to 95 , and in the Toftlund well from 110 to $115 \mathrm{~m}$.

The weights of the samples are no safe basis for an exact calculation of the richness of the fossil assemblages. They are given here, however, in order to obtain a rough estimate of the amount of fossils included.

\section{Remarks on the Description of Species.}

The shell features are in most cases excellently preserved. However, the relatively rough treatment of the fossil material during drilling operations has commonly caused the fossils to be more or less broken. Thick-shelled species 
of both pelecypoda and gastropoda, and gastropoda with varices have had the best possibility of remaining undamaged.

The number of specimens sorted out and investigated more thoroughly is shown at the beginning of the description of each individual species. I have drawn illustrations of most well preserved species which have been determined. The shells were drawn on the basis of eareful observation under the microscope, the outlines being drawn by means of a camera-lucida. One of the reasons why drawings were preferred to photographs was that the minute features of the shells would hardly be reproduceable from photographs with the techniques available. The size of the specimens drawn is included in the explanation to the illustrations.

\section{Analysis of Variates.}

Analysis of the variation of shell dimensions should have been included in each species to make the descriptions complete. However, there was only sufficient well preserved material available for such statistical studies in a few species. It is thus regretable that hardly any of the shells belonging to species of the interesting family of the Turridae could be measured. The thin outer lip of the aperture was broken on almost all shells.

The variation of the height/diameter ratio in gastropoda and the length/ height ratio in pelecypoda has been demonstrated by frequency histograms and dot diagrams in various species, and the mean values of the ratios have been calculated in the ordinary way (see for instance Fisher 1954, Pearl 1940, KEMP 1942). The limits of the mean indicated in each case are $\pm 3 e$ where $e=\frac{s}{\sqrt{n}}$
( $n=$ number of observations, $s=$ standard deviation).

\section{Nomenclature of Shell Morphology.}

The nomenclature used in pelecypoda is self-explanatory since it does not deviate from the commonly accepted terminology.

In the description of the gastropoda I have followed the nomenclature suggested by Cox (1955). His schematic figures illustrating the morphological terms of his nomenclature are reproduced on fig. 3 . 


\title{
DESCRIPTION OF SPECIES
}

\author{
CLASSIS I. PELECYPODA \\ FAMILIA NUCULIDAE D'ORBIGNY 1844
}

VAN DE PoeL (1955) has recently proposed to subdivide the family of the Nuculidae into the genera Nucula Lamarck 1799, and Nuculoma Cossmans 1907, on the basis of the structure of the shell. All Nuculid species in which the outer shell layer is built up of radial elements are referred to the genus Nucula, Nucula nucleus (L.) being the type species. Nuculids with a uniform non-radial shell structure are included in the genus Nuculoma, the type species of which is Nucula castor D'OrBIGNy.

From my earlier studies of Nuculid shells (Sorgenfrei 1937) I had concluded that the perforations of the shell surface located adjacent to the hinge and opposite the tooth pits are only found in Nuculid species devoid of radial shell structure. Study of the Nuculids in the present shell material from South Jutland further strengthened my opinion that the differences in shell structure in the two Nuculid groups may be fundamental. I arrived at the conclusion that the number of radial lines or ribs may be relatively constant in individual species. This was inferred from the observation that the radial lines or ribs very seldom (or practically never) branch, and that secondary ribs do obviously not develop between the primary ribs during growth of the shell. The number of radial elements in the Nuculid shell should, therefore, be less variable than, for instance, the number of hinge teeth, which generally increase with shell growth, as demonstrated below in Nucula nitida, $N$. nucleus, and N. cromata. The development of the hinge during growth as described in N. nucleus may be considered typical of both Nucula and Nucoloma.

VAN DE POEL's suggestion of subdividing the Nuculidae by using the shell structure as a taxonomic feature appears, therefore, to be sound and practical and will be adopted here.

\section{Genus Nucula Lamarck 1799}

Summary of essential features of present day definition:

"La couche moyenne est composée de baguettes radiaires ("outer layer" de WRIGLEY), de section rectangulaire, encastrées dans la couche nacrée, qui les maintient étroitement accolées par un système de rainures arrondies correspondant à des moulures à la face inférieure de chacune des baguettes. ... Les Nuculidae présentant la structure décrite ci-dessus devront être rangées dans le genre Nucula LAMARCK, 1799 - à l'exclusion de toutes les autres, qu'elles aient le bord crénelé ou non". (VAN DE Poel 1955, p. 3-4). 
Remarks. The well known monotony of Nueulid shell features very often renders specific subdivision of fossil shell material a difficult task. In the present material an attempt has, therefore, been made to procure statistical data on the most conspicuous shell features: the radial elements of the outher layer and the hinge teeth. The future will show whether quantitative data of this kind aid progress in the taxonomic subdivision of the genus or not.

Recent:

\section{Nucula nucleus (L.)}

1758. Arca nucleus Linne, Systema Naturae. Edit. 10, p. 695.

1853. Nucula nucleus L. Forbes \& Handey. British Moll. Vol. 2, p. 215, pl. 47, fig. 7-8. 1863. Nucula nucleus L. Jeffreys. British Conch. Vol. 2, p. 143, Vol. 5, (1869) p. 172, pl. 29, fig. 2 .

1867. Nucula nucleus L. WernkaufF. Conch. d. Mittelm. Vol. 1. p. 204.

1891. Nucula nucleus L. sp. Bucquoy, Dautzenberg \& Dollfus. Les Moll. du Roussillon. Vol. 2, p. 210, pl. 37, fig. 15-25.

1934. Nucula nucleus L. Jensen \& SpÄRCK. Saltvandsmuslinger. p. 24, fig. 11.

Fossil:

1870. Nucula nucleus L. Hörnes. Die foss. Moll. d. Tert.-Beckens v. Wien. Vol. 2, p 297 , pl. 38, fig. 2.

1898. Nucula nucleus (L.) SAcco. I Moll. d. terr. terz. d. Piem. e. d. Liguria. 26, p. 44, pl. 10, fig. 24-27.

1907. Nucula nucleus L. sp. Cerdult-Ireldi. Fauna mal. mariana. 1, p. 125, pl. 11, fig. 22-29.

?1912. Nucula Benoisti Cossmann \& Peyrot. Conch. Néogén. d. l'Aquit. Vol. 66, p. 211, pl. 5, fig. 34-37.

1925. Nucula nucleus L. Kautsky. D. Mioe. v. Hemmoor u. Basbeck-Osten. p. 23, pl. 2 fig. 11-12.

1942. Nucula (Nucula) nucleus (L.) IJspeert. Monogr. d. mioz. tax. Bivalv. a. d. Peelgebiete. p. 23, pl. 1, fig. 4 .

1942. Nucula (Nucula) nucleus (L.) Heering. D. Olig. tax. Bivalv. a.d. Peelgebiete. p. 15, pl. 3 fig. 11-13.

1945. Nucula nucleus L. sp. Gribert. Faune mal. du Mioc. de la Belgique. 1, p. 12, pl. 1, fig. 2 .

\section{var. hanleyi Winckworth}

Recent:

Plate 1, fig. 1 a-b.

1853. Nucula radiata Hanley. Forbes \& Hanley. British Moll. Vol. 2, p. 220, pl. 47 fig. $4-5$, pl. 48 , fig. 7 .

1931. Nucula hanleyi Winckworth. On Nucula nitida Sow. Proc. Mal. Soc. Vol. 19, p. 280. 1935. Nucula nucleus L. var. hanleyi Winckworth. Schenck. Neotypes of N. nucleus (L.) Proc. Mal. Soc. Vol. 21, p. 258, fig. 2.

Fossil:

?1861. Nucula trigonula S. Wood. Crag Mollusca 2. p. 86, pl. 10, fig. 7.

1940. Nucula nucleus L. var. hanleyi Winckworth. Sorgenfrer. Mar. Nedre-Mioc. i Klintinghoved p. Als. p. 16.

Original diagnosis of $N$. nucleus: $(A .(r c a))$ testa oblique ovata laviuscula, natibus incurvis, margine crenulato, cardine arcuato ciliari. Testa magnitudine avellance. Inter Nates Rima triangularis, erecta. (LINNe, 1758).

Summary of essential features of present day definition. A Nucula with wide radial ribs separated by narrow interspaces and with crenated ventral margins. The ribs do not cross the escutcheonal area, nor are any present on the 
prodissoconch. The beaks are opisthogyrate. On the interior one sees an arcuate anterior (long) row of teeth and a straight posterior (short) one. There are two subequal muscle scars and additional impressions. Umbonal angle 90-100, ratio of height to length 0.82-0.8\%. Neotype in the Linnean Society, London. (SCHENCK, 1935, p. 259).

Diagnosis and definition of var. hanleyi WINCKWortH.

"Elongated-trigonal, with rufous rays; epidermis but stightly glossy, hinder extremity tapering, its dorsal area not sculptured; inner margin crenated" (HANLEY in Forbes \& Hanley, 1853, p. 220).

This variety is very close to $N$. nucleus, the chief distinctions seem to be (a) the dark-coloured "rays" seen on well-preserved specimens of N. hanleyi, and (b) the profile of $N$. nucleus is not as elongate as that of $N$. hanleyi. (SCHENCK 1935, p. 259).

Shell material referred to $N$. nucleus var. hanleyi:

\begin{tabular}{|c|c|c|c|c|c|}
\hline Location & Depth & Shells & Location & Dept & Shells \\
\hline Glejbjerg & $53.5 \mathrm{~m}$. & 1 frg. *) & Toftlund & $105-110 \mathrm{n}$ & $2 \mathrm{v}$. \\
\hline Bramminge & $70-80$ & $6-$ & & 115 & $2-$ \\
\hline Ribe & $113-114$ & $4-$ & Arnum (13) & $83-94$ & 1 - \\
\hline & 114-115 - & $1-$ & Arnum (25b) & $95-95.3$ & $88-$ \\
\hline Toftlund & $75-100=$ & $70 \mathrm{v} . *)$ & & $104.3-107.5$ & 2 frg. \\
\hline
\end{tabular}

Description. (Mainly based on the shells from Toftlund 75-100 m.).

Prodissoconch smooth, rarely well preserved on the shells investigated. Length and height have been measured on three shells:

$\begin{array}{llll} & \text { I } & \text { II } & \text { III } \\ \text { Length } & 0.7 & 0.8 & 0.9 \mathrm{~mm} . \\ \text { Height } & 0.5 & 0.6 & 0.7 \mathrm{~mm} .\end{array}$

Dissoconch. Exterior with about 40 to 60 fine radial "ribs" which are slightly concave. Each of the ribs corresponds to a notch on the ventral margin. The narrow "striae" between the ribs may be slightly elevated due to the concavity of the ribs. There are two systems of concentric sculpture: common growth lines displayed by concentric ribs and furrows, and minute, hardly perceptible concentric striae which are seen both on the concentric ribs and the furrows. The concentric ribs are often particularly conspicuous on the anterior and posterior ends of the shell. The shells are mainly grayish white, a few darker coloured specimens bear evidence of both concentric and radial colour bands.

Hinge. The number of teeth varies from 12 to 20 in front of the umbo and from 5 to 11 behind the umbo, the number of teeth obviously increasing with size of shell. The tooth length increases away from the umbo until about the middle of both the anterior and posterior hinge segments after which it again decreases. The teeth next to the umbo are much bigger on the posterior part of the hinge than the corresponding anterior teeth. This development is obviously related to a stronger deposition of aragonite around the posterior margin including the hinge teeth. A study of broken shells revealed that throughout

*) frg.= fragment(s), v.=valves. 


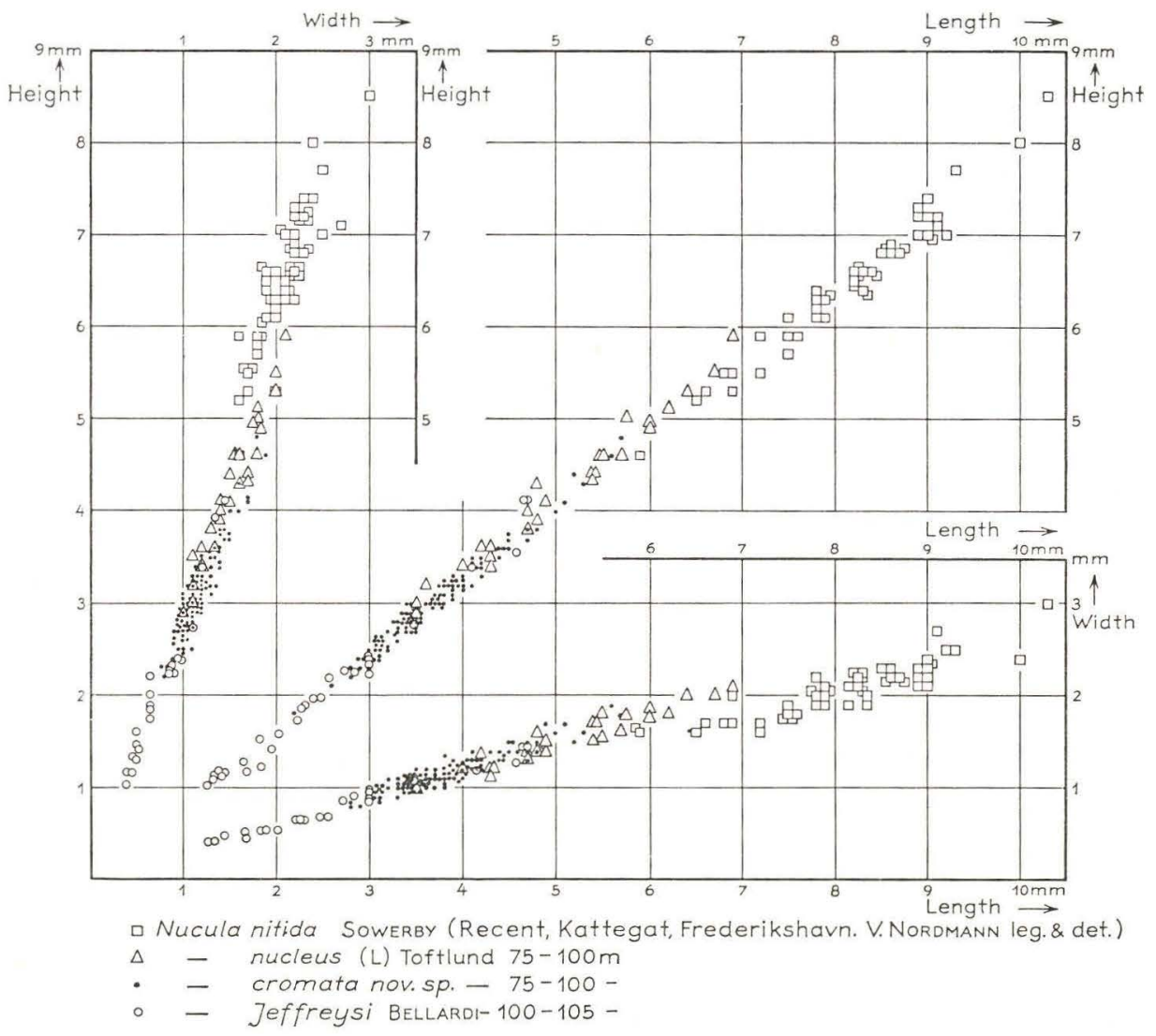

Fig. 4.

growth the posterior tooth nearest the umbo successively covers the oldest parts of the anterior hinge. The beak is simultaneously diverted from the dorsoventral plane into its well known opistogyrate position, and the oldest (proximal) teeth in front of the umbo get out of use. New teeth develop at the distal ends of the hinge during growth of the shell. The resiliophore extends generally from the umbo to the 4th or 5th anterior hinge tooth.

The interior of the shell is nacreous. The anterior adductor scar is somewhat larger than the posterior scar. Pedal muscle scars are hardly perceptible due to the small size of the shells. Notches on the ventral margin become weakly developed at the transition of the dorsal margin.

Variability. The valves were measured with a sliding caliper. The longest $(l)$ and shortest $(s)$ axes of the shell in the dorsoventral plane were defined as length and height respectively, $l$ being practically equal to the true shell length, and $s$ about $95-100 \%$ of true shell height. The dimensions $l$ and $s$ were preferred to true length and height, since $l$ and $s$ could be determined more objectively than true length and height. Besides $l$ and $s$ the width $w$ was measured, but this dimension is subjected to some ambiguity since shells with well preserved and protruding teeth appear wider than specimens with broken teeth. 

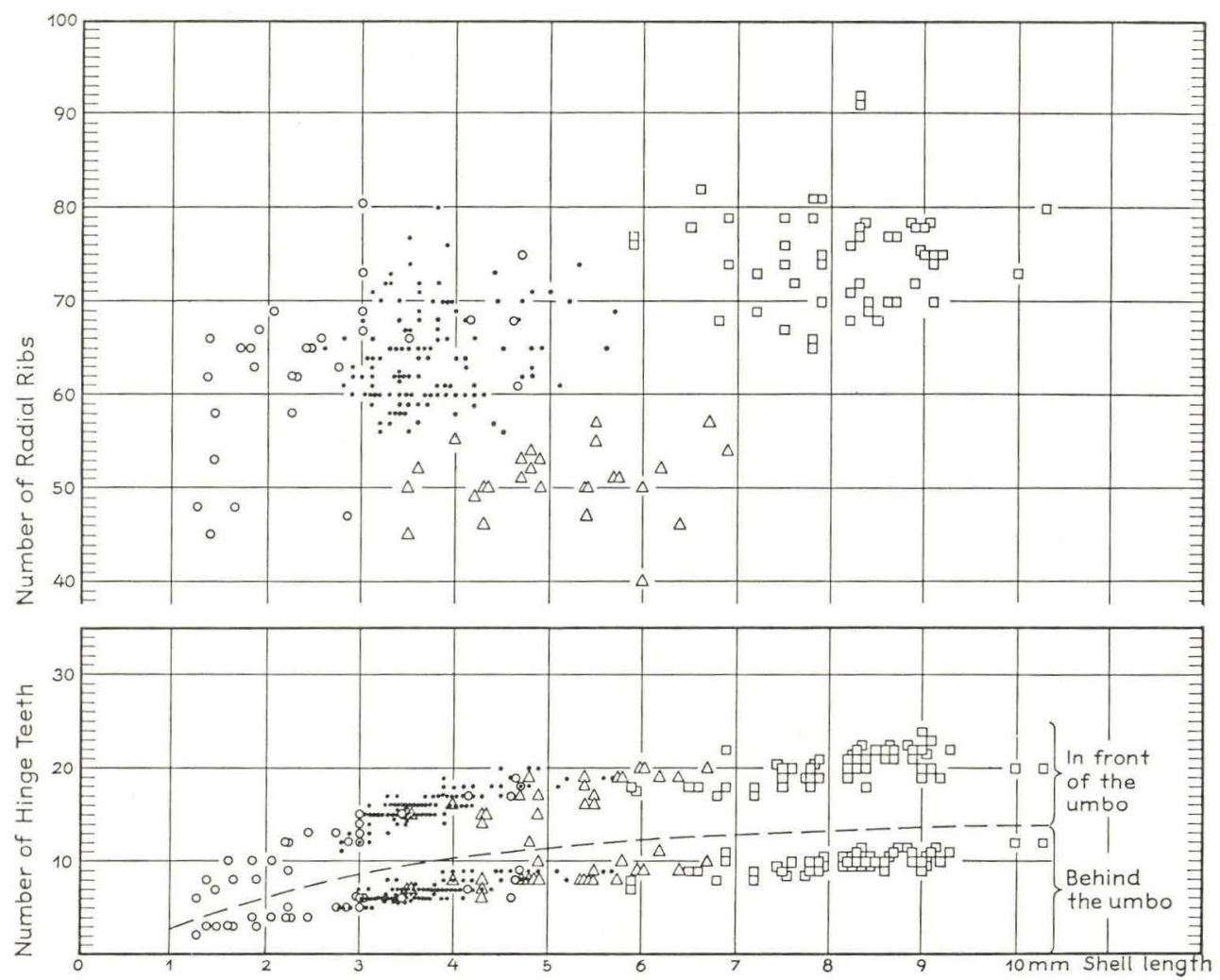

- Nucula nitida SOWERBy (Recent, Kattegat, Frederikshavn. V. Nordmann leg.\& det.)

$\triangle \quad-$ nucleus (L) Toftlund $75-100 \mathrm{~m}$

- - cromata nov.sp. - 75-100-

- - Jeffreysi BeLLARDI-100-105-

Fig. 5.

The diagram fig. 4 relates $l$ to $s ; l$ to $w$; and $s$ to $w$ for $N$. nucleus, $N$. cromata nov sp. and $N$. nitida. The numbers of radial ribs and hinge teeth are plotted against length on fig. 5 .

The graphs show that the length/height ratios of the three species are practically the same, and that variations are of the same order of magnitude. However, the number of radial ribs and hinge teeth obviously indicate more significant differences. (See conclusion p. 46).

Remarks concerning references etc. It is hardly possible to delimit $N$. nucleus from other species on shell characters alone, by simple qualities or quantities. Consequently it is also difficult to decide which of the Nuculid species mentioned in the literature should be listed in the synonymy. The list of references has accordingly been compiled with much hesitation, and the writer would not claim that his decisions are beyond discussion. Much work has still to be done, particularly in the field of shell statistics, before this and related species are clearly recognized and defined both in the living and fossil states. Both the synonymy list and the distribution outlined below which is derived from it, should accordingly be accepted with some reserve. 
Distribution.

Recent: West Coast of Europe from Lofoten to and including the Mediterranean.

Pliocene: England: Coralline Crag; Italy: Piacenziano, Astiano, upper Pliocene of Monte Mario.

Miocene: Aquitanian Basin: (?) Aquitanien; (?) Burdigalien. North Sea Basin: Belgium: Anversien, Holland(m), Germany: Hemmoor stage, Denmark: Arnum formation. Vienna Basin: Grund sands.

Mediterranean Basin: Italy: Colli torinesi (Elveziano).

Oligocene: North Sea Basin: Holland (u).

\section{Nucula Jeffreysi Bellardi}

Plate 1, fig. 2 a-c.

1875. Nucula Jeffreysi Bellardi, Monogr. della Nuculidi del Piemonte e della Liguria*). 1898. Nucula Jeffreysi Beltard. Sacco. I moll. d. terr. terz. d. Piem. e. d. Liguria 26. p. 49 , pl. 11. f. $20-23$.

1907. Nucula Jeffreysi Beltardi. Cerulli-Irelli. Fauna mal. mariana. 1, p. 126. pl. 11, fig. $38-40$.

1912. Nucula Jeffreysi Bellardi. Cossmann \& Peyrot. Conch. Néogén. d. l'Aquit. p. 215 , pl. 5 , fig. $42-45$.

1925. Nucula Jeffreysi Bellardi. Kautsky. D. Mioc. v. Hemmoor u. Basbeck-Osten, p.23, pl. 2, fig. 13 .

1945. Nucula Jeffreysi Bellardr. Glibert. Faune mal. du Mioc. de la Belgique. 1, p. 16, pl. 1 , fig. 3 .

Original diagnosis (from SAcco 1898): Testa parvula, solida, trigona obliqua, valde inflata: longitudinaliter concentrice costulata; costulae crebrae, a sulcis angustis separatae, uniformes, regulares, complanatae. Latus buccale brevissimum subtruncatum: lunula longa, laevis ad latera parum excavata medio inflata. Latus anale longum, acutum. Umbones inflati valde prominentes, subrecurvi. Margo apico-analis subrectus, valde obliquus: margo pallealis parum convexus (BELLARDI).

Shell material.

\begin{tabular}{lrllrl} 
Location & Depth & Shells & Location & Depth & \multicolumn{1}{l}{ Shells } \\
Glejbjerg & $48 \mathrm{~m}$. & $4 \mathrm{frg}$. & Ribe & $124-125 \mathrm{~m}$. & $1 \mathrm{frg}$. \\
& $52-$ & $1-$ & Toftlund & $100-105-$ & $67 \mathrm{v}$. \\
& 53.5 & $9 \mathrm{v}$. & & $100-105-$ & $\left.38-*^{*}\right)$ \\
& $53.75-$ & $4-$ & & $105-110-$ & $93-* *)$ \\
& $54-$ & $2-$ & & $110-115-$ & $24-* *)$ \\
Bramminge & $55-$ & $2-$ & Arnum $(13)$ & $83-94-$ & $2-$ \\
& $70-80-$ & $4-$ & Arnum $(25 \mathrm{~b})$ & $95-95.3-$ & $6-$
\end{tabular}

Description. (Mainly on the basis of the shells from Glejbjerg and Toftlund $100-105 \mathrm{~m})$.

Prodissoconch smooth, concentric striae visible. The prodissoconch is rarely well preserved and may be difficult to delimit on the shell. Lengths and

*) Not available in Danish libraries.

**) N. Jeffreysi or N. cromata nov. sp. 
heights (definition see $N$. nucleus p. 41) of four specimens are given below as examples of dimensions:

$\begin{array}{lclll} & \text { I } & \text { II } & \text { III } & \text { IV } \\ \text { Length } & 0.9 & 0.9 & 1.0 & 0.8 \mathrm{~mm} . \\ \text { Height } & 0.7 & 0.7 & 0.8 & 0.7 \mathrm{~mm} .\end{array}$

Dissoconch. Exterior with about 45 to 80 fine radial striae, and relatively coarse, rounded, concentric ribs divided by sharp furrows. The concentric ribs may be slightly irregular, they are generally the most elevated on the anterior and posterior ends of the shell. The shape of the concentric rib in section is that of a surf wave with the culmination close to the furrow nearest the umbo. Minute concentric striae may be recognized on the concentric ribs and the furrows between them as in N.nucleus (see p. 40). The shells are grayish white or bluish gray and are occasionally ornamented with concentric colour bands; shell surface often glossy.

Hinge. The number of teeth varies from 6 to 19 in front of the umbo and from 2 to 9 behind the umbo. The number of teeth increases with size of the shell, as in $N$.nucleus, and the development of the hinge and its teeth is very much the same as in that species. The resiliophore extends as far as the 4 th to 6 th anterior tooth.

The interior of the shell is less typically nacreous than the interior of the shells referred to $N$.nucleus, and several shells are brownish. The anterior adductor scar is a little larger than the posterior scar; pedal muscle scars rarely distinguishable. Notches on the ventral margin correspond to the radial ribs on the shell surface.

Variability. Measurements of shell dimensions in this species were carried out under the microscope. Length, height, and width have been measured as in $N$. nucleus. It appears from the graphs figs. 4 and 5 that $N$. Jeffreysi hardly differs from $N$. nucleus and $N$. cromata with respect to the length/height ratio while it obviously differs considerably concerning the variation in number of the radial ribs, the range being much wider than in the two other species. See also conclusions below p. 46 .

\section{Distribution.}

Pliocene: Italy: Piacenziano, Astiano, upper Pliocene of Monte Mario.

Miocene: Aquitanian Basin: Burdigalien

North Sea Basin: Belgium: Anversien, NW Germany: Hemmoor stage. Denmark: Arnum formation.

\section{Nucula cromata nov. spec.}

Plate 2, fig. 3 a-b.

Shell material from S. Jutland referred to N. cromata or transitional from $N$. Jeffreysi to $N$. cromata: 


\begin{tabular}{|c|c|c|c|c|c|c|}
\hline \multirow{3}{*}{$\begin{array}{l}\text { Location } \\
\text { Glejbjerg }\end{array}$} & Depth & Shells & Location & \multicolumn{2}{|c|}{ Depth } & Shells \\
\hline & $23 \mathrm{~m}$ & $5 \mathrm{v}$. & Gramby & $92.72-109.29$ & $\mathrm{~m}$. & $8 \mathrm{v}$. \\
\hline & $25-$ & $8-$ & & $109.29-110.86$ & - & \\
\hline & $32-$ & $61-$ & & $110.86-121.51$ & - & \\
\hline & $55-$ & 1 - & Toftlund & $75-100$ & - & 469 \\
\hline Gramby & $82.66-83.76-$ & $88-$ & & $100-105$ & - & \\
\hline & $84.66-87.16-$ & $65-$ & Arnum (13) & $53-83$ & - & 103 \\
\hline & $90.42-92.72-$ & $27-$ & $\operatorname{Arnum}(25 \mathrm{~b})$ & $62.7-62.9$ & - & 147 \\
\hline
\end{tabular}

Diagnosis. Nucula of small size. The radial elements of the shell structure consist of broad units, here referred to as ribs, which correspond to notches on the ventral margin, and striae which are identical with the interspaces between the ribs. The radial striae are slightly elevated above the ribs. The radial ribs and striae are between about 55 and 80 in number. The concentric ornament includes coarse, irregularly distributed growth ribs and minute, concentric striae. N. cromata differs from N. Jeffreysi mainly in its surface being almost smooth and in the irregular occurrence of the concentric growth ribs, if these are present. Holotype: D.G.U. Toftlund 150.9. b. 75-100 m. (plate 2, fig. 3).

Description. (Mainly on the basis of shell material from Toftlund 75$100 \mathrm{~m}$.).

Prodissoconch. Same characters as in N. Jeffreysi. The following measurements of 5 shells from Toftlund give some idea of the size.

$\begin{array}{llllll} & \text { I } & \text { II } & \text { III } & \text { IV } & \text { V } \\ \text { Length } & 0.6 & 0.7 & 0.9 & 0.9 & 1.1 \mathrm{~mm} \text {. } \\ \text { Height } & 0.5 & 0.5 & 0.7 & 0.7 & 0.8 \mathrm{~mm} \text {. }\end{array}$

Dissoconch. Exterior. The surface may be almost devoid of growth ribs or such ribs may only be developed at intervals, particularly at the anterior and posterior parts of the shell. The concentric ribs tend to be more acute than in $N$. Jeffreysi. Minute concentric striae cover the whole shell surface. The shells from South Jutland are commonly of a bluish gray colour, which undoubtedly is a remainder of original colouring. The individual shell may present a uniform colour, or it may display concentric colour bands.

Hinge. The number of hinge teeth has been counted in shells from Glejbjerg $(32 \mathrm{~m}$.$) and Toftlund (75-100 \mathrm{~m}$.$) :$

$$
\text { Number of teeth }\left\{\begin{array}{lcc}
\text { Pre-umbonal } & 8-21 & 11-20 \\
\text { Post-umbonal } & 3-10 & 5-9
\end{array}\right.
$$

The number of hinge teeth obviously increases with size of the shell, although there is some variation in the number of teeth in shells of the same size. No fundamental differences are observed between the development of the hinge in N. Jeffreysi and N. cromata.

The interior of the shell: same characters as in N. Jeffreysi.

Variability. Measurements of the shells from Toftlund $(75-100 \mathrm{~m}$.) were carried out with a sliding caliper as in $N$. nucleus and $l, s$ and $w$ were determined (see p. 41). Fig. 4, p. 41 shows $l$ plotted against $s$ and $l$ against $w$ for the measured shells. The graphs show as previously mentioned that there is no marked difference in length/height ratios in N.nucleus, N. Jeffreysi, and $N$. cromata as pointed out above. See also discussion p. 46.

Distribution.

Miocene: North Sea Basin: Denmark: Arnum formation. 
Comparison of the number of hinge teeth and radial ribs in $N$. nucleus, N. Jeffreysi, N. cromata, and N. nitida.

53 valves of recent shells of $N$. nitida SowERBY from the Kattegat, collected by V. Nordmann and kept in the collection of the Danish Geological Survey, were measured, and the number of radial ribs and hinge teeth were counted and compared with the present fossil material. The results of this investigation are shown on the graphs fig. 4-5, p. 41-42.

It appears from fig. 4 that the length/heigth ratio is practically identical in the four species, variation being on the same scale. The ratios heigth/width and length/width do not differ remarkably in $N$. nucleus, $N$. Jeffreysi, and $N$. cromata, while $N$. nitida differs clearly from the three other species.

The graph fig. 5 which relates the number of radial ribs to the length of shell shows some possibly significant differences among the species as follows:

\begin{tabular}{lcc} 
& \multicolumn{2}{c}{ Number of ribs } \\
total range & main interval \\
N. nucleus & $40-57$ & $45-55$ \\
N. nitida & $65-92$ & $70-80$ \\
N. Jeffreysi & $45-81$ & $65-70$ \\
N. cromata & $56-80$ & $58-70$
\end{tabular}

The graph also illustrates that the number of hinge teeth related to length is practically the same in $N$. Jeffreysi and in $N$. cromata, while there is a smaller number of anterior hinge teeth in $N$.nucleus, and in N.nitida the number of teeth is smallest.

Shells of about $5.5 \mathrm{~mm}$. length would have the following average numbers of hinge teeth:

Average number of:

$N$. nucleus
$N$. nitida
$N$. Jeffreysi and $N$. cromata
anterior and posterior teeth

$18 \quad 9$

$16-7$

$20 \quad 10$

It should be added that more shell material is needed before these tentative estimates can be finally verified. The preliminary indications are, however, presented in order to draw attention to the possibilities of using features of the shell structure in the Nuculidae as taxonomic aids.

The writer has tried to relate the number of anterior and posterior hinge teeth to each other and to the number of radial ribs. The resulting graphs were, however, not suggestive and are, therefore, omitted in the present treatise.

\section{Nucula cf. nitida Sowerby}

Recent:

Plate 1, fig. 4 a-b.

1833. Nucula nitida Sowerby. Conchol. Ill., p. 5, no. 29, fig. 20.

1853. Nucula nitida Sowerby. Forbes \& Handey. British Moll. Vol. 2, p. 218, pl. 47, fig. 9.

1863. Nucula nitida Sowerby. Jeffreys. British Conch. Vol. 2, p. 149. Vol. 5, (1869) p. 172, pl. 29, fig. 3 .

1934. Nucula nitida Sowerby. Jensen \& Spärck. Saltvandsmuslinger. p. 22, fig. 9. 
Fossil:

1898. Nucula nitida Sowerby. Sacco. I moll. d. terr. terz. d. Piem. e d. Liguria 26, p. 47. pl. 11, fig. 5-6.

1907. Nucula nitida Sowerby. Ceruldi-Irelli. Fauna mal. mariana. 1, p. 125, pl. 11, fig. $30-32$.

Original diagnosis. Shell ovate sub-triangular, smooth, shining, white, with an olive-coloured epidermis; posterior slope somewhat rounded, anterior nearly straight, with a central elevation; (length 0.5, breadth 0.25, height 0.4) (G. B. SOWERBy 1833).

The following quotation may be added from Forbes \& Hanley:

"Triangular, either rayless, or with the rays linear and dark grey; epidermis highly lustrous; hinder extremity tapering, its dorsal area not sculptured; inner margin crenated".

Shell material.

$\begin{array}{lccc}\text { Location } & \text { Depth } & \text { Shells } & \begin{array}{c}\text { Numbers } \\ \text { used in text } \\ \text { below }\end{array} \\ \text { Toftlund } & 75-100 \mathrm{~m} . & 2 \text { v. } & \text { I \& I A } \\ & 100-105- & 1- & \text { II } \\ \text { Arnum (25 b) } & 105-110- & 1- & \text { III }\end{array}$

Description (interior only studied in the figured shell, the other shells being filled with sediment).

Prodissoconch smooth, concentric growth lines visible, no radial sculpture. Length and height measured on the figured shell (I) and the two other shells from Toftlund:

$$
\begin{array}{lccc} 
& \text { I (Toftlund } 75-100 \mathrm{~m} .) & \text { II }(100-105 \mathrm{~m} .) & \text { III }(105-110 \mathrm{~m} .) \\
\text { Length } & 0.8 & 0.9 & 0.8 \mathrm{~mm} . \\
\text { Height } & 0.6 & 0.7 & 0.6-
\end{array}
$$

Dissoconch (Mainly on the basis of the shells from Toftlund since the shells from Arnum were hardly developed beyond the prodissoconch stage).

Exterior with about 74 to 76 very fine radial striae and radial "ribs", shell surface glossy, some concentric growth lines occur. Measurements and data on hinge and radial ribs in the four shells from Toftlund gave the following results:

$\begin{array}{lccccc} & \text { I } & \text { I A } & \text { II } & \text { III } \\ \text { Length } & 4.3 & 3.85 & 3.1 & 3.7 \mathrm{~mm} \text {. } \\ \text { Height } & 3.7 & 3.05 & 2.4 & 3.1 & - \\ \text { Width } & 1.3 & 0.9 & 0.8 & 1.0 \quad- \\ \text { Radial ribs } & 74 & 74 & 76 & 76 & \\ \text { Anterior teeth } & 17 & 16 & 12 & 16 & \\ \text { Posterior teeth } & 8 & 7 & 5 & 6\end{array}$

Concerning the size variation of the recent $N$. nitida reference is made to fig. $4-5$ p. $41-42$.

The colour of the shells from Toftlund and Arnum is grayish white and the shape is rounded triangular. The lunula is limited by a slightly concave curved 
furrow extending from the umbo to the margin of the shell in front of the distal anterior tooth. The escutcheonal area is delimited similarly, but the furrow is more distinct. The ventral margin bears notches corresponding to the radial ribs.

Hinge. Nuculid hinge of common development as in the preceding species, for particulars see table above. The resiliophore extends from the umbo to the 4 th to 6 th anterior tooth.

The interior of the shell is nacreous. The adductor scars are located at the distal ends of the hinge. Anterior scar about $1 \frac{1}{2}$ times the size of the posterior scar. Above each of the adductor scars a pedal muscle scar is seen, and three punctiform scars are found behind the anterior adductor scar. The pallial line may be recognized, but it is rather indistinct.

Variability. The shell material is insufficient for an evaluation.

Remarks. The shells compare fairly well with the available recent shells of N. nitida regarding shape, radial elements, and hinge properties. It is, however, not advisable definitely to refer the fossil shells to $N$. nitida in view of the size and small number of the fossils.

Distribution of $N$. nitida.

Recent: West Coast of Europe from the North Sea area and south. Mediterranean.

Pliocene: Mediterranean Basin: Italy: Piacenziano, Astiano, upper Pliocene of Monte Mario.

Miocene: North Sea Basin: Denmark: Arnum formation.

\section{Undetermined Nuculid shells}

\begin{tabular}{|c|c|c|c|c|c|}
\hline Location & Depth & Shells & Location & Depth & Shells \\
\hline Glejbjerg & $52 \mathrm{~m}$. & $1 \mathrm{v}$. & Arnum (13) & $28-40 \mathrm{~m}$. & $14 \mathrm{v}$ \\
\hline Ribe & 124-125 - & 1 frg. & $(25 \mathrm{~b})$ & $101-104.3-$ & 2 frg. \\
\hline Gramby & $84.66-87.16-$ & $5 \mathrm{v}$. & & & \\
\hline
\end{tabular}

These shells and fragments could not be referred to any of the above species with certainty, they probably belong either to one of these or a related species.

The difficulties regarding determination arose from the fragmentary nature of the shells and from structural differences the significance of which could not be recognized.

\section{Genus Nuculoma Cossmann 1907}

Summary of essential features of present day definitions:

"Toutes les Nucules (à l'exception des Acila H. \& A. ADAMs) possédant une couche moyenne sans éléments individualisés seront rangées dans le genre Nuculoma Cossmann, 1907 (espèce-type: Nucula castor D'Orbigny)". (VAN De Poel 1955 , p. 5).

\section{Nuculoma hanseata (Kautsky)}

1925. Nucula hanseata Kautsky. D. Mioc. v. Hemmoor u. Basbeck-Osten. p. 22, pl. 2, fig. 10.

1940. Nucula hanseata Kautsky. Sorgenfrer. Mar. Nedre-Mioc. i Klintinghoved p. Als, p. 15 , pl. 4, fig. $2-3$. 
1942. Nucula (Nucula) hanseata KAutsky. IJSpeert, Monogr. d. mioz. tax. Bivalv. a. d. Peelgebiete. p. 19, pl. 1, fig. 2.

1942. Nucula (Nucula) hanseata Kautsky. Heering. D. olig. tax. Bivalv. a. d. Peelgebiete. p. 15 , pl. 3, fig. 8-10.

Summary of essential features of original description. Shell inequilateral, anterior part about three times as long as the posterior part. Umbonal angle about $115^{\circ}$. Lunula weakly delimited by a curved trend formed by angular bends in the concentric growth lines. Irregular concentric fold on shell surface but no radial sculpture. Hinge strongly developed. (Original description by KaUtSKY does not include any brief diagnosis).

Shell material.

\begin{tabular}{|c|c|c|c|c|c|c|c|}
\hline \multirow{2}{*}{$\begin{array}{l}\text { Location } \\
\text { Glejbjerg }\end{array}$} & \multicolumn{2}{|c|}{ Depth } & Shells & \multirow{6}{*}{$\begin{array}{l}\text { Location } \\
\text { Toftlund }\end{array}$} & \multicolumn{2}{|c|}{ Depth } & Shells \\
\hline & & m. & $3 \mathrm{v}$. & & $75-100$ & $\mathrm{~m}$. & $150 \mathrm{v}$. \\
\hline & 32 & - & $8-$ & & $100-105$ & - & $28-$ \\
\hline & 38 & - & 1 - & & $105-110$ & - & $350-$ \\
\hline & 42 & - & 2 - & & $110-115$ & - & $158-$ \\
\hline & 53 & - & $21-$ & & 115 & - & $51-$ \\
\hline & 53.5 & - & $13-$ & \multirow[t]{2}{*}{ Arnum (13) } & $53-83$ & - & 8 - \\
\hline & 53.75 & - & $8-$ & & $83-94$ & - & $3-$ \\
\hline & 54 & - & (frg.) & \multirow[t]{2}{*}{ Arnum (25b) } & $67.2-67.9$ & - & 1 . \\
\hline & 55 & - & 1 - & & $95.0-95.3$ & - & $25-$ \\
\hline Bramminge & $70-80$ & \multicolumn{2}{|c|}{$\begin{array}{l}\text { - frg. correspon- } \\
\text { ding to about } \\
70 \text { shells }\end{array}$} & & $95.0-95.3$ & - & $\begin{array}{r}36- \\
\text { (juv. \& } \\
\text { frg.) }\end{array}$ \\
\hline \multirow[t]{3}{*}{ Gramby } & $82.66-83.76$ & - & $11 \mathrm{v}$. & & $101-104.3$ & - & 2 (frg.) \\
\hline & $84.66-87.16$ & - & $16-$ & & $104.3-107.5$ & - & $8 \mathrm{v}$. \\
\hline & $90.42-92.72$ & - & (frg.) & & 107.5 & - & 4 - \\
\hline
\end{tabular}

Most of the shell material is very much broken, only a few shells being well enough preserved to show all essential shell features.

\section{Description.}

Prodissoconch smooth, often lighter coloured than the adult shell. The following table shows the length and height of the prodissoconch of 12 shells from Gramby and Toftlund:

Gramby $82.66-83.76 \mathrm{~m}$.

\begin{tabular}{|c|c|c|}
\hline & 740.700 .74 & $0.70 \mathrm{mn}$ \\
\hline Hei & 0.510 .55 & $\begin{array}{llllll}0.55 & 0.55 & 0.51 & 0.55 & 0.51 & 0.55\end{array}$ \\
\hline
\end{tabular}

Dissoconch. Exterior mainly smooth. concentric sculpture may occur at intervals in an irregular manner. Pores or dots indicating the bottoms of the tooth pits may occur along the lines delimiting the lunula and escutcheonal areas as previously described by the writer (SORGENFREI 1937).

Hinge. The number of teeth varies with the size of the shell as in the Nuculid species described above. The pre-umbonal teeth are relatively strong, geniculate and anteriorly concave. The proximal pre-umbonal teeth are thin and leaf-like while the more distal teeth are stronger and compressed-conical in shape. Data on number of teeth and the resiliophore are listed in the table below.

The interior of the shell is nacreous, there is no indication of crenation on the ventral margin. Anterior adductor scar larger than posterior scar. Pedal muscle scars much less distinct than in the shells previously described by the 
writer from Klintinghoved (loc.cit. 1940 pl. 4, fig. 3). Only the scar no. 2 may be recognized in the best preserved shells. The muscle scars at the distal ends of the hinge, which were recognized on the Miocene shells from Holland by IJSPEERT and interpreted as pedal muscle scars, are clearly seen on all shells. (IJSPEERT 1942, p. 19, fig. 2).

Variability. The number of well preserved shells is too small for statistical treatment, but a few valves were investigated and measured. The following table includes the data obtained:

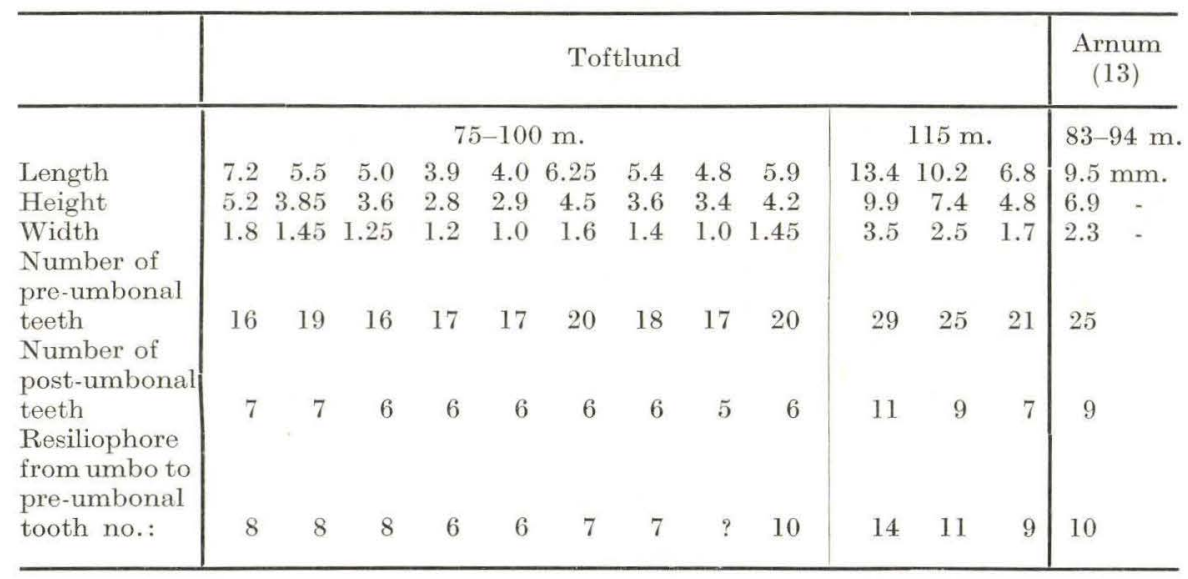

Remarks concerning references etc. The species was defined on a single and partly defect shell by KAUTSKY, who accordingly could not have any idea of the range of variation of shells belonging to the species. The shell material from S. Jutland at the writer's disposal may also be insufficient for a final determination of the validity of the species. However, it should be stated that this type of Nuculid shell may well be within the variation range of shells which by most authors would be referred to $N$. laevigata Sowerby. The inaccessibility of more shell material from the type locality renders a revision of the relationship between $N$. hanseata and $N$. laevigata impossible at present.

Distribution.

Miocene: North Sea Basin: Denmark: Klintinghoved clay, Arnum formation, Germany: Hemmoor stage, Holland (m.).

\section{Nuculoma cf. Haesendonckii (Nyst \& Westendorp)}

1839. Nucula Haesendonckii Nyst \& Westendorp. Nouv. rech. s. les coq. foss. d. la prov. d'Anv., p. 406. pl. 2, fig. 18.

1843. Nucula Haesendonckii Nyst \& Westendorp. Nyst. Deser. Coq. et Polyp. foss. d. Terr. Tert. d. 1. Belg., p. 236, pl. 18, fig. 5 .

1892. Nucula Haesendonckii Nyst \& Westendorp. Lehmann: Die Lamellibranchiaten d. Mioc. v. Dingden. Bd. I, p. 218.

1925. Nucula Haesendoncki Nyst \& Westendorp. Kautsky. D. Mioc. v. Hemmoor u. Basbeck-Osten. p. 21.

1942. Nucula (Nucula) Haesendoncki Nyst \& Westendorp. IJspeert. Monogr. d. mioz. tax. Bivalv. a. d. Peelgebiete. p. 17, pl. 1, fig. 1.

1945. Nucula haesendoncki Nyst \& Westendorp. Glibert. Faune mal. du Mioc. de la Belgique. 1, p. 18, pl. 1, fig. 4. 
Original diagnosis. N. Testa oblonga, globoso-ventricosa, sulcis latis exarata; latere antico brevi; lunula cordata profunda; cardine recurvo; dentibus validis, numerosis, elongatis, erectis, acutis. (NYST \& WESTENDORP 1839).

Shell material from S. Jutland comparable with $N$. Haesendonckii:

Ribe 113-114 m. several fragments, including fragment of hinge.

Remarks. The material is too fragmentary to warrant a definite reference to $N$. Haesendoncki. The nacreous shell and the very pronounced concentric sculpture which is seen on the shell fragments leaves, however, but little doubt with the writer concerning the correct determination of the material.

\title{
Distribution of N. Haesendonckii.
}

Miocene: North Sea Basin: Belgium: Boldérien, horizon of Houthaelen, Anversien. Germany: Hemmoor stage, Reinbek-Dingden stage. Holland (m.). Denmark: Arnum formation.

\author{
Genus Leda Schumacher 1817 \\ Subgenus Jupiteria BeLLARdi 1875
}

\section{Leda (Jupiteria) pygmaea (Münster)}

Recent:

Plate 2, fig. 8a-b.

1853. Leda pygmaea Münster. Forbes \& Hanley. British Moll. Vol. 2, p. 230, pl. 47, fig. 10, pl. P, fig. 3.

1863. Leda pygmaea Münster. Jeffreys. British Conch. Vol. 2, p. 154, pl. 29, fig. 5.

1867. Leda tenuis Philippi. Weinkauff, Conch. d. Mittelmeeres, 1, p. 210.

Fossil:

1835. Nucula pygmaea Münster. Bemerkungen etc. N. Jahrb. f. Min. etc. p. 448.

1837. Nucula pygmaea Münster. Goldfuss. Petrefacta Germaniae. 2, p. 157, pl. 125, fig. 17.

1861. Leda pygmaea Münster. Wood. Monogr. Crag Moll. Vol. 2, p. 95, pl. 10, fig. 11.

1907. Portlandia pygmaea Münster sp. Ravn. Molluskf. Jyll. Tert. p. 260, pl. 1, fig. 9-10.

1913. Portlandia pygmaea v. Münster sp. Harder. De olig. Lag ete. v. Aarhus St.p. 52, pl. 3, fig. 15 .

1914. Leda (Portlandia) pygmaea, Mü. sp. Grrpp. Über eine untermioz. Molluskenf. v. Itzehoe. p. 6.

1916. Portlandia pygmaea Münster sp. NorregandD. M.-mioc. Blokke fra Esbjerg. p. 12.

1925. Leda (Jupiteria) pygmaea Münst. Kautsky. D. Mioc. v. Hemmoor u. BasbeckOsten. p. 24.

1940. Leda (Jupiteria) pygmaea Münst. Sorgenfret. Mar. Nedre-Mioc. i Klintinghoved p. Als. p. 17.

1942. Leda (Jupiteria) pygmaea (Münster). IJspeert. Monogr. d. mioz. tax. Bivalv. a. d. Peelgebiete. p. 31, pl. 1, fig. 7 .

1942. Leda (Jupiteria) pygmaea (von Múnster). Heering. D. olig. tax. Bivalv. a. d. Peelgebiete. p. 17 , pl. 3 , fig. $6-7$.

1945. Leda (Jupiteria) pygmaea Mưnster sp. Gltbert. Faune mal. du Mioc. de la Belgique. 1, p. 31, pl. 1, fig. 6 .

1956. Leda (Jupiteria) pygmaea (Münster). Banke Rasmussen. Upper Mioc. South Jutland. p. 29, pl. 1, fig. 2.

Original diagnosis. Nucula testa obovata convexa laevi, umbonibus submedianis, lunula elliptica subconvexa, angulo cardinali obtuso. (in GoLdFuss 1837, no diagnosis published by voN Mürster 1835). 
Shell material.

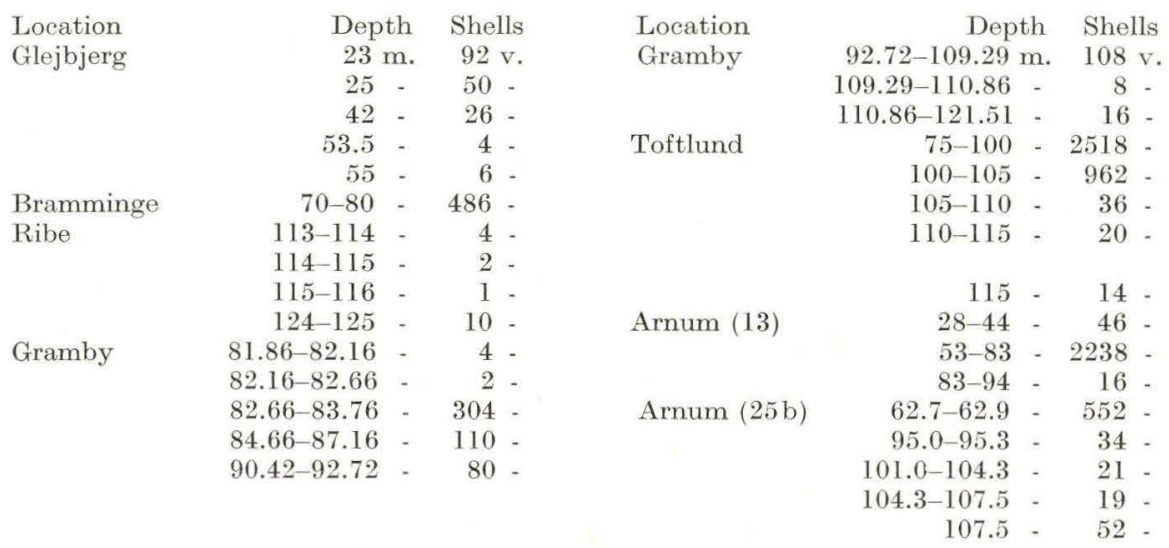

Description. (Mainly on the basis of the shells from Toftlund $75-100 \mathrm{~m}$.).

Prodissoconch, smooth, very small, hardly distinguishable from the adult shell, circular outline. The few specimens in which the prodissoconch could be distinguished suggest a diameter of about $0.23-0.27 \mathrm{~mm}$.

Dissoconch. Exterior generally very smooth, only fine concentric growth lines are seen. The growth lines may occasionally develop into faintly elevated concentric ribs. The outline is rounded triangular and the shell is rather globose. Posterior dorsal margin slightly concave. The posterior end forms a very blunt rostrum with an indistinct rounded keel.

Hinge. Number of teeth practically the same on the anterior and posterior parts of the hinge. The number of teeth increases with growth. The smallest of 40 shells from Toftlund $(75-100 \mathrm{~m}$.) whose hinge teeth were counted was 2.7 $\mathrm{mm}$. long, and had 9 teeth on each part of the hinge. The largest shells were about 4.0 to $4.5 \mathrm{~mm}$. long and had 13 to 15 teeth on each part of the hinge. Deviation from the rule of equal tooth number in the two hinge parts is generally an excess of one anterior tooth, only one of the 40 shells examined having an extra posterior tooth. The resiliophore is very small and triangular.

The interior is glossy. Adductor scars at the distal ends of the hinge; pallial sinus small and rather shallow.

Variability. Length $L$ and height $H$ were measured in 178 shells, the $\frac{L}{H}$ ratios were calculated, and the number of shells was plotted against $\frac{L}{H}$ as shown on the graph fig. 6 . Mean values $(\bar{x})$ of $\frac{L}{H}$ and corresponding mean errors were calculated for these groups: the entire shell material $(A+B)$, shells less than 4 $\mathrm{mm}$. long $(A)$, and shells more than $4 \mathrm{~mm}$. long $(B)$. The following results were obtained:

$$
\begin{aligned}
& L \quad \text { number of shells } \quad \frac{L}{H} \text { mean values } \\
& A+B \quad 2.7-5.1 \mathrm{~mm} . \quad 178 \quad 1.406 \pm 0.0106=\left\{\begin{array}{l}
1.411 \\
1.395
\end{array}\right. \\
& \text { A } \quad 2.7-4.0-115 \quad 1.400 \pm 0.0133=\left\{\begin{array}{l}
1.413 \\
1.387
\end{array}\right. \\
& B \quad 4.0-5.1-63 \quad 1.418 \pm 0.0181=\left\{\begin{array}{l}
1.436 \\
1.400
\end{array}\right.
\end{aligned}
$$


The slight increase in mean value of $\frac{L}{H}$ which is indicated in group $B$ compared with group $A$ suggests that the shell elongates during growth. More measurements must, however, be made before this suggestion can be proved since the upper limit of $\bar{x}$ in group $A$ overlaps the lower limit of $\bar{x}$ in group $B$.
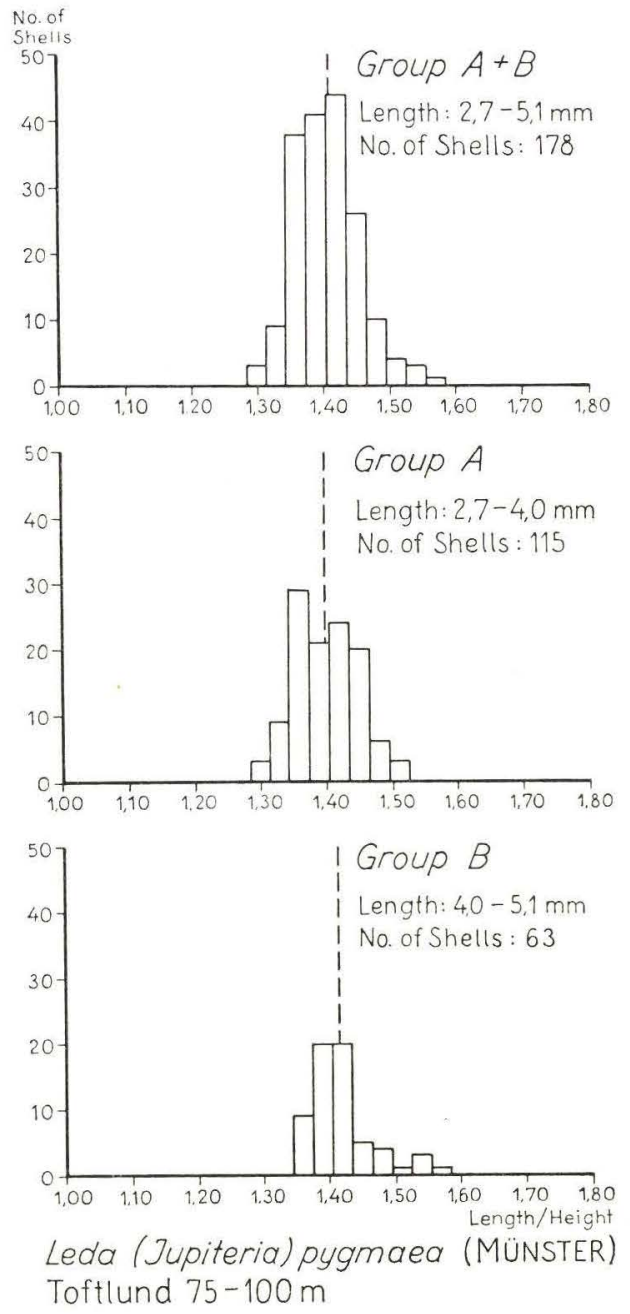

Fig. 6.

Length $L$ and width $W$ were measured on 30 specimens from Toftlund 75$100 \mathrm{~m}$., of which 20 were paired valves. The $\frac{L}{W}$ ratios were calculated for 30 closed paires of valves the ratios for the single valves being divided by 2 . The $\frac{L}{W}$ ratio appears to be rather variable as shown by the following figures:

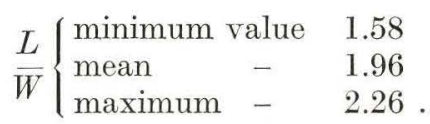


Remarks. Semper (1861) questioned the identity of the fossil and recent shells, and in 1867 WeInKaUfF claimed the recent and Pliocene shells to be different from the other fossil ones with respect to width of the shell and number and size of the hinge teeth. Consequently he referred the Pliocene and recent shells to L. tenuis PHILIPPI (including the specimens described by ForBes \& HANLEY and JeFFreYs). The present survey shows that the number of teeth changes with growth in L. pygmaea, and it might well be that the shape of the shell also alters with growth as stated above. The writer would therefore suggest hat attempts at splitting the shells concerned into different species be discontinued until careful investigation af the variability of each particular shell assemblage has been demonstrated.

Distribution.

Recent: Atlantic coast of Britain, Mediterranean.

Pliocene: England: Coralline Crag.

Miocene: North Sea Basin: Belgium: horizon of Houthaelen, Anversien; Holland (m.); NW Germany: Vierlande, Hemmoor, Reinbek and Glimmerton stages; Denmark: Klintinghoved clay, and Arnum and Gram formations.

Oligocene: North Sea Basin: Holland (u.); Germany (l. m. u.);

Denmark (u.).

Subgenus Ledina SaCco 1898.

Original diagnosis. Gruppo di forme affini ai Lembulus da cui distinguonsi speciamente per mancanza di strie oblique, per costule concentriche piu o meno spiccate e rostro non bicarinato. (Sacco 1898, p. 53) Type species: L. fragilis (Chemnitz).

Thiele (1935) regards Ledina as a synonym of Jupiteria Bellardi. It is, however, correctly maintained by IJSPEERT (1942, p. 31) that Ledina differs from Jupiteria in its pronounced concentric sculpture.

\section{Leda (Ledina) Westendorpii (Nyst \& Westendorp) \\ Plate 3, fig. 9 a-c.}

1839. Trigonocoelia Westendorpii Nyst \& Westendorp Nouv. rech. sur les coqu. foss. d. 1. prov. d'Anv. p. 405, pl. 2, fig. 17.

1907. Leda Westendorpi Nyst sp. Ravn. Molluskf. Jyll. Tert. p. 259, pl. 1, fig. 12.

1914. Leda Westendorpii Nyst sp. GRIPP. Über eine untermioz. Moll. fauna v. Itzehoe. p. 6.

1916. Leda Westendorpi Nyst sp. NørRegaArd. Mioc. Blokke fra Esbjerg. p. 11.

1925. Leda (Ledina) Westendorpi Nyst. Kautsky. D. Mioc. v. Hemmoor u. BasbeckOsten. p. 24, pl. 2, fig. 15-16.

1942. Leda (Ledina) Westendorpi (Nyst.). IJspeert. Monogr. d. mioz. tax. Bivalv. a. d. Peelgebiete. p. 28, pl. 1, fig. 6.

1942. Leda (Ledina) Westendorpi (Nyst.). Heering. D. olig. tax. Bivalv. a. d. Peelgebiete. p. 19, pl. 2, fig. 12-14.

1945. Leda Westendorpi Nyst sp. Glibert Faune mal. du Mioc. de la Belgique. 1, p. 26, pl. 1, fig. 5 .

Original diagnosis. Testa transverse ovata, striataque; latere postico productiore, attenuato, sub apice sinuato, lunula lanceolata angulato. (Nyst \& WESTENDORP 1839). 
Shell material.

\begin{tabular}{|c|c|c|c|c|c|c|c|}
\hline \multirow{3}{*}{$\begin{array}{l}\text { Location } \\
\text { Glejbjerg }\end{array}$} & \multicolumn{2}{|c|}{ Depth } & Shells & Location & \multicolumn{2}{|c|}{ Depth } & Shells \\
\hline & 23 & & 1 (frg.) & Toftlund & $75-100^{\circ}$ & $\mathrm{m}$. & $406 \mathrm{v}$. \\
\hline & 25 & - & $1 \mathrm{v}$ & & $100-105$ & - & $196-$ \\
\hline & 32 & - & $6-$ & & $105-110$ & - & $450-$ \\
\hline & 38 & - & 1 (frg.) & & $110-115$ & - & $40-$ \\
\hline & 53.5 & - & $(2) \quad-*)$ & & 115 & - & $42-$ \\
\hline & 53.75 & - & $1-$ & Arnum (13) & $53-83$ & - & 14 - \\
\hline & 54 & - & 1 & & $83-94$ & - & 1 . \\
\hline & 55 & - & 1 & Arnum (25b) & $62.7-62.9$ & - & 1 (frg.) \\
\hline Bramminge & $70-80$ & - & $70 \mathrm{v}$. & & $95.0-95.3$ & - & $303 \mathrm{v}$. \\
\hline Ribe & $113-114$ & - & 1 (frg.) & & $101.0-104.3$ & - & 4 - \\
\hline & $117-118$ & - & $1-$ & & $104.3-107.5$ & - & $14-$ \\
\hline & $119-120$ & - & 1 & & 107.5 & - & 4 (frg.) \\
\hline & $123-124$ & - & 1 & & & & \\
\hline & $124-125$ & - & 1 & & & & \\
\hline Gramby & $81.86-82.16$ & - & 1 & & & & \\
\hline & $82.66-83.76$ & - & $22 \mathrm{v}$. & & & & \\
\hline & $92.72-109.29$ & - & I (frg.) & & & & \\
\hline & $109.29-110.86$ & - & $2 \mathrm{v}$. & & & & \\
\hline
\end{tabular}

Description. (Mainly on the basis of the shells from Toftlund $75-100 \mathrm{~m}$.).

Prodissoconch small, glossy, with minute growth lines. Length and height of 10 well preserved prodissoconchs on shells from Toftlund $(75-100 \mathrm{~m}$.) were as follows:

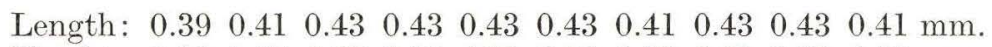

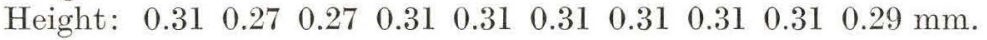

Dissoconch. Exterior. The outline of the shell and the sculpture are as shown on the figured specimen. The concentric sculpture ist most conspicuous at the posterior end of the shell. The relief and number of ribs vary in shells of the same size. The ribs on densely ribbed shells are often lower than those on shells with wider interspaces between the ribs. Eight nearly smooth shells were found in the material from Toftlund $(75-100 \mathrm{~m}$.); they undoubtedly show one extreme of the range of variation of the species.

The concentric ribs cease at the weak fold running from the junction of the dorsal margin and the anterior end of the shell to the umbo. This fold delimits the lunule which is the area of the shell above the anterior row of the hinge teeth. The sculpture of this area consists of growth lines.

The posterior end of the shell is shaped as an acute beak on which the sculpture is developed analogously to the anterior end exept for the deviations following from the difference in shape of these two parts of the valve. A pronounced keel on which the concentric ribs are very distinct and elevated extends from the umbo to the posterior end; the ribs may occasionally be developed into lamellae. The posterior keel delimits the escutcheonal area. The dorsal margin forms a well defined angle at the posterior end of the hinge. It corresponds to a subordinate keel above the keel delimiting the escutcheonal area. The sculpture between the upper keel and the dorsal margin is confined to growth lines. The area concerned may thus in all respects correspond to the lunule in front of the umbo.

A shallow fold is found below the posterior keel as shown on fig. $9 \mathrm{c}$, plate 3 .

Hinge. The numbers of teeth in front of and behind the umbo are practically the same (number of shells examined: 39). The number of teeth increases with growth as in the other Taxodonta discussed. The largest shells from Toftlund $(75-100 \mathrm{~m}$.) are about $9 \mathrm{~mm}$. long and have about 20 teeth in front of and

*) No umbonal parts. 

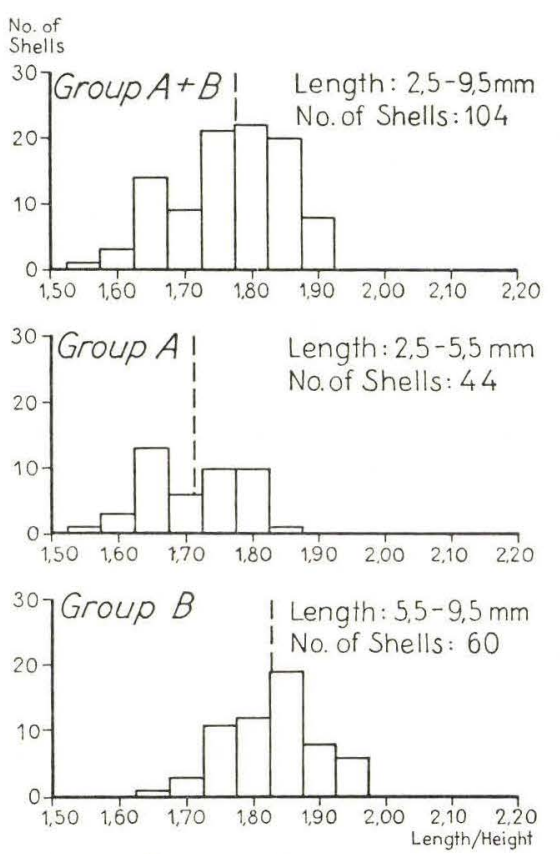

Leda (Ledina) Westendorpii

NYST \& WESTENDORP

Toftlund 75-100m

Fig. 7. behind the umbo, and the smallest shells, about $4 \mathrm{~mm}$. long, have 14-15 teeth. There may occasionally be an excess of 1-2 teeth in one of the hinge parts, generally in the anterior part.

The interior of the shell is smooth and glossy. Anterior adductor scar relatively large, situated at the anterior end of the hinge. Posterior adductor scar about $1 / 3$ of the size of the anterior is below the distal end of the hinge. Two additional muscle scars, probably pedal muscle scars, are seen on the under side of the hinge plate, one immediately in front of the posterior adductor scar and one behind the anterior adductor scar. Two other scars shown below the umbo on plate 3 , fig. 9 a, are probably also pedal muscle scars. The pallial line and pallial sinus are shown on the figured specimen.

Variability. Length $L$ and height $H$ were measured on 104 shells and the $\frac{L}{H}$ ratios were calculated. The graph fig. 7 shows the number of shells plotted against $\frac{L}{H}$ ratio. Mean values $\bar{x}$ of $\frac{L}{H}$

were calculated for all 104 shells measured. The shells were divided into two groups, $A$ and $B$, with lengths less than and greater than $5.5 \mathrm{~mm}$. respectively, and mean values were calculated for these two groups as follows:

\begin{tabular}{|c|c|c|c|c|}
\hline & No & $L$ & $\frac{L}{H}$ mean values & \\
\hline Total shell material $(A+B)$ & 104 & $2.5-9.5 \mathrm{~mm}$. & $1.7846 \pm 0.0262=$ & $\left\{\begin{array}{l}1.811 \\
1.758\end{array}\right.$ \\
\hline$A$ & 44 & $2.5-5.5 \quad-$ & $1.7125 \pm 0.0328=$ & $\left\{\begin{array}{l}1.745 \\
1.680\end{array}\right.$ \\
\hline$B$ & 60 & $5.5-9.5 \quad-$ & $1.8275 \pm 0.0313=$ & $\left\{\begin{array}{l}1.859 \\
1.796\end{array}\right.$ \\
\hline
\end{tabular}

The figures illustrate that the $\frac{L}{H}$ ratio increases with growth. Adult shells are in other words relatively longer than juvenile shells.

Thirty shells from Toftlund $75-100 \mathrm{~m}$, including 3 paired shells, were measured for length $L$ and width $W$ and the $\frac{L}{W}$ ratios for paired valves were calculated (ratios for single valves were divided by 2 ). The following figures illustrate the variation of the dimensions concerned. 


$$
\bar{L}\left\{\begin{array}{lll}
\text { minimum value } & 2.33 \\
\text { mean } & - & 2.62 \\
\text { maximum } & - & 2.85
\end{array}\right.
$$

Width appears thus to vary but little in relation to the length of shell in L. Westendorpii.

Remarks. This species may have some affinity with L.fragilis Chemnitz which, however, differs regarding the fold which runs from the umbo to the antero-ventral region on the shell surface (Cossmand \& Peyrot 1912, p. 227, Ceruldi-Ireldi 1907, p. 129). There may be other differences which are not to be clearly determined except by direct comparison of shell material, which was impossible during the present investigation since no specimens of $L$. fragilis were available.

Distribution.

Miocene: North Sea Basin: Belgium: horizon of Houthaelen and Anversien; Holland (m.); NW Germany: Vierlande, Hemmoor and Reinbek stages (GотTsche 1878 p. 186); Denmark: Arnum formation.

Oligocene: North Sea Basin: Holland (u.).

Subgenus Lembulus LEACH 1826.

\section{Leda (Lembulus) emarginata (Lamarck)}

Plate 2, fig. 10 a-e.

1819. Nucula emarginata LAMARCK. Hist. nat. d. animaux sans vert. 6, p. 60.

1870. Leda pella (L.) Hörnes. Die foss. Moll. d. Tert. B.v. Wien. 2, p. 305, pl. 38, fig. 7.

1898. Lembulus undatus (Defr.) SAcco. I moll. d. terr. terz. d. Piem. e d. Liguria. 26, p. 53, pl. 11, fig. 37-40.

1912. Leda (Lembulus) emarginata Lk. Cossmann \& Peyrot Conch. Néogén. d. l'Aquit. p. 224, pl. 5, fig. 52-60.

1925. Leda (Lembulus) emarginata Laмk. KaUtsky. D. Mioc. v. Hemmoor u. BasbeckOsten. p. 23, pl. 2 fig. 14

1942. Leda (Lembulus) emarginata (LAMk.) IJspeert. Monogr. d. mioz. tax. Bivalv. a d. Peelgebiete. p. 25, pl. 1, fig. 5.

1945. Leda (Lembulus) emarginata Lamarck sp. Glibert. Faune mal. du Mioc. de la Belgique. 1, p. 29, pl. 1, fig. 7 .

Original diagnosis. Testa ovata; striis transversis, obliquis; latere antico productiore, attenuato, angulato, emarginato. (LAMARCK 1819).

Shell material.

$\begin{array}{lrrlrr}\text { Location } & \text { Depth } & \text { Shells } & \text { Location } & \text { Depth } & \text { Shells } \\ \text { Glejbjerg } & 32 \mathrm{~m} . & 10 \mathrm{v} . & \text { Toftlund } & 105-110 \mathrm{~m} . & 22 \mathrm{v} \text {. } \\ \text { Gramby } & 82.66-83.76- & 2- & & 110-115- & 6- \\ & 84.66-87.16- & 9- & & 115- & 4- \\ \text { Gramby } & 90.42-92.72- & 2- & \text { Arnum }(13) & 53-83- & 8- \\ \text { Toftlund } & 110.86-121.51- & 1 \text { (frg.) } & \text { Arnum }(25 \mathrm{~b}) & 62.7-62.9- & 4-\end{array}$

Description (Mainly on the basis of the shells from Toftlund $75-100 \mathrm{~m}$.).

Prodissoconch relatively large with growth lines; anterior end rounded, posterior end drawn out into a blunt beak. Length and height were measured on 9 shells with well preserved prodissoconchs (Toftlund $75-100 \mathrm{~m}$.): 


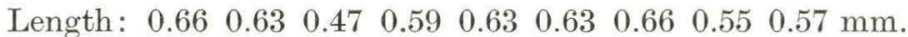
$\begin{array}{lllllllllll}\text { Height: } & 0.41 & 0.39 & 0.27 & 0.39 & 0.39 & 0.37 & 0.33 & 0.31 & 0.35 & -\end{array}$

It appears from the above figures that the dimensions of the prodissoconch are rather variabel.

Dissoconch. Exterior. The figured specimens illustrate the general nature of the shell outline and the remarkably variable sculpture in this species. See also the paragraph below on variation.

The sculpture includes two elements: 1.) common concentric growth lines and 2.) oblique lines or ribs which cut the concentric lines at rather acute angles and run from the anterior end of the shell towards the posterior end converging here against the ventral margin.

The number and the relief of the oblique ribs varies considerably. Shells with very pronounced ribs, and also nearly smooth shells may be found (pl. 2, fig. $10 \mathrm{a} \& 10 \mathrm{~b}$ ). The posterior end is characterized by its rostrate shape, and the concave bend in the margin opposite the pallial sinus which gives rise to the development of two keels on the shell surface during growth. The lower of these keels is relatively sharp, while the upper keel bears knots or lamellae which are the terminations of oblique ribs and interspaced secondary ribs. The secondary ribs are only found on the concave area between the two keels.

The escutcheonal area is limited by the dorsal margin and a weak fairly smooth keel of low relief extending from the umbo to the margin above the posterior tooth. The lunula in front of the umbo is analogous but less distinct.

Hinge. The proximal hinge teeth are more or less geniculate, the concavities being directed away from the umbo. The teeth immediately in front of the umbo are approximately symmetrical, while the oldest teeth behind the umbo have a longer lower limb which extends under the succeeding tooth. The number of teeth varies, an excess of 1 to 3 teeth behind the umbo compared with the number of teeth in front of it being general. The number of well preserved shells is insufficient for a safe statistical evaluation of the relationship between number of teeth and size. The largest shells did not always have the greatest number of teeth, however, the few shells examined suggest that the number of teeth increases with growth as in the preceeding taxodont species.

The interior of the shell is smooth and glossy. Adductor muscle scars and pallial line could only be studied on a few shells, one of which is figured on plate 2, fig. $10 \mathrm{~d}$.

Variability. Data on shell material from Toftlund $(75-100 \mathrm{~m}$.) are shown in the following table:

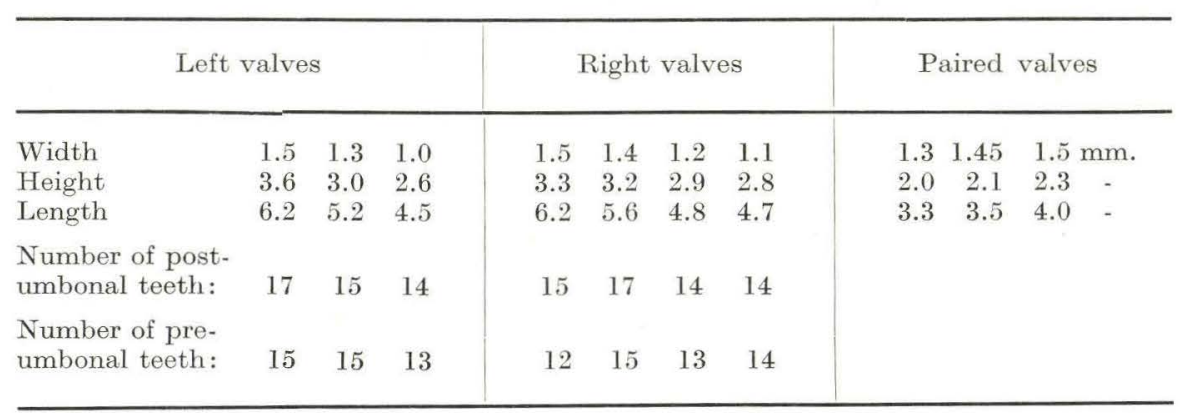


The present species appears to have very variable shell features, among which the following should be emphasized: prodissoconch, oblique sculpture, and number of hinge teeth. It should be added simultaneously that in spite of the great differences between extreme specimens, there are no sharp distinctions whatsoever which would warrant any further systematic subdivision of the shell material. The concept of a single, but very variable species has thus to be maintained.

Remarks. The above discription of the sculptural elements of the shell agrees generally with that given by Cossmann \& Peyrot, but it differs from the description by IJSPEERT regarding the interpretation of the sculpture on the concave area of the rostrum. The writer's opinion is that the oblique sculpture really continues onto the rostrum and that the secondary ribs terminate at the lower keel of the rostrum. The concentric sculpture is generally most conspicuous just below the lower keel of the rostrum. This may have given rise to the belief that the sculpture of the rostrum is a concentric sculpture which may occasionally extend somewhat beyond the lower keel as shown on IJSPEERT's fig. $3-4$.

Cossmann \& Peyrot have attempted to define differences between the recent. L. pella and the present species as follows:

\section{L. emarginata}

1. Concave part of the rostrum deeper than in $L$. pella.

2. Upper keel on rostrum more elevated.

3. Coarse wave-formed concentric ribs occur occasionally near the umbo.

\section{L. pella}

1. The shell is relatively higher than in $L$. emarginata.

2. The umbo is situated more medial than in L. emarginata.

3. Number of hinge teeth about the same in front of and behind the umbo.

4. Escutcheonal area limited by two faint lines which are absent in L. emarginata.

Items 1-2 in L. emarginata are very difficult to verify since the features dealt with seem to be very variable, and in case of $L$. pella the characters mentioned under 2-4 may also be found in L. emarginata as has been shown above in the description of the shell material from South Jutland.

Therefore more research, particularly concerning the variation of the shell, has to be carried out before the relationships and differences of the two species are clearly understood.

Distribution.

Miocene: Aquitanian Basin: Aquitanien, Burdigalien, Helvétien. North Sea Basin: Belgium: Boldérien, horizon of Houthaelen; Holland (m.); NW Germany: Hemmoor stage. Denmark: Arnum formation.

Mediterranean Basin: Italy: Elveziano (Colli torinesi).

Vienna Basin: Deposits at Grund.

\section{Genus Yoldia Müller 1842}

\section{Yoldia gllaberrima (Münster)}

Plate 4, fig. 11 a-b.

1835. Nucula glaberrima von Münster. Bemerkungen ete. N. Jahrb. f. Min. etc. p. 448. 1837. Nucula glaberrima Münster. Goldfuss. Petrefacta Germaniae. 2, p. 157, pl. 125, fig. 14.

1907. Yoldia glaberrima Münster sp. Ravn. Molluskf. Jyll. Tert. p. 261, pl. 1, fig. 13. 
1912. Yoldia Dumasi Cossmann \& Peyrot. Conch. Néogén. d. l'Aquit. p. 239, pl. 6, fig. $5-8$.

1913. Yoldia glaberrima v. Münster sp. Harder. De olig. Lag etc. v. Aarhus St. p. 52, pl. 3, fig. 16 .

1914. Yoldia glaberrima Mü. sp. Gripp. Über eine untermioz. Molluskenf. v. Itzehoe. p. 6.

1916. Yoldia glaberrima Münster sp. Nørreganrd. M.-mioc. Blokke fra Esbjerg. p. 12.

1925. Yoldia glaberrima Münst. KAUtsky. D. Mioc. v. Hemmoor u. Basbeck-Osten. p. 24.

1940. Yoldia glaberrima Münst. Sorgenfrei. Mar. Nedre-Mioc. i Klintinghoved p. Als. p.18, pl. 4 , fig. 4 .

1942. Yoldia glaberrima v. Münster. Görges. D. Oberolig.-fauna von Rumeln a. Niederrhein. p. 162.

1942. Yoldia glaberrima (Münster). Ijspeert. Monogr. d. mioz. tax. Bivalv. a. d. Peelgebiete. p. 33 , pl.1, fig. 8 .

1942. Yoldia glaberrima (von Múnster). Heering. D. olig. tax. Bivalv. a. d. Peelgebiete. p. 21, pl. 3, fig. 1-3.

1945. Yoldia (Yoldia) glaberrima Münster sp. Gltbert. Faune mal. du Mioc. de la Belgique. 1, p. 33, pl. 1, fig. 9.

1956. Yoldia (Yoldia) glaberrima (Münster). Banke Rasmussen. Upper Miocene South Jutland. p. 30.

Original diagnosis. Nucula testa ovata convexa glaberrima pellucida, umbonibus retusis submedianis, angulo cardinali valde obtuso, dentibus exiguis. (in Goldfuss 1837, no diagnosis published by vox Münster 1835).

Shell material.

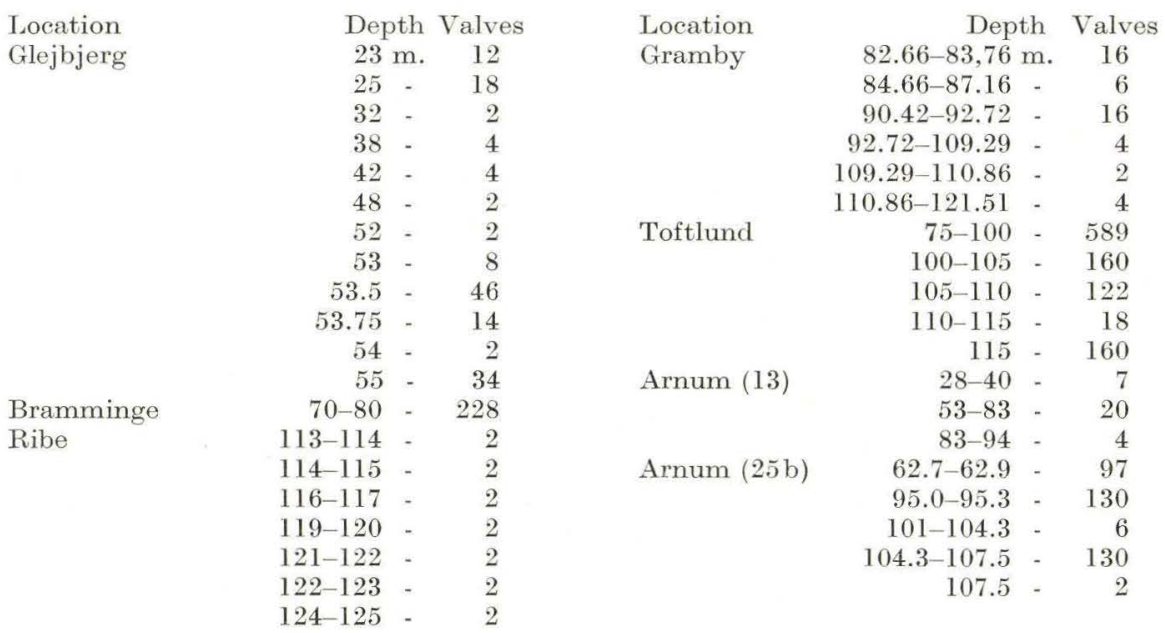

Description (Mainly on the basis of the shells from Toftlund $75-100 \mathrm{~m}$.).

Prodissoconch oblong, glossy, small. Length and height were determined on 10 shells from Toftlund $(75-100 \mathrm{~m}$.):

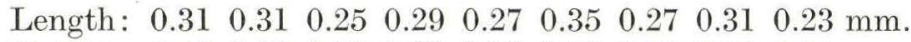
Height: $\begin{array}{lllllllll}0.22 & 0.20 & 0.20 & 0.20 & 0.20 & 0.22 & 0.18 & 0.20 & 0.18\end{array}$

Dissoconch. Exterior. The figured specimen shows the typical elliptical outline of the shell. The shell is spindle shaped as seen from above. The shell 
surface is generally smooth and glossy, the only indication of sculpture being very fine concentric striae. However, in some shells there is a fairly distinct concentric sculpture of fine concentric ribs which particularly may be well developed on the juvenile part of the shell around the umbo. There are transitional types between the smooth and the sculptured forms. The sculptured forms should therefore only be considered as extremes within the variation range of the species. Ribbed shells have been recognized particularly in the material from Arnum (25 b) 95.0-95.3 m.*). Two minute ribs extending from the umbo to the posterior and anterior ends of the hinge demarcate the escutcheonal area and the area of the lunula.

Hinge. Number of teeth approximately the same in front of and behind the umbo. About $50 \%$ of the shells display an excess of one tooth on either of the hinge parts (38 specimens investigated). The number of teeth increases with shell length (i.e. with growth), the minimum number of teeth in the specimens examined was 11 (length of shells about $5 \mathrm{~mm}$ ) and the maximum number 18 (length of shells about $8-9 \mathrm{~mm}$.).

The interior of the shell, is smooth and glossy. Adductor scars and pallial line very difficult to recognize (shown on the figured specimen). Anterior adductor scar about $1 \frac{1}{2}$ times the size of the posterior scar. A shallow furrow running from the umbonal region to the antero-ventral margin may be seen in some shells as shown on fig. 11 a, plate 4 .

Variability. Length $(L)$ and height $(H)$ were measured on 126 shells from Toftlund $\left(75-100 \mathrm{~m}\right.$.) and mean values $(\bar{x})$ of the $\frac{L}{H}$ ratios were calculated for the entire shell material and for shells with lengths greater and less than $6 \mathrm{~mm}$. as listed in the following table:

$\begin{array}{lccl}\text { Groups } & L & \begin{array}{c}\text { Number of } \\ \text { shells }\end{array} & \frac{L}{H} \text {-mean values. } \\ (A+B) & 3-10 \mathrm{~mm} . & 126 & 1.8911 \pm 0.0183\left\{\begin{array}{l}1.909 \\ 1.873\end{array}\right. \\ A & 3-6-67 & 1.8509 \pm 0.0214\left\{\begin{array}{l}1.872 \\ 1.830\end{array}\right. \\ B & 6-10- & 59 & 1.9368 \pm 0.0185\left\{\begin{array}{l}1.955 \\ 1.918\end{array}\right.\end{array}$

The $\frac{L}{H}$ mean values of the groups $A$ and $B$ show clearly that $\frac{L}{H}$ increases with the size of the shells (i.e. with growth) as is also illustrated by the diagrams fig. 8 , p. 62 . Length $(L)$ and width $\left(\frac{W}{2}\right)$ were determined in 26 single valves and the
$\frac{L}{W}$ ratios for paired valves were calculated on the basis of this material. The

*) Such concentric sculpture has previously been recognized by GLIBERT (1945, p. 34) on shells from Belgium. 

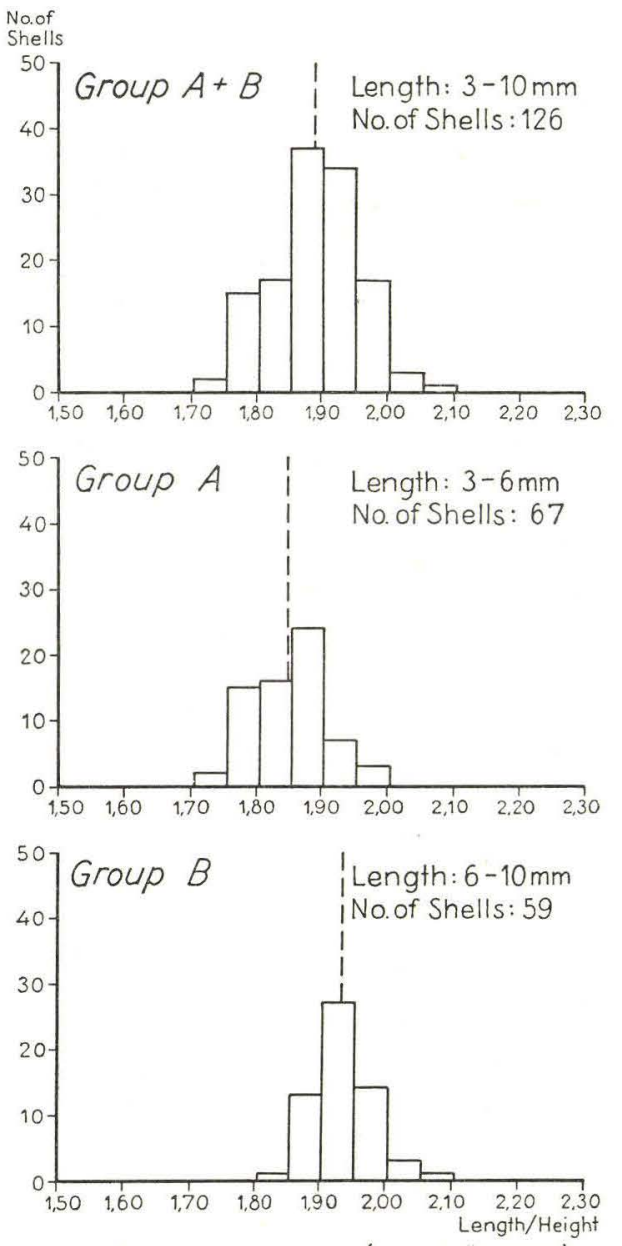

Yoldia glaberrima (VON MÜNSTER) Toftlund 75-100m

Fig. 8 . following figures illustrate the variation range:

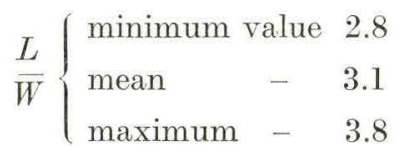

Thus it appears that $Y$. glaberrima has a relatively wide range in width related to length.

Remarks. Y. Dumasi Cossmann \& Peyrot has been included in the synonymy of this species since it obviously agrees with it in all general characters. However, there may be a remarkable difference in the hinge dentition if the authors of the species have correctly reported the number of teeth (about 25 in front of and about 18 behind the umbo). The figures of $Y$. Dumasi published by Cossmann \& Peyrot reveal that the specimen from Leognan appears to have about 20 teeth on both the anterior and posterior hinge parts while the specimen from Saubrigues may be the shell which Cossmann \& PEYROT regarded as the type, since it apparently has about 25 teeth in front of the umbo and about 18 behind it. Judging from the figure the latter shell might be somewhat damaged, and the writer has therefore disregarded the potential difference since this shell may not in fact be representative.

Distribution.

Miocene: Aquitanian Basin: Burdigalien, Helvétien.

North Sea Basin: Belgium: horizon of Houthaelen, Anversien; Holland (m.); NW Germany: Vierlande, Hemmoor, Reinbek (GotTSCHe 1878) and Glimmerton (STAESCHE 1930) stages; Denmark: Klintinghoved clay, and Arnum and Gram formations.

Oligocene: North Sea Basin: Holland (u.), NW Germany (u.), Denmark (u.). 
FAMILIA ARCIDAE FLEMING 1828

\section{Genus Arca Linne 1758}

\section{Arca diluvii Lamarck}

Recent:

Plate 3, fig. 12 a-c.

1891. Arca dituvii Lamarck. Bucquoy, Dautzenberg \& Dollfus. Moll. mar. du Roussillon. 2, p. 191, pl. 31, fig. 13-17.

Fossil:

1819. Arca diluvii LAMARck. Hist. nat. des animaux sans vertèbres. 6, p. 45.

1843. Arca diluvii Lamarck. Nyst. Coqu. et polyp. foss. de Belgique. p. 255, pl. 20, fig. 3.

1843. Arca latesulcata Nyst. Ibid. p. 256, pl. 18, fig. 8.

1870. Arca diluvii Lamarck. Hörnes. D. foss. Moll. d. Tert.-Beckens von Wien. 2, p. 333, pl. 44 , fig. $3-4$.

1898. Anadara diluvii (Lk.) SAcco. I moll. d. terr. terz. d. Piemonte e d. Liguria. 26, p. 20, pl. 4, fig. 7-12.

1907. Arca (Anadara) diluvii Lk. Cerulli-Irelli. Fauna mal. mariana. p. 115, pl. 8, fig. 12-13.

1912. Arca (Anadara) diluvii Lamk. Cossmann \& Peyrot. Conch. Néogén. d. l'Aquit. p. 269 , pl. 8, fig. 3-6, pl. 10, fig. 53.

1914. Arca (Arca) diluvii Lamk. Roth v. Telegd. Eine oberolig. Fauna a. Ungarn. p. 62. 1916. Arca sp. NøRRegaARd. M.-mioc. Blokke fra Esbjerg. p. 13.

1925. Arca (Anadara) diluvii Lamk. Kautsky. D. Mioc. v. Hemmoor u. Basbeck-Osten. p. 15, pl. 1, fig. 7 .

1942. Arca (Arca) diluvii Lank. IJspeent. Monogr. d. mioz. tax. Bivalv. a. d. Peelgebiete. p. 37 , pl. 2, fig. 1-6.

1942. Arca (Arca) diluvii Lamarck. Heering. D. olig. tax. Bivalv. a. d. Peelgebiete, p. 22 , pl. 3, fig. $24-27$, pl. 4, fig. 1-4.

1945. Arca (Arca) diluvii Lamarck. Glibert. Faune mal. du Mioc. de la Belgique. 1, p. 35 , pl. 1, fig. 12 .

Original diagnosis. A. testa ovato-transversa, ventricosa, multicostata; costis planulatis, transverse striatis; area dectivi; margine crenato. (LAMARCK).

Shell material.

\begin{tabular}{|c|c|c|c|c|c|c|}
\hline \multirow{2}{*}{$\begin{array}{l}\text { Location } \\
\text { Glejbjerg }\end{array}$} & Depth & Shells & Location & \multicolumn{2}{|c|}{ Depth } & Shells \\
\hline & $\begin{array}{l}23 \mathrm{~m} . \\
32 .\end{array}$ & $\begin{array}{l}1 \mathrm{v} . \\
\left.1 \text { (frg. })^{*}\right)\end{array}$ & Gramby & $\begin{array}{l}82.66-83.76 \\
84.66-87.16\end{array}$ & m. & $\begin{array}{l}1 \mathrm{v} . \\
13 \text { - }\end{array}$ \\
\hline & $42-$ & $1 \mathrm{v}$. & & $90.42-92.72$ & - & 1 . \\
\hline & $53-$ & 2 (frg.) & Toftlund & $75-100$ & - & 47 - \\
\hline & $53.5 \quad-$ & 1 & & $100-105$ & - & 1 (frg.) \\
\hline & 53.75 - & & & $105-110$ & - & $24 \mathrm{v}$. \\
\hline & $55-$ & $1 \mathrm{v}$. & & $110-115$ & - & 11 . \\
\hline Bramminge & $70-80$ & abt.8v. & & 115 & - & $5-$ \\
\hline Ribe & $123-124$ & 1 (frg.) & Arnum (13) & $28-40$ & - & 1 - \\
\hline & & & & $53-83$ & - & 6 - \\
\hline & & & Arnum ( $25 \mathrm{~b})$ & $62.7-62.9$ & - & 7 - \\
\hline & & & & $95-95.3$ & - & 1 - \\
\hline & & & & $104.3-107.5$ & - & 1 - \\
\hline & & & & 107.5 & - & 1 - \\
\hline
\end{tabular}

Description. (Mainly on the basis of the shells from Toftlund 75-100 m.). The main part of the shell material consists of juvenile shells and fragmentary specimens.

Prodissoconch rounded triangular; minute concentric striae may be seen under the microscope. For dimensions see table below.

Dissoconch. Exterior. The largest shells do not differ essentially from

*) All fragments are not determined with certainty. There is, however, no reason to refer them to other species at present, and they are therefore listed under A. diluvii. 
those figured in the literature, and the juvenile shells may best be illustrated by fig. $12 \mathrm{a}-\mathrm{b}$ on table 3 . The radial ribs (about 30 ) form the most prominent feature; they are connected by concentric ribs on the juvenile shell. The sculpture on this part of the shell is more or less reticulate since the concentric ribs are nearly as well developed as the radial ribs. The adult shell is dominated by the much elevated radial ribs, the concentric ribs being very subordinate and developed preferably in the interspaces between the radial ribs. A shallow furrow extends from the umbo to the ventral margin on the juvenile shell, but it is obliterated on mature shells. The numbers of ribs and dimensions of the shells from Toftlund $75-100 \mathrm{~m}$. are listed in the table below.

Hinge. It appears from the table that the number of hinge teeth increases with growth. The anterior part of the hinge however, does not contribute markedly to this increase, since the maximum number of teeth on this part in the shells from Toftlund is about 6 , while the posterior hinge part bears as many as 12-13 teeth. New teeth emerge during growth primarily at the distal end of the posterior row of teeth, and secondarily at the proximal end of same below the umbo. The space between the anterior and posterior hinge teeth is thus successively filled by new teeth, and the hinge of the adult shell finally has a continuous row of hinge teeth which have fine longitudinal ribs on the sides facing the tooth pits.

The ligamental area displays no particular features which have not been mentioned by previous authors, the shells being too small to yield data on the number and development of the minute furrows ordinarily seen on the area on larger shells.

The interior of the juvenile shell is illustrated in fig. $12 \mathrm{~b}, \mathrm{pl} .3$ the most conspicuous feature being the adductor scars which are of different sizes, as shown on the figures. Muscle scars below the hinge plate, as reported by IJSPEERT, may be recognized on some of the best preserved shells.

Variability. This species is obviously rather variable in shape and sculptural elements, although the number of radial ribs, for instance, is remarkably constant. It should, however, be mentioned that one shell from Gramby $(90.42-92.70 \mathrm{~m}$.) has 26 radial ribs and one from Glejbjerg (55 m.) has 25 radial ribs. These two shells exhibit in all other respects the features of the specimens here referred to $A$. dituvii.

Since the number of well preserved shells is too small for a statistic evaluation, some dimensions and data on sculptural features and hinge teeth of shells from Toftlund are given in the table below.

Arca diluvii Lamarck, Toftlund 75-100 m.

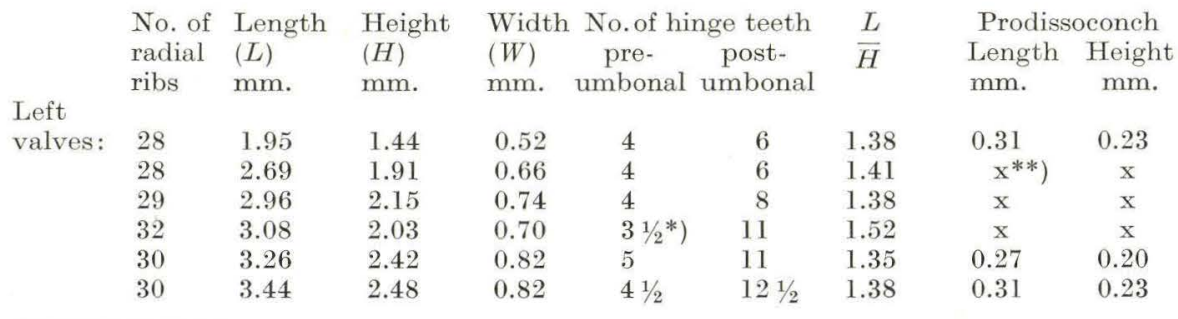

*) $\frac{1}{2}=$ not fully developed tooth.

**) $\mathrm{x}=$ badly preserved. 


\begin{tabular}{|c|c|c|c|c|c|c|c|c|c|}
\hline & \multirow{3}{*}{$\begin{array}{l}\text { No. of } \\
\text { radial } \\
\text { ribs }\end{array}$} & \multirow{3}{*}{$\begin{array}{l}\text { Length } \\
(L) \\
\mathrm{mm} \text {. }\end{array}$} & \multirow{3}{*}{$\begin{array}{l}\text { Height } \\
(H) \\
\mathrm{mm} .\end{array}$} & \multirow{3}{*}{$\begin{array}{l}\text { Width } \\
(W) \\
\text { mm. }\end{array}$} & \multirow{3}{*}{\multicolumn{2}{|c|}{$\begin{array}{l}\text { No. of hinge teeth } \\
\text { pre- post- } \\
\text { umbonal umbonal }\end{array}$}} & \multirow{3}{*}{$\frac{L}{H}$} & \multicolumn{2}{|c|}{ Prodissoconch } \\
\hline & & & & & & & & Length & Height \\
\hline & & & & & & & & & \\
\hline \multirow{7}{*}{$\begin{array}{l}\text { Left } \\
\text { valves: }\end{array}$} & 31 & 3.40 & 2.50 & 0.86 & 5 & 12 & 1.36 & $\mathrm{x}$ & $\mathrm{x}$ \\
\hline & 30 & 3.70 & 2.61 & 0.94 & 5 & $11 \frac{1}{2}$ & 1.42 & 0.35 & 0.23 \\
\hline & 30 & 3.66 & 2.69 & 1.04 & 6 & $121 / 2$ & 1.36 & 0.35 & 0.23 \\
\hline & 30 & 3.69 & 2.92 & 1.05 & (dam: & iged) & 1.29 & $\mathrm{x}$ & $\mathrm{x}$ \\
\hline & 31 & 4.42 & 3.08 & 1.15 & 5 & $111 / 2$ & 1.44 & $\mathrm{x}$ & $\mathrm{x}$ \\
\hline & 32 & 4.75 & 3.55 & 1.31 & $5 \frac{1 / 2}{2}$ & 12 & 1.34 & $\mathrm{x}$ & $\mathrm{x}$ \\
\hline & 29 & 4.90 & 3.55 & 1.29 & $41 / 2$ & 11 & 1.38 & 0.35 & 0.23 \\
\hline \multirow{10}{*}{$\begin{array}{l}\text { Right } \\
\text { valves: }\end{array}$} & & & & & & & & & \\
\hline & 30 & 1.80 & 1.19 & 0.39 & 3 & 6 & 1.51 & 0.36 & 0.2 \\
\hline & 28 & 1.80 & 1.19 & 0.39 & 3 & 6 & 1.51 & 0.32 & 0.23 \\
\hline & 30 & 2.96 & 2.08 & 0.70 & 4 & 10 & 1.42 & 0.31 & 0.23 \\
\hline & 29 & 3.03 & 2.07 & 0.66 & $31 / 2$ & 8 & 1.46 & 0.29 & 0.21 \\
\hline & 26 & 3.28 & 2.36 & 0.78 & 4 & 10 & 1.39 & $\mathrm{x}$ & $\mathrm{x}$ \\
\hline & 28 & 3.61 & 2.57 & 0.90 & 5 & $111 / 2$ & 1.40 & $\mathrm{x}$ & $\mathrm{x}$ \\
\hline & 28 & 4.19 & 3.08 & 1.26 & 5 & 12 & 1.36 & $\mathrm{x}$ & $\mathrm{x}$ \\
\hline & 28 & 4.42 & 3.32 & 1.18 & 5 & 11 & 1.33 & $\mathrm{x}$ & $\mathrm{x}$ \\
\hline & 27 & 5.25 & 4.10 & 1.66 & 5 & 13 & 1.28 & $\mathrm{x}$ & $\mathrm{x}$ \\
\hline
\end{tabular}

Remarks. The difference in the number of radial ribs between the recent (see Bucquoy, Dautzenberg \& Dollfus) and fossil species has been mentioned briefly by IJSPEERT. It is impossible at present to assess the significance of this difference since no statistics on recent material are available. The records of literature indicate that $A$. diluvii may include several varieties, and it has consequently been deemed advisable for the present to include the recent and fossil species in one taxonomic unit.

\section{Distribution.}

Recent: Mediterranean, Atlantic Ocean at the Cape Verde Islands.

Pliocene: North Sea Basin: England (Lenham, acc.to Bucquoy, Dautzenberg \& Dollfus).

Mediterranean Basin: Italy: Piacenziano, Astiano, upper Pliocene of Monte Mario.

Miocene: Aquitanian Basin: Burdigalien, Helvétien.

North Sea Basin: Belgium: Boldérien, horizon of Houthaelen, Anversien; Holland (m.) NW Germany: Hemmoor, Reinbek and Glimmerton stages (GotTsCHe 1878, Staesche 1930); Denmark: Arnum formation.

Mediterranean Basin: Italy: Elveziano, Tortoniano. Vienna and Hungarian Basins: Vienna: Grund sands, Baden clay, etc. Hungary: Eger.

Oligocene: North Sea Basin: Holland (m.).

\section{Bathyarca pectunculoides (Scacchi)}

Recent.

1863. Arca pectunculoides Scacchi. Jefrreys. Brit. Conch. 2, p. 171. 5, pl. 30, fig. 3.

1892. Arca pectunculoides Scacchi. Locard. Coq. mar. des côtes de France. p. 327.

1898. Arca pectunculoides Scacchi. Bucquoy, Dautzenberk \& Dollfus. Moll. mar. du Roussillon. 2, p. 802.

1934. Arca (Bathyarca) pectunculoides Scacchi. AD. S. Jensen \& Spärck. Saltvandsmuslinger. p. 37. 
Fossil:

1898. Bathyarca pectunculoides (SCACCHI). SACCO. I Moll. d. terr. terz. d. Piemonte e d. Liguria. 26, p. 12, pl. 2, fig. 36-40.

1907. Arca (Bathyarca) pectunculoides ScACChI. Cerulli-Irelli. Fauna mal. mariana. p. 110 , pl. 7 , fig. 30 .

1912. Bathyarca polyfasciata (Sism.) Cossmann \& Peyrot. Conch. Néogén. d. l'Aquit. p. 317 , pl. 10, fig. 48-51.

1925. Bathyarca pectunculoides SCACCHI var. minutissima KAUtsky. D. Mioc. v. Hemmoor u. Basbeck-Osten. p. 18, pl. 2, fig. 1 .

1945. Arca (Bathyarca) pectunculoides Scacchi. Glibert. Faune mal. du Mioc. de la Belgique. 1, p. 42, pl. 1, fig. 11 .

Original diagnosis not known, ScACCHI's paper not available.

Shell material. Arnum (25 b) 104.3-107.5 m. 1 right valve.

Description. Prodissoconch smooth with growth lines. Length 0.61 mm., height $0.35 \mathrm{~mm}$.

Dissoconch. The shell is a little broken. Height $1.61 \mathrm{~mm}$., length $1.86 \mathrm{~mm}$. (originally about $2 \mathrm{~mm}$.). Width $0.65 \mathrm{~mm}$. Exterior with 46 radial striae and at intervals distinct concentric lines.

Hinge (right valve). Two slightly oblique teeth at the anterior part, and two teeth posteriorly, which are parallel with the dorsal margin. The teeth are grooved perpendicular to the dorsoventral plane. The dorsal margin of the hinge plate is straight but with numerous minute incisions. The ligamental area cannot be studied in detail due to a cover of sedimentary film.

Interior smooth. Indistinct adductor scars below the two ends of the hinge. Ventral margin smooth.

Distribution.

Recent: North Atlantic Ocean from Greenland and Spitzbergen to the Gulf of Mexico and the Mediterranean.

Pliocene: Mediterranean Basin: Upper Pliocene Monte Mario.

Miocene: Aquitanian Basin: Helvétien.

North Sea Basin: Belgium: Anversien. Germany: Hemmoor stage, Glimmerton (BANKe Rasmussen 1956). Denmark: Arnum formation.

Mediterranean Basin: Italy: Elveziano.

\section{FAMILIA GLYCYMERIDAE \\ Genus Glycymeris Da Costa 1778}

14. Glycymeris sp.

One worn fragment of a Glycymeris was found in the sample from $115 \mathrm{~m}$. at Toftlund. It is impossible to determine its specific relations.

FAMILIA LIMOPSIDAE DALL 1895

Genus Limopsis Sassi 1827

Recent:

\section{Limopsis aurita (Brocchi)}

1863. Limopsis aurita Brocchi. Jefreneys. Brit. Conch. 2, p. 161, 5, (1869) pl. 30, fig. 1. 1898. Limopsis aurita (BrocchI) Posselt \& AD. S. Jensen. Grönlands Brach. og Blöddyr. p. 50 . 
1898. Limopsis aurita (Broccht) Bucquoy, Dautzenberg \& Dollfus. Moll. mar. du Roussillon. 2, p. 802.

1931. Limopsis aurita (BROCCHI). Plymouth mar. fauna, p. 238.

1934. Limopsis aurita (Brocchi). Ad. S. Jensen \& Spärok. Saltvandsmuslinger, p. 40.

Fossil:

1814. Arca aurita Brocchi. Conch. Foss. Subap. 2, p. 485, pl. 11, fig. 9.

1861. Limopsis aurita Brocchi. Wood. Monogr. Crag Moll. 2, p. 70, pl. 9, fig. 2.

1892. Limopsis aurita Brocchi. Lehmann. D. Lam. d. Mioc. v. Dingden 1, p. 212.

1898. Limopsis aurita Brocchi. SAcco. I moll. d. terr. terz. d. Piemonte e d. Liguria. 26, p.39, pl. 9, fig. $23-28$.

1907. Limopsis aurita Brocchi. Ravn. Molluskf. Jyll. Tert. p. 265, pl. 1, fig. 18.

1907. Limopsis aurita Brocohi sp. Ceruldi-Irelli. Fauna mal. mariana. p. 122, pl. 11, fig. 10-12.

1912. Limopsis Dumasi Cossmann \& Peyrot. Conch. Néogén. d. l'Aquit p. 320, pl. 7, fig. 4-6.

1913. Limopsis aurita Brocchi sp. var. parva Harder. De olig. Lag etc. v. Aarhus St. p. 53, pl. 3, fig. 19-21.

1914. Limopsis aurita Brocchi sp. Gripp. Über eine untermioz. Molluskenf. v. Itzehoe, p. 7 .

1925. Limopsis aurita BRocchi var. taurobliqua SACC. \& var. minuta KAUtSky. D. Mioc. v. Hemmoor u. Basbeck-Osten. p. 19, pl. 2, fig. 3-5.

1940. Limopsis aurita Brocchi. Sorgenfrei. Mar. Nedre-Mioc. i Klintinghoved p. Als, p. 19 , pl. 4, fig. 5-6.

1942. Limopsis aurita (Brocchi). IJspeert. Monogr. d. mioz. tax. Bivalv. a. d. Peelgebiete. p. 56, pl. 4, fig. $3-6$.

1942. Limopsis aurita (Brocchi). Henring. D. olig. tax. Bivalv. a. d. Peelgebiete. p. 30 , pl. 4, fig. 9-16.

1945. Limopsis (Limopsis) aurita (Brocchi) sp. Glibert. Faune mal. du Mioc. de la Belgique. 1 , p. 47 , pl. 2 , fig. 2 .

1956. Limopsis (Limopsis) aurita (Brocchi). Banke Rasmussen. Upper Mioc. South Jutland. p. 31, pl. 1, fig. 3 .

Original diagnosis. Testa ovata obliqua, superne angustata, transversim circinnatim rugosa, rugis crebris, elevatis, cardine aurito, foveola triangulari notato, margine integro. (BROCCHI 1814).

Shell material.

$\begin{array}{lrrlrr}\text { Location } & \text { Depth } & \text { Shells } & \text { Location } & \text { Depth } & \text { Shells } \\ \text { Glejbjerg } & 52 \mathrm{~m} . & 1 \mathrm{v} & \text { Ribe } & 113-114 \mathrm{~m} . & 7 \mathrm{v} . \\ & 53.5- & 1- & & 122-123- & 1- \\ 53.75- & 1- & & & & \\ & 55- & 1- & & & \end{array}$

The material is very fragmentary and relatively little may accordingly be contributed to the elucidation of the species.

Description.

Prodissoconch almost circular with minute concentric striae. Length and height could be measured only on two shells viz.

$\begin{array}{lrcl}\text { Location } & \text { Depht } & \text { Length } & \text { Height } \\ \text { Glejbjerg } & 52 \mathrm{~m} . & 0.37 & 0.33 \mathrm{~mm} . \\ & 53.5- & 0.35 & 0.33 \quad-\end{array}$

Dissoconch. There is only one well preserved adult shell in the material which yields but little information concerning structure of the shell. It is rather oblique and its dimensions and data are the following: 


$\begin{array}{lcccccc}\text { Location Depth } & \text { Length } & \text { Height } & \text { Width } & \begin{array}{c}\text { Long } \\ \text { axis }\end{array} & \begin{array}{c}\text { Short } \\ \text { axis }\end{array} & \begin{array}{c}\text { Hinge teeth } \\ \text { anterior posterior }\end{array} \\ \text { Ribe } 113-114 \mathrm{~m} . & 7.1 \mathrm{~mm} . & 6.73 \mathrm{~mm} . & 2.05 \mathrm{~mm} . & 7.35 \mathrm{~mm} . & 5.93 \mathrm{~mm} . & 6\end{array} 6$

Exterior. The sculpture of this species is rather characteristic and may be described briefly in its typical development (shell material from Klintinghoved has been included in this survey see SORGENFREI 1940). The significant elements of the sculpture are the concentric ribs which may be designated as inversely imbricated. The imbricate structure arises from the peculiar deposition of new shell material during growth. An elevated edge is first formed protruding above the previous shell margin while the succeeding shell surface below the edge is dipping downwards against the dorso-ventral plane. The elevated concentric edges have round indentations like the indentations of stamps. Short radial ribs may be developed below the individual indentations. The indentations of succeeding concentric edges and the corresponding radial ribs are mostly found below each other to form a relatively regular radial pattern on the shell surface.

The sculpture is of rather variable relief. Some shells are nearly smooth, and then the type of sculpture described above may hardly be recognized.

Hinge. About 6 teeth both in front of and behind the umbo in the well preserved shell from Ribe. The dependence of the number of teeth on the size of the shell may not be questioned although the material is insufficient to furnish significant statistical data. The sides of the teeth are grooved with minute longitudinal furrows.

The interior of the shells can either not be studied in detail, or is too much damaged for study of significant features.

Remarks. The species probably has a wide range of variation in shape (e. g. obliqueness) and sculpture, judging from the shells from Klintinghoved and Dingden. The varieties listed in the synonymy, and L. Dumasi of Cossmann \& PeYrot have accordingly been included in the present species without much hesitation, and in this the writer is in agreement with IJSPEERT (1942).

Distribution.

Recent: Northern Atlantic Ocean from West Greenland to the Gulf of Mexico and Bermudas and from the Shetland Islands to Gibraltar.

Mediterranean.

Pliocene: North Sea Basin: England: Coralline Crag.

Mediterranean Basin: Italy: Piacenziano, u. Plioc. of Monte Mario.

Miocene: Aquitanian Basin: Burdigalien.

North Sea Basin: Belgium: Anversien. Holland (m.), NW Germany: Vierlande, Hemmoor,

Reinbek and Glimmerton*) stages.

Denmark: Klintinghoved clay, and Arnum and Gram formations.

Mediterranean Basin: Italy: Elveziano, Tortoniano.

Oligocene: Holland (u.), Denmark (u.).

*) Gottsche 1878 \& Staesche 1930. 


\title{
16. Limopsis anomala (Eichwald)
}

\author{
Plate 4, fig. 16 a-b.
}

1830. Pectunculus anomalus Eichwald. Nat. Skizze v. Lithauen Volh. u. Podol. p. 211. 1853. Trigonocoelia anomala EICHWALD. Lethaea Rossica 3, p. 75, pl. 4, fig. 10.

1870. Limopsis anomala Eichwald. Hörnes. D. foss. Moll. d. Tert.-Beckens von Wien. 2 , p. 312 , pl. 39 , fig. $2-3$.

1892. Limopsis anomala Eichwald. Lehmann. D. Lam. d. Mioc. v. Dingen. 1, p. 214.

1898. Pectunculina anomala Eichwadd. SAcco. I moll. d. terr. terz. d. Piemonte e d. Liguria. 26, p. 41.

1898. Pectunculina anomala var. minuta PHIL. SAcco. Ibid. p. 41, pl. 10, fig. 11-18.

1907. Limopsis (Pectunculina) anomala Eichw. sp. Cerruldi-Ireldi Fauna mal. mariana. 1, p. 122, pl. 11, fig. 13-15 var. minuta PHIL. p. 123, pl. 11, fig. 16. var. cancellata Miсн. p. 123, pl. 11, fig. 17-18.

1912. Limopsis (Pectunculina) minuta (Phil.). Cossmann \& Peyrot. Conch. Néogén. d. l'Aquit. p. 321, pl. 7, fig. 9-12.

1914. Limopsis anomala EıcHw. Gripp. Über eine untermioz. Molluskenf. v. Itzehoe. p. 7.

1925. Limopsis (Pectunculina) minuta Phit. Kautsky. D. Mioc. v. Hemmoor u. BasbeckOsten. p. 20

1942. Limopsis anomala (Eichwald). IJspeert. Monogr. d. mioz. tax. Bivalv. a. d. Peelgebiete. p. 59, pl. 4, fig. 7-8.

1945. Limopsis (Pectunculina) minuta Philippi sp. Glibert. Faune mal. du Mioc. de la Belgique. p. 49 , pl, 2, fig. 3 .

Original diagnosis. Testa minima trapezoidalis, cardine recto, lateralibus dentibus externis majoribus, numerosis, margine inferiore dilatato, uno latere protracto, denticulato; testa vix 2 lineas lata, extus transversim striata, striis longitudinalibus tenuissimis transversas decussantibus (EICHWALD 1830).

Shell material.

\begin{tabular}{|c|c|c|c|c|c|}
\hline Location & Depth & Shells & Location & Depth & Shells \\
\hline Glejbierg & $53.75 \mathrm{~m}$. & $1 \mathrm{v}$. & Toftlund & $105-110 \mathrm{~m}$ & $3 \mathrm{v}$. \\
\hline Bramminge & $70-80=$ & $5-$ & & $110-115=$ & 4. \\
\hline Ribe & 113-114 - & $5-$ & Arnum (25b) & $95.0-95.3-$ & 1 - \\
\hline Toftlund & $75-100-$ & $2-$ & & & \\
\hline
\end{tabular}

\section{Description.}

Prodissoconch smooth, almost circular, preserved on 3 shells from Ribe in which length and height were measured as follows:

$\begin{array}{lccc} & \text { I } & \text { II } & \text { III } \\ \text { Length } & 0.9 & 1.1 & 1.1 \mathrm{~mm} \text {. } \\ \text { Height } & 0.9 & 1.1 & 1.1 \quad \text { - }\end{array}$

Dissoconch. Exterior. The sculpture includes two elements: a concentric and a radial seulpture. Inversely imbricate concentric ribs are found, as in L. aurita described above. They are formed by the deposition of new shell material upon the shell surface along the margin of the shell after a period without growth. The upwardly directed edge of the new shell material, facing the umbo has round indentations as in L. aurita, and short radial, wedgeshaped ribs are found on the shell surface below most of the indentations. The short radial ribs of succeeding concentric belts of the shell are generally found in line with each other, thus contributing to the impression of continuous ribs 
radiating from the umbo. The sculpture of $L$. anomala, although essentially the same as in L. aurita is generally more strongly developed.

Hinge. The hinge teeth are more or less compressed and grooved with fine longitudinal furrows as in $L$. aurita. For number of hinge teeth see the table below. The increase in number of teeth with growth is obvious, although the material is too slight to furnish supporting statistical data. The teeth in front of the umbo are almost radial to the shell margin, while the teeth behind the umbo form a more acute angle with the margin. Resiliophore small, triangular.

The interior is smooth and glossy between the margin and the pallial line, while it appears somewhat less glossy above the pallial line. The posterior adductor scar is about $1 \frac{1}{2}$ to twice the size of the anterior scar. One punctiform pedal muscle scar may be recognized in some shells above each of the adductor scars. The shell margin is crenated. The marginal notches do not agree either in number or position with the radial ribs.

Variability. The following measurements of a few well preserved valves are the only quantitative data available:

\begin{tabular}{|c|c|c|c|c|c|c|}
\hline \multirow[b]{2}{*}{ Length } & \multicolumn{2}{|c|}{ Ribe $113-114 \mathrm{~m}$. } & \multirow{2}{*}{$\begin{array}{c}\text { Glejbjerg } 53.75 \mathrm{~m} \text {. } \\
2.8\end{array}$} & \multicolumn{3}{|c|}{ Toftlund $75-100 \mathrm{~m}$. } \\
\hline & 1.95 & 2.25 & & 3.98 & 4.00 & $\mathrm{~mm}$. \\
\hline Height & 1.97 & 2.15 & 2.93 & 4.02 & 4.10 & - \\
\hline Width & 0.60 & 0.66 & 0.86 & 1.25 & 1.17 & - \\
\hline Shortest axis & 1.91 & 2.15 & 2.77 & 3.75 & 3.72 & - \\
\hline Longest - & 1.99 & 2.26 & 3.08 & 4.10 & 4.35 & - \\
\hline Teeth $\int$ pre-umbonal & 3 & 4 & 4 & 7 & 5 & - \\
\hline Ieetn $\{$ post-umbonal & 2 & 3 & 2 & 5 & 5 & - \\
\hline
\end{tabular}

The sculpture described above should be regarded as an idealized development, since there is considerable variety. The radial elements predominate in some shells while in others the concentric sculpture is the most conspicuous.

Remarks. The most prominent difference between. L. aurita and L. anomala is the nature of the shell margin. It is not yet possible to assess the significance of crenation, but it should not be accepted uncritically as a character of specific value. It should be borne in mind, for instance, that about $50 \%$ of the shells of Astarte Reimersi have a crenated margin while the other $50 \%$ is devoid of crenation (see Banke Rasmussen 1956, p. 34). The fact that the ratio between the number of specimens of $L$. aurita and $L$. anomala in Belgium (Glibert 1945), Holland (IJspeert 1942) and Dingden in Germany (LehmanN 1892 ) is almost the same viz. about $5 / 1,4 / 1$, and $6 / 1$, respectively, calls for attention in this connection. It might suggest, that a certain fraction of $L$. aurita has always the aspect of $L$. anomala i.e. the latter species may only be a variety of $L$. aurita.

\section{Distribution.}

Pliocene: Mediterranean Basin: Italy: Piacenziano, Astiano, u. Pliocene of Monte Mario.

Miocene: Aquitanian Basin: Burdigalien, Helvétien. North Sea Basin: Belgium: Anversien. Holland (m.) Germany: Vierlande, Hemmoor, and Reinbek stages. Denmark: Arnum formation.

Mediterranean Basin: Italy: Elveziano.

Vienna Basin: Baden clay. 
FAMILIA MYTILIDAE FLEMING 1828

Genus Modiolus Lamarck 1799

\section{Modiolus sp. a.}

Plate 5. fig. $17 \mathrm{a}-\mathrm{b}$.

Shell material. Arnum (25 b) 62.7-62.9 m. 2 frg. of left valves.

Description.

Prodissoconch smooth with concentric striae. For dimensions see below.

Dissoconch. Exterior smooth with growth lines. The small fragments leave very little possibility of recognizing general characters. The shell may be rather oblong and pointed at the umbonal region. Surface smooth and glossy.

Hinge. One or two teeth in front of the umbo. Ligament pit not preserved.

Interior. No significant features recognized.

$\begin{array}{clcc}\text { Dimensions. } & \text { Fragment: } & \text { I } & \text { II } \\ \text { Prodissoconch } & \begin{array}{l}\text { length } \\ \text { height }\end{array} & 0.29 & 0.27 \mathrm{~mm} . \\ \text { length of frg. } & 0.25 & 0.23 \quad- \\ \text { Dissoconch } & \begin{array}{l}\text { Number of } \\ \text { pre-umbonal } \\ \text { teeth: }\end{array} & & 1.56 \quad- \\ & & & \\ & & \end{array}$

Remarks. The fragments are too small for any further specific determination. The observed differences in prodissoconch, hinge properties and shape (as estimated by means of the growth lines) between these two shells and the shell described below prove that they belong to two different species.

\section{Modiolus sp. b.}

Plate 5, fig. 18 a-b.

Shell material. Toftlund $110-115 \mathrm{~m} ., 1 \mathrm{frg}$. of right valve.

Description.

Prodissoconch smooth, minute concentric striae. Length $0.39 \mathrm{~mm}$, height $0.33 \mathrm{~mm}$.

Dissoconch. Exterior smooth, with growth lines. The shell may be broader at the umbonal end then the shells described above. Length of fragment $1 \mathrm{~mm}$.

Hinge. No teeth in front of the umbo, indication of a minute crenation on the dorsal margin behind the umbo and above the ligament furrow.

Interior filled with sediment.

Remarks. See above under Modiolus sp. a.

Genus Musculus (Bolten) Röding 1798

(Synonym: Modiolaria Beck 1838)

19. Musculus saucatsensis (Cossmann)

Plate 5, fig. 19 a-d.

1895*). Modiolaria saucatsensis Cossmann. Sur qq. formes nouv. Bordelais, p. 21, pl. 5, fig. 29-31.

1914. Modiolaria (Planimodiola) saucatsensis Cossmann. Cossmann \& Peyrot Conch. Néogén. d. l'Aquit. p. 29, pl. 11, fig. 5-8.

*) Ref. from Cossmann \& Peyrot 1914, paper unknown to the writer. 
Summary of essential features of Cossman's description 1914.

Musculus with tripartite shell surface of which the anterior part carries about 9-10 radial ribs with interjacent punctate forrows. About 5-6 hinge teeth in front of the umbo (no real diagnosis in Cossmann's discription).

Shell material.

\begin{tabular}{|c|c|c|c|c|c|}
\hline $\begin{array}{l}\text { Location } \\
\text { Glejbjerg }\end{array}$ & $\begin{array}{l}\text { Depth } \\
42 \mathrm{~m}\end{array}$ & $\begin{array}{l}\text { Shells } \\
1 \text { fro. (of) }\end{array}$ & Location & Depth & Shells \\
\hline Gramby & $84.66-87.16-$ & $1-1$ & Toftlund & $110-115 \mathrm{~m}$. & 4 \\
\hline Toftlund & $100-105=$ & $2-$ & & 115 & I \\
\hline & $105-110=$ & $5-$ & Arnum (25b) & $\begin{array}{r}95.0-95.3- \\
107.5\end{array}$ & $\begin{array}{l}4 \\
1\end{array}$ \\
\hline
\end{tabular}

The specimens are either fragments or very small valves which hardly developed beyond the prodissoconch stage.

Description.

Prodissoconch smooth, with minute concentric striae. What has been defined as the prodissoconch in this species is the smooth shell devoid of radial ribs or striae. In several specimens it is possible to discriminate between an initial orbicular shell and the final obliquely elliptical prodissoconch which has already approached the shape of the adult. The following table shows the dimensions which could be measured:

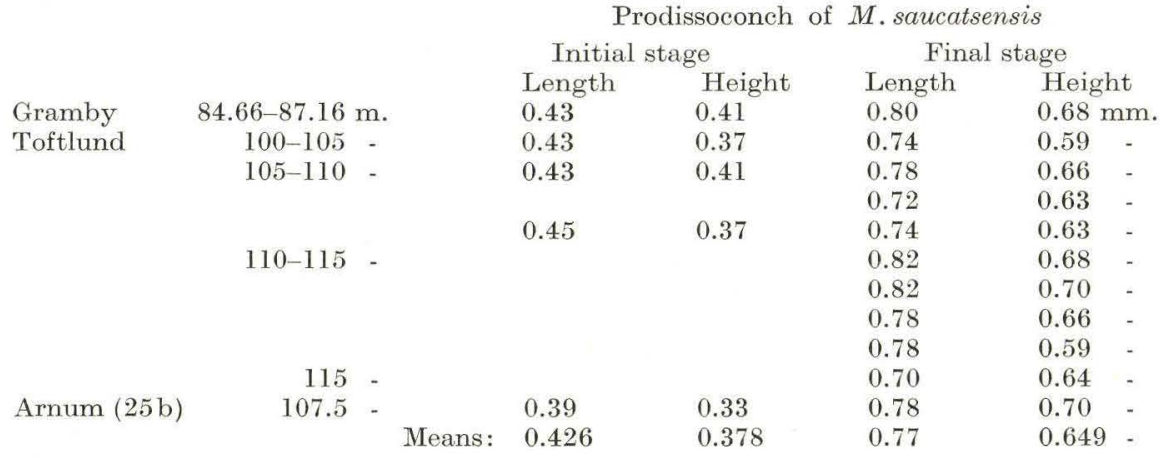

Dissoconch. Exterior. Most of the material represents juvenile stages just emerged from the prodissoconch stage. Relatively little may therefore be contributed concerning the features of the adult shell. However, a specimen from Toftlund 105-110 m. (plate 5, fig. $19 \mathrm{c-d}$ ) displays some of the characteristic features described by Cossmann. The anterior part of the shell surface carries 9 rather distinct radial ribs. The radial furrows between the ribs are punctate due to the development of rung-like connections between the ribs. On the middle part of the shell surface some faint radial striae are seen adjacent to the prodissoconch, but they soon die out on most shells leaving only concentric growth lines or weakly developed growth ribs. The posterior part of the shell surface has 22 radial ribs, with intervening punctate furrows as in the anterior division of the shell.

Hinge. The above mentioned shell from Toftlund $105-110 \mathrm{~m}$. and another specimen from 110-115 m. show 7 hinge teeth in front of the umbo. The two proximal teeth in front of the umbo are very small.

The interior of the shell shows no significant features. The shell margin may be crenated judging from the fragments. 
Remarks. This species is undoubtedly closely related to or identical with M. discors (L.) and/or M. condita (Mayer) although Cossmann \& Peyrot favour the opinion that the three species should be kept separated. In view of the fact that the Mytilidae represent one of the most variable groups of molluses a final conclusion concerning the validity of the species may accordingly not yet be drawn.

The description of the shells from South Jutland shows that there may be some differences between them and the shells described by Cossmans (e.g. one more hinge tooth). However, on account of the variability of the group the differences are considered to be within the probable range of variation of the species.

\section{Distribution.}

Miocene: Aquitanian Basin: Aquitanien, Burdigalien.

North Sea Basin: Denmark: Arnum formation.

\section{Genus Arcoperna}

\section{Arcoperna sp. (?)}

A few very poor shell fragments show sculptural features like those of Arcoperna. The fragments were found in the following samples: Glejbjerg $55 \mathrm{~m}$., Ribe 113-114 m., $115-116 \mathrm{~m}$. and 117-118 m.

\section{FAMILIA PECTINIDAE LAMARCK 1819}

A number of fragments of Pectinid shells and a few juvenile valves were included in the material under discussion. Some of the fragments and shells could easily be referred to particular species on the basis of their sculptural features, while others, among which were well preserved juvenile shells with characteristic and distinct sculpture, could not be determined with certainty.

The impossibility of specific determination in the last-named cases results from the absence of detailed records on juvenile shell stages in the literature. The writer therefore studied young stages of recent Pectinid shells in order to get an idea of the possibility of taxonomic subdivision on the basis of the sculptural features of the juvenile parts of the shells. It appeared that it is clearly possible to distinguish at least three shell stages: 1) the prodissoconch 2 ) the initial stage of the dissoconch and 3) the dissoconch proper. Each of these stages has its own shell features. In most species the prodissoconch is apparently smooth and glossy, while the initial stage of the dissoconch has a sculpture rather different from that of the adult stage. Of particular interest are the differences between the two valves during the initial dissoconch stage, as observed both in the fossil and the recent shell material examined.

The following table summarizes shell features of the prodissoconch and the initial dissoconch stages of five recent species: Pecten septemradiatus MüLLER, $P$. opercularis (L.), $P$. varius (L.), $P$. tigerinus MüLLER and $P$. islandicus MüLLER. The shell material examined was all collected in Danish and Icelandic waters by V. Nordmann, Ph.D. and G. Barmason and is kept at the Geological Survey of Denmark. Concerning the sculpture of the adult stage reference is made to the manuals by Forbes \& Hanley, Jefrreys, and Bucquoy, DautZENBERG \& DOLlfus, and others. 
TABLE 1

\section{Species \\ Pecten septem - Smooth, glossy, diameter radiatus MüL- about $0.25 \mathrm{~mm}$. LER}

CHARACTERS OF THE SHELL SURFACE AND DIMENSIONS OF JUVENILE SHELL STAGES OF SOME RECENT PECTINIDAE

P. opercularis Smooth, glossy, indica-tions of hardly perceptible pits on surface of left valve. Diameter about $0.26 \mathrm{~mm}$.

P.varius (L.) Apparently smooth and glossy. (Prodisoconch partly damaged).

$\begin{array}{ll}\text { P.tigerinus } & \text { Smooth and glossy. } \\ \text { MüLLER } & \text { Diameter about } \\ & 0.22 \mathrm{~mm} \text {. }\end{array}$

P. islandicus Mílter

\begin{abstract}
Smooth and glossy. Height about $0.225 \mathrm{~mm}$. Length about $0.22 \mathrm{~mm}$.
\end{abstract}

Initial stage of Dissoconch

Right valve: smooth, slightly granulated surface.

Left valve: more convex than right valve, concentric and radial striae. Height about 1.45 $\mathrm{mm}$, length about $1.52 \mathrm{~mm}$.

Right valve: smooth and glossy.

Left valve: moreconvex than rightvalve, shell surface with numerous distinct pits of about $10-12 \mu$ diameter. (These pits are also seen on the first part of the adult shell with radial sculpture). Height and length about $1.02 \mathrm{~mm}$.

Right valve: smooth and glossy, microscopic, cellular structure in the shell surface.

Left valve: more convex than right valve, shell surface with pits as in $P$. opercularis, but less distinct and arranged in concentric rows parallel with concentric striae. Height and length about $1.1 \mathrm{~mm}$.

Right valve: smooth and glossy with microscopic, cellular structure in the shell surface as in $P$. varius.

Left valve: minute radial striae. Height about $1.4 \mathrm{~mm}$, length about $1.2-1.3 \mathrm{~mm}$.

Right valve: sculpture of concentric ribs and minute pits in the interspaces as in $P$. varius.

Left valve: glossy with microscopic cel lular pattern as in $P$. varius. Two shells investigatedheight $1.2 \quad 1.5 \mathrm{~mm}$. length $1.3 \quad 1.7$

Although the study had to be restricted to a very few recent species, it shows that a thorough study of the juvenile stages of Pectinid shells might well be significant, and would undoubtedly reveal the presence of several distinct characters by means of which determination and taxonomic subdivision might be made easier.

\section{Pecten ex aff. Brummelii Nyst \& liberata Cossmann \& Peyrot \\ Plate 7, fig. 21 a-d.}

Pecten Brummelii NysT:

1864. Pecten Brummelii Nyst. Notice sur une nouv. espèce de Pecten etc. No. 7, p. 27.

1925. Pecten Brummelii Nyst. Kautsky. D. Mioc. v. Hemmoor u. Basbeck-Osten, p. 13, pl. 1, fig. 5 .

1945. Pecten (Pecten) Brummelii Nyst. Gribert. Faune mal. du Mioc. de la Belgique. 1, p. 57, pl. 2, fig. 12, pl. 3. fig. 2 . 
Essential features of original description: Coquille fortement inéquivalve, quinze fortes côtes longitudinales, qui portent chacune quatre sillons fortement squamuleux; à interstices profonds et lisses avec trois ou quatre stries médianes également longitudinales et finement écailleuses vers la base (Nrst 1864).

Pecten liberata Cossmann \& Peyrot:

1914. Chlamys (Aquipecten) liberata Cossmann \& Peyrot. Conch. Néogen. d. l'Aquit. p. 126, pl. 17, fig. 14-17.

Essential features of original description: Angle apicale $105^{\circ}$; oreitlettes de la valve droite inégales, encoche byssale étroite et peu profonde, munie de cinq dents pectinidiales. Oreillettes de la valve gauche subégales, l'anterieure légèrement plus longue. Surface externe ornée sur chaque valve d'environ vingt côtes radiales étroites, Saillantes, presque quadrangulaires; lisses et indivises dans la région umbonale, se subdivisant en costules étroites, arrondies, dont le nombre varie avec la distance au crochet. Il y en a quatre au maximum. Lamelles concentrique sur les intervalles des côtes dans la région umbonale. Plus bas les lamelles deviennent plus saillates et déterminent — tant sur les côtes que sur les intervalles des squamules saillantes et imbriquées. (Cossmann \& Peyrot 1914).

Shell material.

$\begin{array}{lrllrl}\text { Location } & \text { Depth } & \text { Shells } & \text { Location } & \text { Depth } & \text { Shells } \\ \text { Bramminge } & 70-80 \mathrm{~m} . & 15 \mathrm{frg} . & \text { Toftlund } & 105-110 \mathrm{~m} . & 2 \mathrm{sh} . \\ \text { Gramby } & 82.66-83.76- & 4- & & 110-115- & 2 \mathrm{frg} . \\ \text { Toftlund } & 75-100- & 36- & & 115- & 2 \\ & & 2 \mathrm{sh} . & \text { Arnum } & 53-83- & -\end{array}$

Prodissoconch. Smooth, obliquely orbicular, rather convex. Dimensions measured on specimen figured pl. 7, fig. $21 \mathrm{a}-\mathrm{b}$ : Length $0.31 \mathrm{~mm}$., height 0.29 $\mathrm{mm}$. (left valve).

Dissoconch. Initial stage. Right valve: smooth and glossy, with minute cellular structure, as in P.varius and P.tigerinus to be seen in shell surface under the microscope. Left valve: concentric ribs and minute radial striae in the interspaces. Height and length $1.3-2 \mathrm{~mm}$. Adult stage. The transition from the initial to the adult stage is shown by an area with reticulate sculpture, the concentric ribs and the developing radial ribs being almost of the same order of magnitude. The radial ribs become successively more elevated, minute radiating striae are found in their interspaces, and radial strings may develop on the radial ribs. The number of radial ribs on the juvenile shell is about 20 to 25 . The figured specimen should otherwise give an idea of the general appearance of the shell.

Several of the fragments of the Pectinid shells listed above show spines and scales on the radial ribs which are very similar to the sculpture of $P$. Brummelii (see for instance GLIBERT, 1945).

Remarks. The fragments and shells listed above may belong to one or to two species. There are obviously transitional types between fragments with very simple and rather smooth radial ribs, and others which have spines and scales. The latter might be referred to P. Brummelii, but while this species has about 15 radial ribs the juvenile shells included in the present Pectinid shell material have about 20 radial ribs. The juvenile shells thus agree with $P$. liberata 
concerning the number of radial ribs. The final answer to the question whether the shell material belongs to more than one species, and whether it should be referred to one or both of the above species, or to a different species, can therefore not be given at present. However, it should be noted that the shells here referred to are distinctly different from those referred to the following species, P.radians*).

Distribution.

\section{Pecten Brummelii}

Miocene: North Sea Basin: Belgium:

Horizon of Houthaelen, Anversien. Germany: Hemmoor stage

\section{P. liberata}

Miocene: Aquitanian

Basin : Aquitanien, Burdigalien, Helvétien.

\section{Pecten radians Nyst}

Plate 8, fig. 22.

1839. Pecten radians Nyst. Nyst \& Westendorp. Nouv. rech. etc. de la prov. d'Anvers. p. 407 , pl. 3, fig. 19.

1945. Pecten (Aequipecten) radians Nyst. Glibert. Faune mal. de Mioc. de la Belgique. 1 , p. 65 , pl. 3 , fig. 5 .

Original diagnosis. Testa subaequivalvi, suborbiculata, depressa; costis 16-17 radiantibus instructa; transversim squamoso-lamellosa; auriculis inaequalibus. (Nyst 1839).

Shell material.

\begin{tabular}{|c|c|c|}
\hline Location & Depth & \\
\hline Bramminge & $70-80 \mathrm{~m}$. & \\
\hline Toftlund & $75-100$ & 2 \\
\hline & $\begin{array}{l}100-105=- \\
105-110=\end{array}$ & $\begin{array}{l}1 \\
3\end{array}$ \\
\hline
\end{tabular}

Location
Toftlund
Arnum $(25 \mathrm{~b})$

Arnum $(25 \mathrm{~b})$

\author{
Depth Shells \\ $110-115 \mathrm{~m} .1 \mathrm{frg}$. \\ $115-2$ - \\ (1 with umbo) \\ $95.0-95.3-1$.
}

\section{Description.}

Prodissoconch. (1 specimen examined). Smooth, cyprinoid, length 0.25 mm., height $0.23 \mathrm{~mm}$.

Dissoconch. Initial stage studied in a fragment of a right valve. Surface apparently smooth (shell a little worn). Height about $1.75 \mathrm{~mm}$.

Adult stage. Exterior. The fragments display the characteristic sculptural features described by GLIBERT. Well preserved fragments carry blunt spines on the radial ribs, and the concentric lamellae are curved. These lamellae are convex towards the umbo on the flanks of the radial ribs, while they are concave towards the umbo in the interspaces. Both the ribs and their interspaces are furthermore covered with fine, radiating striae. Four pectinidial teeth on right valve.

Hinge and interior. The shells are too fragmentary to yield any data of significance.

Remarks. The sculpture of this species is obviously very well defined and

*) Roger (1939, p. 134) has referred to P. radians one of Cossmann \& Peyrots shells defined as $P$. liberata by these authors. 
characteristic, and in spite of the admittedly poor material there can hardly be any doubt as to the correct determination of the material.

Distribution.

Miocene: North Sea Basin: Belgium: Anversien. Denmark: Arnum formation.

\section{Pecten tigerinus Müller}

Recent:

Plate 8, fig. 23.

1776. Pecten tigerinus Müller. Zoologiae Danicae Prodr. p. 248, no. 2993.

1778. Pecten tigerinus MüLler. Zool. Dan., p. 248, pl. 60, fig. 6-8.

1853. Pecten tigrinus Múlter. Forbes \& Hanley, Brit. Moll. 2, p. 285, pl. 51, fig. 8-11.

1863. Pecten tigrinus Mülter. Jeffreys. Brit. Conch. 2, p. 65. (1869) 5, pl. 23, fig. 2.

1878. Pecten tigrinus Müller. Sars. Moll. Reg. Aret. Norvegiae, p. 18.

1892. Pecten tigrinus MÜlter. Locard. Coq. mar. d. côtes d. France p. 352.

1931. Chlamys (Palliolum) tigerina (O. F. Múller) Plymouth Mar. Fauna, p. 240.

1932. Pecten tigrinus MüLlter. Nobre. Moluscos mar. de Portugal, p. 291, pl. 45, fig. 8, pl. 50, fig. $6-8$.

1934. Pecten tigrinus Müller. Ad. S. Jensen \& Spärck, Saltvandsmusl. p. 64.

Fossil:

1843. Pecten tigerinus Mülter. Nyst. Coqu. et polyp. foss. p. 303, pl. 23, fig. 4-12.

1861. Pecten tigrinus Mülter. Wood. Monogr. Crag Moll. 2, p. 27, pl. 5, fig. 2.

1897. Flexopecten tigrinus var. laeviligustica SACCO. I moll. d. terr. terz. d. Piemonte e d. Liguria 24, p. 44, pl. 13, fig. 11-13.

1925. Pecten tigrinus Mưlt. var. praecedens Kautsky. D. Mioc. v. Hemmoor u. BasbeckOsten. p. 13.

1939. Chlamys tigrina Mülter. Roger. Le Genre Chlamys. p. 196, pl. 21, fig. 11-21.

1944. Pecten (F'lexopecten) tigerinus Müller. Heering. D. oberolig. Biv. a. d. Peelgebiete. p. 14, pl. 2, fig. 9-18.

1945. Pecten (Pallium) tigerinus Müller. Glibert. Faune mal. du Mioc. de la Belgique. 1 , p. 79 , pl. 5 , fig. 2.

1950. Pecten (Chlamys) tigerinus Müller. Heering. Plioc. and older Plistoc. Netherlands p. 45.

Original diagnosis. Testa subaequivalvi striata glabra, rubra maculis albis (Müller 1776).

Utraque valvula extus striata, glabra, rubra; striae in superiore profundiores et paene sulci, maculaeque magnae undulatae confluentes, pallide lutae, in inferiore vero minutissimae punctiformes et quasi guttatae, interstitia striarum oculo ornato rugulosa sulpunctulis adeo exarata, ut pro situ testae lineolas tum transversales tum longitudinales fingere udeantur. Intus rubra nitida striata; maculae pulchre pellucent, at in interstitiis striarum, uti in congeneribus, nec lineolae, nec puncti ullius vestigium (MÜLLER 1778).

Shell material.

$$
\begin{aligned}
& \text { Location Depth Shells } \\
& \text { Glejbjerg } 23 \mathrm{~m} .2 \mathrm{frg} \text {. } \\
& \text { Toftlund } \quad \begin{array}{r}
25-110-115-15 \\
-
\end{array} \\
& 115-1 \text { - (umbonal part) }
\end{aligned}
$$

Description.

Prodissoconch. The umbonal part of a left valve (Toftlund $115 \mathrm{~m}$.) shows a fairly well preserved orbicular prodissoconch which is smooth. Height about $0.34 \mathrm{~mm}$., length about $0.31 \mathrm{~mm}$. 
Dissoconch. Initial stage as described above under the comments to the genus, with minute radial striae and growth lines. Height about $1.37 \mathrm{~mm}$., length about $1.10 \mathrm{~mm}$.

Adult stage. The fragments have broad shallow undulating radial ribs, with minor radial ribs, or they are more or less smooth with radiating striae which tend to be almost perpendicular to the shell margin on the anterior and posterior parts of the shell.

The fragment with preserved umbo shows a straight dorsal margin with a sharp upper edge, and below that a rounded edge or fold on the inner side. Minute, somewhat irregular folds are seen on the lower edge adjacent to the umbo. A small part of the adductor scar can be seen on the fragment.

Remarks. The typical umbonal features and the relatively well characterized sculptural elements leave hardly any doubt as to the identity of the material. It must be admitted, however, that the material is rather meager.

\section{Distribution.}

Recent: Atlantic Ocean: West coast of Europe from Western Finmark to the west coast of Portugal.

Pliocene: North Sea Basin: England: Coralline Crag, Red Crag. Holland. Belgium: Scaldisien.

Mediterranean Basin: Italy: Piacenziano.

Miocene: North Sea Basin: Belgium: Horizon of Houthaelen, Anversien. Germany: Hemmoor stage, Glimmerton (Banke Rasmussen 1956). Denmark: Arnum formation.

Oligocene: North Sea Basin: Holland (u.).

\section{Pecten Gerardii Nyst}

Plate 5, fig. 24.

*)1835. Pecten Gerardii Nyst. Rech. coq. foss. prov. d'Anvers, p. 19, pl. 3, fig. 75.

1843. Pecten Gerardii Nyst. Coq. et polyp. foss., p. 300, pl. 18, fig. 11 .

1861. Pecten Gerardii Nyst. Wood. Monogr. Crag Moll. 2. p.24, pl. 5, fig. 5.

1907. Pecten sp. Ravn. Molluskf. Jyll. Tert. p. 252.

1925. Lissochlamys cf. Gérardi Nyst. Kautsky. D. Mioc. v. Hemmoor u. Basbeck-Osten. p.12.

1940. Lissochlamys cf. Gérardi Nyst. Sorgenfrei. Mar. Nedre-Mioc. i Klintinghoved p. Als. p. 14. pl. 4. fig. 1.

1950. Pecten (Pseudamussium) Gerardi Nyst. Henring. Plioc. and older Plistoc. Netherlands., p. 50, pl. 14, fig. 12.

Diagnosis. P. testa aquivalvi, orbiculari, plano-convexa, subinoequilatera, longitudinaliter argutissime striata: striis undulatis; auriculis incequalibus, radiatim costatis, majore in valva dextra, basi sinuata (NYST 1845).

Shell material.

$\begin{array}{lrl}\text { Location } & \text { Depth } & \text { Shells } \\ \text { Glejbjerg } & 23 \mathrm{~m} . & \text { frg. right v. } \\ \text { Toftlund } & 105-110- & \text { frg. right } \mathrm{v} . \\ \text { Arnum (25b) } & 107.5- & \text { frg. left } \mathrm{v} .\end{array}$

*) Paper not available to the author. 
Description. The shell material is very fragmentary. However, significant shell features are displayed particularly by the shell fragment from Arnum, as shown by the following.

Prodissoconch orbicular, apparently with a rather dull lustre. Height about $0.18 \mathrm{~mm}$, length about $0.22 \mathrm{~mm}$.

Dissoconch. Initial stage. Left valve: Shell surface not glossy, only growth lines break the smoothness of the surface. Umbo relatively elevated, height about $0.78 \mathrm{~mm}$., length about $0.70 \mathrm{~mm}$. The fragments of the right valves are worn and do not show any details of sculpture etc.

Adult stage. Left valve: surface glossy, with faint growth lines and minute, curved, radial striae almost perpendicular to the growth lines. Dorsal margin straight. Auricules with growth lines and radiating striae as on the rest of the shell surface.

Remarks. This is considered to be a Pliocene species by GLIBERT (1945, p. 82), who questions the correctness of KAUTSKY's determination of the shell casts from Hemmoor. This question may possibly never be settled. However, the material here treated obviously demonstrates features which are regarded as typical of $P$. Gerardii according to GLIBERT, and it must therefore obviously be accepted that $P$. Gerardii existed during Miocene time.

Distribution.

Pliocene: North Sea Basin: England: Coralline Crag; Belgium: Scaldisien, Diestien. Holland.

Miocene: North Sea Basin: Germany: Hemmoor stage(?), Glimmerton (Banke Rasmussen 1956). Denmark: Klintinghoved clay, Arnum formation.

\section{Pecten sp. sp. indet}

Indeterminable shell fragments of Pectinid shells were found in the following samples:

Location

Glejbjerg

$\begin{aligned} \text { Depth } & \text { Shells } \\ 23 \mathrm{~m} . & 1 \text { frg. } \\ 25- & 3 \text { - } \\ 53.75- & 1-\end{aligned}$

\author{
Location \\ Gramby \\ Toftlund
}

Arnum (25b)

$\begin{aligned} \text { Depth } & \text { Shells } \\ 84.66-87.16 \mathrm{~m} . & 1 \\ 100-105- & 1 \mathrm{frg} . \\ 62.7-62.9- & 3\end{aligned}$

FAMILIA LIMIDAE D'ORBIGNY 1847

Genus Lima Chemnitz 1787

Subgenus Limea BRonN 1831

\section{Lima (Limea) strigilata (Brocchi)}

Plate 6, fig. 26 a-c.

1814. Ostrea strigilata Brocchr. Conch. Foss. Subapennina. 2, p. 571, pl. 14, fig. 15.

1870. Limea strigilata Brocchi. Hörnes. D. foss. Moll. d. Tert.-Beckens von Wien. 2, p. 392, pl. 54, fig. 7 .

1898. Limea strigilata (BR.). SAcco. I moll. d. terr. terz. d. Piemonte e d. Liguria. 25, p. 21 , pl. 6 , fig. $4-7$.

1907. Limea strigilata (Br.). Cerulli-Irelli. Fauna mal. mariana. p. 89, pl. 4, fig. 45.

1925. Limea strigilata (Br.). Kautsky. D. Mioc. v. Hemmoor u. Basbeck-Osten. p. 11, pl. 1, fig. 3 . 
Original diagnosis. Testa ovato-oblonga, longitudinaliter subtilissime striata, parum convexa, cardine recto, auriculis suboqualibus, margine crenulato (BRoCCHI 1814).

Shell material. Toftlund $100-104 \mathrm{~m} .2$ right valves.

Description.

Prodissoconch orbicular, glossy. For dimensions see table below.

Dissoconch. Exterior. Shell surface with about 40 radial ribs which are most elevated on the posterior part of the shell, and rather faint on the anterior part. Concentric striae visible in the interspaces between the ribs.

Hing e. 5 to 6 nodular teeth on either side of the ligament area which appears as a rounded pit below the umbo. It is very tempting to interpret the hinge teeth as specially developed marginal knobs.

Interior. The adductor scar is faintly indicated on the smaller of the two valves. Shell margin with knobs corresponding to the radial ribs on the shell surface.

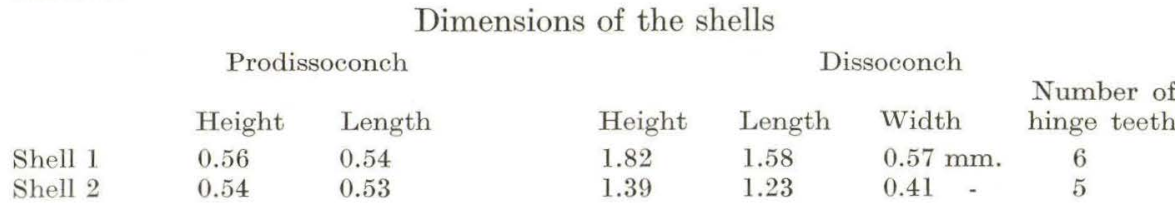

Distribution.

Pliocene: Mediterranean Basin: Italy: Astiano, Piacenziano, upper Pliocene of Monte Mario.

Miocene: North Sea Basin: Germany: Hemmoor stage. Denmark: Arnum formation.

Mediterranean Basin: Italy: Tortoniano, Elveziano. Vienna Basin: Baden clay.

\section{FAMILIA ANOMIIDAE GRAY 1840 \\ Genus Anomia (Linne) Müller 1776}

\section{Anomia squamula Linne}

Recent:

Plate 6, fig. 27 a-c, plate 10, fig. 27 a-c.

1758. Anomia squamula Linne. Syst. Nat. Ed. Dec. p. 701

1853. Anomia aculeata Müller. Forbes \& Hanley. British Moll. 2, p. 332, pl. 55, fig.4.

1863. Anomia ephippium Linne, var. squamula. Jeffreys. 2, p. 32, 5, pl. 20, fig. 1. c.

?1867. Anomia squamula Linne. Weinkauff. Conch. d. Mittelmeeres p. 279.

1878. Anomia squamula Linne, var. squamula SARs. Moll. Reg. Arct. Norwegiae. p. 14.

?1888. Anomia ephippium Linne var. squamula Linne. Bucquoy, Dautzenberg \& DolLFUs. Moll. mar. du Roussilon. 2, p. 37, pl. 9, fig. 4-7.

1892. Anomia aculeata Müller. Locard. Coq. mar. des côtes de France p. 361.

1931. Heteranomia squamula (L.). Plymouth Mar. Fauna p. 237.

1932. Anomia aculeata Müller. Nobre. Moluscos mar. de Portugal. p. 275, pl. 48, fig. 10 .

1934. Anomia (Heteranomia) squamula L. AD. S. JensEn \& R. SPÄrck. Saltvandsmuslinger p. 51 .

Fossil:

1814. Anomia squamula L. Brocchr. Conch. Foss. Subapennina. p. 461.

1851. Anomia aculeata Müller. Wood. Monogr. Crag Moll. p. 9. pl. 1, fig. 2.

1897. Anomia ephippium var. squamula L. SAcco. I. moll. d. terr. terz. d. Piemonte e d. Liguria. 23, p. 32, pl. 10, fig. 3-4. 
1907. Monia aculeata Müller sp. Cerulli-Ireldi. Fauna mal. mariana. p. 78, pl. 4, fig. 8-12.

1950. Anomia (Heteranomia) squamula (Linne). Heering. Plioc. and older Plistoc. Netherlands p. 54.

Original diagnosis. Testa orbiculata integerrima plana margine altero gibba laevi (Linne 1758).

Shell material.

Location

Glejbjerg

Toftlund

Description.

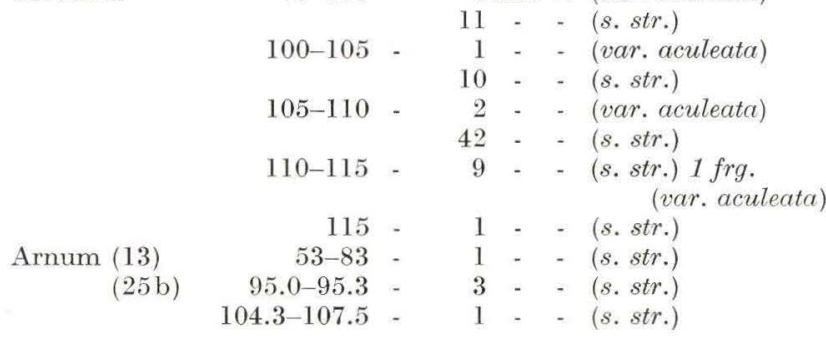

Prodissoconch. Right valve relatively flat, left valve arched. Surface glossy, with faint growth lines. The only right valve available is partly covered by the fold of the dorsal margin of the dissoconch, it is about $0.28 \mathrm{~mm}$. high and about $0.29 \mathrm{~mm}$ long. Two left valves showed the following dimensions:

\begin{tabular}{lccll}
\multicolumn{4}{c}{ Prodissoconch } \\
Location & Depth & Height & Length & Width \\
Toftlund & $100-105 \mathrm{~m}$. & 0.36 & 0.36 & $0.155 \mathrm{~mm}$. \\
Arnum & $53-83-$ & 0.36 & 0.36 & 0.108 -
\end{tabular}

Dissoconch. Exterior of the fossil species as varied as in recent representatives. Both the typical form, var. aculeata, and var. cepa (see FonBes \& HANLEY) can be distinguished among the shells found. Many shells reflect the substratum in their sculpture (see plate 6 , fig. 27 a). The umbo of the left prodissoconch is somewhat turned towards the posterior end of the shell which thus appears opistogyrate.

The interior does not exhibit any significant feature, except for the adductor scar which is situated below the umbo. The byssus muscle scar cannot be seen while the ligament pit is distinct in several shells.

Dimensions. The bulk of the material consists of small, more or less fragmentary valves. The following list includes dimensions of some of the best preserved specimens.

Anomia squamula. Dimensions of shells.

\begin{tabular}{|c|c|c|c|c|c|c|c|c|}
\hline \multirow{2}{*}{ Location } & \multirow{2}{*}{\multicolumn{2}{|c|}{ Depth }} & & & \multicolumn{4}{|c|}{ Dissoconch } \\
\hline & & & & & Height & Length & Widtl & \\
\hline Glejbjerg & $23 n$ & $\mathrm{~m}$. & righ & alve & 2.26 & 2.70 & & $\mathrm{~nm}$. \\
\hline \multirow[t]{5}{*}{ Toftlund } & $75-100$ & - & left & - & 4.6 & 5.2 & & - \\
\hline & & & - & - & 5.5 & 6.3 & 2.7 & - \\
\hline & & & - & - & 1.6 & 2.05 & 0.55 & - \\
\hline & $100-105$ & - & - & - & 3.6 & 3.45 & 1.25 & - \\
\hline & & & - & - & 2.42 & 2.62 & & - \\
\hline Arnum (13) & $53-83$ & - & - & - & 2.3 & 2.54 & 0.90 & - \\
\hline Arnum (25b) & $95-95.3$ & - & - & - & 3.2 & 3.2 & & - \\
\hline
\end{tabular}


Remarks. The wide range of variation of this species renders the delimitation of its specific characters rather difficult. The presence in the fossil material of the same morphologic types as in recent shells of A. squamula may, however, justify the reference of the shells to this species.

Distribution.

Recent: Northern Atlantic Ocean from the temperate area of the White Sea to Portugal, and from Labrador to Cape Hatteras.

Possibly in the Mediterranean.

Pliocene: North Sea Basin: England: Coralline Crag. Holland. Mediterranean Basin: Italy: Piacenziano, Astiano, upper Pliocene of Monte Mario.

Miocene: Mediterranean Basin: Italy, Elveziano of Colli torinesi.

North Sea Basin: Arnum formation.

FAMILIA OSTREIDAE FLEMING 1828

Genus Ostrea Linne 1758

28. Ostrea sp.

Shell material.

Plate 9, fig. 28 a-i.

Location
Glejbjerg
Gramby
Toftlund

$\begin{aligned} \text { Depth } & \text { Shells } \\ 55 \mathrm{~m} . & 1 \text { right valve } \\ 82.66-83.76- & 1 \text { left v. } \\ 75-100- & 2 \text { right. v. and } 2 \text { frg. } \\ 100-105- & 3 \text { right v. and } 2 \text { undefined v. } \\ 105-110- & 1 \text { right v. and } 1 \text { frg. } 1 . \text { v. } \\ 110-115- & 1 \text { frg. } \mathrm{r.} \text { v. }\end{aligned}$

Description. All shells are very small juvenile specimens. It was accordingly deemed inadvisable definitely to refer the shells to any particular species on account of the insufficient information available concerning juvenile stages.

Prodissoconeh smooth, cyprinoid. The umbo often worn, with a resulting more or less circular perforation of the prodissoconch (plate 9 , fig. $28 \mathrm{~h}-\mathrm{i}$ ). The size of the shells appears from the following table.

\begin{tabular}{|c|c|c|c|c|c|c|c|c|}
\hline \multirow{5}{*}{$\begin{array}{l}\text { Location } \\
\text { Toftlund }\end{array}$} & & \multicolumn{3}{|c|}{ Prodissoconch } & \multicolumn{4}{|c|}{ Dissoconch } \\
\hline & Depth & Height & Length & Width & Height & Length & Width & $\mathrm{mm}$. \\
\hline & $75-100 \mathrm{~m}$. & 0.41 & $0.50^{\circ}$ & - & 2.54 & 2.07 & 0.70 & - \\
\hline & $100-105$ & 0.45 & 0.51 & 0.17 & 5.52 & 4.74 & 0.79 & - \\
\hline & $105-110$ & & & & & & & \\
\hline
\end{tabular}

Dissoconch. Exterior. The outline of the shell is more or less irregular. The surface layer appears to be finely granulated, the granules being arranged in a cellular pattern. The individual granules are about $0.015 \mathrm{~mm}$, or less, in diameter. Dimensions of two shells are shown in the above table.

The interior shows a relatively broad adductor muscle scar. No other 
significant feature can be recognized. The shape of the ligament area can be seen on the figured specimens.

Remarks. A study of shells of recent Ostrea edulis revealed that the shell surface of this species may also be granulated or microscopically striated. It would be necessary to examine the shells of other oysters before it could be decided whether granulation of this kind is a "generic" or a "specifje" character.

\section{FAMILIA ASTARTIDAE D'ORBIGNY 1845 \\ Genus Astarte J. Sowerby 1816}

\section{Astarte cf. concentrica Goldfuss}

1837. Astarte concentrica Goldfuss.Petrefacta Germaniae. 2, p. 195, pl. 135, fig. 7

1884. Astarte concentrica Goldfuss. Speyer \& v. Koenen. D. Bivalv. d. Casseler tert. Bild. pl. 4, fig. 5-7.

1907. Astarte concentrica Goldfuss. Ravn. Molluskf. Jyll. Tert. p. 268, pl. 1, fig. 23.

?1913. Astarte Kickxi NyST, Harder. De olig. Lag etc. v. Aarhus St. p. 56, pl. 4, fig. 9-15.

1914. Astarte concentrica Goldf. Gripp. Über eine untermioz. Molluskenf. v. Itzehoe. p. 7 , pl. 1, fig. 1-2.

1916. Astarte cf. concentrica Goldf. Norregand. Mellem-mioc. Blokke fra Esbjerg, p. 13. 1925. Astarte concentrica Goldf. \& var. gracilis Münst. Kautsky. D. Mioc. v. Hemmoor u. Basbeck-Osten. p. 25, pl. 2, fig. 17-18.

1940. Astarte concentrica GoldF. Sorgenfrei. Mar. Nedre-Mioc. i Klintinghoved p. Als. p. 20 , pl. 4 , fig. 8 .

1944. Astarte concentrica Goldf. Heering. Die oberolig. Bivalv. a. d. Peelgebiete. p. 22, pl. 8, fig. 1-24, pl. 9, fig. 1-2.

1945. Astarte (Astarte) concentrica Goldf. Glibert. Faune mal. du Mioc. de la Belgique 1, p. 97 , pl. 6 , fig. 2.

Original diagnosis. Astarte testa convexa ovato-orbiculari, umbonibus submedianis, lunula eliptica costis convexis elevatis, interstitiis latioribus planis striatis. (GoLdFuss 1837).

\begin{tabular}{|c|c|c|}
\hline Location & Depth & Shells \\
\hline Bramminge & $70-80 \mathrm{~m}$. & frg. of 2 left and 4 right valves \\
\hline Ribe & $113-114-$ & frg. of 1 left and 1 right valves \\
\hline & $115-116-$ & frg. of 1 worn right valve \\
\hline Toftlund & $110-115-$ & frg. of 1 left and 1 right valve \\
\hline Arnum (25b) & $95.0-95.3=$ & frg. of 3 right valves \\
\hline
\end{tabular}

Remarks. The shell material is too fragmentary to contribute the data necessary for final specific determination. However, several of the fragments exhibit features which agree fairly well with those of shells which have been referred to $A$. concentrica by earlier authors.

Distribution.

Miocene: North Sea Basin: Belgium: Horizon of Houthaelen, Anversien. Germany: Vierlande, Hemmoor, and Reinbek-Dingden stages (LeHmann 1892). Denmark: Klintinghoved clay, Arnum formation.

Oligocene: North Sea Basin: Holland (u.), Germany (u.), Denmark (u.). 


\title{
30. Astarte (Goodallia) triangularis (Montagu)
}

\author{
Plate 10, fig. 30 a-c.
}

Recent:

1803. Mactra triangularis Montagu.Test. Brit. 1. p. 99, pl. 3, fig. 5.

1846. Mactra triangularis Montagu. Chenu. Bibl. Conchyl. 4, p. 43, pl. 1, fig. 15.

1853. Astarte triangularis Montagu. Forbes \& Hanley. Brit. Moll. 1, p. 467, pl. 30, fig. $4-5$.

1863. Astarte triangularis Montagu. Jeffreys. Brit. Conch. 2, p. 318, 5, pl. 37, fig. 5.

1867. Astarte triangularis Montagu. Wennkauff. Conch. d. Mittelmeeres. 1, p. 126.

1892. Astarte triangularis Montagu. Locard. Coq. mar. des côtes de France, p. 301.

1932. Astarte triangularis Montagu. Nobre. Moluscos mar. de Portugal. p. 322.

1934. Goodallia triangularis Montagu. AD. S. Jensen \& R. Spärck. Saltvandsmuslinger, p. 87.

\section{Fossil:}

1861. Astarte triangularis Montagu. Wood. Monogr. Crag Moll. 2, p. 173, pl. 17, fig. 10.

1870. Astarte triangularis Montagu. Hörnes. D. foss. Moll. d. Tert.-Beckens v. Wien 2 , 282, pl. 37, fig. 1. (pro parte).

1912. Astarte (Goodallia) Mayeri. Cossmann \& Peyrot. Conch. Néogén. d. l'Aquit., p. 146, pl. 1, fig. 51-57.

1945. Astarte (Goodallia) triangularis Montagu. sp. Glibert. Faune mal. du Mioc. de la Belgique. 1, p. 115, pl. 6, fig. 7 .

1950. Astarte (Goodallia) triangularis (Montagu). Heering. Plioc. and older Plistoc. Netherlands. p. 79.

Diagnosis. A strong, sub-triangular, opaque, white shell; umbo prominent, obtuse; sides a little unequal: hinge strong; primary tooth in one valve large, bifid; in the other two small teeth, with a triangular cavity between; lateral ones depressed. Inside white, not very glossy, margin strongly crenated. (MonTAGU 1803).

Shell material. One right valve from Toftlund (110-115 m.). Dimensions: height $1.76 \mathrm{~mm}$., length $2.3 \mathrm{~mm}$., width $0.47 \mathrm{~mm}$., and one smaller right valve from the same location $(115 \mathrm{~m}$.).

Remarks. The general features are shown by the illustrations of the shell on plate 10. In particular it can be seen that the shell margin is a little worn and devoid of crenation. It is impossible clearly to distinguish the prodissoconch from the dissoconch on this shell. The smaller shell is slightly crenated on the shell margin.

For further details concerning this species reference is made to the papers cited in the synonymy.

Distribution.

Recent: Western North Sea, Atlantic Ocean from the British Isles to the Canaries.

Pliocene: North Sea Basin: England: Coralline Crag, Red Crag. Holland.

Miocene: Aquitanian Basin: Burdigalien, Helvétien.

North Sea Basin: Belgium: horizon of Houthaelen, Anversien. Denmark: Arnum formation.

Basin of Vienna: Steinabrunn beds. 
FAMILIA CARDITIDAE FLEMING 1820

Genus Cardita Bruguière 1792

Subgenus Cyclocardia ConRAD 1867.

\section{Cardita (Cyclocardia) orbicularis (Sowerby)}

1825. Venericardia orbicularis Sowerby. Min. Conch. 5, p. 145, pl. 490, fig. 2.

1861. Cardita orbicularis Leathes' Ms. Wood. Monogr. Crag Moll. 2, p. 167, pl. 15, fig. 4.

1867. Venericardia tuberculata Münst. v. Koenen. D. mar. Mittel-Olig. ete. p. 110.

1907. Venericardia orbicularis Sowerby. Ravn. Molluskf. Jyll. Tert. p. 267.

1925. Pteromeris orbicularis Sowerby. Kautsky. D. Mioc. v. Hemmoor u. Basbeck Osten. p. 27 , pl. 3, fig. 5-6.

1941. Cardita tuberculata V. Münster. Görges. D. Oberolig.-fauna v. Rumeln a. Niederrhein p. 167.

1944. Cardita orbicularis (Sowerby). Heering. D. oberolig. Bivalv. a. d. Peelgebiete. p. 25 , pl. 6, fig. 1-8.

1945. Cardita (Cyclocardia) orbicularis Sowerby sp. Glibert. Faune mal. du Mioc. de la Belgique. 1, p. 123, pl. 6, fig. 14 .

1950. Cardita orbicularis (Leathe's Ms, J. Sowerby). Heering Plioc. and older Plistoc. Netherlands. p. 85.

1956. Cardita (Cyclocardia) orbicularis (Sowerby 1825). Banke Rasmussen. Upper Mioc. South Jutland. p. 40.

Original diagnosis. Orbicular, rather convex, concentrically striated; ribs about 16, not close, crenated; hinge small (Soweriy 1825).

Shell material.

\begin{tabular}{|c|c|c|}
\hline Location & Depth & Shells \\
\hline Bramminge & $70-80 \mathrm{~m}$. & $\begin{array}{c}1 \text { juvenile left valve and } 2 \text { frag- } \\
\text { mentary right valves }\end{array}$ \\
\hline Ribe & $113-114$ - & 2 fragments. (cf. orbicularis) \\
\hline Arnum (13) & $28-40-$ & 1 fragment of left valve \\
\hline Arnum (25b) & $62.7-62.9 \quad-$ & I fragment of left valve. \\
\hline
\end{tabular}

Description.

Prodissoconch almost circular, diameter about $0.20 \mathrm{~mm}$, shell surface obviously slightly granulated.

Dissoconch. Exterior: about 17 crenated ribs with fine concentric striae in their interspaces. Interior: distinct, rather larger adductor scars. A minor scar, probably a pedal muscle scar, is found above the anterior adductor scar.

Hinge. It may be mentioned that the hinge teeth and the tooth pits are minutely striated perpendicular to the dorso-ventral plane.

Distribution.

Pliocene: North Sea Basin: England: Coralline Crag and Red Crag. Holland.

Miocene: North Sea Basin: Belgium: horizon of Houthaelen, Anversien. Germany: Hemmoor stage, Glimmerton (Banke Rasmussen 1956). Denmark: Arnum and Gram formations.

Oligocene: North Sea Basin: Germany (m., u.). 


\section{FAMILTA KELLYELLIDAE FISCHER 1887 \\ Genus Kellyella M. Sars 1870 \\ Subgenus Lutetia Deshayes 1860}

\section{Kellyella (Lutetia) rotunda nov.sp.}

Plate 10, fig. 32 a-e.

1956. Kellyella (Kellyella) sp. Banke Rasuussen. Upper Mioc. South. Jutland. p. 41.

Diagnosis. Kellyella of almost circular outline with test of medium strength. Shell surface generally smooth and glossy, with growth lines which may occasionally develop into irregular concentric ribs. Lunule delimited by a distinct curved furrow. Right valve with one relatively strong tooth in front of the umbo and above the tooth a deep pit for the single tooth of the left valve. Tooth of the left valve with a notch on the under side to accomodate the tooth of the right valve. A narrow, slightly triangular ligament pit beneath the umbo. Shell margin with a minute furrow generally extending from the anterior end of the hinge to the posterior side of the ligament pit, but interrupted where the furrow of the lunule merges into the shell margin. Holotype plate 10, fig. $32 \mathrm{c}$-d. Geological Survey of Denmark. Well file no. 150.13, Arnum 53-83 m. Derivatio nominis: rotunda - round.

Shell material.

\begin{tabular}{|c|c|c|c|c|c|c|c|}
\hline \multirow{2}{*}{$\begin{array}{l}\text { Location } \\
\text { Glejbjerg }\end{array}$} & \multicolumn{2}{|c|}{ Depth } & Shells & Location & \multicolumn{2}{|c|}{ Depth } & Shells \\
\hline & 23 & & 5 & Toftlund & $75-100$ & & 244 \\
\hline & 25 & - & 12 & & $100-105$ & - & 290 \\
\hline & 32 & - & 41 & & $105-110$ & - & 292 \\
\hline & 42 & - & 3 & & $110-115$ & - & 316 \\
\hline & 52 & - & 1 & & 115 & - & 15 \\
\hline & 53.5 & - & 2 & Arnum (13) & $28-40$ & - & 5 \\
\hline Bramminge & $70-80$ & - & 2 & & $53-83$ & - & 53 \\
\hline Ribe & $113-114$ & - & 1 & Arnum (25b) & $62.7-62.9$ & - & 158 \\
\hline & $124-125$ & - & 3 & & & & \\
\hline Gramby & $81.86-82.16$ & - & 3 & & $95.0-95.3$ & - & 102 \\
\hline & $82.66-83.76$ & - & 7 & & $101.0-104.3$ & - & 12 \\
\hline & $84.66-87.16$ & - & 75 & & $104.3-107.5$ & - & 32 \\
\hline & $90.42-92.72$ & - & 30 & & 107.5 & - & 32 \\
\hline & $92.72-109.29$ & - & 20 & & & & \\
\hline & $102.29-110.86$ & - & 22 & & & & \\
\hline & $110.86-121.51$ & - & 8 & & & & \\
\hline
\end{tabular}

Description.

Prodissoconch smooth and glossy, height practically equals length. Mean height of 10 shells from Arnum $0.25 \mathrm{~mm}$.

Dissoconch very small, length/height about 1. Maximum sizes measured were:

$\begin{array}{lrlr} & & \text { Length } & \text { Height } \\ \text { Arnum (25 b) } & 95.0-95.3 \mathrm{~m} . & 1.68 & 1.68 \mathrm{~mm} . \\ & 104.3-107.5- & 1.86 & 1.92- \\ \text { Toftlund } & 110-115- & 1.86 & 1.78 \quad-\end{array}$

Variation. There is some variation in smoothness of the shell surface, height, strength of hinge elements, etc., but these variations are not large. The following table gives the dimensions of some specimens from Toftlund (75-100 m.). 
Kellyella (Lutetia) rotunda nov.sp. Toftlund 75-100 m. Dimensions of shells

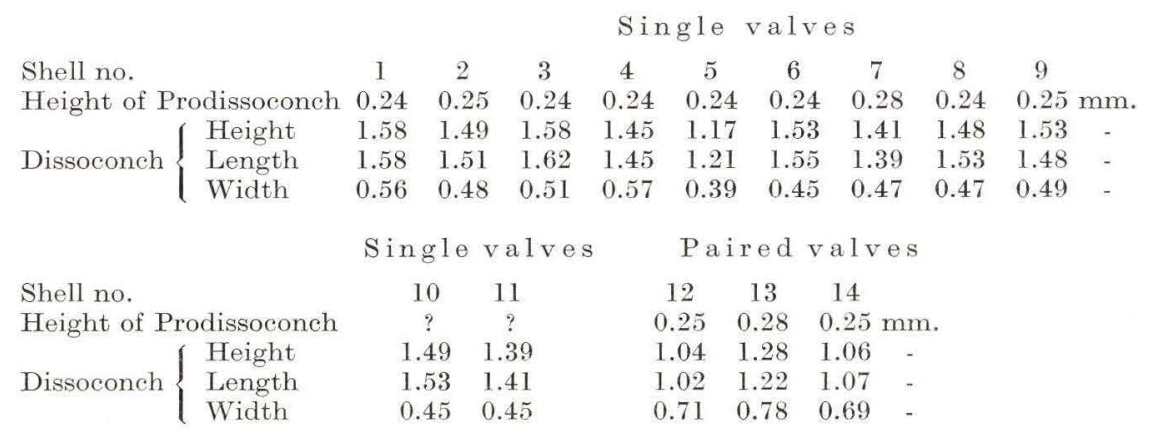

Remarks. There are obviously remarkable differences between shells which have been referred to Kellyella s.str. and to Lutetia as described in original literature, particularly concerning the development of the hinge. The name of the subgenus has accordingly been included in the present species since it is to be expected that increased knowledge concerning shells of related species will make it practical in the future to define more generic units than are known at present.

The precent species is doubtless closely related to $L$. girondica CossMann \& Peyrot. However, the very scarce information on the dimensions of shell material from the Aquitanian basin furnished by the authors of the species indicates that $L$. girondica is more trigonal and higher in relation to length than the species from South Jutland. It must be added that some of the shells of $K$. rotunda approach $L$. girondica fairly much in shape as for instance shown in plate 10 fig. 32 a but this is very exceptional. The possibility nevertheless exists that $K$. rotunda represents juvenile stages of $L$. girondica, and it might, therefore, be useful to examine young shell stages of the latter species in order to throw light on this point of obscurity. This the writer was unable to do.

\section{Distribution. \\ Miocene: North Sea Basin: Denmark: Arnum and Gram for- mations.}

\section{Kellyella (Lutetia) patera nov. sp.}

Plate 11, fig. $33 a-b$.

Diagnosis. Shell almost circular, with relatively strong test. Surface smooth with growth ribs. Lunule delimited by minute curved furrow. Right valve with one strong central tooth below the umbo, above which another tooth is found, consisting of a small lamelliform anterior part, and a strong posterior part. A shallow, internal ligament pit behind the umbo. Minute furrow on the posterior shell margin. Left valve unknown. Holotype plate 11, fig. 33 a-b. Geological Survey of Denmark. Well file no. 150.13. Arnum 53-83 m. Derivatio nominis : patera — bowl.

Shell material: Arnum 53-83 m.; 1 right valve.

Description.

Prodissoconch smooth and glossy, approximately circular, not sharply delimited from the dissoconch; height about $0.20 \mathrm{~mm}$. 
Dissoconch very small, height $0.93 \mathrm{~mm}$., length $0.97 \mathrm{~mm}$., width $0.25 \mathrm{~mm}$. Interior shows pallial line and adductor scars as shown on figure.

Remarks. The shell described is clearly different from $K$. rotunda both concerning hinge features and proportions. The shell margin of the specimen is somewhat broken, and it was thus impossible to decide whether the marginal furrow extends over the whole margin, as on $K$. rotunda, or not.

Distribution.

Miocene: North Sea Basin: Denmark: Arnum formation.

\section{FAMILIA ISOCARDIIDAE GRAY 1840 \\ Genus Isocardia (Klein) Lamarck 1799}

\section{Isocardia $\mathrm{sp.}$}

Plate 11, fig. 34 a-f.

A number of juvenile shells and fragments of adult shells of Isocardia were found. Some of the fragments have fine elevated dots on the shell surface, and might therefore belong to Isocardia punctata KAUTSKY (1925 p. 27), but this cannot be decided with certainty.

Shell material.

\begin{tabular}{|c|c|c|c|c|c|c|}
\hline \multirow{6}{*}{$\begin{array}{l}\text { Location } \\
\text { Glejbjerg }\end{array}$} & \multicolumn{2}{|c|}{ Depth } & Shells & Location & Depth & Shells \\
\hline & 23 & & $2 \mathrm{v}$. & Toftlund & $110-115 \mathrm{~m}$. & $68 \mathrm{v}$. \\
\hline & 42 & - & $1 \mathrm{frg}$. of umbo & & 115. & 5 - and frg. \\
\hline & 53 & - & 1 fro. of umbo & & & of $16 \mathrm{v}$. \\
\hline & 53.5 & - & 1 v. and frg. & & & (ef. $I$. \\
\hline & 55 & - & $1 \mathrm{frg}$. of umbo & & & punc- \\
\hline Bramminge & $70-80$ & - & $3 \mathrm{frg}$. of hinge & & & tata) \\
\hline \multirow[t]{3}{*}{ Gramby } & $84.66-87.16$ & - & $18 \mathrm{v} .$, and 1 frg. & Arnum (13) & $53-83-$ & $4 \mathrm{v}$. \\
\hline & & & cf. I. punctata & Arnum (25b) & $62.7-62.9-$ & $6-$ \\
\hline & $92.72-109.29$ & - & 1 frg. of hinge & & $95.0-95.3$ & $13-$ \\
\hline \multirow[t]{5}{*}{ Toftlund } & $75-100$ & - & $3 \mathrm{v}$. and $1 \mathrm{frg}$. & & $101.0-104.3-$ & $5-$ \\
\hline & & & of hinge & & $104.3-107.5$ & 4 - and \\
\hline & $100-105$ & - & $1 \mathrm{frg}$. & & & $1 \mathrm{frg}$. of \\
\hline & $105-110$ & - & 32 frg. (cf. $I$. pur & ctata) & & hinge \\
\hline & & & and $32 \mathrm{v}$. & & $107.5-$ & $11 \mathrm{v}$. \\
\hline
\end{tabular}

\section{Description.}

Prodissoconch smooth and glossy almost orbicular. For dimensions see table below.

Dissoconch rhomboidal in the juvenile stage shell surface smooth.

Dimensions of juvenile Isocardia sp. from Toftlund 105-110 m:

\begin{tabular}{|c|c|c|c|c|c|c|c|c|c|c|c|c|}
\hline $\begin{array}{l}\text { Leig } \\
\text { beo }\end{array}$ & & 0.25 & 0 & 3 & 0.25 & 0.23 & 0.2 & 0.23 & 0.23 & 0.25 & 0.24 & $3 \mathrm{~mm}$ \\
\hline \multirow{3}{*}{ Dissoconch } & Height & & 0.88 & 1.03 & 1.21 & 1.09 & 1.32 & 1.03 & 1.56 & 1.06 & 2.20 & $1.07 \quad-$ \\
\hline & Length & 1.29 & 0.98 & 1.17 & 1.33 & 1.27 & 1.49 & 1.13 & 1.73 & 1.41 & 2.30 & $1.23-$ \\
\hline & Width & 0.43 & 0.29 & 0.35 & 0.43 & 0.35 & 0.39 & 0.33 & 0.57 & 0.31 & 0.74 & 0.33 \\
\hline
\end{tabular}

The general shell features are shown by the illustrations on plate 11 . 
FAMILIA SPORTELLIDAE DALL 1900

Genus Sportella Deshayes 1858

\section{Sportella cimbrica Kautsky}

Plate 11, fig. 35a-b.

1925. Sportella cimbrica KaUtsky. D. Mioc. v. Hemmoor u. Basbeck-Osten. p. 34, pl. 4, fig. 1.

1945. Sportella cimbrica Kautsky. Glibert. Faune mal. du Mioc. de la Belgique. 1, p. 148, pl. 10, fig. 8 .

Essential features of original description. Shell small, elliptical, equilateral. One cardinal tooth; large, obliquely triangular ligament pit (No particular diagnosis in KAUTSKY's original description).

Shell material.

$\begin{array}{lrl}\text { Location } & \text { Depth } & \text { Shells } \\ \text { Gramby } & 82.66-83.76 \mathrm{~m} . & 1 \text { left v. (frg.) } \\ & 84.66-87.16- & 1 \text { left v. } 2 \text { right v. (frg.) } \\ \text { Toftlund } & 75-100- & 5 \text { left v. } 3 \text { right v. (frg.) } \\ & 100-105- & 3 \text { left v. } 2 \text { right v. (frg.) } \\ & 105-110- & 1 \text { left v. } 2 \text { right v. (frg.) } \\ & 110-115- & 3 \text { left v. 1 right v. (frg.) } \\ \text { Arnum (25 b) } & 62.7-62.9- & 3 \text { left v. } 6 \text { right v. (frg.) } \\ & 104.3-107.5- & 3 \text { right v. (frg.) }\end{array}$

Description. Very little ean be added to the characteristics given by KaUtsky and GLIBERT perhaps because of the fragmentary nature of the shells.

Prodissoconch smooth and glossy. The size varies obviously rather much, as illustrated by the following measurements of shells from Arnum $(62.7-62.9 \mathrm{~m})$ :

$\begin{array}{lllllllllc}\text { Height (H) } & 0.295 & 0.320 & 0.370 & 0.370 & 0.420 & 0.350 & 0.340 & 0.370 & \mathrm{~mm} . \\ \text { Length (L) } & 0.340 & 0.360 & 0.430 & 0.450 & 0.480 & 0.403 & 0.395 & 0.434 & - \\ \text { H/L ratio } & 0.87 & 0.89 & 0.86 & 0.82 & 0.87 & 0.87 & 0.86 & 0.85 & -\end{array}$

Dissoconch. The general features of the shells agree fairly well with GLiberT's description. Concerning the dorsal margin of the right valve, it should be added that this forms an overhang which extends over the rounded margin of the left valve.

Distribution.

Miocene: North Sea Basin: Belgium: Horizon of Houthaelen, Anversien. Germany: Hemmoor stage. Denmark: Arnum formation.

FAMILIA UNGULINIDAE H. \& A. ADAMS 1858

Genus Thyasira (Leach) Lamarck 1818

\section{Thyasira cf. flexuosa (Montagu)}

Recent:

Plate 11, fig. $36 \mathrm{a}-\mathrm{b}$.

1803. Tellina flexuosa Montagu. Test. Brit. p. 72 .

1853. Lucina flexuosa Montagu. Forbes \& Hanley. Brit. Moll. 2, p. 54, pl. 35, fig. 4.

1863. Axinus flexuosus Montagu. Jefremes. Brit. Conch. 2, p. 247, 5, pl. 33, fig. 1.

1867. Axinus flexuosus Montagu. Weinkauff. Conch. d. Mittelmeeres. p. 170.

1892. Axinus flexuosus Montagu. Locard. Coq. mar. d. côtes d. France. p. 316.

1931. Thyasira flexuosa Montagu. Plymouth Mar. Fauna. p. 241. 
1932. Axinus flexuosus Montagu. Nobre Moluscos mar. de Portugal p. 354, pl. 63, fig. 5. 1934. Thyasira flexuosa Montagu. Ad. S. Jensen \& Spärck. Saltvandsmuslinger, p. 92. Fossil:

1909. Thyasira flexuosa Montagu sp. Cerulli-Irelli. Fauna mal. mariana. p. 155, pl. 18, fig. 29.

(?)1925. Cryptodon hanseatus Kautsky. D. Mioc. v. Hemmoor u. Basbeck-Osten. p. 30, pl. 3, fig. 12-13.

1945. Thyasira flexuosa Montagu. sp. Glibert. Faune mal. du Mioc. de la Belgique. 1, p. 153 , pl. 6 , fig. 5 .

Original diagnosis. Thin, pellucid, fragile, convex, sub-orbicular, white shell: from behind the umbo to the lower angle of the margin, a sulcus runs parallel with the cartilage slope, and forms a sinus or flexure at the edge. It is finely, but irregularly striated concentrically, and is not very glossy: umbo placed central, much produced, and turns to one side at the apex: hinge with an obsolete tooth; along the margin, from behind the umbo, a groove in which is fixed the connecting cartilage: Inside smooth, glossy white. (Montagu 1803).

Shell material.

\begin{tabular}{|c|c|c|c|c|c|}
\hline \multirow{2}{*}{$\begin{array}{l}\text { Location } \\
\text { Glejbjerg }\end{array}$} & Depth & Shells & Location & Depth & Shells \\
\hline & $32 \mathrm{~m}$ & 1 & Toftlund & $110-115 \mathrm{~m}$ & 40 \\
\hline & $53.5-$ & 1 (undamaged) & & $115-$ & $\begin{array}{l}3 \\
3\end{array}$ \\
\hline Ribe & $124-125-$ & 1 & Arnum (25b) & $62.7-62.9=$ & 3 \\
\hline Gramby & $84.66-87.16-$ & 1 & & $95.0-95.3-$ & 30 \\
\hline Toftlund & $75-100-$ & 5 (1 undamaged & & $101-104.3$ & 3 \\
\hline & & valve & & 104.3-107.5 - & 20 \\
\hline & $105-110=$ & $\begin{array}{l}118 \text { (1 undamaged } \\
\text { valve) }\end{array}$ & & 107.0 & 3 \\
\hline
\end{tabular}

Description.

Prodissoconch hardly distinguishable from the adult shell. Height and length measured on 5 valves from Arnum (95.0-95.3m.) were as follows:

$\begin{array}{llllll}\text { Height } & 0.155 & 0.144 & 0.140 & 0.140 & 0.140 \mathrm{~mm} \text {. } \\ \text { Length } & 0.170 & 0.175 & 0.170 & 0.170 & 0.163 \text { - }\end{array}$

Dissoconch. Only three juvenile shells are sufficiently well preserved for study of all shell features. The specimen drawn on plate 11 , fig. 36 is representative of these shells. It shows the characteristic straight anterior dorsal margin, a feature which this species has in common with the recent $T$. flexuosa, and also the orbicular outline which is characteristic of the fossil shells treated here.

Remarks. Recent shells are apparently more elongate than the fossil shells from South Jutland, although orbicular varieties do occur (NobRe 1932). However, the fossil material is insufficient to warrant an objective estimate of the significance of this feature in the fossil material, and data on recent shells are too poor to give a true record of the variability. Therefore, the fossils were not definitely referred to $T$. flexuosa.

Distribution.

Recent: Almost omnipresent; from the Bering Sea and NE Greenland to the Canaries and the Mediterranean in the northern hemisphere. Reported from New Zealand and Australia in the southern hemisphere.

Pliocene: Mediterranean Basin: Italy (Upper Pliocene of Monte Mario).

Miocene: North Sea Basin: Belgium: Anversien. Germany: Hemmoor stage (?), Glimmerton (Banke Rasuussen 1956). Denmark: Arnum formation. 
FAMILIA LUCINIDAE FLEMING 1828

Genus Phacoides Blainville 1825

\title{
37. Phacoides cf. Schloenbachi (von Koenen)
}

Plate 12, fig. 37 a-c.

1867. Lucina Schloenbachi v. Koenen. D. mar. M.-Olig. Norddeutschl. p. 101, pl. 5, fig. 9. ?1907. Lucina Schloenbachi v. Koenen. Ravn. Molluskf. Jyll. Tert. p. 275, pl. 1, fig. 24. 1916. Lucina cf. Schloenbachi v. Koenen. NørregaArd. M.-mioc. Blokke fra Esbjerg. p. 13.

1925. Lucina (Phacoides) Schloenbachi v. Koenen. Kautsky. D. Mioc. v. Hemmoor u. Basbeck-Osten. p. 33, pl. 3, fig. 17-18.

1941. Lucina Schloenbachi v. Koenen. Görges. D. Oberolig. Fauna v. Rumeln a. Niederrhein. p. 163.

Essential features of original description. Relatively flat valves with fine, concentric striae occasionally developing into pointed scales on the posterior dorsal margin. Well defined lunule. (no real description or diagnosis given by v. Koenen).

Shell material.

$\begin{array}{lrl}\text { Location } & \text { Depth } & \text { Shells } \\ \text { Glejbjerg } & 53.5 \mathrm{~m} . & 1 \text { frg. of right valve. } \\ & 53.75- & 1-\text { of umbo of left } \mathrm{v} . \\ \text { Toftlund } & 110-115- & 1 \text { juvenile right } \mathrm{v} .\end{array}$

Description.

Prodissoconch unknown.

Dissoconch. Exterior of the initial part of the adult shell is rather glossy between the concentric ribs, which are developed as minute, slightly projecting lamellae. The hinge of the left valve includes two cardinal teeth. Lateral teeth are not preserved. Interior unknown. Dimensions of juvenile right valve: height 0.9 , length 1.05 , width $0.30 \mathrm{~mm}$.

Remarks. There seems to be rather good evidence that the shell fragments should be referred to Phacoides Schloenbachi, but the determination is not certain.

Distribution.

Miocene: North Sea Basin: Germany: Hemmoor stage. Denmark: Arnum formation.

Oligocene: North Sea Basin: Germany (m.-u.) Denmark (u.) (HARDER 1913).

\section{Genus Loripes Poli 1791}

\section{Loripes cf. niveus (Eichwald)}

\author{
Plate 12, fig. 38 a-c.
}

1830. Lucina nivea Eichwald. Nat. Skizze v. Lithauen Volh. u. Podol. p. 206.

1853. Lucina nivea Eichwald. Lethaea Rossica 3, p. 83, pl. 5, fig. 2-3.

1911. Loripes (Microloripes) cf. niveus (Eichwald). Cossmann \& Peyrot. Conch. Néogén. d. l'Aquit. p. 265, pl. 26, fig. 77-80.

1925. Lucina (Loripes) dentata Bast. var. laevigata. Kautsky. D. Mioc. v. Hemmoor u. Basbeck-Osten. p. 32, pl. 3, fig. 15-16. 
Original diagnosis. Testa nivea, subrotunda, tenuis, fragilis, extus laevis, vix transversim striata, lunula profundiore; dentes laterales conspicui. (EICHWALD 1830).

Shell material. One small right valve from Arnum $53-83 \mathrm{~m}$.

Description.

Prodissoconch smooth, height $0.19 \mathrm{~mm}$., length $0.21 \mathrm{~mm}$.

Dis s o con ch somewhat damaged. Ex terior with relatively strong concentric ribs and furrows and slight indications of shallow radial furrows. Hinge of the specimen worn. One strong tooth is found below the umbo. Indications of a lateral tooth on each side of the umbo. Shell margin with knobs and interior of the shell with radial traces of the earlier stages of the knobs. Dimensions of the shell: height 1.08, length 1.1 and width $0.33 \mathrm{~mm}$.

Remarks. The worn nature of the shell, its small size, and insufficient data on EichwaLD's species leave considerable doubt concerning the reference of the shell to this species, while there is less doubt about grouping the shell in one taxonomic unit with Cossmann \& Peyrot's and KaUtsky's species. However, since the two French authors had shells of $L$. niveus from Poland at their disposal, the provisional reference to L. niveus has been maintained.

Distribution.

Miocene: Aquitanian Basin: Burdigalien, Helvétien.

North Sea Basin: Germany: Hemmoor stage. Denmark: Arnum formation.

Genus Lucina Lamarck 1799

Subgenus Loripinus Monterosato 1883

\section{Lucina (Loripinus) Nörregaardi nov. sp.}

Plate 12, fig. 39 a-e.

Diagnosis. Shell fragile, oblique; anterior part larger than posterior part. Antero-dorsal margin and front margin meet in a very obtuse angle. Hinge of right valve with one nodular tooth in front of the umbo. Shell surface smooth. Holotype: plate 12, fig. 39 c-e. Geological Survey of Denmark. Well file no. 150.9. b. Toftlund 105-110 m. Derivatio nominis: See 'Remarks' below.

Shell material.

$\begin{array}{lrl}\text { Location } & \text { Depth } & \text { Shells } \\ \text { Ribe } & 124-125 \mathrm{~m} . & 1 \text { frg. } \\ \text { Gramby } & 84.66-87.16- & \text { 1 left valve (frg.) } \\ & 75-100- & \text { 1 right v. (frg.) } \\ \text { Toftlund } & 105-110- & 3 \text { left and 1 right v. (frg.) and } \\ & & 1 \text { well preserved left v. } \\ & 110-115- & 2 \text { right v. } \\ \text { Arnum } & 53-83- & 1 \text { right v. (frg.) }\end{array}$

Description.

Prodissoconch smooth and glossy. Height $0.22 \mathrm{~mm}$, length $0.26 \mathrm{~mm}$. (measured on the shell from Arnum).

Dissoconch. The following may be added to the diagnosis: Exterior smooth, but not very glossy due to the presence of delicate concentric striae. Indication of faint, irregular, microscopic radial striae on some parts of the 
shell. Lunule delimited by a rather sharp edge corresponding to the anterior angle on the dorsal margin.

Hinge of the left valve devoid of teeth, but with anterior dorsal margin slightly protruding horizontally. Ligament internal below the postero-dorsal margin, in a shallow and narrow furrow extending backwards from the umbo.

Interior very glossy, adductor scars difficult to distinguish. Dimensions of the two well preserved shells:

\begin{tabular}{|c|c|c|c|c|c|}
\hline \multirow{3}{*}{ Toftlund } & & & Height & Length & Width \\
\hline & $105-110 \mathrm{~m}$. left v. & about & 1.4 & 1.44 & $0.34 \mathrm{~mm}$. \\
\hline & $110-115 \mathrm{~m}$. right $\mathrm{v}$. & & 1.24 & 1.36 & $0.32 \quad-$ \\
\hline
\end{tabular}

Remarks. The obliquity of the shell separates this species from any other species of the subgenus Loripinus known to the author. It is very similar to L. fragilis (see for instance Cossmann \& Peyrot 1911, p. 253-257) but is obviously more oblique and apparently less globose than that species.

The species has been named in honour of E. M. NörRegaArd M. Sc. who has contributed valuable studies on the fauna of the Danish Miocene.

Distribution.

Miocene: North Sea Basin: Denmark: Arnum formation.

\section{Genus Codokia Scopoli 1777}

\section{Codokia jutensis nov. sp.}

Plate 13, fig. 40 a-h.

Diagnosis. Shell inequilateral, anterior part larger than posterior part. Surface with strong, concentric ribs occasionally developing into thin, projecting lamellae on the posterior part of the shell. Radial sculpture very subordinate: minute, radial striae may be found in the interspaces between the concentric ribs and on the lamellae. Well defined, relatively smooth, lancet-shaped lunule with growth lines. Left valve with one cardinal tooth and one anterior lateral tooth. Right valve with two cardinal teeth and one lateral tooth in the adult stage; obviously no lateral tooth during the earliest shell stage. Ligament external. Shell margin smooth. Holotype: plate 13, fig. 40 f-h. Geological Survey of Denmark, Well file no. 150. 9. b. Toftlund 110-115 m. Derivatio nominis: jutensis — from (South) Jutland.

Shell material.

Location
Ribe

Ribe
Toftlund

Arnum (25b)

$$
\begin{array}{r}
\text { Depth } \\
124-125 \mathrm{~m} . \\
105-110 \text { - } \\
110-115 \text { - }
\end{array}
$$

$62.7-62.9$

$104.3-107.5$
Shells

1 right valve

1 left valve

2 paired v., 1 left $v$. and 1 frg. of right $\mathrm{v}$.

1 frg. of left v.

2 frg. of left v.

Description.

Prodissoconch smooth and glossy, (preserved on the valve from Toftlund $105-110 \mathrm{~m}$ and on the paired valves from the same well at $110-115 \mathrm{~m}$ ). For dimensions see table below.

Dissoconch. Reference is made to the diagnosis, to which may be added that the lunule is delimited by a relatively sharp keel at which the concentric sculpture described in the diagnosis terminates. A narrow escutcheonal area analogous to the lunule is found behind the umbo, and it is delimited by a keel which is similar to the lunular keel, only less sharp. 


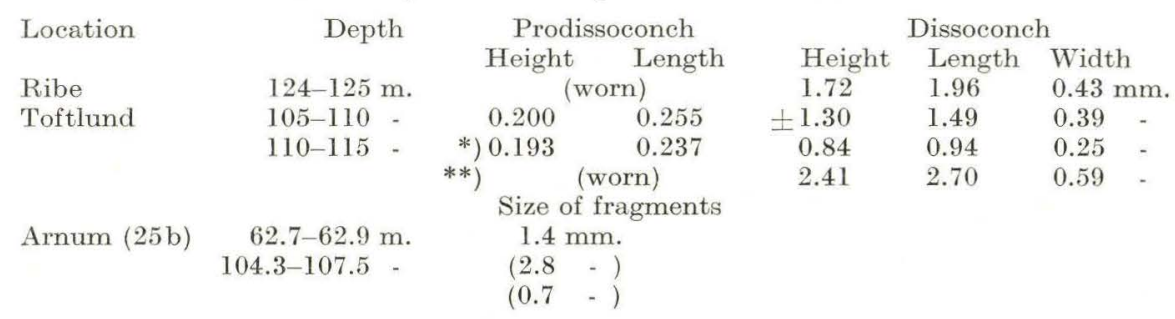

Remarks. It has been impossible to refer the shells concerned to any of the Lucinid species known to the author. There may be some although very

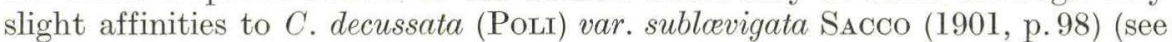
for instance Cossmann \& Peyrot 1911, p. 303, pl. 28, fig. 42-46). However the absence particularly of radial elements in the sculpture of $C$.jutensis excludes it from $C$. decussata.

Distribution.

Miocene: North Sea Basin: Denmark: Arnum formation.

\section{Codokia sp.}

Shell material. Glejbjerg $53.5 \mathrm{~m}$. One fragment of a left valve.

Description.

Exterior. The fragment shows some of the features of $C$.jutensis described above. It has irregular concentric ribs on the anterior part of the shell (posterior part unknown) and minute, microscopic, concentric striae between the ribs.

Minute, radial striae are seen adjacent to the umbo, while a coarser rib structure is seen on the shell at some distance from the umbo and at the margin, where the shell surface is rather smooth.

Hinge partly broken. One cardinal tooth is preserved, and a lateral tooth occurs at some distance from the umbo, as in C. jutensis.

Interior smooth, shell margin crenated.

Remarks. The sculpture of this shell is very similar to that of $C$. decussata var. sublaevigata referred to above. The radial sculpture and the crenation of the margin separate the present shell from those described under C.jutensis.

\section{FAMILIA ERYCINIDAE DESHAYES 1857}

Genus Erycina Lamarck 1804

Subgenus Scacchia PHILIPPI 1844

\section{Erycina (Scacchia) Degrangei Cossmann \& Peyrot}

Plate 13, fig. $42 \mathrm{a}-\mathrm{b}$.

1911. Erycina (Scacchia) Degrangei. Cossmann \& Peyrot. Conch. Néogén. d. l'Aquit. p. 172 , pl. 24, fig. 1-6.

1925. Erycina (Scacchia) Degrangei. Cossm. Kautsky. D. Mioc. v. Hemmoor u. BasbeckOsten. p. 33, pl. 3, fig. 19.

1939. Erycina (Scacchia) Degrangei. Cossm. \& Peyr. Kautsky. D. Erycinen d. niederöst. Mioc., p. 594, pl. 19. fig. 15-16.

*) Paired valves pl. 13 , fig. $40 \mathrm{a}$-d.

**) Left valve pl. 13, fig. $40 \mathrm{f}$-h. 
Essential features of original description. "Taille petite; forme orbiculaire ou elliptique, trigone vers le crochet, médiocrement convexe, presque. symmetrique ... crochets petits, peu saillants, prosogyres, situés très peu en arrière de la ligne médiane... Surface dorsale peu bombée, non déprimée cependant vers les bords, couverte de stries d'acroissement fines et serrées, que croissent — surtout vers les extrémitées - des rayons divergents et divariqués, qu'on n'aperçoit que sous un fort grossissement.

Charnière peu épaisse ... 1 formée d'un petit talon oblique qui fait saillie sur le contour inférieure du bord cardinal; ... A I et P I bien visibles, longues, dédoublant - pour ainsi dire - le bord supérieur dans sa partie rectiligne, assez loin du crochet; 2 oblique et pointue, 4 b beaucoup plus courte sous le crochet; $A$ II et P II complètement confondues avec le bord ... (Cossmann \& Peyrot 1911).

Shell material.

$\begin{array}{lrrrrr}\text { Location } & \text { Depth } & \text { Shells } & \text { Location } & \text { Depth } & \text { Shells } \\ \text { Gramby } & 84.66-87.16 \mathrm{~m} & 14 & \text { Toftlund } & 110-115 \mathrm{~m} . & 10 \\ & 90.42-92.72- & 1 & \text { Arnum }(13) & 53-83- & 1 \\ \text { Toftlund } & 109.29-110.86- & 2 & (25 \mathrm{~b}) & 62.7-62.9- & 5 \\ & 75-100- & 5 & & 95.0-95.3- & 2 \\ & 100-105- & 1 & & 104.3-107.5- & 2 \\ & 105-110- & 23 & & 107.5- & 2\end{array}$

Description.

Prodissocon ch large, trigonal elliptical, smooth and glossy. For dimensions see table below.

Dissoconch. It agrees completely with the shells from the Aquitanian Basin, judging from Cossmann \& PEYRoT's description. It may, however, be added that the dorsal margin of the right valve is sharp and a little projecting, while the margin of the left valve is rounded. A I and P I, as described by the original authors, may only be secondary thickenings of the lower part of the dorsal margin and not true lateral teeth. Together with the protruding edge of the right dorsal margin these thickenings obviously form a bearing for the left dorsal margin.

\begin{tabular}{|c|c|c|c|c|c|c|c|}
\hline \multirow{5}{*}{$\begin{array}{l}\text { Location } \\
\text { Arnum (13) } \\
\qquad(25 \mathrm{~b})\end{array}$} & \multicolumn{5}{|c|}{ Erycina (Scacchia) Degrangei. Dimensions of shells } & & \\
\hline & \multirow[t]{2}{*}{ Depth } & \multicolumn{2}{|c|}{ Prodissoconch } & \multicolumn{4}{|c|}{ Dissoconch } \\
\hline & & Height & Length & Height & Length & Widt & \\
\hline & $53-83 \mathrm{~m}$. & 0.650 & 0.780 & 1.41 & 1.76 & 0.44 & $\mathrm{~mm}$. \\
\hline & $62.7-62.9-$ & 0.685 & 0.805 & & & & - \\
\hline & & 0.645 & 0.745 & & & & - \\
\hline & & 0.630 & 0.720 & & & & - \\
\hline & $95.0-95.3-$ & 0.667 & 0.780 & 1.76 & 2.16 & 0.49 & - \\
\hline & & 0.580 & 0.650 & & & & - \\
\hline
\end{tabular}

Remarks. E. Degrangei seems to be very well defined, and there can be no doubt about the correctness of the specific determination, while there may be some doubt as to the taxonomic position of the genus. However, this question cannot be solved at present.

Variability. The radial sculpture of fine radial striae, which is particularly well developed at the anterior and posterior ends, may be indistinct on some shells. The size of the prodissoconch obviously varies considerably.

Distribution.

Miocene: Aquitanian Basin: Helvétien.

North Sea Basin: Germany: Hemmoor stage. Denmark: Arnum formation.

Vienna Basin: Grund sands. Baden clay. 


\title{
43. Erycina (Hemilepton) coarctata (Wood)
}

\author{
Plate 13, fig. 43 a-b.
}

1851. Kellia coarctata S. Wood. Monogr. Crag Moll. 2, p. 123, pl. 12, fig. 10.

?1945. Montacuta (Montacuta) coarctata Wood sp. Glibert. Faune mal. du Mioc. de la Belgique. 1, p. 166, pl. 10, fig. 13.

Original diagnosis. Testa minuta transversa, oblonga, lavigata, polita, compressa, suboquilaterali; antice majore, dente cardinali unico in utraque valva, laterabilus nullis; margine ventrali recto, vel coarctato. (Wood 1851).

Shell material.

$\begin{array}{lcl}\text { Location } & \begin{array}{c}\text { Depth } \\ 100-105 \mathrm{~m} .\end{array} & \begin{array}{l}\text { Shells } \\ 1 \text { left and } 1 \text { right valve } \\ \text { Toftlund }\end{array} \\ \begin{array}{ll}3 \text { left and } 2 \text { right valves and } \\ 2 \text { paired valves }\end{array} \\ \text { Arnum (13) } & 53-83- & \begin{array}{l}1 \text { right valve }\end{array}\end{array}$

Description.

Prodissoconeh smooth and glossy of intermediate size. For dimensions see table below.

Dissoconch oblong trapezoidal, anterior end larger than posterior end, right valve more convex than left valve. The shell margin not in a plane; appears contorted.

Exterior smooth, with concentric lines; on some shells indication of very faint, microscopic, radial striae particularly at the ends of the shell. Dorsal margin of the right valve protrudes over the dorsal margin of the left valve.

Hinge of right valve with one cardinal tooth below the umbo; one very fine, hardly perceptible dental "rib" parallel with the margin on either side of the umbo, somewhat below the dorsal margin. Ligament in a shallow furrow below the umbo. Hinge of the left valve with one cardinal tooth, but whithout ribs as in the right valve. Dorsal margin of left valve rounded.

Interior smooth and glossy, with indications of radial elements in the inner shell layer. Adductor scars indicated on accompanying figure on plate 13 .

\begin{tabular}{|c|c|c|c|c|c|c|c|c|}
\hline \multirow[t]{2}{*}{ Location } & \multirow[t]{2}{*}{ Depth } & \multirow[t]{2}{*}{ Valve } & \multicolumn{2}{|c|}{ Prodissoconch } & \multicolumn{4}{|c|}{ Dissoconch } \\
\hline & & & Height & Length & Height & Length & Wic & th \\
\hline \multirow[t]{3}{*}{ Toftlund } & $100-105 \mathrm{~m}$. & left & 0.340 & 0.375 & 1.69 & 2.62 & 0.39 & $\mathrm{~nm}$. \\
\hline & & right & 0.355 & 0.395 & 1.15 & 1.80 & 0.33 & - \\
\hline & $105-110$ & $\{$ left*) & 0.387 & 0.435 & 1.78 & 2.73 & 0.39 & - \\
\hline cnum (13) & $53-83=$ & right & 0.305 & 0.313 & 0.98 & 1.56 & 0.27 & - \\
\hline
\end{tabular}

Remarks. The present shells apparently exhibit all the characters of $K$. coarctata as described by WooD, except for the delicate dental ribs on the right valve. Even the twisted appearance may be observed in the shells from South Jutland. The hinge otherwise displays the features of Hemilepton as defined by Cossmann. By comparison with E. Degrangei, described above, it appears that the relations between the left and right valves, and hinge features, are essentially the same in the two species. The writer has, therefore, grouped the

*) Paired valves. 
two species closely together although the proposed genus and subgenera may not necessarily be final.

The specimens from Belgium are included in the synonymy with some doubt since the figured shell looks a little different in outline, and the hinge could not be seen on the illustration.

Distribution.

Pliocene: North Sea Basin: England: Coralline Crag.

Miocene: North Sea Basin: Belgium: Anversien (?). Denmark: Arnum formation.

\section{Erycina (Hemilepton) striatissima (Cerulli-Irelli)}

Plate 15, fig. 44 a-f.

1908. Lepton striatissimum Cerulli-Irellt. Fauna mal. mariana. p. 3, pl. 1, fig. 6-7.

Essential features of original description. Conchiglia sub-rettangolare, allungata, molto depressa ed inequilaterale, fragile... Umbone acuto, poco sporgente, situato presso il margine posteriore ad ${ }^{1 / 3}$ circa dell'intera lunghezza.

Superficie esterna fortemente striata per traverso: strie lamelliformi, numerose, spesso confluenti, concentriche ma non circolari, bensi divise, lungo linee che iradiano dall'umbone, in tanti segmenti sub-rettilinei, paralleli fra loro. Cardine della valva destra constituito due dente laterali lamelliformi, robusti, separati dal margine da una fossetta ampia, ma non molto profunda, il dento posteriore appare, benchè oscuramente, doppio per un relievo dentiforme del margine dorsale: nella valva sinistra pure due denti laterali, quasi confusi col margine dorsale, il posteriore piu breve e piu vicino all'umbone; non vi è traccia di dentino apicale, solamente il dente laterale anteriore presenta presso l'umbone una piccola sporgenza. Fosseta legamentare piccola, triangolare, leggermente obliqua indietro. (Cerulli-Irelli 1908).

Shell material.

Toftlund $105-110 \mathrm{~m}$. 1 left and 1 right valve. The dimensions of the shells are as follows:

*) left valve

right valve

\begin{tabular}{llll} 
& \multicolumn{3}{c}{ Prodissoconch } \\
Height & Length Width \\
about & 0.5 & 0.530 & \\
0.52 & 0.572 & 0.128
\end{tabular}

\begin{tabular}{lcl}
\multicolumn{3}{c}{ Dissoconch } \\
Height Length Width \\
1.6 & 2.2 & $0.40 \mathrm{~mm}$. \\
1.41 & about 1.8 & $0.33 \quad$ -
\end{tabular}

Description.

Prodissoconch relatively large, smooth and glossy.

Dissoconch. Exterior. The undulating concentric striae are very characteristic of this species, and it is particularly significant that the shell outline is trapezoidal on account of the well developed shoulders on the dorsal margin.

The Hinge is relatively strongly developed, with one capital tooth dipping forward from the umbo in either valve and a broad tooth pit above the tooth of the right valve to accomodate the tooth of the left valve. The dorsal margin forms more or less pronounced angles with the anterior and posterior shell margins, as particularly well seen on the figured left valve. The writer would not interpret the features of the posterior dorsal margin as dental features, as has obviously been done by Ceruldi-IRELLI.

*) Damaged. 
The interior is smooth, with the pallial line and the adductor muscle scars clearly seen. The anterior adductor scar is apparently the more important, but this may not be a consistent feature of the species. A significant feature of this species (as also in E. Degrangei described above) is the reflection of the prodissoconch concavity on the interior of the shell.

Remarks. There can hardly be any doubt as to the morphological relationship between $E$. Degrangei, $E$. coarctata, and the present species. The hinge of the present species may be interpreted as an exaggerated derivative of the typical Hemilepton hinge as described by Cossmann \& Peyrot (1911 p. 166). The dorsal margin of E. striatissima is short compared with E. coarctata, while the size and development of the prodissoconch and the dissoconch are very similar to the corresponding features and parts of the shell of $E$. Degrange $i$.

The writer therefore included the species in the genus Erycina.

Distribution.

Pliocene: Mediterranean Basin: Italy: upper Pliocene of Monte Mario.

Miocene: North Sea Basin: Denmark: Arnum formation.

\section{Genus Lepton Turton 1822}

\section{Lepton nitidum Turton}

Recent:

Plate 15, fig. $45 \mathrm{a}-\mathrm{b}$.

1822. Lepton nitidum Turton. Conch. Ins. Brit. p. 63.

1853. Kellia nitida Turton. Forbes \& Handey 2, p. 92, pl. 36, fig. 3-4. 4, p. 255.

1863. Lepton nitidum Turton. Jefrreys. Brit. Conch. 2, p. 198. 5, pl. 31, fig. 3.

1867. Lepton nitidum Turton. Weinkauff. Conch. d. Mittelmeeres 1, p. 181.

1892. Lepton nitidum Turton. Locard. Coq. mar. d. côtes d. France p. 321.

1934. Lepton nitidum Turton. Ad. S. Jensen \& R. Spärck. Saltvandsmuslinger, p. 96.

Fossil:

1861. Lepton nitidum Turton. Wood. Monogr. Crag Moll. 2, p. 116, pl. 11, fig. 7.

1908. Lepton nitidum Turton. Cerulli-Ireldi. Fauna mal. mariana. p. 1, pl. 1, fig. 1-4.

Original diagnosis. Lepton testa nitida, transversim substriata (TURTON 1822).

Shell material and dimensions.

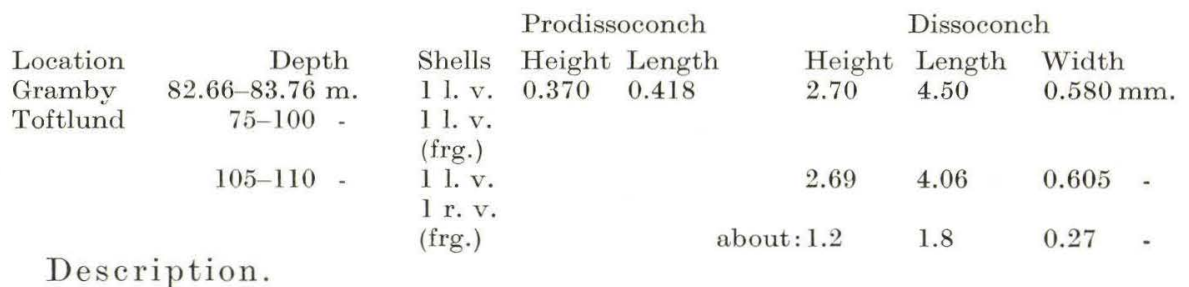

Prodissoconch smooth and glossy on the single shell where it is preserved. It is generally corroded due to the formation of the well known punctation around the umbo.

Dissoconch apparently rather oblong compared with the typical recent forms, but otherwise it shows the features of the species. No further comments will therefore be made. 
Distribution.

Recent: North Atlantic Ocean: Western Norway to the Mediterranean.

Pliocene: North Sea Basin: England: Coralline Crag.

Mediterranean Basin : Italy: upper Pliocene of Monte Mario.

Miocene: North Sea Basin: Denmark: Arnum formation.

FAMILIA MONTACUTIDAE

\section{Genus Montacuta Turton 1822}

\section{Montacuta substriata (Montagu)}

Recent:

Plate 14, fig. $46 \mathrm{a}-\mathrm{b}$.

1808. Ligula substriata Montagu. Test. Britannica. Supplem. p. 25.

1853. Montacuta substriata Montagu. Forbes \& Hanley. Brit. Moll. 2, p. 77, pl. 18, fig. 8, pl. O, fig. 2.

1863. Montacuta substriata Montagu. Jeffreys. Brit. Conch. 2, p. 205, 5, pl. 31, fig. 6. 1867. Montacuta substriata Montagu. Weinkauff. Conch. d. Mittelmeeres, p. 177.

1878. Montacuta substriata Montagu. Sars. Moll. Reg. Arct. Norvegiae. I, p. 68, pl. 19, fig. 16.

1892. Montacuta substriata Montagu. Locard. Coq. mar. d. côtes d. France p. 321.

1934. Montacuta substriata Montagu. AD. S. Jensen \& R. Spärck. Saltvandsmuslinger p. 100.

Fossil:

1861. Montacuta substriata Montagu. Wood. Monogr. Crag Moll. 2, p. 128, pl. 12, fig. 12. 1908. Montacuta substriata Montagu sp. Ceruldi-Ireldi. Fauna mal. mariana p. 12, pl. 1, fig. $29-31$.

1939. Montacuta substriata Montagu. Kautsky. D. Erye. d. niederöst. Mioc. p. 621, pl. 21 , fig. $22-25$.

Original diagnosis. Shell sub-ovate, white, and sub-pellucid, wrought with distant, obsolete, elevated, longitudinal striae: umbo prominent, but not inclined. Inside plain, and the margin smooth: the hinge furnished with a slight projection inwards, margined so as to form a concavity. (Montagu 1808).

Shell material and dimensions.

\begin{tabular}{|c|c|c|c|c|c|c|}
\hline \multirow[b]{2}{*}{ Gramby } & \multirow[b]{2}{*}{$84.66-87.16 \mathrm{~m}$. } & \multirow[b]{2}{*}{ 1 l. v. } & \multicolumn{2}{|c|}{ Prodissoconch } & \multicolumn{2}{|r|}{ Dissoconch } \\
\hline & & & $\begin{array}{l}\text { Height } \\
0.240\end{array}$ & $\begin{array}{l}\text { Length } \\
0.264\end{array}$ & $\begin{array}{l}\text { Height } \\
1.14\end{array}$ & $\begin{aligned} \text { Length } & \text { Width } \\
\text { abt.1.24 } & 0.255 \mathrm{mr}\end{aligned}$ \\
\hline
\end{tabular}

Description.

Both prodissoconch and dissoconch smooth and very glossy, translucent. Dissoconch with about 25 more or les curved radial riblets. The number of riblets increases with growth by the irregular formation of new riblets between the primary riblets particularly on the anterior part of the shell. Hinge formed by projecting shell margin in front of the umbo and a minute tooth behind the umbo. Resiliophore indistinct.

The internal features are very indistinct because of the small size of the shell.

Distribution.

Recent: North Atlantic Ocean from Western Finmark to and including the Mediterranean. 


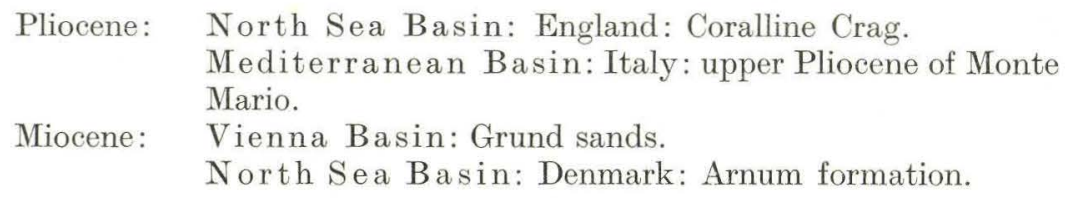

\section{FAMILTA CARDIIDAE FISCHER 1887}

\section{Genus Laevicardium Swainson 1840}

\section{Laevicardium cyprium (Brocchi)}

1814. Venus cypria G. Brocchi. Conchiol. Foss. Subapennina. 2, p. 545, pl. 13, fig. 14.

1867. Cardium cingulatum Goldfuss. v. Koenen. D. mar. M.-Olig. Nordd. p. 97.

1870. Cardium fragile Brocchi. Hörnes. D. foss. Moll. d. Tert.-Beckens v. Wien 2, p. 178, pl. 30 , fig. 6 .

1899. Laevicardium cyprium (BR.) SAcco. I moll. d. terr. terz. d. Piemonte e d. Liguria 27, p. 52, pl. 12, fig. 1-3.

1907. Cardium comatulum Bronn. Ravn. Molluskf. Jyll. Tert,, p. 276, pl. 1, fig. 25.

1907. Cardium fragile BRocchi. Ibid. p. 277.

1911. Cardium (Lovicardium) leptocolpatum. Cossmann \& Peyrot. Conch. Néogén. d. l'Aquit. p. 138, pl. 23, fig. 25-27.

1913. Cardium comatulum Bronn. Harder. De olig. Lag. etc. v. Aarhus St., p. 58, pl. 4, fig. 21.

1925. Cardium (Laevicardium) cyprium Brocchi. KaUtsky. D. Mioc. v. Hemmoor u. Basbeck-Osten. p. 37, pl. 4, fig. 7.

1940. Cardium comatulum BRONN. GöRGES. D. Oberolig.-fauna v. Rumeln a. Niederrhein, p. 162.

1944. Laevicardium comatulum (Bronn). HeEring. D. oberolig. Biv. a. d. Peelgebiete. p. 31, pl. 10, fig. 1-4, 13-14.

Original diagnosis. Testa cordiformis inflata, longitudinaliter obsolete striata, latere antico sulcis muricatis exasperato, apicibus conniventibus, margine argute denticulato. (BrocchI 1814).

Shell material.

\begin{tabular}{|c|c|c|}
\hline Location & Depth & Shells \\
\hline Ribe & $113-114 \mathrm{~m}$. & 5 frg. \\
\hline Gramby & $82.66-83.76-$ & 1 frg. \\
\hline \multirow[t]{4}{*}{ Toftlund } & $75-100-$ & 3 left $\mathrm{v} .1$ right $\mathrm{v}$. \\
\hline & $100-105-$ & 3 r. v. (frg.) \\
\hline & $105-110-$ & l l. v. 1 r. v. +12 v. (frg.) \\
\hline & 115 - & 10 frg. \\
\hline \multirow{3}{*}{ Arnum $(25 \mathrm{~b})$} & $95.0-95.3-$ & 1 frg. \\
\hline & $104.3-107.5$ & 2 frg. 1 r. v. \\
\hline & 107.5 & $1 \mathrm{fr}$. \\
\hline
\end{tabular}

Description. The fragmentary shell material prevents detailed description of the development of the species in the Danish deposits. However, some comments may be made on the first shell stages.

Prodissoconch smooth and glossy, orbicular. See table below for dimensions.

Dissoconch. The initial adult shell is characterized by being practically devoid of radial sculpture. The exterior is smooth and glossy, and the fine concentric striae may only be seen under hand lens. 
The radial ribs emerge about $2 \mathrm{~mm}$. from the umbo. The adult shell has 65 to 80 ribs which are obsolete laterally and most strongly developed on the posterior end.

The Hinge is of the common Cardium-type with two lateral teeth in front of and two behind the umbo in the right valve, while the left valve having two lateral teeth in front of the umbo and only one behind.

The Interior could not be studied except for the margin, which is crenated with somewhat pointed knobs opposite the interspaces between the ribs.

\section{Laevicardium cyprium. Dimensions of shells.}

\begin{tabular}{|c|c|c|c|c|c|c|c|c|c|}
\hline \multirow{5}{*}{$\begin{array}{l}\text { Location } \\
\text { Gramby } \\
\text { Toftlund }\end{array}$} & \multirow{4}{*}{$\begin{array}{c}\text { Depth } \\
82.66-83.76 \mathrm{~m} . \\
75-100-\end{array}$} & \multicolumn{3}{|c|}{ Prodissoconch } & \multicolumn{4}{|c|}{ Dissoconch } & \multirow{2}{*}{$\begin{array}{l}\text { Number of } \\
\text { radial ribs }\end{array}$} \\
\hline & & Shells & Height & Length & Height & Length & Widtl & & \\
\hline & & l l. v. & 0.425 & 0.425 & 3.80 & 4.11 & \multicolumn{2}{|c|}{$1.29 \mathrm{~mm}$. } & about 70 \\
\hline & & $1 \mathrm{l} . \mathrm{v}$. & 0.387 & 0.403 & 3.07 & 3.48 & 0.98 & - & 75 \\
\hline & \multirow{4}{*}{$105-110$} & $1 \mathrm{l} . \mathrm{v}$. & \multicolumn{2}{|c|}{ (worn) } & 3.60 & 3.79 & 1.18 & - & $-65-70$ \\
\hline & & $1 \mathrm{r} . \mathrm{v}$. & 0.43 & 0.43 & 2.93 & 3.06 & 0.98 & - & 70 \\
\hline & & $1 \mathrm{l} . \mathrm{v}$. & 0.39 & 0.43 & 3.95 & 4.22 & 1.33 & - & \multirow[t]{2}{*}{$-70-75$} \\
\hline & & $1 \mathrm{r} . \mathrm{v}$. & 0.43 & 0.41 & 1.91 & 2.01 & 0.66 & - & \\
\hline num $(25 \mathrm{~b})$ & $95.0-95.3-$ & 1 r.v. & (wo & orn) & 3.55 & 3.87 & 1.18 & - & - 65 (?) \\
\hline
\end{tabular}

Distribution.

Pliocene: Mediterranean Basin: Italy: Piacenziano.

Miocene: Aquitanian Basin: Burdigalien, Tortonien.

North Sea Basin: Germany: Hemmoor stage. Denmark: Arnum formation.

Mediterranean Basin: Elveziano, Tortoniano.

Vienna Basin: Geinfahren clay.

Oligocene: North Sea Basin: Holland (u.) Germany (m.-u.) Denmark (u.).

\section{Laevicardium dingdense (Lehmann)}

Plate 16, fig. 48 a-e.

1892. Cardium Dingdense Lehmans. D. Lam. d. Mioc. v. Dingden. 1, p. 238, pl. 4, fig. 9 1911. Cardium (Laevicardium) pantecolpatum. Cossmann \& Peyrot. Conch. Néogén. d. l'Aquit. p. 136, pl. 23, fig. 32-35.

1916. Cardium sp. NørRegaArd. Mellem-mioc. Bl. fra Esbjerg. p. 14, pl. 1, fig. 5.

1925. Cardium (Laevicardium) Dingdense Lehmann. Kautsky. D. Mioc. v. Hemmoor u. Basbeck-Osten. p. 38, pl. 4, fig. 8 .

Essential features of original description. Shell almost equilateral, indistinct keel from the umbo to the postero-ventral margin. About 40 smooth, flat, radial ribs separated by interspaced narrower furrows. Shell surface smooth adjacent to the umbo. (No real diagnosis in Lehmann's paper from 1892).

Shell material.

$\begin{array}{cccrcc}\text { Location } & \text { Depth } & \text { Shells } & \text { Location } & \text { Depth } & \text { Shells } \\ \text { Glejbjerg } & 23 \mathrm{~m} . & 4 \text { frg. } & \text { Glejberg } & 52 \mathrm{~m} . & 1 \mathrm{frg} . \\ & 25- & 6 \text { frg. } 1 \text { r.v. } & & 53- & 30 \text { frg. } \\ & 32- & 9 \text { frg. } 1 \text { r.v. } & & 53.5- & 17 \text { v. (frg.) } \\ & 42- & \text { 10 frg. } 1 \text { r.v. } & & 53.75- & 3 \text { v. } \\ & 48- & \text { (frg.) } & 54 \text { frg. } & 55- & 1 \text { v. (sev.frg.) }\end{array}$




\begin{tabular}{|c|c|c|c|c|c|c|c|}
\hline Location & Dept & & Shells & Location & Dep & & Shells \\
\hline Bramminge & $70-80$ & & $13 \mathrm{v}$. & Toftlund & $110-115$ & & $9 \mathrm{v} \cdot($ ptly frg.) \\
\hline Gramby & $82.66-83.76$ & - & 20 frg. $4 \mathrm{v}$ & & 115 & - & $12 \mathrm{v} \cdot($ ptly frg.) \\
\hline & & & (frg.) & Arnum (13) & $53-83$ & - & $1 \mathrm{v} \cdot(\mathrm{ptly}$ fr \\
\hline & $84.66-87.16$ & - & $\begin{array}{l}3 \text { frg. } 4 \text { v. } \\
\text { (frg.) }\end{array}$ & & $83-94$ & - & $\begin{array}{l}3 \mathrm{frg} . \\
2 \mathrm{frg} .\end{array}$ \\
\hline & $92.72-109.29$ & - & $1 \mathrm{frg}$. & Arnum (25b) & $62.7-62.9$ & - & $4 \mathrm{v} \cdot($ ptly frg.) \\
\hline Toftlund & $75-100$ & - & $19 \mathrm{v} \cdot$ (ptly frg. & & $104.5-107.5$ & - & $4 \mathrm{v}$. \\
\hline & $100-105$ & - & 6v.(ptly frg. & & 107.5 & - & $1 \mathrm{frg}$. \\
\hline & $105-110$ & - & $10 \mathrm{v}$. (ptly frg. & & & & \\
\hline
\end{tabular}

Description. The fragmentary material is insufficient for a description of all shell features, however, some significant characters will be discussed.

Prodissoconch smooth and glossy, almost circular, it is difficult to distinguish on the adult shell which is smooth, and without radial ribs at the umbo. The dimensions of two distinguishable prodissoconchs are given in the table below.

Dissoconch. Exterior. The radial ribs, of which there are about 40, are more elevated than in $L$. cyprium. They emerge somewhat below the umbo, but probably a little earlier than in the above-named species.

The hinge includes one major cardinal tooth in each valve, a less strong tooth adjacent to it, and, in the right valve, two lateral teeth both in front of and behind the umbo. The left valve has only one posterior lateral and two anterior teeth.

The interior shows no features which have not been described by earlier authors. It is significant that there are marginal "ribs", corresponding to the rib interspaces on the external surface, which may occasionally be traced back for a short distance into the internal of the shell. These ribs are furnished with a shallow furrow at the margin.

Laevicardium dingdense. Dimensions of shells.

\begin{tabular}{|c|c|c|c|c|c|c|c|c|c|c|}
\hline & & & Prodis & oconch & & Dissocor & ich & & Numb & $\operatorname{erc}$ \\
\hline Location & Depth & Shells & Height & Length & Height & Length & Wid & & $\mathrm{rad}$ & \\
\hline Glejbjerg & $32 \mathrm{~m}$. & $1 \mathrm{r}, \mathrm{v}$. & $0.31^{\circ}$ & $0.39^{\circ}$ & 3.9 & 4.0 & 1.29 & $\mathrm{~nm}$. & about & \\
\hline Gramby & $84.66-87.16-$ & $1 \mathrm{l} . \mathrm{v}$. & & orn) & 5.1 & 5.4 & 1.6 & - & - & \\
\hline Toftlund & $75-100-$ & $1 \mathrm{r} . \mathrm{v}$. & 0.35 & 0.43 & 6.25 & (damag & ed) & & & \\
\hline & $115-$ & 1 l. v. & & orn) & 7.9 & 8.25 & 2.45 & - & & \\
\hline & & l l. v. & & 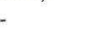 & 6.65 & 6.75 & 2.37 & - & & \\
\hline
\end{tabular}

Distribution.

Miocene: Aquitanian Basin: Burdigalien.

North Sea Basin: Germany: Hemmoor and ReinbekDingden stages, Denmark: Arnum formation.

\section{Genus Cardium Linné 1758}

\section{Cardium Straeleni Glibert}

Plate 16, fig. 49 a-b.

1925. Cardium (Parvicardium) Kochi Semper. Kautsky. D. Mioc. v. Hemmoor u. BasbeckOsten. p. 37 , pl. 4, fig. 5-6.

1945. Cardium (Parvicardium) straeleni Guıbert. Faune mal. du Mioc. de la Belgique. I, p. 174, pl. 11, fig. 1 . 
Essential features of original description. Shell orbicular, subequilateral; about 25 radial ribs with scale-shaped knobs of same width as the ribs. Interspaces between the radial ribs with closely spaced minute concentric ribs. (No real diagnosis in GLIBERT's paper from 1945).

Shell material.

$\begin{array}{lrrlrr}\text { Location } & \text { Depth } & \text { Shells } & \text { Location } & \text { Depth } & \text { Shell } \\ \text { Glejbjerg } & 25 \mathrm{~m} . & 1 & \text { Arnum (13) } & 28-40 \mathrm{~m} . & 1 \\ & 42- & 1 & & 53-83- & 2 \\ \text { Ribe } & 53.5- & 1 & \text { Arnum (25b) } & 62.7-62.9- & 6 \\ \text { Gramby } & 113-114- & 1 & & 95.0-95.3- & 2 \\ \text { Toftlund } & 82.66-83.76- & 2 & 101-104.3- & 1 \\ & 75-100- & 3 & 104.3-107.5- & 1 \\ & 100-105- & 1 & 107.5- & 1 \\ & 105-110- & 15 & & & \end{array}$

Description.

Prodissoconch smooth and glossy, generally easily distinguishable on the adult shell. Outline orbicular to slightly oblong, size variable (see table below).

Dissoconch. Only small specimens and fragments are available. Outline rounded, height almost equal to length, umbo somewhat anterior.

Exterior with 24-26 radial ribs bearing knobs or blunt spines. The knobs are particularly well developed on the anterior and posterior parts of the shell, where more pointed spines may be found. The knobs are generally convex on the umbonal side and flat on the marginal side. The interspaces between the ribs show fine concentric striae. The radial ribs do not all emerge during the initial bottom-living stage, and it is therefore possible to discriminate between primary and secondary ribs on the oldest part of the shell. One rib is commonly stronger than the others; it occasionally forms a ridge on the shell. It is generally found between the 14th and 19th rib from the antero-dorsal margin.

Hinge. Left valve with a main cardinal tooth, and a subordinate tooth which most authors consider to be a branch of the former; there are two lateral teeth behind and one in front of the umbo. Right valve similar to left valve, but two lateral teeth both in front of and behind the umbo.

Interior. Adductor muscle scars of almost equal size. Shell margin with dentitions corresponding to the interspaces between the ribs on the shell surface.

Cardium straeleni. Dimensions of shells.

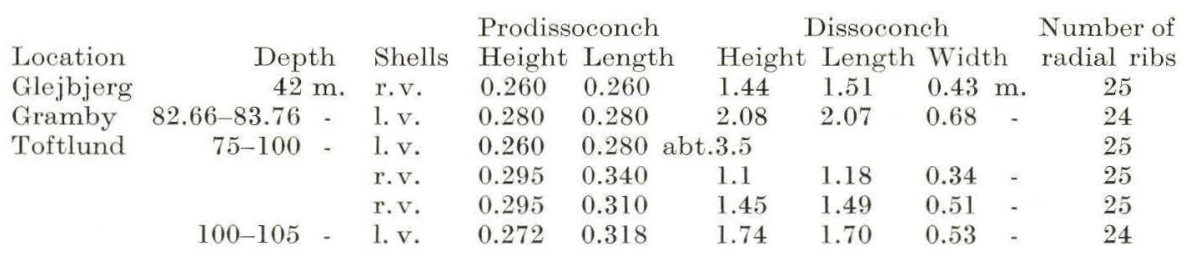

Remarks. C. Straeleni belongs to a group of Cardium species which includes among others $C$. papillosum Poli, C. Kochi Semper, C. Benoisti Cossmann, and $C$. sonense Cossmann all of which are very difficult to distinguish (see for instance Semper 1861, p. 136, Cossmant \& Peyrot 1911 p. 127-128 and KAUTSKY 1925, p. 37). Features commonly regarded as of specific value are: 
shell outline, number of radial ribs, spines and knobs on shell surface, differences in the development of the hinge etc. Study of recent species of the genus has, however, shown that practically all these features may vary notably in a single species, and that the outline of the shell and number of radial ribs, for instance, may be dependent on environment. (see e.g. Bucquoy, DautzeNBERG \& Dollfus 1898 pl. 40-49 and this paper p. 365). There is thus some reason to question the validity of the above mentioned species, and the writer has accordingly been in doubt concerning the reference of the shells from South Jutland.

Regarding the present determination and the synonymy it may be added that there is little doubt as to the identity of the shells described by GLIBERT and Kautsky with the shells described above. C. Benoisti and $C$. sonense are probably also identical with $C$. Straeleni. No final decision could, however, be made by the present author, since the available literature does not include detailed records of the variation of the species.

Distribution.

Miocene: Aquitanian Basin: ? Aquitanien, ? Burdigalien.

North Sea Basin: Germany: Hemmoor stage. Belgium: Anversien. Denmark: Arnum formation.

\section{Cardium cf. hanseatum Kautsky}

Plate 14, fig. 50a-b.

1925. Cardium hanseatum Kautsky. D. Mioc. v. Hemmoor u. Basbeck-Osten. p. 35, pl. 4, fig. $2-3$.

1945. Cardium (Acanthocardia) hanseatum Kautsky. Glibert. Faune mal. du Mioe. de la Belgique. 1, p. 176, pl. 11, fig. 2.

Essential features of original description. Shell orbicular, subequilateral, low umbo, about 18-20 radial ribs with short spines. (No real diagnosis in KaUtskY's paper from 1925).

Shell material and dimensions.

\begin{tabular}{|c|c|c|c|c|c|c|c|c|}
\hline & & & Prodis & ssoconch & & issocone] & & Number of \\
\hline $\begin{array}{l}\text { Location } \\
\text { Gramby }\end{array}$ & $\begin{array}{r}\text { Depth } \\
90.42-92.72 \mathrm{~m} .\end{array}$ & $\begin{array}{l}\text { Shells } \\
1 \text { frg. }\end{array}$ & Height & Length & Height & Length & Width & radial ribs \\
\hline Toftlund & $\begin{array}{r}75-100- \\
110-115=\end{array}$ & $\begin{array}{l}1 \mathrm{r.v} . \\
1 \mathrm{frg} .\end{array}$ & 0.240 & 0.295 & 2.8 & 2.8 & $0.94 \mathrm{~mm}$. & 24 \\
\hline
\end{tabular}

Description.

The fragments display the sculptural features of $C$. hanseatum, but the number of radial ribs, etc., cannot be determined.

The right valve from Toftlund is figured on plate 14, fig. 50. All essential features are shown by this illustration and the dimensions of the prodissoconch and the dissoconch are listed above.

Remarks. It is impossible to arrive at a safe conclusion regarding the relationships of the figured juvenile shell, since very little has been reported in the literature on the juvenile stages of the Cardium species concerned. There are obvious differences between this shell and most related species, particularly regarding number of radial ribs, which is relatively high in the specimen from Toftlund compared with, for instance, C. hanseatum Kautsky and C. leogna- 
nense Mayer (in Cossmann \& Peyrot 1911, p. 21, fig. 1-2, 10-13). Reference should be made to the remarks on $C$. Straeleni p. 104. The present valve has provisionally been included in $C$. hanseatum.

A statistical investigation of the variability of the great number of species and varieties of Cardium which, for instance, have been determined among the fossils from the Aquitanian Basin, Italy etc., would be very important. However, if the delimitations of species were kept in agreement with the evidence of modern biology several of the species would probably be invalidated.

Distribution.

Miocene: North Sea Basin: Germany: Hemmoor stage. Belgium: Boldérien. Denmark: Arnum formation.

FAMILIA VENERIDAE LEACH 1819

Genus Gouldia Adams 1847

\section{Gouldia minima (Montagu)}

Recent:

Plate 14, fig. 51 a-c.

1803. Venus minima Montagu. Testacea Brit. 1, p. 121, pl. 3, fig. 3.

1853. Circe minima Montagu. Forbes \& Handey. Brit. Moll. 1, p. 446, pl. 26, fig. 4-6, 8, pl. M, fig. 3.

1863. Circe minima Montagu. Jefreness. Brit. Conch. 2, p. 322. (1869) 5, pl. 37, fig. 6.

1867. Circe minima Montagu. Weinkauff. Conch. d. Mittelmeeres. 1, p. 122.

1892. Circe minima Montagu. Locard. Coq. mar. d. côtes d. France. p. 301.

1893. Gouldia minima Montagu. sp. Bucquoy, Dautzenberg \& Dollfus. Moll. mar. du Rousillon 2, p. 335, pl. 59, fig. 24-35.

1932. Circe minima Montagu. Nobre. Molluscos mar. de Portugal. p. 342, pl. 79, fig. 2. 1934. Gouldia minima Montagu. Ad. S. Jensen \& R. Spärck. Saltvandsmusl. p. 127.

Fossil:

1861. Circe minima Montagu. Wood. Monogr. Crag Moll. 2, p. 198, pl. 19, fig. 2.

1870. Circe minima Montagu. Hörnes. D. foss. Moll. d. Tert.-Beckens v. Wien 2, p. 158, pl. 19, fig. 5 .

1900. Gouldia minima Montagu. Sacco. I moll. d. terr. terz. d. Piemonte e d. Liguria. 28 , p. 47 , pl. 11, fig. 1-6.

1908. Gouldia minima Montagu. sp. Cerdlui-Irelli. Fauna mal. mariana, p. 44, pl. 9, fig. 12-19.

?1910. Circe (Gouldia) dosinioides Cossmann \& Peyrot. Conch. Néogén. d. l'Aquit. p. 433, pl. 18, fig. 26-29.

1925. Circe (Gouldia) minima Monta. Kautsky. D. Mioc. v. Hemmoor u. Basbeck-Osten. p. 42 , pl. 4 , fig. 12 .

1945. Gouldia minima Montagu. Gribert. Faune mal. du Mioc. de la Belgique. 1, p. 192, pl. 12, fig. 1.

1950. Gouldia minima Montagu. Heering. Plioc. and older Plistoc. Netherlands p. 118.

Essential features of original description: Sub-orbicular, somewhat compressed, very glossy with broad concentric striae. Umbo prominent, pointed, a little turned to one side. Inside glossy white, margin plain. The shell is very thick and strong in proportion to its size (MoNTAGU 1803). 
Shell material.

$\begin{array}{lrrlrr}\text { Location } & \text { Depth } & \text { Shells } & \text { Location } & \text { Depth } & \text { Shells } \\ \text { Bramminge } & 70-80 \mathrm{~m} & 2 & \text { Toftlund } & 115 \mathrm{~m} . & 1 \\ \text { Gramby } & 82.66-83.76- & 2 & \text { Arnum }(13) & 53-83 . & 3 \\ \text { Toftlund } & 75-100- & 5 & \text { Arnum }(25 \mathrm{~b}) & 62.7-62.9- & 10 \\ & 100-105- & 8 & & 95.0-95.3- & 2 \\ & 105-110- & 10 & & 104.3-107.5- & 1\end{array}$

Description. A few characters should be mentioned to supplement earlier descriptions.

Prodissoconch smooth and glossy, relatively globose. Dimensions of height and length of some prodissoconchs preserved on adult shells listed in table below.

Dissoconch. The outline of the shell is somewhat triangular in most specimens. The exterior is rather smooth, but there are also some shells with conspicuous concentric growth ribs. The furrow which delimits the lunule ends at a point where a curved line extending from the umbo on the internal shell margin touches the outher edge of the margin. The shell margin, which perfectly follows the dorso-ventral plane, meets the external and internal surfaces of the shell in well defined edges.

There is some variation in the depth of the pallial sinus, which is generally rather shallow.

The hinge features are illustrated by the accompanying figures no. 51 $a$ and $c$.

\begin{tabular}{|c|c|c|c|c|c|c|c|c|}
\hline \multirow{4}{*}{$\begin{array}{l}\text { Location } \\
\text { Gramby }\end{array}$} & \multirow{3}{*}{$\begin{array}{r}\text { Depth } \\
82.66-83.76 \mathrm{~m} .\end{array}$} & \multirow{3}{*}{$\begin{array}{l}\text { Valve } \\
\text { 1. (1) }\end{array}$} & \multicolumn{2}{|c|}{ Prodissoconch } & \multicolumn{4}{|c|}{ Dissoconch } \\
\hline & & & Heig & Length & Height & Length & Widt & \\
\hline & & & & rn) & 2.2 & 2.34 & $0.55 \mathrm{I}$ & $\mathrm{nm}$. \\
\hline & & r. v. & 0.28 & 0.28 & 1.76 & 1.76 & 0.47 & - \\
\hline \multirow[t]{8}{*}{ Toftlund } & $75-100-$ & 1. & & rn) & 2.95 & 3.17 & 0.69 & - \\
\hline & & 1. & & - & 1.68 & 1.84 & 0.45 & - \\
\hline & & r. & & - & 1.35 & 1.37 & 0.37 & - \\
\hline & & r. & & - & 3.17 & 3.35 & 0.79 & - \\
\hline & $100-105$ & 1. & 0.27 & 0.28 & 1.58 & 1.72 & 0.41 & - \\
\hline & & 1. & 0.30 & 0.33 & 0.98 & 1.02 & 0.29 & - \\
\hline & & 1. & 0.29 & 0.30 & 1.15 & 1.22 & 0.34 & - \\
\hline & & r. & 0.30 & 0.33 & 1.73 & 1.80 & 0.47 & - \\
\hline Arnum (13) & $53-83-$ & r. & & rn) & 2.25 & 2.33 & 0.59 & - \\
\hline
\end{tabular}

Remarks. The characters which Cossmans \& Peyrot have claimed as specific for $G$. dosinioides are not very convincing, and their figures of shells from SW France do not show any features which would support the concept of a new species. Since the shells are obviously very similar to G. minima, the present writer has, with some doubt referred them to this species.

Distribution.

Recent: Atlantic Ocean from southern Norway to the Canaries, Madeira and the Azores, Mediterranean.

Pliocene: North Sea Basin: England: Coralline Crag and Red Crag; Holland.

Mediterranean Basin: Italy: Piacenziano, Astiano, upper Pliocene of Monte Mario. 
Miocene: Aquitanian Basin:? Helvétien.

North Sea Basin: Belgium: Horizon of Houthaelen, Anversien; Germany: Hemmoor Stage, Reinbek stage (Gotтsche 1878). Denmark: Arnum formation.

Mediterranean Basin: Tortoniano, Elveziano.

Vienna Basin: Deposits at Grund, and Baden clay.

\section{Genus Pitar Römer 1857}

\section{Pitar chione (Linné)}

Plate 17, fig. 52 a-b.

Recent :

1758. Venus chione Linné. Syst. Nat. Ed. Dee. p. 686.

1853. Cytherea chione Linné. Forbes \& Hanley. Brit. Moll. 1, p. 396, pl. 27, pl. L, fig. 8.

1863. Venus chione Linné. Jeffreys. Brit. Conch. 2, p. 332, pl. 38, fig. 3.

1867. Cytherea chione Linné. Weinkauff. Conch. d. Mittelmeeres. p. 116.

1892. Cytherea chione Linné. Locard. Coq. mar. d. côtes d. France. p. 284.

1893. Meretrix chione Linné. Bucquoy, Dautzenberg \& Dollfus. Moll. mar. du Roussillon 2, p. 323, pl. 52, fig. 1-10.

1932. Meretrix chione Linné. Nobre. Moluscos mar. de Portugal. p. 340, pl. 62, fig. 1-2.

Fossil:

1861. Cytherea chione Lrnné. Woon. Monogr. Crag Moll. 2, p. 207, pl. 20, fig. 4.

1900. Callista chione Linné. SAcco. I moll. d. terr. terz. d. Piemonte e d. Liguria 28, p. 12, pl. 2, fig. 3-6.

1908. Meretrix (Callista) chione Linné sp. Ceruldi-Ireldi. Fauna mal. mariana. p. 43, pl. 8, fig. 8-10, pl. 9, fig. 1-3.

1910. Meretrix (Callista) chione Linné. Cossmann \& Peyrot. Conch. Néogén. d. l'Aquit. p. 394 , pl. 15, fig. 1-2.

1945. Pitar (Callista) chione Linné sp. Glibert. Faune mal. du Mioc. de la Belgique. I, p. 183, pl. 11, fig. 6 .

1950. Pitaria (Paradione) chione (Linné). Henring. Plioc. and older Plistoc. Netherlands. p. 121.

Original diagnosis. Testa cordata transverse subrugosa lavi, cardinis dente primario posteriori lanceolato (LINNÉ 1758).

Shell material.

$\begin{array}{rrl}\text { Location } & \text { Depth } & \text { Shells } \\ \text { Glejbjerg } & 53.5 \mathrm{~m} . & 2 \text { right valves (frg.) } \\ & 53.75- & 1 \text { right valve (frg.) } \\ & 55- & 1 \text { right valve (frg.) } \\ \text { Toftlund } & 75-100- & 1 \text { right valve (frg.) } \\ & & \text { (length of frg. } 8.55 \mathrm{~mm} . \text {.) }\end{array}$

Description.

Prodissoconch unknown, umbo worn on all specimens.

Dissoconch. The largest fragment (Toftlund 75-100 m., plate 17, fig. 52) displays the following features: Exterior smooth and glossy, with flat bandlike concentric ribs on the distal parts of the shell. The hinge and the interior of the shell are shown on the accompanying figure, and it is clearly seen that the typical dentition of $P$. chione is excellently developed: there are two anterior lateral teeth, two cardinal teeth, and one posterior lateral tooth above which the resiliophore may be distinguished. There is a distinct furrow on the posterior dorsal margin. 
Remarks. There can hardly be any doubt as to the reference of the shells to $P$. chione in spite of their fragmentary nature. The species is of considerable interest in view of its present geographic distribution. It has not been reported farther north than to the southern and south-western coasts of England and Ireland (JEFFrEys).

Distribution.

Recent: Atlantic Ocean: Coasts of Europe from the south and west coast of England and Ireland, and southward to the Canaries, Madeira and the Azores, Mediterranean.

Pliocene: North Sea Basin: England: Coralline Crag;

Mediterranean Basin: Italy: Piacenziano, Astiano, upper Pliocene of Monte Mario.

Miocene: Aquitanian Basin: Burdigalien, Helvétien.

North Sea Basin: Belgium: Anversien. Denmark:

Arnum formation.

Mediterranean Basin: Italy: Elveziano.

Genus Meretrix Lamarck 1799

\section{Meretrix cf. incrassata (Sowerby)}

Plate 17, fig. 53 a-b.

1818. Venus incrassata Sowerby. Miner. Conch. 2, p. 126, pl. 155, fig. 1-2.

1900. Amiantis incrassata Sowerby var. Sacco. I moll. d. terr. terz. d. Piemonte e d. Liguria. p. 21, pl. 4, fig. 31-33.

1907. Meretrix incrassata Sowerby sp. Ravn. Molluskf. Jyll. Tert. p. 278, pl. 2, fig. 10. 1910. Meretrix (Cordiopsis) cf. incrassata (Sow.) Cossmann \& Peyrot. Conch. Néogén. d. l'Aquit. p. 407, pl. 17, fig. 5, 7, pl. 18, fig. 14-16, 30.

?1910. Meretrix (Cordiopsis) intercalaris. Cossmann \& Peyrot. Ibid. p. 409, pl. 17, fig. 17-18, pl. 18, fig. 6 .

1925. Meretrix (Cordiopsis) incrassata Sow. var. Kautsky. D. Mioc. v. Hemmoor u. Basbeck-Osten. p. 40, pl. 4, fig. 10.

?1925. Meretrix (Pitaria) cimbrica. Kautsky. Ibid. p. 41, pl. 4, fig. 11.

1940. Meretrix (Cordiopsis) incrassata Sow. var. Songenfrer. Mar. Nedre Mioc. i Klintinghoved p. Als. p. 22, pl. 4, fig. 9-10.

?1944. Pitaria (Pitaria) cimbrica (Kautsky). Heering. D. oberolig. Biv. a.d. Peelgebiete. p. 33 , pl. 5, fig. 16-17.

1944. Pitaria (Amiantis) incrassata (Sowerby). et. var. Heering. Ibid. p. 35. pl. 5, fig. $1-5$.

1945. Pitar (Cordiopsis) incrassata nysti Orbigny sp. Glibert. Faune mal. du Mioc. de la Belgique. 1, p. 177, pl. 11, fig. 3.

Original diagnosis. Orbicular, oblique, subdepressed, smooth; posterior slope straightish; lunula large, obscure; edge entire; a conical tooth under the lunula (Sowerby, 1818).

Shell material.

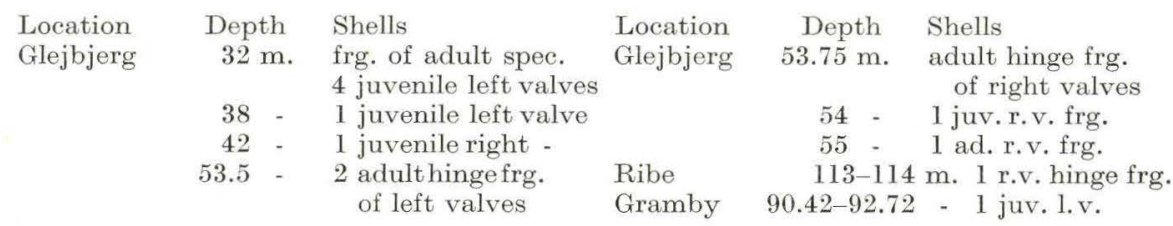




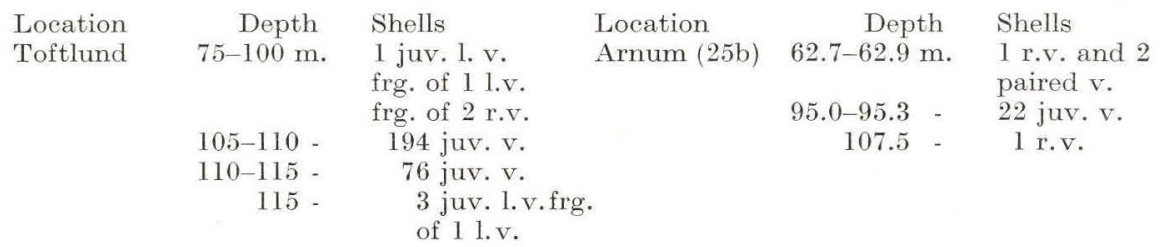

Description. The shell material consists partly of fragments of adult shells and partly of juvenile specimens. There is no serious doubt as to the reference of the fragments of the adult shells to $M$. incrassata i.e. to $M$. incrassata as described by the writer in 1940. The juvenile shells are of the type described by Kautsky and Heering as Pitaria cimbrica (see plate 17, fig. 53).

No further comments need be made on the adult shell fragments, but the juvenile specimens will be briefly described and discussed.

Prodissoconch orbicular, small, smooth, and glossy. Dimensions of three specimens are listed in the table below.

Dissoconch. Exterior covered with relatively coarse concentric ribs which may be somewhat irregular on the posterior part of the shell. Lunula faintly demarcated by an indistinct furrow. Shell outline orbicular.

Hinge. The left valve with bi-partite cardinal tooth and one posterior lateral tooth. A furrow runs parallel to the margin from the umbo to the point where the lunular furrow reaches the margin, and an elongated ridge extends backwards from the umbo along the dorsal margin. The right valve has two cardinal teeth and one anterior lateral tooth; there is a ridge on the shell margin in front of the umbo corresponding to the furrow on the left valve extending to the lunular furrow. The dorsal margin behind the umbo is furnished with a furrow for the dorsal ridge of the left valve.

The interior of the shell shows no particular features, the sinus is rather shallow in the youngest forms.

\begin{tabular}{|c|c|c|c|c|c|c|c|c|}
\hline \multirow{3}{*}{$\begin{array}{l}\text { Location } \\
\text { Glejbjerg }\end{array}$} & \multirow{3}{*}{$\begin{array}{l}\text { Depth } \\
32 \mathrm{~m} .\end{array}$} & \multirow[t]{2}{*}{ No. } & \multicolumn{2}{|c|}{ Prodissoconch } & \multicolumn{4}{|c|}{ Dissoconch } \\
\hline & & & Height & Length & Height & Length & \multirow{2}{*}{\multicolumn{2}{|c|}{$\begin{array}{l}\text { Width } \\
0.47 \mathrm{~mm}\end{array}$}} \\
\hline & & 1. & \multicolumn{2}{|c|}{ worn } & 1.68 & 1.74 & & \\
\hline & & 2. & 0.178 & 0.202 & 1.64 & 1.76 & 0.49 & - \\
\hline & & 3. & 0.174 & 0.202 & 1.37 & 1.46 & 0.37 & - \\
\hline & & 4. & & m & 3.27 & 3.43 & 1.07 & - \\
\hline \multirow[t]{12}{*}{ Toftlund } & $75-100 \mathrm{~m}$. & 1. & 0.176 & 0.217 & 3.36 & 3.62 & 1.07 & - \\
\hline & & 2. & & orn & 3.75 & 3.97 & 1.13 & - \\
\hline & & 3. & & - & 3.64 & 3.83 & 1.12 & - \\
\hline & & 4. & & - & 3.50 & 3.61 & 1.07 & - \\
\hline & & 5. & & - & 3.49 & 3.60 & 0.99 & - \\
\hline & & 6. & & - & 3.12 & 3.15 & 0.90 & - \\
\hline & & 7. & & - & 3.10 & 3.07 & 0.86 & - \\
\hline & & 8. & & - & 2.54 & 2.64 & 0.75 & - \\
\hline & & 9. & & - & 2.66 & 2.74 & 0.78 & - \\
\hline & & 10. & & - & 2.46 & 2.52 & 0.71 & - \\
\hline & & 11. & & - & 2.11 & 2.19 & 0.57 & - \\
\hline & & 12. & & - & 2.00 & 2.09 & 0.59 & \\
\hline
\end{tabular}

Remarks. $M$. incrassata is obviously a very variable species according to the literature. It is therefore very difficult to define specific limits for the species. 
In the case of the shells for which KaUTSkY proposed the name "cimbrica" it must, however, be added that they are in all probability the juvenile stages of Meretrix incrassata var. flexicostulata. This was suggested by a close study of the shells at the writer's disposal, and therefore $M$. cimbrica is provisionally included in the synonymy of $M$. incrassata, until a critical study of the shells referred to this taxonomic unit may decide whether it should be made permanent or rejected.

Distribution.

Miocene: Aquitanian Basin: ? Aquitanien, ? Burdigalien.

North Sea Basin: Germany: Hemmoor stage. Denmark: Klintinghoved clay, Arnum formation. Belgium: Boldérien, horizon of Houthaelen, Anversian.

Oligocene: North Sea Basin: Holland (u.).

Mediterranean Basin: Italy: Tongriano.

Genus Dosinia Scopoli 1777

\section{Dosinia cf. Basteroti (Agassiz)}

Plate 18, fig. 54 a-b.

1845. Arthemis Basteroti Agassiz. Icon. d. Coqu. Tert. p. 24, pl. 3, fig. 7-10.

1870. Dosinia Adansoni Hörnes. D. foss. Moll. d. Tert.-Beckens v. Wien 2, p. 147, pl. 16, fig. 4 .

1900. Dosinia lupinus var. cf. Basteroti (AG.). SAcco. I Moll. d. terr. terz. d. Piemonte e d. Liguria. 28, p. 50, pl. 11, fig. 20.

1910. Dosinia Basteroti (Agassiz). Cossmann \& Peyrot. Conch. Néogén. d. l'Aquit. p. 420 , pl. 18, fig. 1-4.

1925. Dosinia Basteroti Agassiz. Kautsky. D. Mioc. v. Hemmoor u. Basbeck-Osten. p. 38 , pl. 4 , fig. 9 .

Essential features of original description. "La surface est ornée de rides très-fin et fort régulières. A la valve gauche, la dent accessoire est trèsdéveloppée et à-peu-près aussi forte que la dent lunulaire, qui est réduite à une très-petite lame. La dent cardinale est la plus forte de toutes. La dent ligamentaire est très-mince et se détaches à peine des callosités nymphales. La valve droite: une première fossette qui est pour ainsi dire double, en ce qu'elle reçoit à la fois la dent accessoire et la dent ligamentaire. La dent lunulaire est une lame oblique et assez mince, fossette cardinale large et triangulaire. La dent ligamentaire est oblique, arquée et a-peu-près parallèle au bord de la coquille. Face interne: quelques traces de stries rayonnantes sur le bord de la coquille. (AgAssiz 1845).

Shell material and dimensions.

\begin{tabular}{|c|c|c|c|c|c|c|c|}
\hline \multirow[t]{2}{*}{ Location } & \multirow[t]{2}{*}{ Depth } & \multirow[t]{2}{*}{ Shells } & \multirow{2}{*}{ Prodissoconch } & \multicolumn{4}{|c|}{ Dissoconch } \\
\hline & & & & Height & Length & Wid & \\
\hline Gramby & $90.42-92.72 \mathrm{~m}$ & 1 right $\mathrm{v}$. & 0.233 & 1.47 & 1.48 & 0.43 & $\mathrm{~mm}$ \\
\hline & & 1 left v. & 0.248 & 1.80 & 1.80 & 0.52 & - \\
\hline Toftlund & $110.86-121.51-$ & 1 l. v. frg. & worn & 399 & 3.40 & 0.90 & - \\
\hline Iortiuna & & $\begin{array}{l}\text { l. v. } \\
2 \text { l. v. } \\
2 \text { r.v. frg. }\end{array}$ & $\begin{array}{c}\text { worn } \\
-\end{array}$ & $\begin{array}{l}3.29 \\
2.29\end{array}$ & $\begin{array}{l}3.40 \\
2.34\end{array}$ & $\begin{array}{l}0.90 \\
0.62\end{array}$ & - \\
\hline
\end{tabular}


Description. The material consists only of juvenile shells.

Prodissoconch orbicular and glossy.

Dissoconch. Plate 18, fig. 54 shows the largest of the well preserved shells from Toftlund; this adequately illustrates the shell features. Since the lunule does not show on the figure, it may be added that it is very distinctly delimited by a furrow.

Remarks. It is impossible to arrive at a safe conclusion regarding the determination of the shells if one considers their youthfulness and the great variability of the species of the genus Dosinia. The postero-dorsal margin of the shells from South Jutland is apparently straighter than in the other species included in the synonymy. This may, however, be an unspecific, juvenile feature.

Distribution of D. Basteroti.

Miocene: Aquitanian Basin: Aquitanien, Burdigalien.

North Sea Basin: Germany: Hemmoor stage. Denmark: Arnum formation.

Mediterranean Basin: Italy: Elveziano.

Vienna Basin: Gauderndorf beds.

Oligocene: Mediterranean Basin: Italy: Tongriano.

\section{Genus Venus Linné 1758}

Subgenus Ventricola Römer 1857

\section{Venus (Ventricola) multilamella (Lamarck)}

Plate 18, fig. 55 a-d.

1818. Cytherea multilamella LAмARCK. Hist. Nat. d. anim. sans vert. 5, p. 581.

1870. Venus multilamella Lay. Hönnes. D. foss. Moll. d. Tert. Beckens v. Wien 2, p. 130, pl. 15, fig. 2-3.

1893. Venus rugosa. Lehmann. D. Lam. d. Mioc. v. Dingden p. 274.

1900. Ventricola rugosa Lam. Sacco. I moll. d. terr. terz. d. Piemonte e d. Liguria. 28, p. 30 , pl. 8, fig. 1-8.

1908. Venus (Ventricola) multilamella LK. sp. Cerulli-Irelli Fauna mal. mariana p. 52, pl. 10, fig. 10-18, pl. 11, fig. 1-7.

1910. Chione (Ventricoloidea) multilamella (Lamk.) Cossmann \& Peyrot. Conch. Néogén. d. l'Aquit. p. 373, pl. 13, fig. 26-28.

1910. Venus (Ventricola) multilamella Lam. Schaffer. D. Mioc. v. Eggenburg p. 86, pl. 40, fig. 8-9.

1925. Chione (Ventricoloidea) multilamella Lamk. Kautsky. D. Mioc. v. Hemmoor u. Basbeck-Osten. p. 39.

1945. Venus (Dosina) multilamella Lamarck sp. Glibert. Faune mal. du Mioc. de la Belgique. 1, p. 186, pl. 11, fig. 5.

Original diagnosis. Testa cordato-rotundata, inequilatera; sulcis transversis distinctis, erectis, lamellceformibus; ano cordato. (LAMARCK 1818).

Shell material.

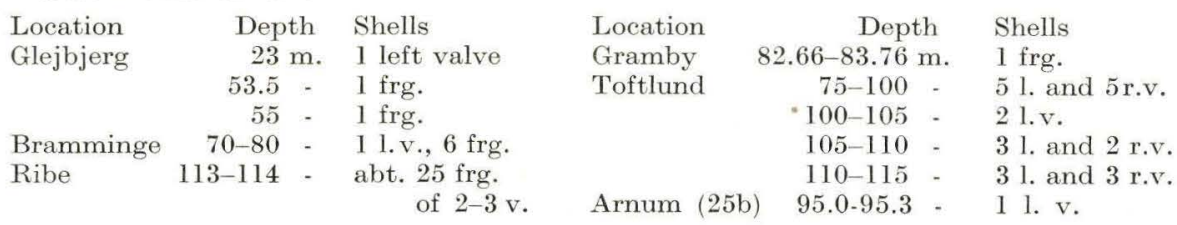


Description. The shells are mainly juvenile. The fragments from Ribe and a few fragments from other samples represent the adult stage.

Prodissoconch smooth and glossy, rather convex. Dimensions of some shells listed in the table below.

Dissoconch. The figures 55 a-d on plate 18 display the typical features of the shells from South Jutland. Exterior: The lunule is demarcated by a fine furrow, the trace of which is also seen on the lamellae. Very fine concentric striae occur both between and on the lamellae. In some specimens microscopic, somewhat irregularly directed radial striae are also seen between the lamellae.

The hinge of the left valve has two cardinal teeth and one posterior lateral tooth. In the right valve there are two cardinal teeth, and one lateral tooth both in front of and behind the cardinal teeth.

The interior of the shell is glossy. The pallial line has a blunt sinus, and the adductor scars are oval. The shell margin is occasionally crenated with irregular knobs or ribs which may disappear towards the extremities of the shell and are absent on some specimens.

Venus multilamella. Dimensions of shells

\begin{tabular}{|c|c|c|c|c|c|c|c|c|c|}
\hline \multirow{4}{*}{$\begin{array}{l}\text { Location } \\
\text { Glejbjerg } \\
\text { Toftlund }\end{array}$} & \multirow[b]{2}{*}{ Depth } & \multirow[b]{2}{*}{ Shell } & \multicolumn{2}{|c|}{ Prodissoconch } & \multicolumn{4}{|c|}{ Dissoconch } & \multirow{2}{*}{$\begin{array}{l}\text { Number of } \\
\text { knobs on } \\
\text { shell margin }\end{array}$} \\
\hline & & & Height & Length & Height & Length & \multicolumn{2}{|c|}{ Width } & \\
\hline & $23 \mathrm{~m}$. & l. v. & 0.310 & 0.310 & 1.15 & 1.18 & \multicolumn{2}{|c|}{$0.32 \mathrm{~mm}$. } & no knobs \\
\hline & $75-100$ & r. v. & \multicolumn{2}{|c|}{ (worn) } & 3.1 & 3.27 & 0.9 & - & ab. 45 \\
\hline & & 1. v. & 0.232 & 0.263 & 2.12 & 2.19 & 0.6 & - & ab. $30+?$ \\
\hline & & r. v. & 0.230 & 0.280 & 1.9 & 1.94 & 0.6 & - & ab. $30+$ \\
\hline & $100-105=$ & 1. v. & 0.255 & 0.263 & 2.81 & c. 2.5 & 0.7 & - & no knobs \\
\hline & $110-115-$ & r. v. & \multicolumn{2}{|c|}{ indistinet } & 4.43 & 4.6 & 1.37 & - & ab. 50 \\
\hline $\begin{array}{l}\text { Arnum } \\
25 \mathrm{~b})\end{array}$ & $62.7-69.9=$ & r. v. & 0.225 & 0.225 & 1.40 & 1.47 & 0.39 & - & ab. 40 \\
\hline
\end{tabular}

Variability. The few measurements which could be made, indicate that the size and shape of the prodissoconch vary rather widely.

The dissoconch may apparently vary considerably concerning the number of concentric lamellae, and it is probable that the outline of the shell also varies. However, information is at present limited due to the scarcity of shell material.

Remarks. The morphological relationship between this form and $V$. casina of recent seas has been discussed by earlier authors. It might, however, be worth-while to revise the arguments brought forward for keeping the two forms separate some time in the future, since they display several similar shell features.

Distribution.

Pliocene: Mediterranean Basin: Italy: Piacenziano, Astiano, Upper Pliocene of Monte Mario.

Miocene: Aquitanian Basin: Burdigalien, Helvétien.

North Sea Basin: Belgium: Boldérien, horizon of

Houthaelen, Anversien. Germany: Hemmoor stage, Dingden-Reinbek stage, Glimmerton (Banke RasuusSEN 1956). Denmark: Arnum formation.

Mediterranean Basin: Tortoniano.

Vienna Basin: Eggenburg beds, Grund beds (SIEBer 1946), Baden clays. 


\title{
FAMILIA MESODESMATIDAE FISCHER 1887
}

\section{Genus Ervilia Turton 1822}

\section{Ervilia pusilla (Philippi)}

\author{
Plate 56 a-d, fig. 18.
}

1836. Erycina pusilla PhILIPPI. Enum. Molluscorum Siciliae. 1, p. 13, pl. 1, fig. 5.

1901. Ervilia castanea var. pusilla (PHIL.) SAcco. I moll. d. terr. terz. d. Piemonte e d. Liguria. 29, p. 21, pl. 5, fig. 18-19.

1908. Ervilia pusilla Phil. sp. Cerulli-Ireldi. Fauna mal. mariana. p. 137, pl. 14, fig. 6-9.

1909. Ervilia pusilla (Philippi). Cossmann \& Peyrot. Conch. Néogén. d. l'Aquit. p. 281, pl. 6, fig. 30-32.

1925. Ervilia pusilla (Philippi). Kautsky. D. Mioc. v. Hemmoor u. Basbeck-Osten. p. 47 , pl. 5 , fig. 3 .

1945. Ervilia pusilla Philippi sp. Glibert. Faune mal. du Mioc. de la Belgique. 1, p. 193, pl. 3 , fig. 4 .

Essential features of original description. Testa minuta, oblongoovata, aequilatera, compressa laevi; tenuissime striata, plerumque autem stratum externum decorticatum. A pices parvi, acuti, prominuli. Cardo fovea triangulari ligamentali, denticuloque antico in utraque valvula componitur. Dentes laterales nulli. Impressiones musculares minutae, subrotundae, sinus palliaris semiovatus fere usque ad mediam testam productus. (PHILIPPI 1836).

Shell material.

\begin{tabular}{|c|c|c|c|}
\hline \multirow{2}{*}{$\begin{array}{l}\text { Location } \\
\text { Toftlund }\end{array}$} & Depth & \multicolumn{2}{|c|}{ Shells } \\
\hline & $75-100 \mathrm{~m}$ & & alves \\
\hline & $105-110=$ & 9 & - \\
\hline & $110-115$ & 36 & - \\
\hline & 115 & 3 & - \\
\hline Arnum (13) & $28-40$ & 4 & - \\
\hline & $53-83=$ & 17 & - \\
\hline
\end{tabular}

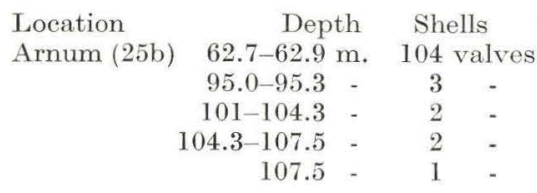

Description.

Prodissoconch smooth and glossy with minute concentric striae visible under the microscope; relatively arched. Dimensions see table below.

Dis soconch of triangular to suboval outline, externally smooth with growth lines. Hinge of the right valve with one strong cardinal tooth; longitudinal furrow on the antero and postero-dorsal margins to accomodate the sharp margin of the left valve. Ligament pit triangular, situated beneath the umbo and behind the cardinal tooth. The left valve with one cardinal tooth, smaller than the tooth of the right valve. In front of the pit for the tooth of the right valve there is a narrow rib, which may be interpreted as a hinge tooth. The ligament pit occupies the same position as in the right valve. Dorsal margin sharp.

Interior: Adductor scars oval, pallial sinus rounded.

Ervilia pusilla. Dimensions of shells.

\begin{tabular}{|c|c|c|c|c|c|c|c|c|}
\hline \multirow{3}{*}{$\begin{array}{l}\text { Location } \\
\text { Toftlund }\end{array}$} & \multirow{3}{*}{$\begin{array}{r}\text { Depth } \\
75-100 \mathrm{~m} .\end{array}$} & & \multicolumn{2}{|c|}{ Prodissoconch } & \multicolumn{4}{|c|}{ Dissoconch } \\
\hline & & Shell & Height & Length & Height & Length & Widt & \\
\hline & & right valve & 0.225 & 0.272 & 2.50 & 3.43 & 0.69 & nm. \\
\hline & & left & 0.240 & 0.279 & 1.41 & 1.72 & 0.51 & - \\
\hline & & right & 0.249 & 0.279 & 1.37 & 1.80 & 0.35 & - \\
\hline & & left & 0.264 & 0.295 & 1.51 & 1.88 & 0.43 & - \\
\hline & & right & 0.249 & 0.295 & 1.41 & 1.80 & 0.41 & - \\
\hline
\end{tabular}




\begin{tabular}{|c|c|c|c|c|c|c|c|c|}
\hline \multirow{7}{*}{$\begin{array}{l}\text { Location } \\
\text { Toftlund }\end{array}$} & \multirow{3}{*}{ Depth } & \multirow[b]{2}{*}{ Shells } & \multicolumn{2}{|c|}{ Prodissoconch } & \multicolumn{4}{|c|}{ Dissoconch } \\
\hline & & & Heigl & Length & Heig & Leng & Widtl & \\
\hline & & right valve & 0.264 & 0.325 & 1.52 & 1.97 & 0.35 & $\mathrm{~mm}$. \\
\hline & & right - & 0.264 & 0.295 & 1.29 & 1.58 & 0.35 & - \\
\hline & $110-115=$ & left & 0.264 & 0.295 & 2.15 & 2.8 & 0.57 & - \\
\hline & & left & 0.248 & 0.287 & 1.52 & 2.01 & 0.39 & - \\
\hline & & left & 0.248 & 0.279 & 1.56 & 1.99 & 0.45 & - \\
\hline
\end{tabular}

Variability. The size of the prodissoconch varies somewhat judging from the above figures, and the outline of the dissoconch is also rather variable. Oval, triangular, equilateral, and inequilateral specimens are encountered in the shell material, and it is not possible to further subdivide the shell material into well defined morphological groups.

Distribution.

Pliocene: Mediterranean Basin: Italy: upper Pliocene of Monte Mario.

Miocene: Aquitanian Basin: Aquitanien, Burdigalien, Helvétien.

North Sea Basin: Belgium: Anversien, Germany: Hemmoor stage. Denmark: Arnum formation.

Mediterranean Basin: Italy: Elveziano.

FAMILIA MACTRIDAE GRAY 1840

Genus Spisula Gray 1837

\section{Spisula subtruncata (Da Costa) var.}

Recent:

Plate 19, fig. 57 a-c.

1778. Trigonella subtruncata DA Costa. Hist. Nat. Testacearum Britanniæ, p. 198.

1853. Mactra subtruncata Da Costa. Forbes \& Hanley. Brit. Moll. 1, p. 358, pl. 21, fig. 8 , pl. 22 , fig. 2 , pl. L, fig. 3 .

1863. Mactra subtruncata DA Costa. Jeffreys. Brit. Conch. 2, p. 419, 5, pl. 43, fig. 3.

1867. Mactra triangula Renieri. Weinkauff. Conch. d. Mittelmeeres, p. 48.

1878. Mactra subtruncata DA Costa. Sars. Moll. Reg. Aret. Norvegiae. p. 72.

1892. Mactra subtruncata DA Costa. Locard. Coq. mar. d. côtes d. France, p. 266.

1896. Mactra subtruncata Da Costa. sp. Bucquoy, Dautzenberg \& Dolifus. Moll. mar. du Roussillon. 2, p. 559, pl. 82, p. 1-21.

1932. Mactra subtruncata DA Costa. Nobre. Moluscos mar. de Portugal. p. 369, pl. 71, fig. 7.

1934. Spisula subtruncata DA Costa. Ad. S. Jensen \& R. Spärck. Saltvandsmuslinger, p. 158 .

Fossil:

1814. Mactra triangula Renieri. Brocchi. Conchiol. Foss. Subapennina. 2, p. 535, pl. 13, fig. 7.

1861. Mactra subtruncata Da Costa. Wood. Monogr. Crag Moll. 2, p. 247, pl. 24, fig. 3. 1866. Mactra trinacria Semper. Speyer. D. o.-olig. Tertiärgebilde etc. Lippe-Detmold, p. 34, pl. 3, fig. 4 .

1870. Mactra triangula Ren. Hörnes. D. foss. Moll. d. Tert.-Beckens v. Wien 2, p. 66, pl. 7 , fig. 11 .

1893. Mactra triangula Ren. Lehmann. D. Lam. d. Mioc. v. Dingden 2, p. 286.

1901. Spisula subtruncata (DA Costa). SAcco. I moll. d. terr. terz. d. Piemonte e d. Liguria. 29 , p. 25 , pl. 6 , fig. $3-6$.

1907. Mactra trinacria Semper. Ravn. Molluskff. Jyll. Tert., p. 281, pl. 3, fig. 1-2.

1908. Mactra (Spisula) subtruncata DA Costa. Cerutur-Irectir. Fauna mal. mariana, p. 140, pl. 14, fig. 21-37. 
1909. Mactra (Spisula) subtruncata DA Costa, var. triangula Renteri. Cossmann \& Peyrot. Conch. Néogén d. l'Aquit. p. 258, pl. 6, fig. 15-17.

1916. Mactra subtruncata var. trinacria Semp. NørregandD. Mell.-mioc. Blokke fra Esbjerg. p. 17.

1925. Mactra (Spisula) subtruncata Da Costa, var. triangula Renieri. Kautsky. D. Mioc. v. Hemmoor u. Basbeck-Osten. p. 46.

1941. Mactra trinacria Semper. Görges. D. Oberolig.-fauna v. Rumeln a. Niederrhein. p. 173.

1944. Spisula (S.) subtruncata (DA Costa) var. trinacria Semper. Heering. D. oberolig. Biv. a d. Peelgebiete. p. 38, pl. 7, fig. 1-6.

1945. Spisula (S.) subtruncata triangula Renier sp. Glibert. Faune mal. du Mioe. de la Belgique. 1, p. 195, pl. 12, fig. 5.

1950. Spisula subtruncata (DA Costa). Heering. Plioc. and older Plistoc. Netherlands. p. 145. pl. 16, fig. 13-24.

1956. Spisula (S.) subtruncata (DA Costa) var. triangula Renieri. Banke Rasmussen. Upper Mioc. South Jutland, p. 45, pl. 2, fig. 6.

Original diagnosis. Trigonella albescens lovis, lateribus subtruncatis (DA Costa 1778).

Shell material.

\begin{tabular}{|c|c|c|c|c|c|c|c|c|c|}
\hline \multirow{2}{*}{$\begin{array}{l}\text { Location } \\
\text { Glejbjerg }\end{array}$} & \multicolumn{2}{|c|}{ Depth } & \multicolumn{2}{|c|}{ Shells } & Location & \multicolumn{2}{|c|}{ Depth } & \multicolumn{2}{|r|}{ Shells } \\
\hline & $23 \mathrm{r}$ & & 10 & lves & Arnum (13) & $53-83$ & & 144 & valves \\
\hline & 25 & - & 6 & - & & $83-94$ & - & 4 & - \\
\hline & 32 & - & 12 & - & Bramminge & $70-80$ & - & 32 & - \\
\hline & 38 & - & 1 & - & Ribe & $114-115$ & - & 1 & - \\
\hline & 42 & - & 30 & - & & $116-117$ & - & 1 & frg. \\
\hline & 52 & - & 4 & - & Gramby & $81.86-82.16$ & - & 4 & valves \\
\hline & 53 & - & 5 & - & & $82.66-83.76$ & - & 38 & - \\
\hline & 53.5 & - & 32 & - & & $84.66-87.16$ & - & 192 & - \\
\hline & 53.75 & - & 14 & - & & $90.42-92.72$ & - & 106 & - \\
\hline & 54 & - & 1 & - & & $92.72-109.29$ & - & 24 & - \\
\hline & 55 & - & 10 & - & & $109.29-110.86$ & - & 50 & - \\
\hline Toftlund & $75-100$ & - & 918 & - & & $110.86-121.51$ & - & 20 & - \\
\hline & $100-105$ & - & 398 & - & Arnum (25b) & $62.7-62.9$ & - & 490 & - \\
\hline & $105-110$ & - & 308 & - & & $95.0-95.3$ & - & 88 & - \\
\hline & $110-115$ & - & 104 & - & & $101-104.3$ & - & 10 & - \\
\hline & 115 & - & 158 & - & & $104.3-107.5$ & - & 112 & - \\
\hline Arnum (13) & $28-40$ & - & 28 & - & & 107.5 & - & 15 & - \\
\hline
\end{tabular}

Description.

The greater part of the material consists of broken shells and hinge fragments. Several complete valves were, however, found, mostly among the shells from Toftlund.

Prodissoconch orbicular, smooth and glossy, very difficult to distinguish on the dissoconch. Diameter about $0.30 \mathrm{~mm}$.

Dissoconch. The shells of this species have been repeatedly described by earlier authors. Reference will therefore only be made to the accompanying figures, and to the statistical data concerning the shells from South Jutland, which otherwise display the normal features of the species.

Variability. Length $(L)$ and height $(H)$ were measured on 110 valves from Toftlund $\left(75-100 \mathrm{~m}\right.$.) and the $\frac{L}{H}$ ratios were afterwards calculated. The data were grouped in accordance with the shell length, as was done in Yoldia glaberrima ete. treated above (p. 61). Mean values of $\frac{L}{H}$ were calculated for all shells and for the individual size groups $A, B$, and $C$ as displayed by the following table and fig. 9 . 


\begin{tabular}{|c|c|c|c|c|}
\hline & $\begin{array}{l}\text { Number of } \\
\text { specimens }\end{array}$ & $L$ & $\frac{L}{H}$ mean values & \\
\hline $\begin{array}{l}\text { Total shell } \\
\text { material }(\mathrm{A}+\mathrm{B}+\mathrm{C})\end{array}$ & 110 & $3-9 \mathrm{~mm}$. & $1.2375 \pm 0.0171$ & $\begin{array}{l}1.2546 \\
1.2204\end{array}$ \\
\hline Group A & 37 & $3-4 \quad-$ & $1.1797 \pm 0.0157$ & $\begin{array}{l}1.1954 \\
1.1640\end{array}$ \\
\hline$-B$ & 39 & $4-5 \quad-$ & $1.2487 \pm 0.0202$ & $\begin{array}{l}1.2689 \\
1.2285\end{array}$ \\
\hline$-\quad \mathrm{C}$ & 34 & $5-9 \quad-$ & $1.2853 \pm 0.0242$ & $\begin{array}{l}1.3095 \\
1.2611\end{array}$ \\
\hline
\end{tabular}
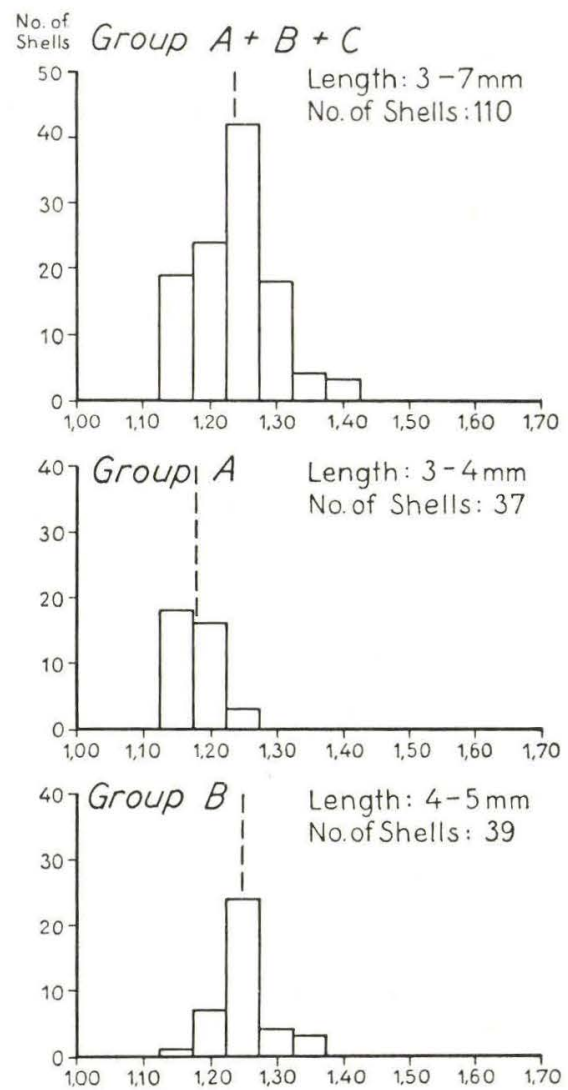

It is obvious that the $\frac{L}{H}$ ratio increases with the size of the shell, and development during shell growth is thus similar to that in the taxodont species treated above.

Remarks. It is clear from the literature that S. subtruncata is a very variable species. Many authors have used special names for the fossil shells, a procedure which has not been followed in the present case. The main reason why the shells mentioned in the synonymy are included is that no objective significant difference which might justify the separation of one or more of them could be recognized by the writer.

\section{Distribution.}

Recent: West Coast of Europe from Finmark to Moroceo, Mediterranean.

Pliocene: North Sea Basin: England: Red Crag. Holland. Mediterranean Basin: Italy: Piacenziano, Astiano, upper Pliocene of Monte Mario.

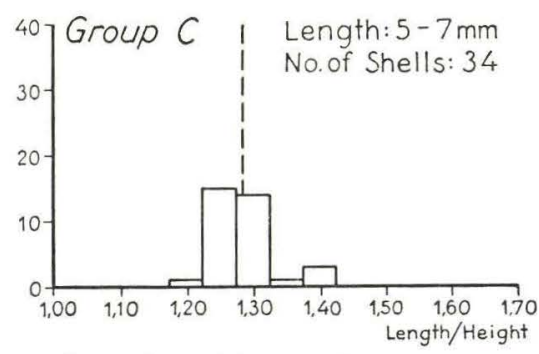

Spisula subtruncata (DA COSTA) var. Fig. 9. 
Mediterranean Basin: Italy: Elveziano, Tortoniano.

Vienna Basin: Grund sands.

Oligocene: North Sea Basin: Holland (u.) Germany (u.).

\title{
58. Spisula solida (Linné)
}

Recent:

\author{
Plate 19, fig. 58.
}

1758. Cardium solidum Linné. Syst. Nat. Ed. Dec. p. 681.

1853. Mactra sotida Linneus. Forbes \& Hantey. Brit. Moll. 1, p. 351, pl. 22, fig. 1, 5; pl. L, fig. 2 .

1863. Mactra solida Linnaus. Jeffreys. Brit. Conch. 2, p. 415, 5, pl. 43, fig. 2.

1878. Mactra elliptica Bronn. G. O. Sars. Moll. Reg. Arct. Norvegiae. p. 72.

1892. Mactra solida Linné. Locard. Coq. mar. d. côtes d. France. p. 265.

1932. Mactra solida Linné. Nobre. Moluscos mar. de Portugal. p. 368, pl. 71, fig. 6, pl. 79, fig. 4 .

1934. Spisula solida Linné. AD. S. Jensen \& R. Spärck. Saltvandsmuslinger, p. 160.

Fossil:

1861. Mactra solida Linnzus. Wood. Monogr. Crag Moll. 2, p. 245, pl. 24, fig. 4.

1901. Spisula solida Linnaus. SAcco. I moll. d. terr. terz. d. Piemonte e d. Liguria. 29, p. 24.

1950. Spisula (S.) solida Linneus. Henring. Plioc. and older Plistoc. Netherlands. p. 148, pl. 17, fig. 3-4.

Original diagnosis. Testa triangulari rotundata opaca laviuscula, cardinibus foveola pyriformi. (Linné 1758).

Shell material.

Toftlund 75-100 m.: 11 left valves and 13 right valves.

Description.

Prodissoconch very difficult to distinguish on the adult shell. Outline orbicular, diameter about $0.30 \mathrm{~mm}$. Surface smooth and glossy.

Dissoconch. The dissoconch has been extensively described by earlier authors to whose work reference should be made concerning the trivial features of the shell.

The shells from Toftlund are equilateral, and approach the variety elliptica with respect to outline. The particularly deep pallial sinus is observed in those specimens which are not filled with sediment.

Spisula solida from Toftlund 75-100 m. Dimensions of shells.

$L=$ length, $H=$ height, $W=$ width. $1=$ left, $\mathrm{r}=$ right.

$\begin{array}{ccccccccccccc}\text { No. } & 1 & 2 & 3 & 4 & 5 & 6 & 7 & 8 & 9 & 10 & 11 & 12 \\ \text { Valve } & 1 & 1 & 1 & 1 & \mathrm{r} & \mathrm{r} & \mathrm{r} & \mathrm{l} & \mathrm{r} & \mathrm{r} & \mathrm{r} & \mathrm{r} \\ L & 7.2 & 7.1 & 7.0 & 6.4 & 6.0 & 5.6 & 5.6 & 5.5 & 5.4 & 5.4 & 5.4 & 5.3 \\ H & 5.0 & 4.9 & 4.8 & 4.9 & 4.5 & 4.1 & 4.1 & 4.1 & 4.2 & 3.8 & 4.1 & 4.1 \\ W & 1.9 & 1.7 & 1.7 & 2.0 & 1.5 & 1.4 & 1.4 & 1.5 & 1.5 & 1.3 & 1.4 & 1.4 \\ \frac{L}{H} & 1.44 & 1.45 & 1.46 & 1.3 & 1.33 & 1.37 & 1.37 & 1.34 & 1.28 & 1.42 & 1.32 & 1.29 \\ \frac{L}{W} & 3.8 & 4.18 & 4.12 & 3.2 & 4.0 & 4.0 & 4.0 & 3.67 & 3.6 & 4.15 & 3.85 & 3.8\end{array}$




$\begin{array}{ccccccccccccc}\text { No. } & 13 & 14 & 15 & 16 & 17 & 18 & 19 & 20 & 21 & 22 & 23 & 24 \\ \text { Valve } & \mathrm{r} & 1 & \mathrm{r} & 1 & 1 & \mathrm{r} & \mathrm{r} & \mathrm{r} & 1 & 1 & \mathrm{r} & 1 \\ L & 5.3 & 5.1 & 5.0 & 5.0 & 4.7 & 4.7 & 4.5 & 4.4 & 3.9 & 3.8 & 3.5 & 3.2 \\ H & 3.7 & 3.8 & 3.8 & 3.7 & 3.7 & 3.6 & 3.3 & 3.35 & 2.95 & 2.9 & 2.7 & 2.6 \\ W & 1.25 & 1.3 & 1.2 & 1.2 & 1.3 & 1.2 & 1.2 & 1.2 & 1.1 & 1.1 & 0.9 & 1.0 \\ \frac{L}{H} & 1.43 & 1.34 & 1.32 & 1.35 & 1.27 & 1.30 & 1.36 & 1.31 & 1.32 & 1.31 & 1.30 & 1.23 \\ \frac{L}{W} & 4.22 & 3.9 & 4.15 & 4.15 & 3.6 & 3.9 & 3.75 & 3.65 & 3.55 & 3.1 & 3.9 & 3.2\end{array}$

\begin{tabular}{|c|c|c|}
\hline \multirow{3}{*}{ Mean values: } & Shells no. 1-12, & no. $13-24$ \\
\hline & $\frac{L}{H} 1.364$ & 1.320 \\
\hline & $\frac{L}{W} 3.86$ & 3.76 \\
\hline
\end{tabular}

The variability of the dimensions of the shells from Toftlund is clearly shown in the table above. The number of specimens is too small to warrant a statistical verification of the potential tendency of increase in the $\frac{L}{H}$ and $\frac{L}{W}$
ratios with age as indicated by the mean values.

Remarks. It is very difficult to discriminate juvenile shells of $S$. solida from shells of S. subtruncata, and it should, therefore, be remarked that some shells of $S$. solida may have been included in the shell material described above as S. subtruncata.

\section{Distribution.}

Recent: West Coast of Europe from East Finmark to Portugal.

Pliocene: North Sea Basin: Holland, England: Red Crag. Mediterranean Basin: Italy: Piacenziano.

Miocene: North Sea Basin: Denmark: Arnum formation.

\section{FAMILIA DONACIDAE FLEMING 1828}

\section{Genus Donax Linné 1758}

Shell material.

\section{Donax sp.}

Arnum 104.3-107.5 m. fragment of right valve.

Description.

The fragment is very worn, it is about $3.5 \mathrm{~mm}$. long and $1.4 \mathrm{~mm}$. wide, the posterior and ventral parts are missing.

About 50 radial striae are seen on the external surface.

The hinge has one strong cardinal tooth and one minor lamelliform tooth on either side. A furrow is found on the antero-dorsal margin, and a relatively strong lateral tooth (very worn) is indicated on the posterior part of the hinge. In spite of the uncertainty arising from the fragmentary and rolled state of the hinge, there is resemblance to the hinge of the recent D. vittatus.

The preserved part of the anterior ventral margin is crenated. 
FAMILIA SFMELIDAE

\title{
Genus Abra (Leach) Lamarck 1818
}

\section{Abra prismatica (Montagu) var.}

Recent:

\author{
Plate 19, fig. 60.
}

1803. Ligula prismatica Montagu. Test. Britannica. Suppl. p. 23, pl. 26, fig. 3.

1853. Syndosmya prismatica Montagu. Forbes \& Hanley. Brit. Moll. 1, p. 321, pl. 17, fig. 15 .

1863. Scrobicularia prismatica Montagu. Jeffreys. Brit. Conch. 2, p. 435; 5, pl. 45, fig. 1. 1867. Syndosmya angulosa Renieri. Weinkauff Conch. d. Mittelmeeres p. 55.

1878. Abra prismatica Mont. Sars. Moll. Reg. Aret. Norvegiae, p. 75.

1892. Syndesmya prismatica Montagu. Locard. Coqu. mar. d. côtes d. France, p. 273.

1932. Syndesmia prismatica (LAskey). Nobre. Moluscos mar. de Portugal, p. 392.

1934. Syndosmya prismatica (Montagu). Ad. S. Jensen \& Spärck. Saltvandsmuslinger. p. 141 .

Fossil:

1861. Abra prismatica Montagu. Wood. Monogr. Crag Moll. 2, p. 239, pl. 22, fig. 13.

1901. Abra prismatica (LASK. Montg.) Sacco. I moll. d. terr. terz. d. Piemonte e d. Liguria. 29 , p. 121, pl. 26, fig. 22-24.

1909. Syndesmya (Abra) prismatica (LAsk.) MTG. sp. Cerrulli-Irelti. Fauna mal. mariana, p. 179, pl. 21, fig. $27-36$.

?1909. Abra Degrangei (Cossm.). Cossmann \& Peyrot. Conch. Néogén. d. l'Aquit. p. 289, pl. 7, fig. 3-4 \& 13 .

1925. Abra angulosa Ren. Kautsky. D. Mioc. v. Hemmoor u. Basbeck-Osten. p. 45.

1940. Abra angulosa Ren. Sorgenfrei. Mar. Nedre-Mioc. i Klintinghoved p. Als, p. 25, pl. 4, fig. 13-14.

1950. Abra prismatica (Montagu). Henring. Plioc. and older Plistoe. Netherlands, p. 162 , pl. 16, fig. $5-6$.

1950. Abra prismatica (Montagu). Henring. Mioc. Pelec. of the Netherlands, p. 39, pl. 7, fig. 171-172.

1956. Abra (Abra) prismatica (Montagu). Banke Rasmussen. Upper Mioc. South Jutland, p. 46 , pl, 1, fig. 4 .

Essential features of original description. Shell oblong, flat, thin, glossy, white, considerably attenuated at one end, and obsoletely striated concentrically; the umbo very small, placed nearest to, and turning towards the smaller end. Hinge furnished with a horizontal tooth - a sub-triangular depression for the cartilage, and a minute erect tooth in both valves, besides a small lamina or lateral tooth in one valve on each side, remote; of which the other is destitute (MONTAGU 1803).

Shell material investigated.

\begin{tabular}{|c|c|c|c|c|c|c|c|c|c|}
\hline \multirow{2}{*}{$\begin{array}{l}\text { Location } \\
\text { Glejbjerg }\end{array}$} & \multicolumn{2}{|c|}{ Depth } & \multicolumn{2}{|c|}{ Shells } & Location & \multicolumn{2}{|c|}{ Depth } & \multicolumn{2}{|c|}{ Shells } \\
\hline & \multicolumn{2}{|c|}{$23 \mathrm{~m}$. } & \multicolumn{2}{|c|}{6 valves } & \multirow[t]{3}{*}{ Gramby } & \multicolumn{2}{|c|}{$92.72-109.29 \mathrm{~m}$} & \multicolumn{2}{|c|}{2 valves } \\
\hline & & - & 8 & - & & $109.29-110.86$ & - & 2 & - \\
\hline & 32 & - & 6 & - & & $110.86-121.51$ & - & 2 & - \\
\hline & 42 & - & 28 & - & \multirow[t]{5}{*}{ Toftlund } & $75-100$ & - & 94 & - \\
\hline & 52 & - & 6 & - & & $100-105$ & - & 34 & - \\
\hline & 53 & - & 10 & - & & $105-110$ & - & 54 & - \\
\hline & 53.5 & - & 48 & - & & $110-115$ & - & 124 & - \\
\hline & 53.75 & - & 12 & - & & 115 & - & 4 & - \\
\hline & 54 & - & 2 & - & \multirow[t]{2}{*}{ Arnum (13) } & $28-40$ & - & 85 & - \\
\hline & 55 & - & 8 & - & & $53-83$ & - & 5 & - \\
\hline \multirow[t]{3}{*}{ Ribe } & $115-116$ & - & 2 & - & \multirow[t]{5}{*}{$-\quad(25 b)$} & $62.7-62.9$ & - & 23 & - \\
\hline & $122-123$ & - & & (frg.) & & $95-95.3$ & - & 8 & - \\
\hline & $124-125$ & - & 1 & - & & $101-104.3$ & - & 10 & - \\
\hline \multirow[t]{2}{*}{ Gramby } & $82.66-83.76$ & - & 10 & alves & & $104.3-107.5$ & - & 134 & - \\
\hline & $84.66-87.16$ & - & 26 & - & & 107.5 & - & 7 & - \\
\hline
\end{tabular}


Description.

The shells of this species are very fragile and are rarely well preserved in the samples. The bulk of the material consists of fragments with preserved hinge.

Prodissoconch not observed.

Dissoconch. The shell is less oblong than those of the recent species at the writers disposal, which have been taken at various places in the North Atlantic region (Iceland, Faroes, Jutland). The umbonal angle of the fossil species is apparently less on average than in the recent representative and the posterodorsal margin is straighter. The fossils from South Jutland apparently resemble Cerulli-Irelti's form B (loc. cit. p. 21, fig. 29-31), and they agree fairly well with Heering's shells from the Miocene.

The exterior does not differ from the recent shells concerning smoothness and growth lines, and the hinge is very similar to that of the living species. Concerning the interior, no particulars have been noticed compared with recent shells apart from morphological differences resulting from the variations in shell outline.

Dimensions of 4 valves of Abra prismatica var. from Toftlund $115 \mathrm{~m}$.

$\begin{array}{lrrrrr}\text { Valve } & \mathrm{r} & \mathrm{r} & \mathrm{l} & \mathrm{l} \\ \text { Length } & 10.6 & 10.1 & 7.4 & 6.7 \mathrm{~mm} \text {. } \\ \text { Height } & 6.65 & 6.2 & 4.6 & 4.0 & - \\ \text { Width } & 1.9 & 1.74 & 1.22 & 0.98 \quad-\end{array}$

Remarks. The present shells and possibly some other fossil shells, e.g., the shells cited from the Miocene of the Netherlands, deviate from recent shells with respect to shell outline. This difference in shell outline might justify the separation of some of the fossil forms from $A$. prismatica and their inclusion in an independant species. Lack of data on shell variation, both of recent and fossil shells renders, however, objective decision impossible at present.

\section{Distribution.}

Recent: North Atlantic from Finmark and Iceland to and including the Mediterranean.

Pliocene: North Sea Basin: England: Coralline Crag. Holland. Mediterranean: Italy: Piacenziano, upper Pliocene of Monte Mario.

Miocene: Aquitanian Basin: Burdigalien(?), Helvétien (?). North Sea Basin: Holland (m.), Germany: Hemmoor stage; Reinbek stage (Gotтsche 1878), Glimmerton (Banke Rasmussen 1956), Denmark: Klintinghoved clay, and Arnum and Gram formations.

FAMILIA TELLINIDAE DESHAYES

\section{Genus Anǵulus Megerle von Mühlfeld 1811}

\section{Angulus donacinus (Linné)}

Recent:

Plate 20, fig. $61 \mathrm{a}-\mathrm{b}$.

1758. Tellina donacina Linné. Syst. Nat. Ed. Dec., p. 676.

1853. Tellina donacina Linné. Forbes \& Hanley. Brit. Moll. 1, p. 292, pl. 20, fig. 3-4, pl. K, fig. 4 . 
1863. Tellina donacina Linné. Jefreneys. Brit. Conch. 2, p. 386, 5, pl. 41, fig. 4.

1867. Tellina donacina Linné. Weinkauff. Conch. d. Mittelmeeres. p. 84.

1892. Tellina donacina Linné. Locard. Coq. mar. d. côtes d. France. p. 275.

1898. Tellina donacina Linné. Bucquoy, Dautzenberg \& Dollfus. Moll. mar. du Roussillon. 2, p. 648, pl. 91, fig. 13-19.

1932. Tellina donacina Linné. Nobre. Moluseos mar. de Portugal p. 383, pl. 76, fig. 4, pl. 77 , fig. 3 .

1934. Tellina donacina Linné. Ad. S. Jensen \& R. Spärok. Saltvandsmuslinger. p. 134, fig. 118.

Fossil:

1861. Tellina donacina Linné. Wood. Monogr. Crag Moll. 2, p. 233, pl. 22, fig. 5.

1870. Tellina donacina Linné. Hörnes. D. foss. Moll. d. Tert.-Beckens von Wien. 2, p. 86, pl. 8, fig. 9 .

1901. Moerella donacina Linné. SAcco. I moll. d. terr. terz. d. Piemonte e d. Liguria 29, p. 105, pl. 22, fig. $24-27$.

1908. Tellina (Moerella) donacina Linné. Ceruldi-Ireldi. Fauna mal. mariana. p. 168, pl. 20, fig. 5-10.

1910. Tellina (Moerella) donacina Linné. Cossmann \& Peyrot. Conch. Néogén. d. l'Aquit. p. 244, pl. 8, fig. 13-18.

?1916. Tellina cf. donacina. NørRegandD. Mel.-mioc. Blokke fra Esbjerg. p. 16.

1925. Tellinia (Moerella) donacina Linné. Kautsky. D. Mioc. v. Hemmoor u. BasbeckOsten. p. 44, pl. 4, fig. 15 .

1950. Angulus (Moerella) donacinus Linné. Heering. Mioc. Pelec. Netherlands. p. 41, pl. 8, fig. 197.

1950. Angulus (Moerella) donacinus Linné. Heering. Plioc. and older Plistoc. Netherlands. p. 172, pl. 15, fig. 17-20.

Original diagnosis. Tellina testa ovata compresso-planiuscula lovviuscula: antice obtussissima (LINNÉ 1758).

Shell material.

\begin{tabular}{|c|c|c|c|c|c|}
\hline Location & Depth & Shells. & Location & Depth & Shells \\
\hline jbjerg & $55 \mathrm{~m}$. & 1 r.v. frg. & Toftlund & $105-110 \mathrm{~m}$. & 1 r.v. frg. \\
\hline Gramby & $\begin{array}{r}84.66-87.16- \\
92.72-109.29-\end{array}$ & $\begin{array}{l}\text { 1 l. v. (?)- } \\
\text { l r.v. }\end{array}$ & $\begin{array}{c}\text { Arnum }(13) \\
-\quad(25 \mathrm{~b})\end{array}$ & $\begin{array}{r}53-83- \\
62.7-62.9\end{array}$ & $\begin{array}{l}\text { I r.v. frg. } \\
\text { l l. v. frg. }\end{array}$ \\
\hline
\end{tabular}

Description.

Prodissoconch smooth, glossy, oval. Dimensions: Gramby 92.72$109.29 \mathrm{~m}$.: height $0.279 \mathrm{~mm}$., length $0.340 \mathrm{~mm}$.; Glejbjerg $55 \mathrm{~m}$.: height $0.294 \mathrm{~mm}$., length $0.387 \mathrm{~mm}$.

Dissoconch. Apart from a minute juvenile shell from $92.72-109.29 \mathrm{~m}$. at Gramby all shells are fragmentary.

The largest fragment is shown on plate 20, fig. 61. It displays the following characteristic shell features of the species: The external sculpture consists of flat, glossy, closely spaced concentric "ribs" on the anterior and medial part of the shell, and less numerous, more widely spaced, and more elevated ribs on the posterior part of the shell. No comments will be made on the interior or the hinge except that there is obviously no important deviation from the normal aspect of both the fossil and recent forms recorded in literature.

Distribution.

Recent: North Atlantic Ocean from Scotland to Madeira and the Azores, western and southern North Sea, Mediterranean.

Pliocene: North Sea Basin: England: Coralline Crag. Holland. Mediterranean: Italy: Piacenziano, Astiano, upper Pliocene of Monte Mario. 
Miocene: Aquitanian Basin: Aquitanien, Burdigalien, Helvétien.

North Sea Basin: Holland (m.); Germany: Hemmoor stage; Denmark: Arnum formation.

Mediterranean Basin: Italy: Elveziano, Tortoniano. Vienna Basin: Deposits at Grund and Vöslau.

\section{Genus Tellina Linné 1758}

\section{Tellina cf. fallax Beyrich}

1867. Tellina fallax Beyrich. v. Koenen. D. mar. M.-Olig. Nordd. p. 113.

1893. Tellina fallax Beyrich. Lehmann. D. Lam. d. Mioc. v. Dingden. 2, p. 277.

1907. Tellina fallax Beyrich. Ravn. Molluskf. Jyll. Tert,, p. 280.

1914. Tellina fallax Beyrich. Gripr. Itzehoe. p. 9.

1916. Tellina Benedenii Nyst \& Westendorp. Nørregand. M.-mioc. Blokke fra Esbjerg. p.16.

1925. Tellina fallax Beyrich. Kautsky. D. Mioc. v. Hemmoor u. Basbeck-Osten. p. 42.

1940. Tellina fallax Beyrich. Sorgenfrei. Mar. Nedre-Mioc. i Klintinghoved p. Als. p. 23, pl. 4, fig. 11-12.

1945. Angulus (Angulus) fallax Beyrich sp. Glibert. Faune mal. du Mioc. de la Belgique. 1, p. 207, pl. 12, fig. 4 .

1950. Tellina fallax Bexrich. Heering. Mioc. Pelec. Netherlands. p. 42, pl. 8, fig. 188.

Original statement of the species included in the description of Tellina Nysti in von Koenen's paper from 1867. No diagnosis or description is given, but it is stated that the Miocene Tellina fallax, related to the Pliocene T. Benedenii, differs from T. Nysti by the bend of the posterior end of the shell. The species has generally been accepted by later authors in spite of the incomplete first record.

Shell material.

\begin{tabular}{|c|c|c|c|c|c|c|c|}
\hline & \multicolumn{2}{|c|}{ Depth } & Shells & Location & \multicolumn{2}{|c|}{ Depth } & Shells \\
\hline & 32 & & 1 r.v. frg. & \multirow[t]{6}{*}{ Toftlund } & $75-100$ & & 2 l. v. fr \\
\hline & 42 & - & I r.v. frg. (?) & & $100-105$ & - & 1 l. v. \\
\hline & 53 & - & 1 r.v. frg. & & & & 3 r.v. fr \\
\hline \multirow{2}{*}{$\begin{array}{l}\text { Location } \\
\text { Glejbjerg }\end{array}$} & 53.5 & - & 1 l. v. frg. & & $105-110$ & - & 6 v. frg. \\
\hline & 53.75 & - & $1 \mathrm{r} . \mathrm{v}$. & & $110-115$ & - & 3 v. frg. \\
\hline Bramminge & $70-80$ & - & $13 \mathrm{v}$. & & 115 & - & 9 v. frg. \\
\hline \multirow[t]{4}{*}{ Gramby } & $84.66-87.16$ & - & $1 \mathrm{r} . \mathrm{v}$. & \multirow{4}{*}{$\begin{array}{r}\text { Arnum }(13) \\
(25 \mathrm{~b})\end{array}$} & $83-94$ & - & 1 v. frg. \\
\hline & $90.42-92.72$ & - & 1 frg. & & $104.3-107.5$ & - & 3 v. frg. \\
\hline & 106 & - & $1 \mathrm{l} . \mathrm{v}$. & & 107.5 & - & I v. frg. \\
\hline & $10.86-121.51$ & - & 1 l. v. frg. & & & & \\
\hline
\end{tabular}

Description. The shell from Gramby $106 \mathrm{~m}$. is an almost complete left valve about $32 \mathrm{~mm}$. high, $47 \mathrm{~mm}$. long, and $6 \mathrm{~mm}$. wide. It agrees with the shells from Klintinghoved referred to T.fallax by the writer in 1940, and is also very similar to the shells described by GLIBERT and HeERING from Belgium and Holland respectively.

The other shells listed are all very fragmentary, but the hinge parts preserved are compatible with the hinge features of $T$. fallax. Since the determination of $T$. fallax is dependant on the shell outline these fragments could, however, not definitely be referred to $T$. fallax. 
Distribution of $T$. fallax.

Miocene: North Sea Basin: Belgium: Boldérien, horizon of Houthaelen, Anversien. Holland (m.) Germany: Vierlande, Hemmoor and Dingden stages. Denmark: Klintinghoved clay and Arnum formation.

FAMILIA SOLENIDAE LATREILLE 1825

Genus Pharus (Leach) Brown 1844

\section{Pharus saucatsensis (Des Moulins)}

Plate 21, fig. 63 a-c.

1871. Polia saucatsensis Des Moulins. Notes sur le G. Polia, p. 39, fig. 1-6.

1909. Pharus saucatsensis (Des Moulins). Cossmann \& Peyrot. Conch. Néogén. d. l'Aquit. p. 227, pl. 4, fig. 15-16, 20.

Essential features of original description. The paper by Des MouLINS has not been available to the writer, however, in default of the original definition of the species the differences between the recent Pharus legumen and Pharus saucatsensis as stated by Des Mounins should be cited according to Cossmann \& Peyrot (1909, p. 229): il (Des Moulins) â surtout insisité sur les côtes ou barres internes (clavicules) dont on constate l'existence à l'intérieur des valves, et auquelles il â attaché... une grande importance au point de vue générique: il y en a deux divergentes, dans le genre Pharus; or la côte cardinale du antérieure se détache en courbe chez le fossile tandis qu'elle est rectiligne chez P. legumen; en outre, la côte postérieure est moins oblique et plus robuste chez ce dernier que chez P. saucatsensis.

Shell material: fragments of one right valve from Gramby 82.66-83.76 m. and fragments of two left valves and one right valve from Arnum (25b) $62.7-62.9 \mathrm{~m}$.

Description.

Prodissoconch corroded.

Dissoconch. Exterior smooth and glossy with distinct growth lines and some irregular, obscure, radial striae as described by Cossmann \& Peyrot. Furrow in front of the umbo.

Hinge of right valve with two diverging teeth; one beneath the umbo is broken, the other one extends backwards sloping towards the postero-ventral margin without reaching it. Resilium in narrow furrow on the dorsal margin.

Left valve with two cardinal teeth below the umbo; they are broken on both specimens available. They have apparently been directed downwards.

The interior is characterized by reinforcement ribs, as defined above, citing Des Moulins. The anterior rib may not be as strongly curved as indicated by the specimen figured by Cossmann \& Peyrot (loc, cit. pl. 4, fig. 16). However, there is a clear distinction from $P$. legumen, in which the anterior rib is almost parallel with the dorsal margin. The posterior rib is much weaker; it runs backwards and downwards from the umbonal region.

A part of the anterior adductor scar is preserved below the distal end of the anterior rib on the right valve from Gramby. 
Remarks. The similarities between the shells described from southwestern France and the shell fragment from South Jutland are impressive. There is thus little doubt as to the identity of the shell from Gramby, in spite of its incomplete preservation.

Distribution.

Miocene: Aquitanian Basin: Burdigalien, Helvétien.

North Sea Basin: Denmark: Arnum formation.

\section{Genus Gultellus Schumacher 1817}

\section{Cultellus sp.}

Plate 22, fig. 64 a-b.

Shell material. Gramby $84.66-87.16 \mathrm{~m}$; hinge fragment of right valve. Arnum (25. b.) $62.7-62.9 \mathrm{~m}$. hinge fragment of left valve; $104.3-107.5 \mathrm{~m}$. hinge fragment of right valve.

Remarks. The fragments are rather poor. There is, however, little doubt as to the correct determination of the genus. The hinge is similar to the hinge of the recent species Cultellus pellucidus Pennant which has been recorded from Hemmoor by KaUtsky (1925, p. 45), but otherwise is only known from Pliocene and Pleistocene deposits.

\section{Genus Ensis Schumacher 1817}

\section{Ensis Degrangei Cossmann \& Peyrot}

Plate 21, fig. 65 a-b.

1909. Ensis Degrangei Cossmann \& Peyrot. Conch. Néogén. d. l'Aquit. p. 225, pl. 4, fig. $6-7,9-11,18-19$.

Essential features of original description. Taille au dessous de la moyenne; forme étroite, arquée, très déprimée, inéquilaterale; côté antérieur court, ovale, dépourvu de sillon rayonnant; côté postérieur formant presque toute la longeur de la valve, tronqué à son extrémité. (Cossmann \& Peyrot 1909).

Shell material.

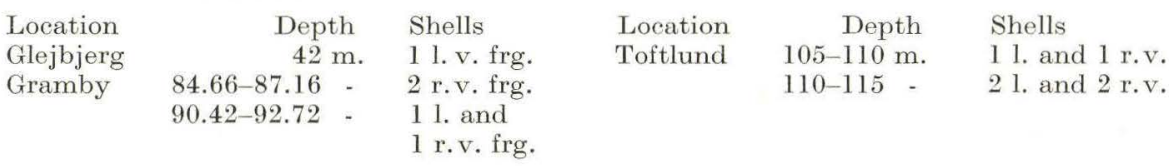

Description. The entire material consists of fragments, and only the anterior shell features could be studied.

Prodissoconch smooth and glossy with minute concentric striae. Outline transversely oval. Dimensions of one of the shells from Toftlund 110-115 m.: height about $0.28 \mathrm{~mm}$., length $0.387 \mathrm{~mm}$.

Dissoconch. Exterior smooth with growth lines, occasionally a furrow around the umbo. Anterior end rounded protruding beyond the umbo.

Hinge: typical Ensis hinge; left valve with two closely placed carinate teeth formed as a pair of nippers and two similarly developed posterior lateral 
teeth; right valve with one narrow cardinal tooth and one posterior lateral tooth which is parallel to the dorsal margin.

Interior: Anterior adductor scar visible on a few shells; it is seen beneath the umbo as a horisontal, relatively well defined scar. A narrow branch extends from the anterior end of the scar towards the ventral margin.

Remarks. The characters of the anterior end of the shell seem to be sufficiently distinct to justify the reference of the shells to the species established by Cossmann \& Peyrot.

Distribution.

Miocene: Aquitanian Basin: Aquitanien, Burdigalien.

North Sea Basin: Denmark: Arnum formation.

FAMHLIA SAXICAVIDAE

\section{Genus Saxicava Fleuriau de Bellevue 1802}

\section{Saxicava arctica (Linné)}

Recent:

Plate 20, fig. 66 a-e.

1767. Mya aretica Lrnné. Syst. Nat. Ed. Duodec. 2, p. 1113.

1853. Saxicava arctica Linné. Fonbes \& Hanley. Brit. Moll. 1. p. 141, pl. 6, fig. 4-6.

1865. Saxicava rugosa Linné. var. arctica. Jeffreys. Brit. Conch. 3, p. 82, 5, pl. 51, fig. 4. 1867. Saxicava arctica Linné. Weinkauff. Conch. d. Mittelmeeres. p. 20.

1878. Saxicava arctica Linné. Sars. Moll. Reg. Aret. Norvegiae, p. 95, pl. 20, fig. 8.

1892. Saxicava arctica Linné. Locard. Coq. mar. d. côtes d. France. p. 251.

1896. Saxicava arctica Linné. sp. Bucquoy, Dautzenberg \& Dolifus. Moll. mar. du Roussillon. 2, p. 589, pl. 86, fig. 1-4 \& 5-11.

1932. Saxicava arctica Linné. Nobre. Moluscos mar. de Portugal. p. 375, pl. 63, fig, 8

1934. Saxicava arctica Linné. Ad. S. Jensen \& R. Spärck. Saltvandsmuslinger. p. 165. (pro parte).

Fossil:

1861. Saxicava arctica Linné. Wood. Monogr. Crag Moll. 2, p. 287, pl. 29, fig. 4.

1867. Saxicava aretica Linné. V. Koennen. D. mar. M.-Olig. Nordd. p. 120.

1893. Saxicava arctica Linné. Lehmann. D. Lam. d. Mioc. v. Dingden. 2, p. 283.

1901. Saxicava arctica Linné et var. SAcco. I moll. d. terr. terz. d. Piemonte e d. Liguria. 29 , p. 47 , pl. 13 , fig. $1-8$.

1907. Saxicava arctica Linné. Ravn. Molluskf. Jyll. Tert., p. 282, pl. 1, fig. 26.

1909. Saxicava artica Linné. sp. Cerulli-Irelli. Fauna mal. mariana. p. 151, pl. 18, fig. $3-10$.

1909. Saxicava arctica Linné. Cossmann \& Peyrot. Conch. Néogén. d. l'Aquit. p. 203, pl. 3, fig. 20-27.

1914. Saxicava arctica Linné. Gripp. Über eine untermioz. Molluskenf. v. Itzehoe, p. 10

1916. Saxicava arctica Linné sp. NørregaARD. M.-mioc. Blokke fra Esbjerg, p. 17.

1925. Saxicava aretica Linné. Kautsky. D. Mioc. v. Hemmoor u. Basbeck-Osten. p. 47.

1941. Saxicava arctica Linné. Göraes. D. Oberolig.-fauna v. Rumeln a. Niederrhein. p. 172.

1944. Saxicava arctica Linné. Heering. D. oberolig. Biv. a. d. Peelgebiete. p. 42, pl. 3 , fig. 19-20.

1945. Saxicava (Saxicava) arctica Linné sp. Glibert. Faune mal. du Mioc. de la Belgique. 1, p. 209, pl. 11, fig. 7 .

1950. Saxicava (Saxicava) arctica Linné. Heering. Plioc. and older Plistoc. Netherlands. p. 184.

1950. Saxicava (Saxicava) arctica Linné. Heering. Mioe. Pelec. Netherlands. p. 43, pl. 6, fig. $133,146$. 
Original diagnosis. Testa striata: valvulis carinis duabus spinulosis; cardine edentulo. (LINNÉ 1767).

Shell material.

\begin{tabular}{|c|c|c|c|c|c|c|c|}
\hline \multirow{3}{*}{$\begin{array}{l}\text { Location } \\
\text { Glejbjerg }\end{array}$} & \multicolumn{2}{|c|}{ Depth } & Shells & \multirow{2}{*}{$\begin{array}{l}\text { Location } \\
\text { Toftlund }\end{array}$} & \multicolumn{2}{|c|}{ Depth } & Shells \\
\hline & $23 n$ & & $3 \mathrm{v}$. & & $75-100$ & & \\
\hline & 32 & - & 1 - & & $100-105$ & - & 36 \\
\hline & 42 & - & $5-$ & & $105-110$ & - & 152 \\
\hline & 53.5 & - & $2-$ & & $110-115$ & - & $64-$ \\
\hline & 53.75 & - & 1 - & & 115 & - & 9 \\
\hline Bramminge & $70-80$ & - & $4-$ & Arnum (13) & $28-40$ & - & 1 - \\
\hline Ribe & $113-114$ & - & $1-$ & & $53-83$ & - & $34-$ \\
\hline Gramby & $82.66-83.76$ & - & $7-$ & Arnum (25b) & $62.7-62.9$ & - & $31-$ \\
\hline & $84.66-87.16$ & - & $7-$ & & $95.0-95.3$ & - & $16-$ \\
\hline & $90.42-92.72$ & - & 1 - & & $101.0-104.3$ & - & 2 - \\
\hline & $109.29-110.86$ & - & $1-$ & & $104.3-107.5$ & - & $10-$ \\
\hline & $110.86-121.51$ & - & 1 - & & 107.5 & - & 9 - \\
\hline
\end{tabular}

Description. The bulk of the material consists of more or less fragmentary specimens. However, a few shells were well enough preserved to permit the measurement of various dimensions.

Prodissoconch smooth and glossy, relatively much arched. Shell outline similar to that of e. g. Cyprina. Height and length of the prodissoconch measured on 10 specimens from Toftlund $(75-100 \mathrm{~m}$.) as follows:

\begin{tabular}{|c|c|c|c|c|c|c|c|c|c|c|}
\hline & 1 & 1 & 1 & 1 & 1 & $\mathrm{r}$ & $\mathrm{r}$ & $\mathbf{r}$ & $\mathrm{r}$ & $\mathbf{r}$ \\
\hline & 0.450 & .387 & .380 & .38 & 0.434 & 0.440 & 0.435 & 0.418 & 0.375 & 0.5 \\
\hline Hgon & 0.510 & 0.449 & 0.457 & 0.465 & 0.510 & 0.526 & 0.472 & 0.527 & 0.438 & 0.425 \\
\hline
\end{tabular}

It is obvious from these figures that the size of the prodissoconch varies markedly.

Dissoconch inequivalve, trapezoidal.

Left valve. Outline trapezoidal, height of anterior end greater than the posterior end. External surface with two radial ribs extending from the umbo to the upper and lower corner of the posterior extremity of the valve. The ribs carry scales or low spines. The shell surface is otherwise ornamented with irregular growth ribs generally most strongly developed on the part of the shell lying below and in front of the lower radial rib. The hing e has one more or less distinct cardinal tooth in front of which the pit for the tooth of the right valve is seen.

The interior shows the posterior adductor scar to be about $1 \frac{1}{2}$ times the size of the anterior sear. The posterior scar is situated at a distance of about $2 / 3$ of the dorsal length behind the umbo in the part of the shell corresponding to the interspace between the radial ribs. A minor, but distinct muscle scar is seen above both the anterior and the posterior adductor scars. The pallial line is demarcated ventrally by more or less conspicuous scars; the pallial sinus does not show up very clearly.

Right valve almost rectangular trapezoidal. Exterior: radial ridges and other sculptural elements as in the left valve, except for the dorsal area above the upper radial ridge which may have coarse growth ribs as on the anterior part of the shell. Height of the shell at the posterior end equal to the height at the umbo or greater. Hinge with one cardinal tooth and a shallow pit behind it. The interior shows adductor scars and pallial line as in the left valve. A shallow ridge extending from the umbonal part of the shell downwards some- 


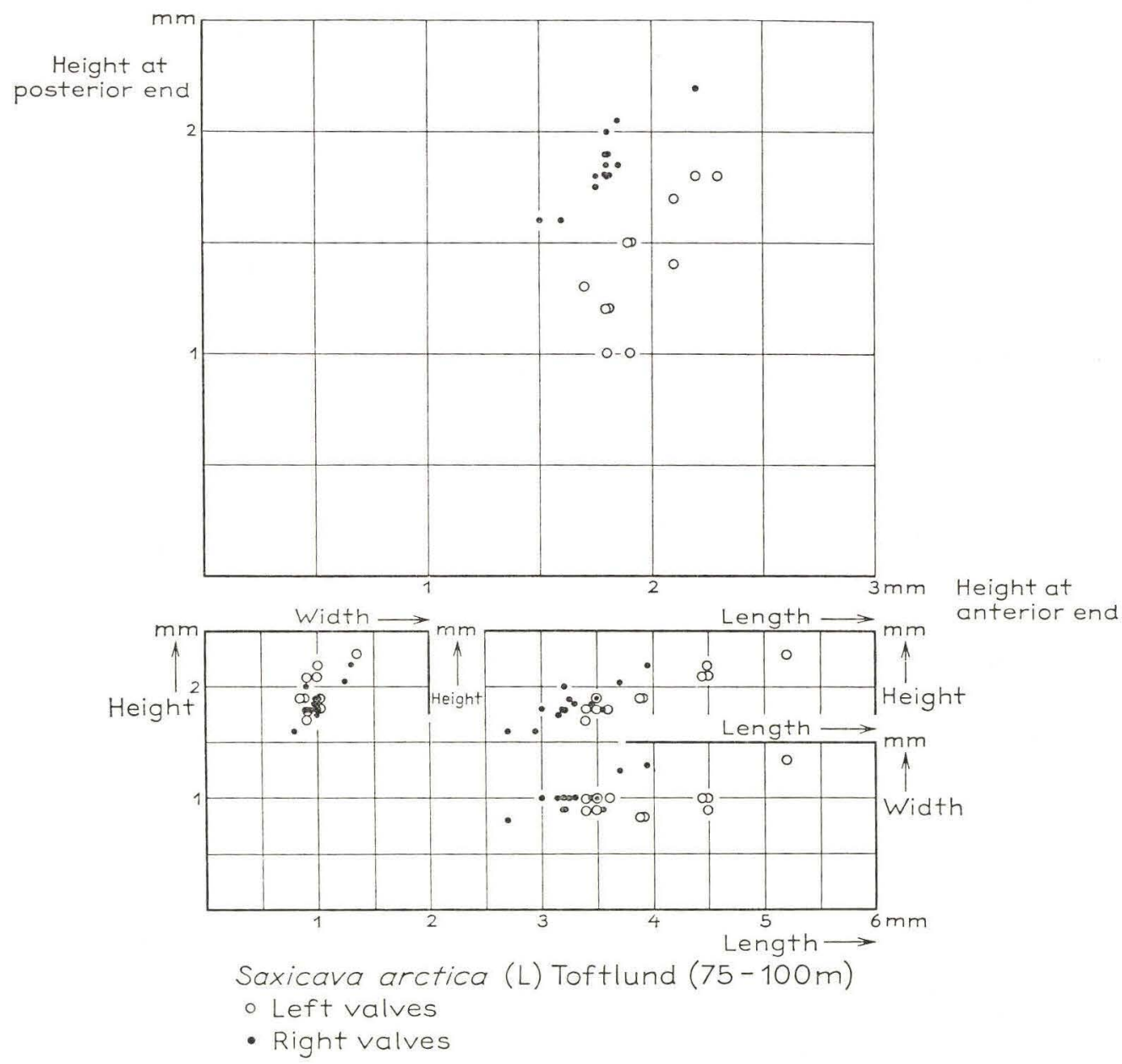

Fig. 10 .

what below the dorsal margin, and forming an acute angle with the dorsal margin is a specific feature of the right valve. It serves as a support for the dorsal margin of the left valve which lies inside the right valve. (The valves shown in fig. 66 e plate 20 are not actual paired valves, however, they serve to illustrate the relationships between the valves).

Variability. Measurements of length, height and width have been made on 25 valves from Toftlund. The diagram fig. 10 shows the results. The differences between the left and right valves may clearly appear from the different ratios which also may give some idea of the variation range of the left and the right valve.

Remarks. The problem of the possible subdivision of the Saxicavidae known as Saxicava rugosa and S. artica has not yet been settled satisfactorily. The only solutions would be minutely to describe the shells and animals concerned in order to furnish exact data on the animals and their habitat for future evaluation of the specific validity of the two forms. 
The present writer has followed Bucquoy, Dautzenberg \& Dollfus in defining $S$. arctica as the inequivalve form which in recent seas is fixed by its byssus to stones, dead shells, etc.

\section{Distribution.}

Recent: North Atlantic Ocean from Finmark to the Canaries and the Azores, the Mediterranean, the South Atlantic Ocean, parts of the Pacific.

Pliocene: North Sea Basin: Holland. Belgium (Scaldisien). England: Coralline Crag, Red Crag.

Mediterranean Basin: Italy: Piacenziano, Astiano, upper Pliocene of Monte Mario.

Miocene: Aquitanian Basin: Aquitanien, Burdigalien, Helvétien.

North Sea Basin: Belgium: horizon of Houthaelen, Anversian; Holland (m.). Germany: Vierlande, Hemmoor, and Dingden stages and Glimmerton*); Denmark: Arnum formation.

Mediterranean Basin: Italy: Elveziano, Tortoniano.

Oligocene: North Sea Basin: Holland (u.), Germany (m., u.). Denmark (m.).

\section{Genus Saxicavella Fischer 1870}

\section{Saxicavella pusilla nov. sp.}

Shell material.

Plate 24, fig. 67 a-c.

\begin{tabular}{|c|c|c|c|c|c|}
\hline Location & Depth & Shells & Location & Depth & Shells \\
\hline Ribe & $123-124 \mathrm{~m}$. & 2 l. v. frg. & Toftlund & $75-100 \mathrm{~m}$. & 1 l. v. \\
\hline Gramby & $\begin{array}{l}84.66-87.16 \\
90.42-92.72\end{array}$ & $\begin{array}{l}\text { 1 l. v. frg. } \\
\text { l r.v. frg. }\end{array}$ & & $105-110$ & $11 .+1 \mathrm{r} . \mathrm{v}$ \\
\hline
\end{tabular}

Diagnosis. Ovoid and slightly inequivalve Saxicavella with radial rib extending from the umbo to the junction of the ventral and posterior margin on both valves. Left valve with a radial rib parallel with the dorsal margin. Otherwise only ornamented with growth lines. One nodular tooth in the right valve. Holotype: Geological Survey of Denmark, file no. 150. 9. b. 75-100 m., plate 24, fig. 67 . Derivatio nominis: pusilla-small.

Description.

Prodissoconch smooth and glossy, slightly oblong. For dimensions see table below.

Dissoconch ovoid, slightly inequivalve.

Left valve. Exterior with minute radial rib extending from the umbo to the junction of the ventral and the posterior margin of the shell. Irregular radial rib along the dorsal margin from the umbo to the posterior end-It acts apparently as a support for the dorsal margin of the right valve. Hinge devoid of teeth, resiliophore below the umbo, projecting lamella adjacent to the

*) Staesche 1930. 
resiliophore behind the umbo. Interior: Adductor scars rounded, of almost equal size. Pallial line with shallow, curved sinus.

Right valve. Exterior: Sculpture corresponding to that of the left valve except for the absence of the irregular radial rib along the dorsal margin. Proportionally higher at the posterior end than the left valve. The entire valve appears to be more arched than the left valve. Hinge with one nodular tooth immediately in front of the umbo and resiliophore below the umbo.

Interior A shallow ridge runs from the umbonal region towards the posterior end of the valve. It is doubtless homologous with the ridge in the same position mentioned above in Saxicava arctica. It may have a similar function and be a support for the dorsal margin of the left valve. Features of the interior otherwise as in the left valve.

The differences between the two valves indicate that in closed position the left valve is lying inside the right valve as in Saxicava arctica.

\begin{tabular}{|c|c|c|c|c|c|c|c|c|}
\hline \multirow{3}{*}{$\begin{array}{l}\text { Location } \\
\text { Ribe }\end{array}$} & \multirow{3}{*}{$\begin{array}{l}\text { Depth } \\
123-124 \mathrm{~m} .\end{array}$} & \multirow{3}{*}{$\begin{array}{c}\text { Valve } \\
1 . \\
1 .\end{array}$} & \multirow{2}{*}{\multicolumn{2}{|c|}{$\begin{array}{l}\text { Prodissoconch } \\
\text { Height Length }\end{array}$}} & \multicolumn{3}{|c|}{ Dissoconch } & \multirow{3}{*}{$\begin{array}{c}\text { Remarks } \\
\text { frg. }\end{array}$} \\
\hline & & & & & Height & Length & Width & \\
\hline & & & & & *) $(0.9)$ & $(1.3)$ & & \\
\hline \multirow{2}{*}{ Gramby } & $84.66-87.16$ & $\begin{array}{l}1 . \\
1 .\end{array}$ & 0.263 & 0.295 & $\begin{array}{c}(1.4) \\
0.9\end{array}$ & $(1.4)$ & & - \\
\hline & $90.42-92.72$ & r. & 0.243 & 0.264 & 1.13 & $(1.8)$ & 0.41 & - \\
\hline \multirow{3}{*}{ Toftlund } & $75-100=$ & 1. & 0.237 & 0.271 & 1.05 & 1.6 & 0.31 & - \\
\hline & $105-110$ & 1. & 0.233 & 0.264 & 0.92 & (1.64) & 0.29 & - \\
\hline & & r. & 0.256 & 0.295 & & (2) & & - \\
\hline
\end{tabular}

Remarks. The valves described above are all in a rather juvenile stage, and it is accordingly not known whether the outline of the shell is constant throughout growth. There are some similarities with S. plicata (MonTAGU) which, however, is relatively much higher at the posterior end than S. pusilla.

Distribution.

Miocene: North Sea Basin: Denmark: Arnum formation.

\title{
Genus Panopea Ménard de la Groye 1807
}

\section{Panopea sp.}

Shell fragments including hinge parts of two right valves from Gramby $84.66-87.16 \mathrm{~m}$. may be referred to a species of the genus Panopea. It is possible that the species is Panopea Ménardi.

\author{
FAMILIA CORBULIDAE BRODERIP 1839 \\ (see Varicorbula gibba below) \\ Genus Varicorbula Grant \& Gale 1931
}

\section{Varicorbula gibba (Olivi)}

Recent:

Plate 23, fig. 69 a-g.

1792. Tellina gibba OLIvi. Zoologia Adriatica. p. 101.

1853. Corbula nucleus Lamarck. Forbes \& Hanley. British Moll. 1. p. 180, pl. 9, fig. 712, pl. G. fig. 3.

\footnotetext{
*) Figures in brackets for fragments.
} 
1865. Corbula gibba Olivi. Jeffreeys. Brit. Conch. 3, p. 56, 5, pl. 49, fig. 6.

1867. Corbula gibba Olivi. Weinkauff. Conch. d. Mittelmeeres. p. 25.

1878. Corbula gibba Olivi. Sars. Moll. Reg. Arct. Norvegiae. p. 91.

1892. Corbula gibba Olivi. Locard. Coq. mar. d. côtes d. France. p. 257.

1896. Corbula gibba Olivi sp. Bucquoy, Dautzenberg \& Dollfus. Moll. mar. du Roussillon. 2, p. 578, pl. 85, fig. 1-23.

1932. Corbula gibba Olivi. Noвre. Molluseos mar. de Portugal, p. 372, pl. 63, fig. 16.

1934. Corbula gibba Olivi. AD. S. Jensen \& R. SpärCk. Saltvandsmuslinger. p. 171, fig. 156.

1945. Varicorbula gibba Otrvi. Vokes. Supraspec. groups of the Pelec. Fam. Corbulidae p. 12.

Fossil:

1861. Corbula striata Walker \& Boys. Wood. Monogr. Crag Moll. 2, p. 274, pl. 30, fig. 3

1867. Corbula gibba Olrvi. v. Koenen. D. mar. M.-Olig. Nordd. p. 116

1870. Corbula gibba Otrvi. Hörnes. D. foss. Moll. d. Tert. Beckens v. Wien. 2, p. 34, pl. 3 , fig. 7 .

1893. Corbula gibba Olivi. Lehmann. D. Lam. d. Mioc. v. Dingden. 2, p. 288.

1901. Corbula gibba Olivi. Sacco. I moll. d. terr. terz. d. Piemonte e d. Liguria. 29, p. 34 , pl. 9, fig. $1-11$.

1907. Corbula gibba Olivi sp. Ravn. Molluskf. Jyll. Tert., p. 285.

1909. Corbula gibba Olivi sp. Cerruldi-Irelit. Fauna mal. mariana. p. 148, pl. 16, fig. $15-19$.

1909. Corbula (Agina) gibba Orrvi.. Cossmann \& Peyrot. Conch. Néogén. d. l'Aquit.p. 176 , pl. 2, fig. $98-101$, pl. 5, fig. 22.

1913. Corbula gibba Olivi sp. Harder. De olig. Lag etc. v. Aarhus St. p. 62, pl. 4, fig. 27. 1916. Corbula gibba Olivi sp. NørregandD. M.-mioc. Blokke fra Esbjerg. p. 18, pl. 2, fig. 3.

1925. Corbula gibba Olivi sp. Kautsky. D. Mioc. v. Hemmoor u. Basbeck-Osten. p. 51.

1941. Corbula gibba Olivi. Görges. D. Oberolig.-fauna v. Rumeln a. Niederrhein. p. 170. 1944. Aloidis (A.) gibba Olivi. Heering. D. Oberolig. Biv. a. d. Peelgebiete. p. 45, pl. 6 , fig. 16-17, pl. 7, fig. 22-28, pl. 10, fig. 9, 10, 15 .

1945. Aloidis (Varicorbula) gibba Olivi sp. Glibert. Faune mal. du Mioc. de la Belgique. 1, p. 215, pl. 3, fig. 10 .

1950. Aloidis (A.) gibba Olivi. Heering. Plioc. and older Plistoc. Netherlands. p. 191.

1950. Aloidis gibba Olivi. Heering. Mioc. Pelec. Netherlands. p. 45, pl. 5, fig. 101, 102, 109.

Original diagnosis. Conca minima di color bianco osseo, e lucido (OLIVI 1792 ).

Shell material.

\begin{tabular}{|c|c|c|c|c|c|c|c|c|c|}
\hline \multirow{2}{*}{$\begin{array}{l}\text { Location } \\
\text { Glejbjerg }\end{array}$} & \multicolumn{2}{|c|}{ Depth } & \multicolumn{2}{|c|}{ Shells } & \multicolumn{3}{|l|}{ Location } & \multicolumn{2}{|c|}{ Shells } \\
\hline & \multicolumn{2}{|c|}{$23 \mathrm{~m}$. } & \multicolumn{2}{|c|}{87 valves } & Gramby & \multicolumn{2}{|c|}{$90.42-92.72 \mathrm{~m}$. } & 39 & lves \\
\hline & 25 & - & 43 & . & & - & 12 & - \\
\hline & 42 & - & 2 & - & & & - & 1 & - \\
\hline & 52 & - & 1 & - & \multirow{3}{*}{ Toftlund } & $109.29-110.86-$ & - & 5 & - \\
\hline & 53 & - & 6 & - & & $75-100$ & - & 8470 & - \\
\hline & 53.5 & - & 19 & - & & $100-105$ & - & 26 & - \\
\hline & 53.75 & - & 7 & - & & $105-110$ & - & 53 & - \\
\hline & 55 & - & 5 & - & & $110-115$ & - & 38 & - \\
\hline Bramminge & $70-80$ & - & 850 & - & & 115 & - & 5 & - \\
\hline \multirow[t]{4}{*}{ Ribe } & $113-114$ & - & 7 & - & \multirow[t]{3}{*}{ Arnum (13) } & $28-40$ & - & 5 & - \\
\hline & $115-116$ & - & 1 & - & & $53-83$ & - & 276 & - \\
\hline & $123-124$ & - & 1 & - & & $83-94$ & - & 6 & - \\
\hline & $124-125$ & - & 3 & - & \multirow[t]{2}{*}{ Arnum (25b) } & $62.7-62.9$ & - & 59 & - \\
\hline \multirow[t]{3}{*}{ Gramby } & $82.16-82.66$ & - & 3 & - & & $95.0-95.3$ & - & 35 & - \\
\hline & $82.66-83.76$ & - & 8 & - & & $100-104.3$ & - & 1 & - \\
\hline & $84.66-87.16$ & - & 739 & - & & $04.3-107.5$ & - & 2 & - \\
\hline
\end{tabular}

Description.

Prodissoconch hardly perceptible on the adult shell. No particulars can be given. 
Dissoconch. The shells from South Jutland do not deviate from the fossil and recent representatives of the species in any general characters. They will accordingly not be made the subject of a detailed discussion, but reference should be made to the descriptions by Forbes \& Hanley; Jefrreys; Bucquoy, Dautzenberg \& Dollfus, and Cossmann \& Peyrot. One particular feature may, however, be mentioned briefly.

The right valve consists of a strongly developed outer crossed lamellar layer and an inner layer of complex structure (BöGGILD 1930, p. 292) which easily separate. The boundary between the layers is identical with the groove for the ventral margin of the left valve.

The posterior extremity of the right valve which forms a blunt rostrum is slightly concave above and below forming couches for the anal and oral orifices of the mantle. A small pore is found at the junction line between the two shell layers in the anal hollow of this valve. The pore is seen outside the shell margin of the left valve in paired, closed valves as displayed by figures $69 \mathrm{a}-\mathrm{b}$ on plate 23. Figures 69 e-f on plate 23 show a broken right valve. The inner shell layer is seen in situ in fig. $69 \mathrm{e}$ in which the pore can be noticed at the broken shell margin behind the posterior adductor scar. In fig. $69 \mathrm{f}$ the inner layer is: detached and it is shown how the pore can be traced back into the interior of the shell. The pore is obviously partly filled with calcite.

The function of this marginal pore of the rostrum is not yet known to the writer. The final answer to the question would no doubt appear from a study of the living animal, in which the pore is filled with a gelous mass.

The marginal pore has apparently not been mentioned by earlier authors although it obviously is a very characteristic feature of several species of the genus as proved by a close examination of illustrations of various species in literature. The following is a list of Corbulidae with a marginal pore pictured, but not mentioned in VokEs' paper from 1945.

$\begin{array}{lll}\text { Species } & \text { Age } & \text { Locality } \\ \text { Corbula sulcata LAMARcK } & \text { Recent } & \text { Senegal } \\ \text { Caryocorbula alabamiensis LeA. } & \text { Eocene } & \text { South Carolina to } \\ & \text { (Claiborne) } & \text { Rio Grande River } \\ \text { Varicorbula gibba (OLIVI) } & \text { Recent } & \text { Zetland (British Isles) } \\ \text { Bothrocorbula viminea (GUPPY) } & \text { Miocene } & \text { Jamaica } \\ \text { Nothocorbula vicaria IREDALE } & \text { Recent } & \text { Australia } \\ \text { Caestocorbula henckeliusiana (NYST) } & \text { Eocene } & \text { Belgium }\end{array}$

Variability. Length $L$ and height $H$ were measured in a number of left and right valves from Toftlund $(75-100 \mathrm{~m}$.).

The length/height ratios were calculated, and mean values of the ratios were finally calculated for different size groups as shown in the following table.

1. Left valves.

\begin{tabular}{|c|c|c|c|c|}
\hline Group & $\begin{array}{l}\text { Number of } \\
\text { shells }\end{array}$ & $L$ & $\frac{L}{H}$ mean values & \\
\hline$A$ & 37 & $2.5-3.5 \mathrm{~mm}$. & $1.2592 \pm 0.0074=$ & $\begin{array}{l}1.2666 \\
1.2518\end{array}$ \\
\hline$B$ & 56 & $3.5-4.5-$ & $1.2832 \pm 0.0084=$ & $\begin{array}{l}1.2916 \\
1.2748\end{array}$ \\
\hline C & 8 & $4.5-5.5 \quad-$ & $1.2788 \pm 0.016$ & $\begin{array}{l}1.2948 \\
1.2628\end{array}$ \\
\hline
\end{tabular}



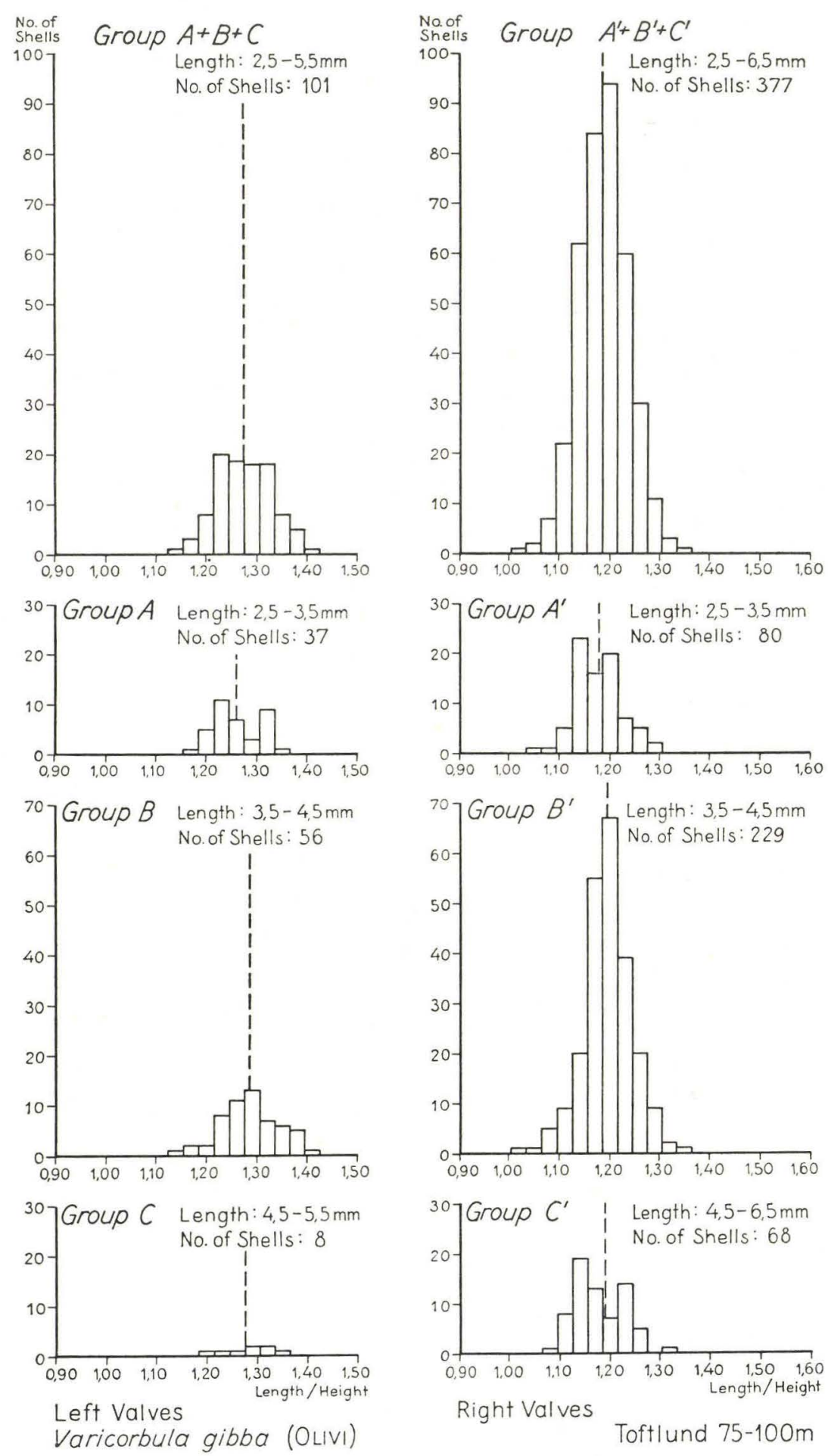

Fig. 11. 
2. Right valves.

\begin{tabular}{|c|c|c|c|c|c|}
\hline Group & $\begin{array}{l}\text { Number } \\
\text { of shells }\end{array}$ & $L$ & & $\frac{L}{H}$ mean values & \\
\hline$A^{\prime}$ & 80 & $2.5-3.5 \mathrm{~m}$ & im. & $1.1775 \pm 0.0052=$ & $\begin{array}{l}1.1827 \\
1.1723\end{array}$ \\
\hline$B^{\prime}$ & 229 & $3.5-4.5$ & - & $1.1941 \pm 0.0032=$ & $\begin{array}{l}1.1973 \\
1.1909\end{array}$ \\
\hline \multirow{2}{*}{$C^{\prime}$} & 62 & $4.5-5.5$ & - & $1.1815 \pm 0.0061=$ & $\begin{array}{l}1.1876 \\
1.1754\end{array}$ \\
\hline & 6 & $5.5-6.5$ & - & $1.168 \pm 0.019=$ & $\begin{array}{l}1.187 \\
1.149\end{array}$ \\
\hline
\end{tabular}

From the above figures and the diagram fig. 11 may be concluded that the $L / H$ ratio attains a maximum value when the shell is in the $3.5-4.5 \mathrm{~mm}$. group which means that the shell is relatively low in this stage. This is a peculiar development not noticed in other species treated where the $L / H$ ratio generally increases with size. The special variation of the $L / H$ ratio in Varicorbula gibba is obviously related to the development of the gibbosity of the shell, and one might thus infer that the gibbosity is an adult or gerontic feature.

Distribution of V.gibba.

Recent: North Atlantic Ocean from West Finmark to the Canaries, Mediterranean to the Marmara Sea.

Pliocene: North Sea Basin: England: Coralline Crag and Red Crag. Holland.

Mediterranean Basin: Italy: Astiano, Piacenziano, upper Pliocene of Monte Mario.

Miocene: Aquitanian Basin: Burdigalien, Helvétien.

North Sea Basin: Belgium: Boldérien, Horizon of Houthaelen, Anversien. Holland (m.). Germany: Hemmoor and Dingden stages and "Glimmerton"*). Denmark: Arnum formation.

Mediterranean Basin: Italy: Elveziano, Tortoniano. Vienna Basin: Eggenburg, Grund, and Baden beds.

Oligocene: North Sea Basin: Holland (u.). Germany (m. u.). Denmark (u.).

\section{Genus Lentidium Christofori \& Jan 1832}

\section{Lentidium donaciformis (Nyst)}

Plate 24, fig. 70 a-d.

1836. Corbula donaciformis Nyst. Rech. sur d. coq. foss. d. Kleyn Spauwen et Housselt. p. 3 , pl. 1, fig. 6 .

1843. Corbulomya complanata Nyst. Coq. et polyp. foss. p. 59, pl. 2, fig. 2. pro parte (var. B.).

1909. Corbulomya burdigalensis Benoist. Cossmann \& Peyrot. Conch. Néogén. d. l'Aquit. p. 182, pl. 3, fig. 1-4.

1925. Corbulomya donaciformis Nyst. Kautsky. D. Mioc. v. Hemmoor u. Basbeck-Osten. p. 49 , pl. 5 , fig. 6-9.

*) Staesche 1930 . 
Original description not available to the author.

Shell material.

$\begin{array}{lrllrl}\text { Location } & \text { Depth } & \text { Shells } & \text { Location } & \text { Depth } & \text { Shells } \\ \text { Glejbjerg } & 25 \mathrm{~m} . & \text { 1 left valve } & \text { Gramby } & 110.86-121.51 \mathrm{~m} . & 1 \mathrm{l.v} . \\ \text { Gramby } & 82.66-83.76- & 1 \mathrm{l} \text {. \& 1 r.v. } & \text { Toftlund } & 75-100- & 1 \mathrm{l} . \mathrm{v} . \\ & 84.66-87.16- & 2 \mathrm{r.v} . & \text { Arnum (25b) } & 104.3-107.5- & 1 \mathrm{l} \text { v. frg. }\end{array}$

Description. The shells are more or less fragmentary and generally of small size. It is, however, possible to get a clear picture of significant shell features.

Prodissoconch smooth, orbicular. For dimensions see table below.

Dissoconch slightly inequivalve and inequilateral. Right valve larger than left valve, and anterior part of the valve somewhat longer than posterior part.

Exterior smooth, with growth lines. Indistinct keel from the umbonal area to the transition between posterior and ventral part of the margin. Occasional irregular, more or less radially orientated, "wrinkles" on posterior shell extremity.

Hinge of left valve with one tooth in front of the resiliophore and behind it another bipartite tooth. The posterior branch of this tooth is directed obliquely backwards, and the anterior branch is perpendicular to the dorso-ventral plane. Right valve with one strong tooth which emerges from the umbo into the interior of the shell and is directed obliquely forward. Shallow furrow on the dorsal margin in front of and behind the umbo to accomodate the margin of the left valve. Excision in the umbo, probably for the resilium.

Interior. Adductor scars unequal. Anterior scar lancet-shaped, posterior scar rounded. Pallial line rather far from the shell margin, pallial sinus very shallow.

\begin{tabular}{|c|c|c|c|c|c|c|c|}
\hline \multirow[t]{2}{*}{ Location } & \multirow[t]{2}{*}{ Depth } & \multirow[t]{2}{*}{ valve } & \multicolumn{2}{|c|}{ Prodissoconch } & \multicolumn{3}{|c|}{ Dissoconch } \\
\hline & & & Heigh & Length & Height & Length & Width \\
\hline Glejbjerg & $25 \mathrm{~m}$. & 1. & 0.248 & 0.279 & 1.16 & 1.84 & $0.42 \mathrm{~mm}$. \\
\hline \multirow[t]{3}{*}{ Gramby } & $82.66-83.76-$ & r. & 0.264 & 0.310 & (fragm & entary) & - \\
\hline & & 1. & 0.256 & 0.310 & $2.0 \mathrm{ab}$ & t. 3.5 & 0.57 \\
\hline & $84.66-87.16-$ & r. & 0.24 & 0.29 & 1.52 & 2.36 & 0.43 \\
\hline
\end{tabular}

Remarks. The shells from South Jutland agree very well with the descriptions by Nyst, Cossmann \& Peyrot, and Kautsky. It should, however, be added that the illustrations accompanying these descriptions are all rather poor. This renders the determination a little doubtful.

Distribution.

Miocene: Aquitanian Basin: Burdigalien.

North Sea Basin: Germany: Hemmoor stage. Denmark: Arnum formation.

Oligocene: North Sea Basin: Belgium (u.).

FAMILTA MYIDAE GRAY

Genus Sphenia Turton 1822

\section{Sphenia sp.}

Shell material.

Plate 25, fig. 71 a-c.

Location

Toftlund

Arnum (25b)
Depth

105-110 m. 110-115.

115 .

$95.0-95.3$
Shells

$3 \mathrm{l}$. v. and $1 \mathrm{r}$. v. (frg.)

1 r. v. (frg.)

l r. v. (frg.)

2 l. v. and frg. 


\section{Description.}

Prodissoconch corroded on the shells available.

Dissoconch. Outline unknown due to the fragmentary nature of the shells.

Exterior concentrically corrugated. The concentric ribs are rather regularly spaced on the initial part of the shell; there are, however, indications of the shell becoming less rugose during growth. The concentric ribs are most elevated on the anterior end. An angular keel separates the ventral and the posterior sections of the shell; the concentric ribs are almost reduced to growth lines on the latter area.

Hinge of left valve with a short groove parallel to the shell margin. It delimits a weak tooth-like process on the lower edge of the margin beneath the umbo. A rounded tooth pit is found below the umbo and behind the process it receives the strong tooth of the right valve. The posterior dorsal margin of the left valve carries a broad spoon-shaped process, on the front of which remnants of the resilium may be seen. The process is almost perpendicular to the dorsoventral plane of the shell and has a shallow ridge running from the umbo to its lateral edge. Hinge of the right valve with a strong, curved tooth beneath the umbo, and a broad cavity-in which parts of the resilium are preserved in two of the valves-on the underside of the umbo.

No particulars may be reported on the interior of the shell due to the broken state of the material.

Remarks. Shells of individuals of the genus Sphenia may erroneously have been divided into different species according to Cossmann \& Peyrot (1909, p. 160) who suggest that this may be partly due to the differences between the two valves. These authors have reported four species of Sphenia from the Aquitanian basin. Of these $S$. panopcooides MaYer shows resemblances with our present species concerning the structure of the hinge. However, the broken state of the shell material, and the poor illustrations of the shells from the Aquitanian basin, do not permit further specific determination of the present shell material.

\section{FAMILIA PHOLADIDAE LAMARCK}

\section{Genus Pholas Linne 1758}

\section{Pholas sp.}

Plate 25, fig. 72 a-b.

Shell material. Umbonal fragments of two left valves from Arnum (25 b) from sample $62.7-62.9 \mathrm{~m}$. The two lamellae and the connecting septae at the dorsal margin, which are considered of generic significance, are clearly seen. The generic determination should thus not be questioned, but the shell material is insufficient for specific reference. Length of fragments: 3.0 and $1.8 \mathrm{~mm}$.

\section{Genus Pholadidea (Goodall) Turton 1819}

\section{Pholadidea sp.}

Plate 25, fig. $73 \mathrm{a}-\mathrm{b}$.

Shell material. Fragment of umbo of left valve Toftlund 110-115 m. Length of fragment $1.5 \mathrm{~mm}$. 
Description. Prodissoconeh unknown.

Dissoconch. Outline unknown. External surface divided by shallow medial furrow extending from the umbo to the ventral margin into differently sculptured anterior and posterior areas. The anterior area has lamelliform concentric ribs with spines which are arranged radially in 7 rows. The two posterior rows emerge somewhat below the umbo, while the other 5 rows apparently originate adjacent to the umbo. However, this cannot be verified due to the state of preservation of the shell. The posterior area is almost devoid of sculpture, faint growth lines being the only feature to be seen.

Interior with a shallow furrow corresponding to the posterior limit of the anterior area on the shell surface. A curved muscular process of almost circular section projects from the interior of the umbo. The reflected dorsal margin covering the umbo has a furrow turning forward around the dorsal margin from the base of the muscular process. A strong rib emerges at the same point and extends upward and backwards as a thread arounded the margin.

Remarks. There may be some doubt as to the genetic relationships of the present shell, since both the genus Pholadidea and the genus Martesia include species with a medial furrow on the shell surface. The shape of the anterior margin, as indicated by the growth lines, has been accepted for the present determination. In Pholadidea the anterior margin is less sinuate than in Martesia, The margin of Pholadidea is similar to the margin of Pholas, while the margin of Martesia approximates the margin of the Teredidae (Cossmand \& Peyrot 1909, p. 135).

\title{
Genus Martesia (Leach) Blainville 1825
}

\section{Martesia cf. rugosa (Brocchi)}

\author{
Plate 25, fig. $74 \mathrm{a}-\mathrm{b}$.
}

1814. Pholas rugosa Brocchi. Conchiol. Foss. Subapennina. 2, p. 591, pl. 11, fig. 12. 1901. Aspidopholas rugosa Brocchi. SAcco. I moll. d. terr. terz. d. Piemonte e d. Liguria. 29 , p. 56, pl. 13 , fig. $56-60$.

1945. Martesia (Aspidopholas) rugosa Brocchi sp. Glibert. Faune mal. du Mioc. de la Belgique. 1. p. 216, pl. 11, fig.9.

Original diagnosis. Testa ovalis, turgida, antice obsolete carinata; rugis flexuosis, transversis. (BRocCHI 1814).

Shell material. Frament of one juvenile left valve from Toftlund 105$110 \mathrm{~m}$.

Description. Prodissoconch unknown, covered by the reflected dorsal margin of the dissoconch.

Dissoconch. External surface divided by shallow, radial furrow. The anterior half with slightly lamelliform oblique growth ribs and the posterior half almost smooth with only minute growth lines. There are about 8 growth ribs per $\frac{1}{2} \mathrm{~mm}$. on the anterior part close to the umbo. The ribs carry low spines or knobs which are irregularly scattered and give the ribs a wavy profile.

The ribs of the anterior part of the shell form an angle of about $90-100^{\circ}$ with the growth lines of the posterior part.

Interior with shallow ridge corresponding to the medial furrow on the shell surface. A slightly curved, rib-like, muscular process projecting from the lower edge of the reflected margin beneath the umbo. The muscular process is flatly 
oblong in section. A strongly elevated ridge begins immediately behind the root of the muscular process. It runs upward and ends as the very strong lancetshaped, pointed, upper process of the reflected margin, which protrudes above the shell surface behind the umbo.

No particulars may be given concerning muscular impressions etc.

Remarks. There are some differences between the present shell and the shells described by GLiBeRT. The shells from Belgium have about 7-10 concentric ribs per $\mathrm{mm}$. on the anterior part of the shell which is about one half of the density encountered in the shell from Toftlund. The upper marginal process is curved above the shell surface in the Belgian species, while it is almost straight in the Danish shell, etc. These differences are, however, considered of minor importance, and they are assumed to be related mainly to the different growth stages of the shells compared.

The present specimen was not definitely referred to $M$. rugosa because of its fragmentary nature and the morphological differences between it and the shells recorded in literature.

Distribution.

Pliocene: Mediterranean Basin: Italy: Piacenziano, Astiano.

Miocene: North Sea Basin: Belgium: Anversian. Denmark: Arnum formation.

FAMILIA TEREDINIDAE GRAY

Genus Teredo Linné 1758

\section{Teredo cf. saucatsensis Benoist}

Plate 26, fig. 75 a-c.

1876. Teredo saucatsensis Benoist. Monographie d. Tubic., Pholadaire etc. p. 318, pl. 20, fig. 4.

1909. Teredo saucatsensis Benorst. Cossman \& Peyrot. Conch. Néogén. d. l'Aquit. p. 144, pl. 2, fig. 30-31.

Original description. Testa tumida convexa, utraque hiante, hiatu antico angulato, postico ovato; angularibus striatis, subutroque umbone apophysis, arcuata interna in interiorem valvam prceminens, margine cardinali calloso. (BENOIST 1877).

Shell material.

\begin{tabular}{|c|c|c|c|c|c|}
\hline Location & Depth & Shells & Location & Depth & Shells \\
\hline Glejbjerg & $\begin{array}{r}32 \mathrm{~m} . \\
53.5\end{array}$ & $\begin{array}{l}1 \text { frg. } \\
1 \text { frg. }\end{array}$ & Arnum (25b) & $\begin{array}{r}95.0-95.3 \mathrm{~m} . \\
104.3-107.5-\end{array}$ & $\begin{array}{l}1 \text { r.v. frg. } \\
\text { l l.v. }\end{array}$ \\
\hline Toftlund & $105-110=$ & $\begin{array}{l}1 \text { right } \mathrm{v} \text {. } \\
1 \text { left } \mathrm{v} \text {. (frg.) }\end{array}$ & & & \\
\hline
\end{tabular}

Description. Prodissoconch unknown.

Dissoconch. The right valve from Toftlund is the only almost complete valve available. It has been figured on plate 26 , fig. 75 a-c, which show all observable features, both external and internal, except for the broken muscular process within the umbonal cavity below the umbo. Only the basal part of the process is preserved, and it cannot be observed with the shell in the figured. positions. 
The external sculpture consists of coarse ribs on the anterior lobe and the anterior part of the median lobe. The posterior half of the median lobe is furnished with growth lines, and faint ribs parallel to the growth lines are found at intervals, in continuation of the coarse ribs of the anterior part of the shell. The posterior lobe, including the auricula, bears only growth lines.

The coarse ribs on the anterior shell-lobe are grooved perpendicular to the shell surface on their upper side and look like minute files. They are connected with the longitudinal ribs of the median shell-lobe, which have low, pointed nodules. Each anterior rib and corresponding longitudinal rib represent a shell margin, as do the varices in the gastropoda.

Internal features. The muscular process within the umbonal cavity has been mentioned above. Another feature which might escape notice, although it is shown on the accompanying illustrations, is the broad adductor scar which covers practically the whole auricula. Other features may easily be recognized on the figures.

Remarks. The Teredinidae are very difficult to determine on the shell characters alone. This circumstance and poor illustrations in the literature explain why the shells are not definitely referred to $P$. saucatsensis in spite of the apparently excellent agreement with Cossmann \& Peyrot's description. The only difference to be aware of is that the posterior part, the auricula, is apparently somewhat larger in T. saucatsensis than in the present shell. It is, however, impossible to decide whether this feature is of "specific" significance.

The shell has been compared with shells of the recent $T$. navalis $L$. which it resembles in various respects. There is a remarkable difference in that $T$. navalis has a distinct suture between the anterior, ribbed part of the shell and the anterior, vertically ribbed part of the median lobe. A suture of this kind is not found in the shells from South Jutland.

Distribution.

Miocene: Aquitanian Basin: Burdigalien.

North Sea Basin: Denmark: Arnum formation.

FAMILIA PANDORIDAE GRAY 1840

Genus Pandora Chemnitz 1795

76. Pandora copiosa nov. sp.

Shell material.

Plate 24, fig. 76 a-d.

Location
Glejbjerg
Gramby
Toftlund

Arnum (13)

Arnum (25b)

$\begin{aligned} \text { Depth } & \text { Shell } \\ 23 \mathrm{~m} . & 5 \text { left valves } \\ 84.66-87.16- & 2 \text { left valves, } 1 \mathrm{r.v} . \\ 75-100- & 7 \text { left valves } \\ 100-105- & 8 \text { left valves, } 1 \mathrm{r} . \mathrm{v} . \\ 105-110- & 17 \text { left valves, } 1 \mathrm{r} . \mathrm{v} . \\ 110-115- & 7 \text { left valves } \\ 53-83- & 1 \mathrm{r} . \mathrm{v} . \\ 62.7-62.9- & 1 \text { left valves, } 1 \mathrm{r.v} . \\ 95.0-95.3- & 3 \text { left valves, } 1 \mathrm{r} . \mathrm{v} . \\ 104.3-107.5- & 2 \text { left valves }\end{aligned}$


Diagnosis. Pandora with one radial keel, bearing squamules or knobs, on each valve. Slight depression of the shell surface below the umbo on left valve. Anterior end rather narrowly rounded, posterior end truncated, wide. Holotype: Geological Survey of Denmark, file no. 150. 9. b. Toftlund $105-110 \mathrm{~m}$.; plate 24, fig. 76 a-c. Derivatio nominis: copiosa-luxuriant.

\section{Description.}

Prodissoconch smooth and glossy; difficult to distinguish on the adult shell.

Dissoconch. Dimensions of holotype: Length $6.1 \mathrm{~mm}$., height $3.28 \mathrm{~mm}$,, width $1.21 \mathrm{~mm}$.

Left valve rather concave, umbo situated at about $1 / 3$ of the total shell length behind the anterior end of the shell. Outline oval, greatest height at about the middle of the shell. Anterior end bluntly pointed, posterior end truncated. Exterior: A relatively sharp, slightly elevated radial keel extends from the umbo to the lower edge of the posterior margin, it disappears on the distal parts of the shell on some of the largest specimens. Low scales are occasionally developed at the intersections of coarse growth lines and the radial keel. The shell surface is otherwise only sculptured with the somewhat irregular growth lines. There is a slight upward bend in the growth lines below the umbo where a slight depression may be seen. The hinge consists of the anterior hinge plate, which is thickened on its lower edge, the wide notch for the tooth of the right valve in which a delicate tooth is seen immediately beneath the umbo, and the rounded, thickened, posterior margin. The dorsal margin is straight. Interior: The adductor scars are of almost the same size, the posterior scar is circular while the oblong anterior scar is vertically extended. It is impossible to recognize the pallial line in most specimens. A faint feature assumed to be the pallial line is shown on plate 24 , fig. $76 \mathrm{~b}$ of the holotype. If the interpretation of this feature is correct the pallial sinus is relatively deep, and the pallial line is rather far removed from the shell margin.

The right valve is angular. It consists of an upper narrow shelf along the straight dorsal margin, and a broad and flat lower area which meet at an angle of about $90^{\circ}$, forming a distinct keel on which low scales or spines are generally developed. This keel is homologous to the keel of the left valve. The hinge includes a strong projecting cardinal tooth and behind this a subsidiary, lower tooth.

There are no particular features on the inside of this valve except for the adductor scars.

Remarks. P. copiosa differs from P. granum Benoist by its shape, since the latter has a posterior rostrum, a concave dorsal margin, and the greatest height is found at the umbo. However, the two species agree concerning the radial keel. $P$. copiosa differs from $P$. Degrangei, another species known from the Aquitanian Basin, by having only one radial keel. $P$. copiosa is also very different from $P$. inaequivalvis $L$. of recent seas, particularly in shell outline. For $P$. granum and $P$. Degrangei, reference is made to Cossmann \& Peyrot (1909). P. inaequivalvis is well illustrated and described by Bucquoy, DautZENBERG \& Dollfus (1898).

Distribution.

Miocene: North Sea Basin: Denmark: Arnum formation. 
FAMILIA THRACIIDAE DALL

\section{Genus Thracia (Leach) Blainville 1824}

\section{Thracia sp.}

A number of shell fragments belonging to a Thracia (possibly T. ventricosa PhILIPPI) have been determined.

Shell material.

$\begin{array}{lrl}\text { Location } & \text { Depth } & \text { Shells } \\ \text { Glejbjerg } & 53.5 \mathrm{~m} . & 1 \text { frg. (1. v.) } \\ \text { Bramminge } & 70-80- & 1 \text { frg. (r. v.) } \\ \text { Ribe } & 113-115- & 1 \text { frg. (l. v.) } \\ \text { Gramby } & 82.66-83.76- & 3 \text { frg. (1 l. v., 1 r. v.) } \\ & 84.66-87.16- & 1 \text { frg. (l. v.) } \\ \text { Toftlund } & 75-100- & 2 \text { frg. } \\ & 100-105- & 1 \text { frg. } \\ & 105-110- & 3 \text { frg. }(2 \text { l. v., } 1 \text { r. v.) }\end{array}$

Recent:

FAMILIA CUSPDARIIDAE FISCHER

Genus Guspidaria Nardo 1840

78. Cuspidaria cf. cuspidata (Olivi)

1792. Tellina cuspidata Olrvi. Zoologia Adriatica p. 101, pl. 4, fig. 3.

1853. Neaera cuspidata Olivi. Forbes \& Hanley. Brit. Moll. 1. p. 195, pl. 7, fig. 4-6, pl. G, fig. 4-7.

1865. Neaera cuspidata Olivi. Jeffreys. Brit. Conch. 3, pl. 53; 5, p. 49, fig. 5.

1867. Neaera cuspidata Olivi. Weinkauff. Conch. d. Mittelmeeres. p. 27.

1892. Cuspidaria cuspidata Olivi. Locard. Coq. mar. d. côtes d. France. p. 259.

1934. Cuspidaria cuspidata Olivi. Ad. S. Jensen \& R. Spärck. Saltvandsmuslinger. p. 193.

Fossil:

1861. Neaera cuspidata Olivi. Woon. Monogr. Crag. Moll. 2, p. 273, pl. 30, fig. 6 .

1870. Neaera cuspidata Olivi. Hörnes. D. foss. Moll. d. Tert. Beckens v. Wien. 2, p. 42, pl. 5, fig. 1-2.

1901. Cuspidaria cuspidata Olivi. Sacco. I. moll. d. terr. terz. d. Piemonte e d. Liguria. 29 , p. 123 , pl. 26 , fig. $31-34$.

1909. Cuspidaria cuspidata Olivi. Cerulti-Ireltr. Fauna mal. mariana. p. 180, pl. 21, fig. 37-41.

1914. Neaera (Cuspidaria) cuspidata OL. sp. GRIPP. Über eine untermioz. Molluskenf. v. Itzehoe. p. 10.

1916. Neaera cuspidata Olivi. NørregaArd. M.-mioz. Blokke fra Esbjerg. p. 19, pl. 2, fig. 2.

1925. Cuspidaria cuspidata Olivi. Kautsky. D. Mioc. v. Hemmoor u. Basbeck-Osten. p. 51.

1945. Cuspidaria (Cuspidaria) cf. cuspidata Olivi sp. Glibert. Faune mal. du Mioc. de la Belgique. 1, p. 220, pl. 4, fig. 4.

1950. Cuspidaria (C.) cuspidata (Otrvi). Heering. Mioc. Pelec. Netherlands. p. 47, pl. 5, fig. $114-117$.

Original diagnosis. Testa subcordato-globosa. angulata rostro canaliculari, natibus antice inflexis, epidermide subrugosa (OLIVI 1792). 
Shell material.

\begin{tabular}{|c|c|c|c|c|c|c|}
\hline \multirow{10}{*}{$\begin{array}{l}\text { Location } \\
\text { Glejbjerg }\end{array}$} & Depth & \multicolumn{2}{|c|}{ Shells } & Location & Depth & Shells \\
\hline & $23 \mathrm{~m}$. & \multicolumn{2}{|c|}{2 frg. (rostrum) } & Toftlund & $75-100 \mathrm{~m}$. & 7 frg. (1.v., r.v., \\
\hline & $25-$ & 1 & $-\quad \quad-$ & & & 5 rostr.) \\
\hline & $32-$ & 2 & - & & $100-105-$ & 2 l.v. 3 r.v.(frg.) \\
\hline & & \multicolumn{2}{|c|}{$\& 1$ r.v. } & & $105-110-$ & 40 valves (frg.) \\
\hline & 42 - & 2 & - & & $110-115-$ & 10 valves (frg.) \\
\hline & $52-$ & 1 & - & & $115-$ & 4 valves (frg.) \\
\hline & $53.5-$ & 1 & - & Arnum (13) & $53-83-$ & 2 frg. (rostr.) \\
\hline & $53.75-$ & 1 & - & Arnum (25b) & $62.7-62.9-$ & 1 l.v. 10 frg. \\
\hline & $55-$ & 1 & - & & & (rostr.) \\
\hline Bramminge & $70-80-$ & 2 & - & & $95.0-95.3-$ & 4 v. 10 frg. - \\
\hline \multirow{2}{*}{$\begin{array}{r}\text { Gramby } 82.66 \\
84.66\end{array}$} & $-83.76-$ & 2 & - $\quad$ (right v.) & & $101-104.3-$ & $1--$ \\
\hline & -87.16 & 2 & - (left v.) & & $104.3-107.5=$ & 1 l.v.., 1 r.v. \\
\hline \multirow[t]{2}{*}{$110.86-$} & 121.51 - & 1 & - (rostrum) & & & 2 frg. (rostr.) \\
\hline & & & & & $107.5-$ & 3 frg. (rostr.) \\
\hline
\end{tabular}

Description. The shell material is very fragmentary and no certain specific determination is possible. The rostra, the posterior parts of the shell, are, however, practically identical in shape with the rostra of C. cuspidata as described and pictured in the literature. The resiliophore is preserved in a number of specimens, and also this agrees with the corresponding part of $C$. cuspidata.

Distribution of C.cuspidata.

Recent: Northern Atlantic Ocean from Spitzbergen and Southern Greenland to Teneriffa. Mediterranean.

Pliocene: North Sea Basin: England: Coralline Crag.

Mediterranean Basin: Italy: Piacenziano, Astiano, upper Pliocene of Monte Mario.

Miocene: North Sea Basin: Belgium: Anversien. Holland (m.). Germany: Vierlande and Hemmoor stages, Reinbek stage (GotTsche 1878). Denmark: Arnum formation.

Mediterranean Basin: Italy: Elveziano.

Vienna Basin: Grund sands, Baden clay.

\section{Cuspidaria cf. rostrata (Spengler)}

Recent:

1793. Mya rostrata Spenglen. Om Slægterne Chaena, Mya og Unio. p. 42, pl. 2, fig. 16.

1865. Neaera rostrata Spengler. Jeffreys. Brit. Conch. 3, p. 51, 5, pl. 49, fig. 4 .

1867. Neaera rostrata Spencler. Weinkauff. Conch. d. Mittelmeeres. p. 28.

1892. Cuspidaria rostrata Spengler. Locard. Coq. mar. d. côtes d. France. p. 259.

1934. Cuspidaria rostrata Spengler. Ad. S. Jensen \& R. Spärck. Saltvandsmuslinger p. 192.

Fossil:

1901. Cuspidaria rostrata Spengl. Sacco. I moll. d. terr. terz. d. Piemonte e d. Liguria 29 , p. 124 , pl. 26, pl. 35-37.

1909. Cuspidaria rostrata Spengl. sp. Cerulli-Ireldr. Fauna mal. mariana. p. 181. pl. 21, fig. $42-43$.

Original diagnosis. Testa membranacea, parva, ventricosa, antice rostro cylindrico producto, cardinis dente minuto excavato (SPENGLER 1793).

Shell material: 3 fragments of rostra have been found in the sample from Toftlund $105-110 \mathrm{~m}$. 
Description. The rostra are long and corrugated on the upper edge as in C. rostrata. The specimens may not be specifically determined with certainty due to the fragmentary nature of the shells.

Distribution.

Recent: West coast of Europe from Southern Norway to and including the Mediterranean and farther South to the Canaries. Possibly also at the east coast of N. America and off Patagonia (Deep water species).

Pliocene: Mediterranean Basin: Italy: Piacenziano, Astiano, upper Pliocene of Monte Mario.

Miocene: North Sea Basin: Germany: Glimmerton (Banke Rasmussen 1956). Denmark: Arnum formation.

Recent:

\section{Cuspidaria cf. costellata (Deshayes)}

*) 1832. Corbula costellata Deshayes. Exped. Scient. de Morée. 3, p. 86, pl. 24, fig. 1-3. 1853. Neaera costellata Deshayes. Forbes \& Hanley. Brit. Moll. 1, p. 199, pl. 7, fig. 8-9, pl. G, fig. 8-9.

1865. Neaera costellata Deshayes. Jeffreys. Brit. Conch. 3, p. 49; 5, pl. 49, fig. 3 .

1867. Neaera costellata Deshayes. Weinkauff. Conch. d. Mittelmeeres. p. 29.

1892. Cuspidaria costellata Deshayes. Locard. Coq. mar. d. côtes d. France p. 259.

1932. Neaera costellata Deshayes. Nobre. Moluscos mar. de Portugal. p. 395.

1934. Cuspidaria costellata Deshayes. Ad. S. Jensen \& R. Spärck. Saltvandsmuslinger p. 194.

Fossil:

1901. Cardiomya costellata Deshayes. Sacco. I moll. d. terr. terz. d. Piemonte e d. Liguria. 29 , p. 127 , pl. 26 , fig. $62-63$.

1908. Cuspidaria (Cardiomya) costellata Desh. sp. Ceruldi-Ireldr. Fauna mal. mariana. p. 181, pl. 21, fig. 45 .

1909. Cuspidaria (Cardiomya) cf. costellata (Desh.) Cossmann \& Peyrot. Conch. Néogén. d. l'Aquit. p. 108.

1940. Cuspidaria (Cardiomya) costellata Deshayes. Sorgenfrei. Mar. Nedre-Mioc. i Klintinghoved p. Als. p. 27, pl. 4, fig. 17.

1945. Cuspidaria (Cardiomya) costellata Desh. sp. Glibert. Faune mal. du Mioc. de la Belgique. 1, p. 221, pl. 4, fig. 5, pl. 11, fig. 10.

1950. Cuspidaria (Cardiomya) costellata Deshayes. Heering. Mioc. Pelec. Netherlands. p. 47.

Original description not available.

Shell material: fragments of left valve including the umbo from Toftlund 75-100 m. and Ribe 124-125 m., rostrum of right valve, from Toftlund 100$105 \mathrm{~m}$.

Description. Only a few features may be recognized on account of the poor state of preservation.

Prodissoconch small, oblong, glossy; about $0.16 \mathrm{~mm}$. high and about $0.19 \mathrm{~mm}$. long.

Dissoconch. Initial stage devoid of radial ribs and only growth lines are seen. Size of the shell in this stage: length about $0.95 \mathrm{~mm}$., height about 0.55 $\mathrm{mm}$. Five widely spaced radial ribs occur on the posterior half of the shell

*) Not available in Danish libraries. 
beyond the limits of the initial stage, and about 8 more closely spaced radial ribs are found on the anterior globose part. Secondary radial ribs are furthermore initiated in two of the interspaces. The size of the shell fragment concerned (Toftlund $75-100 \mathrm{~m}$ ) is about $2 \mathrm{~mm}$.

Hing e devoid of teeth, only the ligament pit is seen.

Remarks. There is hardly any doubt as to the identity of the shells. They have, however, not been definitely referred to C. costellata since they are fragmentary.

\section{Distribution.}

Recent: North Atlantic Ocean: from Western Norway to the Canaries and from New England to the Gulf of Mexico. The Mediterranean.

Pliocene: Mediterranean Basin: Italy: Astiano, upper Pliocene of Monte Mario.

Miocene: Aquitanian Basin: Burdigalien.

North Sea Basin: Belgium: Anversien. Holland (m.). Germany: Reinbek stage (Gottsche 1878). Denmark: Klintinghoved clay, Arnum formation.

\section{CLASSIS SCAPHOPODA BROWN 1892 \\ FAMILIA SIPHONODENTALIIDAE THIELE 1935 \\ Genus Gadulus Philippi 1844}

\section{Cadulus gadus (Montagu)}

Recent:

1803. Dentalium gadus Montagu. Test. Brit. 2, p. 496, pl. 14, fig. 7.

Fossil:

1856. Dentalium gadus Montagu. Hönnes. D. foss. Moll. d. Tert.-Beckens v. Wien 1, p. 661 , pl. 50, fig. 40.

1897. Gadila gadus Montagu. SAcco. I moll. d. terr. terz. d. Piemonte e d. Liguria. 22, p. 116, pl. 10, fig. 79-85.

1915. Gadila gracillina Sacco. Cossmann \& Peyrot. Conch. Néogén. d. l'Aquit. p. 183, pl. 2, fig. 4-7.

1925. Cadulus (Gadila) gadus Montg. Kautsky. D. Mioc. v. Hemmoor u. Basbeck-Osten. p. 54.

1930. Cadulus (Gadila) gadus Montg. Stansche. Z. Glied. d. obermioz. Glimmertons. p. 65 .

1956. Cadulus (Gadila) gadus Montg. Banke Rasmussen. Upper Mioc. South Jutland. p. 49 , pl. 3 , fig. 3 .

Original diagnosis. Dentalium with a sub-pellucid, sub-arcuated shell, tapering to a small point, pervious, contracting a little towards the larger end; is white, glossy, and perfectly smooth, without the smallest appearance of wrinkles or striae. (Montagu 1803).

Shell material. It is difficult to relate the fragments found to original individuals and the writer has decided to consider any shell or fragment in which the swollen part is preserved as an individual. The major populations listed below have been checked by recounting. Almost identical figures were obtained in the different countings. 


$\begin{array}{lrrlrr}\text { Location } & \text { Depth } & \text { Shells } & \text { Location } & \text { Depth } & \text { Shells } \\ \text { Glejbjerg } & 23 \mathrm{~m} & 1 & \text { Toftlund } & 75-100 \mathrm{~m} . & 100 \\ & 25- & 2 & & 100-105- & 1 \\ \text { Bramminge } & 70-80- & 60 & & 105-110- & 2 \\ \text { Ribe } & 124-125- & 1 & & 110-115- & 7 \\ \text { Gramby } & 82.66-83.76- & 5 & \text { Arnum (13) } & 28-40- & 2 \\ & 84.66-87.16- & 1 & & 53-83- & 30 \\ & 90.42-92.72- & 4 & & 83-94- & 2 \\ & 110.86-121.51- & 1 & \text { Arnum }(25 \mathrm{~b}) & 62.7-62.9- & 5\end{array}$

Description. The shells from South Jutland are in good agreement with the original description. It may be added that the growth lines are oblique. The individual growth line lies in a plane which is perpendicular to the dorsoventral plane and forms a minor angle with the shell axis. Some shells display light and dark bands parallel with the growth lines, as observed in the specimens from Gram by Banke Rasmussen. A single abnormal shell from Bramminge is sculptured parallel with the growth lines due to regular variation of the deposition of shell material during growth.

Remarks. The main difference between this species and the related C. subfusiformis SARS is displayed by the location of the swollen part of the shell. In the latter form it is found in the middle of the shell whilst $C$. gadus attains its maximum diameter anteriorly.

Distribution.

Recent: North Atlantic Ocean: British Channel(?).

Pliocene: Mediterranean Basin: Italy: Piacenziano.

Miocene: Aquitanian Basin: Burdigalien, Helvétien.

North Sea Basin: Germany: Hemmoor and Glimmerton*) stages. Denmark: Arnum and Gram formations. Mediterranean Basin: Italy:? Elveziano, Tortoniano. Basin of Vienna: Baden clay.

FAMILIA DENTALIIDAE GRAY 1840

Genus Dentalium Linné 1758

\section{Dentalium cf. Michelottii Hörnes var. costulatissima Sacco.}

1856. Dentalium Michelottii Hörnes. D. foss. Moll. d. Tert.-Beckens v. Wien. 1, p. 654, pl. 50, fig. 33 .

1897. Dentalium Michelottii Hörnes. SAcco. I moll. d. terr. terz. d. Piemonte e d. Liguria. 22 , p. 96 , pl. 7 , fig. $84-86$.

Var. costulatior. Ibid. p. 97. pl. 7, fig. 93-94.

1910. Dentalium Michelottii Hörn. Cerulli-Irelli. Fauna mal. mariana. p. 23, pl. 3, fig. 1-2.

?1915. Dentalium (Antale) peyreirense. Cossmann \& Peyrot. Conch. Néogén. d. l'Aquit. p. 166, pl. 1, fig. 32-33.

1925. Dentalium Michelotti HöRn. var. costulatior SAcco. Kautsky. D. Mioc. v. Hemmoor u. Basbeck-Osten. p. 52, pl. 5, fig. 11.

Original diagnosis of the species. Dentalium testa tereti, subrecta, nitida, sex costata, basi sublaevigata. (HöRNES 1870).

*) Banke Rasmussen 1956. 
Original diagnosis of var. costulatissima. Testa affinis var. costulatior, sed costulae numerosiores, plerumque 14-16 (SAcco 1897).

Shell material.

\begin{tabular}{|c|c|c|c|c|c|c|c|}
\hline \multirow{4}{*}{$\begin{array}{l}\text { Location } \\
\text { Gramby }\end{array}$} & \multicolumn{2}{|c|}{ Depth } & \multirow{4}{*}{$\begin{array}{l}\text { Shells } \\
3 \text { frg. = abt. } \\
2 \text { indiv. } \\
2 \text { frg. }= \\
1 \text { indiv. } \\
5 \text { frg. = abt. } \\
2 \text { indiv. }\end{array}$} & \multirow{2}{*}{$\begin{array}{l}\text { Location } \\
\text { Toftlund }\end{array}$} & \multicolumn{2}{|c|}{ Depth } & \multirow{2}{*}{$\begin{array}{l}\text { Shells } \\
11 \text { frg. = abt. }\end{array}$} \\
\hline & $82.66-83.76$ & & & & $110-115$ & & \\
\hline & $84.66-87.16$ & - & & Arnum (13) & $53-83$ & - & 1 frg. = abt. \\
\hline & $90.42-92.72$ & - & & & $83-94$ & - & $\begin{array}{l}1 \text { frg. = abt. } \\
1 \text { indiv. }\end{array}$ \\
\hline & $10.86-121.51$ & - & 1 frg. $=$ & Arnum (25b) & $62.7-62.9$ & - & $\begin{array}{l}7 \text { frg. }=\text { abt. } \\
6 \text { indiv. }\end{array}$ \\
\hline Toftlund & $\begin{array}{r}75-100 \\
105-110\end{array}$ & - & $\begin{array}{l}5 \text { frg. }=\text { abt. } \\
2 \text { indiv. } \\
44 \text { frg. }=\text { abt. } \\
25 \text { indiv. }\end{array}$ & & $95.0-95.3$ & - & $\begin{array}{l}8 \text { frg. }=\text { abt. } \\
7 \text { indiv. }\end{array}$ \\
\hline
\end{tabular}

Only fragments are found. The corresponding individuals listed above represent the best estimate, but not exact numbers, since no objective criteria for defining a part of the shell as representative of an individual could be determined.

Description. The shell fragments from South Jutland are very variable concerning number and relief of the longitudinal ribs on the posterior part of the shell. There are generally 14-16 ribs on the juvenile part of the shell, but secondary ribs emerge very soon, and the primary ribs become simultaneously weaker. The shell surface is almost devoid of ribs for a short distance from the posterior end, and it is there smooth and glossy except for slight undulations in the surface in continuation of the ribs.

Remarks. Several species of the genus Dentalium display similar morphologic characters to $D$. Michelottii. Considerable doubt as to the validity of the different species and the specific determinations achieved is, therefore, appropriate, and D. Michelottii and related species are accordingly less significant stratigraphically than other molluscan species.

Distribution.

Pliocene: Mediterranean Basin: Italy: Piacenziano, Astiano, upper Pliocene of Monte Mario.

Miocene: ? Aquitanian Basin: Burdigalien, Helvétien.

North Sea Basin: Germany: Hemmoor stage. Denmark: Arnum formation.

Mediterranean Basin: Italy: Elveziano, Tortoniano. Basin of Vienna: Baden clay.

\section{Dentalium novemcostatum Lamarck var. mutabilis Doderlein}

1818. Dentalium novemcostatum Lamarck. Hist. nat. des anim. s. vert. 5, p. 344.

1856. Dentalium mutabile Doderlein. Hörnes. D. foss. Moll. d. Tert.-Beckens v. Wien. 1 , p. 654 , pl. 50, fig. 32 .

1882. Dentalium mutabile Doderlein. v. Koenen. D. Nordd. Mioc. u. s. Molluskenf. 2. p. 325.

1897. Antale novemcostatum var. mutabilis DoD. SAcco. I moll. d. terr. terz. d. Piemonte e d. Liguria. 22. p. 102, pl. 8, fig. 61-62.

1907. Dentalium mutabile Doderlein. Ravn. Molluskf. Jyll. Tert., p. 288, pl. 3, fig. 5. 
1910. Dentalium (Antale) novemcostatum Lk. Ceruldi-Ireldi. Fauna mal. mariana p. 26, pl. 3, fig. 37-41.

1915. Dentalium (Antale) mutabile Doderlein. Cossmann \& Peyrot. Conch. Néogén. d. l'Aquit. p. 167, pl. 1, fig. 34-35.

1925. Dentalium mutabile novemcostatum Lk. var. mutabilis DoD. KaUtsky. D. Mioc. v. Hemmoor u. Basbeck-Osten. p. 53.

Original diagnosis of $D$. novemcostatum: D. testa parvula, albido-viridula, novemcostata, striis transversis subdecussata (LAMARCK 1818).

Diagnosis of var. mutabilis: Striae transversae minores. Costae magnae, 8-9, costicillis 1-.3 alternatae (SACCO 1897).

Shell material.

\begin{tabular}{|c|c|c|c|c|c|c|c|}
\hline \multirow{5}{*}{$\begin{array}{l}\text { Location } \\
\text { Glejbjerg }\end{array}$} & \multicolumn{2}{|c|}{ Depth } & \multirow{2}{*}{$\begin{array}{l}\text { Shells } \\
8 \text { frg. }=\text { abt. } \\
8 \text { indiv. }\end{array}$} & Location & \multicolumn{2}{|c|}{ Depth } & Shells \\
\hline & 53.5 & & & Gramby & $2.72-109.29$ & $\mathrm{~m}$. & $\begin{array}{l}1 \text { frg. }= \\
1 \text { indiv. }\end{array}$ \\
\hline & 53.75 & - & $\begin{array}{l}4 \text { frg. = abt. } \\
4 \text { indiv. }\end{array}$ & Toftlund & $75-100$ & - & $\begin{array}{l}7 \text { frg. }=\text { abt. } \\
7 \text { indiv. }\end{array}$ \\
\hline & 54 & - & $\begin{array}{l}2 \text { frg. }=\text { abt. } \\
2 \text { indiv. }\end{array}$ & & $105-110$ & - & $\begin{array}{l}2 \text { frg. }=\text { abt. } \\
\text { I indiv. }\end{array}$ \\
\hline & 55 & - & $\begin{array}{l}2 \text { frg. = abt. } \\
2 \text { indiv. }\end{array}$ & & $110-115$ & - & \\
\hline Bramminge & $70-80$ & - & abt. 16 indiv. & Arnum (13) & $53-83$ & - & 2 frg. $=a b$ \\
\hline Ribe & $113-114$ & - & $\begin{array}{l}1 \text { frg. = abt. } \\
1 \text { indiv. }\end{array}$ & Arnum (25b) & $62.7-62.9$ & - & $\begin{array}{l}1 \text { indiv. } \\
1 \text { fro. }=\end{array}$ \\
\hline & $114-115$ & - & $\begin{array}{l}1 \text { frg. }= \\
1 \text { indiv. }\end{array}$ & & & & 1 indiv. \\
\hline
\end{tabular}

The number of individuals listed above is estimated (see D. cf. Michelottii p. 145).

Description. The fragments collected have from 8 to 10 relatively sharp and elevated longitudinal ribs. The anterior and posterior ends are not intact on any of the fragments. No observations have thus been made concerning the notch. Only one secondary stria has been observed in each of the rib interspaces. Growth lines are seen, but otherwise the shell surface is smooth and glossy. The shell is more or less curved.

Remarks. A very characteristic feature of this species is the smoothness of the shell surface by which it may be easily distinguished, e.g. from $D$. badensis.

Distribution.

Pliocene: Mediterranean Basin: Italy: Piacenziano, Astiano, upper Pliocene of Monte Mario.

Miocene: Aquitanian Basin: Helvétien.

North Sea Basin: Germany: Hemmoor and Dingden stages and Glimmerton*). Denmark: Arnum formation. Mediterranean Basin: Italy: Tortoniano.

Basin of Vienna: Steinabrunn clay.

\section{Dentalium cf. badensis Partsch}

1856. Dentalium badense Partsch. Hörnes. D. foss. Moll. d. Tert.-Beckens v. Wien. 1, p. 652 , pl. 50, fig. 30 .

1882. Dentalium badense Partsch. v. Koenen. D. Nordd. Mioc. u. s. Moll. f. 2, p. 323.

*) Banke Rasmussen 1956. 
1897. Entalis badense Partsch et var. SAcCo. I moll. d. terr. terz. d. Piemonte e d. Liguria. 22 , p. 107 , pl. 9, fig. 17-30.

1907. Dentalium badense Partsch. Ravn. Molluskf. Jyll. Tert. p. 288, pl. 3, fig. 3.

1915. Entalis badensis (Partsch). Cossmann \& Peyrot. Conch. Néogén. d. l'Aquit. p. 175 , pl. 1, fig. $12-13,16$.

1925. Dentalium (Entalis) badense Partsch. var. Kautsky. D. Mioc. v. Hemmoor u. Basbeck-Osten. p. 53, pl. 5, fig. 12.

1940. Dentalium (Entalis) badense Partsch. Sorgenfrei. Mar. Nedre-Mioe. i Klintinghoved p. Als. p. 29.

Original diagnosis. D. testa maxima, parum arcuata, basi valde dilatata, versus apicem duodecim costata, versus aperturam multistriata; fissura postica, magna. (HörNes 1870).

Shell material.

$\begin{array}{lrl}\text { Location } & \text { Depth } & \text { Shells } \\ \text { Glejbjerg } & 53.75 \mathrm{~m} . & 1 \text { frg. }=1 \text { indiv. } \\ \text { Bramminge } & 70-80- & 1-=1 \\ \text { Ribe } & 113-114- & \text { sev.- }=1\end{array}$

The fragments included here differ from the shells referred to D. novemcostatum by fine longitudinal striae which cover both the longitudinal ribs and their interspaces, and which may be cut into granules by the crossing growth lines. This feature is characteristic of $D$. badense according to v. KoEnEN.

The material is too fragmentary for final determination.

Distribution.

Pliocene: Mediterranean Basin: Italy: Astiano.

Miocene: Aquitanian Basin: Burdigalien.

North Sea Basin: Germany: Hemmoor and Glimmerton*) stages. Denmark: Klintinghoved clay, Arnum formation.

Mediterranean Basin: Italy: Aquitaniano, Langhiano, Elveziano.

Basin of Vienna: Baden clay.

\section{CLASSIS GASTROPODA CUVIER 1798 \\ SUBCLASSIS PROSOBRANCHIATA MILNE EDWARDS 1848 \\ FAMILIA ACMAEIDAE THIELE 1931}

Genus Acmaea Eschscholtz 1830

\section{Acmaea compressiuscula (Karsten)}

1849. Patella compressiuscula Karsten. Verz. etc. Sternberger Gest. p. 12.

1868. Patella compressiuscula Karsten. Koch \& Wiechmann. D. oberolig. Fauna d. Sternberger Gest. p. 562, pl. 12, fig. 12.

1882. Patella compressiuscula Karsten. v. Koenen. D. Nordd. Mioc. u. s. Moll. f. 2, p. 323.

1925. Acmea compressiuscula Karsten. Kautsky. D. Mioc. v. Hemmoor u. BasbeckOsten. p. 55 .

The name of the species was published without a clear definition or description by Karsten.

*) Banke Rasmussen 1956. 
Essential features of first description. "Die kleine, sehr zusammengedrückte, länglich schildförmige Schale hat einen erhabenen zitzenförmigen Buckel, der fast in der Mitte liegt ... kräftig ausgeprägte Anwachsfältchen ... Basis convex ... der vordere und hintere Rand in die Höhe gezogen oder verkürzt. Die Hinterseite der Schale ist stark gewölbt, die Vorderseite fast eben und in die Länge gestreckt. (KARSTEN 1849).

Shell material and dimensions.

\begin{tabular}{|c|c|c|c|c|c|c|}
\hline Location & Depth & Shells & Height & Length & Width & \\
\hline Glejbjerg & $53.5 \mathrm{~m}$. & $\begin{array}{l}1 \text { (frg.) } \\
1 \text { (frg.) }\end{array}$ & $\begin{array}{r}\text { abt. } 1.2 \\
-\quad 0.9\end{array}$ & abt. 1.7 & abt. $1.1 \mathrm{~mm}$. & \\
\hline Ribe & $113-114-$ & 1 & $-\quad 1.5$ & $-\quad 2.5$ & 1.17 & $\begin{array}{l}\text { (slightly } \\
\text { damaged) }\end{array}$ \\
\hline Toftlund & $110-115=$ & 3 (frg.) & $\begin{array}{ll}- & 0.6 \\
- & 0.8 \\
- & 1.1\end{array}$ & & & \\
\hline
\end{tabular}

Description.

Protoconch hardly perceptible, appears as a small, glossy button on top of the shell.

Teleoconch smooth, with slight irregular growth lines. The shell margin is not preserved on any of the shells, but from the course of the growth lines it may be inferred that it bends upward at the anterior and posterior ends. The shell is relatively high and laterally compressed, as shown by the dimensions of the shell from Ribe.

Distribution.

Miocene: North Sea Basin: Germany: Hemmoor stage. Denmark: Arnum formation.

Oligocene: North Sea Basin: Germany: Sternberg rock (u.).

\section{FAMILIA TROCHIDAE D'ORBIGNY 1837}

\section{Genus Calliostoma Swainson 1840}

\section{Calliostoma $\mathrm{sp.}$}

Shell material.

Location
Ribe
Toftlund
Arnum (13)
Arnum (25b)

$\begin{aligned} \text { Depth } & \text { Shells } \\ 113-114 \mathrm{~m} . & 3 \mathrm{frg} . \\ 105-110- & 8- \\ 83-94- & 1- \\ 95.0-95.3- & 1-\end{aligned}$

Description: The shell fragments belong probably to one species with an apical angle of $70^{\circ}$ to $90^{\circ}$. The sculpture of the whorls consist of spirals bearing low spines, while the base of the body whorl has spirals, but no spines. The suture is formed at the edge of the whorl below a relatively strong double spiral of the preceding whorl. 


\section{FAMILIA SKENEIDAE WENZ 1938}

A number of genera comprising species of comparatively small size, with more or less flat, discoidal shells have been separated from the Trochidae as a particular family by Wenz (1938, p. 326). This was undoubtedly an attempt at dividing the heterogenous accumulation of genera represented by the family Trochidae, as defined by Thiele, into more harmonious groups. Wenz emphasized, however, that the taxonomic relations of a number of genera in his family Skeneidae are in fact unknown, due to lack of knowledge concerning the soft parts of the animals. This is of course particularly true of the fossil representatives of the family.

The shell characters by which the genera are identified are: the shell outline, the body whorl and the aperture, and the presence or absence of an umbilical callosity, etc. There are remarkably few representatives distributed in several genera. This might indicate that reasonable limits for the erection of supraspecific groups have been exceeded. Qualities to which probably only specific rank should have been attributed have obviously been ascribed too great a significance. One of these is the umbilical callosity, which has been discussed by previous authors. The following four species illustrate the problem concerned insofar as the similarity of the shells is so pronounced that it would be inadequate to group them in different supraspecific groups. However, "Teinostoma" hanseata has an umbilical callosity, while "Starkeyna" jutensis, S. striata, and S. sp. have open umbilica. These species should therefore be grouped into two different genera in accordance with the generic diagnoses given by Thiele (1931) and Wenz (1938).

The writer is thus forced to believe either that the umbilical callosity is of minor significance in the present group or that we are faced with a new genus in which the umbilical callosity is a specific feature.

Lack of knowledge on the significance of the criteria delimiting the genera of the Skeneidae renders an objective decision concerning this problem impossible at present. The writer decided, therefore, preliminarily to refer the four species below to Starkeyna and to suggest that Starkeyna should embrace forms with shells similar to Teinostoma, with or without umbilical callosity, and with a more or less angular body whorl. This procedure was preferred to the erection of a new genus, since the genera of the family have certainly to be revised at some time in the future.

\section{Genus Starkeyna Iredale 1930

$$
\text { (= Stipator IREDALE 1924) }
$$

\section{Starkeyna hanseata (Kautsky)}

Plate 27, fig. 87 a-c.

1925. Tinostoma hanseata KaUtsky. D. Mioc. v. Hemmoor u. Basbeck-Osten. p. 61, pl. 6, fig. 6-7.

Essential features of original description. Klein, kreisrund. Vertiefte, schmale Nähte; drei Umgänge erheben sich etwas über den letzten Umgang. Schatenoberfläche glatt und glänzend mit Zuwachsstreifen. Spiralskulptur fehlt. Letzter Umgang geht in winkliger Rundung in die fast ebene glatte Basis über. Die Innenlippe bedeckt mit einer starken Schwiele einen grossen Teil des tiefen Nabels. 
Bei einigen Exemplaren laufen in den Nabel zwei ziemlich tiefe gerade Radialfurchen. (KAUTSKY 1925).

Shell material and dimensions.

\begin{tabular}{|c|c|c|c|c|c|c|c|c|c|c|c|}
\hline \multirow[t]{2}{*}{ Location } & \multirow{2}{*}{\multicolumn{2}{|c|}{ Depth }} & \multirow[t]{2}{*}{ Shells } & \multicolumn{3}{|c|}{ Protoconch } & \multicolumn{4}{|c|}{ Teleoconch } & \multirow[b]{2}{*}{$\begin{array}{l}\text { No. of } \\
\text { whorls }\end{array}$} \\
\hline & & & & Dian & eter & $\begin{array}{l}\text { No. of } \\
\text { whorls }\end{array}$ & Heig & & Diar & eter & \\
\hline \multirow[t]{3}{*}{ Gramby } & $84.66-87.16 \mathrm{r}$ & & 1 & 0.59 & $\mathrm{~nm}$. & $2 \frac{1}{2}$ & 0.59 & $\mathrm{~nm}$. & 1.13 & $\mathrm{~nm}$. & $1 / 2$ \\
\hline & $90.42-92.72$ & - & 2 & 0.59 & - & $21 / 2$ & 0.59 & - & 1.17 & - & $2 / 3$ \\
\hline & & & & 0.63 & - & $21 / 2$ & 0.66 & - & 1.29 & - & $1 / 2$ \\
\hline \multirow[t]{4}{*}{ Toftlund } & $75-100$ & - & 2 & 0.55 & - & $21 / 2$ & 0.74 & - & 1.27 & - & $3 / 4$ \\
\hline & & & & 0.59 & - & $21 / 2$ & 0.68 & - & 1.56 & - & 1 \\
\hline & $105-110$ & - & 4 & & & & & & & & \\
\hline & $110-115$ & - & 1 & 0.47 & - & 2 & 0.41 & - & 0.94 & - & $1 / 2$ \\
\hline Arnum (13) & $53-83$ & - & 1 & 0.55 & - & $21 / 4$ & 0.59 & - & 1.21 & - & $3 / 4$ \\
\hline \multirow[t]{2}{*}{ Arnum (25b) } & $\quad 62.7-62.9$ & - & $\left.24^{*}\right)$ & 0.59 & - & $21 / 2$ & $0.6 \mathrm{I}$ & - & 1.21 & - & $3 / 4$ \\
\hline & & & & 0.55 & - & $21 / 2$ & 0.63 & - & 1.17 & - & 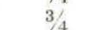 \\
\hline
\end{tabular}

\section{Description.}

Protoconch smooth and glossy, no particulars observed. The termination of the protoconch indicated by the beginning of the keel and the spiral furrow delimiting the base of the adult part of the shell (see below). Average diameter $0.58 \mathrm{~mm}$., number of whorls $2 \frac{1}{2}$.

Teleoconch. Test relatively thick. Spire smooth with growth lines, occasionally developing into ribs or folds towards the upper suture. Body whorl with rather distinct rounded keel, delimiting the flat, basal part of the whorl. A spiral furrow is developed just inside the keel on the whorl base on most of the shells. A very delicate spiral furrow encircles the umbilicus in a number of specimens, as shown on pl. 27, fig. $87 \mathrm{~b}$. Aperture very oblique, the upper margin protruding considerably beyond the margin of the whorl base forming a gutter at the suture. The lower part of the apertural margin is thickened; it continues into a massive callosity, partly or wholly concealing the umbilicus in most shells. The suture is formed a little above the keel.

Remarks. This species differs from the commonly adopted concept of Teinostoma by the keel on the shell periphery, the occasional absence of the umbilical callosity, and the scutelliform shape of the shell.

\section{Distribution.}

Miocene: North Sea Basin: Germany: Hemmoor stage. Denmark: Arnum formation.

\section{Starkeyna jutensis nov. sp.}

Plate 27, fig. 88 a-c.

Diagnosis. Very flat discoidal shell with sharp keel at the periphery. Strong spiral rib on the base a little inside the keel, open umbilicus. Derivatio nominis: jutensis: from jutia i.e. (South) Jutland. Holotype: Toftlund 105-110 m. D.G.U. File no. 150. 9. b.

\footnotetext{
*) Most specimens with broken aperture. Dimensions of two of the largest and best preserved shells shown in the table.
} 
Shell material and dimensions.

\begin{tabular}{|c|c|c|c|c|c|c|c|c|}
\hline \multirow[t]{2}{*}{ Location } & \multirow[t]{2}{*}{ Depth } & \multirow[t]{2}{*}{ Shells } & \multicolumn{2}{|c|}{ Protoconch } & \multicolumn{3}{|c|}{ Teleoconch } & \multirow[b]{2}{*}{$\begin{array}{l}\text { No. of } \\
\text { whorls }\end{array}$} \\
\hline & & & Diameter & $\begin{array}{l}\text { No. of } \\
\text { whorls }\end{array}$ & Heig & & Diameter & \\
\hline \multirow[t]{3}{*}{ Toftlund } & $105-110 \mathrm{~m}$. & 3 & $0.55 \mathrm{~mm}$. & $21 / 4$ & 0.61 & $\mathrm{~nm}$. & $1.64 \mathrm{~mm}$. & 1 \\
\hline & & & 0.57 & $21 / 4$ & 0.49 & - & 1.21 & \\
\hline & & & 0.63 & $21 / 4$ & 0.55 & - & 1.29 & $2 / 3$ \\
\hline rnum $(25 b)$ & $95.0-95.3$ & 1 & 0.59 & $21 / 4$ & 0.55 & - & 1.37 & 30 \\
\hline
\end{tabular}

All shells are a little broken.

Description.

Protoconch smooth and glossy, deep sutures, hardly elevated spire.

Teleocon ch discoidal, rather fragile. Body whorl with very sharp keel which divides the whorl into an upper and a basal part. Upper part with minute, distinct growth lines and occasional delicate spiral lines visible under the microscope. The upper part of the body whorl tends to form an eave-like extension over the keel. Very slight undulations in the shell surface correspond to bends in the growth lines about the middle of the upper part of the whorl and adjacent to the suture.

Basal wall of body whorl with distinct spiral furrow immediately inside the keel, and strong spiral rib at a distance of about one quater of the whorl width from the keel. The surface of the basal wall is generally smooth and glossy, although it is rather corrugated on the holotype due to the development of growth lines into irregular growth ribs. Very fine spiral lines, only visible with strong magnification, may occasionally be observed. The wall between the keel and the spiral rib is flat with inverted s-shaped growth lines.

Aperture very oblique, shallow gutter at the suture. The upper margin sharp, projecting far beyond the lower margin, which is slightly thickened towards the umbilicus. Bend of the lower margin (inverted s-shaped) between the spiral rib and the keel. Umbilicus wide, no trace of a callosity. The suture is formed a little above the keel of the preceding whorl. Inner lip thin.

Remarks. This species differs sharply from $S$. hanseata due to the absence of the umbilical callosity, the presence of the sharp keel and the strong spiral rib. The shells of the two species are otherwise much alike and should not be placed in different genera.

Distribution.

Miocene: North Sea Basin: Denmark: Arnum formation.

\section{Starkeyna nov. sp.}

Shell material. Toftlund $105-110 \mathrm{~m}$. one broken specimen.

Description.

Protoconch lacking (see remarks below).

Teleoconch flat, discoidal, with keel, fragile. Upper wall of body whorl arched with distinct growth ribs. Slight depression along suture and at about the middle of the whorl. The upper wall extends beyond the keel and forms eaves-like extensions. (see also $S$.jutensis). It is a typical feature that the "eaves" are locally reflected upward giving the shell a slightly ragged outline. There are very faint indications of spiral lines somewhat coarser than in the preceding species. 
The basal wall has coarse growth ribs which are more irregular than those on the upper wall. A strong spiral at about one quater of the whorl width inside the furrow marks the beginning of the "eaves" of the upper wall. The growth ribs bend forward from the umbilicus to the spiral rib, and hence they are almost perpendicular to the shell periphery in the interspace between the spiral rib and the spiral furrow. This interspace has a slight depression parallel and adjacent to the spiral rib.

Aperture oblique, upper margin sharp, projecting beyond the lower margin. No indication of umbilical callosity. Umbilicus wide.

Remarks. The differences between this shell and the shells referred to S.jutensis are undoubtedly distinct enough to justify the separation into different species. The present shell broke during preparation, but it was previously noticed that the protoconch was smooth and of the size and type described under S. jutensis. The poor state of the shell is the only reason why a new species name and holotype was not suggested. The shell would be a very poor reference for future workers.

FAMILIA TURBINIDAE ALDER 1838

Genus Liotia Gray 1847

\section{Liotia miosuturalis Kautsky}

Plate 27, fig. 90 a-c.

1925. Liotia miosuturalis KAutsky. D. Mioc. v. Hemmoor u. Basbeck-Osten. p. 59, pl. 6, fig. 1-3.

Essential features of original description. Protoconch with one whorl, smooth. Teleconch with angular whorls. Body whorl with 4 relatively strong spirals of which two are exposed on the spire. The uppermost of these two spirals runs along the edge of the whorl. Two or three weak spirals and one strong spiral on the base of the shell. Broad indistinct ribs extend from low knobs on the strong spirals. (No real diagnosis in KAUTSKY's paper).

\section{Shell material:}

Glejbjerg $53.75 \mathrm{~m}$ : 1 shell corroded, height $3 \mathrm{~mm}$., diameter $3.4 \mathrm{~mm}$. $55 \mathrm{~m}$. : 1 shell, height $1.65 \mathrm{~mm}$, diameter $2.3 \mathrm{~mm}$.

Description.

Protoconch. Slightly heterostrophe, smooth, and glossy. Some (about 5) very delicate spiral furrows are seen on the shell surface under the microscope. Diameter of the shell at the aperture on the specimen from Glejbjerg $55 \mathrm{~m}$. about $0.37 \mathrm{~mm}$.

Teleoconch. The shell from $55 \mathrm{~m}$. has a body whorl with two strong spirals on the outer side, one strong spiral with wavy knobs on the edge between the upper horizontal side and the outer side, and one strong spiral with knobs delimiting the umbilicus. The umbilicus enlarges very rapidly: A weak spiral is seen on the inner side of the whorl in the umbilicus. The suture is immediately below the lowermost of the two spirals on the outer side. Aperture broken on the two specimens. 
Remarks. The only difference between KaUTsky's shell and the shells above is obviously the absence of the two weak spirals on the base between the spiral delimiting the umbilicus and the lowermost outer spiral. However, this difference is believed to be insignificance as all other characters agree perfectly.

Distribution.

Miocene: North Sea Basin: Germany: Hemmoor stage. Denmark: Arnum formation.

\section{FAMILIA RISSOIDAE H. \& A. ADAMS 1854}

Investigations by LeBour and Thorson (see Thorson 1946) indicate that the protoconchs of a number of recent species generally referred to Rissoa and Alvania have very fine microscopic spiral striae and other sculptural features. Thiele (1931) has on the other hand stated that the protoconch of Rissoa and Alvania are smooth. He points out that species of the genus Merelina Iredale 1915 have spirals on their protoconchs.

It is therefore possible, either that THIELE was unaware of the true morphology of the protoconch of various genera of the Rissoidae, or that the adequate genus for species with spiral striae should be Merelina Iredale.

The general lack of reliable information on protoconch features in older literature makes a thorough analysis of the problem rather difficult. This circumstance, the inaccessibility of type specimens, and the experience that significant protoconch features have been overlooked in the past are the reasons why the writer finally decided to refer the species below to Alvania and Rissoa respectively in spite of the presence of spirals on the protoconchs.

\section{Genus Alvania Risso 1826}

\section{Alvania Partschi Hörnes}

Plate 27, fig. 90 a-e.

1856. Rissoa Partschi Hörnes. D. foss. Moll. d. Tert.-Beckens v. Wien I. p. 573, pl. 48, fig. 19.

1882. Rissoa Partschi Hörnes. v. Koenen. D. Nordd. Mioc. u. s. Moll. f. p. 316, pl. 7, fig. 4 .

1925. Alvania Partschi Hörnes. Kautsky. D. Mioc. v. Hemmoor u. Basbeck-Osten p. 72 .

Original diagnosis. $R$. testa lanceolato-turrita, acuta; anfractibus 5 valde convexis, suturis coarctatis, longitudinaliter costatis, costis tenuissimis in ultimo anfractu 14-16, ad basin evanescentibus, transversim tenuiter striatis ac reticulatis; apertura ovata; labro sinuato, extus incrassato, intus laevigato ad basin producto. (HÖRNES 1856).

Shell material.

$\begin{array}{lrclrc}\text { Location } & \text { Depth } & \text { Shells } & \text { Location } & \text { Depth } & \text { Shells } \\ \text { Bramminge } & 70-80 \mathrm{~m} . & 4 & \text { Toftlund } & 100-105 \mathrm{~m} . & 3 \\ \text { Gramby } & 90.42-92.72- & 1 & \text { Arnum }(13) & 53-83- & 5 \\ \text { Toftlund } & 75-100- & 5 & \text { Arnum }(25 \mathrm{~b}) & 62.7-62.9- & 3\end{array}$


Description.

Protoconch. Slightly heterostrophe. A well preserved initial whorl on a specimen from Toftlund $(75-100 \mathrm{~m}$.) exhibits 3 hardly perceptible delicate spiral striae under the microscope. All well preserved protoconchs have 1-2 fine spiral striae exposed immediately above the anterior suture, the shell is otherwise smooth. Number of protoconch whorls $2-2 \frac{1}{2}$. The diameter varies accordingly as appears from the following figures for specimens from Toftlund $75-100 \mathrm{~m}$.

$$
\begin{array}{lcccc}
\text { diameter: } & 0.325 & 0.420 & 0.404 & 0.390 \mathrm{~mm} . \\
\text { number of whorls: } & 2 & 21 / 2 & 21 / 2 & 21 / 2
\end{array}
$$

Teleoconch. The body whorl has 16 to 18 rather strong, collabral ribs which emerge at the suture, and 7 to 9 spiral ribs of similar strength. The collabral ribs terminate at the 5 th or 6 th spiral rib and are thus crossed by the uppermost 4 or 5 spirals. Knobs or low spines are found at the intersections of ribs and spirals. The shell is smooth between the ribs except for growth lines. The suture is developed beneath the 4 th or 5 th spiral. The aperture is round, and the outer lip is occasionally thickened. No umbilicus is found.

\begin{tabular}{|c|c|c|c|c|c|c|}
\hline \multirow[t]{2}{*}{ Location } & \multirow[t]{2}{*}{ Depth } & \multirow[t]{2}{*}{ Height } & \multirow[t]{2}{*}{ Diameter } & \multicolumn{2}{|c|}{$\begin{array}{l}\text { Body whorl } \\
\text { Number of: }\end{array}$} & \multirow{2}{*}{$\begin{array}{c}\text { Protoconch } \\
\text { Number of } \\
\text { whorls }\end{array}$} \\
\hline & & & & spirals & ribs & \\
\hline \multirow[t]{2}{*}{ Bramminge } & \multirow[t]{2}{*}{$70-80 \mathrm{~m}}$. & $1.84 \mathrm{~mm}$. & $0.98 \mathrm{~mm}$. & 7 & 16 & $21 / 2$ \\
\hline & & $2.35 \quad-$ & 1.46 & 8 & 16 & $21 / 2$ \\
\hline Gramby & $90.42-92.72$ - & 1.48 & 0.94 & 9 & 18 & $21 / 2$ \\
\hline \multirow[t]{2}{*}{ Toftlund } & $75-100=$ & 2.00 & 1.09 & 9 & 16 & 2 \\
\hline & & 1.56 & 0.94 & 9 & 17 & $21 / 2$ \\
\hline
\end{tabular}

Alvania Partschi. Dimensions and sculpture.

Distribution.

Miocene: North Sea Basin: Germany: Hemmoor stage. Dingden (-Reinbek) stage. Denmark: Arnum formation.

Basin of Vienna: Baden clay.

\section{Genus Rissoa (Fréminville) Desmarest 1814}

\section{Rissoa Ravni nov. sp.}

Plate 30, fig. 92.

Diagnosis. Globose Rissoa with spiral striae on the protoconch and generally with a spiral stria immediately above the suture on early adult whorls. The shell is otherwise smooth, but specimens with indistinct and irregularly scattered collabral ribs may be found. Holotype: D.G.U. Well. file no. 150. 13. Arnum 53-83, plate 30, fig. 92. Derivatio nominis: named in honour of the late J.P.J. RAVN who first gave comprehensive descriptions of the Tertiary molluscan fauna of Denmark. 
Shell material.

$\begin{array}{lrrlrr}\text { Location } & \text { Depth } & \text { Shells } & \text { Location } & \text { Depth } & \text { Shells } \\ \text { Glejbjerg } & 23 \mathrm{~m} . & 2 & \text { Toftlund } & 100-105 \mathrm{~m} . & 1 \\ & 25- & 5 & & 110-115- & 1 \\ \text { Bramminge } & 70-80- & 1 & & 115- & 2 \\ \text { Gramby } & 81.16-82.16- & 1 & \text { Arnum }(13) & 53-83- & 9 \\ & 84.66-87.16- & 1 & \text { Arnum }(25 \mathrm{~b}) & 62.7-62.9- & 39 \\ \text { Toftlund } & 75-100- & 15 & & 95.0-95.3- & 1\end{array}$

Description.

Protoconch slightly heterostrophe, about 1 whorl exposed. Surface generally ornamented with a varying number of delicate spiral striae which probably are furrows. The spiral striae are occasionally only found on the lateral part of the whorl, where 1-2 of them may be visible above the suture of the first adult whorl. Diameter of the protoconch about $0.250 \mathrm{~mm}$.

Teleoconch. Body whorl mostly smooth, often with one distinct spiral rib at the transition from the lateral to the basal part of the whorl. Very delicate spiral striae may be observed in many specimens under the microscope. In some specimens more or less regular collabral ribs are developed. There may also be remnants of original colouring visible, since dark and light gray collabral bands are found in some shells.

A perture circular. It is sinuous near the suture of the first adult whorl judging from the shape of the growth lines. In later stages it is almost in the axial plane of the shell except for a slight sinuousity of the basal part of the margin.

A narrow umbilicus is found in most shells. The suture is formed at the transition between the lateral and basal parts of the whorl and immediately below the spiral rib, if that rib is developed.

\begin{tabular}{lcccccccccccccc}
\multicolumn{1}{c}{ Rissoa Ravni nov. sp. Dimensions of shells from Toftlund $75-100 \mathrm{~m}$. } \\
No. & 1 & 2 & 3 & 4 & 5 & 6 & 7 & 8 & 9 & 10 & 11 \\
Height & $H$ & 2.65 & 2.75 & 2.80 & 2.85 & 2.85 & 2.85 & 2.90 & 2.92 & 2.92 & 3.15 & $3.45 \mathrm{~mm}$. \\
Diameter & $D$ & 2.12 & 2.12 & 2.22 & 2.21 & 2.20 & 2.23 & 2.35 & 2.22 & 2.22 & 2.30 & 2.55 & - \\
& $H / D$ & 1.25 & 1.30 & 1.27 & 1.29 & 1.30 & 1.28 & 1.23 & 1.31 & 1.32 & 1.37 & 1.35 & -
\end{tabular}

Remarks. This species should probably be grouped together with $R$. Sarsii of recent seas since it displays similar morphologic features both on the protoconch and the teleoconch.

Distribution.

Miocene: North Sea Basin: Denmark: Arnum formation.

\section{Rissoa cf. succincta Nyst}

1843 Rissoa succincta Nyst. Coqu. et Polyp Foss. p. 419, pl. 38, fig. 13.

Original diagnosis. Testa lanceolato-turrita, acuta; longitudinaliter plicata: plicis transversim striatis, subreticulatis; anfractibus rotundatis, sutura excavata separatis; apertura ovato-rotundata, labro extus reflexo, marginato (NYST 1843).

Shell material: Gramby $84.66-87.16 \mathrm{~m} .1 \mathrm{sh}$.

Description.

Protoconch worn, nucleus broken, probably originally about $1 \frac{1}{2}$ whorls.

Teleoconch. Spire conical with about $4 \frac{1}{2}$ whorls. Diameter $0.87 \mathrm{~mm}$., height $1.68 \mathrm{~mm}$. Spire with low collabral ribs formed by undulations in the shell surface. There are about 20 ribs per whorl. The ribs are obsolete on the third and fourth whorl. 
Base of the body whorl with 6 indistinct spiral lines. Outer lip broken, inner lip slightly thickened, no umbilicus.

Remarks. The shell has not been finally referred to $R$. succincta because of the obliterated sculpture. The shell may, however, well be within the variation range of $R$. succincta.

Distribution.

Miocene: North Sea Basin: Belgium (Kleyn Spauwen). Denmark: Arnum formation.

\section{Genus Rissoina D’Orbigny 1840}

\section{Rissoina Ödumi nov. sp.}

Plate 30, fig. 94.

Diagnosis. Rissoina with an approximately single whorled smooth protoconch, a ribbed teleoconch with about 22 to 28 collabral ribs on the outer part of the adult whorl, and a smooth base on the body whorl. Aperture unknown. Holotype at the Geological Survey of Denmark. File no. 150. 25. b. Arnum 62.7-62.9 m. Derivatio nominis: named in honour of H. ÖDum Ph.D. director of the Geological Survey, who has contributed valuable papers on the paleontology of Denmark, and promoted the present paper in many ways.

Shell material: One shell from Arnum (25b) 62.7-62.9 m. (holotype).

Description.

Protoconch slightly heterostrophe, about one whorl, smooth, diameter about $0.17 \mathrm{~mm}$.

Teleoconch. Four whorls, each with 22-28 distinct, narrow, collabral $\mathrm{S}$-shaped ribs. The shell appears otherwise smooth, but a close study under the microscope reveales extremely delicate, short, microscopical striae adjacent and perpendicular to the ribs. Interspaces between the ribs about twice as wide as the ribs. Body whorl with 22 ribs which terminate at a spiral rib delimiting the smooth base of the whorl. Aperture broken. A slight notch is indicated at the columella. The apical angle is about $40^{\circ}$.

Distribution:

Miocene: North Sea Basin: Denmark: Arnum formation.

\section{FAMILIA ADEORBIIDAE MONTEROSATO 1884}

\section{Genus Adeorbis S. Wood 1842}

The fossils described in the following have been referred to Adeorbis, following Thiele, who suggested Tornus to be a synonym of Adeorbis. It should, however, be mentioned that the writer has been unable to define any objective shell characters by means of which shells of the genus Circulus of the family of the Cyclostromatidae may be distinguished from Adeorbis, and in fact GLIBERT for instance, has referred Adeorbis praecedens to Circulus.

The taxonomic reference of the three following species is, therefore, subject to considerable doubt. The writer decided finally to accept the determinations 
as to genus and family arrived at by Cossmann \& PeYrot and earlier students until valid arguments to the contrary have been put forward.

\title{
95. Adeorbis subcirculus (Cossmann \& Peyrot)
}

\author{
Plate 28, fig. 95 a-b.
}

1917. Tornus subcirculus Cossmann \& Peyrot. Conch. Néogén., d. l'Aquit. p. 36, pl. 7, fig. $54-56$.

Essential features of original description. Protoconque lisse. Ornementation composée de cinq ou six funicules spiraux, assez réguliers, peu proéminents, séparés par des sillons peu profonds et d'égale largeur. Dernier tour embrassant toute la coquille, vaguement subanguleux à la périphérie. Base arrondie, largement ombiliquée, non sillonnée, complètement lisse jusque sur la paroi ombilicale. (Cossmann \& Рeyrot 1917).

Shell material.

$\begin{array}{lrrlrc}\text { Location } & \text { Depth } & \text { Shells } & \text { Location } & \text { Depth } & \text { Shells } \\ \text { Bramminge } & 70-80 \mathrm{~m} . & 1 & \text { Toftlund } & 105-110 \mathrm{~m} . & 5 \\ \text { Gramby } & 82.66-83.76- & 1 & & 110-115- & 2 \\ & 84.66-87.16- & 2 & \text { Arnum }(13) & 53-83- & 2 \\ \text { Toftlund } & 75-100- & 4 & \text { Arnum (25b) } & 95.0-95.3- & 1 \text { frg. }\end{array}$

Description.

Protoconch slightly heterostrophe, $2 \frac{1}{4}$ to $2 \frac{1}{2}$ smooth and glossy whorls. Diameter about $0.51 \mathrm{~mm}$. (average of 14 shells).

Teleoconch circular. The whorls of the adult stage have spiral ribs of nearly equal strength all round. A total of 15-17 spiral ribs have been counted immediately in front of the protoconch on 3 specimens. A number of ribs on the basal part of the whorls very soon weaken, and finally almost disappear.

After the development of one adult whorl the situation is the following: There are about 8 to 10 spiral ribs which generally are relatively strong on the upper and outer sides of the shell. At about the 6th spiral rib from the suture a weak keel may occasionally be developed.

The base of the whorl is smooth, or bears only very weak remnants of the spirals emerging at the protoconch. The whorls have generally about 3 spirals in the umbilical part of the shell. Very fine growth lines are found, and a delicate, regular, lamellar structure is noticed in the test of some specimens.

The suture is commonly developed at the 5th or 6th spiral. The aperture is oblique with a shallow angular gutter at the upper connection with the preceding whorl. The umbilicus is wide.

Variability. Fourteen well preserved shells have been investigated thoroughly. The following observations bearing on variation may have some interest, although the number of shells is too small for a reliable estimate of the degree of variation.

The features of the protoconch are obviously very constant: number of whorls $2 \frac{1}{4}-21 / 2$, variation range of diameter 0.41 to $0.57 \mathrm{~mm}$., mean $0.51 \mathrm{~mm}$.

The variation of adult shell features is mainly concerned with the strength of the spiral ribs and the development of a keel on the outer side. Eight of the 14 shells investigated have a keel. This suggest that the keel might be developed in about $50 \%$ of the shells. It should be added that the keel is more or less distinct, and that it is impossible to subdivide the shells on the basis of the presence or 
absence of the keel, since transitional forms occur. The spiral ribs may be more or less elevated. Shells with very little rib relief are found.

Diameter of the shells investigated 0.9-2.4 mm., diameter/height 1.9-2.4, mean 2.2 .

Remarks to the taxonomic reference. The shells treated here have obviously a greater number of spiral ribs than the species described by COSSMANN \& PEYROT, since these authors report that $A$. subcirculus has five or six spiral ribs. This must be an erroneous record of facts, since fig. 54-56 on plate 7 in their paper shows that $A$. subcirculus has about 5-6 spiral ribs on the upper side of the shell and about 3-4 spiral ribs on the outer and basal parts of the bodywhorl. There is, therefore, perfect agreement between the shells from southwestern France and South Jutland.

Distribution.

Miocene: Aquitanian Basin: Aquitanien, Burdigalien.

North Sea Basin: Denmark: Arnum formation.

\section{Adeorbis cf. carinata (Philippi)}

Plate 28, fig. 96 a-c.

1843. Delphinula carinata PHILIPPI. Beitr. z. Kenntn. d. Tert.-verst. etc. p. 21, pl. 3, fig.26. 1866. Adeorbis carinatus PHIL. spec, SpeYer. Ober-olig. Lippe Detmold, p. 23, pl. 3, fig. 1. 1870. Adeorbis carinatus spec. SPEYer. D. Conch. d. Casseler Tert. I. p. 159, pl. 23, fig. $10-12$.

1882. Adeorbis carinata PhiL. v. Koenen. D. Nordd. Mioc. u. s. Moll. f. p. 313.

1914. Adeorbis carinata PHIL. GRIPP. Über eine u. mioz. Moll. f. v. Itzehoe. p. 11.

1956. Adeorbis carinatus Phil. Banke Rasmussen. Upper Mioc. South Jutland. p. 51, pl. 3 , fig. 4 .

Original diagnosis. Schale klein, flach kegelförmig, weit genabelt, die letzte Windung mit drei Kielen von denen der oberste undeutlich ist. (РншIIPPI 1843).

Shell material. I shell from Toftlund $(75-100 \mathrm{~m}$.$) .$

Description.

Protoconch smooth and glossy, 3 whorls, diameter $0.77 \mathrm{~mm}$.

Telecocnch. It consists of about $1^{1 / 8}$ whorl. There are three keels on the whorl: 1 on the upper side, 2 forming the periphery of the shell, and 3 on the under side of the shell. A relatively strong spiral rib is found on each keel, the strongest being that on keel 2 .

Weak spiral ribs or striae are found over the entire shell. There are 6 spiral striae between the suture and keel (1), 6 spiral striae between keels (1) and (2), and 7 spiral striae between keels (2) and (3). About 11 spiral striae are found between keel (3) and the inner suture in the umbilicus. Fine growth lines cover the shell. The suture runs along the third spiral rib above keel (2).

The aperture is oblique; it forms a narrow gutter at the upper suture. Umbilicus wide.

A very fine, parallel, lamellar structure is seen in the partly transparent shell. Height of the shell: $0.97 \mathrm{~mm}$., diameter: $2.14 \mathrm{~mm}$.

Remarks. Records in the literature and their accompanying illustrations disagree in various respects, particularly concerning the number of spirals, development of keels etc. This is the main reason why the shell described could not be finally referred to $A$. carinata in spite of its fine state of preservation. 


\section{Distribution.}

Miocene: North Sea Basin: Germany: Vierlande stage Glimmerton (Banke Rasmussen 1956). Reinbek-Dingden stage. Denmark: Arnum and Gram formations.

Oligocene: North Sea Basin: Germany (u.).

\section{Adeorbis planorbillus (Dujardin) \\ Plate 28, fig. 97 a-c.}

1835. Solarium planorbillus DuJARdin. Sur les couches du sol en Touraine p. 284, pl. 19, fig. 13 .

1882. Adeorbis praecedens v. Koenen. D. Nordd. Mioc. u. s. Moll. f. p. 312, pl. 5, fig. 15. (?)1896. Adeorbis trigonostoma (BAst.). SAcco. I moll. d. terr. terz. d. Piemonte e d. Liguria. 21, p. 53, pl. 4, fig. 69.

1917. Tornus planorbillus (DuJ.). Cossmann \& Peyrot. Conch. Néogén. d. l'Aquit. p. 33, pl. 7, fig. 57-62.

1925. Adeorbis praecedens v. Koen. Kautsky. D. Mioc. v. Hemmoor u. Basbeck-Osten. p. 60 .

1952. Circulus praecedens v. Koen. Glibert. Faune mal. du Mioc. de la Belgique 2, p. 12, pl. 2, fig. 1 .

Original diagnosis. Testa minima, discoidea, superne vix convexa, inferne concava, late umbilicata; anfractibus rotundatis, extus vix carinatis, in umbilico sulcatis (DUJARDIN 1835).

Shell material: Toftlund 75-100 m.: 4 broken shells; Arnum 53-83 m.: 1 shell.

Description.

Protoconch smooth and glossy, about $2 \frac{1}{2}$ whorls; diameter varying between 0.51 and $0.63 \mathrm{~mm}$.

Teleoconch smooth and glossy except for the three keels: one of which is found on the upper side (1), one on the shell periphery (2), and one on the under side of the whorl (3). Keel (2) is the most prominent. Very delicate spiral furrows are seen under the microscope between keels (1) and (2) in one of the shells from Toftlund and in the specimen from Arnum. Fine parallel, lamellar structure in the partly transparent test as in $A$. cf. carinata. Two spiral striae are found in the umbilical wall of one of the shells from Toftlund. Aperture oblique, suture somewhat above keel (2). Diameter of the shell from Arnum about $1.5 \mathrm{~mm}$., height $0.7 \mathrm{~mm}$.

Remarks. The present shells are similar to the shell described above as A. $c f$. carinata. However, the difference in sculpture seems to justify the reference to two different taxonomic units.

It may hardly be questioned that $A$. praecedens should be included in the synonymy of $A$. planorbillus. No decisive difference may be recognized between the shells figured by Cossmann \& Peyrot and the shells from South Jutland.

Distribution.

Miocene: Aquitanian Basin: Helvétien.

North Sea Basin: Belgium: Anversien, Germany: Hemmoor and Dingden-Reinbek stages. Denmark: Arnum formation.

Mediterranean Basin: Italy: Elveziano. 


\section{Genus Turritella Lamarck 1799}

\section{Turritella tricarinata (Brocchi)}

Plate 29, fig. 98 a-b.

1814. Turbo tricarinatus Brocchi. Conchiol. Foss. Subapennina. 2, p. 374, pl. 6, fig. 21.

1848. Turritella communis Risso. Wood. Monogr. Crag Moll. 1, p. 74, pl. 9, fig. 9.

1895. Turritella tricarinata var. communis (Risso). SACCO. I moll. d. terr. terz. d. Piemonte e d. Liguria. 19, p. 6. pl. 1, fig. 15.

1907. Turritella tricarinata Brocchi sp. Ravn. Molluskf. Jyll. Tert. p. 296, pl. 3, fig. 16. ?1921. Turritella (Haustator) turris Basterot. Cossmann \& Peyrot. Conch. Néogén. d. l'Aquit. p. 39, pl. 1, fig. 25, pl. 2, fig. 21-24.

1925. Turritella tricarinata Brocc. var. communis Riss. Kautsky. D. Mioc. v. Hemmoor u. Basbeck-Osten, p. 79.

?1944. Turritella (Haustator) eryna D'Orbigny. Van Voorthuysen. Mioz. Gastr. a. d. Peelgebiet. p. 20, pl. 2, fig. 14. pl. 3, fig. 1-14.

1952. Turritella (Turritella) tricarinata Brocchi sp. GLtbert. Faune mal. du Mioc. de la Belgique 2, p. 27, pl. 1, fig. 10.

1956. Turritella (Turritella) tricarinata (Brocchi). Banke Rasmussen. Upper Mioc. South Jutland, p. 52, pl. 4, fig. 1.

Original diagnosis. Testa turrita, subulata, anfractibus convexis, carinis tribus acutiusculis distinctissimis, interstitiis leviter striatis (BRосCHI 1814).

Shell material generally broken. The listed numbers of specimens represent accordingly only the best estimates, they do not lay claim to be exact totals of individuals.

$\begin{array}{lrclrc}\text { Location } & \text { Depth } & \text { Shells } & \text { Location } & \text { Depth } & \text { Shells } \\ \text { Glejbjerg } & 23 \mathrm{~m} . & 1 & \text { Toftlund } & 100-105 \mathrm{~m} . & 8 \\ & 25- & 1 & & 105-110- & 14 \\ \text { Bramminge } & 55- & 1 & & 110-115- & 15 \\ \text { Ribe } & 70-80- & 107 & & 115- & 20 \\ \text { Gramby } & 113-114- & 1 \text { (ef.) } & \text { Arnum (13) } & 28-40- & 3 \\ & 82.66-83.76- & 7 & & 53-83- & 26 \\ & 90.42-92.72- & 6 & & 83-94- & 1 \\ & 92.72-109.29- & 2 & \text { Arnum (25b) } & 62.7-62.9- & 66 \text { (juv.) } \\ & 109.29-110.86- & 1 & & 95.0-95.3- & 8 \\ \text { Toftlund } & 110.86-121.51- & 1 & & 101-104.3- & 1 \\ & 75-100- & 83 & & 104.3-107.5- & 1\end{array}$

Description.

Protoconch. About 2-21/2 apparently smooth whorls which, however, have an indistinct sculpture of minute dots perceptible under the microscope. The protoconch is slightly heterostrophe. The following list shows the dimensions of shells from Toftlund $75-100 \mathrm{~m}$.:

\begin{tabular}{|c|c|c|c|c|c|c|c|c|c|c|}
\hline Height: & 0.33 & 0.31 & 0.33 & 0.31 & 0.39 & 0.33 & 0.33 & 0.33 & 0.31 & $0.35 \mathrm{~mm}$ \\
\hline Diameter: & 0.35 & 0.35 & 0.35 & 0.35 & 0.39 & 0.31 & 0.31 & 0.31 & 0.35 & 0.35 \\
\hline $\begin{array}{l}\text { Number of } \\
\text { whorls: }\end{array}$ & & $21 / 2$ & 2 & $21 / 2$ & $21 / 2$ & 2 & $21 / 2$ & 2 & 2 & $21 / 2$ \\
\hline
\end{tabular}

Teleoconch. The turreted spire starts with rounded whorls carrying 3 spiral ribs of almost equal strength. From about the fourth or fifth whorl one or two additional delicate spirals develop adjacent to the upper suture. The 3 first spirals get successively stronger; the lowermost but one of these, now number 4 from the upper suture, being the strongest. In the majority of shells the strong 4th spiral gives the whorls a carinated outline from about the fifth to the 
eighth or ninth whorl. Later whorls as a rule become more rounded again, and some full-grown shells end with almost flat whorls. Secondary spirals may occasionally develop between the primary spirals. The spiral sculpture is crossed by very faint growth lines which indicate the outer apertural margin to be sinuous. The aperture is not preserved on any specimen. Fragments of body whorls show that the basal and lateral walls form a rounded angle.

Remarks. The shape and sculpture of the whorls of this species vary considerably from shell to shell as well as in the individual shell. There can thus hardly be any adoubt that such shells may have been split in different taxonomic units. The writer is accordingly somewhat suspicious concerning the value of the morphologic differences between $T$. tricarinata and some of the shells referred to $T$. turris BASTERoT and $T$. eryna D'OrBigny.

\section{Distribution. \\ Pliocene: North Sea Basin: Red Crag. Mediterranean Basin: Italy: Piacenziano, Astiano. \\ Miocene: Aquitanian Basin: ? Aquitanien, ? Burdigalien. North Sea Basin: Belgium: Anversien. Holland (m.); Germany: Hemmoor stage, Glimmerton (Banke Ras- MUSSEN 1956). Denmark: Arnum and Gram formations. Mediterranean Basin: Italy: Elveziano, Tortoniano. Oligocene: Mediterranean Basin: Italy: Tongriano.}

\section{Turritella subangulata (Brocchi)}

Plate 30, fig. 99 a-b.

1814. Turbo subangulatus Brocchi. Conchiol. Foss. Subapennina 2, p. 374, pl. 6, fig. 16. 1856. Turritella subangulata Brocc. Hörnes. D. foss. Moll. d. Tert.-Beckens v. Wien 1; p. 428 , pl. 43 , fig. $5-7$.

1895. Zaria subangulata (BR.) et var. SAcco. I moll. d. terr. terz. d. Piemonte e d. Liguria. 19 , p. 9-11, pl. 1, fig. 30-35.

1907. Turritella subangulata Brocchi sp. Ravn. Molluskf. Jyll. Tert., p. 296.

1921. Turritella (Zaria) subangulata Brocchi var. spirata Brocchi. Cossmann \& Peyrot. Conch. Néogén. d. l'Aquit. p. 17, pl. 2, fig. 12-13.

1921. Turritella (Zaria) subangulata BRocснI var. subacutangulata D'ORB. Tbid. p. 18, pl. 1, fig. 13-14.

1925. Turritella (Zaria) subangulata Brocchi. Kautsky. D. Mioc. v. Hemmoor u. Basbeck-Osten. p. 79

1944. Turritella (Zaria) subangulata Brocchi. Van Voorthuysen. Mioz. Gastr. a. d. Peelgebiet. p. 22, pl. 1, fig. 13-23, pl. 2, fig. 1-3, 13.

1952. Turritella (Zaria) subangulata Brocchi sp. Glibert. Faune mal. du Mioc. de la Belgique 2, p. 25, pl. 2, fig. 12 .

Original diagnosis. Testa turrita, subulata, anfractubus tumidiusculis subcarinatis, striis confertis incequalibus undique cincta. (BROCCHI 1814).

Shell material. Only broken shells are available.

\begin{tabular}{|c|c|c|c|c|c|}
\hline Location & Depth & Shells & Location & Depth & Shells \\
\hline Glejbjerg & $53.5 \mathrm{~m}$. & 1 & Toftlund & $75-100 \mathrm{~m}$. & 4 \\
\hline Bramminge & $70-80-$ & 4 & & $105-110-$ & 4 \\
\hline Gramby & $82.66-83.76-$ & 1 & $\begin{array}{l}\text { Arnum (13) } \\
\text { Arnum }(25 \mathrm{~b})\end{array}$ & $\begin{array}{r}53-83= \\
95.0-95.3=\end{array}$ & 11 (juv.) \\
\hline
\end{tabular}


Description.

Protoconch apparently smooth, 2 to $2 \frac{1}{2}$ whorls, unmistakably heterostrophe. The number of whorls and dimensions of three shells from Toftlund $105-110 \mathrm{~m}$. were as follows.

$\begin{array}{llll}\text { Number of worls } & 2 & 2 & 21 / 2 \\ \text { Heighth } & 0.9 & 0.9 & 1.0 \mathrm{~mm} . \\ \text { Diameter } & 0.9 & 0.9 & 0.9-\end{array}$

Teleoconch. The adult whorls have a strong, median spiral rib forming a distinct keel already on the first whorl. The whorls are otherwise covered with delicate spiral striae in most specimens. There is one relatively conspicuous somewhat stronger stria on either side of the keel on the initial whorl. These two striae develop into subordinate spiral ribs. A few more ribs of this kind emerge on later whorls. The aperture is not preserved on any shell.

Remarks. VAN VooRTHUYSEN has stated the great variability of this species. It is hardly possible to distinguish between well defined varieties according to this author, who has had a considerable number of shells at his disposal. The varieties established by Sacco and Cossmax \& Peyrot have accordingly been listed in the synonymy.

Distribution.

Pliocene: Mediterranean Basin: Italy: Piacenziano, Astiano.

Miocene: Aquitanian Basin: Burdigalien, Helvétien.

North Sea Basin: Belgium: Boldérien, Anversien.

Holland (m.). Germany: Hemmoor stage, Reinbek stage (Gottsche 1878), Glimmerton (Banke Rasmussen 1956). Denmark: Arnum formation.

Mediterranean Basin: Italy: Elveziano, Tortoniano. Vienna Basin: Baden clay.

FAMILIA SOLARIIDAE CHENU 1859

Genus Solarium Lamarck 1799

\section{Solarium carocollatum Lamarck}

Plate 29, fig. 100 a-c.

1822. Solarium carocollatum LAMARCK. Hist. nat. des animaux sans vertèbres. 7, p. 6 . 1825. Solarium carocollatum Lamarck. Basterot. Mém. geol. env. Bordeaux. p. 34, pl. 1, fig. 12.

1856. Solarium carocollatum Lamarck. Hörnes. D. foss. Moll. d. Tert.-Beckens v. Wien 1, p. 462 , pl. 46 , fig. $1-2$.

1892. Solarium carocollatum LAMARCK. SACCO. I moll. d. terr. terz. d. Piemonte e d. Liguria. 12, p. 40.

1916. Solarium carocollatum Lamarck. Nørregandd. Mell. mioc. Bl. Esbjerg. p. 21, pl. 3, fig. 1.

1918. Solarium carocollatum Lamarck. Cossmann \& Peyrot. Conch. Néogén. d. l'Aquit. p. 454 , pl. 15, fig. 18-20.

1925. Solarium carocollatum Lamarck. Kautsky. D. Mioc. v. Hemmoor u. BasbeckOsten. p. 64, pl. 6, fig. 10 .

Original diagnosis. Testa orbiculato-conoidea, transversim sulcata, long- 
itudinaliter striata; ultimo anfractu acute angulato; umbilico pervio, crenis crassis obvallato (LAMARCK 1822).

Shell material. All shells partly broken.

$\begin{array}{lrrrrr}\text { Location } & \text { Depth } & \text { Shells } & \text { Location } & \text { Depth } & \text { Shells } \\ \text { Glejbjerg } & 53.50 \mathrm{~m} & 1 & \text { Toftlund } & 75-100 \mathrm{~m} . & 9 \\ & 55- & 1 & & 100-105- & 1 \\ \text { Bramminge } & 70-80- & 15 & \text { Arnum (13) } & 105-110- & 1 \\ \text { Gramby } & 82.66-83.76- & 1 & 53-83- & 3\end{array}$

Description.

Protoconch heterostrophe, smooth, about 21/2 whorls. Aperture trumpet shaped; last whorl slightly narrowed behind the aperture. A single delicate spiral rib on the last whorl at the transition to the umbilicus. Diameter and height could be measured in three specimens:

$\begin{array}{lrcc} & & \text { Height } & \text { Diameter } \\ \text { Toftlund } & 75-100 \mathrm{~m} . & 0.50 & 1.25 \mathrm{~mm} \text {. } \\ & 100-105- & 0.48 & 0.99- \\ \text { Bramminge } & 70-80- & 0.55 & 1.18-\end{array}$

Teleoconch. The body whorl has 3 spiral furrows on its upper side, which divide the surface of the shell into 4 spiral bands. Irregular flat ribs are developed parallel with the growth lines on this part of the whorl. Some shells are, however, almost devoid of such ribs. The periphery of the whorl bears a rounded keel with transverse constrictions. The base carries a narrow spiral rib immediately within the peripheral keel, and a distinct furrow demarcates the umbilical spiral belt which has strong radial knobs directed towards the umbilicus. The area between the umbilical belt and the spiral rib is otherwise practically devoid of spiral sculpture. Indistinct radial ribs emerge at the umbilical belt, but they have almost disappeared adjacent to the spiral rib.

The suture develops along the peripheral keel. The aperture is broken on all specimens. It could be observed, however, that there is a shallow gutter at the junction between the basal wall and the umbilical wall, and another in the middle of the umbilical wall.

The exterior of the umbilical wall is smooth.

Distribution.

Miocene: Aquitanian Basin: Aquitanien, Burdigalien, Helvétien.

North Sea Basin: Germany: Hemmoor stage. Denmark: Arnum formation.

Mediterranean Basin: Italy: Elveziano.

Vienna Basin: Grund sands, Baden clay.

Oligocene: Mediterranean Basin: Italy: Tongriano.

\section{Solarium trochleare nov. sp.}

Plate 30, fig. 101 a-c.

Diagnosis. Solarium with 4 spiral furrows and flat collabral ribs on the upper side of the whorls. Body whorl with two strong, rounded, lateral keels and interjacent narrow spiral rib; underside with spiral furrow and transverse ribs. Holotype: Geological Survey of Denmark, file no. 150. 9. b. Toftlund 100-105m. 
Shell material: One shell (Holotype).

Description.

Protoconch heterostrophe, smooth; aperture trumpet-shaped; delicate spiral rib on the last whorl at the edge of the umbilicus. Last whorl somewhat narrowed towards the aperture. Diameter $0.93 \mathrm{~mm} . ; 21 / 4$ whorls.

Teleoconch. 11/2 whorls, diameter $3.2 \mathrm{~mm}$., height $1.4 \mathrm{~mm}$. width of last whorl $0.96 \mathrm{~mm}$.

Upperside: Four spiral furrows of which the second from the apical suture is rather indistinct and maybe incomplete. Forty-six flat, but rather strong collabral ribs of which 25 are found on the first whorl.

Underside: Body whorl with two relatively strong, rounded peripheral keels with constrictions, like strings of pearls. The upper keel projects beyond the lower keel. Interspace between the keels with growth lines, occasionally developed into flat ribs. In the middle of the interspace a distinct narrow spiral rib. The lower peripheral keel forms the edge of the basal wall proper.

The basal wall which is rather flat and almost perpendicular to the axis of the shell, is delimited by a spiral furrow by the lower peripheral keel. Another more distinct spiral furrow divides the base into an inner, narrow, umbilical ring with strong marginal knobs at the umbilicus and an outer broad ring with flat, fan-shaped, collabral ribs. The ratios of widths of the lower peripheral keel, the outer ring, and the umbilical ring are about $1.2: 2.5: 2.0$.

The umbilical wall is smooth. The suture develops along the upper peripheral keel. The aperture, which is broken is trapezoidal, it has a furrow in the middle of its umbilical section and a shallow gutter at the edge of the umbilicus.

Remarks. Despite the fact that only one shell is available there is hardly any doubt that it belongs to a species different from the Solaria previously described from the deposits of the European Oligocene, Miocene, and Pliocene basins. The characteristic features of this species are the two peripheral keels and the flat basal wall of the body whorl. There is a slight similarity with S. micromphalus Cossmann \& Perrot (Conch. Néogén. d. l'Aquit. 1918 p. 459, pl. 15, fig. 48-50) which also has two peripheral keels. However, in this species the base is convex, and the sculptural features are different in several respects.

\section{Distribution.}

Miocene: North Sea Basin: Denmark: Arnum formation.

\section{Solarium angustiforatum Cossmann \& Peyrot}

Plate 31, fig. 102 a-d.

1918. Solarium (Pseudotorinia) angustiforatum Cossmann \& Peyrot. Conch. Néogén. d. l'Aquit. p. 471, pl. 15, fig. 30-32.

Essential features of original description. Forme un peu bombée, conoidale, spire en dôme surbaissé; protoconque lisse. Tours ornés de quatre cordonnets spiraux presque égaux, découpés en granules arrondies par des stries d'accroissement obliques et incurvées. Dernier tour subanguleux à la péripherie qui est marquée par deux cordons presque égaux; base assez convexe, ornée de six cordonnets, sur lesquels les stries d'accroissement découpent des granulations. (Cossmann \& Peyrot 1918). 
Shell material and dimensions.

\begin{tabular}{|c|c|c|c|c|c|c|c|}
\hline \multirow[t]{2}{*}{ Location } & \multirow[t]{2}{*}{ Depth } & \multirow[t]{2}{*}{ Shells } & \multicolumn{2}{|c|}{ Protoconch } & \multicolumn{2}{|c|}{ Teleoconch } & \multirow[b]{2}{*}{$\begin{array}{l}\text { No. of } \\
\text { whorls }\end{array}$} \\
\hline & & & Diameter & $\begin{array}{l}\text { No. of } \\
\text { whorls }\end{array}$ & Height & Diameter & \\
\hline Glejbjerg & $53.5 \mathrm{~m}$. & 1 & $0.65 \mathrm{~mm}$. & $21 / 2$ & $1.14 \mathrm{~mm}$. & $2.8 \mathrm{~mm}$. & 2 \\
\hline Gramby & $82.66-83.76-$ & 1 & 0.77 & $21 / 4$ & 1.1 & $2.23-$ & $11 / 2$ \\
\hline Toftlund & $105-110=$ & $1 \mathrm{frg}$. & & & & & \\
\hline
\end{tabular}

Description.

Protoconch heterostrophe, smooth; aperture trumpet shaped, no spiral on last whorl. Dimensions see above.

Teleoconch rounded conoidal, depressed. Upper side of whorls with 4 to 5 spiral ribs crossed by relatively strong collabral ribs. Rounded knots on the intersections between the collabral and spiral ribs. Two "string of pearl" keels on the periphery of the body whorl, the upper projecting slightly beyond the lower. Fine connecting striae between the keels. The base of the body whorl rather convex, with six spiral ribs of decreasing strength from the umbilicus to the lower peripheral keel. Radiating collabral ribs which form strong knobs over the umbilicus and divide in somewhat irregular manner towards the periphery. They form knobs on the three succeeding spiral ribs and flatten out to a multitude of striae and low ribs on the interspace between the fourth spiral rib and the lower peripheral keel.

Aperture broken. Umbilical wall of the body whorl smooth. Suture formed at the upper peripheral keel. Dimensions see above.

Remarks. The strength of the spiral ribs on the upper and undersides of the whorls, as well as their number, varies appearently. This is due to the emergence of new spirals at intervals in the interspaces. There is some similarity between this species and S. planulatum Grat. (Cossmann \& Peyrot Conch. Néogén. d. l'Aquit. 1918, p. 475, pl. 15, fig. 57-58, 71-73, 77).

Distribution.

Miocene: Aquitanian Basin: Burdigalien.

North Sea Basin: Denmark. Arnum formation.

\section{FAMILIA CERITHIIDAE FERUSSAC 1821 \\ Genus Bittium (Leach) Gray 1847}

\section{Bittium spina (Partsch)}

Plate 31, fig. 103.

1842. Cerithium spina Partsch. Neue Aufst. d. Petref.-Samml. d. K. K. Hof-Miner.-lab. in Wien Nr. 1038.*)

1856. Cerithium spina Partsch. Hörnes. D. foss. Moll. d. Tert.-Beckens v. Wien 1, p. 409, pl. 42, fig. 15 .

1882. Cerithium spina Partsch. von Koenen. D. Nordd. Mioc. u. s. Moll. f. 2, p. 274, pl. 6, fig. 20.

1895. Bittium spina PARTsch et var. convexorudis SACCo. I moll. d. terr. terz. d. Piemonte e d. Liguria. 17, p. 41, pl. 2, fig. 120-121.

1907. Cerithium spina Partsch. Ravn. Molluskf. Jyll. Tert. p. 301, pl. 3, fig. 26.

1921. Bittium convexorude Sacco. Cossmann \& Peyrot. Conch. Néogén. d. l'Aquit. p. 281, pl, 7, fig. 21-24.

*) unavailable. 
1925. Bittium spina Partsch. Kautsky. D. Mioc. v. Hemmoor u. Basbeck-Osten. p. 85. 1940. Bittium convexorude SAcco. Sorgenfrer. Mar. Nedre-Mioc. i Klintinghoved p. Als. p. 35 , pl. 5, fig. 10 .

1944. Bittium (Bittium) spina (PARTSCH). VAN VoorthuYsen pro parte. Mioz. Gastr. a.d. Peelgebiet. p. 27, pl. 12, fig. 27-28.

Diagnosis. Testa elongato-turrita, angusta, minima, acuminata; anfractibus convexis, costis longitudinalibus et striis transversis decussatis; apertura minima, ovata, basi late emarginata (HöRNES 1856). Original description by PARTSCH unavailable.

Shell material.

$\begin{array}{lrrlrr}\text { Location } & \text { Depth } & \text { Shells } & \text { Location } & \text { Depth } & \text { Shells } \\ \text { Glejbjerg } & 53.5 \mathrm{~m} & 2 & \text { Toftlund } & 110-115 \mathrm{~m} . & 5 \\ & 53.75- & 1 & & 115- & 2 \\ \text { Bramminge } & 70-80- & 4 & \text { Arnum }(13) & 53-83- & 16 \\ \text { Gramby } & 82.66-83.76- & 1 \text { (cf.) } & \text { Arnum }(25 \mathrm{~b}) & 62.7-62.9- & 1 \\ \text { Toftlund } & 75-100- & 21 & & 95.0-95.3- & 12 \\ & 100-105- & 6 & & 104-107.5- & 4 \\ & 105-110- & 2 & & & \end{array}$

Description.

Protoconch with $3 \frac{1 / 2}{2}$ to 4 whorls. About the first $1-1 \frac{1}{2}$ whorls are smooth and glossy. The nucleus is slightly heterostrophe. The succeeding whorls have two distinct spiral riblets at about the middle of the whorl. One or two rows of granules are seen with strong magnification adjacent to the upper suture. The surface of the whorls with riblets is less glossy than that of the initial whorl; the surface of the ribbed whorls is obviously subgranulated. The aperture of the protoconch is sinuous between the upper spiral and the suture. Lower part of the protoconch aperture not known.

Height and diameter of 9 protoconchs were measured. The following results were obtained:

$\begin{array}{lccc} & \text { Mean } & \text { Minimum } & \text { Maximum } \\ \text { Height } & 0.465 & 0.43 & 0.51 \mathrm{~mm} . \\ \text { Diameter } & 0.360 & 0.35 & 0.39-\end{array}$

Teleoconch. Two spiral ribs are found on the initial whorl of the adult stage in continuation of the spiral ribs of the protoconch. They are crossed by 9 to 12 collabral ribs, and low spines are developed at the intersections. A secondary spiral emerges between the upper spiral and the suture, at about the second or third whorl, and another develops adjacent to the upper suture on the 5th or 6th whorl. The entire shell surface is covered with delicate spiral striae visible under the microscope.

The number of collabral ribs per whorl increases generally slowly with size as shown in table 2, p. 170. A slight reduction has, however, been noticed in a few cases. Such reduction may particularly be related to the presence of varices. The number of full grown shells is too small for a safe calculation of the relationship between the number of ribs and growth, but the means listed in table 2 indicate the scale of increase.

The body whorl has initially two smooth spiral ribs on the outer part of its base. The suture is formed along the upper rib. One to three weak spirals appear successively on the base of later whorls between the columella and the inner primary spiral rib. 
The aperture is broken on all shells. Varices show, however, that the outer lip is thickened. The columella is almost straight, and the canal has the shape of a pointed gutter.

Remarks. It is very difficult to define the differences between $B$. spina and $B$.tenuispina at first sight. It should, therefore, be pointed out, that the following features were found to be characteristic of $B$. spina: the relation between the smooth and ornamented part of the protoconch, the granulations adjacent to the suture on the last whorls of the protoconch, and the comparatively small number of both spiral and collabral ribs on the teleoconch.

Reference is made to the remarks concerning $B$. tenuispina below.

Distribution.

Pliocene: Mediterranean Basin: Italy: Piacenziano, Astiano.

Miocene: Aquitanian Basin: Burdigalien.

North Sea Basin: Holland (m.). Germany: Hemmoor stage, Glimmerton (Banke Rasmussen 1956). Denmark: Klintinghoved clay and Arnum formation.

Mediterranean Basin: Italy: Elveziano, Tortoniano. Vienna Basin: Baden clay.

\section{Bittium tenuispina nov. sp.}

Plate 31, fig. 104.

1944. Bittium spina VAN Voorthuysen pro parte. Mioz. Gastr. a. d. Peelgebiet. p. 27, pl. 12, fig. 29-30.

Diagnosis. Bittium with protoconch consisting of $2 \frac{1}{2}$ to 3 whorls of which the last half to whole whorl has 1 to 2 spiral riblets. Adult shell stage with 3 to 5 spiral ribs. Initial whorl with 11 to 15 collabral ribs. Number of collabral ribs increases with about 1 rib per whorl. Derivatio nominis: tenuispina-with delicate spines. Holotype: D.G.U. Well file no. 150. 9. b. Toftlund 75-100 m.

Shell material.

\begin{tabular}{|c|c|c|c|c|c|c|c|}
\hline \multirow{4}{*}{$\begin{array}{l}\text { Location } \\
\text { Glejbjerg }\end{array}$} & \multicolumn{2}{|c|}{ Depth } & Shells & \multirow{2}{*}{$\begin{array}{l}\text { Location } \\
\text { Toftlund }\end{array}$} & \multicolumn{2}{|c|}{ Depth } & Shells \\
\hline & $23 n$ & & 7 & & $75-100_{1}$ & $\mathrm{~m}$. & 260 \\
\hline & 25 & - & 2 & & $100-105$ & - & 118 \\
\hline & 55 & - & 1 & & $105-110$ & - & 33 \\
\hline Bramminge & $70-80$ & - & 62 & & $110-115$ & - & 40 \\
\hline \multirow[t]{3}{*}{ Ribe } & $113-114$ & - & 1 (?) & Arnum (13) & $28-40$ & - & 25 \\
\hline & $114-115$ & - & 1 & & $53-83$ & - & 457 \\
\hline & $123-124$ & - & 1 & & $83-94$ & - & 2 \\
\hline \multirow[t]{6}{*}{ Gramby } & $82.66-83.76$ & - & 55 & Arnum $(25 \mathrm{~b})$ & $62.7-62.9$ & - & 452 \\
\hline & $84.66-87.16$ & - & 26 & & $95.0-95.3$ & - & 4 \\
\hline & $90.42-92.72$ & - & 1 & & $101.0-104.3$ & - & 1 \\
\hline & $92.72-109.29$ & - & 7 & & $104.3-107.5$ & - & 6 \\
\hline & $109.29-110.86$ & - & 1 & & & & \\
\hline & $110.86-121.51$ & - & 1 & & & & \\
\hline
\end{tabular}

\section{Description.}

Protoconch with $2 \frac{1}{2}$ to 3 globular whorls, of which the last $1 / 2$ to 1 whorl has 1 to 2 spiral riblets. The whorls are otherwise smooth and glossy, and the nucleus is slightly heterostrophe. The protoconch aperture has a very deep sinus above the spiral riblets adjacent to the suture. 
The heights and diameters of 20 protoconchs were measured. The following figures were obtained:

$\begin{array}{lccc} & \text { Mean } & \text { Minimum } & \text { Maximum } \\ \text { Height } & 0.388 & 0.32 & 0.43 \mathrm{~mm} . \\ \text { Diameter } & 0.336 & 0.31 & 0.36 \quad-\end{array}$

Teleoconch. The initial whorl starts with two primary spiral ribs opposite the spiral riblets of the protoconch. Close to the protoconch they are joined by a third spiral rib which emerges at the suture. From about the second or third whorl a fourth spiral is inserted between the sutural spiral and the upper primary spiral. A fifth spiral has been noticed from about the fifth or sixth whorl. It develops in the interspace between the upper primary spiral rib and the secondary rib above.

The spiral ribs are crossed by 11 to 15 collabral ribs on the first whorl. There is an average increase of one collabral rib per whorl with growth, although whorls with varices generally show abnormal numbers of ribs. Low spines or knobs are developed at the intersections of the spirals and the collabral ribs. The shell surface is covered with microscopic spiral striae.

The base of the body whorl has two distinct spiral ribs at its periphery between which the suture is formed. There are one or two more spiral ribs encircling the columella. The aperture is rounded with a short, pointed canal. Outer lip thickened. Varices occur abundantly from about the fourth or fifth whorl.

Remarks. A careful comparison of the shells here described as B. spina and $B$. tenuispina reveals that there are a number of well defined specific features both in the juvenile and adult stages. They may be summarized as follows:
B. spina
Protoconch a) $31 / 2-4$ whorls
b) $21 / 2$ whorls with spiral
riblets
c) granules on shell surface
a) $2 \frac{1}{2}-3$ whorls
B. tenuispina
b) $1 / 2-1$ whorl with spiral riblets
c) Shell surface smooth and glossy
Teleoconch a) Maximum 4 spiral ribs
b) Number of collabral ribs increases slowly with
a) Maximum 5 spiral ribs
b) Number of collabral ribs increases with about one rib per whorl.

These differences are very characteristic indeed, and if the fundamental difference in the mode of development of secondary spiral ribs is kept in mind the separation of the shells into two species seems to be fully justified.

The statistics on B. spina and B. tenuispina are outlined in table 2, p. 170, and figs. 12-13. The true height of the teleoconch was not measured on account of the broken aperture of many shells. Height from apex to 4 th and $3 \mathrm{~d}$ whorl in $B$. tenuispina and B. spina respectively correspond fairly well with each other. The " $H$ " $/ D$ ratios illustrate the variation of the apical angle in the two species. The graph fig. 12 shows that the apical angle is smaller in B. tenuispina than in B. spina.

Distribution of B.tenuispina:

Miocene: North Sea Basin: Holland (m.). Denmark: Arnum formation. 


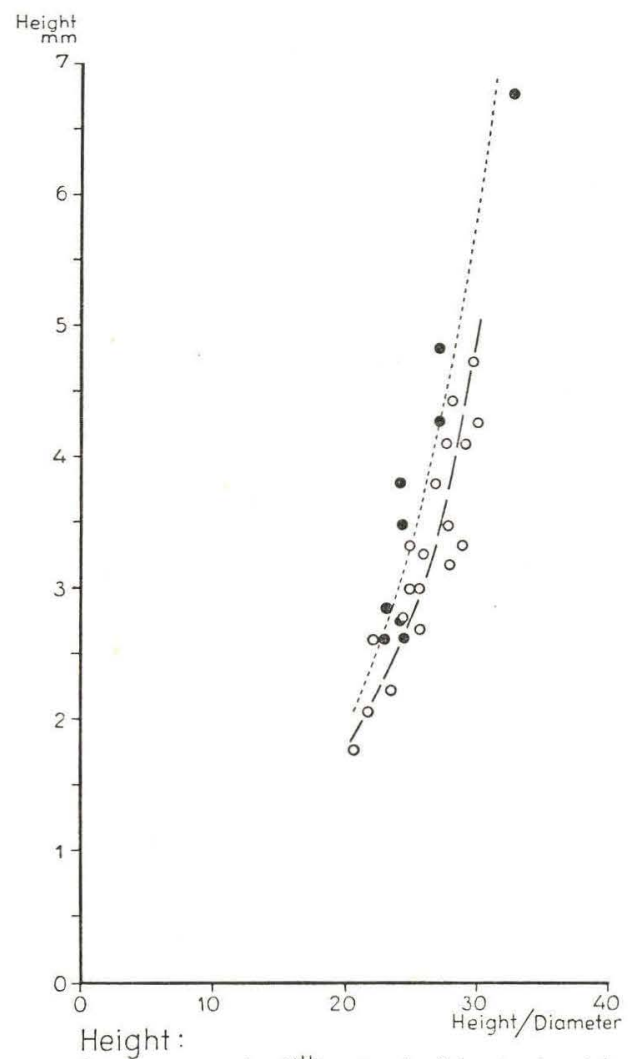

Fig. 12.

- from apex to $4^{\text {th }}$ spiral of last whorl in

- B. tenuispina nov sp., and from

apex to $3^{\prime d}$ spiral of last whorl in

- B.spina Partsch Toftlund $100 \mathrm{~m}$

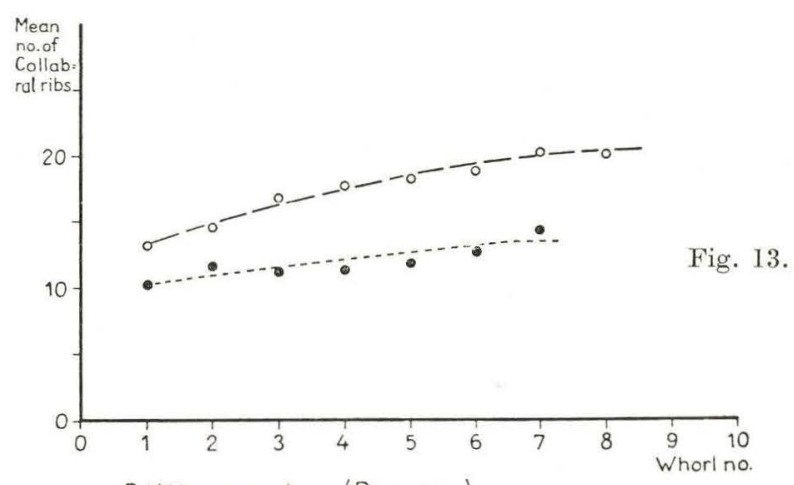

- Bittium spina (PARTSCH)

- " tenuispina nov sp.

Toftlund 75-100m 
Table 2. Number of collabral ribs.

Bittium spina Partsch. Toftlund 75-100 m.

\begin{tabular}{|c|c|c|c|c|c|c|c|c|c|c|}
\hline Shell & Number of & llabr & ribs o & & & & & & \multirow[b]{2}{*}{8} & \multirow[b]{2}{*}{9} \\
\hline no. & whorl no.: & 1 & 2 & 3 & 4 & 5 & 6 & 7 & & \\
\hline 1 & & 10 & 11 & 10 & 9 & 9 & 11 & & & \\
\hline 2 & & 10 & 11 & 12 & 11 & & & & & \\
\hline 3 & & 11 & 12 & 12 & 12 & 12 & 12 & 13 & & \\
\hline 4 & & 9 & 10 & 11 & 11 & 12 & & & & \\
\hline 5 & & 9 & 11 & 11 & 12 & 13 & & & & \\
\hline 6 & & 12 & 12 & 10 & 12 & 13 & 14 & 15 & & \\
\hline 7 & & 10 & 12 & 12 & 11 & 11 & 13 & 15 & & \\
\hline 8 & & 11 & 11 & 11 & 12 & 12 & 13 & 14 & 17 & 17 \\
\hline 9 & & 10 & 11 & 12 & 11 & 12 & & & & \\
\hline & Mean: & 10.3 & 11.6 & 11.2 & 11.2 & 11.8 & 12.6 & 14.3 & & \\
\hline & Minimum & 9 & 10 & 10 & 9 & 9 & 11 & 13 & & \\
\hline & Maximum & 12 & 12 & 12 & 12 & 13 & 14 & 15 & & \\
\hline
\end{tabular}

Bittium tenuispina nov. sp. Toftlund 75-100 m.

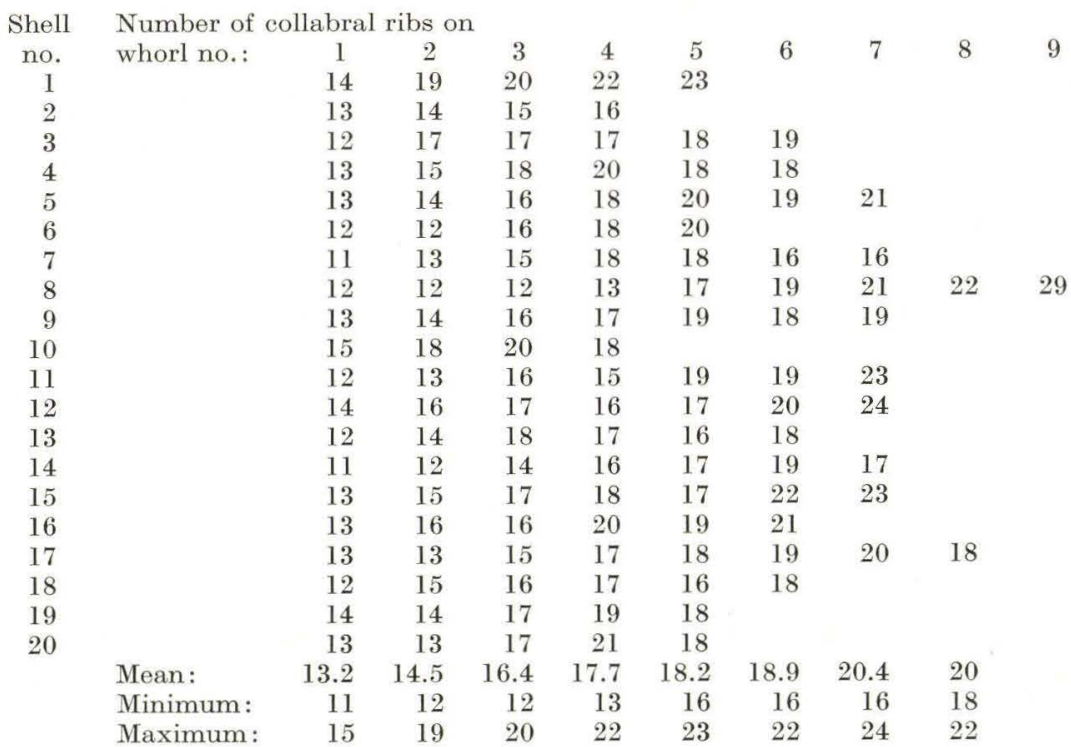

FAMILIA CERITHIOPSIDAE H. \& A. ADAMS 1854

Genus Cerithiopsis Forbes \& Hanley 1849

\section{Cerithiopsis Vignali Cossmann \& Peyrot}

Plate 31, fig. 105a-b.

1921. Cerithiopsis Vignali Cossmann \& Peyrot. Conch. Néogén. d. l'Aquit. p. 292, pl. 7, fig. $70-71$.

1949. Cerithiopsis (Cerithiopsis) Vignali Cossmann \& Peyrot. Glibert. Gastr. du Mioc. moy. du bassin d. 1. Loire. p. 151, pl. 10, fig. 3.

Essential features of original description. "Protoconque lisse, styliforme, composée de quatre tours et demi, dont le nucléus est obtusément mammillé; 
tours post-embryonnaires nombreux, plans. Ornementation cancellée, composée de trois cordons spiraux et tranchants, munis de petites aspérités granuleuses à l'intersection des nombreuses costules axiales. Dernier tour muni d'un quatrième cordon à la périphérie de la base qui est excavée et lisse". (Cossmann \& Peyrot 1921).

Shell material.

Toftlund 105-110 m. 1 shell, 110-115m. 2 shells.

Description.

Protoconch preserved on one of the shells from $110-115 \mathrm{~m}$. The shell surface is somewhat corroded, but sufficiently well preserved to show that it is smooth. The protoconch consists of about 5 whorls with a slightly heterostrophe nucleus. Height $0.83 \mathrm{~mm}$., diameter $0.39 \mathrm{~mm}$.

Teleoconch. All whorls have 3 strong spiral ribs intersected by 14 to 18 collabral ribs which are pratically as strong as the spiral ribs. Low rounded knobs are generally developed at the intersections.

The body whorl has an almost smooth spiral rib at the edge of the whorl base, which is smooth. A delicate spiral stria encircles the notched canal on the base. Aperture rounded. Inner lip with thin callosity in one of the shells from 110$115 \mathrm{~m}$. The suture develops on the smooth spiral rib at the edge of the whorl, which is being covered by the new whorl.

Remarks. No difference of importance has been noticed in comparing the shells from Toftlund with the descriptions of the shells from southwestern France.

Distribution:

Miocene: Aquitanian Basin: Aquitanien, Burdigalien, Helvétien.

Loire Basin: Vindobonien.

North Sea Basin: Denmark: Arnum formation.

FAMILIA TRIPHORIDAE JOUSSEAUME 1884

Genus Triphora Blainville 1828

\section{Triphora perversa (Linné)}

Recent:

Plate 32, fig. 106.

1758. Trochus perversus Linné. Syst. Nat. Ed. Dec. p. 760.

1853. Cerithium adversum Montagu. Forbes \& Hanley. Brit. Moll. 3, p. 195, pl. 91, fig. 5-6.

1867. Cerithium perversum Linné. Jefrereys. Brit. Conch. 4, p. 261. 5, pl. 80, fig. 5.

1868. Triforis perversa Linné. Weinkauff. Conch. d. Mittelmeeres. 2, p. 167.

1884. Triforis perversus Linné $s p$. Bucquoy, Dautzenberg \& Dollfus. Moll. mar. du Roussillon. 1, p. 209, pl. 26, fig. 8-17.

1888. Triphoris perversa L. Petersen. De skalbærende Moll. Udbredn. p. 98.

1892. Triphoris perversus L. Locard. Coq. mar. d. côtes d. France. p. 120.

1931. Triphora perversa (L.) Plymouth Mar. Fauna. p. 259.

1932. Triforis perversus (Linn.) Nobre. Moluscos. mar. d. Portugal. p. 134, pl. 27, fig. 17. 
Fossil:

1856. Cerithium perversum Linné. Hörnes. D. foss. Moll. d. Tert.-Beckens v. Wien 1, p. 414 , pl. 42 , fig. 20 .

1866. Triphoris perversus Linné sp. SPEyer. Ober olig. Lippe Detmold. p. 21.

1870. Triphoris perversus Linné sp. Speyer. D. Conch. d. Casseler Tert. p. 139, pl. 20, fig. 7.

1895. Monophorus perversus var. adversa (Mont.). Sacco. I moll. d. terr. terz. d. Piemonte e d. Liguria. 17 , p. 63 , pl. 3 , fig. 62.

1921. Triphora adversa (Montagu) mut. miocanica. Cossmann \& Peyrot. Conch. Néogén. d. 1'Aquit. p. 307, pl. 7, fig. 61-62.

1925. Triphora perversa Linné var. borealis. Kautsky. D. Mioc. v. Hemmoor u. BasbeckOsten. p. 85, pl. 7, fig. 8.

1941. Triphora perversa Linné. Görges. D. Oberolig.-fauna v. Rumeln. p. 142.

1949. Triphora (Triphora) perversa Linné sp. Glibert. Gastr. du Mioc. moy. du bassin d. 1. Loire. p. 157, pl. 10, fig. 13.

Original diagnosis and description: Diagnosis: Trochus testa imperforata turrita glabra, anfractibus serie duplici excavato punctatis. Habitat in M. Mediterraneo.

Description: Testa parva, anfractibus cylindricis duplici serie excavato punctatis, prceter margines anfractuum etiam crenato punctata. A pertura quadrata, columella basi prominula, at non in canalem evidentem. Color fere corneus. (Linné 1758).

Shell material. Fragments of two shells from Toftlund $105-110 \mathrm{~m}$.

Description.

The fragment including the most whorls is shown on plate 32, fig. 106. This shell represents the initial whorls of the adult shell stage with two strong spiral ribs connected by 18 or 19 oblique collabral ribs. Strong knobs are developed on the spiral ribs at the intersections. A weak spiral emerges between the primary spirals on the last whorl of the shell fragment.

The second fragment belongs to a larger shell and shows the last whorl only; it has three strong spiral ribs corresponding to the three ribs noticed on the last whorl of the other fragment. The strength of the spiral ribs decreases going from the upper to the lower rib. On the edge of the whorl there is another spiral at which the ribs terminate in low knobs.

The short canal is notched and carries two strong spiral ribs.

Distribution.

Recent: West coast of Europe from southern Norway to the Canaries; Mediterranean. West coast of N. America (?) (acc. to JEFFREYs).

Pliocene: North Sea Basin: England: Coralline Crag (S. Wood) Mediterranean Basin: Italy: Piacenziano, Astiano.

Miocene: Aquitanian Basin: Burdigalien, Helvétien.

North Sea Basin: Germany: Hemmoor stage. Denmark: Arnum formation.

Mediterranean Basin: Italy: Elveziano, Tortoniano. Vienna Basin: Steinabrunn beds.

Oligocene: North Sea Basin: Germany (u.). 
FAMILIA SCALIDAE BRODERIP 1839

Genus Cirsotrema Mörch 1852

\section{Cirsotrema Thais De Boury}

Plate 32, fig. 107.

1912. Cirsotrema Thais de Boury. Cossmann. Essais d. Paléoconch. comp. 9, p. 180, pl. 6, fig. 16 .

1921. Cirsotrema Thais de Boury. Cossmann \& Peyrot. Conch. Néogén. d. l'Aquit. p. 153. pl. 4, fig. $68-70$.

Essential features of original description. Forme allongée; tours à sutures profondes, ornés de lamelles axiales, épaisses et feuilletées ou crépues qui s'alignent un peu obliquement formant auprès de la suture inférieure une auricule peu saillante et obtuse. La surface est, en outre, ornée de quatre gros cordonnets spiraux, très larges. Dernier tour muni de quatorze ou quinze lamelles et un cordon périphérique. (De Bouny. in Cossmann 1912).

Shell material.

$\begin{array}{lrllrc}\text { Location } & \text { Depth } & \text { Shells } & \text { Location } & \text { Depth } & \text { Shells } \\ \text { Bramminge } & 70-80 \mathrm{~m} . & 17 \text { (frg.) } & \text { Toftlund } & 105-110 \mathrm{~m} . & 1 \\ \text { Toftlund } & 75-100- & 11- & \text { Arnum (13) } & 53-83- & 1 \text { (frg.) }\end{array}$

Description. All shells are more or less fragmentary.

Protoconch partly preserved in a few specimens: surface smooth and glossy, with probably about 3 to 4 whorls, and deep sinus at upper suture.

Teleoconch. The initial whorl is covered by 10 to 15 spiral striae which are intersected by about 14 to 17 lamellated collabral ribs. The collabral ribs grow into strong lamellae from about the second or third whorl. Their lower (vertical) half displays a honeycomb-like structure, while the upper shoulder is more simply lamellated. An angular process is generally developed at the transition between the shoulder and the vertical part of the lamella. The spiral striae on the vertical part of the whorl coalesce into four groups which appear as the more conspicuous radial "ribs" mentioned by De Boury. Each radial rib includes 3 to 4 spiral striae, and a total of about 20-25 spiral striae have been counted on the whorls from the upper to the lower suture.

The number of collabral lamellae per whorl is rather constant (14-17).

The lamellae break up into several thinner lamellae on the basal part of the body whorl. They radiate toward the columella after turning backwards on the edge of the whorl.

Aperture round; suture formed at the edge of the whorl.

Remarks. C. Thais, C. crassicostatum, C. sallomacense, and others form a group of variable mollusca which are often difficult to distinguish from each other. It should be pointed out here, therefore, that the variability of shells referred to these species ought to be studied in detail in order to determine whether the specific characters claimed are valid. Reference is made to CossmanN \& Peyrot concerning the above-mentioned and related species.

Distribution:

Miocene: Aquitanian Basin: Aquitanien.

North Sea Basin: Denmark: Arnum formation. 


\section{Genus Scala (Klein 1753) Bruguière 1792.}

\section{Scala cf. frondicula (Wood)}

1848. Scalaria frondicula S. Wood. Monogr. Crag Moll. 1, p. 92, pl. 8, fig. 16.

1891. Hirtoscala (vel Linctoscala) frondicula (WOOD). SAcco. I moll. d. terr. terz. d. Piemonte e d. Liguria. 9, p. 26.

1907. Scalaria frondicula S. Wood. Ravn. Molluskf. Jyll. Tert. p. 295, pl. 3, fig. 14.

1918. Scala (Linctoscala) frondicula (S. V. Wood). Harmer. Plioc. Moll. 2, p. 531, pl. 48, fig. 19-20.

1925. Scala (Spiniscala) frondicula Wood. KaUtsky. D. Mioc. v. Hemmoor u. BasbeckOsten. p. 79 , pl. 6, fig. 35 .

1952. Scala (Spiniscala) frondicula Wood sp. Gribert. Faune mal. du Mioc. de la Belgique. 2, p. 47 , pl. 3 , fig. $12-13$.

Original diagnosis. Testa elongata, turrita; spira subulata; apice acuto; anfractibus rotundatis, contiguis costellatis; costellis lamellosis, superne angulatis, spiniferis; interstitiis lavigatis; apertura rotundata. (Wood 1848).

Shell material.

Toftlund 100-105 m. 1 frg.; 105-110 m. 3 frg.

Description.

Protoconch. Four smooth whorls with delicate microscopical growth lines. Height $0.62 \mathrm{~mm}$., diameter $0.40 \mathrm{~mm}$.

Teleoconch. Whorls smooth with 14 to 16 projecting collabral lamellae. The spines on the lamellae, which are typical for S. frondicula cannot be identified with certainty due to the bad state of preservation. The largest fragment (about $3 \mathrm{~mm}$. long) includes slightly less than two whorls.

Remarks. The reference of the above fragments to $S$. frondicula is made with much reservation, partly on account of the insufficient shell material and partly due to the difficulties associated with the determination of Scalae in general.

Distribution.

Pliocene: North Sea Basin: England: Coralline Crag.

Mediterranean Basin: Italy: Piacenziano, Astiano.

Miocene: North Sea Basin: Belgium: Anversien. Germany:

Hemmoor stage, Glimmerton (Banke Rasmussen 1956);

Denmark: Arnum formation.

Subgenus (Acrilla) H. Adams 1860.

109. Scala (Acrilla) cf. amoena Philippi

Plate 32, fig. 109.

1843. Scalaria amoena PhiLippi. Tert.-Verst. d. nordw. Deutschlands. p. 54, pl. 3, fig. 23. 1856. Scalaria amoena Philippi. Hörnes. D. foss. Moll. d. Tert. Beckens v. Wien. 1, p. 479 , pl. 46 , fig. 11 .

1882. Scalaria subreticulata D'Orb. v. Koenen. D. Nordd. Mioc. u. s. Moll. f. p. 293. 
1891. Acrilla amoena (PHIL.) var. subreticula (D'OrB.). SAcco. I moll. d. terr. terz. d. Piemonte e d. Liguria. 9, p. 61, pl. 2, fig. 51.

1914. Scalaria (Acrilla) amoena PhIL. Gripr. Über eine u. mioz. Moll. f. v. Itzehoe. p. 11. ?1921. Acrilla phoenix de Boury. Cossmann \& Peyrot. Conch. Néogén. d. l'Aquit. p. 157, pl. 4, fig. 91-92.

1925. Acrilla amoena Phil. var. subreticula D'Orb. Kautsky. D. Mioc. v. Hemmoor u. Basbeck-Osten. p. 80.

1952. Scala (Acrilla) amoena $f$. subreticula d'Orbigny sp. GLibert. Faune mal. du Mioe. de la Belgique. 2, p. 44, pl. 7, fig. 1 .

Original diagnosis. Thurmförmig undurchbohrt; Windungen ziemlich stark gewölbt, mit etwa 26 sehr dünnen rippenartigen Lamellen und fünf erhabenen Quergürteln; ein Kiel am Grunde; die Basis durch Verlängerung der Rippen gestreift. (PhILIPpi 1843).

\section{Shell material.}

\begin{tabular}{|c|c|c|c|c|c|}
\hline Location & Depth & Shells & Location & Depth & Shells \\
\hline Glejbjerg & $32 \mathrm{~m}$ & $1 \mathrm{frg}$. & Toftlund & $110-115 \mathrm{~m}$ & 1 \\
\hline Bramminge & $\begin{array}{r}53.5- \\
70-80-\end{array}$ & $\begin{array}{r}1 \\
12\end{array}$ & Arnum (13) & $\begin{array}{r}115- \\
53-83=\end{array}$ & $\begin{array}{l}1 \\
2\end{array}$ \\
\hline Ribe & $114-115$ & $1-$ (cf.) & Arnum (25b) & $95.0-95.3=$ & $1 \mathrm{frg}$. \\
\hline Toftlund & $\begin{array}{r}75-100- \\
105-110=\end{array}$ & $\begin{array}{l}1 \\
3\end{array}$ & & 107.5 & 1 \\
\hline
\end{tabular}

Description. All shells are more or less fragmentary, the largest fragment being shown on plate 32, fig. 109.

Protoconch preserved on one shell (Toftlund 105-110 m.). Five smooth whorls with minute inverted s-shaped growth lines. Height $0.88 \mathrm{~mm}$., diameter $0.53 \mathrm{~mm}$.

Teleoconch. The ornamentation of the whorls consists of 6 to 7 spiral ribs and from 20 to 30 collabral, lamellated ribs. Well preserved shells show that the entire surface is furthermore covered by delicate spiral striae. A strong spiral is formed at the periphery of the basal wall of the body whorl and the suture follows this spiral.

Remarks. The difficulty of defining strict taxonomic units in the genus Scala has been fully recognized by previous authors. The writer would only add that he is not confident of the validity of those specific units which are established solely on the number of collabral ribs. GLIBERT has already shown that the number of ribs increases with size (i.e. with growth) in the shells from Belgium. Although the present material does not contribute data of this kind due to its fragmentary nature; it can be stated that there is considerable variation from shell to shell.

Distribution.

Miocene: Aquitanian Basin:? Aquitanien, ? Burdigalien.

North Sea Basin: Belgium: horizon of Houthaelen, Anversien. Germany: Vierlande and Hemmoor stages. Denmark: Arnum formation.

Mediterranean Basin: Italy: Elveziano.

Vienna Basin: Baden elay.

Oligocene: North Sea Basin: Germany (u.). 


\title{
Genus Janthina Bolten 1798
}

\section{Janthina cimbrica nov. sp.}

\author{
Plate 32, fig. 110.
}

Diagnosis. Ianthina with globose, translucent shell. Protoconch smooth. Teleoconch with recticulate sculpture of spiral and collabral striae. Number of collabral striae per whorl increases with growth. Body whorl with divaricate ornamentation: reticulation of lowest third of the whorl oblique to that of upper two thirds. Outer lip apparently with shallow sinus. Holotype: D.G.U. Well file no. 122.24. Glejbjerg $55 \mathrm{~m}$. Derivatio nominis: cimbrica - from Cimbria i. e. Jutland.

Shell material.

$\begin{array}{lrllrc}\text { Location } & \text { Depth } & \text { Shells } & \text { Location } & \text { Depth } & \text { Shells } \\ \text { Glejbjerg } & 55 \mathrm{~m} . & 1 & \text { Arnum }(25 \mathrm{~b}) & 62.7-62.9 \mathrm{~m} . & 1 \mathrm{frg} . \\ \text { Bramminge } & 70-80- & 1 \mathrm{frg} . & & 101-104.3- & 1 \\ \text { Gramby } & 84.66-87.16- & 1- & & \end{array}$

Description. Only the shell from Glejbjerg is perfectly preserved. The fragmentary specimens from the other wells are sufficiently well preserved to permit safe determination.

Protoconch smooth and glossy; it consists of about one whorl and projects very slightly.

Teleoconch globose. The visible part of the first whorl has about 3 to 4 spiral striae, while the number of spirals increases on the following whorls due to a successively lower position of the suture. The spiral striae are intersected by a great number of collabral, curved striae which increases rapidly with growth. The third whorl of the holotype has about 65 collabral striae while the fourth (= body whorl) has about 80 striae.

Body whorl with about 25 spiral striae on its upper two thirds, whereas there are only about 15 oblique spiral striae on the lower third outside the aperture.

The aperture is somewhat broken, but the growth lines and the course of the collabral striae indicate that there is a shallow sinus on the outer lip; it is situated opposite the division line of the divaricate sculpture. The columella is straight; thin, smooth deposition of shell material at the visible upper part.

Remarks. Shells of the genus Ianthina attract considerable interest since they may prove very useful as a correlation tool because of their pelagic habit and probable wide dispersal. However, since the present find seems to be unique we cannot yet attempt any regional correlation.

Distribution.

Miocene: North Sea Basin: Denmark: Arnum formation.

FAMILIA MELANELLIDAE THIELE 1931

Genus Niso Risso 1826

\section{Niso acarinatoconica Cossmann \& Peyrot}

Plate 32, fig. 111.

1856. Niso eburnea Risso. Hörnes. D. foss. Moll. d. Tert.-Beckens v. Wien. 1, p. 549, pl. 49, fig. 18. 
1892. Niso terebellum var. acarinatoconica SACCo. I moll. d. terr. terz. d. Piemonte e d. Liguria. 11, p. 604, pl. 1, fig. 45.

1914. Niso terebellum var. eburnea Risso. Gripp. Über eine u. mioz. Moll. f. v. Itzehoe. p. 13, pl. 1, fig. 14-16.

1918. Niso acarinatoconica Cossmavn \& Peyrot. Conch. Néogén. d. l'Aquit. p. 82, pl. 10, fig. $42-43$.

1925. Niso terebellum Chemn. var. acarinatoconica SACco. Kautsky. D. Mioe. v. Hemmoor u. Basbeck-Osten. p. 78 .

1944. Niso (Niso) terebellum (Dillwyn) var. acarinatoconica SACCo. VAN Voorthuysen. Mioz. Gastr. a. d. Peelgebiet. p. 35, pl. 8, fig. 26-31.

1952. Niso terebellum Chemnitz. Guibert. Faune mal. du Mioc. de la Belgique. 2, p. 52, pl. 4 , fig. 5 .

Essential features of original description. Taille moyenne; protoconque obtuse et un peu déviée. Tours légèrement convexes, dont la hauteur atteint à peine le tiers de la largeur, lisses. Sutures profondes. Dernier tour cinq treizièmes de la hauteur totale. Large entonnoir ombilical avec une rainure interne correspondant au bec antérieur de l'ouverture (Cossmans \& Peyrot 1918).

Shell material.

$\begin{array}{lrclrc}\text { Location } & \text { Depth } & \text { Shells } & \text { Location } & \text { Depth } & \text { Shells } \\ \text { Bramminge } & 70-80 \mathrm{~m} . & 9 & \text { Toftlund } & 110-115 \mathrm{~m} . & 1 \text { (frg.) } \\ \text { Toftlund } & 75-100- & 8 & & 115- & 1 \text { - } \\ & 100-105- & 2 & \text { Arnum (25 b) } & 62.7-62.9- & 2 \text { - }\end{array}$

\section{Description.}

Protoconch. About $3 \frac{1}{2}$ smooth and glossy whorls. The growth lines have a shallow sinus adjacent to the upper suture. Nucleus heterostrophe. Two shells were measured:

$\begin{array}{lll}\text { Height } & 0.57 & 0.61 \mathrm{~mm} . \\ \text { Diameter } & 0.40 & 0.42-\end{array}$

Teleoconch smooth and glossy, forming an almost regular cone. Shell surface occasionally with collabral striae or bands of colour lighter than the rest of the shell. Outer edge of the body whorl more or less rounded. Umbilical edge generally distinct. Dimensions and number of whorls in three almost undamaged shells are as follows.

\begin{tabular}{|c|c|c|c|c|}
\hline Location & Depth & Height & Diameter & $\begin{array}{l}\text { Number of } \\
\text { adult whorls }\end{array}$ \\
\hline Bramminge & $70-80 \mathrm{~m}$. & $\begin{array}{l}9.3 \mathrm{~mm} . \\
4.35-\end{array}$ & $\begin{array}{l}3.95 \mathrm{~mm} . \\
1.9\end{array}$ & $\begin{array}{l}10^{1 / 2} \\
6^{1 / 2}\end{array}$ \\
\hline Toftlund & $75-100=$ & $4.78=$ & $2.16 \quad-$ & $63 / 4$ \\
\hline
\end{tabular}

Remarks. Several of the authors cited in the synonymy agree regarding the impossibility of a concise definition of shell characters by which it may be possible to delimit specific units in the genus $\mathrm{Niso}$. The species of Niso are therefore of very doubtful significance with regard to stratigraphy.

In accordance with articles 21 and 25 of the International Rules of Zoölogical Nomenclature Cossmann \& Peyrot are the authors of the species since they were the first to apply acarinatoconica as a species name. 
Distribution.

Pliocene: Mediterranean Basin: Italy: Piacenziano, Astiano. Miocene: Aquitanian Basin: Helvétien.

North Sea Basin: Belgium: Anversien; Holland (m.). Germany: Vierlande and Hemmoor stages. Denmark: Arnum formation.

Mediterranean Basin: Italy: Tortoniano.

Basin of Vienna: Baden clay.

\section{Genus Melanella Bowdich 1822}

\section{Melanella similis (d'Orbigny)}

Plate 33, fig. 112.

1852. Eulima similis D'Orbigny. Prodrome de paléontologie strat. 3, p. 34, no. 482.

1918. Eulima similis d'Orbigny. Cossmann \& Peyrot. Conch. Néogén. d. l'Aquit. p. 64, pl. 8 , fig. $35-38$.

Essential features of the species. Since no diagnosis or description of the species has been given by D'ORBIGNY the following extract of the description by Cossmann \& Peyrot should be quoted: "Forme turriculée conique, très souvent tordue ou infléchie; protoconque obtuse et un peu déviée. Sutures fines, rainurées. Dernier tour inférieur au tiers de la hauteur totale, toujours subanguleux à la périphérie de la base. Ovverture courte, très faiblement versante en avant. Labre un peu obliquement incliné en avant et un peu sinueux vers la suture. Columelle oblique, presque rectiligne et assez calleuse. (CossMANN \& Peyrot 1917).

Shell material: One shell from Toftlund $75-100 \mathrm{~m}$.

Description. (The shell is somewhat corroded).

Protoconch smooth heterostrophe. About 4 sligtly convex whorls. Height $0.65 \mathrm{~mm}$., diameter $0.36 \mathrm{~mm}$.

Teleoconch. The shell has 4 adult whorls. Total height is $2.4 \mathrm{~mm}$. while the diameter is $0.9 \mathrm{~mm}$. The whorls are almost flat and smooth, the only feature of ornamentation being the slightly sinous lines of earlier apertural margins. The lateral and basal parts of the body whorl join in a rather distinct, rounded edge.

Aperture somewhat broken: outline oval and pointed towards the suture. Columella straight, slightly inclined, and somewhat thickened. It can be recognized on previous aperture scars that the outer apertural margin is a little sinous adjacent to the suture. From here it bends forward to the rounded edge of the whorl, and it then recedes a little before it joins the columella in a smooth curve.

The axis of the shell is faintly deflected.

Remarks. There is hardly any doubt that this shell belongs to the same species as the one described by Cossmann \& Peyrot.

The question arises of the validity of D'ORBIGNY's species names first published in his "Prodrome". Since D'Orbigny's list of fossils is unaccompanied by diagnoses, real descriptions, or illustrations of the fossils, his species should not be accepted. The impossibility of obtaining all pertinent literature on the subject renders a careful analysis of this problem impossible for the writer at present, and therefore D'ORBIGNY's name has been retained preliminarily. 


\section{Distribution.}

Miocene: Aquitanian Basin: Aquitanien, Burdigalien.

North Sea Basin: Denmark: Arnum formation.

\section{Melanella taurostricta (Cossmann \& Peyrot)}

Plate 33, fig. 113 a-b.

?1892. Eulima (Subularia) subulata var. taurostricta. SAcco. I moll. d. terr. terz. d. Piemonte e d. Liguria. 11, p. 596, pl. 1, fig. 22.

1918. Eulima (Subularia) taurostricta Sacco. Cossmann \& Peyrot. Conch. Néogén. d. 1'Aquit. p. 75, pl. 8, fig. 63-65, pl. 9, fig. 101.

Essential features of original description. Sutures visibles sous la couche de vernis. Dernier tour marqué d'un angle très obtus, ou d'une courbure plus subitements arquée, à la périphérie de la base. Labre à peu près vertical et rectiligne. (Cosmana \& Peyrot 1918).

Shell material.

\begin{tabular}{|c|c|c|c|c|c|c|}
\hline Location & Depth & Shells & Location & Dep & & Shells \\
\hline Glejbjerg & $53.5 \mathrm{~m}$. & $1 \mathrm{frg}$. & Toftlund & $75-100$ & & 13 \\
\hline Bramminge & $70-80-$ & 2 & & $105-110$ & - & $1 \mathrm{frg}$. \\
\hline Gramby & $82.66-83.76-$ & 1 & Arnum (13) & $53-83$ & - & $1 \mathrm{frg}$. \\
\hline & $84.66-87.16$ - & 3 & & $83-94$ & - & 1 \\
\hline & $90.42-92.72-$ & 1 & Arnum (25b) & $62.7-62.9$ & - & 5 \\
\hline
\end{tabular}

Description.

Protoconch smooth and glossy. Nucleus heterostrophe, about 31/2-4 slightly convex whorls. Dimensions of 5 specimens as follows:

\begin{tabular}{|c|c|c|c|c|}
\hline \multirow[b]{2}{*}{ Location } & \multicolumn{4}{|c|}{ Protoconch } \\
\hline & Depth & Height & Diameter & $\begin{array}{l}\text { Number of } \\
\text { whorls }\end{array}$ \\
\hline Gramby & $84.66-87.16 \mathrm{~m}$. & $\begin{array}{l}0.57 \mathrm{~mm} . \\
0.57\end{array}$ & $\begin{array}{l}0.33 \mathrm{~mm} . \\
0.28\end{array}$ & $\begin{array}{l}4 \\
31 / 2\end{array}$ \\
\hline Toftlund & $75-100-$ & $0.65-$ & $0.31 \quad-$ & 4 \\
\hline Arnum (13) & $53-83-$ & 0.58 & 0.33 & 4 \\
\hline & $83-94-$ & 0.57 & 0.31 & $31 / 2$ \\
\hline
\end{tabular}

Teleoconch. Whorls smooth and glossy. Suture visible through the thin test. The straight growth lines are almost perpendicular to the suture. Body whorl very faintly angular at the transition from the lateral to the basal part of the whorl. Aperture drop-shaped; outer lip straight, perpendicular to the suture as the growth lines. Columella oblique. The dimensions of the largest shell (from Arnum (13) 83-94 m.) are: height $5.8 \mathrm{~mm}$., diameter $1.45 \mathrm{~mm}$.

Remarks. Specific features are difficult to define in the Melanellae. In the present case leading criteria have been the course of the outer lip in relation to the suture, the features of the body whorl, and the orientation of the columella.

Cossmann \& Peyrot have been cited as the authors of this species since SAcCo did not erect a new species, but only a variety.

Distribution.

Miocene: Aquitanian Basin: Helvétien.

Mediterranean Basin: Elveziano.

North Sea Basin: Denmark: Arnum formation. 


\section{FAMILIA CALYPTRAEIDAE BRODERIP 1835 \\ Genus Calyptraea Lamarck 1799}

\section{Calyptraea chinensis (Linné)}

Recent:

Plate 33, fig. 114 a-b.

1758. Patella chinensis Linné. Syst. Nat. Ed. Dec. p. 781.

1853. Calyptraea sinensis Linné. Forbes \& Hanley. Brit. Moll. 2, p. 463, pl. 60, fig. $3-5$.

1865. Calyptraea chinensis Linné. Jefrereys. Brit. Conch. 3, p. 273, 5, pl. 60, fig. 1.

1868. Calyptraea chinensis Linné. Wernkauff. Conch. d. Mittelmeeres. 2, p. 332.

1886. Calyptraea chinensis Linné $s p$. Bucquoy, Dautzenberg \& Dollfus. Moll. mar. du Roussillon 1, p. 456, pl. 55, fig. 1-7.

1892. Calyptraea sinensis Linné. Locard. Coq. mar. d. côtes d. France. p. 217.

1932. Calyptraea Chinensis Linné. Nobre. Moluscos mar. de Portugal. p. 171, pl. 24, fig. $3-5$.

Fossil:

1848. Calyptraea chinensis Linné. Woon. Monogr. Crag Moll. 1, p. 159, pl. 18, fig. 1.

1856. Calyptraea chinensis Lrnnḱ. Hönnes. D. foss. Moll. d. Tert.-Beckens v. Wien I, p. 632 , pl. 59 , fig. $17-18$.

1896. Calyptraea chinensis Linné. Sacco. I moll. d. terr. terz. d. Piemonte e d. Liguria. 20 , p. 29 , pl. 4 , fig. $6-12$.

1918. Calyptraea chinensis Linné var. taurostriatellata Sacco. Cossmann \& Peyrot. Conch. Néogén. d. l'Aquit. p. 271, pl. 13, fig. 9-12.

1921. Calyptraea chinensis Linné. Harmer. Plioc. Moll. 2, p. 772, pl. 61, fig. 19-20.

1925. Calyptraea chinensis Linné. Kautsky. D. Mioc. v. Hemmoor u. Basbeck-Osten p. 62.

1946. Calyptraea (Calyptraea) chinensis Linné. Beets. Plioc. and Lower Pleistoc. Gastr. p. 55.

1949. Calyptraea chinensis taurostriatellata Sacco. Glibert. Gastr. du Mioc. moy. du bassin de la Loire, 1, p. 204, pl. 12, fig. 16.

1952. Calyptraea chinensis Linné sp. Gribert. Faune mal. du Mioc. de la Belgique. 2, p. 65 , pl. 5 , fig. 5 .

Original diagnosis: Testa integra subconica lavi, labio Taterali. (Linné 1758).

Shell material and dimensions.

\begin{tabular}{|c|c|c|c|c|c|}
\hline Location & Depth & Shells & $\begin{array}{l}\text { Approx. } \\
\text { diameter }\end{array}$ & $\begin{array}{l}\text { Diameter of } \\
\text { coiled ini- } \\
\text { tial shell }\end{array}$ & $\begin{array}{l}\text { Number o } \\
\text { whorls of } \\
\text { coiled shel }\end{array}$ \\
\hline \multirow[t]{5}{*}{ Toftlund } & $75-100 \mathrm{~m}$ & 1 (frg.) & $4.5 \mathrm{~mm}$. & $0.86 \mathrm{~mm}$. & about $1 \frac{1 / 2}{1}$ \\
\hline & $100-105$ & 1 & $1.5-$ & 0.74 & $11 / 2$ \\
\hline & $105-110$ & $2-$ & $1.2-$ & $0.86 \quad-$ & $13 / 4$ \\
\hline & & & $4.5=$ & $0.82 \quad-$ & $1 \frac{1}{2}$ \\
\hline & $115-$ & 1 & (corroded & specimen) & \\
\hline
\end{tabular}

Description. There are no discontinuities in the shell surface of the coiled stage which may be interpreted as the delimitation of the protoconch. It is thus natural to assume the entire coiled stage to represent the protoconch.

The adult stage is characterized by the irregular growth lines. The base of the shell is glossy. The inner columellar lip of the aperture is curved. There is a fissure-like umbilicus from which a curved furrow descends along the inner lip.

Distribution.

Recent: Atlantic Ocean from the southern coasts of Britain to Guinea, including the Mediterranean. 
Pliocene: North Sea Basin: England: Coralline Crag, Red Crag. Holland.

Mediterranean Basin: Italy: Piacenziano, Astiano.

Miocene: Aquitanian Basin: Burdigalien, Helvétien.

North Sea Basin: Belgium: Anversien. Germany: Hemmoor stage, Reinbek stage (Gotrsche 1878). Denmark: Arnum formation.

Mediterranean Basin: Italy: Elveziano, Tortoniano. Vienna Basin: Grund and Steinabrunn beds etc.

\title{
FAMILIA XENOPHORIDAE DESHAYES 1864 \\ Genus Xenophora Fischer von Waldheim 1807
}

\section{Xenophora Deshayesi (Michelotti)}

\author{
Plate 34, fig. 115a-b.
}

1847. Phorus Deshayesi Michelotti. Descr. des foss. mioc. de l'Italie septentr. p. 173.

1856. Xenophora Deshayesi Michelotru. Hörnes. D. foss. Moll. d. Tert.-Beckens v. Wien. 1, p. 442 , pl. 44 , fig. 12 .

1896. Xenophora Deshayesi Micheцotтi. Sacco. I moll. terr. terz. d. Piemonte e d. Liguria. 20 , p. 20, pl. 2, fig. 20 .

1916. Xenophora Deshayesi Michelotti. Nørregand. Mell. mioc. Blokke Esbjerg. p. 20.

1918. Xenophora Deshayesi Michelotrt. Cossmann \& Peyrot. Conch. Néogén. d. l'Aquit. p. 261 , pl. 13, fig. 7-8.

1925. Xenophora Deshayesi Michelottr. Kautsky. D. Mioc. v. Hemmoor u. BasbeckOsten. p. 63, pl. 6, fig. 9.

1940. Xenophora Deshayesi Michelotti. Songenfrei. Mar. Nedre-Mioc. i Klintinghoved p. Als, p. 30, pl. 5, fig. 1-2.

1949. Xenophora Deshayesi Michelotti sp. Glibert. Gastr. du Mioc. moy. du bassin d. 1. Loire. 1, p. 207, pl. 12, fig. 20.

1952. Xenophora Deshayesi Michelotti. Glibert. Faune mal. du Mioc. de la Belgique. 2 , p. 67, pl. 5, fig. 3 .

Original diagnosis. Testa conica, corpora varia agglutinante; anfractibus planis, superne rugis laxe cancellata; basi sulcis radiantibus obliquis instructa: umbilico tecto; margine simplici (Мiснецотті 1847 acc. to Sacco).

Shell material.

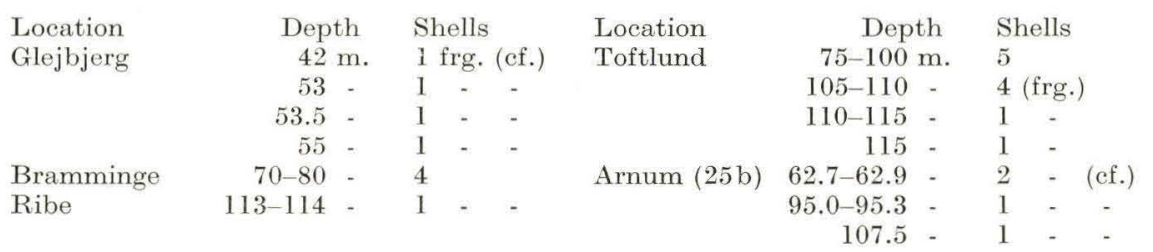

Description. The shell material is rather fragmentary. It is practically lmpossible to make specific determinations of those fragments marked cf. in the above list.

Protoconch very large trochiform, consisting of 4 to $4 \frac{1}{2}$ glossy whorls. The last whorl is subangular at its periphery, where the upper suture of the first adult whorl develops. There is a very delicate obliquely reticulate striation on this part of the protoconch in the shell from Toftlund $110-115 \mathrm{~m}$. The aperture has a wide sinus on the outer lip extending from the suture to the subangular keel 
of the last whorl. Diameter and number of whorls of a few well preserved shells as follows.

$\begin{array}{llcc}\text { Location } & \text { Depth } & \text { Diameter } & \begin{array}{c}\text { Number of } \\ \text { whorls }\end{array} \\ \text { Toftlund } & 75-100 \mathrm{~m} . & 1.29 \mathrm{~mm} . & 4 \\ & & 1.31- & 4 \\ & & 1.41- & 4 \\ & 105-110 & 1.32- & 4 \\ & & 1.68- & 41 / 4\end{array}$

Tele oc on ch. The apical angle is about 80 to $85^{\circ}$. The largest specimen from Toftlund, 75-100 m., has a diameter of about $3.6 \mathrm{~mm}$. and includes 2 adult whorls. The sculpture is not very typical; it is dominated by the shells affixed to the spire. The growth lines on the base of the body whorl may approximate those of X. Grateloupi (Cossmann \& Peyrot Conch. Néogén. d. l'Aquit. 1918, p. 265, pl. 13, fig. 4).

Remarks. The Xenophoridae are very difficult to determine to species. Several of the species are certainly only at the level of varieties, and no great significance should therefore be attached to fossil species of Xenophora before they have been carefully revised with full regard to features of both protoconch and teleoconch.

Distribution.

Pliocene: Mediterranean Basin: Italy: Piacenziano, Astiano. Miocene: Aquitanian Basin: Helvétien.

North Sea Basin: Belgium: Boldérien, Horizon of Houthaelen, Anversien. Germany: Hemmoor stage, Reinbek stage (Gotтsche 1878). Denmark: Klintinghoved clay, Arnum formation.

Mediterranean Basin: Italy: Elveziano.

Vienna Basin: Grund and Steinabrunn beds. etc.

Oligocene: Mediterranean Basin: Italy: Tongriano.

\section{FAMILTA APORRHAIDAE TROSCHEL}

Genus Aporrhais Da Costa 1778

\section{Aporrhais alata (Eichwald)}

Plate 33, fig. 116.

1830. Rostellaria alata EichWALD. Naturh. Skizze etc. p. 225.

1853. Chenopus pes pelecani Phil. Eichwatd. Lethaea Rossica 3, p. 211, pl. 8, fig. 19.

1854. A porrhais alata Eıchw. sp. Beyrich. Die Conchylien ete. p. 176, pl. 11, fig. 7-8.

1856. Chenopus pes pelecani PHIL. Hörnes. D. foss. Moll. d. Tert.-Beckens v. Wien. 1, p. 194, pl. 18, fig. 2-4.

?1893. Chenopus pespelicani var. taurominor et var. dertominor. SAcco. I moll. d. terr. terz. d. Piemonte e d. Liguria. 14, p. 29, pl. 2, fig. 30-31.

1907. Aporrhais alata Eichwald sp. Ravn. Molluskf. Jyll. Tert. p. 304, pl. 3, fig. 25.

1922. Chenopus burdigalensis d'Orbigny. Cossmann \& Peyrot. Conch. Néogén. d. l'Aquit. p. 277 , pl. 8, fig. 11-13.

1925. Chenopus alatus Eichw. Kautsky. D. Mioc. v. Hemmoor u. Basbeck-Osten. p. 86. 1944. A porrhais (Aporrhais) alata (Eichwald). VAN Voorthursen. Mioz. Gastr. a. d. Peelgebiet. p. 40. pl. 4, fig. 6-14 \& 16-20. 
1952. Aporrhais alata Eichwald sp. Glibert. Faune mal. du Mioc. de la Belgique 2, p. 68, pl. 5, fig. 7 .

1956. A porrhais alata Eichwatd. Banke Rasmussen. Upper Mioc. South Jutland. p. 56, pl. 4 , fig. 4 .

Original diagnosis. Testa turrita, transversim striata longitudinaliter costata, anfractu ultimo in marginem latum excurrente, bicarinato, carina utraque tuberculata in processum digitiformem prolongata; tertio processu columellari ad tertium usque anfractum adscendente, spira extrema omnio libera. (EICHWALD 1830).

Shell material.

\begin{tabular}{|c|c|c|c|c|c|}
\hline \multirow{3}{*}{$\begin{array}{l}\text { Location } \\
\text { Glejbjerg }\end{array}$} & Depth & Shells & Location & Depth & Shells \\
\hline & $23 \mathrm{~m}$ & 11 & Gramby & $81.66-82.16 \mathrm{~m}$ & 1 \\
\hline & 25. & 4 & & $82.16-82.66$ & 1 \\
\hline & 32. & 53 & & $82.66-83.76$ - & 148 \\
\hline & $38-$ & 1 & & $84.66-87.16-$ & 62 \\
\hline & 52. & 9 & & $90.42-92.72 \quad-$ & 8 \\
\hline & 53. & 37 & & $92.72-109.29$ & 1 \\
\hline & $53.5-$ & 116 & & $109.29-110.86-$ & 1 \\
\hline & $53.75-$ & 72 & & $110.86-121.51-$ & 2 \\
\hline & $54-$ & 4 & Toftlund & $75-100$ & 1333 \\
\hline & $55-$ & 60 & & $100-105-$ & 334 \\
\hline Bramminge & $70-80=$ & 464 & & $105-110-$ & 528 \\
\hline Ribe & $113-114$ & 3 & & $110-115-$ & 82 \\
\hline & $114-115$ & 1 & & 115 & 136 \\
\hline & $118-119=$ & 1 (cf.) & Arnum (13) & $28-40=$ & 1 \\
\hline & $119-120$ & $1-$ & & $53-83-$ & 44 \\
\hline & $120-121$ & 1 & & $83-94$. & 56 \\
\hline & $121-122$ & 1 & Arnum (25b) & $95.0-95.3=$ & 273 \\
\hline & $123-124$ & 1 & & $104.3-107.5$ & 3 \\
\hline & $124-125$ & 1 & & 107.5 & 1 \\
\hline
\end{tabular}

Description. Very few shells have the outer lip and the protoconch intact. The shells have mostly been broken by the drilling operations. It has accordingly been rather difficult to arrive at an objective decision regarding the number of individual shells in the samples. It is, however, believed that the figures obtained are within an error of $\pm 5 \%$.

Protoconch. The globular protoconch is smooth and rather glossy, it consists of $2 \frac{1}{2}$ to 3 whorls. The nucleus is slightly heterostrophe. There is no sharp discontinuity between the protoconch and the first adult whorl, the spiral striae typical of the initial adult shell emerge imperceptibly. The protoconch diameter was measured in 10 shells from Toftlund $110-115 \mathrm{~m}$. The readings were: minimum $0.78 \mathrm{~mm}$; mean: $0.84 \mathrm{~mm}$; and maximum $0.94 \mathrm{~mm}$. The species has thus a rather large protoconch.

Teleoconch. It is rather difficult to give a concise account of this very variable shell due to the badly broken material. However, referring to the types outlined by VAN VoorthuYsen, it should be stated that his types 2,3 and 5 are approximated in some specimens. The ornament starts with spiral striae on the first adult whorl; which are then crossed by curved collabral striae on about the second whorl. The collabral striae develop downwards into ribs and knots as described by VAN VooRTHUYSEN.

The outer lip is more or less distinctly digitate, and has generally two processes. In the material from Toftlund $115 \mathrm{~m}$. there is a specimen with a regenerated outer lip which has three digitations corresponding to the three spirals ribs. this feature has also been noticed on another lip fragment in the same sample. 
The digitation is attached to the spire in a rather variable manner. The attachement extends only to the preceding whorl in some shells, while it almost reaches the top of the spire in other specimens. The uppermost tip is withdrawn from the spire in a few individuals.

Remarks. It has not yet been possible for the writer to estimate the objective value of VAN VOORTHUYSENS types. The types are not very sharply defined. Percentages indicating their abundance in the shell materials may accordingly be somewhat misleading. The types may nevertheless serve the purpose of classifying this species, which is very cumbersome from the taxonomic viewpoint until a better classification can be suggested.

Distribution.

Miocene: Aquitanian Basin: Burdigalien, Helvétien.

North Sea Basin: Belgium: Boldérien, Horizon of Houthaelen, Anversien. Holland (m.).Germany: Hemmoor stage. Reinbek stage (Gotтsche 1878), Glimmerton (Banke Rasmussen 1956). Denmark: Arnum and Gram formations.

Mediterranean Basin: ? Elveziano, ? Tortoniano. Vienna Basin: Grund sands, Baden clays, Gainfahren beds. etc.

\section{FAMILIA NATICIDAE FORBES 1838}

The scarcity of distinctive sculptural shell features in this family makes the subdivision of fossil shell material troublesome. Living animals referred to the Naticidae are generally determined to species on the basis of features of the soft parts, the shell, and the operculum. The paleontologist is almost always required to use the shell features alone. The operculum is very seldom found in situ and is, therefore, practically useless as a systematic aid in this connection. Dealing with fossil Naticae, one feels the need of a detailed correlation of specific features in the soft parts, the shell and the operculum in living species. Such a correlation has not yet been made to the writer's knowledge, and we are accordingly faced with the probability that several fossil species are not of the same specific value as the living species.

The shell material treated here includes different types of Naticidae. Many of the shells are badly broken, and others which are not very typical have not been referred to species. All Naticidae counted for the statistical lists at the end of the paper have therefore been included in one group because of the great number of indeterminable shells. The specimens listed under the following species are the best preserved shells or fragments with significant shell features.

All species are accompanied by illustrations of typical shells. The description of the individual species is, therefore, restricted to a minimum, emphasis being laid upon significant features and pronounced morphologic differences.

It is generally impossible to discriminate between Polynices and Natica in fossil species due to the fact that the separating character according to THIELE and others is the nature of the operculum. In the present case Polynices has, therefore, been included in Natica as a subgenus following Cossmann (Essais de Paléoconchologie comparée 13, p. 125). Subgenus names have been added 
in the species names since it seemed justifiable to distinguish between supraspecific morphologic types within Natica. This decission does not mean that the writer has confidence in the taxonomic significance of the subgenera concerned.

\section{Genus Natica Adanson 1757 \\ Subgenus Lunatia GRAY 1847 \\ (Umbilicus without funiculus)}

\section{Natica (Lunatia) catena (Da Costa)}

Recent:

Plate 34, fig. 117 a-b.

1778. Cochlea catena Da Costa. Hist. Nat. Testacearum Britanniae p. 83, pl. 5, fig. 7.

1853. Natica monilifera Lamarck. Forbes \& Hanley. Brit. Moll. 3, p. 326. pl. 100, fig. 1.

1867. Natica catena Da Costa. Jeffreys. Brit. Conch. 4, p. 220, 5, pl. 78, fig. 4.

1868. Natica helicina Brocchi. Weinkauff. Conch. d. Mittelmeeres 2, p. 249.

1883. Natica catena Da Costa. Bucquoy, Dautzenberg \& Dollfus. Moll. mar. du Roussillon 1. p. 146, pl. 17, fig. 5-6.

1888. Natica catena Da Costa. Petersen. De skalb. Moll. ete. p. 100.

1931. Natica (Lunatia) catena DA Costa. Plymouth Mar. Fauna p. 258.

1932. Natica catena Da Costa. Nobre. Moluseos mar. de Portugal p. 175, pl. 20, fig. 9-10.

Fossil:

1848. Natica catena DA Costa. Woon. Monogr. Crag Moll. 1, p. 142, pl. 16, fig. 8.

1891. Natica catena var. prohelicina SACCO. I moll. d. terr. terz. d. Piemonte e d. Liguria, 8, p. 291 , pl. 2 , fig. 38 .

1891. Natica catena var. helicina (BRocch.). Ibid. p. 294, pl. 2, fig. 43.

1907. Natica helicina Brocchi. Ravn. Molluskf. Jyll. Tert. p. 294, pl. 3, fig. 11.

1914. Natica helicina Brocсні. Gripp. Über eine u. mioz. Moll. f. v. Itzehoe. p. 11.

1916. Natica helicina Brocchi. NørregaArd. Mellem-mioc. Blokke Esbjerg. p. 22.

(?)1918. Natica (Lunatia) helicina (Brocchi). Cossmann \& Peyrot. Conch. Néogén. d. l'Aquit. p. 228, pl. 11, fig. 39-41, pl. 12, fig. $29 \& 54$.

1919. Natica (Lunatia) catena (DA Costa). Harmer. Plioc. Moll. 2, p. 681, pl. 54, fig. 1-3. 1925. Natica (Naticina) catena DA Costa var. mioaperta \& var. depressa. Kautsky. D. Mioc. v. Hemmoor u. Basbeck-Osten. p. 68, pl. 6, fig. 19-20.

1940. Natica (Lunatia) helicina Brocchi. Sorgenfrer. Mar. Nedre-Mioc. i Klintinghoved p. Als, p. 32 , pl. 5 , fig. 5 .

1952. Polynices (Lunatia) catena $f$. helicina Brocchi sp. Glibert. Faune mal. du Mioc. de la Belgique. 2, p. 69, pl. 5, fig. 8.

1956. Polynices (Lunatia) helicina (Brocchi). Banke Rasmussen. Upper Mioc. South Jutland, p. 58, pl. 4, fig. 6.

Original diagnosis. Cochlea umbiticata albo rufescens fasciis maculatis, maxime ad imos orbes distincta. (DA Costa 1778).

Shell material.

$\begin{array}{lrrlrr}\text { Location } & \text { Depth } & \text { Shells } & \text { Location } & \text { Depth } & \text { Shells } \\ \text { Glejbjerg } & 32 \mathrm{~m} . & 12 & \text { Toftlund } & 75-100 \mathrm{~m} . & 40 \\ & 53- & 3 & & 100-105- & 13 \\ & 53.5- & 41 & & 105-110- & 5 \\ & 53.75- & 1 & & 110-115- & 113 \\ \text { Bramminge } & 55- & 9 & & 115- & 11 \\ \text { Gramby } & 82.66-83.76- & 24 & \text { Arnum }(13) & 53-83- & 28 \\ & 84.66-87.16- & 3 & \text { Arnum }(25 \mathrm{~b}) & 104.3-107.5- & 8 \\ & & & & 107.5- & 7\end{array}$

Description. The shell material consists mainly of small shells. 
Protoconch. It is difficult to distinguish between the protoconch and the teleoconch in most shells. A few shells display different lustre and colour on about the two first whorls. The diameter of this part of the shell, which may be identical with the protoconch, is from about $0.60 \mathrm{~mm}$. to about $0.80 \mathrm{~mm}$.

Teleoconch. The shape of the spire varies somewhat with respect to the apical angle. Depressed and elongated types occur among the shells. Spiral striae are found on the surface in the umbilicus in some shells. Very weak, irregular spiral striae have occasionally been observed with the microscope also outside the umbilicus.

Remarks. It is not deemed advisable to retain $N$. helicina as a distinct species. The original illustration by BRocchI shows a shell which may well be referred to $N$. catena (Brocchr 1814, 2. p. 297, pl. 1, fig. 10) and also the other shells eited in the synonymy show close morphologic relationships with the recent representative. Unless yet unknown obvious differences can be demonstrated it is therefore suggested to include $N$. helicina in the synonymy of N. catena.

Distribution.

Recent: North Atlantic Ocean from Southern Scandinavia (Bohuslän) to Gibraltar, and the Mediterranean.

Pliocene: North Sea Basin: England: Red Crag.

Mediterranean Basin:Italy: Piacenziano and probably Astiano.

Miocene: Aquitanian Basin: (?) Burdigalien, (?) Helvétien, (?) Tortonien.

North Sea Basin: Belgium: Anversien. Germany: Vierlande and Hemmoor stages, Reinbek stage (GotTSCHE 1878), Glimmerton. Denmark: Klintinghoved clay, Arnum and Gram formations.

Mediteranean Basin: Italy: Elveziano, Tortoniano.

Oligocene: Mediterranean Basin: Italy: Tongriano.

Subgenus Naticina GuILDING 1834

(Umbilicus with funiculus)

\section{Natica (Naticina) hanseata Kautsky}

Plate 34, fig. 118a-b.

1925. Natica hanseata Kautsky. D. Mioc. v. Hemmoor u. Basbeck-Osten. p. 66, pl. 6, fig. 14-15.

Essential features of original description. Stark eingesenkte Nähte. Der innere Mundrand ist gerade und legt sich hinten etwas verdickt auf den Umgang. Der Nabel ist verhältnismässig klein. Ganz vorn im Nabel von dem sich einsenkenden Umgang nur durch eine schmale Furche getrennt, verläuft ein sehr hoher und breiter gegen vorn und hinten scharf abgegrenzter Nabelpflock. (KAUTSKY 1925). 
Shell material.

$\begin{array}{lrrlrc}\text { Location } & \text { Depth } & \text { Shells } & \text { Location } & \text { Depth } & \text { Shells } \\ \text { Glejbjerg } & 32 \mathrm{~m} . & 2 & \text { Toftlund } & 100-105 \mathrm{~m} . & 2 \\ \text { Bramminge } & 70-80- & 9 & & 105-110- & 4 \\ \text { Gramby } & 82.66-83.76- & 7 & & 110-115- & 2 \\ & 84.66-87.16- & 4 & & 115- & 2 \\ \text { Toftlund } & 75-100- & 19 & \text { Arnum (13) } & 53-83- & 13\end{array}$

Description. The shell material is more or less fragmentary.

Protoconch. About the first 2 $\frac{1 / 2}{2}$ to $23 / 4$ whorls differ from the succeeding whorls by having a smooth surface devoid of growth lines, and also generally in colour. The diameter and number of whorls in 6 shells from Toftlund 75-100 m. were:

$$
\begin{array}{lcccccl}
\text { Diameter: } & 1.11 & 1.10 & 1.13 & 1.17 & 1.10 & 1.11 \mathrm{~mm} . \\
\text { Number of whorls: } & 23 / 4 & 23 / 4 & 21 / 2 & 21 / 2 & 2 \frac{1}{2} & 2 / 3
\end{array}
$$

This part of the shell is probably identical with the protoconch which accordingly is rather large.

Teleoconch. A typical shell feature is the almost vertical lower part of the inner lip which looks like a column carying the shell globe. Remnants of original colour bands conforming with the growth lines are occasionally found. The largest shell from Toftlund $115 \mathrm{~m}$. measures: Height $7.1 \mathrm{~mm}$. ; diameter $7.3 \mathrm{~mm}$. (21/3 adult whorls).

Remarks. The features described by Kautsky have practically all been observed in the shells. $N$. hanseata is one of the most characteristic species among the Naticidae found in South Jutland.

Distribution.

Miocene: North Sea Basin: Germany: Hemmoor stage. Belgium: ? Boldérien (Glibert 1952, p. 77). Denmark: Arnum formation.

\section{Natica (Naticina) Beyrichi von Koenen}

Plate 35, fig. 119 a-c.

1882. Natica Beyrichi von Koenen. D. Nordd. Mioc. u. s. Moll. f. p. 223, pl. 5, fig. 1-3. 1891. Natica epiglottina var. exfuniculata SAcco. I moll. d. terr. terz. d. Piemonte e d. Liguria 8, p. 284, pl. 2, fig. 28.

1919. Natica Beyrichi von Koenen \& var. Goodmani Harmer. Plioc. Moll. 2, p. 680, pl. 56, fig. $12,13,18$.

1925. Natica Beyrichi von Koenen. Kautsky. D. Mioc. v. Hemmoor u. Basbeck-Osten. p. 68 , pl. 6, fig. 17 (?).

1952. Natica (Natica) beyrichi von Koenen. Glibert. Faune mal. du Mioc. de la Belgique. 2 , p. 75 , pl. 6 , fig. 3 .

Diagnosis. Von Koenen has not given any diagnosis or concise description of the species. One is accordingly forced to use only his illustration as a reference until the holotype has been described.

Shell material.

$\begin{array}{lrl}\text { Location } & \text { Depth } & \text { Shells } \\ \text { Bramminge } & 70-80 \mathrm{~m} . & 5 \text { (cf.) } \\ \text { Toftlund } & 75-100- & 5 \\ & 115- & 5\end{array}$


Description. The shells are relatively well preserved, but the protoconch area is corroded in most specimens.

Protoconch difficult to delimit. In two shells Toftlund $75-100 \mathrm{~m}$. the two initial whorls, approximately differ from the others by the absence of recognizable growth lines, and by their colour. This part of the shell has been interpreted as the protoconch. The diameter and corresponding number of whorls were:

$$
\begin{array}{lcl}
\text { Diameter } & 0.92 \mathrm{~mm} . & 1.10 \mathrm{~mm} . \\
\text { Number of whorls } & 2 & 21 / 2
\end{array}
$$

Teleoconch with more or less pointed to flat spire. The umbilicus varies from wide to narrow. Funiculus situated adjacent to the wall of the preceding whorl, it is obsolete in some shells. Faint indications of irregular spiral striae in the shell surface.

Remarks. The situation of the funiculus is obviously the most characteristic feature.

If one compares KaUtsky's illustrations of Natica Beyrichi with von Koenen's figure of the species it looks, as if KaUTSKr has erroneously figured a shell of N.Hörnesi as N. Beyrichi and a shell of N. Beyrichi as N. Hörnesi. This assumption is supported by comparison with Fischer \& Tournouer's illustration of N. Hörnesi (Fischer \& Tournouer 1873, p. 133, pl. 18, fig. 20).

The shell plate 35, fig. $119 a$ in the present paper is of the type defined as var. Goodmani by Harmer. The writer has not deemed it advisable to give this variety the rank of a species.

N. plicatelloides Cossmann \& Peyrot (1918, p. 201, pl. 11, fig. 22-25) is apparently closely related to if not identical with $N$. Beyrichi, This is evidenced by the situation of the funiculus, the shape of the shell, and the indication of spiral striae.

Distribution.

Pliocene: Atlantic Basin: England (St. Earth Cornwall).

Mediterranean Basin: Italy: Piacenziano.

Miocene: North Sea Basin: Belgium: Boldérien, Horizon of Houthaelen, Anversien. Germany: Hemmoor stage. Denmark: Arnum formation.

\section{Natica (Naticina) protostriata nov. sp.}

Plate 36, fig. 120 a-b.

Diagnosis. Naticina with a protoconch including $1 \frac{1}{2}$ to 2 smooth, initial whorls succeeded by about 1 whorl with a sculpture of spiral striae. Whorls of the teleoconch commonly with collabral folds conformable with the growth lines at the upper suture. The funiculus occupies a major part of the umbilicus.

Holotype: Geological Survey of Denmark. File no. 150.9. b. Toftlund 75-100 m. (Plate 36, fig. 120). Derivatio nominis : protostriata -initially striated.

Shell material.

$\begin{array}{lrrlrr}\text { Location } & \text { Depth } & \text { Shells } & \text { Location } & \text { Depth } & \text { Shells } \\ \text { Glejbjerg } & 23 \mathrm{~m} . & 1 & \text { Toftlund } & 75-100 \mathrm{~m} . & 13 \\ \text { Gramby } & 82.66-83.76- & 4 & & 100-105- & 5 \\ & 84.66-87.16- & 1 & \text { Arnum } & 53-83- & 12 \\ & 90.42-92.72- & 1 & & & \end{array}$


Description.

Protoconch. To the diagnosis may be added that the suture is of intermediate depth and that there is a slight indication of heterostrophism. The protoconch diameter could be measured in four shells the data of which are:

N. protostriata nov. $s p$, data on the Protoconch.

\begin{tabular}{lcccc} 
& & Protoconch & \multicolumn{2}{c}{ Number of : } \\
Location & Depth & Diameter & smooth and: striated whorls \\
Toftlund & $75-100 \mathrm{~m}$. & $1.04 \mathrm{~mm}$. & $11 / 2$ & 1 \\
& $100-105-$ & $0.98-$ & $1 \frac{1}{2}$ & 1 \\
Arnum (13) & $53-83-$ & $0.95-$ & $1 \frac{1}{2}$ & $11 / 4$ \\
& & $0.79-$ & $1 \frac{1}{2}$ & 1
\end{tabular}

Teleoconch. The beginning of the teleoconch is emphasized by the emergence of distinct growth lines and collabral folds at the suture. The apical angle varies and may at most be about $130^{\circ}$. The shell exhibits otherwise the general naticoid shape. The centrally situated funiculus is separated from the umbilical wall by a narrow lunate opening. Other particulars may be studied on the accompanying illustrations.

Remarks. The spiral striation on the protoconch was a very surprising discovery since the first observation was made in 1944, at a time when such striation had never before been recorded in species of the genus Natica. Two years later THoRson published his observations on a similar, but not identical, sculpture in the recent $N$. nitida (Thorson 1946, p. 217). Spiral striation is accordingly a feature which occasionally occurs in Naticidae.

It is of interest in the present species to note the dimorphism in the protoconch whorls. The biological significance of the two parts of the protoconch is as yet quite unknown. It is, however, natural to assume some correlation with stages in larval development. One might suggest that the first smooth part of the shell could correspond to the stage in the egg-mass while the striated shell might indicate a pelagic veliger stage (see Thorson 1946). It is hoped that the study of recent shells of the family will explain this phenomenon.

Attention should finally be drawn to the amazing parallelism in shell morphology between the protoconch of $N$. protostriata and the entire shell of species of Sigaretus, since the latter starts with a smooth protoconch and continues with a spirally striated teleoconch.

Distribution.

Miocene: North Sea Basin: Denmark: Arnum formation.

\section{Natica (Naticina) praeclausa Kautsky}

Plate 35, fig. 121 a-c.

1925. Natica (Tectonataca) praeclausa KAUtSky. D. Mioc. v. Hemmoor u. Basbeck-Osten. p. 70 , pl. 6 , fig. 21 .

Essential features of original description. Gewinde sehr flach und niedrig. Der hintere Abschnitt der Umgänge fällt sehr schwach konkav gegen die Naht ein. An der Naht erheben sich die Zuwachsstreifen zu schmalen kleinen Fältchen. Der Nabel ist zum grössten Teil durch die stark verdickte Innenlippe bedeckt, so dass nur ein schmaler sichelartig gekrümmier Spalt offen bleibt. (KAUTSKY 1925). 
Shell material.

\begin{tabular}{|c|c|c|c|c|c|}
\hline Location & Depth & Shells & Location & Depth & Shells \\
\hline Bramminge & $70-80 \mathrm{~m}$. & 11 & Toftlund & $75-100 \mathrm{~m}$. & 13 \\
\hline \multirow[t]{3}{*}{ Gramby } & $82.66-83.75$ - & 10 & & $100-105=$ & 7 (cf.) \\
\hline & $84.66-87.16$ - & 2 & Arnum (13) & $53-83$ & 3 \\
\hline & & & Arnum (25b) & $95.0-95.3-$ & 1 \\
\hline
\end{tabular}

Description.

Protoconch smooth and glossy with about $2 \frac{1}{2}$ whorls. Suture relatively deep.

Teleoconch. Globular with very low spire. Collabral folds conform with the growth lines at upper suture. Umbilicus partly filled by the central funiculus leaving only narrow lunate opening.

Remarks. This shell is so similar to $N$. protostriata, that it is impossible with certainty to determine specimens in which the protoconch is worn. The spire seems generally to be somewhat lower, and the suture to be deeper in this species than in $N$. protostriata but these differences are too slight to be easily recognized.

It could be objected that the conspicuous similarity of the two species might amount to identity, since the absence of spiral striation on the protoconch could be simply matter of wear. This has been considered, but the presence of shells with extremely well preserved smooth and glossy protoconch whorls excludes the possibility.

Distribution.

Miocene: North Sea Basin: Germany: Hemmoor stage. Denmark: Arnum formation.

\section{Natica (Naticina) tectula Bonelli}

Plate 38, fig. 122 a-c.

$\left.1829^{*}\right)$. Natica tectula Bonellr. Cat. m. s. Museo zool. Torino, n. 3480.

1891. Tectonatica tectula (Bon.) SAcco. I moll. d. terr. terz. d. Piemonte e d. Liguria 8, p. 305 , pl. 2 , fig. 53 .

1918. Natica (Tectonatica) tectula Bonelli mut. bearnensis Cossmann \& Peyrot. Conch. Néogén. d. 1'Aquit. p. 212, pl. 11, fig. 43-44.

Diagnosis. The original paper is not available. Since the shell illustrated by SACCO may be considered as the holotype according to Cossmann \& Peyrot, SACCO's diagnosis should be cited: Testa parva, subconica; spira sat elata, acuta. Anfractus quinque convexi, ad suturam laeviter depressi; ultimus permagnus, fortiter convexus. Superficies albula vel grisea. A pertura semilunata. Labium externum simplex, gracile, valde arcuatum. Labium columellare obliquum, perexpansum. Umbilicus callo columellari expanso, semilunato, fere omnino tectus (SACCo 1891).

Shell material.

$\begin{array}{lrrlrc}\text { Location } & \text { Depth } & \text { Shells } & \text { Location } & \text { Depth } & \text { Shells } \\ \text { Bramminge } & 70-80 \mathrm{~m} & 13 & \text { Toftlund } & 105-110 \mathrm{~m} . & 2 \\ \text { Gramby } & 82.66-83.75- & 4 & & 115- & 8 \text { (cf.) } \\ \text { Toftlund } & 75-100- & 18 & \text { Arnum (13) } & 53-83- & 6\end{array}$

*) Not available. 
Description. The shell material consists mainly of rahter small shells several of which, however, are excellently preserved.

Protoconch rather large. In a number of specimens it is possible to see an initial shell consisting of the nucleus and about one whorl, which almost looks like a diminutive boxing glove. The surface of this part of the shell is possibly sculpturred with faint dots. This can not be stated with certainty, since the observed structure in the shell might be of secondary origin. The initial shell terminates in an apertural margin.

The succeeding part of the protoconch consists of about $1^{1 /} / 3$ to $1^{1 / 2}$ relatively convex, smooth and glossy whorls with a deep suture.

Five shells from Toftlund 100-105 m. had the final whorls of the protoconch complete, and the number of whorls exclusive of the initial shell were as follows:

$\begin{array}{lccccc}\text { Diameter } & 1.23 & 1.11 & 1.17 & 1.11 & 1.12 \mathrm{~mm} . \\ \text { Number of whorls } & 1^{1 / 2} & 1^{1 / 3} & 1^{1 / 2} & 1^{1 / 3} & 1^{1 / 2}\end{array}$

Teleoconch. Spire very much depressed; shape of the shell globularoviform. The last whorl covers the bulk of the spire. Differing from the protoconch, the suture of the teleoconch is very little indented, and the curvature of the shell outline is hardly discontinued at the suture. Aperture semilunular with an almost straight inner lip. Angle between the outer lip and the inner lip at the suture very small. Umbilicus open, but for a large part occupied by the funiculus which continues in a callosity extending onto the preceding whorl.

The shell is almost as wide as high. Dimensions of the largest shell from Toftlund $75-100 \mathrm{~m}$.: diameter $=$ height $=$ about $5.3 \mathrm{~mm}$.

Remarks. The determination is made with some hesitation due to the small size of the shells described, the poor illustrations in some of the literature concerned, and the absence of detailed descriptions of the protoconch in earlier papers.

Distribution.

Pliocene: Mediterranean Basin: Italy: Piacenziano, Astiano.

Miocene: Aquitanian Basin: Helvétien.

Mediterranean Basin: (?) Elveziano, Tortoniano.

North Sea Basin: Denmark: Arnum formation.

\section{Natica (Naticina) miopusilla Kautsky}

Plate 37, fig. 123 a-c.

1925. Natica (Tectonatica) miopusilla KаUтsкy. D. Mioe. v. Hemmoor u. Basbeck-Osten. p. 70 , pl. 6 , fig. 22 .

Essential features of original description: Die Umgänge des sehr niedrigen Gewindes sind flach konvex und durch etwas eingesenkte Nähte getrennt. Durch das niedrige Gewinde und den stark gleichmässig konvexen letzten Umgang erhält die Schale einen fast kugeligen Umriss. Die Innenlippe ist gerade verdickt und legt sich mehr oder weniger weit über den mässig breiten Nabel. (KAUTSKY 1925). 
Shell material.

\begin{tabular}{|c|c|}
\hline Location & Dep \\
\hline \multirow[t]{5}{*}{ Glejbjerg } & 23 \\
\hline & 25 \\
\hline & 32 \\
\hline & 53.5 \\
\hline & 53.75 \\
\hline Bramminge & $70-80$ \\
\hline \multirow[t]{2}{*}{ Gramby } & $82.66-83.75$ \\
\hline & $84.66-87.16$ \\
\hline
\end{tabular}

Shells
4
2
3
4
1
30
5
1

Location
Toftlund

$\begin{array}{rc}\text { Depth } & \text { Shells } \\ 75-100 \mathrm{~m} . & 73 \\ 100-105- & 5 \\ 105-110- & 12 \\ 110-115- & 9 \\ 115- & 28 \\ 53-83- & 4 \\ 4.3-107.5- & 8 \mathrm{cf} .\end{array}$

Description.

Protoconch difficult to delimit from the adult shell. It consists of about 2 smooth and glossy convex whorls with deep suture.

The diameter of the exposed spire of the protoconch in four specimens from Toftlund $(75-100 \mathrm{~m}$.) which all had 2 protoconch whorls were: $0.87 ; 0.79$; 0.79 ; and $0.95 \mathrm{~mm}$. The last measurement is the best approximation to the real diameter of the entire protoconch shell since the last protoconch whorl is exposed in the specimen concerned.

Teleoconch. The shell has a globular outline, which is a very typical feature. The spire is very low and the whorls have generally a tendency to form a shoulder at the upper suture. The umbilicus is more or less open depending on the size of the funiculus, which is situated adjacent to the wall of the preceding whorl. There is a shallow furrow on the inner lip indicating the upper delimitation of the funiculus in some shells. The funiculus is very slightly convex.

Remarks. The globular outline of the shell is excellently illustrated in KaUtSkY's paper. The species is obviously very characteristic and easily recognizable.

Distribution.

Miocene: North Sea Basin: Germany: Hemmoor stage. Denmark: Arnum formation.

\title{
124. Natica (Naticina) submamillaris d'Orbigny
}

\author{
Plate 36, fig. 124 a-c.
}

1852. Natica submamillaris D'Orbigny. Prodr. d. Paleont. p. 38, no. 566.

1891. Polinices submamillaris (D'ORB.) SAcco. I moll. d. terr. terz. d. Piemonte e d. Liguria 8, p. 314, pl. 2, fig. 62. var. mioclausa. SAcco. Ibid. p. 315, pl. 2, fig. 66.

1907. Natica Josephinia Risso sp. Ravn. Molluskf. Jyll. Tert. p. 291, pl. 3, fig. 7.

1916. Natica Josephinia Risso sp. NørregaArd. Mellemmioc. Bl. Esbjerg. p. 22.

1925. Natica (Polinices) submamillaris D'Orb. KAUtSky. D. Mioc. v. Hemmoor u. BasbeckOsten. p. 71, pl. 6, fig. 24-25.

1940. Natica (Polinices) submamillaris D'Orbigny. Sorgenfrei. Mar. Nedre-Mioc. i Klintinghoved p. Als. p. 33.

1956. Polynices (Polynices) submamillaris (D'Orbigny). Banke Rasmussen. Upper Mioc. South Jutland, p. 60, pl. 5, fig. 1 .

Diagnosis. D'Orbigny's publication of the species was not accompanied by any diagnosis or illustration. Since SACCO was obviously the first to formulate a diagnosis and give an illustration of the species his diagnosis is cited: Testa parva, oblongo-ovata; spira sat elata, subconica. Anfractus quatuor-quinque, convexi, ultimus permagnus, ad suturam depressus. A pertura subovato-faseoli- 
formis. Labium externum simplex, arcuatum. Umbiticus latus, maxima in parte detectus; funiculus umbilicalis depressus vel suboblitus. (SACCO 1892).

Shell material.

$\begin{array}{lrc}\text { Location } & \text { Depth } & \text { Shells } \\ \text { Glejbjerg } & 53.75 \mathrm{~m} . & 2 \\ \text { Toftlund } & 75-100- & 2 \\ & 100-105- & 1\end{array}$

Description.

Protoconch. $2 \frac{1}{2}$ smooth and glossy whorls. Diameter of the exposed part of the protoconch in the two shells from Toftlund $75-100 \mathrm{~m} .: 0.82$ and $0.79 \mathrm{~mm}$. respectively. Relatively deep suture.

Teleoconch. Spire depressed, shape globular, suture shallow. Umbilicus open. Inner lip thickened at the junction with the preceding whorl. This thickening is undoubtedly homologous with the funiculus, and it may be interpreted as an obliterated or extremely flat funiculus.

Remarks. The species has been referred to the subgenus Naticina since the labial thickening is interpreted as a funiculus.

P. submamillaris $f$. dertomamilla as described by GLIBERT (1952, p. 73, pl. 5, fig. 12) has not been included in the synonymy, since it has a much stronger callosity on the inner lip than the shells cited from the other papers.

Distribution.

Miocene: North Sea Basin: Germany: Hemmoor stage, Glimmerton (Banke Rasmussen 1956). Denmark: Klintinghoved clay, Arnum and Gram formations.

Mediterranean Basin: Elveziano, Tortoniano.

Subgenus Polynices Montfort 1810

(Umbilicus filled up with funiculus and callosity)

\section{Natica (Polynices) affinis (Gmelin)}

Plate 38, fig. 125 a-c.

Recent:

1790. Nerita affinis GMeLin. Linne. Syst. Nat. Ed. Tred., p. 3675.

1869. Natica affinis Jefrereys. Brit. Conch. 5, p. 215, pl. 102, fig. 3.

1878. Natica affinis Gmel. SArs. Moll. Reg. Arct. Norvegiae. p. 160, pl. 21, fig. 14.

Fossil :

1918. Natica angyglossa Cossmann \& Peyrot. Conch. Néogén. d. 1'Aquit.p. 205, pro parte, pl. 11, fig. 51-52.

1921. Natica affinis (Gmelin). Harmer. Plioc. Moll. 2, p. 674, pl. 56, fig. 6-7.

Original diagnosis. Testa globoso-subacuta crassiore: spira submucronata; anfractibus tribus (GMELIN 1790). 
Shell material.

$\begin{array}{lrrlrc}\text { Location } & \text { Depth } & \text { Shells } & \text { Location } & \text { Depth } & \text { Shells } \\ \text { Glejbjerg } & 53 \mathrm{~m} . & 1 & \text { Toftlund } & 105-110 \mathrm{~m} . & 1 \\ \text { Bramminge } & 70-80- & 13 & \text { Arnum }(13) & 53-83- & 2 \\ \text { Gramby } & 84.66-87.16- & 2 & & 83-94- & 2 \\ \text { Toftlund } & 75-100- & 29 & \text { Arnum }(25 \mathrm{~b}) & 107.5- & 1\end{array}$

Description.

Protoconch of 2 to $2 \frac{1}{2}$ smooth and glossy whorls with deep suture, very depressed. Exposed part of protoconch about 0.7 to $1.0 \mathrm{~mm}$.

Teleoconch globular, spire very low, suture smooth, almost devoid of relief. Height of the body whorl about nine tenth of total height. Aperture semi-lunular. Umbilicus closed by funiculus which is also semi-lunular.

Remarks. These shells belong unquestionably to a distinct taxonomic group different from the previous species. They approximate rather closely to $N$. tectula, which, however, has a partly open umbilicus. From the view point of shell morphology the shells here referred to $N$. affinis are intermediate between $N$. tectula and $N$. Josephinia particularly with respect to umbilical features. $N$. Josephinia is much lower in relation to shell diameter than $N$. affinis, and the callosity is generally much thicker and almost circular.

The determination of the shell material to $N$. affinis was made with some hesitation, since it is very likely that the recent and fossil species are not quite identical. The morphologic agreement is, however, very striking, and since no objective arguments could be mobilized against the reference to $N$. affinis this reference became the final decision.

Regarding the definition of the recent species reference is made to SARS (1878) and HARMER (1921).

\section{Distribution.}

Recent: North Atlantic Ocean: West coast of Norway from the Lofoten Islands and southwards to and including the Mediterranean. Possibly also West Atlantic (Massachusetts).

Pliocene: North Sea Basin: England: Red Crag.

Miocene: Aquitanian Basin: ? Burdigalien.

North Sea Basin: Denmark: Arnum formation.

Subgenus Neverita RIsso 1826

(Spire very low, umbilicus almost filled up with funiculus and callosity).

\section{Natica (Neverita) Josephinia (Risso)}

Recent:

Plate 39, fig. 126 a-c.

1826. Neverita Josephinia Risso. Hist. Nat. L'Europe Méridionale. 4, p. 149, pl. 4, fig. 43. 1868. Natica Josephinia Risso. Weinkauff. Conch. d. Mittelmeeres. 2. p. 256.

1883. Natica Josephinia Risso sp. Bucquoy, Dautzenberg \& Dollfus. Moll. mar. du Roussillon. p. 151, pl. 18, fig. 1-6.

Fossil:

1856. Natica Josephinia Risso. Hörnes. D. foss. Moll. d. Tert.-Beckens v. Wien. 1, p. 523, pl. 47 , fig. $4-5$. 
1891. Neverita Josephinia Risso. et var. clausodepressa. SAcco. I moll. d. terr. terz. d. Piemonte e d. Liguria. 8, p. 307-310. pl. 2, fig. 54 \& 57.

1918. Natica (Neverita) olla Marcel de Serres. Cossmann \& Peyrot. Conch. Néogén. d. l'Aquit. p. 215, pl. 12, fig. 5-7 pars.

1925. Natica (Neverita) Josephinia Risso. Kautsky. D. Mioc. v. Hemmoor u. BasbeckOsten. p. 71, pl. 6, fig. 23 .

Original diagnosis. Testa glaberrima, lucida, polita, nitente; epidermide pallide carnea; anfractubus superioribus et basilari superne pallidis; operculum linea argentea circumdatum. (RIsso 1826).

Shell material.

$\begin{array}{lrllrc}\text { Location } & \text { Depth } & \text { Shells } & \text { Location } & \text { Depth } & \text { Shells } \\ \text { Glejbjerg } & 48 \mathrm{~m} . & 1 \text { (ef.) } & \text { Toftlund } & 75-100 \mathrm{~m} . & 6 \\ & 53- & 3 & \text { Arnum }(13) & 28-40- & 1 \\ & 53.5- & 2 & & 53-83- & 1\end{array}$

Description.

Protoconch very depressed consisting of about 2 to $2 \frac{1}{2}$ smooth and glossy whorls with relatively deep suture. Diameter of exposed part of protoconch about 0.7 to $1.0 \mathrm{~mm}$.

Teleoconch. Spire depressed, wide; very oblique aperture. The thick callosity of the funiculus which fills the umbilicus in most shells is a very typical feature.

Remarks. This species is very characteristic and may hardly be mistaken. The differences from $N$. affinis have been mentioned above.

N. olla as described by Cossmann \& Peyrot (l. c.) and Glibert (1952 a-b) is very similar to $N$. Josephinia. The main difference is the more elevated spire in $N$. olla. It is possible that this difference is not as significant as claimed by previous authors. An analysis of morphologic variation of the recent species would throw light on this point.

\section{Distribution.}

Recent: Mediterranean.

Pliocene: Mediterranean Basin: Italy: Piacenziano, Astiano. Miocene: Aquitanian Basin: Burdigalien.

North Sea Basin: Germany: Hemmoor stage. Denmark: Arnum formation

Mediterranean Basin: Italy: Elveziano, Tortoniano. Vienna Basin: Grund, Vöslau, etc.

Oligocene: Mediterranean Basin: Italy: Tongriano.

\section{Natica sp.}

Plate 37, fig. 127.

A fragment of a naticoid shell from Toftlund $115 \mathrm{~m}$. should be mentioned on account of its peculiar protoconch.

The protoconch consists of an initial whorl which is slightly, but distinctly heterostrophe; it terminates with a growth line. The initial whorl is sculptured with microscopic granules. The protoconch includes at least one more whorl, on which the granules tend to be arranged in spiral rows which, however, are rather irregular. Diameter of the exposed part of the protoconch about $0.60 \mathrm{~mm}$. 
The small preserved part of the teleoconch displays growth lines and a smooth and glossy shell surface as in Natica.

\title{
Genus Globularia Swainson 1840
}

\section{Globularia sp.}

Shell material.

\author{
Plate 37, fig. 128.
}

Glejbjerg $53.75 \mathrm{~m}$ : 1 shell; $55 \mathrm{~m}: 1$ shell (figured specimen).

Description. Both shells are juvenile. The specimen from $53.75 \mathrm{~m}$. is partly corroded. The following description applies accordingly mainly to the shell from $55 \mathrm{~m}$.

Proto con ch partly corroded. Two and one half apparently smooth and glossy whorls. Diameter of the exposed part of the protoconch, which includes the periphery of the protoconch aperture: $1.12 \mathrm{~mm}$. This dimension is assumed to be only slightly less than the protoconch diameter which is probably about $1.2 \mathrm{~mm}$. Spire flat with deep sutures.

Teleoconch. Only one whorl developed. Surface smooth with growth lines. Aperture oblique, forming an angle of about $30^{\circ}$ with the shell axis. Outer lip partly broken, obviously sharp. Inner lip with rather thick callosity, which covers the umbilical region except for a narrow fissure. Basal part of the apertural margin thickened by internal shell layer which extends a little beyond the margin onto the external shell surface. For further particulars of shell morphology reference is made to the accompanying illustration on plate 37 .

Remarks. This shell is not, apparently, identical with any of the species of the genus known to the writer. There is some similarity with Ampullina peyreirensis Cossmann \& Рexrot (1918, p. 246, p. 12, fig. 39-40) which, however, is wider at the base than the present shell.

A new species has not been suggested on account of the small size of the adult part of the shell and the corroded state of the protoconch.

\section{Genus Sigaretus Lamarck 1799}

\section{Sigaretus sulcatus (Grateloup) \\ Plate 39, fig. 129 a-b.}

1825*). Natica sulcata Grateloup. Tabl. Dax (Bull. Soc. Lin. de Bordeaux. T. 2, p. 157.

1840. Natica sulcata Grateloup. Conch. foss. d. terr. tert. du bass. de l'Adour. 1, pl. 5, fig. $22-23$.

1918. Sigaretus (Sigaretotrema) sulcatus (Grat.). Cossmann \& Peyrot. Conch. Néogén. d. l'Aquit. p. 240, pl. 12, fig. 37-38.

Diagnosis. Testa ovato-globosa, transversim sulcosa umbilicata. (GRATELouP 1840).

Shell material. Toftlund $75-100 \mathrm{~m}$.; 3 juvenile shells.

*) The paper is not available to the writer. 
Description.

Protoconch depressed, 21/4 smooth and glossy whorls with deep suture. Initial whorl slightly heterostrophe.

Teleoconch. Shape naticoid. Body whorl with regular spiral furrows separated by relatively wide interspaces on the middle part of the whorl, while adjacent to the suture and the umbilicus the furrows and their interspaces are almost of the same width. Number of spiral furrows 28 to 31 . Umbilicus wide. In the figured shell there are fine spiral striae in the umbilical surface, corresponding to the spiral ornamentation on the external surface of the shell. The two other shells have no such striae, but only growth lines on the umbilical surface.

The aperture is oblique, its plane cuts the shell axis at an angle of about $35-40^{\circ}$. There is a shallow gutter at the junction with the preceding whorl, and the suture is formed at about the middle of this whorl. The dimensions and whorl data of the three shells are:

Sigaretus sulcatus from Toftlund $75-100 \mathrm{~m}$. Dimensions ete.

\begin{tabular}{|c|c|c|c|c|c|}
\hline \multicolumn{2}{|c|}{ Protoconch } & \multicolumn{4}{|c|}{ Teleoconch } \\
\hline Diameter & $\begin{array}{c}\text { Number of } \\
\text { whorls }\end{array}$ & Diameter & Height & $\begin{array}{l}\text { Number } \\
\text { of whorls }\end{array}$ & $\begin{array}{l}\text { Number of spiral fur- } \\
\text { rows on body whorl }\end{array}$ \\
\hline $1.02 \mathrm{~mm}$. & $21 / 4$ & $2.03 \mathrm{~mm}$. & $1.92 \mathrm{~mm}$. & $3 / 4$ & 28 \\
\hline$\left.(0.96-)^{*}\right)$ & $21 / 4$ & $2.33-$ & $2.16-$ & 1 & 30 \\
\hline$(0.92-)^{*}$ & $21 / 4$ & $2.54 \quad-$ & $2.23-$ & 1 & 31 \\
\hline
\end{tabular}

Remarks. This species differs from $S$. aquensis, described below, by the more elevated spire, the more open umbilicus, and the regular spiral ornamentation. The shells are apparently very similar to the shell shown in Cossmann \& PEYRot's paper, but they are much more depressed than the varieties figured by Grateloup. The determination is accordingly based on the authority of Cossmann \& Peyrot.

Distribution.

Miocene: Aquitanian Basin: Burdigalien.

North Sea Basin: Denmark: Arnum formation.

\title{
130. Sigaretus cf. aquensis Recluz
}

\author{
Plate 40, fig. 130 a-b.
}

1843. Sigaretus aquensis Recluz in Deshayes Traité élém. de Conch.

1874. Sigaretus aquensis Recluz. Benorst. Cat. syn. des test. foss. Saucats. p. 326.

1891. Sigaretus aquensis Recluz. Sacco. I moll. d. terr. terz. d. Piemonte e d. Liguria 8, p. 322 , pl. 1, fig. 59-65.

1918. Sigaretus aquensis Recluz. Cossmann \& Peyrot. Conch. Néogén. d. l'Aquit. p. 234, pl. 12 , fig. $47-48$.

1925. Sigaretus (Sigaretotrema) Michaudi. Мich. var. exclathrata SAcco. Kautsky. D. Mioc. v. Hemmoor u. Basbeck-Osten. p. 65, pl. 6, fig. 11.

1952. Sigaretus (Sigaretus) aquensis $f$. Deshayesi Michelotтi. Glibert. Faune mal. du Mioe. de la Belgique 2, p. 78, pl. 6, fig. 7 .

Original description of the species not available. The determination has been made on the authority of Cossmann \& Peyrot and Glibert (see "Remarks" below).

\footnotetext{
*) Lower part of body whorl of the protoconch not exposed.
} 
Shell material.

$\begin{array}{lcclrc}\text { Location } & \text { Depth } & \text { Shells } & \text { Location } & \text { Depth } & \text { Shells } \\ \text { Glejbjerg } & 32 \mathrm{~m} . & 1 \mathrm{frg} . & \text { Bramminge } & 70-80 \mathrm{~m} . & 2 \\ & 53.5- & 1 & \text { Toftlund } & 75-100- & 3 \\ & 55- & 1 & & 105-110- & 2 \mathrm{frg} .\end{array}$

Description. The material is very fragmentary and it is hardly possible to determine the shells definitely.

Protoconch of about $2 \frac{1}{2}$ whorls. Diameter about $1.0 \mathrm{~mm}$. There are about 2 smooth whorls, while the last $1 / 2$ whorl has a delicate spiral striation similar to that in Natica protostriata, described above. The spiral striation of the protoconch is clearly different from the much coarser spiral ornamentation which emerges on the teleoconch beyond the protoconch aperture. The protoconch of the figured shell is a little worn on the apex.

Teleoconch. Very depressed spire with wide whorls and narrow umbilicus. Closely spaced, undulating, low spiral ribs. Aperture unknown.

Remarks. The references in earlier literature to the original description are all insufficient. It is accordingly impossible to state with certainty whether the present material belongs to $S$. aquensis as defined by RECLUZ or not. There is, however, rather good evidence that the shells described by SACCO, Cossmann \& Pexrot, and Glibert, and the shells under discussion here belong to the same species.

\section{Distribution.}

Miocene: Aquitanian Basin: Aquitanien, Burdigalien.

North Sea Basin: Belgium: Horizon of Houthaelen. Anversien. Germany: Hemmoor stage. Denmark: Arnum formation.

Mediterranean Basin: Italy: Elveziano.

Oligocene: Mediterranean Basin: Italy: Tongriano.

\section{FAMILIA CASSIDIDAE HERRMANNSEN 1845}

\section{Genus Semicassis (Klein) Mörch 1852}

\section{Semicassis sp.}

Shell material.

Plate 41, fig. 131.

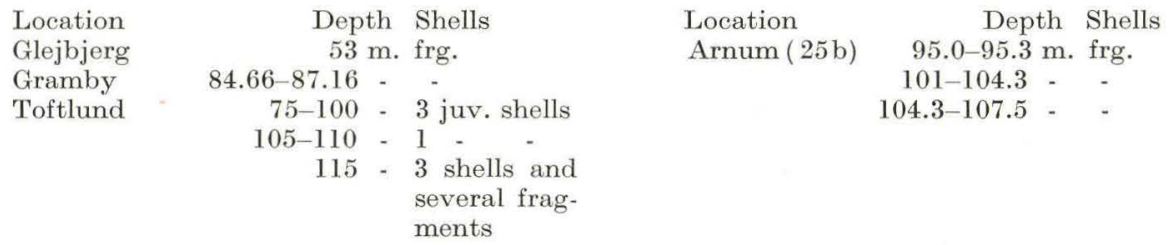

Description. The fragments display spiral ribs of various strength. There are probably shells of the types as known in $S$. megapolitana, S. bicoronata, and S. miolaevigata (KAUTSKY 1925).

Of particular interest is the large protoconch. The three shells from Toftlund

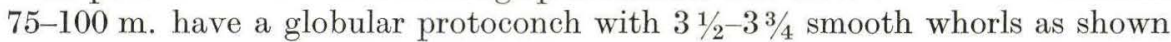


on the accompanying illustration. The diameter of the protoconch varies from 1.7 to $2.0 \mathrm{~mm}$.

\section{FAMILIA TRITONIDAE BRODERIP 1839 \\ Genus Tritonium Link 1807}

\section{Tritonium sp.}

Shell material. Toftlund $115 \mathrm{~m}$.: a few fragments.

Description. The fragments are too poor for further determination, they do not include anything but whorl fragments with the varices typical of the genus.

\section{FAMILIA PIRULIDAE THIELE 1931 \\ Genus Pyrula Lamarck 1799}

\section{Pyrula simplex Beyrich}

1856. Pyrula simplex Beyrich. Die Conchylien etc. p. 230, pl. 15, fig. 3.

1870. Pyrula simplex Beyrich. Speyer. D. Conch. d. Casseler Tert. 1, p. 83, pl. 9, fig. $16-17$.

1907. Ficula simplex Beyrich sp. Ravn. Molluskf. Jyll. Tert. p. 310.

1925. Pyrula simplex Beyrich. Kautsky. D. Mioc. v. Hemmoor u. Basbeck-Osten. p. 87, pl. 7 , fig. 10.

1940. Pyrula simplex Beyrich. Sorgenfrer. Mar. Nedre-Mioc. i Klintinghoved p. Als. p. 39 , pl. 5, fig. 14 .

1944. Ficus (Ficus) simplex Beyrich. Van Voorthuysen. Mioz. Gastr. a. d. Peelgebiet. p. 56, pl. 3, fig. 17-19.

1952. Pirula simplex Beyrich. Glibert. Faune mal. du Mioc. de la Belgique. 2, p. 88, pl. 3, fig. 11 .

Essential features of original description. Das Gewinde hat ein stumpfes glattes Embryonalende von 2 Windungen. Die Schale ist dicht mit starken, breiten, oben platten Querleisten bedeckt, in deren etwa gleich breiten Zwischenräumen nur schwache haarförmige Anwachsstreifen sichtbar sind. An jüngeren Stücken sind die Querleisten weniger breit und kreuzen sich noch mit schwachen Längsstreifen, die beim weiteren Anwachsen der Schale verschwinden. (BEYRICH 1856).

\section{Shell material.}

$\begin{array}{lrllrc}\text { Location } & \text { Depth } & \text { Shells } & \text { Location } & \text { Depth } & \text { Shells } \\ \text { Glejbjerg } & 53.5 \mathrm{~m} . & 1 \mathrm{frg} . & \text { Toftlund } & 105-110 \mathrm{~m} . & 1 \\ \text { Ribe } & 113-114- & 1-\text { (cf.) } & \text { Arnum (25b) } & 104.3-107.5- & 1\end{array}$

Description. The shells are relatively much worn and fragmentary. The fragment from Ribe can hardly be determined with certainty, while the three other shells are less dubious.

Protoconch. This part of the shell is preserved in the specimens from Toftlund and Arnum; it has smooth whorls. Protoconch diameter in these two shells about $1.6 \mathrm{~mm}$. and number of whorls 3 and $2 \frac{1}{2}$ respectively.

Teleoconch. No information since the shells are too broken. The sculpture agrees with BEYRICH's description, and also with the sculpture of the shells from Klintinghoved cited in the synonymy. 
Distribution.

Miocene: North Sea Basin: Belgium: Anversien. Holland (m.). Germany: Hemmoor, Reinbek (Goтtsche 1878), and Glimmerton (Banke Rasmussen 1956) stages. Denmark: Klintinghoved elay, Arnum formation.

Oligocene: North Sea Basin: Germany (u.).

\section{Pyrula condita Brongniart}

Plate 41, fig. 131.

1823. Pyrula condita Brongniart. Mém. Terr. sup. calc.-trap. Vicentin. p. 75, pl. 6, fig. 4. 1848. Pyrula reticulata Lam. Wood. Monogr. Crag Moll. 1, p. 42, pl. 2, fig. 12.

1856. Pyrula reticulata Lam. Beyrich. Die Conchylien etc. p. 231 , pl. 15, fig. 5, 6, 9, 10. 1856. Pyrula condita Brong. Hörnes. D. foss. moll. d. Tert.-Beckens v. Wien 1, p. 270, pl. 28 , fig. 4-6.

1891. Ficula condita Brong. et var. SAcco. I moll. d. terr. terz. d. Piemonte e d. Liguria 8, p. 247 , pl. 1, fig. 27-32.

1907. Ficula reticulata LaMarck sp. Ravn. Molluskf. Jyll. Tert. p. 310.

1914. Ficula reticulata Lamarck sp. Gripp. Über eine u. mioz. Moll. f. v. Itzehoe. p. 16.

1922. Pirula condita Brongniart. Cossmann \& Peyrot. Conch. Néogén. d. l'Aquit. p. 333 , pl. 10 , fig. 46,47 .

1925. Pyrula geometra Bors. var. berilla De Greg. Kautsky. D. Mioc. v. Hemmoor u. Basbeck Osten. p. 87, pl. 7, fig. 11.

1944. Ficus (Ficus) condita (Brongniart). Van Voorthuysen. Mioz. Gastr. a.d. Peelgebiete. p. 57 , pl. 2 , fig. 12 , pl. 3 , fig. 15 , 16, pl. 4, fig. $1-5$.

1952. Pirula condita Brongntart. Glibert. Faune mal. du Mioc. de la Belgique. 2, p. 89, pl. 7 , fig. 4.

1956. Pyrula condita Brongniart. Banke Rasmussen. Upper Mioc. South Jutland, p. 65 , pl. 5, fig. 5 .

Original diagnosis. Testa pyriformis, spira retusa, decussata, transversim sulcata, poreis latis, striis duabus in sulcis (BRONGNIART 1823).

Shell material.

\begin{tabular}{|c|c|c|c|c|c|c|c|}
\hline \multirow{5}{*}{$\begin{array}{l}\text { Location } \\
\text { Glejbjerg }\end{array}$} & Dept & & Shells & Location & Dept & & \multirow{2}{*}{$\begin{array}{l}\text { Shells } \\
1 \mathrm{frg} .\end{array}$} \\
\hline & $25 \mathrm{n}$ & & $1 \mathrm{frg}$. & \multirow[t]{4}{*}{ Toftlund } & $75-100$ & m. & \\
\hline & 32 & - & $1 \div$ & & $105-110$ & - & \\
\hline & 42 & - & 1 & & $110-115$ & - & $1-$ \\
\hline & 53.5 & - & 1 & & 115 & - & 1 \\
\hline Bramminge & $70-80$ & - & 3 & Arnum (13) & $53-83$ & - & $1-$ \\
\hline Ribe & $113-114$ & - & $1-$ & & $83-94$ & - & $1-$ \\
\hline & $117-118$ & - & 1 - & Arnum (25b) & $62.7-62.9$ & - & 1 \\
\hline Gramby & $84.66-87.16$ & - & 1 & & $101-104.3$ & - & 1 \\
\hline & & & & & $104.3-107.5$ & - & 1 \\
\hline
\end{tabular}

Description. The shell material is very fragmentary and many varieties of reticulate sculpture are found.

Protoconch. About $2 \frac{1}{2}$ whorls, the initial whorl distinctly heterostrophe. Traces of microscopic spiral striae seen on the figured shell from Toftlund $(75-100 \mathrm{~m}$.$) , the surface being otherwise smooth. Diameter of the figured shell$ $1.72 \mathrm{~mm}$.

Teleoconch. There are several varieties of sculpture. In some shells the spiral ribs are the strongest, whereas the spiral and collabral ribs are of equal strength in other shells. It is not possible to give further details on shell morphology because of the fragmentary nature of the material. 
Remarks. This very variable species has undoubtedly been listed under different names. The synonymy given makes no pretence at completeness or reliability. A statistical analysis of the variation of a sufficiently great number of shells is necessary before the number of species concealed under the names cited can be determined.

Distribution. The following outline is given subject to correction due to the above-mentioned uncertainty of the synonymy.

Pliocene: North Sea Basin: England: Coralline Crag.

Miocene: Aquitanian Basin: Aquitanien, Burdigalien.

North Sea Basin: Belgium: Boldérien, horizon of Houthaelen, Anversien. Holland (m.). Germany: Vierlande, Hemmoor and Reinbek (Gotтsche 1878) stages, Glimmerton (Banke Rasmussen 1956). Denmark: Arnum and Gram formations.

Mediterranean Basin: Italy: Elveziano, Tortoniano. Vienna Basin: Grund sands.

Oligocene: North Sea Basin: Germany (u.).

Mediterranean Basin: Italy: Tongriano.

FAMILIA MURICIDAE FLEMING

Genus Murex Linné 1758

\section{Murex cf. aturensis Cossmann \& Peyrot}

Plate 42, fig. $135 \mathrm{a}-\mathrm{b}$.

1923. Murex (Poirieria) aturensis. Cossmann \& Peyrot. Conch. Néogén. d. l'Aquit. p. 134, pl. 15, fig. 15-16.

Essential features of original description. Angle apical de $35^{\circ}$; protoconque lisse, composée de deux tours dont un nucléus papilleux. Tours postembryonnaires anguleux avec neuf côtes axiales, arrondies sur la région antérieure, épineuses et même tubulées sur l'angle médian, presque effacées sur la rampe entre l'angle et la suture inférieure. Ornementation spirale composée de quatre cordonnets granuleux au dessus de l'angle, et trois ou quatre sur la rampe. (CossMANN \& Peyrot 1923).

Shell material.

$$
\begin{aligned}
& \text { Location } \\
& \text { Bramminge } \\
& \text { Toftlund } \\
& \text { Arnum (13) }
\end{aligned}
$$

$\begin{aligned} \text { Depth } & \text { Shells } \\ 70-80 \mathrm{~m} . & 2 \\ 75-100- & 4 \\ 53-83- & 1\end{aligned}$

Description. The shells represent either juvenile stages or are fragmentary with respect to features of the teleoconch.

Protoconch. About 4 to $4 \frac{1}{2}$ whorls including the one coil of the heterostrophe nucleus. The nuclear whorl is ornamented with microscopic granules arranged in spiral rows. Beyond the apertural line of the nucleus a spiral rib emerges immediately above the lower suture of the second whorl. The spiral rib is ornamented with an oblique reticulate striation on its edge. A row of minute, prop-like ribs are found at the upper suture on the second and third whorls. 
The protoconch aperture is characterized by sinuosities on both sides of the projecting median part of the whorl opposite the spiral rib. The margin is reflected upward practically at right angle to the wall of the protoconch in both the upper and the lower sinuses. By comparison with recent prosobranch larvae (see for instance THorson 1946, p. 237) it is seen that the function of the two sinuses undoubtedly was to accomodate the velum. Irregularly scattered granules are seen on the shell surface particularly behind the aperture. The granules are occasionally also found on the remainder of the whorls which are otherwise smooth and glossy with curved growth lines corresponding to the upper sinus of the aperture. There are spirally arranged granules on the anterior canal of the protoconch.

The last whorl of the protoconch is exposed in the specimen from Arnum. The protoconch in this shell is $1.60 \mathrm{~mm}$. high, $1.33 \mathrm{~mm}$. in diameter, and it has $4^{1 / 3}$ whorls, including the nucleus.

Teleoconch. The adult whorls have 8 or 9 collabral ribs which carry concave spines at the more or less angular keel. No spiral ornamentation, or only a single spiral is seen above the keel on the first whorl. On the second whorl there are, however, 1 or 2 spirals above the keel.

The vertical part of the shell has 3 rather strong spiral ribs on the first whorl; they are joined by intercalated secondary ribs on the succeeding whorl. In a specimen from Toftlund in which the first adult whorl represents the body whorl, there are 5 spiral ribs below the keel on the whorl proper, and on the anterior canal there are 8 to 10 weaker ribs.

Remarks. These shells remind very much of $M$. aturensis if allowance is made for their juvenile stage. There is only one remarkable difference: the protoconch has 4 instead of 2 whorls. This may not be a very significant difference, but it is the reason why the shells were not definitely referred to $M$. aturensis.

The protoconch of the present shells is very similar to that of $M$. inornatus, described below, which however is narrower and poorer in sculptural features.

Distribution.

Miocene: Aquitanian Basin: Aquitanien.

North Sea Basin: Denmark: Arnum formation.

\section{Murex inornatus Beyrich}

Plate 42, fig. $136 \mathrm{a}-\mathrm{b}$.

1856. Murex inornatus Beyrich. Die Conchylien etc. p. 210.

1923.? Murex (Haustellum) haudmuticus. Cossmann \& Peyrot. Conch. Néogén. d. l'Aquit. p. 101, pl. 12, fig. $28-30,36$; pl. 18, fig. 4 .

1925. Murex (Haustellum) inornatus Beyr. Kautsky. D. Mioc. v. Hemmoor u. BasbeckOsten. p. 91, pl. 7, fig. 16-20.

1940. Murex (Haustellum) paucispinatus Roth v. Telegd. Sorgenfrei. Mar. NedreMioc. i Klintinghoved p. Als. p. 41, pl. 5, fig. 17.

1944. Murex (Haustellum) inornatus Beyrich. VAN Voorthuysen. Mioz. Gastr. a. d. Peelgebiet. p. 64, pl. 5, fig. 23-39.

1952. Murex (Haustellum) inornatus Beyrich. Guibert. Faune mal. du Mioc. de la Belgique. 2, p. 94, pl. 7, fig. 9 .

Essential features of original description. Embryonalende 2 bis 3 Windungen. Die Mittelwindungen sind stark gewölbt, längsgerippt und quer- 
gestreift. Die unteren Windungen haben 8 Rippen, die oberen einige mehr. In den unteren Mittelwindungen schwellen die Rippen in der unteren Hälfte knotig an, ohne Dornen oder Höcker zu erhalten. (BEYRICH 1856).

Shell material.

\begin{tabular}{|c|c|c|c|c|c|}
\hline Location & Depth & Shells & Location & Depth & Shells \\
\hline \multirow{5}{*}{ Glejbjerg } & $52 \mathrm{~m}$. & 1 & \multirow[t]{3}{*}{ Toftlund } & $105-110 \mathrm{~m}$. & 32 \\
\hline & $53-$ & $1+$ frg. & & $110-115=$ & 9 \\
\hline & $53.5-$ & 5 & & $115-$ & 1 \\
\hline & $53.75-$ & $1 \mathrm{frg}$. & \multirow{2}{*}{ Arnum (13) } & $53-83-$ & 9 \\
\hline & $55-$ & $1-$ & & $83-94 \quad-$ & $1 \mathrm{frg}$. \\
\hline Bramminge & $70-80 \quad-$ & 44 & \multirow{3}{*}{ Arnum $(25 b)$} & $95.0-95.3$ - & 1 \\
\hline \multirow[t]{2}{*}{ Toftlund } & $75-100$ & 21 & & \multirow[t]{2}{*}{107.5} & \multirow[t]{2}{*}{1} \\
\hline & $100-105$ & 10 & & & \\
\hline
\end{tabular}

Description. Most of the well preserved shells are juvenile.

Protoconch. About $4^{1 / 3}$ to $4^{3} /{ }_{4}$ whorls including the heterostrophe nuclear whorl. The latter is covered with microscopical granules hardly perceptible even under the microscope. The granules are apparently partly arranged in spiral rows. The post nuclear whorls have a narrow spiral rib beneath which the suture is found on the middle of the whorl. The spiral rib continues on the projection separating the two sinuses of the aperture. In some specimens there are irregularly scattered granules on the otherwise smooth shell surface. The margin of the upper and lower sinuses are reflected as in $M$. cf. aturensis. From 9 to about 20 spiral rows of relatively coarse granules are found on the apertural canal. Dimensions and number of whorls were determined in the following shells:

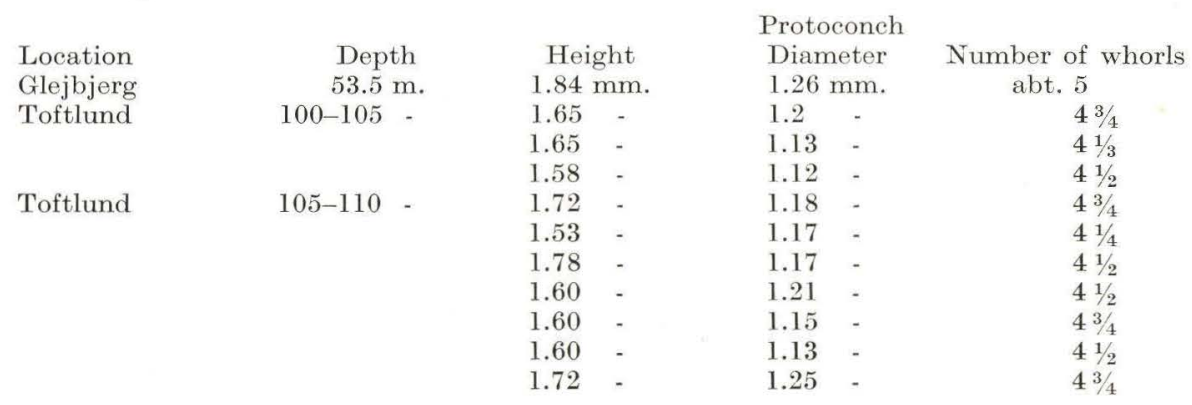

Teleoconch. About 9-11 collabral ribs per whorl and 4 to 6 primary spiral ribs on the first adult whorl. Secondary spiral striae developing into ribs occur on the second whorl, particularly on the upper part of the whorl. Low spines may occasionally appear on every second rib from about the 3rd or 4th whorl.

Remarks. The writer agrees perfectly regarding the inclusion of $M$. paucispinatus in the synonymy of $M$. inornatus as suggested by VAN VOoRTHUYSEN and GLIBERT. The species is obviously very variable and ought accordingly to be studied in detail concerning its variation. When this is done it would also be advisable to check the validity of $M$. Sismondae BeLL (see for instance SACCO, 1904, p. 18, pl. 4, fig. 27-28).

Distribution.

Miocene: Aquitanian Basin: ? Aquitanien, ? Burdigalien.

North Sea Basin: Belgium: Boldérien, horizon of 
Houthaelen, Anversien. Holland (m.). Germany: Hemmoor and Reinbek stages. Denmark: Klintinghoved clay, Arnum formation.

Hungarian Basin: lower Miocene.

\section{Genus Typhis Montfort 1810}

\section{Typhis cf. horridus (Brocchi)}

1814. Murex horridus BrocchI. Conchiol. Foss. Subapennina. 2, p. 405, pl. 7, fig. 17.

1856. Murex (Typhis) horridus Brocchr. Hörnes. D. foss. Moll. d. Tert.-Beckens v. Wien 1, p. 260 , pl. 26 , fig. 9 .

1873. Typhis horridus Brocchi. Bellardi. I moll. d. terr. terz. d. Piemonte e d. Liguria. 1, p. 69.

1907. Tiphys horridus Brocchi sp. Ravn. Molluskf. Jyll. Tert., p. 322.

1923. Typhis horridus Brocchi. Cossmann \& Peyrot. Conch. Néogén, d. l'Aquit. p. 236, pl. 15, fig. 17-18.

1925. Typhis horridus Brocchi. Kautsky. D. Mioc. v. Hemmoor u. Basbeck-Osten. p. 99. 1940. Tiphys horridus Brocchi. Sorgenfrer. Mar. Nedre-Mioc. i Klintinghoved p. Als. p. 43 , pl. 6 , fig. $2-3$.

1944. Typhis (Typhis) horridus Brocchi. Van Voorthuysen. Mioz. Gastr. a. d. Peelgebiete. p. 68, pl. 6, fig. 5, 6, 10, 11 .

1952. Typhis (Typhis) horridus Brocchi sp. Glibert. Faune mal. du Mioc. de la Belgique. 2 , p. 96 , pl. 7 , fig. 13 .

Original diagnosis. Testa ovata. spinis fistulosis, bi-tri-furcatis, apertura orbiculari, labio anulari continuo, cauda clausa, remota, subfimbricata (BRoccHI 1814).

Shell material. One fragment of a whorl from Toftlund $110-115 \mathrm{~m}$.

Description. The fragment is rather poor but exhibits well the hollow spines of Typhis and the divergence of these spines as known in T. horridus and $T$. pungens. It does not belong to $T$. fistulosus described below.

Distribution.

Pliocene: Mediterranean Basin: Italy: Piacenziano (SACco 1904).

Miocene: Aquitanian Basin: Burdigalien, Helvétien. North Sea Basin: Belgium: Anversien. Holland (m.). Germany: Hemmoor and Reinbek stages, Glimmerton; Denmark: Klintinghoved clay, Arnum formation. Mediterranean Basin: Italy: Tortoniano.

Vienna Basin: Baden, Vöslau.

Oligocene: Mediterranean Basin: Italy: Tongriano (Sacco 1904).

\section{Typhis fistulosus (Brocchi)}

Plate 43, fig. 138.

1814. Murex fistulosus BrocchI. Conchiol. Foss. Subapennina. p. 394, pl. 7, fig. 12. 1856. Murex (Typhis) fistulosus Brocc. Hörnes. D. foss. Moll. d. Tert.-Beckens v. Wien. 1 , p. 261 , pl. 26 , fig. 11 .

1873. Typhis fistulosus (Brocchi). Bellardi. I moll. d. terr. terz. d. Piemonte e d. Liguria 1, p. 70 .

1907. Tiphys Schlotheimi Beyrich. Ravn. Molluskf. Jyll. Tert. p. 321, pl. 5, fig. 13.

1923. Cyphonochilus fistulosus (Brocchi). Cossmann \& Peyrot. Conch. Néogén d. l'Aquit. p. 241, pl. 15, fig. 32-33. 
1925. Typhis (Cyphonochilus) fistulosus Brocc. Kautsky. D. Mioc. v. Hemmoor u. BasbeckOsten. p. 99.

1944. Typhis (Cyphonochelus) fistulosus (BRocchi). VAN Voorthuysen. Mioz. Gastr. a. d. Peelgebiet, p. 67, pl. 6, fig. 3, 4, 9, 14.

1952. Typhis (Cyphonochelus) fistulosus Brocchi sp. Glibert. Faune mal. du Mioc. de la Belgique. 2, p. 95, pl. 7, fig. 12.

1956. Typhis (Cyphonochelus) fistulosus (Brocchi). Banke Rasmussen. Upper Mioc. South Jutland, p. 69 , pl. 6 , fig. 1.

Original diagnosis. Testa oblonga, angulis membranaceis acutis, anfractubus omnibus spinis fistulosis coronatis, apertura suborbiculari, canali clauso. (BROCCHI 1814).

\section{Shell material.}

\begin{tabular}{|c|c|c|c|c|c|c|c|}
\hline \multirow{2}{*}{$\begin{array}{l}\text { Location } \\
\text { Glejbjerg }\end{array}$} & \multicolumn{2}{|c|}{ Depth } & Shells & Location & \multicolumn{2}{|c|}{ Depth } & Shells \\
\hline & 25 & $\mathrm{~m}$. & 1 & Toftlund & $75-100$ & $\mathrm{~m}$. & 37 \\
\hline & 53.5 & - & 2 & & $100-105$ & - & 2 \\
\hline & 55 & - & 1 & & $105-110$ & - & 23 \\
\hline Bramminge & $70-80$ & - & 108 & & $110-115$ & - & 7 \\
\hline Gramby & $82.66-83.76$ & - & 5 & & 115 & - & 3 \\
\hline & $84.66-87.16$ & - & 2 & Arnum (13) & $53-83$ & - & 4 \\
\hline & $90.42-92.72$ & - & 1 & Arnum (25b) & $62.7-62.9$ & - & 22 \\
\hline & & & & & $95.0-95.3$ & - & 4 \\
\hline
\end{tabular}

\section{Description.}

Protoconch with $3 \frac{1}{2}$ to 4 whorls which are smooth and glossy except for the nuclear whorl which apparently has microscopic punctiform pits in the shell surface. The nucleus proper is partly concealed in the nuclear whorl. There is a keel a little below the periphery of the last protoconch whorl. The suture is generally above this keel.

Teleoconch with four hollow spines per whorl which are curved and directed upwards and backwards in relation to the shell axis. The spines are generally situated below each other, and the spire therefore looks like a fourarmed wind mill when seen from the apex. There are commonly flat, indistinct, collabral ribs, one in front of and one behind each spine, extending from the base of the spine to the lower suture.

The growth lines have a pointed sinus opposite the spines. The entire shell surface is smooth and glossy.

The aperture, which is oblong oval with a sharp outer lip, continues into a canal of intermediate length.

The data of a well preserved shell from Toftlund $(75-100 \mathrm{~m}$.) are: height $7.3 \mathrm{~mm}$., diameter $3.6 \mathrm{~mm}$., 4 protoconch whorls and $3^{3 / 4}$ adult whorls. The spines have not been included in the measurement of the diameter. A few shells are larger than this specimen.

Distribution.

Pliocene: Mediterranean Basin: Italy: Piacenziano (SAcco 1904).

Miocene: Aquitanian Basin: Burdigalien, Helvétien.

North Sea Basin: Belgium: Anversien. Holland (m., u.). Germany: Hemmoor stage, Glimmerton (BANke Rasmussen 1956). Denmark: Arnum and Gram formations.

Vienna Basin: Baden clay. 


\section{Genus Tritonalia Fleming 1828}

\section{Tritonalia coelata Dujardin}

Plate 42, fig. 139 .

1837. Fusus coelatus Dujardin. Mém. sur les couches du sol en Touraine. p. 294, pl. 19, fig. 1 .

1923. Hadriania mioincrassata Sacco. Cossmann \& Peyrot. Conch. Néogén. d. l'Aquit. p. 230 , pl. 14, fig. 9 and $41-44$.

1944. Ocinebrina sublavata (Basterot). Van Voorthuysen. Mioz. Gastr. a. d. Peelgebiet. p. 69 , pl. 4, fig. 24. pl. 5, fig. $1-12$.

1952. Tritonalia (Hadriania) of. coelata (DujardiN). Glibert. Faune mal. du Mioc. de la Belgique. 2, p. 97, pl. 7, fig. 14 .

1952. Tritonalia (Hadriania) coelata Dujardin sp. Gltbert. Gastr. Mioc. moy. du bassin d. 1. Loire. 2, p. 304, pl. 7, fig. 3 .

Original diagnosis. Testa fusiformi-turrita, transversim cingulata, obsolete plicata; anfractibus convexis, angulatis; cingulis alternatim majoribus; lamellis undulatis, decussantibus, tenuissimis; cauda intorta; canalis scepius clauso; labro intus dentato. (DUJARDIN 1837).

Shell material. Bramminge 70-80 m.: 2 shells, Toftlund $75-100 \mathrm{~m}$. : 2 shells.

Description.

Protoconch preserved on one of the shells from Toftlund: about $2 \frac{1}{2} \mathrm{ob}$ viously smooth whorls (partly covered by a carbonaceous film). The nucleus is concealed in the first whorl.

Teleoconch with about 10 to 15 collabral ribs crossed by spirals which are mostly squamose at the intersection with the growth lines. The whorls are more or less distinctly keeled. Aperture with about 10 knobs on the inside of the outer lip. The canal is closed in the largest of the shells from Bramminge. This specimen is partly broken and the protoconch is lacking; it consists of 5 adult whorls, the height is $18.7 \mathrm{~mm}$. and the diameter might have been about $8 \mathrm{~mm}$. It is shown on plate 42 , fig. 139 .

Remarks. This seems to be a rather variable species. Variable features are: collabral ribs (regarding distinctness and number per whorl), shape of spire and aperture, etc.

The shells from South Jutland remind very much of the shells pictured by Van Voorthuysen, and of the shell from Belgium shown by GLibert.

Distribution.

Miocene: Aquitanian Basin: Helvétien.

North Sea Basin: Belgium: Boldérien, Holland (m.).

Denmark: Arnum formation.

FAMILIA COLUMBELLIDAE TROSCHEL

Genus Pyrene (Bolten) Röding 1798

Subgenus Atilia H. \& A. Adams 1853.

140. Pyrene (Atilia) nassoides (Grateloup)

Plate 43 , fig. 140.

1827*). Fusus nassoides Grateloup. Mém. sur les coq. foss. de Dax. p. 15.

1840. Fusus nassoides Grateloup. Conch. foss. d. terr. tert. du bas d. l'Adour. pl. 24, fig. 40-41.

*) Paper unavailable. 
1856. Columbella nassoides Bell. Hörnes. D. foss. Moll. d. Tert.-Beckens v. Wien. 1, p. 122 , pl. 11, fig. 9 .

1890. Columbella (Macrurella) nassoides Grat. SAcco. I moll. d. terr. terz. d. Piemonte e d. Liguria 6, p. 343, pl. 2, fig. 67.

1907. Columbella nassoides Grateloup sp. Ravn. Molluskf. Jyll. Tert. p. 312, pl. 4, fig. 7.

1925. Atilia (Macrurella) nassoides Grat. Kautsky. D. Mioc. v. Hemmoor u. BasbeckOsten. p. 103, pl. 7, fig. 30.

1925. Atilia (Macrurella) nassoides (Grateloup). Cossmann \& Peyrot. Conch. Néogén. d. l'Aquit. p. 73, pl. 1, fig. 57, 89-91.

1944. Mitrella (Macrurella) nassoides (Grateloup). Van Voorthuysen. Mioz. Gastr. a. d. Peelgebiet. p. 76, pl. 9, fig. 6-11.

1952. Pyrene (Atilia) nassoides Grateloup sp. Glibert. Faune mal. du Mioc. de la Belgique. 2, p. 98, pl. 7, fig. 15.

Diagnosis. Testa fusiformi, turgidula, crassiuscula, nitide lovissima, basi transversim striata; 10 anfractibus convexiusculis; apertura angusta; labro incrassato, intus striato; columella lamellosa; cauda breviuscula, subarcuata canalifera; spira apice acutissima. (GRATELOUP 1840).

Shell material.

$\begin{array}{lrllll}\text { Location } & \text { Depth } & \text { Shells } & \text { Location } & \text { Depth } & \text { Shells } \\ \text { Glejbjerg } & 53.5 \mathrm{~m} . & 2 \text { (cf.) } & \text { Toftlund } & 105-110 \mathrm{~m} . & 1 \\ & 53.75- & 1- & & 110-115- & 2 \\ \text { Bramminge } & 70-80- & 6 & \text { Arnum }(25 \mathrm{~b}) & 62.7-62.9- & 1 \\ \text { Toftlund } & 75-100- & 3 & & & \end{array}$

Description. Some of the shells are very fragmentary or juvenile.

Protoconch with $2 \frac{1}{2}$ to 3 smooth and glossy whorls. Axis of initial whorl slightly oblique. The growth lines show a distinct and relatively deep sinus adjacent to the upper suture; this was certainly the sinus for the right wing of the velum (see also Typhis fistulosus, p. 204).

Teleoconch smooth with plain, conical spire. Apical angle about $30^{\circ}$. Columella with spirals. Body whorl angular to subangular at the periphery where the suture is formed.

The best preserved shell, which is rather small, is $5.6 \mathrm{~mm}$. high and $2.3 \mathrm{~mm}$. in diameter. It is shown on plate 43 , fig. 140. A fragment of a large shell from Bramminge suggests the original height of that shell to be about $18 \mathrm{~mm}$.

Remarks. The material available is insufficient for a thorough evaluation of the validity of VAN VOORTHUYSEN's decision concerning the inclusion of the major part of the shells referred to $P$. subulata and $P$. attenuata in the synonymy of the present species. The Pyrenes have undoubtedly a relatively wide variation range and VAN VOORTHUYSEN may thus theoretically be right. The writer would, however, recommend a detailed revision of the shell morphology and particularly of the protoconch features before VAN VoorthUYsEN's references are generally accepted.

The protoconchs of the present shells and the shell from Klintinghoved referred to $P$. subulata (Sorg ENFrei 1940, p. 44) are clearly different since the obliquity of the first whorl as described above has not been observed in $P$. subulata. It should be added that collabral ribs, as found on the first whorl of $P$. subulata from Klintinghoved have not been noticed in the present material.

Distribution.

Pliocene: Mediterranean Basin: Italy: Pliocene inferiore.

Miocene: Aquitanian Basin: Burdigalien.

North Sea Basin: Belgium: Boldérien, Anversien. 
Holland (m.). Germany: Hemmoor stage, Reinbek stage Gottsche 1878), Glimmerton stage (Banke Rasmussen 1956). Denmark: Arnum formation.

Vienna Basin: Grund, Baden, Vöslau, Steinabrunn.

\section{Subgenus Anachis H. \& A. Adams 1853}

\section{Pyrene (Anachis) sp.}

Shell material.

Plate 43, fig. 141 a-d.

$$
\begin{aligned}
& \text { Location } \\
& \text { Bramminge } \\
& \text { Toftlund } \\
& \text { Arnum (25) }
\end{aligned}
$$

\author{
Depth Shells \\ 70-80 m. $\quad 1$ (protoconch broken) \\ 105-110 - 1 (protoconch and fragment with \\ parts of lst and $2 \mathrm{~d}$ whorl) \\ 62.7-62.9 - 1 (protoconch and 1 whorl, height \\ $1.73 \mathrm{~mm}$., diameter $0.91 \mathrm{~mm}$.)
}

Description.

Protoconch of about 4 smooth whorls. Growth lines with distinct and rather deep sinus at the upper suture (observed on the last whorl of the specimen from Arnum). The lower sinus of the outer lip of the protoconch is exposed in the same shell. It is as deep as the upper sinus.

Teleoconch with 14 to 16 collabral ribs per whorl and with about 10 rather indistinct, flat, spiral ribs on the exposed part of the first whorl. Body whorl of the shell from Bramminge almost without collabral ribs. Aperture narrow oval. Outer lip thickened with 6 knobs on the inside. Short canal.

Remarks. These shells are undoubtedly closely related to the shell described as Anachis terebralis (Grateloup) var. perlonga (Cossmann \& Peyrot, 1925, Conch. Néogén. d. l'Aquit. p. 64, pl. 1, fig. 81). It is believed, however, that this variety should perhaps be given the rank of species. The shell material here described is, however, too poor to serve as a reference for a new species. It was decided, therefore, to postpone the designation of a new species name until the French material has been re-examined.

Distribution.

Miocene: Aquitanian Basin: Burdigalien.

North Sea Basin: Denmark: Arnum formation.

FAMILIA BUCCINIDAE LATREILLE 1825

Genus Phos Montfort 1810

\section{Phos decussatus von Koenen}

Plate 44, fig. 142.

1872. Phos decussatus von Koenen. D. Nordd. Mioc. u. s. Moll. f. p. 201, pl. 1, fig. 9. 1925. Phos decussatus von Koenen. Kautsky. D. Mioc. v. Hemmoor u. Basbeck-Osten, p. 112, pl. 8, fig. 14 .

?1926 Phos polygonum (Brocchi). Cossmann \& Peyrot. Conch. Néogén d. l'Aquit. p. 228 , pl. 4, fig. 31-34.

1944. Phos (Phos) decussatus von Koenen. Van Voorthuysen Mioz. Gastr. a. d. Peelgebiet, p. 83, pl. 7, fig. 8-14.

1952. Phos (Phos) decussatus von Koenen. Glibert. Faune mal. du Mioc. de la Belgique. 2, p. 101, pl. 8, fig. 1. 
Essential features of original description. Das Embryonatende besteht aus vier kegelförmigen, ziemlich stark gewölbten Windungen, deren letzte unten feine Spiralen, erst 3, dann 4 und bald darauf auch feine, schräge Längsrippchen, circa 15 pro Windung, erhält. Zwischen den Spiralen schieben sich auf der folgenden Windung nach einander drei Serien alternirend stärkerer, und schwächerer, flacher, rundlicher Streifen ein. Die Zahl der Längsrippen auf der Schlusswindung etwa 13 bis 17 (von KoEnen 1872).

Shell material.

$\begin{array}{lrllrl}\text { Location } & \text { Depth } & \text { Shells } & \text { Location } & \text { Depth } & \text { Shells } \\ \text { Bramminge } & 70-80 \mathrm{~m} . & 1 & \text { Toftlund } & 110-115 \mathrm{~m} . & 3 \\ \text { Toftlund } & 75-100- & 2 & & 115- & 7 \\ & 105-110- & 7 & \text { Arnum (13) } & 83-94- & 1\end{array}$

Description. Most of the shells are small and represent juvenile stages. Only a few have an entire protoconch, and none is complete.

Protocon $\mathrm{ch}$. This part is preserved in three shells from Toftlund $105-110 \mathrm{~m}$. The nucleus is slightly heterostrophe. The first two protoconch whorls have apparent microscopic punctiform impressions on the shell surface, or the shell surface is more or less granular. Approximately the three following protoconch whorls are smooth and glossy, and they have 1, 2, 3, and 4 delicate spiral ribs on the lower half of the whorl, as shown on the accompanying illustration. The growth lines show a rather wide, oblique upper sinus between the upper and lower sutures. The lower sinus on the protoconch apertural margin could be studied only in a single shell, it is much narrower than the upper sinus. The last $1 / 2$ protoconch whorl may have fine, obliquely curved collabral ribs. This is obviously a transitional ornament indicating the change from swimming to bottom living stages of the animal. The oblique ribs are occasionally not developed, and the adult sculpture then starts abruptly. Dimensions etc. of the three protoconch shells from Toftlund $105-110 \mathrm{~m}$. were:

\begin{tabular}{|c|c|c|c|}
\hline Height & Diameter & $\begin{array}{l}\text { Number of } \\
\text { whorls }\end{array}$ & $\begin{array}{c}\text { Fraction of last whorl } \\
\text { with oblique ribs }\end{array}$ \\
\hline $1.72 \mathrm{~mm}$. & $1.08 \mathrm{~mm}$. & 5 & $1 / 6$ \\
\hline $1.88-$ & $1.17 \quad-$ & 5 & $1 / 5$ \\
\hline $1.95 \quad-$ & $1.21-$ & 5 & $1 / 2$ \\
\hline
\end{tabular}

The protoconch of this species is accordingly of considerable size.

Teleoconch. The largest shell (Arnum 53-83 m.) is $8.8 \mathrm{~mm}$. high, $4.1 \mathrm{~mm}$. wide, and has about 4 protoconch whorls preserved on about $3 \frac{1}{2}$ adult whorls. There are about 10 to 12 collabral ribs per adult whorl. The aperture is broken on all shells. A fragment of an aperture of a full-grown shell shows the outer lip to be thickened and has 15 to 20 narrow ridges on the inside of the margin.

Remarks. There is hardly any doubt that the P. polygonum of Cosmann \& Peyrot should be included in the synonymy of this species.

Distribution.

Miocene: Aquitanian Basin: ?Burdigalien, ?Helvétien.

North Sea Basin: Belgium: Anversien. Holland (m.).

Germany: Hemmoor stage. Denmark: Arnum formation. 
FAMILIA NASSIDAE

\section{Genus Nassa Lamarck 1799}

The family Nassidae has been subdivided into various genera, subgenera and sections by previous authors. With respect to the names applied to supraspecific units reference is made to Cossmann (1901), Cossmann \& Peyrot (1925), Thitele (1931), and Wenz (1944). The characters referred to in these handbooks are partly shell features and partly features of the radula and operculum.

Several authors of fossil Nassidae follow one of the suggested taxonomic subdivisions, or a combination of them, but this has generally been done without comments on the evidence of the shell features on which the subdivisions are based. It is, therefore, considered worth while to remember the fact that shell features of this family as of many other molluscan families, have not yet been correlated with the features of the radula or the operculum. From this it may be inferred that the reference of fossil Nassidae to subgenus or section is often arbitrary.

From the study of the Nassidae from the Miocene of South Jutland, and by comparison with information in the literature, the writer concluded that it is inadvisable to apply subgeneric names without a very thorough revision of the shell features of the family. However, such a revision is beyond the scope of the present work.

The significance of many of the shell features of supraspecific value can be questioned, particularly on account of their variability, and the subjective judgement which often must be exerted in case supraspecific references are intended.

These, and similar considerations decided the writer not to subdivide the shells of the genus Nassa treated below into subgenera as, for instance, suggested by Thiele. It is of interest here to quote Cossmann (1901, p. 196), because the situation has not changed very much since he suggested his subdivision of the Nassidae: "La plupart des Paléontologistes, et même beaucoup de Conchyliologues, continuent, avec raison selon moi, à dénommer simplement Nassa presque toutes les coquilles de la Sous-Famille Nassinae, parce qu'elles ont un aspect de similitude auquel on ne peut se tromper".

\section{Nassa tenuistriata (Beyrich)}

Plate 44, fig. 143.

1854. Buccinum tenuistriatum BEYRICH. Die Conchylien etc. p. 133, pl. 8, fig. 2.

1925. Nassa (Hima) tenuistriatum Beyrich. KaUtsky. D. Mioc. v. Hemmoor u. BasbeckOsten, p. 106, pl. 8, fig. 8-10.

1944. Nassa (Hima) tenuistriatum (Beyrich). Van Voorthuysen. Mioz. Gastr. a. d. Peelgebiet. p. 93 , pl. 10, fig. 18-28.

1952. Nassa (Hima) tenuistriatum Beyrich sp. Glibert. Faune mal. du Mioc. de la Belgique 2. p. 107, pl. 8, fig. 9.

Essential features of original description. Das Embryonalende ist gross, kegelförmig, aus 3 Windungen. Darauf folgen 3 bis 4 flach gewölbte Mittelwindungen, deren Wölbung fast allein durch die Erhebung der Längsrippen bedingt ist. Diese sind stark, viel schmaler als die Zwischenräume, in allen Windungen von gleicher Zahl, 12 bis 13. Sie werden durchsetzt von 6 schmalen-immer den Zwischenräumen an Breite nachstehenden Querstreifen von welchen die obersten 2 
weiter aus einander stehen als die folgenden. Schlusswindung 12 Querstreifen. Etwa 4 Querstreifen auf dem Rücken des Kammes. Die Mündung hat einen äusseren Wulst, innen 10 kurze ungleiche Leistchen. (BЕYRICH 1854).

Shell material.

\begin{tabular}{|c|c|c|c|c|c|c|c|}
\hline \multirow{10}{*}{$\begin{array}{l}\text { Location } \\
\text { Glejbjerg }\end{array}$} & Depth & & Shells & Location & Dep & & Shells \\
\hline & $23 n$ & & 1 & Gramby & $90.42-92.72$ & $\mathrm{~m}$. & 1 (frg.ef.) \\
\hline & 25 & - & 1 & Toftlund & $75-100$ & - & 112 \\
\hline & 32 & - & 3 & & $100-105$ & - & 7 \\
\hline & $38-$ & - & 1 & & $105-110$ & - & 38 \\
\hline & 42 & - & 1 (frg.cf.) & & $110-115$ & - & 14 \\
\hline & 53.5 & - & 8 & & 115 & - & 8 \\
\hline & 53.75 & - & 4 & Arnum (13) & $53-83$ & - & 5 \\
\hline & 54 & - & 1 (frg.cf.) & & $83-94$ & - & 1 (frg.ef.) \\
\hline & 55 & - & 4 & Arnum (25b) & $62.7-62.9$ & - & 7 (juv. -) \\
\hline Bramminge & $70-80$ & - & 29 & & $95.0-95.3$ & - & 5 \\
\hline Ribe & $120-121$ & & 1 & & $95.0-95.3$ & - & 5 \\
\hline \multirow[t]{2}{*}{ Gramby } & $82.66-83.76$ & - & 11 & & $101-104.3$ & - & 1 (cf.) \\
\hline & $84.66-87.16$ & - & 1 & & $104.3-107.5$ & - & $1-$ \\
\hline
\end{tabular}

Description. Most of the shells are more or less fragmentary.

Protoconch globular, about 3 to $33^{2} / 3$ smooth and glossy whorls. The exposed part of the protoconch was measured in 17 shells from Toftlund $75-100 \mathrm{~m}$ :

\begin{tabular}{|c|c|c|c|c|c|c|c|c|c|}
\hline \multicolumn{2}{|l|}{ Height $(h)$} & 0.65 & 0.85 & 0.81 & 0.84 & 0.87 & 0.82 & 0.74 & $0.87 \mathrm{~mm}$. \\
\hline \multicolumn{2}{|l|}{ Diameter $(d)$} & 0.85 & 1.05 & 0.90 & 0.95 & 1.01 & 0.88 & 0.93 & 0.98 \\
\hline \multicolumn{2}{|l|}{$h / d$} & 0.76 & 0.83 & 0.90 & 0.89 & 0.86 & 0.93 & 0.80 & 0.89 \\
\hline \multicolumn{2}{|c|}{ Number of whorls $(w)$} & 3 & $31 / 2$ & 3 & $31 / 2$ & $31 / 2$ & 3 & $31 / 2$ & $31 / 3$ \\
\hline \multicolumn{2}{|l|}{$d / w$} & 0.28 & 0.30 & 0.30 & 0.27 & 0.29 & 0.29 & 0.27 & 0.30 \\
\hline Height $(h)$ & 0.77 & 0.70 & 0.81 & 0.73 & 0.81 & 0.65 & 0.82 & 0.81 & 0.76 \\
\hline Diameter $(d)$ & 0.94 & 0.81 & 0.81 & 0.96 & 0.95 & 0.81 & 0.97 & 0.95 & 0.93 \\
\hline$h / d$ & 0.82 & 0.87 & 1.0 & 0.76 & 0.85 & 0.81 & 0.84 & 0.85 & 0.82 \\
\hline Number of $\mathrm{x}$ & 9) $3 \frac{1}{2}$ & 3 & 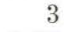 & $3 \frac{1}{2}$ & $31 / 2$ & 3 & $32 / 3$ & $3 \frac{1}{3}$ & $31 / 3$ \\
\hline$d / w$ & 0.27 & 0.27 & 0.27 & 0.27 & 0.27 & 0.27 & 0.27 & 0.29 & 0.28 \\
\hline
\end{tabular}

The mean value of the $d / w$ ratio is 0.28 and the mean value of the $h / d$ ratio is 0.85 .

The table shows that the $h / d$ ratio is rather variable. The variation is mainly related to the position of the suture of the first adult whorl. There are both slender and depressed types of shell with corresponding greater and smaller values of $h$.

Teleoconch. The main morphologic features are shown on the accompanying illustration. It should be added that the number of collabral ribs varies between 12 and 16 per whorl, and in many shells the number increases with about one rib per whorl starting from the protoconch. Four to seven spiral ribs are generally exposed on the whorls. The interspace between the two uppermost spirals is greater than between the lower spiral ribs. The largest almost entire shell, from Toftlund (115 m.), was about $6 \mathrm{~mm}$. high and about $3.5 \mathrm{~mm}$. in diameter.

Remarks. N. tenuistriata seems to be a rather variable species. The writer has not maintained the subdivision into varieties suggested by KAUTSKY, since it is impossible to draw objective limits between the varieties. The species seems to be rather common in the North Sea Basin, while it has not yet been recorded from southern and western Europe. 
Distribution.

Miocene: North Sea Basin: Belgium: Anversien. Holland (m.). Germany: Hemmoor stage. Denmark: Arnum formation.

\title{
144. Nassa serraticosta (Bronn)
}

\author{
Plate 46, fig. 144.
}

1831. Buccinum serraticosta Bronn. Italiens Tertärgebilde, p. 23.

1856. Buccinum serraticosta Bronn. Hörnes. D. foss. Moll. d. Tert.-Beckens v. Wien 1, p. 147, pl. 12, fig. 15 .

1882. Nassa serraticosta Bronn. Bellardi. I moll. d. terr. terz. d. Piemonte e d. Liguria 3, p. 327, pl. 7, fig. 11 .

1911. Nassa (Hima) serraticosta Bronn. sp. Cerulli-Irelli. Fauna mal. mariana, p. 252, pl. 23 , fig. $36-40$.

1925. Nassa (Hima) Rozieri Peyrot. Conch. Néogén. d. l'Aquit. p. 146, pl. 3, fig. 31-33. 1944. Nassa (Hima) serraticosta (Bronn). Van Voorthuysen. Mioz. Gastr. a. d. Peelgebiet. p. 96 , pl. 11, fig. $1-4$.

Original diagnosis. Testa oblongo-turrita, verticaliter costata, costis angustis acutiusculis, area plana interseptis; striis transversis continuis, tenuissimis; anfractibus convexis; labio exteriore extus incrassato, intus striato (BRoNN 1831).

Shell material.

Toftlund $75-100 \mathrm{~m} .8$ shells; $110-115 \mathrm{~m} .1$ shell.

Description.

Protoconch globular, about $3 \frac{1}{2}$ smooth and glossy whorls. Diameter 0.92 to $1.09 \mathrm{~mm}$. Ratio of diameter/number of whorls 0.26 to 0.31 , mean 0.28 . Height of the exposed part of the protoconch 0.70 to $0.85 \mathrm{~mm}$.

Teleoconch. The body whorl has 7 to 10 rather elevated, slightly oblique, collabral ribs, while the initial adult whorl may start with a number of transitional, low and narrow ribs. The number of collabral ribs on the initial whorl varies between 10 and 16 . On the body whorl proper and the canal there are from 21 to 25 relatively narrow spiral ribs which are often obsolete on the collabral ribs. The situation of the suture is rather variable, it may be found as high as the 6th spiral and as low as the 9th spiral of the preceding whorl.

Aperture oviform. Outer lip thickened (varix) with 6 narrow ridges on the inner side. One knob at the upper part of the inner lip, canal short.

Dimensions and number of whorls in 5 shells from Toftlund $(75-100 \mathrm{~m}$.) were:

$\begin{array}{llcc}\text { Height }(H) & \text { Diameter }(D) & H / D & \begin{array}{c}\text { Number of } \\ \text { whorls }\end{array} \\ 5.69 \mathrm{~mm} . & 3.11 \mathrm{~mm} . & 1.83 & 31 / 4 \\ 4.58- & 2.84- & 1.61 & 3 \\ 4.47- & 2.77- & 1.62 & 23 / 4 \\ 3.79- & 2.56- & 1.48 & 21 / 4 \\ 3.0- & 2.05- & 1.46 & 13 / 4\end{array}$

Remarks. The species is rather variable as to protoconch size, number of collabral ribs, and situation of the suture. The shells from South Jutland remind both of VAn Voorthuysen's shells and of Peyrot's shell which, therefore, has 
been included in the synonymy. There is practically no difference between the shell from France and the present shells, and the similarity with CerulLIIRELLI's figured specimens is striking.

Distribution.

Pliocene: Mediterranean Basin: Italy: Pliocene inferiore; upper Pliocene of Monte Mario.

Miocene: Aquitanian Basin: Burdigalien.

North Sea Basin: Holland (m.). Denmark: Arnum formation.

Mediterranean Basin: Italy: Miocene medio and superiore.

Vienna Basin: Baden and Steinabrunn beds.

\section{Nassa bocholtense (Beyrich)}

1854. Buccinum Bocholtense BEYRIch. Die Conchylien etc. p. 136, pl. 8, fig. 1.

1907. Nassa bocholtensis BeyRIch. Ravn. Molluskf. Jyllands Tertiær. p. 316, pl. 5, fig. 5.

1925. Nassa (?Uzita) Bocholtensis Beyr. Kautsky. D. Mioc. v. Hemmoor u. BasbeckOsten. p. 104.

1925. Nassa (Uzita) vulgatissima (Mayer) Peyrot. Conch. Néogén. d. l'Aquit. p. 115, pl. 2, fig. 65-67, 69-71.

1944. Nassa (Telasco) bocholtensis (Beyrich). Van Voorthuysen. Mioz. Gastr. a. d. Peelgebiet. p. 101, pl. 11, fig. 21-24.

1952. Nassa (Hima) bocholtensis Bexrich sp. Gribert. Faune mal. du Mioc. de la Belgique. 2, p. 106, pl. 8 , fig. 8 .

1956. Nassa (Telasco) bocholtensis (Beyrtch). Banke Rasmussen. Upper Mioc. South Jutland. p. 72 , pl. 6 , fig. 5 .

Essential features of original description. Embryonalende von 3 Windungen. Mittelwindungen flach. Die ersten Mittelwindungen 12 bis 15 Längsrippen und 4 schwache Querfurchen, von denen die oberste etwas breiter ist als die folgenden. Schlusswindung: Zahl der Längsrippen bis 20; 10 Querstreifen von der Naht bis zum Kamm. (BEYRICH 1854).

Shell material.

Bramminge 70-80 m. 1 broken shell.

Description.

The Protoconch is worn. Diameter about $0.91 \mathrm{~mm}$., probably about $3 \frac{1}{2}$ smooth whorls.

The Teleoconch has rather flat whorls with 16 to 18 collabral ribs and 5 spiral furrows of which the uppermost is the largest, as mentioned by BEYRICH. Body whorl not preserved.

Remarks. There can hardly be any doubt as to the reference of this fragmentary shell to $N$. bocholtensis. $N$. vulgatissima described by РeYrot is certainly identical with $N$. bocholtensis. Characteristically there is no significant difference between the shell descriptions given by Peyrot and Beyrich.

Distribution.

Miocene: Aquitanian Basin: Burdigalien, Helvétien.

North Sea Basin: Belgium: Anversien. Holland (m.).

Germany: Hemmoor stage, Reinbek stage (Gottsche 
1878), Glimmerton (Banke Rasmussen 1956). Denmark: Arnum and Gram formations.

\section{Nassa turbinella (Brocchi)}

Plate 45, fig. 146.

1814. Buccinum turbinellus BRocchr. Conchiol. Foss. Subapennina. 2, p. 653, pl. 15, fig. 17. 1856. Buccinum turbinellus Brocchr. Hörnes. D. foss. Moll. d. Tert.-Beckens v. Wien 1, p. 150, pl. 12, fig. 17.

1882. Nassa turbinellus Brocchi. Bellardr. I moll. d. terr. terz. d. Piemonte e d. Liguria 3 , p. 338 , pl. 8 , fig. 5 .

1925. Nassa (?Uzita) turbinellus BrocchI. KAUtsky. D. Mioc. v. Hemmoor u. BasbeckOsten, p. 103, pl. 8, fig. 2.

1925. Nassa (Telasco?) turbinella (Brocchi). Peyrot. Conch. Néogén. d. l'Aquit. p. 175, pl. 3, fig. 94-96.

1944. Nassa (Telasco) turbinella (Brocchi). Van Voorthuysen. Mioz. Gastr. a. d. Peelgebiet. p. 100, pl. 11, fig. 17-20.

Original diagnosis. Testa oblonga, longitudinaliter costulata, transversim striata, anfractubus complanatis, margine suturali plicato, linea excavata succincto. (BRocCHI 1814).

Shell material. Toftlund $75-100 \mathrm{~m} .9$ shells of which 3 are rolled.

Description. Six of the shells have well preserved sculptural features, but only the figured specimen has an entire aperture.

Protoconch globular, about $3^{1 / 3}$ to 4 smooth and glossy whorls. Diameter 0.92 to $1.15 \mathrm{~mm}$. Ratio of diameter/number of whorls about 0.29 (range 0.27 to 0.30 ). Height of exposed part of protoconch 0.76 to $1.08 \mathrm{~mm}$.

Tele o c o c $\mathrm{h}$. The initial whorl often starts with $2-5$ relatively faint collabral ribs on about $1 / 8$ to $1 / 4$ of the whorl. Thereafter there are about 9 to 12 strong collabral ribs per whorl crossed by about 3 to 5 distinct, but relatively narrow spiral ribs. The upper spiral rib forms pointed knobs or low spines on erossing the collabral ribs, and above this sutural spiral the whorl forms a narrow shelf. The wall of the whorl is almost vertical below the sutural spiral.

The body whorl has 13 to 16 spiral ribs. The aperture has a thickened outer lip, on the inside of which there are 6 knobs. Three similar knobs are found on the inner lip: one at the upper edge and two on the basal part.

The dimensions of the figured specimen are: height $5.35 \mathrm{~mm}$., diameter $2.90 \mathrm{~mm}$. This shell has 3 adult whorls.

Remarks. This species differs from $N$. Fuchsi by its stronger shell and by the spiral ribs which have a distinct relief. $N$. Fuchsi should accordingly not be included in the synonymy of this species, which was done erroneously by VAN VoORTHUYSEN (1944).

Distribution.

Pliocene: Mediterranean Basin: Italy: Pliocene inferiore.

Miocene: Aquitanian Basin: Burdigalien.

North Sea Basin: Holland (m.): Germany: Hemmoor stage. Denmark: Arnum formation.

Mediterranean Basin: Italy: Miocene superiore. Vienna Basin: Steinabrunn. 


\section{Nassa Fuchsi von Koenen}

Plate 44, fig. 147.

?1854. Buccinum Schlotheimi Beyrich. Die Conchylien ete. p. 134, pl. 7, fig. 8.

1872. Nassa Fuchsi von Koenen. D. Nordd. Mioc. u. s. Moll. f. p. 193.

1907. Nassa Fuchsi von Koenen. Ravn. Molluskf. Jyll. Tert. p. 315, pl. 5, fig. 2.

Essential features of original description. Embryonalende von nur reichlich zwei Windungen. Die Spiralfurchen erscheinen zwischen den Rippen wie eingeritzt und werden nur unten auf der Schlusswindung deutlicher. Gewinde fast eben; die Aussenilippe trägt 5 Zähne, die Innenlippe bis zu 3 Falten. (von KoEnen $1872)$.

Shell material.

$\begin{array}{lrrlrr}\text { Location } & \text { Depth } & \text { Shells } & \text { Location } & \text { Depth } & \text { Shells } \\ \text { Glejbjerg } & 38 \mathrm{~m} & 2 & \text { Gramby } & 82.66-83.76 \mathrm{~m} . & 10 \\ & 48- & 1 & \text { Toftlund } & 84.66-87.16- & 1 \\ & 52- & 1 & 75-100- & 51 \\ & 53- & 1 & & 100-105- & 18 \\ & 53.5- & 182 & & 105-110- & 179 \\ \text { Bramminge } & 53.75- & 94 & & 110-115- & 78 \\ \text { Ribe } & 54- & 10 & & 115- & 76 \\ & 55- & 37 & \text { Arnum (13) } & 53-83- & 9 \\ & 70-80- & 139 & & 83-94- & 3 \\ & 113-114- & 5 & \text { Arnum (25b) } & 95.0-95.3 & 26 \\ & 114-115- & 1 & & 101.0-104.3- & 2 \\ 121-122- & 1 \text { (frg.) } & & 104.3-107.5- & 65 \\ & 122-123- & 1 & & 107.5- & 1 \text { (frg.) } \\ 123-124- & 1 & & & \end{array}$

Description. Many of the shells are broken as the test is rather fragile. Only very few of the shells have an entire aperture.

Protoconch globular, rather large, about $23 / 4$ to $33 / 4$ smooth and glossy whorls. Twenty of the shells from Glejbjerg $53.5 \mathrm{~m}$. were measured. The diameter of their protoconchs varies from 0.68 to $1.09 \mathrm{~mm}$., with a mean value of 0.88 $\mathrm{mm}$. The ratio of diameter/number of whorls ranges from 0.23 to 0.29 , with a mean of 0.27 .

The height of the exposed part of the protoconch, in the following called the height, depends on the number of whorls and on the situation of the upper suture of the first adult whorl. This height is accordingly rather variable, and of less significance than the diameter. The smallest protoconch measured had $23 / 4$ whorls and was $0.57 \mathrm{~mm}$. high, while the largest had $33 / 4$ whorls and was 0.88 mm. high.

Teleoconch. Shell surface generally smooth and glossy. The first adult whorl starts commonly with 5 or 6 rather shallow, curved, collabral ribs. Hereafter these ribs get more elevated, and a sutural spiral rib, with a corresponding spiral furrow below, emerges at the upper suture forming knobs or low spines on crossing the collabral ribs. The interspace between the ribs is either smooth, or there are 5 or 6 fine, rather indistinct spiral grooves on the whorls of the spire. The body whorl has about 15 to 20 spiral grooves of which those on the base of the shell are generally deep and distinct.

The number of collabral ribs is 14 to 18 on the first adult whorl, while there are 11 to 16 on the second and third whorls. Only very few of the shells have more than three whorls; they suggest however that the number of ribs per whorl increases somewhat with the size of the shell. 
One aperture from Glejbjerg $(53.5 \mathrm{~m}$.) shows a thickened outer lip with 13 narrow ridges on its inner side. There is one knob on the upper part of the inner lip and two at the lower end of the columella.

The largest entire individual from Glejbjerg (53.5 m.) is $6.6 \mathrm{~mm}$. high, $3.5 \mathrm{~mm}$. in diameter, and it consists of $41 / 2$ adult whorls.

Remarks. N. Fuchsi seems to be a rather characteristic shell. The smooth, glossy and rather thin test is certainly different from that referred to $N$. turbinella above. It should also be noticed that the protoconch is apparently smaller in N.Fuchsi than in N.turbinella. More material of the latter species is, however, needed before this can be verified. The differences between $N$. Fuchsi and N. Schlotheimi are discussed on p. 218.

Distribution.

Miocene: North Sea Basin: Germany: (?) Reinbek stage (GotтSCHE 1878). Denmark: Arnum formation.

Vienna Basin: Baden beds. (acc. to von Koenes 1872).

\section{Nassa Schlotheimi (Beyrich)}

Plate 45 , fig. 148 .

1854. Buccinum Schlotheimi Beyrich. Die Conchylien ete. p. 134, pl. 7, fig. 7, 9.

1907. Nassa Schlotheimi Beyrich. Ravn. Molluskf. Jyll. Tert. p. 314, pl. 5, fig. 3.

1913. Nassa Schlotheimi Beyrich. Harder. De olig. Lag etc. Aarhus St. p. 76, pl. 6, fig. 4-5.

1914. Nassa Schlotheimi Beyrich. Gripp. Über eine u. mioz. Mollf. v. Itzehoe, p. 19, pl. 2, fig. 8-12.

1916. Nassa Schlotheimi Beyrich. Nørregand. Mellem-mioc. Blokke Esbjerg, p. 26.

1925. Nassa (Telasco) Schröderi Kautsky. D. Mioc. v. Hemmoor u. Basbeck-Osten. p. 109, pl. 8, fig. 11 .

1925. Nassa (Telasco) Neuvillei Pexrot. Conch. Néogén. d. l'Aquit. p. 174, pl. 3, fig. 90-93. 1940. Nassa (Telasco) Schlotheimi Beyrich. Sorgenfrei. Mar. Nedre-Mioc. i Klintinghoved p. Als. p. 44 , pl. 6 , fig. 6 .

1944. Nassa (Telasco) Schröderi Kautsky. Van Voonthuysen. Mioz. Gastr. a. d. Peelgebiet. p. 102, pl. 11, fig. 25-28.

Essential features of original description. "Das Gewinde hat ein grosses kegelförmiges Embryonalende und bis 4 Mittelwindungen. Diese sind sehr flach gewölbt bis ganz flach, und haben stets einen mehr oder minder deutlich ausgebildeten sehr schmalen Absatz an der oberen Naht. Längsrippen von sehr verschiedener Zahl (Mittel etwa 20) sind verbunden mit Querlinien oder schmalen Furchen, welche meist nur wenig in die ersteren einschneiden, mit Ausnahme von gewöhnlich nur einer etwas tieferen Furche unter dem oberen Absatz, welcher das Ansehn eines leicht gekörnten Saumes erhalten kann. (BEYRICH 1854).

Shell material.

$\begin{array}{lrrlrr}\text { Location } & \text { Depth } & \text { Shells } & \text { Location } & \text { Depth } & \text { Shells } \\ \text { Glejbjerg } & 23 \mathrm{~m} & 20 & \text { Ribe } & 113-114 \mathrm{~m} . & 1 \\ & 25- & 15 & \text { Gramby } & 81.86-82.16- & 2 \\ & 32- & 19 & & 82.66-83.76- & 15 \\ & 38- & 3 & & (82.66-83.76- & 79) \\ & 42- & 27 & & 84.66-87.16- & 82 \\ & 52- & 1 & 90.42-92.72- & 23 \\ \text { Bramminge } & 53.5- & 3 & & 92.72-109.29- & 6 \\ & 70-80- & 417 & & 109.29-110.86- & 12\end{array}$




$\begin{array}{lrrlrr}\text { Location } & \text { Depth } & \text { Shells } & \text { Location } & \text { Depth } & \text { Shells } \\ \text { Gramby } & 110.86-121.56 \mathrm{~m} & 1 & \text { Arnum (13) } & 53-83 \mathrm{~m} . & 226 \\ \text { Toftlund } & 75-100- & 612 & & 83-94- & 10 \\ & 100-105- & 218 & \text { Arnum (25b) } & 62.7-62.9- & 165 \\ & 105-110- & 306 & & 95.0-95.3- & 67 \\ & 110-115- & 123 & & 101.0-104.3- & 1 \\ \text { Arnum (13) } & 115- & 140 & & 104.3-107.5- & 15 \\ & 28-40- & 38 & & 107.5- & 7\end{array}$

Description.

Protoconch globular with about $23 / 4$ to $3 \frac{1}{2}$ smooth and glossy whorls. The exposed part of the protoconch was measured on 35 shells from Toftlund $(75-100 \mathrm{~m}$.$) and the following ranges and mean values were obtained:$

$\begin{array}{lcccc} & \text { Number of whorls } & \text { Diameter } & \text { Height of exposed } & \\ & (w) & (d) & \text { protoconch } & d / w \\ \text { Maximum } & 3^{3 / 4} & 0.945 \mathrm{~mm} . & 0.852 \mathrm{~mm} . & 0.274 \\ \text { Minimum } & 2^{3 / 4} & 0.697- & 0.620- & 0.233 \\ \text { Mean value } & 3.2 & 0.818- & 0.730- & 0.256\end{array}$

Teleoconch. The sculpture of the shells from South Jutland is very variable. The relief of the collabral ribs as well as of the spiral grooves varies from conspicuous to rather poor. Forty of the shells from Toftlund $(75-100 \mathrm{~m}$.) were investigated statistically for the number of collabral ribs per whorl. The results are shown below. It should be noticed, however, that only 6 of the shells had more than 4 whorls. The figures for the fourth whorl are accordingly not very reliable, and are therefore shown in parenthesis.

\begin{tabular}{lrrrr} 
& \multicolumn{4}{c}{ Number of collabral ribs on whorl no: } \\
Maximum & 1 & 2 & 3 & 4 \\
Minimum & 26 & 22 & 31 & $(27)$ \\
Mean value & 19.73 & 17.90 & 14 & $(17)$ \\
& 16.23 & $(23.12)$
\end{tabular}

The first whorl has a greater number of ribs than the second. This is associated with the more closely spaced initial ribs which emerge immediately after the termination of the protoconch. The mean values indicate that the number of ribs per whorl increases with growth after the second adult whorl.

From 14 to 19 spiral grooves have been counted on the body whorl. They are often quite obsolete on the upper half of the whorl, except for the strong spiral groove below the suture. The suture is formed at about the 7 th to 9 th spiral groove of the preceding whorl. The outer lip of the aperture is thickened and has 6 to 9 knobs or ridges on the inner side. There is one knob at the upper end of the inner lip, and 1 or 2 knobs or ridges at the base of the columella. The lower of these ridges on the columella, if developed, is found on the edge to the canal, or a little above it.

Variability. The variation of the sculpture has been mentioned above. The variation of the shape of the shell has been checked by a statistical treatment of measurements of height $(H)$ and diameter $(D)$ on 115 shells from Toftlund $(75-100 \mathrm{~m}$.$) .$

The $H / D$ ratio, being a measure of the slenderness of the shell, was calculated, and the mean value of $H / D$ was determined for the entire material and also for 3 size groups based on shell heights as follows : $2.21-3.80 \mathrm{~mm}$. (group A), $3.81-4.60 \mathrm{~mm}$. (group $B$ ), and above $4.61 \mathrm{~mm}$. (group $C$ ). The values obtained were: 
Group

Nassa Schlotheimi $H \mid D$ ratio.

Total shell material

$(A+B+C)$
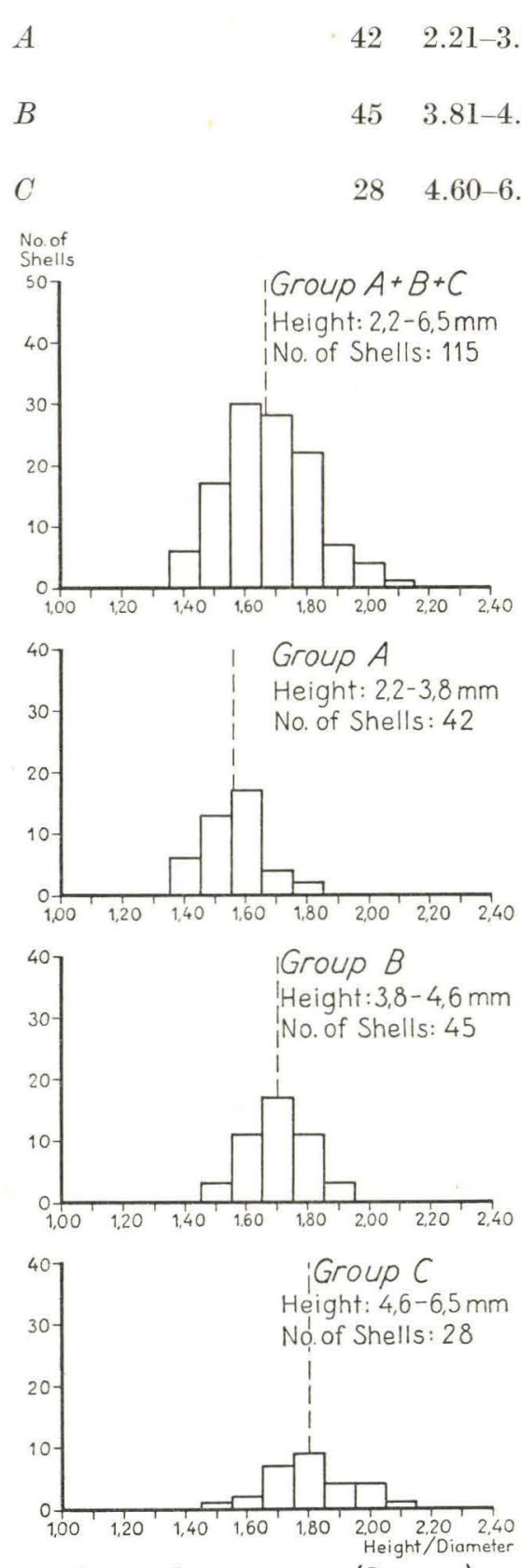

Fig. 14. Nassa Schlotheimi (BEYRICH) Toftlund 75-100m
$H / D$ mean values Entire range of $H / D$ Number of
specimens

$115 \quad 2.21-6.50 \mathrm{~mm} . \quad 1.6739 \pm 0.0416\left\{\begin{array}{l}1.7155 \\ 1.6323\end{array}\right.$

$1.54-2.08$

The graph fig. 14 shows the frequency of the different $H / D$ values. This graph and the mean values of $H / D$ illustrate the change of $H / D$ with size (i.e. with growth) of the species.

The conclusion is that $N$. Schlotheimi increases both its number of ribs per whorl*) and its $H / D$ ratio with growth.

Remarks. The variability of this species makes the validity of $N$. Schröderi very doubtful. The writer accordingly suggests the abandonment of $N$. Schröderi.

It is a question whether the shells referred to as $N$. Schlotheimi by VAN VOORTHUYSEN (1944, p. 103, pl. 11, fig. 29-34) really belong to BEYRICH's species. The shells were thoroughly examined by the writer during a stay at the Geologische Stichting at Harlem in 1947, and the problems concerned were discussed with Dr. VAN VoorThuYsen. $\mathrm{He}$ finally agreed concerning a closer morphological relationship between his $N$. Schlotheimi and N. bocholtensis than between his $N$. Schlotheimi and N. Schröderi. My final decision was to include N. Schröderi from Holland in the synonymy of $N$. Schlotheimi, while VAN Voorthuysen's N. Schlotheimi is considered to differ from BEYRICH's species; it may be referred to $N$. bocholtensis or an allied species.

It is often very difficult to distinguish juvenile shells of N. Schlotheimi and $N$. Fuchsi from each other. It should be stated, therefore, that $N$. Schlotheimi

*) With reservation for whorl no. 1 as pointed out above. 
has a smaller protoconch and more collabral ribs per whorl than N. Fuchsi. Furthermore, the sutural spiral of $N$. Fuchsi generally projects more than the corresponding part of the shell lying above the uppermost spiral furrow in N. Schlotheimi.

Distribution.

Miocene: Aquitanian Basin: Burdigalien.

North Sea Basin: Holland (m.) Germany: Vierlande and Hemmoor stages, Denmark: Klintinghoved clay and Arnum formation.

Oligocene: North Sea Basin: Germany (u.). Denmark(u.).

\section{Nassa holsatica (Beyrich)}

Plate 48, fig. 149 .

1854. Buccinum Holsaticum Beyrich. Die Conchylien etc. p. 137, pl. 7, fig. 11.

?1882. Nassa clathurella Bellardi. I moll. d. terr. terz. d. Piemonte e d. Liguria 3, p. 345, pl. 8, fig. 14.

?1904. Nassa clathurella Bellardi. Sacco. Ibid. 30, p. 69, pl. 16, fig. 35-39.

1944. Nassa (Telasco) holsatica (Beyrich). VAN Voorthuysen. Mioz. Gastr. a. d. Peelgebiet. p. 105 , pl. 12, fig. 8-11.

Essential features of original description. Das Embryonalende ist gross und hat 3 Windungen. Die Mittelwindungen haben zahlreiche (über 20) Längsrippchen, welche von feinen schmalen, allmähtich breiter werdenden Querlinien durchschnitten werden. Die Querlinien zeigen sich unter dem Embryonalende etwas früher als die Längsrippen. Zahl (der Streifen zwischen den Querlinien auf der Schlusswindung) 15 bis 1\%. Die Mündung hat einen schwach verdickten Aussenrand, innen 10 bis 12 schwache Leistchen; die Spindelplatte tritt in bogenförmiger Ausbreitung über den Rand der Mündung vor. (ВEYRICH 1854).

Shell material.

$\begin{array}{lrc}\text { Location } & \text { Depth } & \text { Shells } \\ \text { Bramminge } & 70-80 \mathrm{~m} . & 12 \\ \text { Toftlund } & 75-100- & 2 \\ \text { Arnum (13) } & 53-83- & 1\end{array}$

Description. The shell material is very fragmentary: Two almost entire shells were found in the material from Bramminge, but they are rather rolled.

Protoconch globular, 3 to $3 \frac{1}{2}$ smooth whorls. Diameter 0.93 to $1.05 \mathrm{~mm}$. Ratio of diameter/number of whorls about 0.3 .

Teleoconch. About 20 to 25 more or less distinct collabral ribs per whorl which are cut by relatively deep spiral grooves dividing the shell surface into 13-14 spiral ribs on the body whorl.

The suture is formed between the 5th and the 7th spiral rib of the preceding whorl. Aperture oviform with slightly thickened outer lip, on the inside of which there are 9 to 10 ridges. No knobs on the columella. The inner lip is thickened but otherwise smooth. The grooves between the first and second, and second and third spirals from the suture are often wider than the other grooves. The dimensions of the two entire shells from Bramminge, which both have about 3 adult whorls, are:

$\begin{array}{ll}\text { Height } & \text { Diameter } \\ 5.5 \mathrm{~mm} . & 3.15 \mathrm{~mm} . \\ 4.46- & 2.62-\end{array}$


Remarks. N. Clathurella of BeLlardi is probably identical with $N$. holsatica. The writer has not recognized any differences in the shell morphology which he would consider of specific significance. It should also be noted that BELLARDI's diagnosis agrees almost perfectly with the above quotation from Beyrich's description of $N$. holsatica.

Distribution.

Miocene: North Sea Basin: Holland (m.). Germany: ReinbekDingden stage, Glimmerton (Banke Rasmussen 1956). Denmark: Arnum formation.

Mediterranean Basin: Italy: Miocene medio.

\section{Nassa Facki von Koenen}

Plate 47, fig. 150 .

1854. Buccinum labiosum Sow. Berrich. Die Conchylien etc. p. 140, pl. 8, fig. 5 .

1872. Nassa Facki v. Koenen. D. Nordd. Mioc. u. s. Mollf. p. 199, pl. 2, fig. 4.

1907. Nassa Facki v. Koenen. Ravn. Molluskf. Jyll. Tert. p.317.

1916. Nassa Facki v. Koenen. Nørregand. Mellem-mioc. Bl. Esbjerg, p.26, pl. 3, fig. 5. 1925. Nassa (Amycla) Facki v. Koenen. Kautsky. D. Mioc. v. Hemmoor u. BasbeckOsten, p. 108.

1944. Nassa (Amycla) Facki v. Koenen. Van Voonthuysen. Mioz. Gastr. a. d. Peelgebiet. p. 98 , pl. 9, fig. 22-26.

1952. Nassa (Amyclina) Facki v. Koenen. Glibert. Faune mal. du Mioe. de la Belgique. 2 , p. 105 , pl. 8 , fig. 7 .

Essential features of original description. Vier glatte Embryonalwindungen. 6 bis 8 Spiralfurchen auf den Mittelwindungen. Diese Spiralfurchen sind stets viel schmaler als ihre Zwischenräume. (von Konnen 1872).

Shell material.

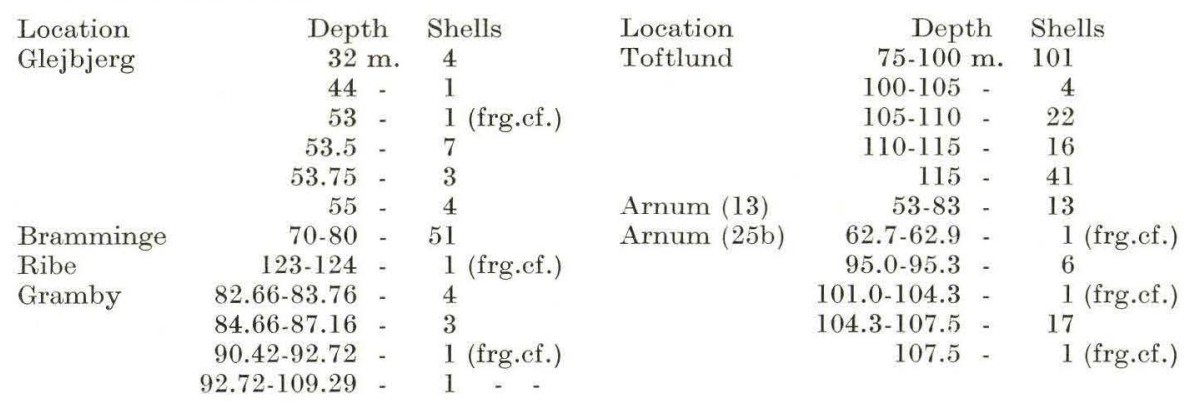

Description. Most of the shells are more or less fragmentary. The protoconch is, however, preserved in the bulk of the material.

Protoconch globular. Number of whorls $(w) 3$ to $33 / 4$. Shell surface smooth and glossy. The protoconch diameter $(d)$ was measured in 20 specimens from Toftlund $(75-100 \mathrm{~m}$.) and the $d / w$ ratios were afterwards calculated. Also the height $(h)$ of the exposed part of the protoconch was measured. The results obtained were as follows: 


$\begin{array}{lcccc} & \begin{array}{c}\text { Number of whorls } \\ (w)\end{array} & \begin{array}{c}\text { Diameter } \\ (d)\end{array} & \begin{array}{c}\text { Height of exposed } \\ \text { protoconch }(h)\end{array} & d / w \\ \text { Maximum } & 33 / 4 & 1.10 \mathrm{~mm} . & 0.96 \mathrm{~mm} . & 0.31 \\ \text { Minimum } & 3 & \left.0.93-{ }^{*}\right) & 0.65- & 0.28 \\ \text { Mean value } & 3.4 & 1.00- & 0.81- & 0.29\end{array}$

Teleoconch. Slightly convex whorls with spiral grooves in which the growth lines appear as delicate, elevated ridges. The spiral grooves are accordingly punctuate if typically developed, as known in several Opisthobranchs such as Actaeon, Roxania etc. The grooves are obsolete in several specimens, and are then simple lines in the shell surface without punctuations.

The body whorl has 14 to 17 spiral grooves on the whorl proper and occasionally 4 to 7 narrow ribs on the canal. The width of the grooves increases considerably on the whorl base where the interspaces between the grooves display relatively strong ribs. The canal is sometimes almost smooth. The aperture has a thickened outer lip with a dentition of up to 15 narrow ridges on the inside in fully developed shells. The inner lip is generally well defined, rather thick and smooth, but an indistinct knob has been observed both on the upper and lower parts of the columella in a single shell (Toftlund $115 \mathrm{~m}$ ).

The suture develops in the interval between the 6th and 8th groove of the preceding whorl.

Height $(H)$ and diameter $(D)$ were measured in the few well preserved shells found:

$$
\begin{aligned}
& \text { Number of adult } \\
& \text { whorls }
\end{aligned}
$$

$\begin{array}{ll}\text { Toftlund } 75-100 \mathrm{~m} . & 2 \\ & 21 / 2 \\ & 3 \\ \text { Toftlund } 115 \mathrm{~m} . & 4\end{array}$

$$
\text { Height }
$$

$3.71 \mathrm{~mm}$.

$4.34-$

$5.45-$

6.64
Diameter

(D) $\quad H / D$

$\begin{array}{ll}2.29 \mathrm{~mm} . & 1.62 \\ 2.42- & 1.80 \\ 3.08- & 1.77 \\ 3.76- & 1.77\end{array}$

Remarks. This species is rather similar to N. semistriata BRoccHI (1814, p. 651 , pl. 15, fig. 15) but differs from it by the complete absence of collabral ribs even on the initial whorls. There seems to be a close morphologic relationship with N. oblita Bellardi (Bellardi 1882, p. 369, pl. 9, fig. 23 and Peyrot 1925 , p. 165, pl. 2, fig. 111-113), and it is impossible to find significant differences between this species and N. Facki comparing by the descriptions and illustrations published by BELLARdi and Peyrot.

Regarding differences and similarities with $N$. laevissima BRUsINA reference is made to the description of this species below.

\section{Distribution.}

Miocene: North Sea Basin: Belgium: Boldérien, Anversien. Holland (m.). Germany: Hemmoor, and Reinbek stages, Glimmerton (Banke Rasmussen 1956). Denmark: Arnum formation.

\footnotetext{
*) A pathologic specimen has a diameter of $0.84 \mathrm{~mm}$. It has been included in the calculation of the mean value, but it is misleading as an expression of the normal minimum value.
} 


\section{Nassa laevissima Brusina}

Plate 48, fig. 151 a-c.

1877. Nassa laevissima Brusina. Fragm. Vindobonensia p. 375.

1882. Buccinum Laevissimum Brus. Hoernes \& Auinger. 1. u. 2. Mioc. Mediterr. St. p. 123 , pl. 15, fig. 21 .

1944. Nassa (Amycla) cf. laevissima Brusina. Van Voorthuysen. Mioz. Gastr. a. d. Peelgebiet. p. 99, pl. 9, fig. 27-29.

Essential features of original description. Sommet complètement lisse. Dernier tour légèrement anguleux. La base possède des sillons profonds et occupant environt $1 / 3$ du dernier tour. (BRUSINA 1877).

Shell material.

Location
Bramminge
Toftlund
Arnum

$\begin{array}{cc}\text { Depth } & \text { Shells } \\ 70-80 \mathrm{~m} . & 12 \\ 75-100- & 10 \\ 53-83- & 4\end{array}$

Description. Shell material rather fragmentary, but shell features well preserved in the shells from Toftlund and Arnum.

Protoconch conical, with slightly heterostrophe nucleus, and convex, smooth and glossy whorls. Number of whorls $(w): 33 / 4$ to $4 \frac{1}{4}$. The protoconch diameter $(d)$ and height $(h)$ of the exposed part of the protoconch were measured in the 10 shells from Toftlund, and the $d / w$ ratio was calculated. The following table gives the results:

$\begin{array}{lcccc} & \begin{array}{c}\text { Number of } \\ \text { whorls }(w)\end{array} & \begin{array}{c}\text { Diameter } \\ (d)\end{array} & \begin{array}{c}\text { Height of exposed } \\ \text { protoconch }(h)\end{array} & d / w \\ \text { Maximum } & 41 / 4 & 1.07 \mathrm{~mm} . & 0.93 \mathrm{~mm} . & 0.25 \\ \text { Minimum } & 33 / 4 & 0.88- & 0.76- & 0.22 \\ \text { Mean value } & 4.0 & 0.97- & 0.83- & 0.24\end{array}$

Teleoconch with rather flat whorls. Initial whorls with faint spiral grooves in which the growth lines occasionally appear as microscopical ridges. The spiral grooves are generally obliterated on later whorls except for one or two spiral grooves adjacent to the upper suture. The body whorl is subangular at its periphery. On the base there are relatively strong spiral ribs which also extend onto the canal. The ribs on the canal are similar to those on the whorl base.

The aperture has a thickened outer lip, on the inside of which 10 narrow ridges have been observed in full grown stages. The inner lip is callous and smooth, and projects considerably in front of the outer lip. The suture is formed almost at the periphery of the preceding whorl (between the 6th and 8th spiral groove when present).

The dimensions of the entire shells present were the following:

$\begin{array}{lccccc}\text { Location } & \text { Depth } & \begin{array}{c}\text { Number of adult } \\ \text { whorls }\end{array} & \text { Height }(H) & \text { Diameter }(D) & H / D \\ \text { Toftlund } & 75-100 \mathrm{~m} . & 13 / 4 & 2.92 \mathrm{~mm} . & 1.85 \mathrm{~mm} . & 1.58 \\ \text { Bramminge } & 70-80- & 2 & 3.71- & 2.29- & 1.62 \\ & & 2 & 3.79- & 2.34- & 1.62 \\ & & 3 & 4.66- & 2.84- & 1.64 \\ & & 4.90- & 3.16- & 1.55\end{array}$


Remarks. These shells were originally included in N. Facki because they were not recognized as being different. By comparison with the description of N. Facki, the following features are considered of significance as discriminating criteria:

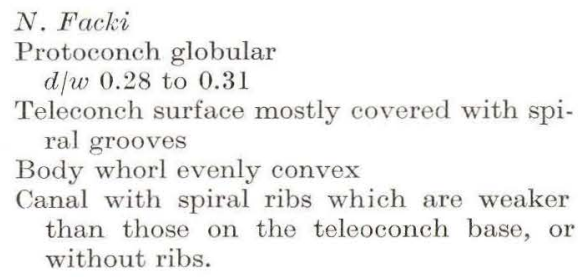

Teleconch surface mostly covered with spiral grooves

Body whorl evenly convex

Canal with spiral ribs which are weaker than those on the teleoconch base, or without ribs.

\section{N. laevissima \\ Protoconch conical d/w 0.22 to 0.25}

Teleoconch surface mostly smooth with only 1 or 2 spiral grooves at upper suture Body whorl subangular

Canal with spiral ribs as strong as those found on the teleoconch base.

\section{Distribution.}

Miocene: North Sea Basin: Holland (m.). Denmark: Arnum formation.

Vienna Basin: Baden beds.

\section{Nassa cavata Bellardi}

1882. Nassa cavata Bellardi. I moll. d. terr. terz. d. Piemonte e d. Liguria. 3, p. 329, pl. 7 , fig. 15 .

1944. Nassa (Hima) cavata Bellardi. Van Voorthuysen. Mioz. Gastr. a. d. Peelgebiet. p. 97 , pl. 11, fig. 11-16.

Original diagnosis. Spira magis aperta.-Anfractus pauciores, 4, a suturis profundioribus separati.-Costae longitudinales minores, compressae, ab interstitiis latioribus separatae: costulae transversae pauciores, 5 in primis et in mediis anfractubus, 9 in ultimo, filiformes, a sulcis latissimis separatae, in intersecatione costarum longitudinalium subspinosae.- Os brevius, orbiculare: rima a labiis subnullis circumscripta. (BELLARDI 1882).

Shell material.

\begin{tabular}{|c|c|c|c|c|c|}
\hline Location & Depth & Shells & Location & Depth & Shells \\
\hline Bramminge & $70.80 \mathrm{~m}$. & 2 & Toftlund & $115 \mathrm{~m}$. & 12 \\
\hline Toftlund & $75-100-$ & 1 (ef.) & Arnum (25b) & $62.7-62.9-$ & 4 (cf.) \\
\hline & $105-110-$ & 7 & & $95.0-95.3 \quad-$ & 1 \\
\hline & 110-115 - & 25 & & $104.3-107.5-$ & 7 (cf.) \\
\hline
\end{tabular}

Description. A few shells are entire and well preserved.

Protoconch globular, 3 to $3 \frac{1}{2}$ smooth and glossy whorls. The following table illustrates the size and variation range of 9 shells from Bramminge (70$80 \mathrm{~m}$.$) and Toftlund (105-110 m., and 110-115 m.):$

$\begin{array}{lcccc} & \begin{array}{c}\text { Number of whorls } \\ (w)\end{array} & \begin{array}{c}\text { diameter } \\ (d)\end{array} & \begin{array}{c}\text { Height of exposed } \\ \text { protoconch }(h)\end{array} & d / w \\ \text { Maximum } & 31 / 2 & 0.84 \mathrm{~mm} . & 0.79 \mathrm{~mm} . & 0.25 \\ \text { Minimum } & 3 & 0.70- & 0.65- & 0.23 \\ \text { Mean value } & 3.33 & 0.79- & 0.70- & 0.24\end{array}$


Teleoconch with rather flat whorls on which there are 10 to 14 elevated collabral ribs per whorl. The ribs are crossed by spirals which are very faint in the interspaces, but they generally form knobs or low spines on crossing the ribs. Twelve shells have been particularly studied for the number of spirals. It

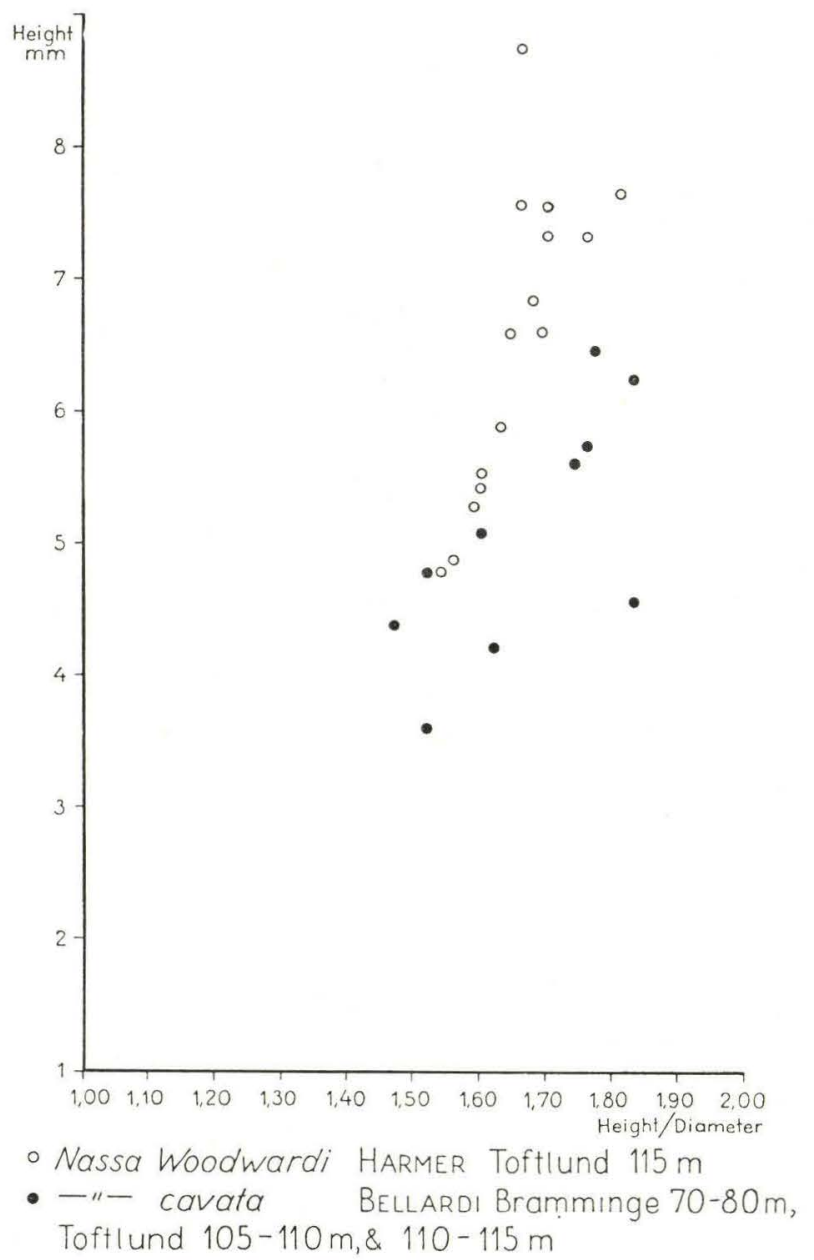

Fig. 15.

appeared that the number varies between 10 and 11 on the body whorl proper, while the ribs on the canal are subject to greater variation. There are shells with an almost smooth canal, while others bear as many as 7 spiral ribs on the canal. The whorls above the body whorl have from 4 to 6 spirals exposed on the spire.

The aperture has a thickened outer lip on the inside of which there are 4 to 6 knobs or ridges. There is generally a knob on the columella at the posterior canal and another is occasionally found at the base.

The dimensions of the largest shell measured were: 
height $(H) 5.44 \mathrm{~mm}$., diameter $(D) 3.08 \mathrm{~mm}$. The $H / D$ ratio was calculated for 10 shells, it varies between 1.47 and 1.83, and is illustrated on the diagram fig. 15.

Remarks. Some variants of this species are difficult to distinguish from $N$. Woodwardi described in the following. $N$. cavata is obviously also similar to N. verrucosa Brocchi (see Brocchi 1814, p. 650, Bellardi 1882. 3, p. 331, pl. 7, fig. 17, GLIBERT 1952 (Loire) 2, p. 340, pl. 10, fig. 5). With respect to criteria separating $N$. cavata and $N$. Woodwardi reference is made to the description of the latter species below. It is not possible to make an acurate statement of differences between $N$. cavata and $N$. verrucosa, since statistical data on $N$. verrucosa are not available.

Distribution.

Pliocene: Mediterranean Basin: Italy: Pliocene inferiore.

Miocene: North Sea Basin: Holland (m.). Denmark: Arnum formation.

Mediterranean Basin: Italy: Miocene superiore.

\section{Nassa Woodwardi Harmer}

Plate 49, fig. 153 .

1913. Nassa Woodwardi Harmer. Plioc. Moll. 1, p. 83, pl. 5, fig. 20-21, pl. 13, fig. 18. 1925. Nassa (Phrontis) Woodwardi Harmer. Kautsky. D. Mioc. v. Hemmoor u. BasbeckOsten. p. 105, pl. 8, fig. 5-7.

Essential features of original description. Shell small, strong, whorls flat, rapidly and regularly diminishing in size, the last much the largest, ornamented by about 12 straight nodular ribs, continuous except as interrupted by the suture, crossed by inconspicuous spiral striae. Mouth ovate, with a labial notch above, and a tooth on the left side; outer lip thickened outside, denticulated within; canal very short. (HARMer 1913).

Shell material.

Toftlund 110-115 m.: 3 shells, 115 m.: 39 shells.

Description. The shells are generally well preserved since they have a very strong test. However, the protoconch is worn off on most specimens.

Protoconch globular with smooth whorls. The number of whorls, and therefore the size of the protoconch, varies rather much if allowance is made for the few (10) shells examined, of which several are rather worn and display the shell features indistinctly. Minimum size is $23 / 4$ whorls and maximum $31 / 2$ whorls. The diameter varies between 0.99 and $0.67 \mathrm{~mm}$., and the ratio of diameter/number of whorls ranges from 0.28 to 0.24 , with a mean of 0.26 .

Teleoconch. Twenty shells have been treated statistically for all measurable morphologic features. It appears that there are 11 to 14 strong collabral ribs on the first whorl, 11 to 15 ribs on the second whorl, 12 to 16 on the third whorl and 14 to 16 on the fourth whorl. The spiral ribs, which are inconspicuous in the interspaces between the collabral ribs, vary from 3 to 4 on the whorls of the spire, while the body whorl has from 8 to 10 spirals on the whorl proper, and 3 to 6 spirals on the anterior canal. 
The outer lip is very much thickened and there are 6 or 7 teeth on the inside. There is a knob at the upper end of the columella in all shells, while some of the most fully grown specimens have up to 4 more knobs immediately below. The most shells have also a knob at the lower end of the columella.

The dimensions of the largest shell from Toftlund $(115 \mathrm{~m}$.$) is: height (H)$ $7.74 \mathrm{~mm}$., diameter $(D) 4.66 \mathrm{~mm}$. The $H / D$ ratio of the entire material varies from 1.54 to 1.81 and increases obviously with growth (see fig. 15, p. 224).

Remarks.

The main differences between $N$. cavata and $N$. Woodwardi are:

$d / w$ of the protoconch:

Number of collabral ribs per whorl:

Number of spirals per whorl on the spire:

Number of spirals on the body whorl (apart from the canal):

Spiral ornamentation in rib interspaces:

$$
\begin{array}{r}
\text { N. cavata } \\
0.240 .25 \\
10-14 \\
4-6 \\
\\
10-11 \\
\text { striae }
\end{array}
$$

N. Woodwardi $0.24-0.28$

$11-16$

bands

The $H / D$ ratio is of the same order in the two species as illustrated by fig. 14 .

Distribution.

Pliocene: North Sea Basin: Belgium: Scaldisien. England: Red Crag.

Miocene: North Sea Basin: Germany: Hemmoor stage. Denmark: Arnum formation.

\section{Nassa subobesa Dégrange-Touzin}

Plate 46, fig. 154.

1894. Nassa subobesa Dégrange-Touzin. Étude prél. Orthez. p. 375.

1925. Nassa (Phrontis) subobesa Dégrange-Touzin. Peyrot. Conch. Néogén. d. l'Aquit.

\begin{tabular}{|c|c|c|c|c|c|}
\hline Location & Depth & Shells & Location & Depth & Shells \\
\hline Bramminge & $70.80 \mathrm{~m}$. & 16 & Toftlund & $75.100 \mathrm{~m}$. & 155 \\
\hline Gramby & $82.66-83.76-$ & 1 (ef.) & Arnum (25 b) & $95.0-95.3-$ & 2 \\
\hline
\end{tabular}
p. 141, pl. 3, fig. 16-18.

Original diagnosis. Distinguunt hanc formam a N. obesa Bellardi, sequentes notae: testa minor; costae longitudinales angustiores, numerosiores, interdum in ventrale ultimi anfractus parte evanescentes. (DÉgRANGE-Touzin 1894).

Shell material.

Description. The shells from Toftlund are generally well preserved, although the bulk of them are more or less rolled. This together with the thick test of the species suggests that $N$. subobesa was a shallow water species.

Protoconch globular with 3 or 4 smooth, convex whorls. The data on the protoconch shown in the following table are based on 14 shells, from Toftlund, in which the protoconch is preserved: 


$\begin{array}{llccc}\begin{array}{c}\text { Number of whorls } \\ (w)\end{array} & \begin{array}{c}\text { Diameter } \\ (d)\end{array} & \begin{array}{c}\text { Heigth of exposed } \\ \text { protoconch }(h)\end{array} & d / w \\ \text { Maximum } & 4 & 0.91 \mathrm{~mm} . & 0.74 \mathrm{~mm} . & 0.25 \\ \text { Minimum } & 3 & 0.70- & 0.51- & 0.20 \\ \text { Mean value } & 3.41 & 0.78- & 0.62- & 0.23\end{array}$

Teleoconch with 9 to 15 coarse round collabral ribs per whorl. There is rather much variation of the number of ribs per whorl in relation to shell growth. There seems to be a tendency for more ribs to be developed on the initial whorl than on the second whorl but thereafter the number of ribs increases generally with growth. The mean number of ribs on the first four whorls calculated on the basis of 20 shells from Toftlund were: $11.3 ; 10.9 ; 11.8$; and 12.9 respectively (the 4 th whorl being only developed on 13 of the shells). The arrangement often deviates considerably from this generalized picture as shown, for instance, by the following two series for the number of ribs: $14,12,12$ and: 12,12 , 13, 11, which have been observed in the shell material.

In some shells it is possible to recognize indistinct spirals on the longitudinal ribs and in their interspaces. A maximum of 4 spirals have been counted on the first and second whorls, while 9 spirals have been observed on the body whorl of a single shell. Most shells are, however, devoid of spirals.

The aperture has a much thickened outer lip on the inside of which there are up to 6 teeth. The third tooth from the suture is always the stronggest. The columella has generally one tooth at its upper end, and one is also
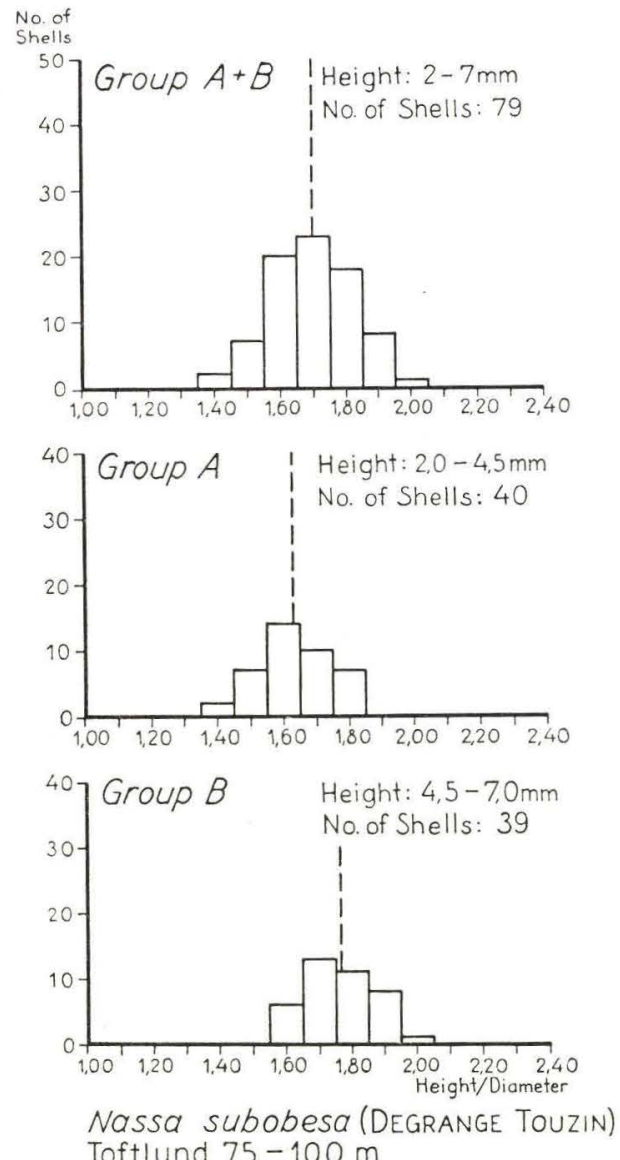

Fig. 16. found at the lower end, on the edge of the canal. Occassionally two teeth are developed on the ends of the columella.

Varia bility. The sculptural features are variable as is mentioned. It remains finally to give an account of the variation of shell shape as illustrated by the variation of the ratio of height/diameter, $(H / D)$ related to the size of the shell. Seventy nine shells from Toftlund were measured, and mean values of $H / D$ calculated 1.) for the entire number of shells with height between 2.0 and 7.0 mm., 2.) for shells with height between 2.0 and $4.5 \mathrm{~mm}$., and 3 .) for shells with height between 4.5 and $7.0 \mathrm{~mm}$. respectively. The values arrived at were: 
Nassa subobesa $H / D$ ratio.

\begin{tabular}{|c|c|c|c|c|}
\hline Group & $\begin{array}{l}\text { Number of } \\
\text { specimens }\end{array}$ & $H$ & $H / D$ mean values & $\begin{array}{l}\text { Range of } \\
H / D\end{array}$ \\
\hline $\begin{array}{l}\text { Total shell } \\
\text { material }(A+B)\end{array}$ & 79 & $2.0-7.0 \mathrm{~mm}$. & $1.696 \pm 0.0427\left\{\begin{array}{l}1.7387 \\
1.6533\end{array}\right.$ & $1.38-1.97$ \\
\hline$A$ & 40 & $2.0-4.5 \quad-$ & $1.6325 \pm 0.053\left\{\begin{array}{l}1.6855 \\
1.5795\end{array}\right.$ & $1.38-1.83$ \\
\hline$B$ & 39 & $4.5-7.0 \quad-$ & $1.7641 \pm 0.0523\left\{\begin{array}{l}1.8164 \\
1.7118\end{array}\right.$ & $1.55-1.97$ \\
\hline
\end{tabular}

The figures show that the $H / D$ ratio increases with height of the shell i.e. with growth. The graph fig. 16. illustrates the variation of $H / D$.

Remarks. BeLlardi (1882, p. 310) reports his $N$. obesa to have 10 collabral ribs per whorl and to have spiral ornamentation. РЕувот (l.c.) is of the opinion that the greater number (12 to 14) of ribs per whorl, and the absence of spiral ornamentation on the last whorls, justifies the separation of $N$. subobesa from N. obesa.

The writer is not convinced that the differences are of "specific" value. The variation of the shell material from Toftlund shows that the stated differences between $N$. obesa and $N$. subobesa might be within the variation range of one single species.

Distribution.

Miocene: Aquitanian Basin: Helvétien.

North Sea Basin: Denmark: Arnum formation.

\section{Nassa cimbrica Ravn}

Plate 47, fig. 155 .

1907. Nassa cimbrica Ravn. Molluskf. Jyll. Tert. p. 315, pl. 5, fig. 4.

1916. Nassa cimbrica Ravn. NørRegaARd. Mell.-mioc. Blokke Esbjerg. p. 26.

1925. Nassa (Hima) cimbrica Ravn. Kautsky. D. Mioc. v. Hemmoor u. Basbeck-Osten. p. 107.

1944. Nassa (Hima) cymbrica Ravn. Van Voorthuysen. Mioz. Gastr. a. d. Peelgebiet. p. 92 , pl. 10, fig. 16,17 .

Essential features of original description. Nucléus formé d'environ trois tours lisses, convexes. A partir du nucléus la sculpture consiste en côtes transverses très étroites (12 environ sur chaque tour), coupées un peu plus loin par deux stries spirales. Les intersections sont marquées par des tubercules assez prononcés. Sur le dernier tour se voient, au-dessous des deux stries spirales supérieures, une dizaine d'autres stries spirales plus serrées. (RAvN 1907).

Shell material.

$\begin{array}{lrr}\text { Location } & \text { Depth } & \text { Shells } \\ \text { Glejbjerg } & 23 \mathrm{~m} . & 143 \\ & 25- & 121 \\ & 32- & 72 \\ & 38- & 38 \\ & 52- & 2 \\ \text { Bramminge } & 70-80- & 1998\end{array}$

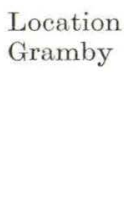

$\begin{array}{rc}\text { Depth } & \text { Shells } \\ 81.86-82.16 \mathrm{~m} . & 5 \\ 82.16-82.66- & 1 \\ 82.66-83.76- & 157 \\ 84.66-87.16- & 335 \\ 90.42-92.72- & 173 \\ 92.72-109.29- & 22\end{array}$




\begin{tabular}{|c|c|c|c|c|c|}
\hline Location & Depth & Shells & Location & Depth & Shells \\
\hline \multirow[t]{2}{*}{ Gramby } & $109.29-110.86 \mathrm{~m}$. & 28 & Toftlund & $115 \mathrm{~m}$. & 200 \\
\hline & $110.86-121.51$. & 24 & Arnum (13) & $53-83-$ & 2279 \\
\hline \multirow[t]{4}{*}{ Toftlund } & $75-100-$ & 4412 & & $83-94 \quad-$ & 35 \\
\hline & 100-105 - & 663 & Arnum (25b) & $95.0-95.3-$ & 239 \\
\hline & $105-110=$ & 1264 & & $107.5-$ & 3 \\
\hline & $110-115$ & 291 & & & \\
\hline
\end{tabular}

\section{Description.}

Protoconch globular with $2 \frac{1}{2}$ to $3 \frac{3}{4}$ smooth and glossy whorls. Diameter $(d)$, height $(h)$ and number of whorls $(w)$ were determined in 49 shells from Toftlund $(75-100 \mathrm{~m}$.). The results were as follows:

$\begin{array}{llll} & \text { Maximum } & \text { Minimum } & \text { Mean } \\ \text { Height }(h) & 0.84 \mathrm{~mm} . & 0.48 \mathrm{~mm} . & 0.64 \mathrm{~mm} . \\ \text { Diameter }(d) & 0.95- & 0.67- & 0.79- \\ \text { Number of whorls }(w) & 33 / 4 & 21 / 2 & 3.22 \\ d / w & 0.28 & 0.22 & 0.246\end{array}$

Teleoconch. The adult whorls are sculptured with narrow collabral ribs and there are indistinct spiral ribs which form spines on the intersections. The spirals often become obsolete in the interspaces.

The number of collabral ribs per whorl has been determined in 53 shells from Toftlund $(75-100 \mathrm{~m}$.$) , as follows:$

\begin{tabular}{ccccc} 
Whorl & \multicolumn{2}{c}{ Number of ribs: } & Number of \\
no. & Maximum & Minimum & Mean & shells \\
1 & 14 & 9 & 12.08 & 53 \\
2 & 13 & 9 & 10.76 & 53 \\
3 & 14 & 9 & 11.83 & 53 \\
4 & 17 & 11 & 13.34 & 38 \\
5 & 16 & 12 & 13.8 & 5
\end{tabular}

The table shows that whorl no. 1 has more collabral ribs than whorl no. 2, while later number of ribs per whorl increases with growth. The body whorl has generally 6 spiral ribs on the whorl proper, and the canal has further 4 to 6 spiral ribs which, however, are often very indistinct or quite obsolete.

A few shells have secondary spirals between the primary spirals, and in others one or several of the lowermost spirals are missing on the body whorl.

The aperture has a thickened outer lip on the inside of which there are up to 6 more or less distinct teeth. A tooth is found on the upper part of the inner lip, and there is occasionally another on the lower edge at the canal. The suture is commonly formed along the third spiral rib of the preceding whorl.

Variability. The variation of sculpture has been treated above. Another variable feature is the shape of the shell, which best can be illustrated by means of the Height/Diameter ratio $H / D .632$ shells from Toftlund were measured for height and diameter and the $H / D$ ratios computed. The ratios were related to height of the shell and their frequency illustrated graphically as shown on fig. 17. The mean value of $H / D$ was finally calculated for the entire shell material and for the different size groups shown in the following table. 

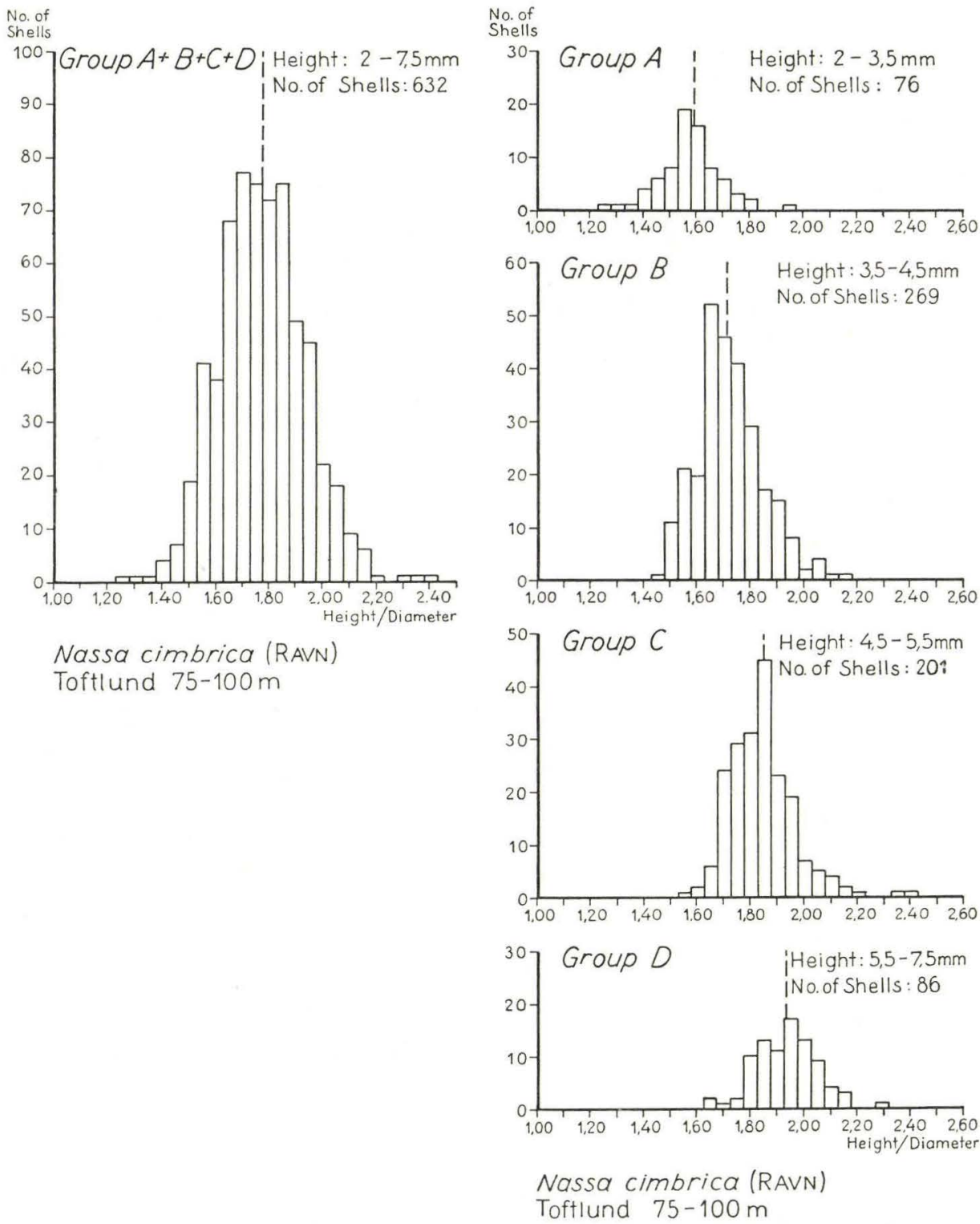

Fig. 17. 
Nassa cimbrica $H / D$ ratios

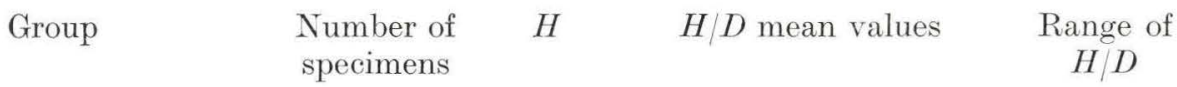

Total shell material

$(A+B+C+D)$

632

$2.0-7.5 \mathrm{~mm} . \quad 1.7736 \pm 0.0190\left\{\begin{array}{l}1.7926 \\ 1.7546\end{array}\right.$

$1.25-2.39$

$A$

$2.0-3.5-1.5842 \pm 0.039\left\{\begin{array}{l}1.6232 \\ 1.5452\end{array}\right.$

$1.25-1.94$

$B$

269

$3.5-4.5 \quad-$

$1.7238 \pm 0.0238\left\{\begin{array}{l}1.7476 \\ 1.7000\end{array}\right.$

$1.44-2.14$

C

201

$4.5-5.5-$

$1.8443 \pm 0.0213\left\{\begin{array}{l}1.8656 \\ 1.8230\end{array}\right.$

$1.57-2.39$

$D$

86

$5.5-7.5-1.9314 \pm 0.0361\left\{\begin{array}{l}1.9675 \\ 1.8953\end{array}\right.$

$1.63-2.31$

It is obvious from these results and the diagrams fig. 17 that the $H / D$ ratio increases with growth.

Remarks. N. cimbrica is a peculiar species which is generally easily determinable on account of its typical sculpture. It has not yet been recorded from southern Europe or elsewhere outside the North Sea Basin. The number of shells prove that it was a very abundant species in a part of the middle Miocene of Jutland, which was already suggested by NörreqaArd (1916 b.)

Distribution.

Miocene: North Sea Basin: Holland (m.) Germany: Hemmoor stage. Denmark: Arnum formation.

\section{Nassa pölsense (Auinger)}

Plate 48, fig. 156.

*) Buccinum Pölsense Autnger. V. Hitber. Neue Conch. a. d. mittelsteir. Mediterr. pl. 1, fig. 11.

1882. Buccinum (Tritia) Pölsense Auinger. Hoernes \& Autnger. 1. u. 2. Mioc. Medit. St. p. 146, pl. 13, fig. 25-26.

1925. Nassa (Phrontis) Pölsense Hoernes \& Autnger. Kautsky. D. Mioc. v. Hemmoor u. Basbeck-Osten, p. 104, pl. 8, fig. 3-4.

1952. Nassa (Phrontis) cf. polsensis Hoernes \& Autnger. Glibert. Faune mal. du Mioc, de la Belgique. 2, p. 106.

Diagnosis by Hoennes \& AUINGer: "Die eikegelförmige Schale wird von sieben bis neun mässig gewölbten Umgängen gebildet, auf welchen sich schmale, wenig gekrümmte Längsrippen befinden, über welche zahlreiche, feine Querlinien setzen. Die letzteren treten jedoch auf den Längsrippen zuweilen sehr zurück und sind nur in den Zwischenräumen derselben stärker ausgeprägt".

Shell material.

$$
\begin{aligned}
& \text { Location } \\
& \text { Glejbjerg } \\
& \text { Arnum (25b) }
\end{aligned}
$$

Depth Shells

$53.5 \mathrm{~m} . \quad 1$ fragment

*) Paper by Hirber not available. 
Description.

The shell fragments are rather poor, but are sufficient for determination. There seems to be no reason to enter into details except for emphasizing the convex shape of the whorls and the characteristic shelf below the upper suture, which is bordered by the distinct uppermost spiral ribs.

Distribution.

Miocene: North Sea Basin: Belgium: (?)Boldérien. Germany: Hemmoor stage. Denmark: Arnum formation.

FAMILIA FASCIOLARIIDAE

Genus Lathyrus Montfort 1810

Subgenus Dolicholathyrus BELLARDI 1883

\title{
157. Lathyrus (Dolicholathyrus) Rothi (Beyrich)
}

\author{
Plate 50, fig. 157.
}

1856. Fusus Rothi Beyrich. Die Conchylien etc. p. 289, pl. 24, fig. 1.

1886. Latirus fornicatus Bellard. I moll. d. terr. terz. d. Piemonte e d. Liguria 4, p. 50, pl. 2, fig. 29-30.

1890. Fusus crispoides Hoennes \& Auinger. 1. u. 2. Mioc. Medit. St. p. 251.

1907. Fusus crispus Borson. Ravn. Molluskf. Jyll. Tert. p. 329, pl. 6, fig. 10.

1925. Dolicholathyrus (Pseudolathyrus) Rothi Beyrich. Kautsky. D. Mioc. v. Hemmoor u. Basbeck-Osten. p. 115, pl. 8, fig. 19.

1928. Lathyrus peyreirensis Peyrot. Conch. Néogén. d. l'Aquit. p. 84, pl. 6, fig. 12-13. 1940. Doticholathyrus (Pseudolathyrus) Rothi Beyrich. Sorgenfret. Mar. Nedre-Mioc. i Klintinghoved p. Als. p. 45, pl. 6, fig. 7.

1952. Lathyrus (Dolicholathyrus) rothi Beyrich sp. Glibert. Faune mal. du Mioc. de la Belgique. 2, p. 111, pl. 8, fig. 11.

Essential features of original description. 9 hohe Längsrippen, in deren Zwischenräumen das Profil der Windungen nur eine geringe Wölbung besitzt. Die Querskulptur besteht aus entfernten Querleisten mit ziemlich regelmässig zwischenstehenden zu je dreien feineren Querstreifen. Die Mittelwindungen haben in ihrer unteren Hälfte nur 2 stärkere Querleisten, in der oberen eine dritte minder starke, welche nur wenig die Zwischenstreifen überragt. Die Spindel ist glatt. (BEYRICH 1856).

\section{Shell material.}

\begin{tabular}{|c|c|c|c|c|c|}
\hline Location & Depth & Shells & Location & Depth & Shells \\
\hline Glejbjerg & $52 \mathrm{~m}$. & 1 & Toftlund & $75-100 \mathrm{~m}$. & 2 \\
\hline Bramminge & $\begin{array}{r}53.5 \\
70-80\end{array}$ & $\begin{array}{r}5 \\
23\end{array}$ & & $\begin{array}{l}105-110= \\
110-115=\end{array}$ & $\begin{array}{l}3 \\
1\end{array}$ \\
\hline
\end{tabular}

Description. The shells are mainly small juvenile specimens and nearly all the shells from Bramminge are worn. It is accordingly not possible to give a detailed account of the adult stage.

Protoconch. Initial whorl slightly heterostrophe with microscopical, punctiform depressions on the shell surface. Next follow $23 / 4$ to $31 / 2$ smooth and glossy whorls with curved growth lines and a thin spiral rib above the lower suture. The protoconch terminates with about $1 / 4$ to $1 / 2$ whorl bearing curved, 
collabral ribs. The last protoconch whorl is angular. It has two spiral ribs at the periphery and a smooth base between the keel and the transition to the canal where 3 spiral ribs are found. There are 5 spiral ribs on the canal. The protoconch suture is formed between the two spiral ribs on the keel.

The entire protoconch is exposed in two specimens, in which height and diameter of the unsculptured part of the shell were measured as follows:

\begin{tabular}{lclllc} 
Location & Depth & Height & Diameter & \multicolumn{2}{c}{$\begin{array}{c}\text { Number of whorls } \\
\text { smooth ribbed }\end{array}$} \\
Toftlund & $105-110 \mathrm{~m}$. & $1.58 \mathrm{~mm}$. & $1.18 \mathrm{~mm}$. & $41 / 2$ & $1 / 3$ \\
Bramminge & $70-80-$ & $1.71-$ & $1.18-$ & $41 / 2$ & $1 / 4$
\end{tabular}

Teleoconch. Initial adult whorl with 11 or 12 collabral ribs, later whorls with about 8 collabral ribs. These ribs are crossed by 3 distinct, strong, spiral ribs on the middle part of the body whorl, a spiral of similar strength along the suture, and two weaker spirals in between. On the base of the whorl there are four, and on the canal about eight weak spirals. Very weak secondary spirals emerge between the three strong spirals on the middle of the whorl.

The suture is developed along the lowermost of the three strong spirals of the preceding whorl. Aperture broken in all shells. Canal obviously short in the juvenile stage.

Distribution.

Miocene: Aquitanian Basin: Aquitanien.

North Sea Basin: Belgium: Anversien. Germany: Hemmoor stage, Glimmerton stage (Banke Rasmussen 1956). Denmark: Klintinghoved clay and Arnum formation.

Mediterranean Basin: Italy: Miocene superiore.

Vienna Basin: Grund and Steinabrunn beds, Baden clay.

\section{Genus Fusus (Klein 1753) Bruguière 1792 \\ 158. Fusus cf. sexcostatus Beyrich}

Plate 50, fig. 158.

1856. Fusus sexcostatus Beyrich. Die Conchylien etc. p. 287. pl. 24, fig. 2.

1907. Fusus sexcostatus Beyrich. Ravn. Molluskf. Jyll. Tert. p. 331.

1925. Streptochetus sexcostatus Beyrich. Kautsky. D. Mioc. v. Hemmoor u. BasbeckOsten. p. 116, pl. 8, fig. 20-21.

1940. Streptochetus sexcostatus Beyrich. Sorgenfrei. Mar. Nedre-Mioc. i Klintinghoved p. Als. p. 46.

1952. Streptochetus sexcostatus Beyrich. sp. Glibert. Faune mal. du Mioc. de la Belgique 2. p. 110 , pl. 8, fig. 4 .

Essential features of original description. Das grosse kegelförmige Embryonalende besteht aus 5 Windungen, von denen die 3 obersten glatt, die beiden folgenden mit feinen haarförmigen Längs- und Querstreifen bedeckt sind. (Die Mittelwindungen) haben in der Regel 6 stark erhobene Längsrippen. Ausnahmsweise kommen 'y Längsrippen vor. Die Querstreifen sind schmal und scharf, 5 in den ersten Mittelwindungen; sie vermehren sich durch Einschiebung von je einem Zwischenstreifen in den unteren Windungen. (BEYRICH 1856). 
Shell material.

$\begin{array}{lrr}\text { Location } & \text { Depth } & \text { Shells } \\ \text { Glejbjerg } & 53.5 \mathrm{~m} . & 1 \\ \text { Bramminge } & 70-80- & 34 \\ \text { Toftlund } & 75-100- & 9 \\ & 100-105- & 4 \\ & 105-110- & 10\end{array}$

Description.

The bulk of the material consists of juvenile shells which include the protoconch and a small part of the adult stage.

Protoconch turreted. Initial whorl slightly heterostrophe with punctiform impressions on the shell surface. The following $1 \frac{1}{2}$ to 2 whorls are either smooth or they are furnished with microscopical knobs. The protoconch terminates with $1 \frac{1}{2}$ to $2 \frac{1}{4}$ convex whorls having a distinct reticulate sculpture of about $35-40$ collabral striae and 4 to 7 spiral striae.

Three of the well preserved specimens were measured as follows:

\begin{tabular}{lrlll} 
Location & Depth & Height & \multicolumn{2}{c}{ Diameter $\begin{array}{c}\text { Number of } \\
\text { whorls }\end{array}$} \\
Glejbjerg & $53.5 \mathrm{~m}$. & $2.15 \mathrm{~mm}$. & $1.25 \mathrm{~mm}$. & $5^{1 / 8}$ \\
Toftlund & $105-110-$ & $2.07-$ & $1.35-$ & $5^{1 / 5}$ \\
& $110-115-$ & $1.88-$ & $1.25-$ & 5
\end{tabular}

Teleoconch. Initial whorl with 9 to 12 collabral ribs and succeding whorls with 8 to 11 ribs (shells with up to 5 whorls occur in the material). The collabral ribs are crossed by 6 to 7 spiral ribs on the first whorl while the number of spirals increases on later whorls due to the intercalation of secondary spirals. The entire body whorl and the canal are covered with spiral ribs. The collabral ribs are occasionally almost obsolete in shells which represent late adult stages.

The aperture is broken in most shells. It can, however, be noted, that there are spiral ridges on the inside of the outer lip in large shells. The canal is relatively short.

Remarks. The present species should not be referred to the section Streptochetus which according to Cossmand (1901, p. 6 and 29) has a globular, paucispiral protoconch. The species also shows some resemblance to Aptyxis which has a polygyrate protoconch like the present shells but Aptyxis has a smooth and not a reticulate protoconch. It was therefore finally decided not to refer $F$. cf. sexcostatus to any subgeneric section, since the shell features disagreed with both the classification of THiele (1931, p. 329) and Cossmann (1901, p. 5).

The doubt implied in the species name used here stresses the questionable identity with BEYRICH's species, since the differences in number of collabral ribs per adult whorl seem to be too great for the variation range of that species. It cannot, on the other hand, be denied that the protoconchs in BEYRICH's species and the present shells are practically identical.

Of considerable interest is the obvious similarity with Fusus (Aptyxis?) salomacensis Peyrot (1928, p. 54, pl. 6, fig. 25) of which, however, the protoconch is not yet known. There is a fair chance that Peyrot's species and the shells described by Ravn, Kautsky, Sorgenfrei, and Glibert belong to one species. Whether this is F. sexcostatus cannot be decided with certainty at present. 
Distribution.

Miocene: Aquitanian Basin: ?Helvétien.

North Sea Basin: Belgium: Horizon of Houthaelen, Anversien. Germany: Hemmoor stage, Reinbek stage (Gottsche 1878), Glimmerton (Banke Rasmussen 1956). Denmark: Klintinghoved clay, Arnum formation.

Subgenus Aquilofusus Kavtsky 1925

\section{Fusus (Aquilofusus) Grippi (Kautsky)}

Plate 50, fig. 159.

1925. Aquilofusus (Eurydike) Grippi Kautsky. D. Mioc. v. Hemmoor u. Basbeck-Osten. p. 127 , pl. 9 , fig. 6 .

Essential features of original description. Knopfförmiges Embryonalgewinde von $2 \frac{1}{2}$ Umgängen. Auf dem letzten Embryonalumgang treten in der Mitte drei kräftige Spiralen auf. Diese vermehren sich durch Einschiebung ausserordentlich rasch, so dass auf der ersten Mittelwindung schon deren $\%$, auf der letzten Mittelwindung 9-12 vorhanden sind. Stark gekrümmte Zuwachsstreifen auf den Mittelwindungen. (Kautsky 1925).

Shell material.

Glejbjerg 53 m.: 1 shell; 53.5 m.: 1 shell.

Description. Both shells are fragmentary, only the protoconch and 2 adult whorls being preserved.

Protoconch. Initial whorl apparently smooth (partly worn). Last whorl with 6 rather strong spiral ribs in the interspaces of which there are conspicuous closely spaced collabral ribs. The data of the two shells are:

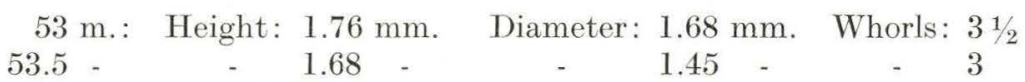

Teleoconch with 8 to 10 spiral ribs on the whorls of the spire. Curved growth lines cross the spiral ribs, and are seen both on the ribs and in their interspaces. Body whorl broken in both specimens.

Remarks. It has been pointed out by WIRTz (1949, p. 70) and by GLiberT (1952, p. 103) that F. Grippi and related species should probably be referred to the genus Sipho. This seems very reasonable, but the writer is of the opinion that both the teleoconch and protoconch should first be studied thoroughly both in Sipho and in the species of a similar appearance referred to Fusus (subgenus Aquilofusus KaUtSKy). A study of this kind has not been possible for the writer, and the reference to Aquilofusus has, therefore, been maintained.

Distribution.

Miocene: North Sea Basin: Germany: Hemmoor stage. Denmark: Arnum formation. 


\title{
FAMILIA OLIVIDAE D'ORBIGNY
}

\section{Genus Ancilla Lamarck 1799}

\section{Ancilla obsoleta (Brocchi)}

\author{
Plate 49, fig. 160 a-b.
}

1814. Buccinum obsoletum Brocchr. Conchiol. Foss. Subapennina. 2, p. 330, pl. 5, fig. 6 . 1853. Ancillaria obsoleta Brocchi sp. Beyrich. Die Conchylien ete. p. 40, pl. 2, fig. 4-5. 1856. Ancillaria obsoleta Brocchi. Hörnes. D. foss. Moll. d. Tert.-Beckens v. Wien. 1, p. 55, fig. 4-5.

1866. Ancillaria obsoleta Brocchi var. Speyer. Ober-olig. Lippe Detmold. p. 11, pl. 1, fig. $3-5$.

1872. Ancillaria obsoleta Brocchi. von Koenen. D. Nordd. Mioc. u. s. Moll. f. p. 211. 1883. Ancillaria obsoleta Brocchi. Bellardi. I moll. d. terr. terz. d. Piemonte e d. Liguria 3 , p. 438 , pl. 12 , fig. 44

1925. Ancilla (Sparella) obsoleta Brocchi. Kautsky. D. Mioc. v. Hemmoor u. BasbeckOsten. p. 135, pl. 9, fig. 20.

1928. Ancilla (Sparella) obsoleta Brocchr. Peyrot. Conch. Néogén. d. l'Aquit. p. 184, pl. 12, fig. 9-10.

1952. Ancilla (Ancilla) obsoleta Brocchi sp. Glibert. Faune mal. du Mioc. de la Belgique 2. p. 113, pl. 8, fig. 14 .

Original diagnosis. Testa oblonga, laevis, anfractubus obsoletis, columella intorta striata, umbilico clauso. (BROcCHI 1814).

Shell material.

\begin{tabular}{|c|c|c|c|c|c|}
\hline \multirow{3}{*}{$\begin{array}{l}\text { Location } \\
\text { Glejbjerg }\end{array}$} & Depth & Shells & Location & Depth & Shells \\
\hline & $52 \mathrm{~m}$. & 1 & Toftlund & $100-105 \mathrm{~m}$. & 1 \\
\hline & $53.5 \quad-$ & 1 & & $105-110-$ & 5 \\
\hline Bramminge & $70-80-$ & 34 & & $115-$ & 2 \\
\hline Gramby & $82.66-83.76-$ & 1 (cf.) & Arnum (13) & $53-83-$ & 1 \\
\hline Toftlund & $75-100-$ & 2 & & & \\
\hline
\end{tabular}

\section{Description.}

The bulk of the material consists of fragmentary shells. It is accordingly not possible to get a complete picture of the shell features.

Protoconch globular-cylindrical with smooth and glossy surface. Two spiral furrows on lower third of last whorl. Data on the two entirely exposed protoconchs were:

$\begin{array}{lclcc}\text { Location } & \text { Depth } & \text { Height } & \text { Diameter } & \begin{array}{c}\text { Number of } \\ \text { whorls }\end{array} \\ \text { Toftlund } & 100-105 \mathrm{~m} . & 0.98 \mathrm{~mm} . & 0.81 \mathrm{~mm} . & 23 / 4 \\ \text { Arnum } & 53-83- & 1.11- & 0.90- & 3\end{array}$

Teleoconch. Spire completely covered by callosity. Body whorl with one spiral furrow at about $1 / 8$ of the height of the body whorl above the edge of the anterior canal. Outer lip thin. Aperture oblong with deeply notched canal. Columella and outside of canal with heavy callosity. Three shallow, indistinct folds on the columella and one fold on the outside of the canal. The largest entire shell (Toftlund $115 \mathrm{~m}$.) is $21.3 \mathrm{~mm}$. high, and the diameter of the last whorl is $9.0 \mathrm{~mm}$.

Distribution.

Miocene: Aquitanian Basin: Burdigalien, Helvétien. 
North Sea Basin: Belgium: Boldérien, horizon of Houthaelen, Anversien. Germany: Hemmoor stage, Reinbek stage (Gоттsche 1878), Glimmerton (Banke RasMUSSEN 1956). Denmark: Arnum formation.

Mediterranean Basin: Italy: Miocene superiore.

Vienna Basin: Baden clays.

Oligocene: North Sea Basin: Germany (u.).

\section{Genus Oliva Bruguière 1789 \\ 161. Oliva minutissima (Kautsky)}

Plate 49, fig. 161 a-c.

1925. Olivella (Lamprodoma) minutissima KAutsky. D. Mioc. v. Hemmoor u. BasbeckOsten. p. 135, pl. 9, fig. 19.

Essential features of original description. Der Umriss des Gewindes ist nicht konkav sondern gerade. Die Trennungslinie zwischen dem vorderen mit einem weisslichen Kalküberzug bedeckten Teil, der nur 1/4 des letzten Umgangs einnimmt, und dem braunen Abschnitt beginnt zirka in der Hälfte des inneren Mundrandes und zieht schief gegen links vorn zum letzten Umgang. (KAUTSKY 1925).

Shell material.

$\begin{array}{lrllrr}\text { Location } & \text { Depth } & \text { Shells } & \text { Location } & \text { Depth } & \text { Shells } \\ \text { Glejbjerg } & 53.5 \mathrm{~m} . & 1 & \text { Toftlund } & 75-100 \mathrm{~m} . & 13 \\ \text { Bramminge } & 70-80- & 2 & \text { Arnum (13) } & 53-83- & 3 \\ \text { Gramby } & 8466-87.16- & 1 & & & \end{array}$

\section{Description.}

Protoconch globular, with depressed spire. Four smooth whorls. Protoconch exposed on one specimen from Toftlund 75-100 m. Height $1.73 \mathrm{~mm}$., diameter $1.19 \mathrm{~mm}$. Growth lines on the spire concave, reflecting the upper sinus which accomodate the velum. Slight indication of a lower sinus on the last whorl.

Teleoconch smooth, ovate cylindroidal; sutural furrow; body whorl with thin callosity on the lower fifth. Aperture relatively narrow; lower half of the columella with 2 to 4 folds; canal deeply notched. The dimensions of one entire specimen from Toftlund were: Height: $4.4 \mathrm{~mm}$., diameter: $2.1 \mathrm{~mm}$., number of whorls: 4 protoconch whorls and $1 \frac{1}{4}$ adult whorls.

Remarks. This species may represent the juvenile stage of $O$. Dufresnei or a related species. However, since the present shell material does not yield sufficient pertinent data, it was decided to list it under KaUtsky's species, although in accordance with the above suggestion the species has been referred to Oliva.

Distribution.

Miocene: North Sea Basin: Germany: Hemmoor stage. Denmark: Arnum formation. 
FAMILIA MITRIDAE

\section{Genus Mitra Lamarck 1799}

\section{Mitra cf. Bellardii Hoernes \& Auinger}

1880. Mitra Bellardii Hoernes \& Auinger. 1. u. 2. Mioc. Medit. St. p. 78, pl. 9, fig. 15-16. 1925. Mitra (Cancilla) orientalis OppenH. Kautsky. D. Mioc. v. Hemmoor u. BasbeckOsten. p. 128, pl. 9, fig. 7 .

1952. Mitra (Mitra) bellardii Hoernes \& Auinger. Glibert. Faune mal. du Mioc. de la Belgique 2, p. 118, pl. 9, fig. 4 .

Essential features of original description. Mit Ausnahmeder längsgerippten obersten Windungen und einiger Querlinien am oberen Theile der Umgänge und an der Basis vollständig glatt. (HoERnes \& AUINGER 1880).

Shell material and Dimensions.

\begin{tabular}{|c|c|c|c|c|c|}
\hline \multirow[b]{2}{*}{ Location } & & & & \multicolumn{2}{|c|}{ Protoconch } \\
\hline & Depth & Shells & Heigh & Diameter & Number of whorls \\
\hline Toftlund & $75-100 \mathrm{~m}$. & 1 (juvenile) & $1,16 \mathrm{~mm}$. & $0,74 \mathrm{~mm}$. & 5 \\
\hline & $105-110-$ & 1 & & & \\
\hline irnum (13) & $83-94 \quad-$ & $2 \mathrm{frg}$. & & & \\
\hline
\end{tabular}

Description. The shells are broken except for the shell from Toftlund 75-100 m., which consists of the protoconch and slightly more than one adult whorl.

Protoconch turreted, smooth and glossy. Curved growth lines visible. Other data in the above table.

Teleoconch almost smooth with indistinct spiral furrows, particularly on the first adult whorls.

Remarks. It is impossible to arrive at a final determination on account of the fragmentary shells.

Distribution of $M$. Bellardii:

Miocene: North Sea Basin: Belgium: Anversien. Germany: Hemmoor stage. Denmark: Arnum formation. Vienna Basin: Baden clay.

\section{Mitra cf. planicostata Bellardi}

1856. Mitra scrobiculata Broc. Hörnes. D. foss. Moll. d. Tert.-Beckens v. Wien. 1, p. 100, pl. 10, fig. 14-18.

1888. Mitra planicostata Bellardi. I moll. d. terr. terz. d. Piemonte e d. Liguria. 5, p. 259, pl. 2 , fig. 9 .

1925. Mitra planicostata Bellardi. Kautsky. D. Mioc. v. Hemmoor u. Basbeck-Osten. p. 128 , pl. 9 , fig. 8 .

Essential features of original description. Distinguunt hanc speciem a M. exornata BELL. sequentes notae: Testa minor: spira brevior, magis aperta. Pliculae longitudinales super costas transversas obliteratae vel passim perspicuae; in parte antica ultimi anfractus costula minuta costis plerumque interposita. (BELLARDI 1888).

Shell material. Braminge 70-80 m.: 4 more or less fragmentary shells.

Description. The shells are both fragmentary and worn. 
Protoconch unknown.

Teleoconch turreted with flat whorls. Each whorl with 5 or 6 rather strong spiral ribs and interjacent furrows which in some cases are subdivided into minute hollows by thin collabral growth ribs. Body whorl with 12 to 14 spiral ribs which extend to the canal. Columella with three strong folds of which the topmost is the strongest.

Distribution.

Pliocene: Mediterranean Basin: Italy: Pliocene inferiore.

Miocene: North Sea Basin: Germany: Hemmoor stage. Denmark: Arnum formation.

Vienna Basin: Baden, Vöslau, Steinabrunn.

FAMILTA CANCELLARIIDAE H. \& A. ADAMS 1853

Genus Cancellaria Lamarck 1799

Subgenus Cancellaria s. s.

164. Cancellaria (Cancellaria) cancellata (L.)

Recent:

Plate 50, fig. 164.

1766. Voluta cancellata Linné. Syst. Nat. Ed. Duod. p. 1191.

1889. Cancellaria cancellata Linné sp. Bucquoy, Dautzenberg \& Dollfus. Moll. mar. du Roussillon. 1, p. 32, pl. 5, fig. 1 .

1932. Cancellaria cancellata Linné sp. Nobre. Moluscos mar. de Portugal, p. 85, pl. 22, fig. 2-3.

Fossil:

1856. Cancellaria cancellata Linné. HöRnes. D. foss. Moll. d. Tert.-Beckens v. Wien. 1, p. 316 , pl. 34 , fig. $20-22$.

1857. Cancellaria cancellata Linné sp. var. praecedens. Beyrich. Die Conchylien etc. p. 321 , pl. 27 , fig. 2 .

1894. Bivetia cancellata Linné var. SAcco. I moll. d. terr. terz. d. Piemonte e d. Liguria. 16, p. 37, pl. 2, fig. 55-61.

1925. Bivetia cancellata LaM. var. praecedens Beyr. Kautsky. D. Mioc. v. Hemmoor u. Basbeck-Osten. p. 136, pl. 10, fig. 1.

1928. Bivetia subcancellata D'Orbigny. Peyrot. Conch. Néogén. d. l'Aquit. p. 199, pl. 12, fig. $26-29$.

1952. Cancellaria (Cancellaria) cancellata f. praecedens Beyrich. Glimert. Faune mal. du Mioc. de la Belgique. 2, p. 120.

Original diagnosis. Testa integra ovata plicata decussatim reticulata, columella triplicata subumbilicata productiuscula. (LinNé 1758).

Shell material.

Toftlund 115 m.: 1 shell and 2 fragments; Arnum (25b) 104.3-107.5 m.: :2 fragmentary shells.

Description.

Protoconch. One well preserved protoconch (Toftlund $115 \mathrm{~m}$.) displays the following features: initial nuclear whorl and following whorl with microscopic granular ornament. The next $1 \frac{1}{4}$ whorls smooth with 10 minute spiral striae. The whole protoconch consists accordingly of $3 \frac{1}{4}$ whorls. Height of the exposed part of the protoconch $1.13 \mathrm{~mm}$., diameter $1.43 \mathrm{~mm}$. Height and 
diameter of the specimen from Arnum: $1.02 \mathrm{~mm}$. and $1.43 \mathrm{~mm}$., number of whorls: 3 .

Teleoconch turreted-globular, 11 or 12 strong collabral ribs per whorl, and characteristic, distinct growth lines having the form of delicate collabral riblets covering the whole shell surface. Body whorl with 22 spiral ribs, of which the 3 ribs adjacent to the suture are weaker than the others. The fourth rib below the suture is the strongest; it develops occasionally blunt spines on crossing the collabral ribs, and the whorl has then a subangular outline.

The suture is formed between the 7th and the 8th spiral rib of the preceding whorl. Aperture slightly triangular, 11 spirals on the inside of the outer lip. Columella with 2 folds and distinct umbilicus. Data on specimen from Toftlund $115 \mathrm{~m}$. : height $8.1 \mathrm{~mm}$., diameter $5.5 \mathrm{~mm}$., number of adult whorls: $23 / 4$.

Remarks. The morphology of the fossil shells has undoubtedly been studied in more detail than the shell of the recent animal as shown by the great number of fossil varieties.

Critical study of the literature suggests that the fossil varieties are barely substantiated. It is the writer's impression, for instance that SACCO (l.cit.) concentrated on the extreme morphological types, while not ascribing transitional forms enough importance. Reviewing the distribution of SACCO's varieties in the deposits of Italy, it appears that most occur in all main fossil localities and horizons. From this may be inferred that SACCO's varieties illustrate the variation range of a single species.

The differences between the recent shells and several of the fossil types are certainly subordinate compared with the variation within the fossil material. It is proposed therefore to include the fossil shells in C.cancellata unless morphological features of greater significance than those known to the writer can be indicated.

If it is possible to prove that the recent species covers the same range of variation as the fossil representative, the identity of the fossil and recent shells, as suggested in the above synonymy will have been finally demonstrated.

\section{Distribution.}

Recent: Mediterranean. Atlantic Ocean: South coast of Portugal, Senegal.

Pliocene: Mediterranean Basin: Italy: Piacenziano, Astiano. Miocene: Aquitanian Basin: Helvétien.

North Sea Basin: Belgium: Boldérien. Germany: Hemmoor stage. Glimmerton (Banke Rasmussen 1956). Denmark: Arnum formation.

Mediterranean Basin: Italy: Elveziano, Tortoniano. Vienna Basin: Grund, Vöslau, Steinabrunn.

\section{Cancellaria (Cancellaria) contorta Basterot}

1825. Cancellaria contorta BASterot. Mém. Geol. Env. Bordeaux. p. 47, pl. 2, fig. 3.

1856. Cancellaria contorta Basterot. Hörnes. D. foss. Moll. d. Tert.-Beckens v. Wien 1, p. 311 , pl. 34 , fig. $7-8$.

1894. Contortia contorta Basterot. Sacco. I moll. d. terr. terz. d. Piemonte e d. Liguria. 16. p. 49 , pl. 3, fig. $24-26$. 
1925. Merica contorta Basterot. Kautsky. D. Mioc. v. Hemmoor u. Basbeck-Osten. p. 137 , pl. 10, fig. 2 .

1928. Merica contorta Basterot. Peyrot. Conch. Néogén. d. l'Aquit. p. 206, pl.12, fig. $30-34 ; 41$.

1952. Cancellaria (Merica) contorta Basterot. Glibert. Faune mal. du Mioc. de la Belgique. 2, p. 121 .

Original diagnosis. Testa oblique contorta, longitudinaliter costata, transverse rugosa; anfractibus rotundatis; columella triplicata (BASTEROT 1825).

Shell material.

Glejbjerg 53.5 m.: 1 fragmentary shell, Arnum. (13) 83-94 m.: 1 rolled shell.

Description.

Protoconch worn. Probably about 3 whorls.

Teleoconch turreted-globular, with 13 to 15 collabral ribs per whorl. Body whorl with about 12 spiral ribs of first order and about 12 interjacent ribs of second order. The total number of spiral ribs is about 30 , as there are a number of third order ribs. The exact number of spirals cannot be given on account of the worn nature of the shell. Aperture rhomboid, with thickened outer lip having 9 teeth on the inner side. Inner lip with three spiral ridges on its posterior part, columella with three folds; no umbilicus. Dimensions of the shell from Arnum: height: $9.5 \mathrm{~mm}$., diameter: $6.7 \mathrm{~mm}$., number of adult whorls about 4 .

Distribution.

Miocene: Aquitanian Basin: Aquitanien, Burdigalien, Helvétien. North Sea Basin: Belgium: Boldérien, horizon of Houthaelen; Germany: Hemmoor stage. Denmark : Arnum formation.

Mediterranean Basin: Italy: Elveziano.

Vienna Basin: Grund and Baden beds.

\section{Subgenus Trigonostoma Blatnville 1826}

\section{Cancellaria (Trigonostoma) acutangula Faujas-De-Saint-Fond}

Plate 51, fig. 166.

1817. Cancellaria acutangula FAU.JAs. Quelq. coq. foss. d. env. Bordeaux. p. 197, pl. 10, fig. 1 .

1825. Cancellaria acutangula Faujas. Basterot. Mém. Géol. Env. Bordeaux. p. 45, pl. 2, fig. 4 .

1894. Gulia acutangula FAujas. SAcco. I moll. d. terr. terz. d. Piemonte e d. Liguria. 16, p. 21 , pl. 2 , fig. $1-4$.

1925. Trigonostoma (Ventrilia) acutangula FaUJ. Kautsky. D. Mioc. v. Hemmoor u. Basbeck-Osten, p. 141, pl. 10, fig. 9.

1928. Trigonostoma (Ventrilia) acutangulum FauJas de saint Fond. Perrot. Conch. Néogén. d. l'Aquit. p. 246, pl. 13, fig. 15, pl. 14, fig. 23-30.

1952. Cancellaria (Ventrilia) acutangula Fadjas. Glibert. Faune mal. du Mioc. de la Belgique. 2, p. 126. pl. 9, fig. 8 .

Diagnosis. (FAUJAS-DE-SATNT-Fond published an illustration of C.acutangula without any diagnosis. The following is a quotation of the first diagnosis of the species, written by BASTEROT in 1825). Testa ovato-acuta, subumbilicata, transversim striata, longitudinaliter et oblique costata; anfractibus superne 
angulatis, supra planis, ad angulum dentibus coronatis; columella subtriplicata (BASTEROT 1825).

Shell material.

\begin{tabular}{|c|c|c|c|c|}
\hline tion & Depth & Shells & Location & Depth \\
\hline $\mathrm{rg}$ & $53.75 \mathrm{~m}$. & 1 frg. (cf.) & Toftlund & $105.110 \mathrm{~m}$. \\
\hline Bramminge & $70-80-$ & 1 & & 115 \\
\hline
\end{tabular}

Description. The only entire shell is the specimen from Toftlund $115 \mathrm{~m}$. The following description applies accordingly mainly to this shell.

Protoconch naticoid, probably smooth (partly worn). Height $1.01 \mathrm{~mm}$., diameter $1.27 \mathrm{~mm}$., number of whorls 3 .

Teleoconch. Body whorl with 14 spiral ribs between which secondary ribs emerge as shown on the accompanying figure. Distinct shelf along the suture without spiral ribs. Twelve to 14 strong collabral ribs per whorl, developed both on the vertical and horizontal parts of the whorl. These ribs form low spines on the edge of the sutural shelf. Aperture triangular, with 8 ridges on the inside of the outer lip and one ridge on the inside of the sutural shelf. Columella with two folds; narrow umbilicus. The suture is formed along the 5 th spiral rib. The entire shell is $5.03 \mathrm{~mm}$. high, $3.62 \mathrm{~mm}$. in diameter; it has 3 protoconch whorls and 2 adult whorls (plate 51, fig. 166).

Remarks. This species is very variable as indicated in the literature. It may very easily be confused with $C$. spinifera which, however, has a much larger umbilicus.

Distribution.

Miocene: Aquitanian Basin: Burdigalien.

North Sea Basin: Belgium: Boldérien. Germany:

Hemmoor stage. Denmark: Arnum formation.

Mediterranean Basin: Italy: Elveziano.

\section{Cancellaria (Trigonostoma) boreobsoleta Kautsky}

1925. Trigonostoma (Ventrilia) boreobsoleta KAutsky. D. Mioc. v. Hemmoor u. BasbeckOsten. p. 142, pl. 10, fig. 12-13.

1952. Cancellaria (Ventrilia) behmi Beyrich. Glibert. Fauna mal. du Mioc. de la Belgique. 2, p. 127, pl. 9, fig. 15 .

Essential features of original description. Glattes Embryonalgewinde von 2 Umgängen. Die Mittelwindung ist ziemlich hoch, mässig konvex gewölbt und hinten vor der Nahtkanalrampe sehr schwach konkav eingeschweift. Alle Spiralen laufen über die schwachen und feinen, dicht stehenden Längsrippen. Schmaler tiefer Nabel. Die Columella trägt drei Falten (Kautsky 1925).

Shell material.

Toftlund $115 \mathrm{~m} .2$ fragmentary shells.

Description.

Protoconch globular, obviously smooth, of about 3 whorls. Height of the exposed part: $1.15 \mathrm{~mm}$., diameter $1.32 \mathrm{~mm}$. 
Teleoconch. First adult whorl devoid of collabral ribs, second whorl with 25 more or less distinct, flat, collabral ribs. Narrow, concave, sutural shelf limited by a spiral rib against the lateral part of the shell wall. The collabral ribs are initially crossed by 7 spiral ribs of first order, between which secondary ribs emerge successively on the following whorls.

Body whorl broken on the two shells. The columella has two strong folds below which there is a very weak, practically negligible indication of a third fold. Narrow umbilicus.

Remarks. KaUtsky's species is certainly not identical with $C$. Behmi as suggested by GLIBERT. This is shown by a comparison of the descriptions by BEYRICH and KAUTSKY, the differences between the two species being summarized as follows:

$\begin{array}{lll}\text { Shape: } & \begin{array}{l}\text { C. Behmi } \\ \text { blunt conical }\end{array} & \begin{array}{l}\text { C. boreobsoleta } \\ \text { oblong-ovoid }\end{array} \\ \begin{array}{l}\text { Number of collabral } \\ \text { ribs per whorl: }\end{array} & \begin{array}{l}14-15 \\ \text { none }\end{array} & \begin{array}{l}\text { about } 25 \\ \text { narrow umbilicus }\end{array}\end{array}$

GLibert's species resembles $C$. boreobsoleta very much, it has apparently about the same number of collabral ribs, and the outer wall of the whorls is convex as in C. boreobsoleta. C. behmi GLIBERT has accordingly been included in the synonymy.

Distribution.

Miocene: North Sea Basin: Belgium: Boldérien; Germany: Hemmoor stage. Denmark: Arnum formation.

Subgenus Narona H. \&. A. Adams 1854

\section{Cancellaria (Narona) calcarata (Brocchi)}

Plate 51, fig. $168 \mathrm{a}-\mathrm{b}$.

1814. Voluta calcarata Brocchi. Conchiol. Foss. Subapennina. 2, p. 309, pl. 3, fig. 7.

1857. Cancellaria calcarata Brocchi sp. Berrich. Die Conchylien etc. p. 333, pl. 28, fig. 3.

1894. Calcarata calcarata Brocchi. SAcco. I moll. d. terr. terz. d. Piemonte e d. Liguria. 16 , p. 32 , pl. 2 , fig. 41-48.

1925. Sveltia (Calcarata) calcarata Brocchi var. mioparva SAcco. KAUtsky. D. Mioc. v. Hemmoor u. Basbeck-Osten. p. 138.

1928. Sveltia (Calcarata) calcarata (Broconi) var. Peyrot. Conch. Néogén. d. l'Aquit. p. 236 , pl. 12, fig. $39-40$, pl. 13, fig. $50-51$.

1956. Cancellaria (Narona) calcarata (Brocchi). Banke Rasmusser. Upper Mioc. South Jutland. p. 78 , pl. 7 , fig. 7 .

Original diagnosis. Testa ovato-acuta, oblique costata, anfractubus scalariformibus carinatis, carina spinis compressis subfornicatis coronata, columella biplicata, basi integra, apertura angulari. (ВвосCH 1814).

Shell material. Bramminge 70-80 m.: 1 juvenile shell and one fragment.

Description.

Protoconch globular, with $3 \frac{1 / 4-31 / 2}{2}$ smooth whorls. Height and diameter of the exposed part of the protoconch: 


$\begin{array}{lll} & \text { juv. shell } & \text { shell frg. } \\ \text { Height: } & 1.01 \mathrm{~mm} . & 0.96 \mathrm{~mm} . \\ \text { Diameter: } & 1.15- & 1.21- \\ \text { Number of whorls: } & 31 / 4 & 31 / 2\end{array}$

Teleoconch turreted, scalariform. Whorls with flat sutural shelf and 8-14 angular collabral ribs per whorl. These ribs show remnants of spines on the edge of the sutural shelf (the spines are worn off on the specimens). One or 2 spiral ribs cross the collabral ribs on the vertical wall of the whorl which thus has a reticulate ornament. Aperture triangular; 8 ridges on the inside of the outer lip; columella with two folds; very narrow umbilicus. The juvenile shell, which has 1 adult whorl, is $3.2 \mathrm{~mm}$. high and $2.2 \mathrm{~mm}$. in diameter.

\title{
Distribution.
}

Pliocene: Mediterranean Basin: Italy: Piacenziano, Astiano.

Miocene: Aquitanian Basin: Burdigalien, Helvétien.

North Sea Basin: Germany: Hemmoor stage. Denmark: Arnum and Gram formations.

Mediterranean Basin: Italy: Elveziano, Tortoniano.

Subgenus Narona H. \& A. Adams 1854

\section{Cancellaria (Narona) varicosa (Brocchi)}

\author{
Plate 51, fig. $169 \mathrm{a}-\mathrm{b}$.
}

1814. Voluta varicosa Brocchr. Conchiol. Foss. Subapennina. 2, p. 311, pl. 3, fig. 8.

1856. Cancellaria varicosa Brocchi. Hörnes. D. foss. Moll. d. Tert.-Beckens v. Wien 1, p. 309 , pl. 34 , fig. 6 .

1894. Sveltia varicosa Brocchi. Sacco. I moll. d. terr. terz. d. Piemonte e d. Liguria. 16, p. 54-56, pl. 3, fig. $42-48$.

1925. Sveltia varicosa Brocchi. Kautsky. D. Mioc. v. Hemmoor u. Basbeck-Osten, p. 138 , pl. 10, fig. 3 .

1928. Sveltia varicosa Brocchi var. Pехrot. Conch. Néogén. d. l'Aquit. p. 217-219, pl. 13, fig. 8 ; pl. 14, fig. 5-7.

1940. Sveltia varicosa BrocchI. Sorgenfrei. Mar. Nedre-Mioc. i Klintinghoved p. Als. p. 47 , pl. 6 , fig. 9 .

1952. Cancellaria (Sveltia) varicosa Brocchi sp. Glibert. Fauna mal. du Mioc. de la Belgique 2, p. 127, pl. 10, fig. 1.

Original diagnosis. Testa turrita, transversim argute striata, longitudinaliter costata, costis teretibus, tuberculis acutis, minimis, raris exasperata, columella triplicata, basi integra, labro sulcato. (BRocCHI 1814).

Shell material.

$\begin{array}{lrllrl}\text { Location } & \text { Depth } & \text { Shells } & \text { Location } & \text { Depth } & \text { Shells } \\ \text { Bramminge } & 70-80 \mathrm{~m} . & 21 & \text { Toftlund } & 110-115 \mathrm{~m} . & 1 \\ \text { Gramby } & 82.66-83.76- & 1 & & 115- & 4 \\ \text { Toftlund } & 75-100- & 3 & \text { Arnum }(13) & 83-94- & 1 \\ & 100-105- & 1 & \text { Arnum }(25 \mathrm{~b}) & 95.0-95.3- & 1\end{array}$


Description. The bulk of the shells from Bramminge are broken and all the other shells are juvenile except for the shell from Arnum 83-94 m.

Protoconch globular, naticoid, smooth and glossy, with 3 to $3 \frac{1}{2}$ whorls. The following table shows the data of a number of well preserved shells. It appears from this table that $C$. varicosa has a large protoconch.

$$
\text { C. varicosa. Protoconch data. }
$$

\begin{tabular}{|c|c|c|c|c|c|c|c|}
\hline \multirow{3}{*}{$\begin{array}{l}\text { Location } \\
\text { Gramby } \\
\text { Toftlund }\end{array}$} & Depth & \multicolumn{2}{|c|}{$\begin{array}{c}\text { Height } \\
(h)\end{array}$} & \multicolumn{2}{|c|}{$\begin{array}{l}\text { Diameter } \\
\text { (d) }\end{array}$} & $\begin{array}{l}\text { Number of } \\
\text { whorls }(w)\end{array}$ & $d / w$ \\
\hline & $82.66-83.76 \mathrm{~m}$ & 1.07 & $\mathrm{~nm}$. & 1.32 & $\mathrm{~nm}$. & $3^{1 / 4}$ & 0.41 \\
\hline & $75-100$ & 1.12 & - & 1.32 & - & 3 & 0.44 \\
\hline & & 1.40 & - & 1.46 & - & $31 / 2$ & 0.42 \\
\hline & $100-105$ & 0.98 & - & 1.22 & - & 3 & 0.41 \\
\hline & $105-110-$ & 1.05 & - & 1.16 & - & $3^{1 / 8}$ & 0.37 \\
\hline & & 1.07 & - & 1.27 & - & $3 \frac{1}{4}$ & 0.39 \\
\hline & $115-$ & 1.55 & - *) & 1.26 & - & $3 \frac{1}{4}$ & 0.39 \\
\hline & & 1.58 & $\left.-*^{*}\right)$ & 1.29 & - & $31 / 2$ & 0.37 \\
\hline Arnum (25b) & $95-95.3 \quad-$ & 1.12 & - & 1.21 & - & $31 / 4$ & 0.37 \\
\hline
\end{tabular}

Teleoconch turreted with 7 to 10 rather projecting collabral ribs per whorl. The helicocone starts initially with 10 to 12 more or less indistinct spiral ribs, the suture being developed below the fourth rib from above. Secondary spirals emerge between the primary spirals on the second and third whorls. From the third whorl there are 16 or 17 spiral ribs from the upper suture down to, and including the canal.

Aperture with thickened outer lip, on the inside of which there are 6 to 9 teeth. The columella has two folds on the juvenile shells. Only the full grown shell from Arnum (13) 83-94 m. has a weak indication of a third fold on the columella. There is no umbilicus.

Remarks. The variability of this species has been sufficiently demonstrated by earlier authors. In this connection the writer questions the taxonomic significance of the varieties which have been established at intervals. The characters on which the different varieties have been founded are obviously of such a flexible nature that it seems quite useless to maintain them by their present definition. It is therefore proposed to neglect all varieties until they can be substantiated on sound statistical grounds.

Distribution.

Pliocene: Mediterranean Basin: Italy: Piacenziano, Astiano.

Miocene: Aquitanian Basin: Burdigalien, Helvétien.

North Sea Basin: Belgium: Boldérien, horizon of Houthaelen, Anversien. Germany: Hemmoor stage. Reinbek stage (GoTTSche 1878), Glimmerton (BANKE Rasuussen 1956). Denmark: Klintinghoved clay, Arnum formation.

Mediterranean Basin: Italy: Elveziano, Tortoniano. Vienna Basin: Beds at Grund and Vöslau.

*) These two shells have just started the adult stage, and the transition from protoconch to teleoconch can be examined from the columella to the upper suture. The height given is accordingly the true height of the protoconch, while the height figures for the other shells indicate the height of the exposed part of the protoconch above the first adult whorl. 


\section{Genus Admete Kröyer 1842}

\section{Admete cf. fusiformis (Cantraine)}

Plate 51, fig. 170.

1835. Cancellaria fusiformis CANTRAINE. Diagnoses moll. p. 391.

1848. Cancellaria subangulosa Wood. Monogr. Crag Moll. 1, p. 66, pl. 7, fig. 20.

1870. Cancellaria subangulosa Wood. Speyer. D. Conch. d. Casseler Tert. 1, p. 99, pl. 11, fig. 10-13.

1894. Admete fusiformis (CANTr.) Sacco. I moll. d. terr. terz. d. Piemonte e d. Liguria 16, p. 71 , pl. 3, fig. 94 .

1907. Cancellaria subangulosa Wood. Ravn. Molluskf. Jyll. Tert., p. 340, pl. 6, fig. 17.

1913. Cancellaria subangulosa Wood. HARDER. De olig. Lag etc. v. Aarhus St. p. 86, pl. 7, fig. 8-9.

1914. Cancellaria subangulosa Wood. GrIPP. Über eine u. mioc. Moll. f. v. Itzehoe. p. 26, pl. 3, fig. 4-6.

1925. Admete (Babylonella) fusiformis Cantr. var. subangulosa Wood. KaUtsky. D. Mioc. v. Hemmoor u. Basbeck-Osten. p. 144.

?1928. Sveltia pyrenaica Peyrot. Conch. Néogén. d. l'Aquit. p. 223, pl. 14, fig. 36-37.

1952. Admete (Babylonella) fusiformis Cantraine sp. Glibert. Faune mal. du Mioc. de la Belgique. 2, p. 131, pl. 8, fig. 18.

1956. Admete (Babylonella) subangulosa Wood. Banke Rasmussen. Upper Mioc. South Jutland. p. 80, pl. 7, fig. 5 .

Original diagnosis. Testa elongata turrita, longitudinaliter costata, transversim striata; anfractibus convexis; columella triplicata, umbilicata. (CANTRATNE $1835)$.

Shell material.

$\begin{array}{lrrlrl}\text { Location } & \text { Depth } & \text { Shells } & \text { Location } & \text { Depth } & \text { Shells } \\ \text { Glejbjerg } & 53.5 \mathrm{~m} & 2 & \text { Toftlund } & 110-115 \mathrm{~m} . & 3 \\ & 53.75- & 2 & & 115- & 1 \\ & 55- & 1 & \text { Arnum (13) } & 53-83- & 1 \\ \text { Bramminge } & 70-80- & 12 & \text { Arnum (25b) } & 62.7-62.9- & 3 \\ \text { Gramby } & 82.66-83.76- & 2 & & 95.0-95.3- & 1 \\ \text { Toftlund } & 75-100- & 4 & & 104.3-107.5- & 3 \\ & 105-110- & 13 & & 107.5- & 1 \text { (frg.) }\end{array}$

Description. Most of the shells are either very small, or more or less broken.

Protoconch. Initial whorl slightly heterostrophe, with minute spiral striation hardly perceptible under the microscope. The striation develops into a bivirgate, forward converging striation on the second whorl. Delicate, curved, collabral riblets, appear on the third whorl, on which the bivirgate striation also continues in the rib interspaces. The apex of the protoconch is depressed.

The protoconch is relatively small in this species compared with the preceding Cancellariidae as shown by the following data.

A. fusiformis. Protoconch data.

\begin{tabular}{|c|c|c|c|c|c|}
\hline Location & Depth & Height $\left.(h)^{*}\right)$ & Diameter $(d)$ & $\begin{array}{l}\text { Number of } \\
\text { whorls }(w)\end{array}$ & $d / w$ \\
\hline \multirow[t]{2}{*}{ Glejbjerg } & $53.5 \mathrm{~m}$. & $0.65 \mathrm{~mm}$ & $0.68 \mathrm{~mm}$. & 3 & 0.23 \\
\hline & $53.75-$ & $0.62-$ & $0.67 \quad-$ & 3 & 0.22 \\
\hline \multirow[t]{2}{*}{ Toftlund } & $75-100$ & 0.71 & $0.74 \quad-$ & 3 & 0.2 \\
\hline & & 0.61 & 0.68 & 3 & 0.2 \\
\hline
\end{tabular}

*) Height of the exposed part of the protoconch. 
Teleoconch turreted, with more or less angular whorls. Ten to 15 strong, collabral ribs per whorl (mean 12 ribs). Distinct spiral ribs are found on the entire body whorl from the suture to the canal. The first whorl has about 8 to 10 spiral ribs, while on later whorls the number is gradually increased by the intercalation of secondary spirals. The suture is generally developed at about the middle spiral rib.

A few well preserved shells were examined for the number of spirals on the whorls of the spire, and for apertural features:

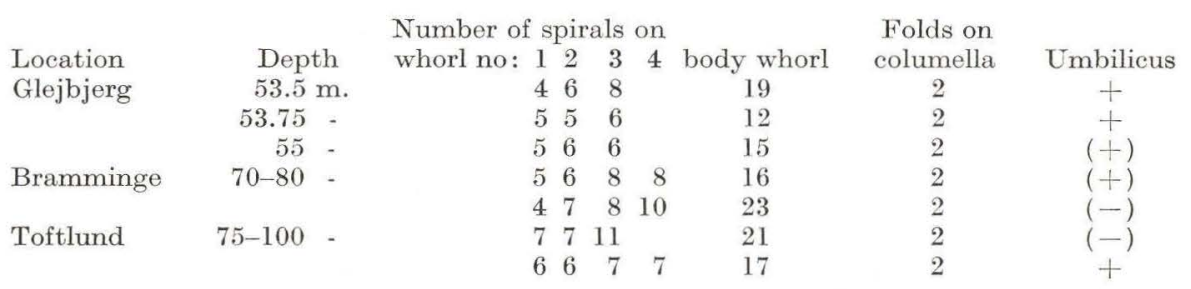

Plus and minus in the above indicate presence and absence of an umbilicus respectively while parentheses indicate doubt. The aperture is triangular, with a simple margin and a flat canal which is occasionally somewhat pointed. Columella with two weak, but distinct folds. A narrow umbilicus is generally developed. The inner lip is thin. The dimensions of three almost entire shells were:

\begin{tabular}{|c|c|c|c|c|}
\hline Location & Depth & Height & Diameter & Number of whorls \\
\hline Glejbjerg & $53.75 \mathrm{~m}$. & $3.9 \mathrm{~mm}$. & $1.98 \mathrm{~mm}$. & $21 / 2(+$ protoconch $)$ \\
\hline Toftlund & $75-100-$ & 5.6 & 3.0 & $31 / 2$ \\
\hline & & 6.8 & 3.48 & $33 / 4$ \\
\hline
\end{tabular}

Remarks. The sculpture of the protoconch can only be studied in very well preserved specimens. GRIPP (1914) was the first to detect the feature, which may be of specific significance. It is unfortunate therefore that other authors have not given a detailed record of the protoconch, and that the published illustrations of the species, except for HARDER's figure, show very little of the details concerned. This lack of information makes a final decision concerning the identity of the shells listed in the synonymy impossible at present.

The uncertainty expressed in the species name is accordingly only due to the poor descriptions in literature, and not to the state of the present shell material, which is excellent.

Peyrot's species is probably identical with A. fusiformis in spite of the fact that it is referred to the genus Sveltia. This shows how questionable the taxonomic value of subgeneric units may be. It is difficult to decide whether the shell in question, as well as the shells from South Jutland, should be referred to Admete or Sveltia. Admete should have three folds on the columella, a canal and no umbilicus according to Cossmann (1899, p. 5), but Sveltia is defined in practically the same way. From this it may be inferred that the subgeneric subdivision has been carried unreasonably far in the present case.

Distribution (reservation is made for the uncertainties stated regarding the synonymy).

Pliocene: North Sea Basin: England: Coralline Crag. Mediterranean Basin: Italy: Piacenziano, Astiano. 
Miocene: Aquitanien Basin: ?Aquitanien.

North Sea Basin: Belgium: Anversien. Germany: Vierlande and Hemmoor stage, Glimmerton (BANke RaSMUSSEN 1956). Denmark: Arnum and Gram formations. Mediterranean Basin: Italy: Tortoniano.

Oligocene: North Sea Basin: Germany (u.), Denmark (u.).

FAMILTA CONIDAE

\title{
Genus Conus Linné 1758
}

\section{Conus Dujardini Deshayes}

\author{
Plate 52, fig. 171.
}

1845. Conus Dujardini Deshayes. Hist. Nat. Anim. s. Vert. 11, p. 158.

1856. Conus Dujardini Deshayes. Hörnes. D. foss. Moll. d. Tert.-Beckens v. Wien. 1, p. 40, pl. 5, fig. 3, 5-8.

1894. Conospirus Dujardini Deshayes et var. Sacco. I moll. d. terr. terz. d. Piemonte e d. Liguria 13, p. 45, pl. 5, fig. 1-7.

1925. Conus (Conospira) Dujardini Deshayes. Kautsky. D. Mioc. v. Hemmoor u. Basbeck-Osten, p. 145, pl. 10, fig. 14-15.

1930. Conus (Conospira) Dujardini Deshayes. Pexrot. Conch. Néogén. d. l'Aquit. p. 85 , pl. 1, fig. $45-51$.

1952. Conus (Conospira) Dujardini Deshayes. Glibert. Faune mal. du Mioc. de la Belgique. 2, p. 132, pl. 10, fig. 3 .

1952. Conus (Conospira) Dujardini Deshayes. Glibert. Gastr. du Mioc. moy. d. basin de la Loire. 2, p. 371, pl. 12, fig. 11.

Original diagnosis. Testa elongato-turbinata, spira conica plus minusque elongata, acuminata; anfractibus angustis, basi angulatis, primis decussatis basi crenulatis, ultimo regulariter conico basi striato; apertura angusta, labro tenui superne vix emarginato. (DESHAYES 1845).

Shell material.

\begin{tabular}{|c|c|c|c|c|c|}
\hline \multirow{4}{*}{$\begin{array}{l}\text { Location } \\
\text { Glejbjerg }\end{array}$} & Depth & Shells & Location & Depth & Shells \\
\hline & $53 \mathrm{~m}$. & 1 & Toftlund & $100-105 \mathrm{~m}$. & 3 (ef.) \\
\hline & $53.5-$ & I (cf.) & & $105-110=$ & $5-$ \\
\hline & 55 & $2-$ & & $110-115$ & $1-$ \\
\hline Bramminge & $70-80=$ & $47-$ & & $115-$ & $1-$ \\
\hline \multirow[t]{2}{*}{ Gramby } & $82.66-83.76-$ & 1 - & Arnum (13) & $53-83-$ & 7 - \\
\hline & $84.66-87.16$ - & 1 - & & $83-94$ - & 1 \\
\hline Toftlund & $75-100-$ & $10-$ & & & \\
\hline
\end{tabular}

Description. The shell material consists mainly of juvenile shells which passed a little beyond the protoconch stage, except for the adult shells from Glejbjerg $53 \mathrm{~m}$. and Arnum 83-94 m. It is believed that all the shells belong to $C$. Dujardini, but it is recognized that the juvenile specimens could not be determined with certainty, as indicated by "cf." in the above list of shells.

Protoconch turreted, slightly heterostrophe, with smooth whorls. Initial whorl apparently with microscopically punctate surface. Other whorls smooth and glossy. The following dimensions of the exposed protoconch spire illustrate the size of the stage. 
Data on the exposed part of the protoconch (Bramminge $70-80 \mathrm{~m}$.)

$\begin{array}{ccc}\text { Height } & \text { Diameter } & \text { Number of whorls } \\ \pm 1.56 \mathrm{~mm} . & 1.33 \mathrm{~mm} . & 51 / 2 \\ \pm 1.56- & 1.21- & 51 / 4 \\ 1.45- & 1.21- & 5^{1 / 3} \\ 1.64- & 1.25- & 51 / 2\end{array}$

Teleoconch with knobs on the angular keel of the whorls. Curved growth lines on the shelf of the whorl, and sometimes also faint spiral threads on this part of the shell. Two to three spiral grooves immediately below the keel. Last whorl with 10 to 15 spiral grooves on its lower part, in which the growth lines occasionally appear as minute, thread-like ribs. Spire rather high.

Remarks. The writer has not included C.Allionii, described by GrIPP (1914), Kautsky (1925), and Sorgenfrei (1940) in the synonymy, since the knobs on the keel of the shells described by these authors are restricted to the first one or two whorls. The writer is aware of GLIBERT's statement that the Belgian shells of C.Dujardini are very variable and include specimens with smooth and nodular keels. This does not imply that all smooth shells should be referred to C.Dujardini. The writer decided therefore to keep the shells of C. Allionii referred to above separated from $C$. Dujardini until further evidence on the specific significance of the shell morphology of Conus has been procured.

\section{Distribution.}

Pliocene: Mediterranean Basin: Italy: Astiano.

Miocene: Aquitanian Basin: Burdigalien, Helvétien.

North Sea Basin: Belgium: Boldérien, Anversien. Germany: Hemmoor stage, Reinbek stage (GotTsche 1878). Denmark: Arnum formation.

Mediterranean Basin: Italy: Elveziano, Tortoniano. Vienna Basin: Grund, Baden.

\section{FAMILIA TURRIDAE MELVILL 1917}

Several authors have been fascinated by the highly varied, and often very beautiful combinations of ornamental features in the shells of the species belonging to this family. The taxonomical grouping of the great number of species has however often caused difficulties.

The vague definitions of genera and other supraspecific groups are undoubtedly very prominent reasons for such difficulties, although indistinctness of definitions is after all probably not more pronounced than in other gastropod families. It is obvious that the Turridae clearly differ from other families by the more varied and gradual variation of a number of uncorrelated shell features. The limitations of our taxonomic methods are therefore more clearly unveiled in the the various attempts to subdivide the Turridae than in subdividing any other family.

The latest comprehensive treatment of the Turridae is by Powell (1942), who discussed the systematical significance of radula dentition and shell features. He also contributed valuable points of view concerning the significance of the protoconch in taxonomy. I would like to quote one of his statements which is a concentrate of his ideas on this feature: "Much criticism has been 
levelled at the employers of protoconch criteria in the family, but in all these objections the fault seems to lie in the failure of rigid application of these criteria. If we refuse to admit more than one style of protoconch in a genus these anomalies disappear, and in justification of this, I may state that the application of this rule in respect to the extensive fauna of New Zealand Tertiary Turridae in particular, has been attended with satisfactory results". (PowelL 1942, p. 26).

The writer agrees with the basic concept of the relations between genetic subdivision and the style on type of protoconch. However, if protoconch features are to be applied in taxonomy, as suggested by Powell then recognition of the essential features which constitute the "style" or "type" of the protoconch becomes critical. Analysis of protoconch features is accordingly the first step towards an adequate evaluation of the type of protoconch.

A study of the protoconchs in the Turridae from South Jutland revealed that there are clearly as many as three different structures in the helicocone of the protoconch. This has been observed in Daphnella, Bathytoma, and Turris. The characteristic protoconch of Daphnella may serve as an illustration of this trimorphism. The helicocone starts with about one slightly heterostrophe initial whorl, which is ornamented with microscopical, punctiform impressions arranged in spiral rows on the shell surface. This sculpture ends abruptly and is followed by 1 or 2 diagonally cancellated medial whorls, the characteristic feature of the Daphnellae. The terminal part of the helicocone consists of $1 / 2$ to 1 whorl which is devoid of diagonal cancellation; it has a distinct keel and one or two spirals above or below the keel.

The entire shell thus described corresponds undoubtedly to the pelagic stage of the animal, and it is possible that the initial sinistral whorl agrees with the larval stage prior to the torsion of the visceral hump. The writer is not yet able to make any suggestions concerning the significance of the medial and terminal divisions of the protoconch.

It will be attempted to designate the type of protoconch in the different species described in the following, while a revision of genera with respect to protoconch features must be postponed until the protoconchs of the genotypes have been described in detail.

It is possible roughly to discriminate between two main types of protoconch spires: the polygyrate more or less conical spire, and the paucigyrate, large and blunt spire. These two main types may be recognized also in the shells illustrated by POWELL, and there are obviously very few transitional forms. The significance of the main protoconch types could usefully be one of the goals of marine conchological research. The paucigyrate shell is perhaps indicative of a short pelagic stage while the polygyrate shell undoubtedly signifies a long pelagic stage. (See also p. 379).

A peculiar textural and ornamental feature, consisting of a thin granular film was observed under the microscope on the shell surface of a few Daphnellae (D. anceps, D. scabra, etc.). This texture was at first assumed to have been unknown to previous writers, since it has not been mentioned in, for instance, previous descriptions of D. anceps or D. scabra. However, HedLey (1902, p. 384) apparently observed the same feature in the recent Pleurotoma (Veprecula) vepratica, Filodrillia tricarinata (loc.cit. p. 389), and in Heterocithara seriliola (Hedley 1922, p. 299) from Australia. Powell (1942, p. 157) also mentions the granulate pattern of Heterocithara, and states that such a pattern is characteristic of the Mangiliinae. This statement is however not in 
agreement with my observations of the granular surface in Daphnella anceps and D. scabra.

Whatever the genetic significance of this particular ornamental feature may be, it deserves to be mentioned since it is certainly a specific shell texture which might be utilized taxonomically. It ought to be emphasized that the granulation here described is fundamentally different from the granulation caused on riblets at the intersection of growth lines, as is well known both in the Turridae and other gastropod families. The granulation of the Daphnellae covers both ribs and interspaces of the teleoconch as a film, it extends onto the terminal part of the protoconch, and may occasionally also cover the medial part of the protoconch.

\section{Genus Gemmula Weinkauff $\mathbf{1 8 7 5}$}

\section{Gemmula cf. rotata (Brocchi)}

Plate 52, fig. 172.

1814. Murex rotatus Brocchr. Conchiol. Foss. Subapennina, p. 434, pl. 9, fig. 11.

1856. Pleurotoma rotata Broc. HönNes. D. foss. Moll. d. Tert.-Beckens v. Wien. 1, p. 354, pl. 38, fig. 18.

1878. Pleurotoma rotata Broc. Beltand. I moll. d. terr. terz. d. Piemonte e d. Liguria. 2, p. 13 , pl. 1, fig. $2-6$.

1907. Pleurotoma rotata Broc. sp. Ravn. Molluskf. Jyll. Tert. p. 355, pl. 8, fig. 4 (pro parte).

1925. Pleurotoma rotata Broc. Kautsky. D. Mioc. v. Hemmoor u. Basbeck-Osten. p. 160, var. pl. 11, fig. 7 .

1940. Pleurotoma rotata Brocchi. Sorgenfrei. Mar. Nedre-Mioc. i Klintinghoved p. Als. p. 51, pl. 6, fig. 14 .

?1954. Turris (Gemmula) coronata Münster sp. GLIBERT. Pleurotomes ete. p. 7, pl. 2, fig. 4.

Original diagnosis. Testa turrita transversim striata, anfractubus carinatis, carina acuta denticulata, labro fisso (BRoccHI 1814).

Shell material.

$\begin{array}{lrc}\text { Location } & \text { Depth } & \text { Shells } \\ \text { Glejbjerg } & 53.5 \mathrm{~m} . & 2 \\ & 53.75- & 1 \\ \text { Bramminge } & 55- & 2 \\ \text { Gramby } & 70-80- & 35 \\ & 82.66-83.76- & 7 \\ \text { Toftlund } & 84.66-87.16- & 1 \\ & 75-100- & 37 \\ & 100-105- & 14\end{array}$

$\begin{array}{lrc}\text { Location } & \text { Depth } & \text { Shells } \\ \text { Toftlund } & 105-110 \mathrm{~m} . & 34 \\ & 110-115- & 5 \\ & 115- & 3 \\ \text { Arnum (13) } & 28-40- & 1 \\ & 53-83- & 1 \\ \text { Arnum (25b) } & 62.7-62.9- & 27 \text { (cf.) } \\ & 101-104.3- & 1 \text { - }\end{array}$

Description. Most of the shells are juvenile and have not passed much beyond the protoconch stage. The features of the shell are, however, generally well preserved, and the identification should be well founded.

\section{Protoconch.}

Initial whorl slightly sinistral with punctiform impressions on shell surface. The succeeding half to whole whorl, generally devoid of sculpture, may be classified as the medial part of the helicocone. The terminal $3 \frac{1}{4}$ to $3 \frac{3}{4}$ whorls have delicate collabral riblets from which minute transverse threads radiate as shown on the accompanying illustration. There are 16 to 28 collabral riblets per whorl. The following table gives important data on the protoconch. 


\begin{tabular}{|c|c|c|c|c|c|c|c|}
\hline \multicolumn{2}{|c|}{$\begin{array}{c}\text { Height } \\
\text { mm. }\end{array}$} & & \multicolumn{4}{|c|}{ Number of whorls } & \multirow{2}{*}{$\begin{array}{l}\text { Number of riblets } \\
\text { per whorl }\end{array}$} \\
\hline Spire & Total & Diameter & Total & Initial & Medial & Terminal & \\
\hline 1.88 & & 1.46 & $51 / 2$ & 1 & $3 / 4$ & $33 / 4$ & 18-19 \\
\hline 1.29 & & 1.22 & $4^{3 / 4}$ & $11 / 2(?)$ & absent & $31 / 4$ & $16-17$ \\
\hline 1.33 & & 1.19 & 5 & 1 & $1 / 2$ & $31 / 2$ & $17-21$ \\
\hline & 12.35 & 1.43 & $51 / 4$ & 1 & $1 / 2$ & $33 / 4$ & $17-19$ \\
\hline 1.35 & & (worn) & 5 & 1 & $1 / 2$ & $31 / 2$ & $18-28$ \\
\hline & ca. 2.4 & 1.49 & $51 / 2$ & 1 & 1 & $31 / 2$ & $15-18$ \\
\hline
\end{tabular}

Teleoconch. The main features may be observed on the accompanying illustration. The keel is mostly furnished with two distinct spiral ribs which form low spines on crossing the collabral ribs. There are about 17 to 20 collabral ribs per whorl on the first three whorls. (The shells available have not passed the fourth whorl).

Remarks. Relationships between G. rotata and allied species as e.g. G. badensis described below, $G$. coronata, $G$. denticula, etc. have not yet been clarified satisfactorily since protoconch features have not been considered by earlier authors. It is thus the absence of records of protoconch features in the literature which renders a final determination of the shells from South Jutland impossible at present. The list of synonymy is accordingly only a tentative suggestion, except for the shells from Klintinghoved, which are conspecific with the present species. Concerning differences between the above shells compared with $G$. rotata and $G$. badensis, reference is made to the description of $G$. badensis below.

Distribution. (Unverified occurrence not recorded).

Miocene: North Sea Basin: Denmark: Klintinghoved clay, Arnum formation.

\section{Gemmula badensis (Hörnes)}

Plate 52, fig. 173.

1856. Pleurotoma monilis Brocc. Hörnes. D. foss. Moll. d. Tert.-Beckens v. Wien. 1, p. 353 , pl. 38 , fig. 14-16.

1875. Pleurotoma Badensis Hörnes. D. Fauna d. Schliers v. Ottnang. p. 357.

1891. Pleurotoma Badensis Hörnes. Hoernes \& AuInger. Gastr. d. ersten u. zweiten mioc. Medit. St. p. 294.

1907. Pleurotoma rotata Brocchi sp. Ravn. Molluskf. Jyll. Tert. p. 355, pl. 8, fig. 4 (pro parte).

1925. Pleurotoma Badensis HöRn. Kautsky. D. Mioc. v. Hemmoor u. Basbeck-Osten, p. 161, pl. 11, fig. 8 .

1956. Turris (Gemmula) badensis (R. Hörnes). Banke Rasmussen. Upper Mioc. South Jutland. p. 84, pl. 8, fig. 2.

Essential features of original description. HöRnes did not give any diagnosis in 1875, the following essentials are from his paper from 1891: "Die Wiener Gehäuse sind grösser, die Umgänge gleichmässiger gewölbt, so dass der Kiel nicht so stark hervortritt wie bei Pl. rotata, der Kiel ist breiter, die Knoten auf demselben gröber und fast stets glatt und glänzend. Die Quersculptur tritt auf dem oberen Theil der Windungen zwischen Kiel und Naht sehr zurück, so dass die Schale dort fast glatt erscheint, während unter dem Kiel kräftige Querreifen und erhabene Querlinien zwischen denselben erscheinen. 
Shell material.

$\begin{array}{lrllrr}\text { Location } & \text { Depth } & \text { Shells } & \text { Location } & \text { Depth } & \text { Shells } \\ \text { Glejbjerg } & 23 \mathrm{~m} . & 1 & \text { Gramby } & 82.66-83.76 \mathrm{~m} . & 4 \\ & 25- & 1 & & 84.66-87.16- & 1 \text { (cf.) } \\ 38- & 1 \text { (cf.) } & \text { Toftlund } & 75-100- & 18 \\ 42- & 1- & & 100-105- & 12 \\ & 48- & 1- & & 105-110- & 16 \\ & 53- & 2 \text { (cf.) } & & 110-115- & 8 \\ & 53.5- & 10 & & 115- & 10 \\ & 53.75- & 2 & \text { Arnum (13) } & 53-83- & 10 \\ \text { Bramminge } & 55- & 5 & & 83-94- & 1 \text { (cf.) } \\ & 70-80- & 68 & \text { Arnum (25b) } & 95.0-95.3- & 2\end{array}$

Description. Most shells are juvenile and several of the juvenile shells have the base of the protoconch exposed. Total height of the protoconch could accordingly be measured in a number of specimens. The largest shells have either the apex or the canal broken; they are from about 10 to $15 \mathrm{~mm}$. high.

Protoconch. Trimorphism of the helicocone conspicuous. One slightly inflated, sinistral, initial whorl with punctiform impressions on shell surface; 1 to $1 \frac{1 / 2}{2}$ smooth medial whorls, and $13 / 4$ to $2 \frac{1}{4}$ terminal whorls with 11 to 15 collabral riblets per whorl. The riblets are occasionally crossed by microscopical transverse grooves, and hardly perceptible threads radiate from the riblets in some specimens.

\begin{tabular}{|c|c|c|c|c|c|c|}
\hline \multirow{3}{*}{$\begin{array}{l}\text { Total height } \\
\text { mm. } \\
\text { Glejbjerg } 23 \mathrm{~m} . \text { : } \\
1.84\end{array}$} & \multirow{2}{*}{$\begin{array}{c}\text { Diameter } \\
\mathrm{mm} \text {. }\end{array}$} & \multicolumn{4}{|c|}{ Number of whorls } & \multirow{2}{*}{$\begin{array}{c}\text { Number of riblets } \\
\text { per whorl }\end{array}$} \\
\hline & & Total & Initial & Medial & Terminal & \\
\hline & 1.07 & $41 / 4$ & 1 & 1 & $21 / 4$ & $12-13$ \\
\hline \multicolumn{7}{|c|}{ Toftlund $75-100 \mathrm{~m} .:$} \\
\hline 1.92 & 1.08 & $41 / 2$ & 1 & $11 / 2$ & 2 & $14-15$ \\
\hline 1.54 & 0.96 & 4 & 1 & $11 / 4$ & $13 / 4$ & $13-15$ \\
\hline 1.72 & 0.99 & $41 / 4$ & 1 & 1 & $21 / 4$ & 13 \\
\hline 1.76 & 0.98 & $41 / 2$ & 1 & $1 \frac{1}{4}$ & $21 / 4$ & $12-13$ \\
\hline 1.72 & 0.96 & $41 / 2$ & 1 & $11 / 2$ & 2 & $12-13$ \\
\hline 1.66 & 0.92 & $45 / 8$ & 1 & $11 / 2$ & $21 / 8$ & $11-12$ \\
\hline
\end{tabular}

Teleoconch. The knobs on the keel are generally round, 13 to 17 in number, and occur on about the first 5 adult whorls. The adapical part of the whorl has either no spiral sculpture, or the spiral element is very weak. There are initially about 10 spiral ribs on the base of the body whorl and the canal. Secondary ribs have developed in the interspaces on large shells. Aperture and canal broken in all specimens.

Remarks. A. comparison of protoconch data in G. cf. rotata and G. badensis shows the following differences:

Number of whorls

Number of riblets per whorl

Height

Diameter

$$
\begin{array}{cccc}
\text { G. cf. rotata } & \multicolumn{2}{c}{\text { G. badensis }} \\
\text { about } & 43 / 4-51 / 2 & \text { about } & 4-45 / 8 \\
- & 15-28 & - & 11-15 \\
- & 2.4 \mathrm{~mm} .) & - & 1.54-1.92 \mathrm{~mm} . \\
- & 1.19-1.49- & - & 0.92-1.08-
\end{array}
$$

To these quantitative differences between the protoconchs may be added that the teleoconch of G. cf. rotata has generally 17 to 20 spines per whorl on the keel of the first whorls, while G. badensis has from 13 to 17 round knobs 
per whorl. Spirals are found on the adapical part of the whorls of G. cf. rotata, while the corresponding shell region in $G$. badensis is generally devoid of spiral sculpture, etc. This shows that differences are distinct on a statistical basis. However, it is often rather difficult in practice to discriminate shells of one species from the other since the variation ranges of the two species overlap in the number of whorls and the number of riblets per whorl on the protoconch. The presence of threads radiating from the riblets suggest in most cases $G$. cf. rotata. The significance of this character is, however, also weakened, since it was discovered that $G$. badensis occasionally may develop similar, but less distinct threads on the riblets on the protoconch terminal whorls.

Distribution. (Unverified occurrence not recorded).

Miocene: North Sea Basin: Germany: Hemmoor stage. Denmark: Arnum and Gram formations.

Vienna Basin: Baden beds.

\section{Gemmula boreoturricula (Kautsky)}

Plate 52, fig. 174 a-c, plate 53, fig. 174.

1925. Pleurotoma (Hemipleurotoma) boreoturricula KAUtsky. D. Mioc. v. Hemmoor u. Basbeck-Osten, p. 165, pl. 11, fig. 14-16.

1954. Turris (Gemmula) boreoturricula KAUtSky sp. GLIBert. Pleurotomes etc. p. 9, pl. 2, fig. 8 .

Essential features of original description. 9 Umgänge, von denen 3 auf das schlanke und glatte Embryonalgewinde entfallen. Auf das Embryonalgewinde folgen 11/2 Umgänge mit etwas gekrümmten Längsrippen. Die übrigen Umgänge mit flach gewölbter Karina. Diese trägt stark sichelförmig gekrümmte schmale Längsrippen. Über sie laufen ca. 6 sehr schwache Spiralen. (KAUTSKY 1925).

Shell material.

$\begin{array}{lrrlrr}\text { Location } & \text { Depth } & \text { Shells } & \text { Location } & \text { Depth } & \text { Shells } \\ \text { Glejbjerg } & 25 \mathrm{~m} . & 1 & \text { Toftlund } & 75-100 \mathrm{~m} . & 9 \\ & 53.5- & 6 & & 100-105- & 1 \\ & 53.75- & 2 & & 105-110- & 15 \\ & 54- & 1 & & 110-115- & 14 \\ \text { Bramminge } & 55- & 3 & & 115- & 39 \\ \text { Ribe } & 70-80- & 33 & \text { Arnum (13) } & 83-94- & 1 \\ & 113-114- & 1 & \text { Arnum (25b) } & 104.3-107.5- & 20 \\ \text { Gramby } & 124-125- & 1 \text { (cf.) } & & 107.5- & 1 \text { (cf.) }\end{array}$

Description. Most of the shells are juvenile. The adult specimens more or less broken.

Protoconch. Initial whorl slightly sinistral, surface granulated, granules occasionally spirally arranged. Two to 3 convex medial whorls generally granulated on their lower half only, although granulation may often be found on the entire shell surface. One and a half to $2 \frac{1}{4}$ terminal, collabrally ribbed whorls with granulations as on the medial whorls. Number of ribs 13-17 per whorl. The data of 6 well preserved shells are listed in the following table. 
Gemmula boreoturricula. Protoconch data.

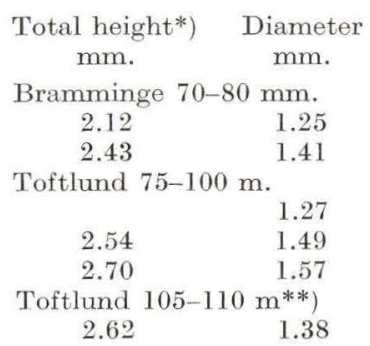

\author{
Number of whorls \\ Total Initial Medial Terminal
}

$\begin{array}{lllll}5 & 1 & 23 / 4 & 11 / 4 & 14 \\ 5 & 1 & 23 / 4 & 11 / 4 & 15 \\ 5 & 1 & 3 & 1 & 13 \\ 51 / 2 & 1 & 3 & 11 / 2 & 14 \\ 53 / 4 & 1 & 21 / 2 & 21 / 4 & 15 \\ 51 / 2 & 1 & 3 & 11 / 2 & 17\end{array}$

Number of riblets per whorl

14

7

Teleoconch. Spire turreted with relatively flat whorls. Sculptural features extremely varied. The sculptural elements subject to variation are the collabral ribs and the spiral cords and ribs.

It is believed that the following may be a more or less normal development of the sculpture: One or two strong spirals at the upper suture; 6 to 10 weak spiral threads on the adapical part of the whorl (3 to 5 opposite the sinus of the growth lines being a little stronger than the others), and a varying number (15-20) of strong spiral ribs on the abapical part of the body whorl and the canal. About 16 to 20 collabral ribs per whorl are occasionally developed on the sinus area. Largest shell (Arnum (25 b) 104.3-107.5 m.): height $10.3 \mathrm{~mm}$., diameter $3.62 \mathrm{~mm} ., 4$ protoconch whorls and 5 adult whorls.

Variation. The greatest variation is displayed by the length of the helicocone in the different subdivisions of the protoconch and by the sculptural development of the teleoconch. There are shells on which no collabral ribs have developed on the teleoconch. In such specimens the spiral ribs are generally well developed, and the spire is often conical. Other shells have the number of spiral ribs considerably reduced compared with the "normal" number suggested above.

Remarks. There can be no doubt about the identity of the present shells with those described by KAUTSKY, in spite of the fact that the protoconch was stated to be smooth by KaUtsky, while all the shells from South Jutland have a granulated protoconch shell surface.

It is very difficult to delimit this highly variable species and to define its specific characters. The protoconch features are certainly of significance and are a practical help in determination, while the number and relief of the ribs of the teleoconch undoubtedly form a very weak basis for delineation of the species from related forms.

$G$. boreoturricula is possibly a synonym for $G$. Annae. The statement by Hörnes (1856 p. 351) that Pleurotoma monilis = G. Annae (HoErnes \& AUINGer 1891, p. 296) has two protoconch whorls is the only reason why the writer did not include $G$. boreoturricula in the synonymy of G. Annae. A comparison of descriptions and illustrations proves that both shell features and variation are otherwise very similar in the two species.

The shell material from South Jutland here described was originally assumed to belong partly to $G$. Annae and partly to G. boreoturricula. It was believed that forms in which the entire protoconch surface is granulated could be

*) Except for one of the measured protoconchs, all specimens had the abapical end of the terminal apertural growth line of the protoconch exposed.

**) Figured specimen, plate 52, fig. 174 a-c. 
referred to G. Annae while others with only the lower part of the whorls granulated were determined as $G$. boreoturricula. Also there seemed to be some correlation between the apical angle and the granulation, since the few shells referred to $G$. Annae had a smaller apical angle than most of the shells referred to $G$. boreoturricula. A critical revision of all the shell material resulted, however, in the rejection of this hypothesis, since a number of transitional forms clearly showed the impossibility of an objective division of the shell material on the basis of the shell features mentioned. The doubt concerning the validity of $G$. boreoturricula, as expressed above, arose in part from this recognition.

Distribution.

Miocene: North Sea Basin: Belgium: Anversien. Germany: Hemmoor stage. Denmark: Arnum formation.

\section{Gemmula Stoffelsi (Nyst)}

Plate 53, fig. 175.

1843. Pleurotoma Stoffelsi Nyst. Deser. de Coq. et d. Polyp. foss. p. 521, pl. 44, fig. 1.

1925. Pleurotoma (Hemipleurotoma) mio-bosqueti Kautsky. D. Mioc. v. Hemmoor u Basbeck-Osten, p. 166, pl. 11, fig. 17.

?1931. Pleurotoma disjuncta Peyrot. Conch. Néogén. d. l'Aquit. p. 83, pl. 6, fig. 2, 10, 12. ?1931. Pleurotoma (Hemipleurotoma) canaliculata Bellardi in sched. Perrot. Conch. Néogén. d. l'Aquit. p. 90, pl. 6, fig. 41, 43, 45, pl. 8, fig. 9.

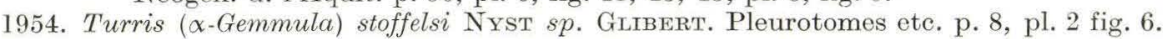

Original diagnosis. Testa elongato-fusiformi, eleganter transversim sulcata, sulcis superne granulosis; spira acuminata, ultimo anfractu longiore; anfractibus convexis, superne subcanaliculatis; apertura ovato-angusta. (NYST 1843).

Shell material.

$\begin{array}{lrrlrr}\text { Location } & \text { Depth } & \text { Shells } & \text { Location } & \text { Depth } & \text { Shells } \\ \text { Glejbjerg } & 53.5 \mathrm{~m} & 1 & \text { Toftlund } & 105-110 \mathrm{~m} . & 5 \\ & 53.75- & 1 & & 110-115- & 4 \\ \text { Bramminge } & 55- & 1 & & 115- & 11 \\ \text { Gramby } & 82.66-83.76- & -1 & & 53-83- & 3 \\ \text { Toftlund } & 75-100- & 11 & & 83-94- & 1\end{array}$

\section{Description.}

Protoconch. One initial, slightly sinistral whorl with punctiform impressions on shell surface. Two three quaters to $3 \frac{1}{4}$ granulated, medial whorls, and about $1 / 3$ to 1 granulated terminal whorl with about 15 collabral riblets. In some shells the granules are only found on the lower half of the medial and terminal whorls.

\begin{tabular}{lrccc} 
& \multicolumn{2}{c}{ Gemmula Stoffelsi. Protoconch data. } \\
Location & Depth & Shell no. & Total height*) & Diameter \\
Glejbjerg & $53.75 \mathrm{~m}$. & 1 & & $1.11 \mathrm{~mm}$. \\
Gramby & $82.66-83.76-$ & 2 & $2.15 \mathrm{~mm}$. & 1.06 \\
Toftlund & $105-110-$ & 3 & $1.92-$ & $1.06-$ \\
& $115-$ & 4 & $2.35-$ & $1.23-$
\end{tabular}

*) The base of the last protoconch whorl was exposed only in a few shells. 


\begin{tabular}{cccccc}
\multicolumn{8}{c}{ Gemmula Stoffelsi. Protoconch data (continued). } \\
Shell no. & Total & Initial & Medial & Terminal & Number of \\
riblets per whorl \\
1 & 5 & 1 & 3 & 1 & 15 \\
2 & $41 / 2$ & 1 & $31 / 4$ & $1 / 3$ & $(6)$ \\
3 & $43 / 4$ & 1 & $23 / 4$ & 1 & 15 \\
4 & $51 / 4$ & 1 & $31 / 4$ & 1 & 15
\end{tabular}

Teleoconch. Most of the shells from Bramminge are badly rolled. None of the shells has an unbroken aperture.

Test rather thick, spire turreted, almost conical. Little sculptural relief. One relatively strong spiral rib at upper suture, two spirals opposite the sinus of the growth lines, and 10 to 12 primary spirals of similar strength or weaker below the periphery of the body whorl and down onto the base of the whorl and the canal. From about whorl no. 5 weakly developed, secondary spiral ribs in the interspaces on the base of the body whorl, approximately the same in number as the primary spirals. The two strong spirals following the sinus of the growth lines are connected with strong, transverse ribs at intervals. The transverse ribs form occasionally knobs on the spire. About 17 to 20 knobs per whorl have been observed, but several shells are devoid of knobs.

Remarks. This is a species in which the variation of the sculptural relief is so great that any separation of forms based on sculptural features is suspicious. The writer is, for instance, convinced that Pleurotoma disjuncta and P. canaliculata described by Рехвот both belong to $G$. Stoffelsi as already indicated by Glibert. None of Peyrot's arguments seem to be strong enough to retain them as independant species.

Distribution.

Miocene: Aquitanian Basin: ?Burdigalien, ?Helvétien.

North Sea Basin: Belgium: Boldérien, Anversien. Germany: Hemmoor stage. Denmark: Arnum formation.

\section{Gemmula Zimmermanni (Philippi)}

Plate 53, fig. 176.

1851. Pleurotoma Zimmermanni PhilipPI. Verz. Magdeburg etc. p. 69, pl. 10a, fig. 3.

1925. Pleurotoma Zimmermanni Phil. Kautsky. D. Mioc. v. Hemmoor u. Basbeck-Osten. p. 161 , pl. 11, fig. 9 .

1954. Turris (Gemmula) zimmermanni Philippi sp. Gliberт. Pleurotomes ete. p. 6, pl. 2, fig. 3 .

Original diagnosis. Testa elongata fusiformi; anfractibus supremis laevibus, longitudinaliter plicatis, reliquis linia transversa elevata infra suturam ornatis, dein canaliculatis, paullo infra medium cingulo eleganti nodulorum munitis; ultimo spiram aequante; cauda gracili, abrupta, lineis transversis elevatis sculpta (PHILIPPI 1851).

Shell material. One shell from Bramminge $70-80 \mathrm{~m}$.

Protoconch. Lowermost $1 \frac{1}{2}$ ribbed whorls preserved, with about 15 collabral ribs on last whorl. The protoconch surface is worn.

Teleoconch. Spire turreted with deep suture situated immediately below the keel. The spiral ornamentation starts with one spiral rib along the suture on the first adult whorl, followed by 3 spiral ribs on the keel. New spirals are successively intercalated between the sutural and carinal spirals on the suc- 
ceeding whorls, resulting in the following arrangement on the body whorl (the fifth whorl after the protoconch): two spirals below the edge of the sutural shelf, two major and two minor spirals above the keel, three spirals on the keel, one minor spiral immediately below the keel, and 22 spirals on the base of the whorl and the canal. The relatively deep sinus of the growth lines is on the keel. The suture is formed along the first strong spiral below the keel.

There are low collabral knobs on the keel as follows:

$\begin{array}{lccccc}\text { Whorl no. } & 1 & 2 & 3 & 4 & 5 \\ \text { Number of knobs: } & 18 & 22 & 23 & 24 & 28\end{array}$

Dimensions of the shell: height $13.4 \mathrm{~mm}$., diameter $5.7 \mathrm{~mm}$.

Distribution.

Miocene: North Sea Basin: Belgium: Boldérien. Anversien.

Germany: Hemmoor stage, Glimmerton (Banke RasmusSEN 1956). Denmark: Arnum formation.

Oligocene: North Sea Basin: Germany: Magdeburg.

\section{Genus Fusiturris Thiele 1929}

\section{Fusiturris Duchastelii (Nyst)}

Plate 54, fig. 177.

1836. Pleurotoma Duchastelii Nyst. Coq. foss. de Kleyn-Spauwen et Housselt, p. 172, pl. 1, fig. 80 .

1867. Pleurotoma Duchastelii Nyst. von Koenen. D. mar. M.-Olig. Nordd. p. 38.

1870. Pleurotoma Duchastelii Nyst. Speyer. D. Conch. d. Casseler Tert. 1, p. 111, pl. 15, fig. 6-13, pl. 16, fig. 1-3.

1907. Pleurotoma Duchasteli Nyst. Ravn. Molluskf. Jyll. Tert. p. 351, pl. 7, fig. 10 \& 15.

1913. Pleurotoma Duchasteli Nyst. Harder. De olig. Lag etc. v. Aarhus St. p. 94, pl. 7, fig. $26-37$.

1914. Pleurotoma Duchasteli Nyst. Gripp. Über eine u. mioz. Moll. f. v. Itzehoe, p. 29.

1914. Pleurotoma Duchastelli Nyst. Roth v. Telegd. Eine oberolig. Fauna aus Ungarn, p. 17, pl. 1, fig. 1-3.

1916. Pleurotoma Duchasteli Nyst. Nørregand. Mell.-mioc. Blokke Esbjerg. p. 32, pl. 3, fig. 9.

1925. Pleurotoma (Hemipleurotoma) Duchasteli Nyst. var. flexiplicata Nyst. KaUtsky. D. Mioc. v. Hemmoor u. Basbeck-Osten. p. 168, pl. 11, fig. 21.

1936. Pleurotoma Duchastelli Nyst. Noszky. Moll. f. v. Eger. p. 75.

1940. Pleurotoma (Hemipleurotoma) Duchastelii Nyst. Sorgenfret. Mar. Nedre-Mioc. Klintinghoved. p. 53, pl. 6, fig. 15.

1954. Turris (Fusituris) duchasteli f. flexiplicata KAUtSky sp. GLIBERT. Pleurotomes etc. p. 10, pl. 2, fig. 9 .

Original description. Coquille fusiforme, composée de 10 tours de spire, convexe vers leur milieu, et concave à la partie supérieure; couverte de fines stries transverses, coupées par d'autres longitudinales onduleuses; ouverture ovale, allongée, rétrécie vers la base (NYST 1836).

Shell material.

$\begin{array}{lrllrr}\text { Location } & \text { Depth } & \text { Shells } & \text { Location } & \text { Depth } & \text { Shells } \\ \text { Glejbjerg } & 25 \mathrm{~m} & 1 & \text { Bramminge } & 70-80 \mathrm{~m} . & 82 \\ & 42- & 3 & \text { Toftlund } & 75-100- & 8 \\ & 53.5- & 6 & & 100-105- & 1 \\ & 55- & 4 & & 105-110- & 22\end{array}$




\begin{tabular}{|c|c|c|c|c|c|}
\hline Location & Depth & Shells & Location & Depth & Shells \\
\hline \multirow[t]{2}{*}{ Toftlund } & $110-115 \mathrm{~m}$. & 15 & Arnum (25 b) & $95.0-95.3 \mathrm{~m}$. & 8 \\
\hline & 115 & 27 & & $104.3-107.5=$ & 8 \\
\hline (13) & $83-94-$ & 1 & & 107.5 - & 1 (ef.) \\
\hline Arnum (25b) & $62.7-62.9$ & 1 & & & \\
\hline
\end{tabular}

Description. The small shells are in a relatively good state of preservation, while many of the larger shells are broken.

Protoconch. Initial whorl generally rather smooth, occasionally with a cellular patern in the shell surface, or with granules. Medial whorls $(23 / 4$ to 4$)$ smooth and glossy, occasionally with curved growth lines. Terminal part of the helicocone, about $1 / 2$ to 1 whorl with curved collabral riblets; two spiral grooves on the periphery opposite the projection of the growth lines, and occasionally up to 5 spiral grooves above the periphery of the last whorl.

Fusiturris Duchastelii. Protoconch data.

\begin{tabular}{|c|c|c|c|c|c|c|}
\hline \multirow{2}{*}{$\begin{array}{c}\text { Total height } \\
\mathrm{mm} .\end{array}$} & \multirow{2}{*}{$\begin{array}{l}\text { Diameter } \\
\mathrm{mm} \text {. }\end{array}$} & \multicolumn{4}{|c|}{ Number of whorls } & \multirow{2}{*}{$\begin{array}{l}\text { Numbe } \\
\text { riblets per }\end{array}$} \\
\hline & & Total & Initial & Medial & Terminal & \\
\hline \multicolumn{7}{|c|}{ Toftlund $75-100 \mathrm{~m}$. : } \\
\hline 2.15 & 1.12 & 5 & 1 & $31 / 2$ & $1 / 2$ & 6 \\
\hline 2.50 & 1.28 & $51 / 4$ & 1 & $31 / 2$ & $3 / 4$ & 13 \\
\hline \multicolumn{7}{|c|}{ Toftlund $105-110 \mathrm{~m}$ : : } \\
\hline 2.0 & 1.09 & $43 / 4$ & 1 & $31 / 4$ & $1 / 2$ & 8 \\
\hline 2.02 & 1.09 & $4^{3 / 4}$ & 1 & $23 / 4$ & 1 & 13 \\
\hline 2.15 & 1.12 & $51 / 4$ & 1 & $33 / 4$ & $1 / 2$ & 8 \\
\hline \multicolumn{7}{|c|}{ Toftlund 110-115 m.: } \\
\hline 2.74 & 1.41 & $51 / 4$ & 1 & $33 / 4$ & $1 / 2$ & 9 \\
\hline 2.4 & 1.23 & $5 \frac{1}{3}$ & 1 & 4 & $1 / 3$ & 6 \\
\hline 2.2 & 1.17 & $43 / 4$ & 1 & $31 / 4$ & $1 / 2$ & 10 \\
\hline 2.42 & 1.37 & $51 / 4$ & 1 & $31 / 4$ & 1 & 11 \\
\hline
\end{tabular}

Teleoconch. Spire turreted, mostly almost conical and devoid of collabral ribs. A varying number of spiral grooves, and growth lines with moderately deep sinus. Aperture broken on all specimens, canal short.

Remarks. Pleurotoma subinornata described by Peyrot (1931. Conch. Néogén. etc. p. 70 , pl. 8, fig. $1,2,15,29,38)$ is obviously related to $F$. Duchastelii to judge from Peyrot's description and illustrations. P. subinornata should therefore be checked since the morphological similarities with $F$. Duchastelii are apparently close enough to suggest the same species.

Distribution.

Miocene: North Sea Basin: Belgium: Boldérien, Anversien. Germany: Vierlande, Hemmoor, and Glimmerton stages (Banke Rasuussen 1956). Denmark: Klintinghoved clay, Arnum formation.

Pannonian Basin: Hungary: Aquitanien.

Oligocene: North Sea Basin: Germany (m. u.). Denmark (m. u.).

\section{Fusiturris inermis (Hörnes)}

Plate 53, fig. 178.

1856. Pleurotoma inermis Partsch. Hörnes. D. foss. Moll. d. Tert.-Beckens v. Wien. I, p. 349 , pl. 38 , fig. 10 .

1878. Pleurotoma inermis Partsch. Bellardi. I moll. d. terr. terz. d. Piemonte e d. Liguria 2, p. 50. 
1904. Pleurotoma inermis PARtsch. SACco ibid. 30, p. 42, pl. 11, fig. 47.

1925. Pleurotoma (Hemipleurotoma) inermis Partsch. Kautsky. D. Mioc. v. Hemmoor u. Basbeck-Osten, p. 168, pl. 11, fig. 20.

Original diagnosis. Testa fusiformi, minutissime transversim sulcata; anfractibus supremis costis obsoletis ornatis, infernis fasciatis vel obsolete carinatis; canali longiusculo, apertura lanceolata. (HöRNEs 1856).

Shell material.

$\begin{array}{lrrlrl}\text { Location } & \text { Depth } & \text { Shells } & \text { Location } & \text { Depth } & \text { Shells } \\ \text { Bramminge } & 70-80 \mathrm{~m} . & 19 & \text { Arnum (13) } & 53-83 \mathrm{~m} . & 2 \\ \text { Toftlund } & 75-100- & 6 & \text { Arnum (25b) } & 62.7-62.9- & 1 \\ & 105-110- & 5 & & 95.0-95.3- & 1 \\ & 110-115- & 1 & & 107.5- & 1\end{array}$

Description. Most shells are fragments; a few well preserved juvenile shells.

Protoconch. Initial whorl with slightly oblique axis, surface smooth and glossy with extremely delicate punctation. Medial whorls smooth, apparently without punctation, but occasionally with faint spiral lines. Terminal whorl with "sinusigera" growth lines, collabral riblets, two relatively strong spiral cords on the periphery, and occasionally spiral lines on the rest of the whorl. The following data refer to shells from Toftlund, two shells from $75-100 \mathrm{~m}$. and one shell from $105-110 \mathrm{~m}$.

\begin{tabular}{ccccccc} 
Height & Diameter & \multicolumn{4}{c}{ Number of whorls } & Number of riblets on \\
mm. & mm. & Total & Initial & Medial & Terminal & $\begin{array}{c}\text { terminal part } \\
1.78\end{array}$ \\
0.93 & $41 / 2$ & 1 & 3 & $1 / 2$ & 6 \\
2.27 & 1.06 & $43 / 4$ & 1 & 3 & $3 / 4$ & 7 \\
2.02 & 1.04 & $41 / 2$ & 1 & 3 & $1 / 2$ & 6
\end{tabular}

Teleoconch. Nodular whorls with 8 to 10 subacute nodules per whorl and with more or less distinct spiral grooves. Sinus moderately open, V-shaped, opposite the nodules. Canal long.

Remarks. The differences in protoconch features compared with F. Duchastelii and other species of this genus might perhaps justify the erection of a new genus for $F$. inermis and allied species. This has, however, been deferred until the validity of the method of systematic subdivision here considered has been further checked.

Distribution.

Miocene: North Sea Basin: Germany: Hemmoor stage, Glimmerton (Banke Rasmussen 1956). Denmark: Arnum formation.

Mediterranean Basin: Italy: Miocene medio.

Vienna Basin: Baden beds.

\section{Genus Bathytoma Harris \& Burrows 1891}

\section{Bathytoma cataphracta (Brocchi)}

Plate 54, fig. 179.

1814. Murex cataphractus BrocchI. Conchiol. Foss. Subapennina 2, p. 427, pl. 8, fig. 16. 1856. Pleurotoma cataphracta Brocc. Hörnes. D. foss. Moll. d. Tert.-Beckens v. Wien. 1, p. 333 , pl. 36, fig. 5-9. 
1878. Dolichotoma cataphracta (Brocch.) Bellardi. I moll. d. terr. terz. d. Piemonte e d. Liguria. 2, p. 230, pl. 7, fig. 20 .

1907. Pleurotoma cataphracta Brocchi sp. Ravn. Molluskf. Jyll. Tert. p. 350, pl. 7, fig. 12. 1913. Dolichotoma cataphracta Brocchi sp. Harder. De olig. Lag etc. v. Aarhus St. p. 99, pl. 9, fig. 16-17.

1914. Pleurotoma (Dolichotoma) turbida Sol. GrIpe. Über eine u. mioz. Moll. f. v. Itzehoe. p. 28.

1925. Bathytoma cataphracta Brocch. Kautsky. D. Mioc. v. Hemmoor u. BasbeckOsten. p. 179, pl. 11, fig. 33 .

1932. Bathytoma cataphracta Brocch. var. et mut. Peyrot. Conch. Néogén. d. l'Aquit. p. 16-19, pl. 8, fig. $45,47,50,51$.

1940. Bathytoma cataphracta Brocch. Sorgenfrer. Mar. Nedre-Mioc. i Klintinghoved p. Als. p. 54, pl. 6, fig. 16 .

1952. Bathytoma mioturbida Kautsky. Hinsch. Leitende Moll. O. mioz. u. U. plioz. p. 172 , pl. C, fig. 6 .

1954. Bathytoma mioturbida Kautsky. Glibert. Pleurotomes etc. p. 12, pl. 2, fig. 11.

1956. Bathytoma cataphracta (Brocchi). Banke Rasmussen. Upper Mioc. South Jutland. p. 91 , pl. 9 , fig. 3 .

Original diagnosis. Testa turrita, striis granulatis moniliformibus undequaque cincta, anfractubus bipartitis, superne excavatis, carina crenulata, labro sinu separato, cauda brevi. (BROcCHI 1814).

Shell material.

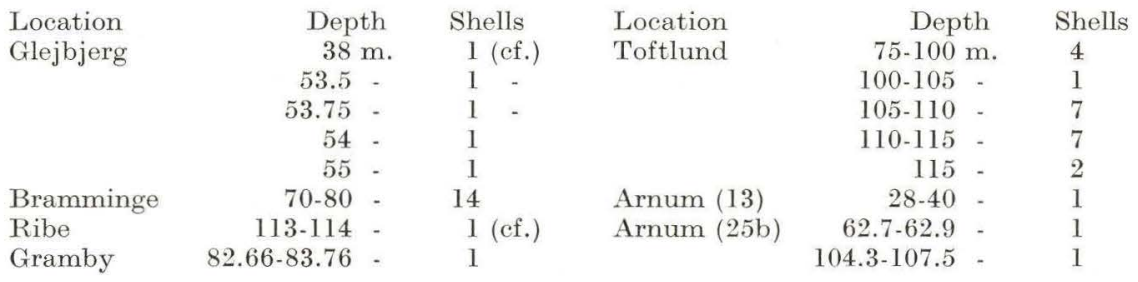

Description. Most shells are juvenile or broken.

Protoconch. Initial whorl slightly sinistral. Surface granulated, granules generally in spiral rows. Medial whorls with granules irregularly scattered over the entire surface or only on the abapical part of the whorl. Terminal stage commonly less than one whorl, with collabral riblets, and partly granulated, as on the medial whorls.

\begin{tabular}{|c|c|c|c|c|c|c|}
\hline \multirow{2}{*}{$\begin{array}{c}\text { Total height } \\
\text { mm. }\end{array}$} & \multirow{2}{*}{$\begin{array}{l}\text { Diameter } \\
\text { mm. }\end{array}$} & \multirow[b]{2}{*}{ Total } & \multicolumn{3}{|c|}{ Number of whorls } & \multirow{3}{*}{$\begin{array}{c}\text { Number of riblets on } \\
\text { terminal part }\end{array}$} \\
\hline & & & Initial & Medial & Terminal & \\
\hline Gramby 82.6 & $83.76 \mathrm{~mm} .:$ & & & & & \\
\hline 1.90 & 1.18 & 4 & 1 & $21 / 2$ & $1 / 2$ & 10 \\
\hline \multicolumn{7}{|c|}{ Toftlund 100-105 m.: } \\
\hline 1.96 & 1.37 & $4 \frac{1}{2}$ & 1 & $2^{3} / 4$ & $1 / 2$ & 9 \\
\hline \multicolumn{7}{|c|}{ Toftlund $105-110 \mathrm{~m}$. : } \\
\hline 2.07 & 1.25 & $43 / 4$ & 1 & $31 / 4$ & $1 / 2$ & 11 \\
\hline 2.23 & 1.47 & 5 & 1 & $31 / 4$ & $3 / 4$ & 16 \\
\hline 2.11 & 1.35 & $43 / 4$ & 1 & 3 & $3 / 4$ & 13 \\
\hline 1.99 & 1.31 & $41 / 4$ & 1 & $23 / 4$ & $1 / 2$ & 12 \\
\hline 2.04 & 1.42 & $43 / 4$ & 1 & $31 / 4$ & $1 / 2$ & 12 \\
\hline
\end{tabular}

Teleoconch. There are very few entire adult shells on which to base a description. The characteristic features of the first whorls are shown on the accompanying figure. Significant are: the small collabral riblets on the sutural shoulder, the round keel, the concave belt above the keel, and the spiral ribs. 
Later whorls often have numerous delicate round knobs at the crossings of the collabral riblets and the spiral ribs. There is oceasionally a fold on the columella.

Remarks. The great variability of this species has been discussed repetedly by previous authors (v. Koenen 1872, p. 215, Gripp 1914, Sorgenfrei 1940, Banke Rasmussen 1956 etc.) It is not advisable to separate shells from $B$. cataphrata as independant species, unless very significant features support the separation, or it is possible to state clear morphologic differences which are well founded statistically. It will be necessary to investigate a great number of shells before the variation range of this species is fully known, and before species such as e.g. B. mioturbida KaUtsky can be approved.

Distribution.

Pliocene: Mediterranean Basin: Italy: Pliocene inferiore et superiore.

Miocene: Aquitanian Basin: Aquitanien, Burdigalien, Helvétien.

North Sea Basin: Belgium: Boldérien, Anversien. Germany: Vierlande, Hemmoor, Reinbek (Pleurotoma turbida, Gottsche 1878) and Glimmerton stages (BANKe RasMUSSEn 1956). Denmark: Klintinghoved clay, Arnum and Gram formations.

Mediterranean Basin: Italy: Miocene inferiore, medio, et superiore.

Vienna Basin: Grund and Baden beds.

Oligocene: North Sea Basin: Denmark (m.).

\section{Genus Turricula Schumacher 1817}

\section{Turricula Steinvorthi (von Koenen)}

Plate 53, fig. $180 a-b$.

1872. Pleurotoma Steinvorthi Semper. von Koenen. D. Nordd. Mioc. u. s. Moll. f. p. 228, pl. 2, fig. 10.

1914. Pleurotoma (Surcula) Steinvorthi Semper. Gripp. Über eine u. mioz. Moll. f. v. Itzehoe. p. 29, pl. 3, fig. 8-10.

1916. Pleurotoma Steinvorthi Semp. Nørregaard. Mel.-mioc. Blokke Esbjerg. p. 33, pl. 3, fig. 10.

1925. Surcula Steinvorthi Semp. Kautsky. D. Mioc. v. Hemmoor u. Basbeck-Osten. p. 158 , pl. 11, fig. 4 .

1940. Surcula Steinvorthi Semp. Sorgenfrer. Mar. Nedre-Mioc. i Klintinghoved p. Als. p. 50 , pl. 6, fig. 13 .

1954. Turricula (s.s.) steinworthi (Semper) Konnen. sp. Glibert. Pleurotomes etc. p. 13, pl. 3 , fig. 1 .

Essential features of original description. Etwas über der Mitte der Windungen, dicht unter dem Sinus der Anwachsstreifen, (befindet) sich eine nach unten scharf begrenzte Einsenkung. Schräge Längsfalten auf dem unteren Theile der ersten Mittelwindungen. In der Regel sind ausser am Kanal nur unter der Naht einige feine Spiralen sichtbar. (VON KoENEN 1872)*).

*) von Koenen accepted Semper's species name from a manuscript, but he did not quote either SEMPER's description or his diagnosis. vON KOENEN is, therefore, the author of the species in accordance with article 21 of the International Rules of Zoölogical Nomenclature. 
Shell material.

$\begin{array}{lrllrl}\text { Location } & \text { Depth } & \text { Shells } & \text { Location } & \text { Depth } & \text { Shells } \\ \text { Glejbjerg } & 42 \mathrm{~m} . & 1 & \text { Toftlund } & 75-100 \mathrm{~m} . & 2 \\ & 53- & 1 & & 105-110- & 1 \mathrm{frg} \text {. (cf.) } \\ & 53.5- & 1 \text { frg. (cf.) } & & 115- & 6 \\ \text { Bramminge } & 70-80- & 2 & \text { Arnum (25b) 104.3-107.5 - } & 2\end{array}$

Description.

Large shells broken, small shells generally well preserved.

Protoconch. Initial whorl slightly sinistral. Shell surface smooth and glossy, with indication of indistinct microscopical punctation. The rest of the shell smooth and glossy, showing occasional traces of sinuous growth lines. The data of only two shells can be given:

$\begin{array}{lrlll}\text { Location } & \text { Depth } & \text { Height } & \text { Diameter } & \begin{array}{l}\text { Number of } \\ \text { whorls }\end{array} \\ \text { Glejbjerg } & 42 \mathrm{~m} . & 2.54 \mathrm{~mm} . & 1.32 \mathrm{~mm} . & 5 \\ \text { Toftlund } & 75-100- & 2.23- & 1.11- & 41 / 4\end{array}$

Teleoconch. The turreted spire is ornamented with spiral threads which are generally absent on the middle part of the body whorl, but occasionally are found over the entire shell surface. There are very indistinct, low, collabral knobs on the first adult whorls of a few specimens.

Remarks. There is a great morphological similarity between T. Steinvorthi and T. striatulata Lamarck (see e.g. Peyrot 1931, p. 60, pl. 5, fig. 12, 14, pl. 6 , fig. $5,7,9,12,14$ ). This has already been pointed out by von KoEnEN (1872), and recently GLIBERT has drawn attention to the close relationships between the two species. Since the latter author emphasized the significance of spiral striation, it should be stressed that this feature certainly varies in $T$. Steinvorthi from South Jutland. The two species deserve, therefore, to be revised.

Distribution.

Miocene: North Sea Basin: Belgium: Boldérien, Anversien. Germany: Vierlande, Hemmoor and Reinbeck*) stages. Glimmerton (Banke Rasmussen 1956). Denmark: Klintinghoved clay and Arnum formation.

\section{Genus Clinura Bellardi 1875}

\section{Glinura sp.}

Plate 54, fig. 181 a-b.

Shell material. Glejberg $53.5 \mathrm{~m}$ : one juvenile shell, height $2.6 \mathrm{~mm}$., diameter $1.6 \mathrm{~mm}$. Bramminge 70-80 $\mathrm{m}$.: one worn fragment of a spire.

Description.

Protoconch. One initial, slightly sinistral whorl with faint traces of spiral striation. One and three fourth smooth and glossy terminal whorls with weak

*) acc. to GotTsche 1878. 
indication of peripheral angularity. Dimensions of the exposed protoconch spire: height $0.45 \mathrm{~mm}$., diameter $0.56 \mathrm{~mm}$.

Teleoconch. Whorls with projecting keel on which there are 13 to 14 sharp, transverse knobs, and a strong spiral rib somewhat below the keel. Shell surface otherwise smooth and glossy. Aperture broken. The growth lines indicate a broad semi-circular apertural sinus occupying the entire shoulder above the keel. The growth lines are opisthocline on and below the keel as far as the spiral rib, below which they are recurrent and form a second sinus before continuing onto the short canal.

Remarks. The protoconch of Clinura is not known in detail, as it has not been described by BELLARDI or later authors. The reference of the present shell to Clinura is only based on the poor additional information on shell features which has been obtained from illustrations in the literature. The reference is accordingly not regarded as final.

A morphological feature of particular interest in the present species is the "sinusigera" development of the apertural margin in the adult shell.

\section{Genus Tahusyrinx Powell 1942}

\section{Tahusyrinx cf. Corneti (von Koenen)}

1872. Pleurotoma Corneti von Koenen. D. Nordd. Mioc. u. s. Moll. f. p. 235, pl. 3, fig. 11. 1925. Surcula (Ancistrosyrinx) Cornety v. Koenen. Kautsky. D. Mioc. v. Hemmoor u. Basbeck-Osten, p. 159, pl. 11, fig. 5 .

1954. Ancistrosyrinx (Tahusyrinx) corneti Koenen. Glibert. Pleurotomes etc. p. 15, pl. 3, fig. 4.

von Koenen did not publish any description or diagnosis of the species.

One very worn and fragmentary shell from Ribe 113-114 m. has with some reservation been referred to $T$. Corneti.

Distribution.

Miocene: North Sea Basin: Belgium: Anversien. Germany: Hemmoor stage, Glimmerton (Banke Rasmussen 1956). Denmark: Arnum formation.

\section{Genus Clavatula Lamarck 1801}

\section{Glavatula boreointerrupta Kautsky}

Plate 54, fig. 183 a-b.

1925. Clavatula boreointerrupta KAUtsky. D. Mioc. v. Hemmoor u. Basbeck-Osten. p. 153, pl. 10, fig. 27.

1954. Clavatula (s.s.) boreointerrupta Kautsky. GLIBert. Pleurotomes ete. p. 17.

Essential features of original description. Auf das Embryonalende folgt ein halber Umgang mit einer Übergangsskulptur von kräftigen Längsrippen. Auf dem folgenden Umgang zwei Spiralfurchen, eine in geringem Abstand von der hinteren Naht, die andere in der Mitte des Umgangs, durch welche jede Längsrippe in drei längliche Knoten zerfällt. Die übrigen Umgänge: breiter Nahtwulst und flache Einsenkung mit Sinus und Spiralen. Gegen vorne wieder ein Wulst mit Längsrippen und 3 stärkere Spiralen. (KaUtsky 1925). 
Shell material.

$\begin{array}{lrllrl}\text { Location } & \text { Depth } & \text { Shells } & \text { Location } & \text { Depth } & \text { Shells } \\ \text { Toftlund } & 105-110 \mathrm{~m} . & 2 & \text { Arnum (13) } & 53-83 \mathrm{~m} . & 1 \\ & 110-115- & 1 & & 83-94- & 1 \\ \text { Arnum (13) } & 53.83- & 1 & \text { Arnum (25b) } & 62.7-62.9- & 7\end{array}$

Description. All the shells correspond to juvenile stages which have passed very little beyond the protoconch stage, except for one of the shells from Arnum (83-94 m.) which is a worn fragment of an adult specimen.

Protoconch. Initial whorl smooth and glossy, depressed, with shallow suture. Medial whorls convex, surface smooth; terminal about $1 / 2$ whorl with curved, collabral riblets. The base of the protoconch is exposed in three shells from Arnum (25 b) $62.7-62.9 \mathrm{~m}$. The data on these shells are:

\begin{tabular}{|c|c|c|c|c|c|c|}
\hline Height & Diameter & & Number & of whor & & Number of riblets \\
\hline $\mathrm{mm}$. & $\mathrm{mm}$. & Total & Initial & Medial & Terminal & on terminal part \\
\hline 1.33 & 0.80 & $31 / 4$ & 1 & 2 & $1 / 4$ & 5 \\
\hline 1.50 & 0.90 & $31 / 2$ & 1 & 2 & $1 / 2$ & 9 \\
\hline 1.47 & 0.86 & $31 / 2$ & 1 & 2 & $1 / 2$ & 8 \\
\hline
\end{tabular}

Teleoconch. Two spiral grooves cross the collabral riblets on the first adult whorl as described by Kautsky. One of the specimens from Toftlund (105$110 \mathrm{~m}$.) has about 15 collabral ribs on the first whorl.

The development of later whorls cannot be recorded since the only shell which might have served as a basis for description is too worn.

Distribution.

Miocene: North Sea Basin: Belgium: Boldérien. Germany: Hemmoor stage. Denmark: Arnum formation.

\section{Clavatula sp.}

Shell material.

$\begin{array}{lrllrl}\text { Location } & \text { Depth } & \text { Shells } & \text { Location } & \text { Depth } & \text { Shells } \\ \text { Bramminge } & 70-80 \mathrm{~m} . & 1 & \text { Toftlund } & 105-110 \mathrm{~m} . & 4 \\ \text { Toftlund } & 100-105- & 1 & \text { Arnum }(25 \mathrm{~b}) & 62.7-62.9- & 3\end{array}$

Description. All the shells are juvenile, they have hardly passed the protoconch stage.

Protoconch. Initial whorl with microscopical cellular pattern or punctate surface. Medial whorls smooth and glossy; terminal whorl with curved, collabral riblets. The data on two shells from Bramminge 70-80 m. and Toftlund 105$110 \mathrm{~m}$. respectively are:

\begin{tabular}{ccccccc} 
Height & Diameter & \multicolumn{4}{c}{ Number of whorls } & Number of riblets \\
mm. & mm. & Total & Initial & Medial & Terminal & on terminal part \\
1.88 & 1.14 & 5 & 1 & 3 & 1 & 12 \\
1.61 & 0.96 & 4 & 1 & $21 / 2$ & $1 / 2$ & 7
\end{tabular}

There are two spiral ribs on the periphery of the terminal whorl. The upper spiral can be traced back to the medial whorls immediately above the suture. 
Teleoconch. Very little is known about this part of the shell. There is a rather strong spiral rib, on which there are relatively strong knobs, following the suture. The area of the sinus is partly smooth and glossy, while rather strong pointed knobs occur below the sinus.

Remarks. The sculptural features suggest that the shells belong to the Clavatula asperulata group. (See e.g. Peyrot 1931 Conch. Néogén. d. l'Aquit. 83 , p. 16).

Lack of information on the protoconch of most allied species renders a final determination of the shells impossible at present.

\title{
185. Clavatula obliplicatula Kautsky
}

\author{
Plate 56, fig. 185.
}

1925. Clavatula (Perrona) obliplicatula Kautsky. D. Mioc. v. Hemmoor u. BasbeckOsten. p. 155, pl. 10, fig. 30-31.

Essential features of original description. Die ersten Umgänge tragen einen glatten reifenartigen Nahtwulst. Vor demselben liegt eine sehr flache Einsenkung, die allmählich gegen vorne in eine schwache Aufwölbung übergeht. Schwache Rippchen, die sich gegen vorne verbreitern und höher werden, bedecken diese Umgänge. Die Umgänge sind mit sehr schwachen flachen Spiralen bedeckt. Der Sinus liegt unmittelbar vor dem hinteren Nahtwulst. (KaUTSKY 1925).

Shell material.

$\begin{array}{lcllcc}\text { Location } & \text { Depth } & \text { Shells } & \text { Location } & \text { Depth } & \text { Shells } \\ \text { Glejbjerg } & 53 \mathrm{~m} . & 2 & \text { Glejbjerg } & 55 \mathrm{~m} . & 1 \\ & 53.75- & 1 & \text { Bramminge } & 70-80- & 4\end{array}$

Description.

Adult shells, more or less broken. Protoconch unknown.

Teleoconch. A distinct spiral groove demarcates the sutural belt as defined by KaUTSKy. Collabral riblets occur occasionally on the periphery of the whorl below the depressed sinus belt. The shell surface is otherwise commonly covered by fine spiral threads which sometimes flatten out to leave only narrow interspaces. Some shells are devoid of collabral ribs.

The accompanying figure illustrates the general shape of the shell although the aperture and the canal is partly broken on the figured specimen.

Remarks. C. obliplicatula is obviously similar to C. Seguini (Mayer) (Peyrot 1931, p. 44, pl. 8, fig. 93, 98, 103, 104) as pointed out by KaUtsky. It is, however, not possible to contribute further remarks on the relationship because of the poor shell material from South Jutland.

Distribution.

Miocene: North Sea Basin: Germany: Hemmoor stage. Denmark: Arnum formation.

Genus Genota H. \& A. Adams 1853

186. Genota ramosa (Basterot)

Plate 55, fig. 186 a-b.

1825. Pleurotoma ramosa Basterot. Mém. Géol.s.l. Environs de Bordeaux. p. 63, pl. 3, fig. 15. 1856. Pleurotoma ramosa Basterot. Hörnes. D. foss. Moll. d. Tert.-Beckens v. Wien. 1, p. 335, pl. 36, fig. 10-14. 
1878. Genota ramosa (Bast.) Bellardi. I moll. d. terr. terz. d. Piemonte e d. Liguria 2, p. 84 , pl. 3 , fig. $2-3$.

1925. Genotia ramosa Bast. Kautsky. D. Mioc. v. Hemmoor u. Basbeck-Osten. p. 147, pl. 10, fig. 19.

1930.Genotia ramosa (Basterot). Peyrot. Conch. Néogén. d. l'Aquit. p. 121, pl. 1, fig. 29-34.

1954. Genota ramosa f. elisae Hoernes \& Auinger. Glibert. Pleurotomes etc. p. 21, pl. 4, fig. 4.

1954. Genota ramosa $f$. parvicarinata Kautsky. Glibert. Ibid. p. 22, pl. 4, fig. 5.

Original diagnosis. Testa fusiformi; anfractibus tuberculatis, transverse striatis; rugis longitudinalibus furcatis, subramosis. (BASTEROT 1825).

Shell material.

$\begin{array}{lrllrl}\text { Location } & \text { Depth } & \text { Shells } & \text { Location } & \text { Depth } & \text { Shells } \\ \text { Glejbjerg } & 55 \mathrm{~m} . & 1 & \text { Toftlund } & 75-100 \mathrm{~m} . & 2 \\ \text { Bramminge } & 70-80- & 3 & & 105-110- & 2 \\ \text { Gramby } & 82.66-83.76- & 1 & & & \end{array}$

Description.

All adult shells are fragmentary, the most complete specimen being the shell figured on plate 55, fig. 186 a.

Protoconch. No difference between the initial whorl and the medial whorls, which are smooth and glossy if undamaged. Terminal part, which is about $1 / 2$ whorl, with 8 to 10 curved, smooth, collabral riblets. It has not been possible to measure the total height of the protoconch. The spire on plate 55, fig. $186 \mathrm{a}$ is $1.06 \mathrm{~mm}$. high and the diameter is $0.82 \mathrm{~mm}$. There are 3 smooth whorls, and $1 / 2$ ribbed terminal whorl.

Teleoconch. All essential features are shown on the accompanying illustrations which show that the shells possess very little sculptural relief. There is no pronounced keel, as in shells from other areas, and even the collabral ribs are often obsolete.

Remarks. It has in the past been attempted to subdivide shells of the $G$. ramosa group into a number of varieties based on morphologic differences. However, intangible boundaries between the established types render the subdivisions inapplicable. The writer decided therefore simply to refer the shells from South Jutland to G. ramosa (BAST.).

Distribution.

Miocene: Aquitanian Basin: Burdigalien, Helvétien.

North Sea Basin: Belgium: Boldérien, Horizon of Houthaelen. Germany: Hemmoor stage, Glimmerton (Banke Rasmussen 1956). Denmark: Arnum formation. Mediterranean Basin: Italy: Miocene medio.

Vienna Basin: Grund and Baden.

Genus Acamptogenotia Rovereto 1899

\section{Acamptogenotia cf. Escheri (Mayer)}

Plate 56, fig. 187.

1861. Pleurotoma Escheri MAYER. Coqu. foss. d. ét. sup. tert. p. 370, pl. 15, fig. 10 .

1925. Genotia (Pseudotoma) Escheri Mayer-Eymar. Kautsky. D. Mioe. v. Hemmoor 1. Basbeck-Osten. p. 148, pl. 10, fig. 22.

1954. Acamptogenotia escheri MaYen sp. GLIBent. Pleurotomes ete. p. 23, pl. 4, fig. 7. 
Original diagnosis. Testa fusiformi, tenui; anfractibus convexis, medio obtuse angulatis, transversim regulariter striatis, primis obsolete oblique costulatis; striis crebris, alternantibus, ultimo spira majore; apertura oblonga, in canalem latum, brevem, desinente; labro acuto, arcuato; sinu vicino suturce, lato obtuso (MAYER 1861).

Shell material. Toftlund $115 \mathrm{~m} .1$ entire and 3 fragmentary shells.

Description.

The shells are too corroded and worn for detailed recognition of the shell features.

Protoconch. Probably about 4 globular whorls. Any subdivision into initial, medial and terminal divisions impossible due to corrosion.

Teleoconch. The accompanying figure illustrates all pertinent morpholog. ical characters.

Distribution.

Miocene: North Sea Basin: Belgium: Boldérien, Anversien. Germany: Hemmoor stage. Denmark: Arnum formation.

\section{Acamptogenotia cf. Straeleni Glibert}

1925. Genotia (Pseudotoma) Morreni De Konink. Kautsky. D. Mioc. v. Hemmoor u. Basbeck-Osten. p. 147, pl. 10, fig. 20-21.

1954. Acamptogenotia straeleni GLIBert. Pleurotomes etc. p. 23, pl. 4, fig. 9.

Essential features of original description. Coquille grande, subfusiforme allongée. Spire haute, étagée, ornée de fins filets spiraux rapprochés. Les cinq ou six premiers tour ne portent pas d'ornementation axiale, mais les suivants sont ornés, habituellement, sur la carène, de nodules arrondis assez larges, plus ou moins saillants. Dernier tour fortement excavé à la base. Sinus largement arrondi. Pas de fente columellaire. (GLIBERT 1954).

Shell material and description.

One very poor fragment from Toftlund $115 \mathrm{~m}$. which exhibits the typical sculpture of growth lines and spiral threads, collabral knobs on the keel, and a broad sinus of the growth lines, as described by GLIBERT, has been compared with $A$. Straeleni.

Distribution.

Miocene: North Sea Basin: Belgium: Anversien. Germany: Hemmoor stage. Denmark: Arnum formation.

\section{Genus Inquisitor Hedley 1918}

\section{Inquisitor obeliscus (Des Moulins)}

Plate 56, fig. 189.

1842. Pleurotoma obeliscus Des Moulins. Rev. Pleurot. p. 176.

1856. Pleurotoma obeliscus des Moulins. Hörnes. D. foss. Moll. d. Tert.-Beckens v. Wien. 1, p. 371, pl. 39, fig. 19. 
1907. Pleurotoma obetiscus Des Moulins. Ravn. Molluskf. Jyll. Tert. p. 353, pl. 8, fig. 1. 1925. Drillia (Crassispira) obeliscus Des M. Kautsky. D. Mioc. v. Hemmoor u. BasbeckOsten. p. 173. pl. 11, fig. 25-26.

1931. Drillia (Crassispira) obeliscus des Moumrs. Рexrot. Conch. Néogén. d. I'Aquit. p. 94, pl. 7, fig. 59-61.

1956. Turris (Crassispira) obeliscus (Des Moulins). Banke Rasmussen. Upper Mioc. South Jutland. p. 87, pl. 8, fig. 4.

Original diagnosis. Testa elongatissima subfusiformi-cylindracea, striis subcqualibus transversim instructa (incrementalibus subdecussata); spira acutissima; anfractibus circiter tredenis 8-10 costatis planiusculis inferne vix tumentibus superne depresso-canaliculatis ad suturam superiorem marginatis; costis verticalibus compressis (dorso acutiusculis) ante canaliculum superiorem anfractuum desinentibus; anfractu ultimo cum cauda brevi angusta acuminata nec emarginata spira multo breviore; apertura minima angusta utrinque acuminata; columella recta. (Des Moulins 1842).

Shell material.

$\begin{array}{lrrlrr}\text { Location } & \text { Depth } & \text { Shells } & \text { Location } & \text { Depth } & \text { Shells } \\ \text { Glejbjerg } & 32 \mathrm{~m} . & 1 & \text { Toftlund } & 100-105 \mathrm{~m} . & 3 \\ & 53.5- & 2 & & 105-110- & 6 \\ & 53.75- & 1 & & 110-115- & 4 \\ \text { Bramminge } & 54- & 1 \text { (frg.) } & & 115- & 13 \\ \text { Gramby } & 70-80- & 65 & \text { Arnum (13) } & 53-83- & 6 \\ \text { Toftlund } & 75-100- & 14 & \text { Arnum (25b) } & 95.0-95.3- & 4 \\ & & & & 104.3-107.5- & 1\end{array}$

Description.

Fragmentary specimens of large shells were found in the samples Glejbjerg $53.5 \mathrm{~m}$., Bramminge $70-80 \mathrm{~m}$. and Toftlund $115 \mathrm{~m}$. The other shells listed are mainly juvenile and consist of the protoconch and a few adult whorls.

Protoconch. Initial whorl with slightly oblique axis and shallow suture; shell surface smooth and glossy. Medial whorls generally smooth and glossy, occasionally with faint spiral striae. Terminal part of the helicocone, about $1 / 4$ to $3 / 4$ whorl, with smooth collabral riblets. Periphery of terminal whorl with two conspicuous spiral riblets opposite the "sinusigera"-projection between the two velum sinuses of the growth lines.

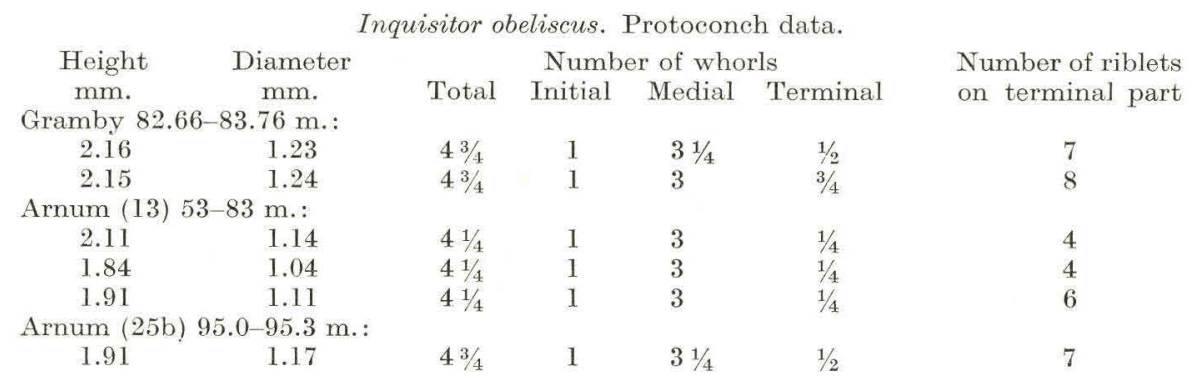

Teleoconch. Closely spaced spiral ribs over all the shell surface, with one strong rib following the adapical suture. About 10 collabral ribs below the sinus belt on the first adult whorls, increasing to about 12 to 14 ribs on later whorls. Columella straight; no umbilicus.

The largest shell (Toftlund $115 \mathrm{~m}$.) comprises 7 adult whorls, it has the protoconch and the canal a little broken and is $21 \mathrm{~mm}$. high and $6 \mathrm{~mm}$. in 
diameter. It is estimated originally to have been about 24 to $25 \mathrm{~mm}$. high and about $6.5 \mathrm{~mm}$. in diameter.

Remarks. In accordance with the systematics suggested by PowelL (1942) this species should correctly be referred to Inquisitor on account of its shape, the type of protoconch, the features of the adult whorls and the absence of an umbilicus.

Distribution.

Miocene: Aquitanian Basin: Burdigalien, Hélvétien.

North Sea Basin: Germany: Hemmoor stage, Reinbek stage (Gottsche 1878), Glimmerton (Banke Rasmussey 1956). Denmark: Arnum and Gram formations.

Vienna Basin: Baden beds.

\title{
Genus Splendrillia Hedley 1922
}

\section{Splendrillia Selenkae (von Koenen)}

\author{
Plate 56, fig. 190 a-c.
}

1872. Pleurotoma Selenkae von Koenen. D. Nordd. Mioc. u. s. Moll. f. p. 241, pl. 3, fig. 4.

1904. Drillia Selenkae (v. Koen.) Sacco. I moll. d. terr. terz. d. Piemonte e d. Liguria 30, p. 46 , pl. 12, fig. 40 .

1925. Drillia (Cymatosyrinx) Selenkae v. Koen. Kautsky. D. Mioc. v. Hemmoor u. Basbeck-Osten. p. 176, pl. 11, fig. 29.

1940. Drillia (Cymatosyrinx) Selenkae v. Komnen. Sorgenfrei. Mar. Nedre-Mioc. i Klintinghoved p. Als, p. 55, pl. 6, fig. 17 .

1954. Clavus (Cymatosyrinx) cf. selenkae (Koenen). Glibert. Pleurotomes etc. p. 31, pl. 5, fig. 2 .

Essential features of original description. Nahe verwandt mit der Pl. Suessii Hörnes unterscheidet sich unsere Art von dieser durch das stumpf zitzenförmige Embryonalende von ca. 11/2 Windungen und durch die Längssculptur, welche nicht aus schrägen Rippen besteht, sondern aus spitzen, auf der Mitte der Windungen befindlichen Höckern, welche schräg nach unten in schnell verschwindende Rippen verlaufen. (voN KoENEN 1872).

Shell material.

$\begin{array}{lrllrl}\text { Location } & \text { Depth } & \text { Shells } & \text { Location } & \text { Depth } & \text { Shells } \\ \text { Bramminge } & 70-80 \mathrm{~m} . & 4 \text { (frg.) } & \text { Toftlund } & 105-110 \mathrm{~m} . & 1 \\ \text { Gramby } & 82.66-83.76- & 1 & \text { Arnum } & 53-83- & 1 \text { (frg.) } \\ \text { Toftlund } & 75-100- & 1 \text { (frg.) } & & & \end{array}$

Description. The shells from Gramby and Toftlund $105-110 \mathrm{~m}$. are protoconchs, the other specimens are fragments of adult shells.

Protoconch. One smooth initial whorl with shallow suture, $1 \frac{1}{2}$ smooth medial whorls, and in the one shell (Gramby): a short terminal section with a few collabral riblets. Periphery of last whorl with two spiral ribs opposite the "sinusigera" projection. Distinct sinuses both above and below the projection. The data of the protoconchs available are: Gramby: height $1.31 \mathrm{~mm}$., diameter $0.89 \mathrm{~mm}$., Toftlund $105-110 \mathrm{~m}$. : height $1.25 \mathrm{~mm}$., diameter $0.78 \mathrm{~mm}$.

Teleoconch. Shell surface smooth and glossy. Spiral ornamentation absent, or hardly perceptible spiral lines on the shell surface. Collabral riblets as round 
projecting knobs on the shoulder, about 7 to 10 per whorl. No subsutural fold. Moderate, parietal insertion callus pad, outer lip apparently with slight "stromboid" notch. (See Powell 1942 p. 84).

Remarks. The general shape of the shell, and particularly the restriction of the collabral ribs to the shoulder, refer this species to Spendrillia.

\section{Distribution.}

Miocene: North Sea Basin: Belgium: Anversien. Germany: Hemmoor stage, Reinbek stage (Gotтsche 1878), Glimmerton (Banke Rasmussen 1956). Denmark: Klintinghoved clay. Arnum formation.

Mediterranean Basin: Italy? (stage unknown).

\section{Genus Boreodrillia n. gen.}

Type: Boreodrillia toftlundensis n. sp.

(Description see below)

The generic name Boreodrillia is suggested for small Drillias with a papillate, paucispiral protoconch, a granulate protoconch shell surface, and adult whorls with both spiral and collabral sculpture.

Boreodrillia resembles Manidrillia Powell (1942) with respect to the papillate type of protoconch, and it is also somewhat similar to Aoteadrillia PoweLL (1942) concerning the morphology of the protoconch and the teleoconch. A remarkable difference is, however, the granular sculpture in the protoconch of Boreodrillia. Concerning other shell characters of the genus reference is made to the following description of $B$. toftlundensis which for the present is the only known species of the genus.

\section{Boreodrillia toftlundensis n. gen. \& n. sp.}

Plate 57, fig. $191 \mathrm{a}-\mathrm{b}$.

Diagnosis. Boreodrillia with spirally arranged granulae on the protoconch. Teleoconch with shallow subsutural sinus subsutural spiral rib, two strong spiral ribs marking the shoulder and the peripheral keel, and about 10 primary spiral ribs on the base of the body whorl and the canal. Nine or 10 strong projecting collabral ribs per whorl. Anterior canal short, no umbilicus and apparently no parietal callus pad.

Holotype: Geological Survey of Denmark, Well file no. 150. 9. b. Toftlund 110-115 m. Dimensions of holotype: height $3.65 \mathrm{~mm}$., diameter $1.85 \mathrm{~mm}$., $3 \frac{1}{4}$ adult whorls.

Derivatio nominis: toftlundensis-from Toftlund.

Shell material. One shell from Toftlund $110-115 \mathrm{~m}$., and 1 frg. from Glejbjerg $55 \mathrm{~m}$. (cf.).

Additional description. Secondary spiral ribs developed on the shoulder between the subsutural spiral rib and the keel after whorl no. 2, starting with one spiral and ending with three secondary spirals on whorl no. 4. Another secondary spiral emerges on the body whorl between the two spirals of the keel.

Distribution.

Miocene: North Sea Basin: Denmark: Arnum formation. 


\section{Genus Asthenotoma Harris \& Burrows 1891}

\section{Asthenotoma cf. pannus (Basterot)}

Plate 57, fig. 192.

1825. Pleurotoma pannus Basterot. Mém. Géol. Envir. d. Bordeaux. p. 63.

1856. Pleurotoma festiva Doderlein. Hörnes. D. foss. Moll. d. Tert. Beckens v. Wien 1, p. 337 , pl. 36, fig. 15 .

1878. Oligotoma pannus (BAst.) Bellardr. I moll. d. terr. terz. d. Piemonte e d. Liguria. 2. p. 236 , pl. 7 , fig. 23 .

1925. Asthenotoma pannus Bast. Kautsky. D. Mioc. v. Hemmoor u. Basbeck-Osten. p. 181, pl. 11, fig. 34 .

1932. Asthenotoma pannus (Bast.) in Bellardi. Peyrot. Conch. Néogén. d. l'Aquit. p. 27,1931 : pl. 7 , fig. 35-39.

1954. Asthenotoma pannus (Basterot) in Beldardi. Glibert. Pleurotomes etc. p. 38, pl. 5, fig. 11 .

?1954. Asthenotoma festiva Hörnes sp. Gumbert, ibid. p. 36, pl. 5, fig. 9.

Original diagnosis. Striis transversis, numerosis, minutis; striis incrementi decussatis (BASTEROT 1825).

Shell material.

$\begin{array}{lrllrl}\text { Location } & \text { Depth } & \text { Shells } & \text { Location } & \text { Depth } & \text { Shells } \\ \text { Glejbjerg } & 42 \mathrm{~m} . & 2 \mathrm{frg} \text {. (cf.) } & \text { Toftlund } & 105-110 \mathrm{~m} . & 2 \\ \text { Bramminge } & 70-80- & 16 & & 110-115- & 1 \\ \text { Gramby } & 90.42-92.72- & 1 \text { frg. (cf.) } & & 115- & 3 \\ \text { Toftlund } & 75-100- & 7 & \text { Arnum (13) } & 53-83- & 1 \text { frg. (cf.) } \\ & 100-105- & 1 & \text { Arnum (25b) 104.3-107.5 - } & 3\end{array}$

Description.

The shells are partly fragmentary and worn; only a few have a well preserved protoconch.

Protoconch. One slightly oblique initial whorl, generally smooth. Faint cellular sculpture observed with strong magnification on the figured specimen. Two medial whorls, and very short terminal part with 3 collabral riblets. Terminal varix with distinct upper velum sinus. Base of protoconch not observed.

The protoconch data of 3 shells from Toftlund $(75-100 \mathrm{~m}$.$) are:$

$\begin{array}{ccccccc}\begin{array}{c}\text { Height of } \\ \text { exposed spire } \\ \text { mm. }\end{array} & \begin{array}{c}\text { Diameter } \\ \text { mm. }\end{array} & \text { Total } & \begin{array}{c}\text { Number of whorls } \\ \text { Initial }\end{array} & \text { Medial } & \text { Terminal } & \begin{array}{c}\text { Number of riblets } \\ \text { on terminal part }\end{array} \\ 0.68 & 0.61 & 27 / 8 & 1 & 13 / 4 & 1 / 8 & 3 \\ 0.74 & 0.65 & 31 / 8 & 1 & 2 & 1 / 8 & 3 \\ 0.78 & 0.65 & 31 / 8 & 1 & 2 & 1 / 8 & 3\end{array}$

Teleoconch. Spire turreted, whorls rather flat. Relatively strong spiral sculpture of one subsutural spiral, two to three carinal spirals, and about 10 to 15 spirals on the base of the body whorl and the anterior canal. Secondary spirals emerge with growth particularly between the sutural and carinal spirals. Collabral ribs (12 to 21 per whorl) of about same strength as the spiral ribs. The number of these ribs increases generally with growth. Sinus of the growth lines at about the upper carinal rib.

Remarks. The sculpture of $A$. pannus is rather variable. In the present material there are types comparable with $A$. pannus as figured by GLIBERT on his plate 5, fig. 11, while others are very close to, or practically identical with his $A$. festiva on pl. 5, fig. 9. These types are connected by transitional forms, 
and it is virtually impossible to divide the material objectively into two well defined morphologic types. I have the impression that the shell identified as $A$. pannus by GLIBERT represents a shallow water specimen, as suggested by the thick test and the strong development of the sculpture, while the type A. festiva may have lived in more quiet water.

Distribution.

Miocene: Aquitanian Basin: Burdigalien.

Loire Basin: Helvétien.

North Sea Basin: Hemmoor stage. Glimmerton (Baxke

Rasmussen 1956). Denmark: Arnum formation.

Mediterranean Basin: Italy: Miocene medio et superiore.

Vienna Basin: Grund and Baden beds.

\section{Genus Brachytoma Swainson 1840}

\section{Brachytoma electa nov. sp.}

Plate 57, fig. 193.

Diagnosis. Brachytoma without traces of diagonal cancellation on the protoconch whorls. Strong subsutural spiral rib and 5 to 7 less strong spiral ribs on the teleoconch whorls. About 25 spiral ribs on the the body whorl and the short canal. Nine or 10 collabral ribs per whorl, extending adapically to the subsutural spiral rib.

Holotype: Geological Survey of Denmark, Well file no. 150. 9. b. Toftlund 75-100 m. Dimensions of holotype: height $4.32 \mathrm{~mm}$., diameter $1.74 \mathrm{~mm}$., $4 \frac{1}{4}$ protoconch whorls, and 3 teleoconch whorls.

Derivatio nominis: electa-the elected.

Shell material. Bramminge 70-80 m. one shell (worn), height: $6.95 \mathrm{~mm}$., diameter: $2.26 \mathrm{~mm}$. Toftlund 75-100 $\mathrm{m}$. one shell (plate 57, fig. 193).

Additional description.

Protoconch. Initial whorl with deviated axis, slightly sinistral, with 8 to 10 spiral lines of microscopic granules. Two and $3 / 4$ smooth, convex medial whorls, and $1 / 2$ terminal whorl with 10 curved collabral riblets. Well defined upper velum sinus. Base of protoconch not exposed. Diameter of protoconch $0.78 \mathrm{~mm}$., estimated total height $1.4 \mathrm{~mm}$.

Teleoconch. The first whorl with 5 spiral ribs and thereafter increment of one spiral rib on each of the following whorls. Sinus of growth lines open and rather shallow, aperture broken.

Remarks. This shell resembles at first sight Drillia Bellardi Des Moulins (see Peyrot 1931, p. 95, pl. 7, fig. 50-51), but a close examination reveals significant differences. It is not possible to make any detailed comparison on account of the inadequate descriptions in the literature. However, the difference in spiral ornamentation: four spiral ribs on the whorls of $D$. Bellardi and 5 to 7 spiral ribs on the whorls of $B$. electa is unquestionably a valid dividing criterion.

B. electa displays more impressive similarities with B. Grateloupi described below. The protoconchs of the two species are practically identical, and it is also possible to find specimens of $B$. Grateloup $i$ which are very close to B. electa in the features of the teleoconch. There are, however, fundamental differences: 
the collabral ribs in $B$. electa are connected with the subsutural spiral rib and do not disappear on the shoulder as in B. Grateloupi, also the collabral ribs are stronger than in the latter species. Further: the spiral ribs on the shoulder of the helicocone are stronger in B. electa than in B. Grateloupi.

The differences from $B$. obtusangula are easily recognizable: B. obtusangula has a larger protoconch with traces of diagonal cancellation and subangular to angular adult whorls.

Distribution.

Miocene: North Sea Basin: Denmark: Arnum formation.

\section{Brachytoma Grateloupi (Peyrot)}

Plate 58, fig. 194 a-c.

1932. Daphnella (Raphitoma) Grateloupi Peyrot. Conch. Néogén. d. l'Aquit. p. 93, 1931: pl. 9, fig. 78-80.

Essential features of original description. Lestrois premiers (tours) convexes, lisses, et un quatrième, muni de costules axiales courbes, fines et serrèes constituent la protoconque; les tours suivants sont ornés de onze côtes axiales assez larges, saillantes, arrondies, inflechies sur la concavité postérieure; celle-ci montre des filets spiraux extrêmement ténus; il en existe d'autres sur la région antérieure, un peu plus saillants (PEYRot 1932).

Shell material.

\begin{tabular}{|c|c|c|c|c|c|}
\hline Location & Depth & Shells & Location & Depth & Shells \\
\hline Glejbjerg & $53.75 \mathrm{~m}$. & 1 & Toftlund & $100-105 \mathrm{~m}$. & 5 \\
\hline Bramminge & $70-80$ & 34 & & $105-110=$ & 5 \\
\hline Gramby & $2.66-83.76-$ & 2 & m (13) & $53-83-$ & 5 \\
\hline Toftlund & $75-100$ & 18 & Arnum (25b) & $62.7-62.9$ & 4 \\
\hline
\end{tabular}

Description. The shell material is relatively well preserved.

Protoconch. Initial whorl slightly sinistral with oblique axis; granules in about 8 spiral rows. Two to $23 / 4$ smooth and glossy medial whorls and $1 / 2$ to $3 / 4$ terminal whorl with curved collabral riblets. Distinct upper and lower velum sinus, and"sinusigera" projection with one relatively strong spiral rib.

\begin{tabular}{|c|c|c|c|c|c|c|}
\hline Height & Diameter & \multicolumn{4}{|c|}{ Number of whorls } & \multirow{3}{*}{$\begin{array}{l}\text { Number of riblets } \\
\text { on terminal part }\end{array}$} \\
\hline $\mathrm{mm}$. & $\mathrm{mm}$. & Total & Initial & Medial & Terminal & \\
\hline Toftlund 7 & $0 \mathrm{~m} .:$ & & & & & \\
\hline 1.45 & 0.86 & $4 \frac{1}{4}$ & 1 & $21 / 2$ & $3 / 4$ & 11 \\
\hline 1.43 & 0.87 & $4 \frac{1}{4}$ & 1 & $23 / 4$ & $1 / 2$ & 10 \\
\hline 1.51 & 0.78 & 4 & 1 & $21 / 2$ & $1 / 2$ & 11 \\
\hline 1.33 & 0.74 & $31 / 2$ & 1 & $21 / 4$ & $1 / 4$ & 6 \\
\hline 1.49 & 0.87 & $31 / 2$ & 1 & 2 & $1 / 2$ & 8 \\
\hline \multicolumn{7}{|c|}{ Toftlund $100-105 \mathrm{~m}$. : } \\
\hline 1.27 & 0.76 & 4 & 1 & $21 / 2$ & $1 / 2$ & 9 \\
\hline 1.49 & 0.82 & $41 / 4$ & 1 & $23 / 4$ & $1 / 2$ & 12 \\
\hline
\end{tabular}

Teleoconch with 10 to 17 collabral ribs per whorl. The number of ribs increases generally with growth, and the ribs often become obsolete on the latest whorls of large shells. The collabral ribs extend to the subsutural spiral rib on the first adult whorls, but are commonly obsolete on the sinus shoulder of later 
whorls. Spiral ornamentation of one strong, subsutural spiral rib with "commashaped", collabral riblets; fine, spiral cords on the sinus shoulder, and about 20 stronger primary and secondary spirals on the periphery and base of the body whorl and the canal.

Remarks. Specimens with strong ornamentation may be mistaken for $B$. electa and B. obtusangula. The differences between these species and $B$. Grateloupi have been outlined above in the description of B. electa to which reference is made.

Distribution.

Miocene: Aquitanian Basin: Burdigalien.

North Sea Basin: Denmark: Arnum formation.

\section{Brachytoma obtusangula (Brocchi)}

Plate 58, fig. 195.

1814. Murex obtusangulus Brocchi. Conchiol. Foss. Subapennina. p. 422, pl. 8, fig. 19. 1856. Pleurotoma obtusangula Brocc. Hörnes. D. foss. Moll. d. Tert.-Beckens v. Wien. 1, p. 365 , pl. 40 , fig. 7,8 .

1878. Drillia obtusangulus (Brocch.) Betcard. I moll. d. terr. terz. d. Piemonte e d. Liguria. 2, p. 98.

1904. Drillia obtusangula (BR.) SAcco. Ibid. 30, p. 45, pl. 12, fig. 15-18.

1907. Mangilia obtusangula Brocchi sp. Ravn. Molluskf. Jyll. Tert. p. 359.

1914. Raphitoma obtusangula Broc. sp. Gripr. Über eine u. mioz. Moll. f. v. Itzehoe. p. 34.

1925. Drillia obtusangula Brocch. KaUtsky. D. Mioc. v. Hemmoor u. Basbeck-Osten. p. 171.

1932. Daphnella (Raphitoma) venusta Perrot. Conch. Néogén. d. l'Aquit. p. 71, 1931: pl. 7 , fig. 6,7 .

1954. Clavus (Brachytoma) obtusangula Brocchi sp. Glibert. Pleurotomes ete. p. 25, pl. 4, fig. 10.

1956. Brachytoma obtusangula (Brocchi). Banke Rasmussen. Upper Mioc. South Jutland, p. 89 , pl. 8 , fig. 6 .

Original diagnosis. Testa turrita, obtuse longitudinaliter costata, transverse confertim striata, anfractubus carinatis, superne lceviusculis (BRoccHI 1814).

Shell material.

Location

Glejbjerg

Bramminge

Ribe

Gramby

Toftlund

$\begin{array}{rc}\text { Depth } & \text { Shells } \\ 53.5 \mathrm{~m} . & 5 \text { (cf.) } \\ 55- & 1 \\ 70-80- & 30 \\ 113-114- & 1 \\ 82.66-83.76- & 4 \\ 75-100- & 15 \\ 100-105- & 3 \\ 105-110- & 37\end{array}$

$\begin{array}{rr}\text { Depth } & \text { Shells } \\ 110-115 \mathrm{~m} . & 11 \\ 115- & 10 \\ 53-83- & 4 \\ 62.7-62.9- & 6 \\ 95.0-95.3- & 4 \\ 101.0-104.3- & 1 \\ 104.3-107.5- & 10 \\ 107.5- & 2\end{array}$

Description.

A number of the shells are very well preserved although the aperture is broken on practically all specimens.

Protoconch. Initial whorl slightly sinistral with oblique axis. Shell surface of this part with 8 to 10 spiral rows of granules. One to $13 / 4$ smooth, medial whorls. Terminal whorls, $1 \frac{1}{2}$ to $21 / 2$ in number at the beginning with fine collabral threads which become successively stronger and appear as collabral 
riblets at the termination of the protoconch. Typical "sinusigera" projection and distinct sinuses above and below it. One relatively strong spiral rib opposite the "sinusigera" projection. Extremely delicate diagonally crossed threads occur on the terminal whorls, and particularly on their abapical parts. The thread pattern is more irregular between and on the collabral riblets adjacent to the termination of the protoconch, where the threads have mainly a spiral trend.

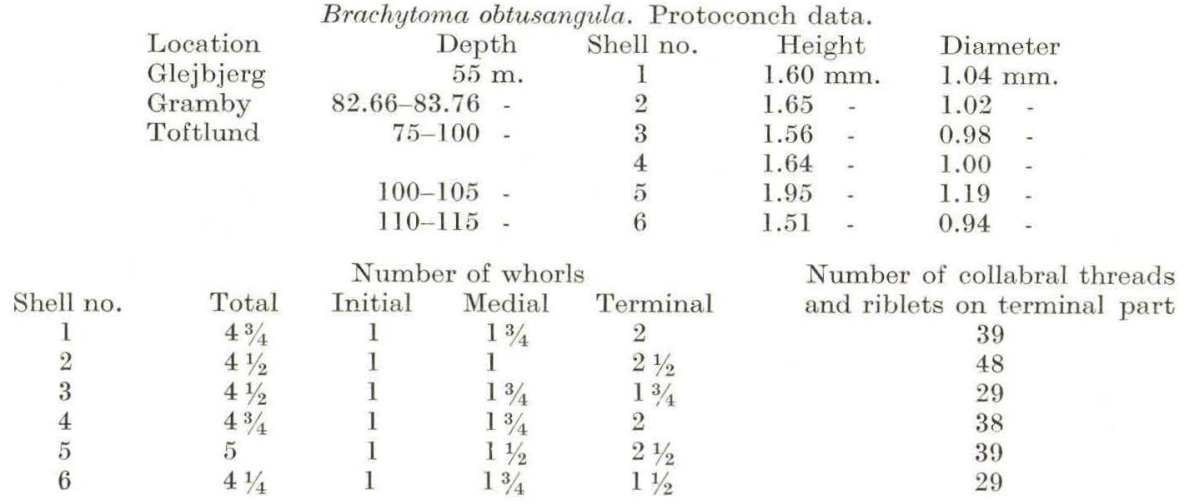

Teleoconch with 9 to 13 collabral ribs per whorl. The number increases apparently somewhat with growth. The collabral ribs generally approach the subsutural spiral rib, but are often rather indistinct or almost obsolete on the shoulder. The ribs are angular on the shell periphery.

In addition to the strong subsutural spiral which has comma-shaped riblets there are fine spiral threads and/or ribs on the sinus shoulder, and still stronger ribs on the peripheral and abapical parts of the whorls. There are generally 4 or 5 strong spirals between the shoulder and the suture below. The body whorl and the canal have 19 to 27 spiral ribs below the shoulder. Sinus of growth lines broad and shallow.

Remarks. This species is variable with respect to the sculpture of the teleoconch which is similar to the sculpture of many other small Turrid species. It is accordingly inadvisable to lay too much emphasis on the specific significance of only adult shell shape and sculptural features such as number of spirals and ribs, and the strenght of these elements. Protoconch morphology and characters of the teleoconch are, however, reliable aids in the determination of this as also of other species.

Peyrot's D. venusta is undoubtedly identical with the present species since all details of his description agree with the features of the South Jutland shelis. It is impossible to recognize any valid grounds for keeping $D$. venusta separated from $B$. obtusangula.

\section{Distribution.}

Pliocene: Mediterranean Basin: Italy: Pliocene inferiore.

Miocene: Aquitanian Basin: Aquitanien.

North Sea Basin: Belgium: Anversien. Germany: Vierlande, Hemmoor, Reinbek (GotTsche 1878), and Glimmerton stages (Staesche 1930). Denmark: Arnum and Gram formations. 
Mediterranean Basin: Italy: Miocene medio et superiore.

Vienna Basin: Baden beds.

\section{Brachytoma sp.}

Plate 57, fig. $196 \mathrm{a}-\mathrm{b}$, plate 58, fig. 196.

Shell material: Glejbjerg $55 \mathrm{~m}$. one shell. Height $5.85 \mathrm{~mm}$. Diameter $2.45 \mathrm{~mm}$. Bramminge $70-80 \mathrm{~m}$., one shell.

\section{Description.}

Protoconch partly broken and worn, apparently polygyrate and probably not keeled. Other protoconch features unknown.

Teleoconch turreted, 10 to 11 strong and projecting collabral ribs per whorl. Strong spiral rib at the suture, two weak spiral ribs on the sinus shoulder, and 2 to 4 strong spiral ribs on the vertical part of the whorls. Body whorl with about 16 relatively strong spirals on the periphery, the base and the canal.

Remarks. The adult sculpture of this species resembles the sculpture of Drillia hannoverana KaUtsky (1925, p. 175, pl. 11, fig. 28), which however, has a keeled protoconch, and is thus probably a different species.

\section{Genus Aphanitoma Bellardi 1875}

\section{Aphanitoma glejbjergensis nov. sp.}

Plate 59, fig. 197.

Diagnosis. Aphanitoma with protoconch of two smooth whorls and with covex teleoconch whorls having a reticulate sculpture of 13 to 16 fold-like, collabral ribs per whorl. Four or 5 distinct spiral ribs, narrower than their interspaces, on the whorls of the spire. Total number of spiral ribs on the body whorl more than 20. Entire surface covered with collabral threads. Collumellar folds almost obsolete. Pratically no sinus indicated by the growth lines.

Holotype: Geological Survey of Denmark, Well file no. 122.24. Glejbjerg $53 \mathrm{~m}$. Dimensions of holotype: height $8.4 \mathrm{~mm}$. (canal broken!), diameter $3.4 \mathrm{~mm} .5$ adult whorls.

Derivatio nominis, glejbjergensis - from Glejbjerg.

Shell material. One shell from Glejbjerg $53 \mathrm{~m}$.

Additional description.

Protoconch. Initial whorl globular with shallow suture. Heigth of protoconch spire $0.62 \mathrm{~mm}$., diameter $0.51 \mathrm{~mm}$.

Teleoconch. The number of spiral ribs is possibly rather constant, as it is not possible to distinguish more than one class of spirals. The growth lines are slightly curved adjacent to the suture. This is the only indication of a sinus. Aperture broken.

Remarks. This species displays features of similarity with the type of the genus: A. labellum Bellardi (1878, p. 242, pl. 7, fig. 28). It differs, however, from this species by the greater number of both spiral and collabral ribs. A. Pecchiolii Bellardi (1878, p. 243, pl. 7, fig. 29) has a shape similar to $A$. glejbjergensis, and also the spiral ribs are apparently similarly developed. However A. Pecchiolii has angular whorls, a distinct depression adjacent to the 
upper suture, and the collabral ribs do not extend to the upper suture. There can thus hardly be any doubt that A.glejbjergensis is a species different from A. Pecchiolii.

Distribution.

Miocene: North Sea Basin: Denmark: Arnum formation.

\section{Genus Neoguraleus Powell 1939}

\section{Neoguraleus calais (Kautsky)}

Plate 59, fig. 198 a-c.

1925. Daphnella (Raphitoma) Calais Kautsky. D. Mioc. v. Hemmoor u. Basbeck-Osten. p. 187, pl. 12, fig. 13-14.

Essential features of original description. Diese Form hat $7 \mathrm{Um}$ gänge, von denen 3 auf das grosse glatte stumpfkonische Embryonalgewinde entfallen, dessen Umgänge sehr stark konvex sind. Dann folgt ein Umgang mit einer Übergangsskulptur von zahlreichen ziemlich kräftigen sichelförmig gekrümmten Längsrippchen. Über die Längsrippen laufen dicht gedrängt sehr schwache Spiralen. Die übrigen Umgänge hinter der Mitte etwas eingedrückt. 13 Längsrippen am vorletzten Umgang. Der hintere Abschnitt der Umgänge trägt zahlreiche dicht gedrängte Spiralen. Die Spiralen des vorderen Abschnitts sind etwas breiter und deutlicher. Der Kanal ist kurz. (KaUtsky 1925).

Shell material.

$\begin{array}{lrrlrr}\text { Location } & \text { Depth } & \text { Shells } & \text { Location } & \text { Depth } & \text { Shells } \\ \text { Glejbjerg } & 23 \mathrm{~m} . & 1 & \text { Toftlund } & 75-100 \mathrm{~m} . & 101 \\ & 25- & 1 & & 100-105- & 7 \\ & 38- & 1 & & 105-110- & 7 \\ \text { Bramminge } & 55- & 1 & & 110-115- & 12 \\ \text { Gramby } & 82.66-83.76- & 42 & & 115- & 3 \\ & 84.66-87.16- & 5 & \text { Arnum }(13) & 53-83- & 17 \\ & 90.42-92.72- & 2 & \text { Arnum }(25 \mathrm{~b}) & 95.0-95.3- & 2\end{array}$

Description.

Shell features are generally distinct, but the shells are with a very few exceptions more or less broken.

Protoconch. Initial whorl smooth and glossy, slightly sinistral. About $1 \frac{1}{2}$ to $13 / 4$ smooth medial whorls, and $3 / 4$ to $1 \frac{1}{4}$ terminal whorls with 4 spiral riblets crossed by 9 to 25 collabral riblets per whorl. The apertural margin of the protoconch is only slightly sinuous above and below the projection which does not protrude very much.

Neoguraleus calais. Protoconch data.

Shells from Toftlund, no. 1-8 from 75-100 m. and no. 9 from 110-115 m.

\begin{tabular}{|c|c|c|c|c|c|c|}
\hline Height mm. & Diameter & \multicolumn{4}{|c|}{ Number of whorls } & Number of riblets \\
\hline Spire: & $\mathrm{mm}$. & Total & Initial & Medial & Terminal & on terminal part \\
\hline 0.78 & 0.68 & $31 / 4$ & 1 & $1 \frac{1}{2}$ & $3 / 4$ & 10 \\
\hline 0.98 & 0.74 & 4 & 1 & $13 / 4$ & $11 / 4$ & 23 \\
\hline 0.86 & 0.74 & $31 / 2$ & 1 & $11 / 2$ & 1 & 21 \\
\hline 0.74 & 0.69 & $31 / 4$ & 1 & $11 \%$ & $3 / 4$ & 19 \\
\hline 0.74 & 0.68 & $31 / 2$ & 1 & $11 / 2$ & 1 & 9 \\
\hline 0.74 & 0.66 & $31 / 4$ & 1 & $1 \frac{1}{2}$ & $3 / 4$ & 8 \\
\hline Total height: & & & & & & \\
\hline 1.06 & 0.74 & $3^{1 / 4}$ & 1 & $11 / 2$ & $3 / 4$ & 18 \\
\hline 1.17 & 0.77 & $31 / 2$ & 1 & $11 / 2$ & 1 & 19 \\
\hline 1.14 & 0.78 & $31 / 4$ & 1 & $11 / 2$ & $3 / 4$ & 21 \\
\hline
\end{tabular}


Teleoconch. The first whorls have distinct collabral ribs which, however, often become obsolete from the 4th or 5th whorl. The number varies from 9 to 16 per whorl as illustrated in the table below, which also shows that there are generally more ribs on whorl no. 1 than on no. 2. while the number thereafter tends to increase with growth. There are 7-12 faint spiral striae on the sinus shoulder and 24-27 somewhat stronger spiral bands on the body whorl below the shoulder, and on the canal. Sinus moderately deep, aperture narrow, canal short. Dimensions of two almost entire shells were:

$\begin{array}{lcclcc}\text { Location } & \text { Depth } & \text { Height } & \text { Diameter } & \begin{array}{c}\text { Number of whorls } \\ \text { Protoconch Teleoconch }\end{array} \\ \text { Gramby } & 82.66-83.76 \mathrm{~mm} . & 7.00 \mathrm{~mm} . & 2.36 \mathrm{~mm} . & 31 / 2 & 41 / 2 \\ \text { Toftlund } & 75-100 \mathrm{~m} . & 7.28- & 2.48- & 31 / 4 & 5\end{array}$

\begin{tabular}{|c|c|c|c|c|c|c|c|}
\hline \multirow{4}{*}{ No. } & \multicolumn{7}{|c|}{$\begin{array}{c}\text { Shells from Toftlund } 75-100 \mathrm{~m} \text {. (Shell no.'s refer to same shells } \\
\text { as in table of Protoconch data p. 278). }\end{array}$} \\
\hline & \multirow{2}{*}{\multicolumn{5}{|c|}{$\begin{array}{l}\text { Number of collabral } \\
\text { ribs on whorl }\end{array}$}} & \multicolumn{2}{|c|}{ Number of spirals on body whorl } \\
\hline & & & & & & On shoulder & Below shoulder \\
\hline & no. 1 & 2 & 3 & 4 & 5 & & \\
\hline 1 & 13 & 12 & 11 & 13 & & 12 & 24 \\
\hline 2 & 11 & 12 & 15 & & & 7 & 27 \\
\hline 3 & 15 & 16 & 16 & 15 & & 8 & 26 \\
\hline 4 & 13 & 11 & 11 & 14 & & 10 & 24 \\
\hline 5 & 11 & 9 & 10 & 12 & & 8 & 25 \\
\hline 6 & 13 & 11 & 13 & 14 & 13 (obsolete) & 10 & 27 \\
\hline
\end{tabular}

Remarks. The protoconch of this species is obviously of the Neoguraleus type as defined by Powell (1942, p. 132), and the general shape of the adult shell also agrees fairly well with species of Neoguraleus deseribed by this author from New Zealand. There are certainly other representatives of the genus in the fossil Tertiary faunas of Europe, and $N$. tenella described below as well as Mangelia Dujardini (GLIBERT 1954, p. 47, pl. 6, fig. 6) should be mentioned in this connection.

\section{Distribution.}

Miocene: North Sea Basin: Germany: Hemmoor stage. Denmark: Arnum formation.

\section{Neoguraleus tenella (Mayer)}

(Plate 59, fig. $199 \mathrm{a}-\mathrm{b}$, plate 61, fig. 199).

1858. Pleurotoma tenella Mayer. Descr. Coq. foss. ét. sup. terr. tert. p. 390, pl. 11, fig. 6. cf. 1925. Daphnella (Raphitoma) hispidula JAN. var. laevigatior KAUTSKY. D. Mioc. v. Hemmoor u. Basbeck-Osten. p. 186, pl. 12, fig. 11.

ef. 1925. Daphnella (Raphitoma) mio Roemeri KAUTSKY. Ibid. p. 186, pl. 12, fig. 12.

cf. 1932. Daphnella (Raphitoma) elegantissima Peyrot. Conch. Néogén. d. l'Aquit. p. 72, 1931: pl. 9, fig. 63,64 .

1932. Daphnella (Raphitoma) tenella Mayer. Peyrot. Ibid. p. 98, 1931: pl. 9, fig. 50, 51.

Original diagnosis. Testa fusiformi, plicis longitudinalibus flexuosis, angustis, elevatis, striisque transversis minutissimis, crebis, incequalibus; anfractibus 6 convexis, prope suturam subcarinatis, subscalatis; apertura oblonga, spirce breviore. (MAYER 1858). 
Shell material.

$\begin{array}{lrrrrr}\text { Location } & \text { Depth } & \text { Shells } & \text { Location } & \text { Depth } & \text { Shells } \\ \text { Glejbjerg } & 23 \mathrm{~m} . & 1 & \text { Toftlund } & 75-100 \mathrm{~m} . & 201 \\ & 25- & 1 & & 100-105- & 4 \\ & 38- & 1 & & 105-110- & 173 \\ & 53.5- & 2 & & 110-115- & 25 \\ \text { Bramminge } & 53.75- & 1 & & 115- & 8 \\ \text { Gramby } & 70-80-66-83.76- & 185 & \text { Arnum (13) } & 53-83- & 18 \\ & 84.66-87.16- & 4 & \text { Arnum (25b) } & 62.7-62.9- & 9 \text { (cf.) } \\ & 82.6-95.3- & 3\end{array}$

Description. The bulk of the material consists of fragments. Very few shells have the outer lip intact.

Protoconch. Initial whorl and medial whorls smooth and glossy. Terminal part of the protoconch with curved collabral riblets crossed by spiral riblets. Commonly with knobs on the crossing of the ribs. The collabral riblets emerge generally somewhat earlier than the spiral ribs although there are specimens in which the opposite is the case.

Projecting spiral rib on the periphery of the terminal whorl, 5 to 6 relatively strong spiral ribs above it and about 10 to 15 weaker spiral ribs on the base of the terminal whorl and the protoconch canal. Velum sinuses very shallow and projection between them rather short.

Neogurateus tenella. Protoconch data on shells from Toftlund 105-110 m.

\begin{tabular}{|c|c|c|c|c|c|c|c|c|}
\hline Height & Diameter & & Numb & $\mathrm{r}$ of whe & & Number of & $\begin{array}{l}\text { No. } \\
\text { abov }\end{array}$ & $\begin{array}{c}\text { spirals } \\
\text { below }\end{array}$ \\
\hline $\mathrm{mm}$. & $\mathrm{mm}$. & Total & Initial & Medial & Terminal & collabral riblets & & ohery \\
\hline 1.33 & 0.78 & $31 / 2$ & 1 & 2 & $1 / 2$ & 15 & 5 & ? \\
\hline 1.33 & 0.84 & $31 / 2$ & 1 & 2 & $1 / 2+$ & 23 & 6 & abt. 15 \\
\hline 1.29 & 0.86 & $31 / 2$ & $1 \frac{1}{4}$ & $13 / 4$ & $1 / 2+$ & 15 & 5 & 10 \\
\hline 1.29 & 0.83 & $31 / 2$ & 1 & $13 / 4$ & $3 / 4$ & 18 & 6 & -10 \\
\hline
\end{tabular}

Teleoconch. Shape turreted with varying apical angle. Ten to 14 collabral ribs per whorl. Shell surface otherwise sculptured by delicate spiral cords on the shoulder, 4 to 6 or more strong spirals on the peripheral and abapical parts of the whorl, and fine spirals in the interspaces of the spirals and on the canal. Spiral elements of the sculpture crossed by growth lines by which the spirals often are intersected into course granules. The strong spirals are occasionally spiny on crossing the collabral ribs.

Aperture long, sinus shallow. Suture formed between the third and fifth strong spiral rib below the shoulder, it generally follows the fourth spiral.

Variation. N. tenella is apparently a very variable species. The following features are subjected to variation: 1 . number of collabral ribs, 2 . strength and spinose development of strong spiral ribs, 3. number and strength of fine spirals, 4. granulation of spirals, 5. angularity of shoulder, and 6. position of suture in relation to periphery, which affects the apical angle and the general shape of the shell.

A great variety of morphologic types result from this variation, and the extremes are so different that they would undoubtedly be considered independant species if they were the only specimens available. Various attempts were therefore made to subdivide the shell material into more than one well defined type. This proved, however, to be impossible, and the only conclusion to be drawn was that we are considering a single species with a wide variation range.

It is not possible to give a detailed statistical account of the variation due to the fragmentary state of the shell material. The table below includes the data 
of a few shells which illustrate the variation range of ornamentation and shape.

A very conspicuous type comprises those shells in which the spiral elements are intersected into granules. A number of these shells have also a highly placed suture and consequently a relatively low spire and wide apical angle (plate 59). This combination forms the greatest temptation with regard to the separation of another species, but there are forms which are transitional to shells of more lender shape and with smooth spiral sculpture, and which thereafter prohibit the separation.

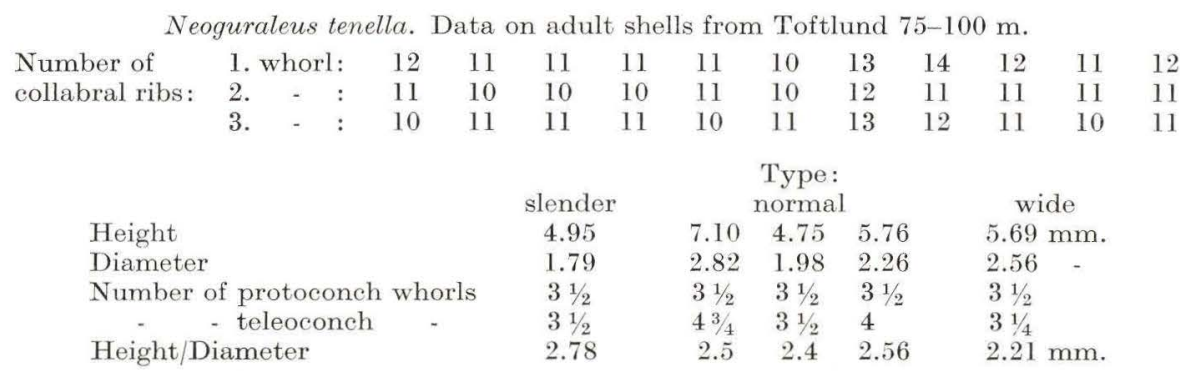

Remarks. The observed great variation range of the shells made the writer suspicious regarding the validity of the species listed in the synonymy with 'cf.'. It is very probable that they should be referred to $N$. tenella.

D. mio Roemeri has previously been referred to D. Roemeri by the writer (Sorgenfrei 1940, p. 112). This referrence is now considered incorrect, and I would add that $D$. Roemeri ought to be revised. The shell from Klintinghoved is a real Daphnella on account of its protoconch, while PHILIPPI's Pleurotoma Roemeri is probably not a Daphnella.

Distribution.

Miocene: Aquitanian Basin: Burdigalien.

North Sea Basin: Germany: Hemmoor stage (?). Denmark: Arnum formation.

\section{Neoguraleus Gürichi (Kautsky)}

Plate 60, fig. $200 \mathrm{a}-\mathrm{b}$.

1925. Mangilia Gürichi Kautsky. D. Mioc. v. Hemmoor u. Basbeck-Osten. p. 183, pl. 12, fig. 5 .

Essential features of original description. 21/2 Umgänge des (Embryonalgewindes) sind glatt, der vorderste trägt flache stark gekrümmte Längsrippen, über die flache und schwache Spiralen verlaufen. Die Mittelwindungen tragen zahlreiche (14 am vorletzten Umgang) schmale und hohe Längsrippen. Im hinteren Drittel der Umgänge sind diese Längsrippen blattartig seitlich zusammengedrückt und entsprechend dem Sinus etwas gekrümmt. Zwischen den Längsrippen Spiralen. (KAUTSKY 1925).

Shell material. Bramminge 70-80 m. one well preserved shell.

Description.

Protoconch. One smooth and glossy slightly sinistral, initial whorl with oblique axis. One and a half smooth and glossy medial whorls and 1 terminal 
whorl with 16 curved, collabral riblets crossed by 4 spiral riblets at the termination of the protoconch helicocone. Exposed spire $0.90 \mathrm{~mm}$. high and $0.74 \mathrm{~mm}$. in diameter.

Teleoconch with 12 elevated and narrow curved collabral ribs which extend from suture to suture on the first adult whorl. The collabral ribs of the body whorl continue on the canal.

There are about 4 indistinct spiral threads in the interspaces below the suture on the sinus belt. Five stronger spiral cords are developed more abapically in the interspaces and sides of the ribs, and thereafter follow 4 indistinct threads. Secondary threads emerge between the 5 strong cords below the sinus belt. There are 12 spiral cords on the canal.

Remarks. There seems to be very good agreement between the features reported by KAUTSKY and the characters observed in the specimen from Bramminge. The only disagreement is that the Hemmoor specimens have 14 collabral ribs while only 12 ribs are found on the shell from Bramminge. This is, however, probably not important.

Distribution.

Miocene: North Sea Basin: Germany: Hemmoor stage. Denmark: Arnum formation.

\section{Genus Pleurotomoides Bronn 1831}

\section{Pleurotomoides Johannæ (Peyrot)}

Plate 60, fig. 201, plate 61, fig. 201.

1932. Mangelia (Clathurella) Johannce Pеyrot. Conch. Néogén. d. l'Aquit. p. 52, 1931: pl. 9, fig. 129-130.

Essential features of original description. Protoconque polygyrée à nucléus petit et subdévié; ses tours lisses deviennent fortement carénés; tours postembryonnaires légèrement concaves et à peu près lisses en arrière, peu convexes en avant, ou ils sont ornés de fortes côtes axiales formées par la superposition de deux gros nceuds arrondis et d'un troisième plus petit, voisin de la suture antérieure. (Peyrot 1932).

\begin{tabular}{lrllrr}
\multicolumn{2}{c}{ Shell material. } & & & \\
Location & Depth & Shells & Location & Depth & Shells \\
Glejbjerg & $53.5 \mathrm{~m}$. & 3 & Toftlund & $105-110 \mathrm{~m}$. & 11 \\
& $53.75-$ & 1 & & $110-115-$ & 2 \\
Bramminge & $70-80-$ & 6 & & $115-$ & 2 \\
Ribe & $113-114-$ & 1 frg.(cf.) & Arnum (13) & $53-83-$ & 3 \\
Toftlund & $75-100-$ & 15 & Arnum (25b) & $95.0-95.3-$ & 1 \\
& $100-105-$ & 3 & & &
\end{tabular}

Description.

Most shells are juvenile, adult shells fragmentary.

Protoc on ch. Initial whorl slightly sinistral with oblique axis. Medial and terminal whorls keeled, with one spiral riblet on the keel and one spiral riblet following the suture. Terminal part of the protoconch occasionally with a few knobs on the keel. Well preserved specimens display the specific granular surface mentioned above (p. 250). The entire protoconch may be granulated, and the granules of the initial whorl are arranged spirally in some specimens. Distinct sinuses above and below the 'sinusigera' projection. 
Pleurotomoides Johannce. Protoconch data.

\begin{tabular}{|c|c|c|c|c|c|c|}
\hline & & & & \multicolumn{3}{|c|}{ Number of whorls } \\
\hline cation & Depth & Height & Diameter & Total & Initial & $\begin{array}{l}\text { Medial \& } \\
\text { Terminal }\end{array}$ \\
\hline ftlund & $75-100 \mathrm{~m}$. & $1.7 \mathrm{~mm}$. & $0.86 \mathrm{~mm}$. & 4 & 1 & 3 \\
\hline & $100-105$ & 1.35 & 0.82 & 4 & 1 & 3 \\
\hline & & 1.41 - & 0.86 & 4 & 1 & 3 \\
\hline & $105-110$ & 1.64 & 0.90 & $43 / 4$ & 1 & $3^{3 / 4}$ \\
\hline num $(25 b)$ & $95.0-95.3$ & 1.46 & 0.82 & 4 & 1 & 3 \\
\hline
\end{tabular}

Teleoconch. Spire turreted. Whorls with slightly concave shoulder, smooth except for the collabral ribs which approach the adapical suture. Strong collabral ribs, 8 to 11 per whorl, crossed by two very strong, bifid spiral ribs below the shoulder, having one minor spiral rib in the interspace, and also a rather strong spiral rib adjacent to the abapical suture. Body whorl with 4 or 5 broad, more or less distinct, spiral ribs on the whorl base, and 9 or 10 spiral ribs on the canal. The collabral ribs are often obsolete on later adult whorls. Aperture broken in all specimens. The growth lines indicate a sinus of moderate depth. Well preserved shells have the entire surface or only parts of it granulated in the same way as the protoconch.

Remarks. The shells agree exceedingly well with Peyrot's description, although this author does not mention the ganular texture of the shell surface. See also p. 285.

Distribution.

Miocene: Aquitanian Basin: Burdigalien.

North Sea Basin: Denmark: Arnum formation.

\section{Pleurotomoides elatior (von Koenen)}

1872. Pleurotoma elatior von Koenen. D. Nordd. Mioc. u. s. Moll. f. p. 240, pl. 3, fig. 7. 1925. Mangilia (Clathurella) elatior v. Koen. Kautsky. D. Mioc. v. Hemmoor u. BasbeckOsten. p. 185, pl. 12, fig. 8 .

Essential features of original description. Das Embryonalende besteht aus vier glatten, gewölbten Windungen. Auf der unteren Hälfte der folgenden Windung finden sich zwei scharfe Spiralen ein, die sich auf den nächsten Windungen durch Einschiebung von anderen, ihnen an Stärke gleich werden vermehren. Die obere Hälfte trägt sechs feine, gedrängte Spiralen. Auf der letzten Mittelwindung finden sich etwa 14 gedrängte, annähernd gleich breite Spiralen. Der untere Theil der Schlusswindung ist mit ähnlichen Spiralen bedeckt. Die ersten Mittelwindungen sind stumpf gekielt, die letzten flach gewölbt. Auf der zweiten Mittelwindung ca. 10 rundliche, breite rippenartige Anschwellungen. (von KowNEN 1872).

Shell material. Glejbjerg $53.5 \mathrm{~m}$. one shell, height $20.1 \mathrm{~mm}$., diameter $3.44 \mathrm{~mm}$. Glejbjerg $55 \mathrm{~m}$. two shells.

Description.

Protoconch. One granulated slightly sinistral, oblique initial whorl. Three and $1 / 4$ subangular to angular medial whorls with spiral riblets on the keel and at the abapical suture. Ornamentation of delicate, oblique threads below the keel and granulation of the shell surface above the keel. One fourth terminal whorl with 5 collabral folds and otherwise threads and granulation as on the medial whorls. The exposed spire on one of the shells from $55 \mathrm{~m}$. is $1.33 \mathrm{~mm}$. high and $1.06 \mathrm{~mm}$. in diameter. 
Teleoconch. The three first whorls have 10 to 12 low, collabral ribs per whorl. These ribs become obsolete on the succeeding whorl. There are 3 strong spirals on the lower part of the first whorl, 6 spirals on the lower part of whorl no. 2 and both whorls have furthermore 5 thin spirals on the shoulder. New spirals emerge almost continuously, and the body whorl has about 50 spiral cords on the whorl proper and canal. Entire shell granulated until about the fifth whorl. Sinus moderately deep.

Remarks. These shells resemble $P$. simplex very much, but differ in the nature of the spiral ornamentation. An outline of relationships between these and allied species is given under $P$. simplex below.

Distribution.

Miocene: North Sea Basin: Hemmoor stage. Denmark: Arnum formation.

\section{Pleurotomoides simplex nov. sp.}

Plate 60, fig. $203 \mathrm{a}-\mathrm{b}$.

Diagnosis. Pleurotomoides with turreted shell. Protoconch of one slightly sinistral, initial whorl and about three subangular to angular, medial and terminal whorls. Teleoconch of slightly curved whorls with about $y$ to 11 collabral ribs crossed by narrow, spiral ribs below the shoulder. The shoulder devoid of ribs adjacent to the suture. Terminal whorl and canal with 25 to 30 spiral ribs. Entire surface granulated. The protoconch is occasionally almost smooth.

Holotype: Geological Survey of Denmark, Well File No. 150. 9. b. Toftlund 75-100 m.; height: $4.8 \mathrm{~mm}$., diameter: $1.8 \mathrm{~mm}$. Derivatio nominis: simplexsimple.

Shell material.

$\begin{array}{lrllrc}\text { Location } & \text { Depth } & \text { Shells } & \text { Location } & \text { Depth } & \text { Shells } \\ \text { Bramminge } & 70-80 \mathrm{~m} . & 26 & \text { Toftlund } & 75-100 \mathrm{~m} . & 32 \\ \text { Gramby } & 84.66-87.16- & 1 & \text { Arnum (13) } & 53-83- & 3 \\ & 110.86-121.51- & 1 \text { frg. (cf.) } & \text { Arnum (25 b) } & 62.7-62.9- & 4\end{array}$

Description. All shells more or less fragmentary, but shell features well preserved and distinct.

Protoconch. Medial whorls with one thin, spiral riblet on the keel and another spiral riblet at the abapical suture. Terminal whorl concave between the two riblets. The riblets correspond to part of the 'sinusigera' projection on which there is a third spiral riblet generally covered by the succeeding teleoconch whorl. Two specimens from Toftlund $75-100 \mathrm{~m}$. which consist of 1 initial and 3 medial-terminal whorls have the following dimensions:

$\begin{array}{cll} & \text { Height } & \text { Diameter } \\ \text { Shell } 1 & 1.45 \mathrm{~mm} . & 0.82 \mathrm{~mm} . \\ -\quad 2 & 1.37- & 0.78-\end{array}$

Teleoconch. Collabral riblets low and indistinct on the sinus shoulder, but projecting on the periphery. Primary spiral ribs on the periphery somewhat stronger than the spiral ribs on the base and the shoulder. Sinus apparently semicircular, eanal rather short.

Remarks. P. simplex is related with P. elatior and P. Boehmi Kautsky (1925, p. 185, pl. 12, fig. 10) with respect to the general shape of the spire, the 
round shoulder and the steeply inclined sinus belt. It differs, however, by the absence of spirals on the sinus belt and by the difference in strength which is observed between spirals of primary and secondary emergence.

$P$. simplex displays also similarities with $P$. Luisae (see e.g. Banke RasMUSSEN 1956 p. 93 pl. 9 fig. 2), which, however, is covered entirely by spiral ribs both on the sinus belt and below it as in P. Boehmi and P. elatior, although the spiral ornamentation is coarser than in the two latter species. In P. Luisae the spiral ribs of the sinus belt are narrower than those below the shoulder, and the species is particularly characterized by its projecting collabral ribs on which there is a relatively distinct shoulder.

$P$. Johanno is in some respects similar to the above-named species as e.g. in protoconch features, granulation etc. However, the two strong spiral ribs which form bulbous knots on the projecting collabral ribs and the absence of spiral ornamentation on the sinus belt renders this species exceedingly characteristic.

$P$. campanulata differs from all others by a sharp boundary between the sinus belt and the spirally ribbed part of the whorl, and by the concave curvature of the sinus belt.

Distribution.

Miocene: North Sea Basin: Denmark: Arnum formation.

\section{Pleurotomoides cf. Luisae (von Koenen)}

Plate 62, fig. $204 \mathrm{a}-\mathrm{b}$.

1872. Defrancia Luisae Semper. von Koenen. D. Nordd. Mioc. u. s. Moll. f. p. 242, pl. 3, fig. 2-3.

1878. Clathurella Luisae (Semp.) Beltard. I moll. d. ter.. terz. d. Piemonte e d. Liguria. 2 , p. 253.

1904. Clathurella Luisae (SEmP.) SACco. Ibid. 30, p. 51, pl. 13, fig. 32-33.

1907. Mangilia Luisae Semper sp. Ravn. Molluskf. Jyll. Tert. p. 259.

1925. Mangilia (Clathurella) Luisae Semp. Kautsky. D. Mioc. v. Hemmoor u. BasbeckOsten. p. 185, pl. 12, fig. 9.

1956. Lienardia Luisae (Semper in v.Koenen). Banke Rasmussen. Upper Mioc. South Jutland. p. 93, pl. 9, fig. 2.

Essential features of original description. Das spitze Embryonalende besteht aus vier bis fünf glatten Windungen, deren letzte einen ziemlich scharfen Kiel erhalten. Der obere, etwas eingedrückte Theil der (folgenden) Windungen trägt einige feine Spiralen. Der seitliche Theil der Windungen trägt zuerst zwei starke Spiralen, die später mit drei anderen, an Stärke ihnen zuletzt gleich werdenden, alterniren. Der untere Theil der Schlusswindung ist mit ähnlichen Spiralen bedeckt. Die Längsrippen, circa 12 auf jeder Windung, können nahe der Mündung verschwinden. (VON KOENEN, 1872).

Shell material. Glejbjerg 55 m.: 1 shell. Bramminge 70-80 m.: 3 frg. shells.

Description.

Protoconch. One slightly sinistral and deviated initial whorl. Shell surface corroded. Three subangular to angular medial and terminal whorls with spiral riblet on the keel and immediately above the abapical suture. Shell surface glossy with sparse granules above the keel and oblique threads below the keel. Velum sinus above the keel. Dimensions of spire: height $0.90 \mathrm{~mm}$., diameter $0.86 \mathrm{~mm}$.

Teleoconch. Whorls with 8 to 9 projecting collabral ribs. Five or 6 fine spiral cords above the shoulder of the collabral ribs, 2 to 4 strong spiral ribs on 
the middle part of the whorls, and 15 spiral ribs on the base of the body whorl and the canal (third whorl). Entire shell surface granulated. Sinus moderately deep (aperture broken).

Remarks. This shell exhibits all features of $P$. Luisae although it is smaller than is normal. The protoconch is smaller, the number of collabral ribs is slightly smaller, and the spiral ornamentation is finer on the shells from Glejbjerg and Bramminge than upper Miocene shells which I have studied for comparison. The differences may be accidental or insignificant, it was, however, deemed advisable not finally to refer the shell to $P$. Luisae.

\section{Distribution.}

Pliocene: Mediterranean Basin: Italy: Pliocene inferiore.

Miocene: North Sea Basin: Germany: Hemmoor and Glimmerton stages (Banke Rasmussen 1956). Denmark: Arnum and Gram formations.

Mediterranean Basin: Italy: Miocene medio.

\section{Pleurotomoides campanulata nov. sp.}

Plate 63, fig. 205.

Diagnosis. Pleurotomoides with trimorph protoconch having oblique, slightly sinistral initial whorl, subangular to angular medial whorls, and terminal division of last whorl with collabral riblets and concave subcarinal belt. Teleoconch whorls with sharp shoulder and 3 to 6 fine spiral ribs below the shoulder. Ten to 12 collabral ribs per whorl, projecting below the shoulder and weak on the sinus belt. Entire shell surface densely granulated. Sinus moderately deep, canal short.

Holotype: Geological Survey of Denmark. Well File no. 150. 9. b. Toftlund $115 \mathrm{~m}$. Dimensions of holotype: height $4.74 \mathrm{~mm}$., diameter $1.87 \mathrm{~mm}, 4$ whorls. Derivatio nominis: campanulata - bell-like.

Shell material.

$\begin{array}{lcclcc}\text { Location } & \text { Depth } & \text { Shells } & \text { Location } & \text { Depth } & \text { Shells } \\ \text { Gramby } & 82.66-83.76 \mathrm{~m} . & 1 & \text { Toftlund } & 115 \mathrm{~m} . & 1 \\ \text { Toftlund } & 110-115- & 3 & \text { Arnum }(25 \mathrm{~b}) & 107.5- & 1\end{array}$

Description. Partly broken shells with well preserved shell features.

Protoconch. I slightly sinistral, initial whorl. Whorl axis oblique and shell surface granulated, with spiral arrangement of granules. Three medial whorls, subangular to angular with spiral thread on the keel and at the abapical suture. Terminal $1 / 4$ whorl with about 4 collabral riblets above the keel. The 'sinusigera' projection corresponds to the portion of the shell opposite the keel and the suture, and extends as far as the third spiral thread which is covered by the adult first whorl in specimens which have passed the protoconch stage. Distinct velum sinus observed above the keel, lower sinus not observed, but probably developed.

The shell from Gramby is about $1.48 \mathrm{~mm}$. high and about $0.86 \mathrm{~mm}$. in diameter, it consists of 1 initial whorl, 3 medial whorls and 1/4 terminal whorl with 4 collabral riblets.

Teleoconch. The number of collabral and spiral ribs of two specimens is outlined in the following table: 


\begin{tabular}{lccccc} 
& & \multicolumn{4}{c}{ Collabral ribs } \\
Location & Depth & \multicolumn{4}{c}{ on whorl no. } \\
& & 1 & 2 & 3 & 4 \\
Toftlund & $110-115 \mathrm{~m}$. & 10 & 12 & 10 & abt. 10 \\
& 115 & 10 & 10 & 10 &
\end{tabular}
Spiral ribs on whorl no. $\begin{array}{llll}1 & 2 & 3 & 4\end{array}$ $\begin{array}{llll}3 & 3 & 5 & 6\end{array}$
$\begin{array}{lll}3 & 4 & 5\end{array}$

Remarks. The absence of spiral ornamentation on the shoulder, the sharp edge of the shoulder, and the features of the spiral ornamentation makes this a very characteristic species which can hardly be confounded with other forms. Reference is made to the discussion of this and allied species included in the description of $P$. simplex p. 285.

Distribution.

Miocene: North Sea Basin: Denmark: Arnum formation.

\section{Genus Teretia Monterosato $\mathbf{1 8 9 0}$}

\section{Teretia anceps (Eichwald)}

Recent:

Plate 62, fig. 206.

1853. Mangelia teres Forbes. Forbes \& Hanley. Brit. Moll. 3, p. 462, pl. 113, fig. 1-2. 1867. Defrancia teres Forbes. Jefrreys. Brit. Conch. 4, p. 362, 5, pl. 88, fig. 5.

1868. Pleurotoma teres Forbes. Weinkauff. Conch. d. Mittelmeeres. 2, p. 122.

1878. Raphitoma anceps Eichw. Sars. Moll. Reg. Aret. Norvegiae. p. 219, pl. 17, fig. 19.

1883. Pleurotoma anceps Eichwald. Bucquoy, Dautzenberg \& Dollfus. Moll. mar. du Roussillon. 1, p. 87.

1892. Pleurotoma anceps Eichwald. Locard. Coq. mar. d. côtes d. France p. 51.

Fossil:

1830. Pleurotoma anceps Eichwald. Naturh. Skizze etc. p. 225.

1853. Pleurotoma anceps Eichwald. Lethaea Rossica. p. 186, pl. 8, fig. 7.

1856. Pleurotoma anceps Eichwald. Hörnes. D. foss. Moll. d. Tert. Beckens v. Wien. 1, p. 368 , pl. 40, fig. 11 .

1878. Homotoma anceps (Eichw.) Bella Rd. I moll. d. terr. terz. d. Piemonte e d. Liguria. 2 , p. 280.

1904. Teres anceps (EтcHw.) SAcco. Ibd. 30, p. 54, pl. 14, fig. 15-17.

1910. Daphnella (Teres) anceps Eichw. sp. Cerulti-Iremlt. Fauna mal. mariana, p. 63, pl. 6, fig. 6-10.

1925. Daphnella (Teres) anceps Erchw. Kautsky. D. Mioc. v. Hemmoor u. BasbeckOsten. p. 191, pl. 12, fig. 20.

Original diagnosis. Testa fusiformi, transversim carinata, carinis anfractuum mediis crassioribus, margine aperturae externo integro, laevi (EICHWALD 1830).

Shell material.

$\begin{array}{lrclrc}\text { Location } & \text { Depth } & \text { Shells } & \text { Location } & \text { Depth } & \text { Shells } \\ \text { Bramminge } & 70-80 \mathrm{~m} & 3 & \text { Arnum }(13) & 53-83 \mathrm{~m} . & 4 \\ \text { Gramby } & 84.66-87.16- & 1 & \text { Arnum }(25 \mathrm{~b}) & 62.7-62.9- & 1 \\ \text { Toftlund } & 75-100- & 4 & & & \end{array}$

\section{Description.}

Protoconch turreted. Initial whorl slightly sinistral, surface with granules in spiral rows. Medial whorls, 3 to $3 \frac{1}{2}$ in number, with diagonal cancellation of minute threads. Terminal $1 / 4$ whorl keeled. The data of two protoconchs from Toftlund 75-100 m. and Arnum (13) 53-83 m. respectively are: 


\begin{tabular}{llcccc} 
& & \multicolumn{4}{c}{ Number of whorls } \\
Height & Diameter & Total & Initial & Medial & Terminal \\
$1.21 \mathrm{~mm}$. & $0.63 \mathrm{~mm}$. & 5 & $1 \frac{1}{4}$ & $31 / 2$ & $1 / 4$ \\
$1.02-$ & $0.57-$ & $43 / 4$ & $1 \frac{1}{4}$ & $31 / 4$ & $1 / 4$
\end{tabular}

Teleoconch turreted. First whorl with 3 projecting spiral ribs of which the adapical rib generally becomes bifid on whorl no. 2. Body whorl with bifid upper spiral rib and 3 strong projecting spiral ribs on the periphery. Whorl base and canal with about 11 to 15 somewhat weaker spirals. Fine collabral riblets appear immediately after the protoconch on the sinus belt extending from the suture and approaching the first spiral rib. Sinus apparently moderately deep (all specimens with broken aperture).

The entire teleoconch is covered with microscopical granules as in the species of Pleurotomoides described above.

Distribution.

Recent: North Atlantic Ocean from Western and Southern Norway to the Canaries and the Mediterranean.

Pliocene: Mediterranean Basin: Italy: Pliocene superiore, upper Pliocene of Monte Mario.

Miocene: North Sea Basin: Germany: Hemmoor stage. Glimmerton (Banke Rasmussen 1956). Denmark: Arnum formation.

Vienna Basin: Baden beds.

\section{Teretia sp.}

Shell material.

$\begin{array}{lrc}\text { Location } & \text { Depth } & \text { Shells } \\ \text { Arnum (13) } & 53-83 \mathrm{~m} . & 1 \\ \text { Arnum }(25 \mathrm{~b}) & 62.7-62.9 & 4\end{array}$

Description. All shells are juvenile specimens which include very little of the teleoconch stage.

Protoconch. About 1 to $1 \frac{1}{4}$ initial whorls with granulated spiral threads and $23 / 4$ to $3 \frac{1}{4}$ convex medial-terminal whorls with diagonal cancellation. No keel on the terminal whorl, two spiral riblets on the periphery of the terminal whorl.

Teretia sp. Protoconch data.

Location

Arnum (13)

Arnum (25b)

$\begin{array}{rcc} & \text { Height } & \text { Diameter } \\ \text { Depth } & \text { mm. } & \text { mm. } \\ 53-83 \mathrm{~m} . & \text { Spire: } 0.59 & 0.57 \\ 62.7-62.9- & \text { Total: } 0.94 & 0.59 \\ & -\quad 0.90 & 0.57\end{array}$

\begin{tabular}{ccc}
\multicolumn{3}{c}{ Number of whorls } \\
Medial- \\
Total & Initial & $\begin{array}{c}\text { Terminal } \\
33 / 4\end{array}$ \\
41 & $23 / 4$ \\
$41 / 2$ & $11 / 4$ & $31 / 4$ \\
$41 / 2$ & $11 / 4$ & $31 / 4$
\end{tabular}

Teleoconch. Teleoconch sculpture starts immediately at the protoconch termination, it consists of 6 to 10 spiral cords of which numbers 1 to 4 on the whorl periphery are stronger than the others. Minute collabral riblets extend down from the suture to about the first spiral cord. Entire shell surface granulated. 
Remarks. The absence of a keeled terminal whorl on the protoconch and the convex outline of the teleoconch whorls are the most obvious differences from T. anceps. These differences may, however, be insignificant. Therefore, because of the insufficiency of the shell material the shells have not been referred to species.

\section{Genus Philbertia Monterosato 1884}

\section{Philbertia scabra (Philippi)}

Plate 62, fig. 208.

1846. Pleurotoma scabrum PhiLrppr. Magdeburg Tertiärverst. p. 68, pl. 10, fig. 4.

1867. Mangelia Rappardi von Koenen. D. mar. M.-Olig. Nordd. p. 42, pl. 1, fig. 12.

1870. Pleurotoma (Mangilia) Rappardi v. Koenen. Speyer. D. Conch. d. Casseler Tert. 1, p. 121, pl. 20, fig. 1 .

1872. Mangelia Rappardi v. Koenen. Koch \& Wiechmann. Sternberger Gestein. p. 78, pl. 2 , fig. 3.

1925. Daphnella (Pleurotomella) scabra PHI. KAutsky. D. Mioc. v. Hemmoor u. BasbeckOsten. p. 190, pl. 12, fig. 18.

Original diagnosis. Testa oblongo-fusiformi, striis elevatis transversis lineisque incrementi tenuissimis scabra; suturis marginatis; anfractuum parte superiore canaliculata, inferiore plicis c. 14 superne in angulum terminatis in cauda demum evanescentibus sculpta; anfractu ultimo spiram aequante; sinu labri latissimo, in parte concava anfractuum sito. (PHILIPPI 1846).

Shell material.

$\begin{array}{lcclrc}\text { Location } & \text { Depth } & \text { Shells } & \text { Location } & \text { Depth } & \text { Shells } \\ \text { Bramminge } & 70-80 \mathrm{~m} . & 3 & \text { Toftlund } & 115 \mathrm{~m} . & 4 \\ \text { Toftlund } & 75-100 & 6 & \text { Arnum }(13) & 53-83- & 3 \\ & 105-110- & 6 & \text { Arnum }(25 \mathrm{~b}) 104.3-107.5- & 2\end{array}$

Description.

Shell features are generally well preserved, but the shells are more or less fragmentary.

Protoconch with $1 \frac{1 / 2}{2}$ slightly sinistral initial whorls showing granulated spiral threads. $23 / 4$ diagonally cancellated, medial whorls and $1 / 2$ keeled, and also cancellated terminal whorl. A spiral rib emerges occasionally both above and below the keel, adjacent to the terminal varix of the protoconch, which is sinuous above the keel. Base of the protoconch not observed.

A microscopic striation is occasionally observed on the smooth shell surface between the meshes of the diagonal cancellation.

The following table includes the height of the exposed protoconch spire only since no specimens were available in which the entire height of the protoconch could be measured.

Philbertia scabra. Protoconch data.

\begin{tabular}{|c|c|c|c|c|c|}
\hline \multirow{2}{*}{$\begin{array}{l}\text { Height of } \\
\text { exposed spire }\end{array}$} & \multirow[b]{2}{*}{ Diameter } & \multicolumn{4}{|c|}{ Number of whorls } \\
\hline & & Total & Initial & Medial & Terminal \\
\hline \multicolumn{6}{|c|}{ Toftlund $75-100 \mathrm{~m}$. } \\
\hline $0.98 \mathrm{~mm}$. & $0.74 \mathrm{~mm}$. & $43 / 4$ & $1 \frac{1}{2}$ & $23 / 4$ & $1 / 2$ \\
\hline $0.86-$ & 0.68 & $43 / 4$ & $1 \frac{1}{2}$ & $23 / 4$ & $1 / 2$ \\
\hline \multicolumn{6}{|c|}{ Toftlund $105-110 \mathrm{~m}$. } \\
\hline $0.80 \mathrm{~mm}$. & $0.68 \quad-$ & $43 / 4$ & $11 / 2$ & $23 / 4$ & $1 / 2$ \\
\hline
\end{tabular}


Teleoconch. Spire turreted with convex whorls. Strong collabral ribs below the sinus belt ( 8 to 10 per whorl) crossed by spiral cords. The first adult whorl with 4 conspicuous cords, above and between which secondary threads emerge on later whorls. Body whorl with 20 to 40 spiral cords on the whorl proper and the anterior canal. The great variation in the number of spiral cords is related to the random emergence of secondary cords. Sinus area generally devoid of spiral ornamentation on the first whorls, but with well defined, closely spaced collabral riblets extending from the suture to the lower boundary of the sinus belt. The riblets are occasionally crossed by spiral threads on the sinus belt of later whorls.

Five to 7 spiral cords on the periphery of the body whorls stronger than the others. The suture is generally formed along the 5 th or between the 4 th and the 5 th of these cords on the preceding whorl. Aperture broken on all specimens. The sinus of the growth lines indicates a semi-circular and moderately deep apertural sinus. Whole teleoconch surface granulated.

The dimensions of an almost entire shell from Toftlund $75-100 \mathrm{~m}$. which consists of $43 / 4$ protoconch whorls and 3 adult whorls are: height $4.90 \mathrm{~mm}$. and diameter $2.21 \mathrm{~mm}$.

Remarks. The list of synonymy is mainly established on the authority of Kautsky who stated that PhILIPPI's species is identical with von Koenen's M. Rappardi. His statement was based on an examination of shells in the Geological Museum of Berlin. It should be emphasized that there are differences between the descriptions in literature and between the accompanying figures concerning both protoconch and teleoconch features. It is believed, however, that these differences are mainly due to the state of preservation of the material.

Distribution.

Miocene: North Sea Basin: Germany: Hemmoor stage. Denmark: Arnum formation.

Oligocene: North Sea Basin: Germany (m.-u.).

\section{Philbertia sinuosula nov. sp.}

Plate 63, fig. 209 a-c, plate 76, fig. 209.

Diagnosis. Philbertia with distinctly trimorph and elaborately sculptured protoconch of about 41/2 to 53/4, whorls. Turreted teleoconch with 9 to 10 projecting collabral ribs extending from suture to suture on the first adult whorls crossed by relatively strong spiral ribs. A pertural sinus wide and shallow. Teleoconch surface granulated.

Holotype: Geological Survey of Denmark, Well file no. 150. 9. b. Toftlund $105-110 \mathrm{~m}$. Data of holotype: height $3.49 \mathrm{~mm}$., diameter $1.74 \mathrm{~mm}$., protoconch $5 \frac{1}{4}$ whorls, teleoconch $1 \frac{1}{2}$ whorls. Derivatio nominis : sinuosula-with shallow sinus.

\section{Shell material.}

$\begin{array}{lrclrr}\text { Location } & \text { Depth } & \text { Shells } & \text { Location } & \text { Depth } & \text { Shells } \\ \text { Glejbjerg } & 55 \mathrm{~m} . & 3 & \text { Toftlund } & 105-110 \mathrm{~m} . & 21 \\ \text { Bramminge } & 70-80- & 2 & & 110-115- & 3 \\ \text { Gramby } & 82.66-83.76- & 1 & & 115- & 2 \\ \text { Toftlund } & 75-100- & 1 & \text { Arnum (13) } & 53-83- & 1\end{array}$


Description.

The shells are practically all juvenile and the material includes a number of shells which have just passed the protoconch stage.

Protoconch. Initial approximately I $1 / 4$ whorls slightly sinistral with spirals of granules. $23 / 4$ to $3 \frac{1}{2}$ medial whorls with diagonal cancellation and $1 / 2$ to 1 terminal keeled whorl with cancellation as in the medial whorls. Generally two conspicuous spiral riblets on the keel of the terminal whorl and occasionally minor spiral threads between these riblets and below them on the protoconch base.

\begin{tabular}{|c|c|c|c|c|c|c|c|c|}
\hline \multirow{5}{*}{$\begin{array}{l}\text { Gramby } \\
\text { Toftlund }\end{array}$} & \multirow{2}{*}{\multicolumn{2}{|c|}{ Height }} & \multirow{2}{*}{\multicolumn{2}{|c|}{ Diameter }} & \multicolumn{4}{|c|}{ Number of whorls } \\
\hline & & & & & Total & Initial & Medial & Terminal \\
\hline & \multirow{2}{*}{\multicolumn{2}{|c|}{$\begin{array}{l}82.66-83.76 \mathrm{~m} \text {. } \\
1.21 \mathrm{~mm} .\end{array}$}} & \multirow{2}{*}{\multicolumn{2}{|c|}{$0.74 \mathrm{~mm}$}} & & & & \\
\hline & & & & & $4 \frac{1}{2}$ & $11 / 4$ & $23 / 4$ & $1 / 2$ \\
\hline & 1.45 & - & 0.90 & - & 5 & $11 / 4$ & $31 / 4$ & $1 / 2$ \\
\hline & 1.41 & - & 0.88 & - & 5 & $11 / 4$ & $31 / 4$ & $1 / 2$ \\
\hline & 1.65 & - & 0.97 & - & $51 / 2$ & $11 / 2$ & 3 & 1 \\
\hline & 1.47 & - & 0.87 & - & 5 & $11 / 4$ & 3 & $3 / 4$ \\
\hline & 1.62 & - & 0.98 & - & $51 / 2$ & $11 / 4$ & $31 / 2$ & $3 / 4$ \\
\hline & 1.60 & - & 0.95 & - & $51 / 2$ & $11 / 4$ & $31 / 2$ & $3 / 4$ \\
\hline & 1.64 & - & 0.98 & - & $5^{3 / 4}$ & $11 / 2$ & $31 / 4$ & 1 \\
\hline
\end{tabular}

Teleoconch. Sinus belt not differentiated sculpturally. Nine or 10 projecting angular to subangular collabral ribs on the two first whorls. Development on later whorls unknown because of the juvenile stage of the shells. Three to five strong spiral ribs on the lower part of the whorl, and three to four minor spiral ribs on the upper (adapical) part of the whorl. Generally having fine, curved collabral riblets extending from the suture to about the middle of the whorl.

Base of body whorl and anterior canal with about 5 to 17 spiral ribs or cords. The number depends on the shell size and also on the rate of emergence of secondary spiral ribs in the primary interspaces, which varies from shell to shell.

Remarks. The protoconch of this species is very similar to the protoconch of $P$. scabra, and the teleoconchs of the two species resemble each other in the granulation of the shell surface. Remarkable differences are, however, otherwise displayed by the features of the teleoconch: P. scabra has a well defined sinus belt, on which the round collabral ribs become obsolete, and it has a semicircular, moderately deep apertural sinus. $P$. sinuosula has no distinct sinus belt, it has relatively narrow, angular collabral ribs which extend from suture to suture, and it has a wide apertural sinus as indicated by the growth lines.

Distribution.

Miocene: North Sea Basin: Denmark: Arnum formation.

\section{Genus Eubela Dall 1889}

\section{Eubela trochlearis (Hörnes)}

Plate 64, fig. 210 a-b.

1856. Pleurotoma trochlearis Hönnes. D. foss. Moll. d. Tert.-Beckens v. Wien 1, p. 363 pl. 39, fig. 14-15.

1878. Clinura trochlearis (Hörn.) Bellardi. I moll. d. terr. terz. d. Piemonte e d. Liguria 2, p. 206. 
1891. Pleurotoma (Clinura) trochlearis M. Hoenn. Hoennes \& Aurnger. Gastr. d. 1. u. 2. Medit. p. 362.

1904. Clinura trochlearis (HöRn.) SAcco. I moll. d. terr. terz. d. Piemonte e d. Liguria 30, p. 49, pl. 13, fig. 14-15.

1940. Genotia trochlearis Hoennes. Sorgenfrer. Mar. Nedre-Mioc. i Klintinghoved p. Als. p. 49 , pl. 6 , fig. 12.

Original diagnosis. Testa fusiformi, subovata; anfractibus acute carinatis, parte supra carinam bis, ter aut saepius inferiorem, latitudine superante, inferne angustatis, striatis, superne infundibuliformibus, laevibus, nonnisi prope carinam tenuiter striatis; carina inermi; suturis profundissimis, simplicibus; ultimo anfractu inferne striis transversis distinctioribus, interpositis minutioribus ornato; apertura subtriangulari; canali breviusculo, striato, contorto; rima valde dilatata. (HöRNES 1856).

Shell material. One juvenile shell from Bramminge 70-80 m.

Description.

Protoconch. About 1 initial whorl, slightly sinistral, surface worn, 3 diagonally cancellated medial-terminal whorls. Height of exposed spire 0.74 mm., diameter $0.78 \mathrm{~mm}$.

Teleoconch. Two whorls, keeled, with spiral cords below the keel and smooth shoulder, except for minute collabral riblets extending from the suture to about the middle of the shoulder. First whorl with indistinct knobs on the periphery. Apertural margin broken. Broad semi-circular sinus occupying the whole shoulder suggested by growth lines.

Remarks. This species has been the subject of much interest on account of its scarcity. It is very remarkable, therefore, that neither HöRNEs nor BELLARDi described the protoconch. The first mention of protoconch features is to be found in my own description of the shells from Klintinghoved in 1940. However, it is now obvious that my statement was erroneous! The smooth protoconch which I studied in 1940 is undoubtedly only smooth on account of wear. Since then I have succeeded in collecting a better preserved juvenile specimen at Klintinghoved, which is shown on plate 64 , fig. $210 \mathrm{~b}$, and which exhibits the typical Daphnelloid protoconch features. This specimen agrees otherwise very closely with the Bramminge shell.

During a stay in Vienna in $1951 \mathrm{I}$ obtained 3 shells of E.trochlearis from Walbersdorf by courtesy of Hofrat Dr. Oskar R. v. Troll-Obergfell. One of the shells has the major part of the protoconch intact. The whorls are diagonally cancellated also in this case, and the shell morphology is in general in good agreement with the shells from South Jutland.

The generic reference of $E$. trochlearis and related species is not yet settled satisfactorily. In 1875 BeLLARDI suggested the genus Clinura with C. Calliope BroccHI as the type and included among others P. trochlearis HöRnEs. But this was done without mentioning the protoconch features of $C$. Calliope at all. Provided $C$. Calliope has the same type of protoconch as $E$. trochlearis the latter should be included in Clinura as suggested by BELLARDI, and Clinura should finally be ranged among the Daphnellidae. However, since there are species which resemble Clinura in several adult features, but which have a smooth protoconch different from that of $E$. trochlearis (see e. g. p. 263) it cannot be excluded that the Clinura protoconch may be different from E. trochlearis. I decided, therefore, preliminarily to refer $P$. trochlearis HöRNEs to the genus Eubela DALL which has a polygyrate, diagonally cancellated protoconch and a relatively smooth teleoconch, except for knobs at the suture. 
Distribution.

Miocene: North Sea Basin: Denmark: Klintinghoved clay, Arnum formation.

Mediterranean Basin: Italy: Miocene medio.

Vienna Basin: Vöslau, Walbersdorf.

\section{Eubela sp.}

Shell material. Toftlund 100-105 m. 1 juvenile specimen.

Description.

Protoconch. One and one fourth slightly sinistral, initial whorls with spiral granulation and $3 \frac{3}{4}$ globular, diagonally cancellated medial-terminal whorls without keel. 'Sinusigera' projection and two spiral threads opposite the projection. Height $1.41 \mathrm{~mm}$., diameter $0.98 \mathrm{~mm}$.

Teleoconch. Less than one fourth whorl developed. Shell surface smooth, keel angular. Very weak spiral lines below the keel, and extremely delicate collabral riblets at the suture.

Remarks. This shell seems to be different from E. trochlearis on account of the greater size of the protoconch and the weakness of the sculpture on the teleoconch.

\section{Genus Metuonella nov. gen. \\ Type Daphnella Grippi Kautsky 1925}

The typical Daphnellid protoconch cancellation is characterized by curved, opisthocline collabral riblets, which generally extend from suture to suture, and are crossed by equally strong prosocline riblets on the lower $1 / 2$ or $2 / 3$ of the whorls. In Daphnella Grippi the pattern seems to be fundamentally different: there are curved collabral riblets as in typical Daphnellid shells, but the crossing threads are weaker, they are prosocline on the lower part of the whorl and spiral on the belt adjacent to the adapical suture; they accordingly converge anteriorly. On the terminal about $1 / 4$ whorl the crossing threads have developed into strong, spiral riblets which continue into the spiral ribs of the teleoconch.

The shape of the teleoconch in Daphnella is elongate-ovate, the body whorl is higher than half of the shell height, and the sculpture is reticulate. D. Grippi differs greatly from this criterion: the shell is fusoid, the body whorl is less than half the height, and the sculpture consists of strong, angular, projecting collabral ribs and granular to squamous spiral ribs and threads.

The genus Metuonella is suggested for this and allied species which have the same type of protoconch.

Derivatio nominis: Pytheas of Massalia who lived about 330 B.C., travelled by boat to northwestern Europe. He mentions the gulf Metuonis which is probably identical with the southeastern part of the North Sea (LA CouR 1941). Metuonella - the genus from the gulf of Metuonis.

\section{Metuonella Grippi (Kautsky)}

Plate 64, fig. 212.

1925. Daphnella (Bellardiella) Grippi Kautsky. D. Mioc. v. Hemmoor u. Basbeck-Osten. p. 188, pl. 12, fig. 15-16. 
Essential features of original description. Embryonalgewinde (von 4 Umgängen). Der erste Umgang ist spitz und glatt. Die übrigen 3 Umgänge tragen dicht gedrängt feine von einer Naht zur anderen etwas schief nach rechts vorne verlaufende Längsrippchen, die durch noch feinere sehr schief nach links verlaufende Rippchen diagonal geschnitten werden. Dann folgt auf einer Viertelwindung eine Übergangsskulptur von undeutlichen Spiralen, über welche die stärker werdenden Längsrippchen hinweglaufen. Die Schalenoberfläche (der übrigen Umgänge) ist mit haarförmigen erhabenen Zuwachsstreifen bedeckt, deren ziemlich flacher Sinus etwas hinter der Mitte des Umganges liegt. 11-15 wulst- oder faltenartige Längs. rippen am vorletzten Umgang. Alle Spiralen laufen über die Längsrippen; die Zuwachsstreifen bilden auf ihnen eine äusserst zierliche Körnelung. (KAUTSKY 1925).

Shell material.

$\begin{array}{lrclcl}\text { Loacation } & \text { Depth } & \text { Shells } & \text { Location } & \text { Depth } & \text { Shells } \\ \text { Gramby } & 82.65-83.76 \mathrm{~m} . & 1 & \text { Toftlund } & 115 \mathrm{~m} . & 1 \\ \text { Toftlund } & 105-110- & 1 & \text { Arnum }(25 \mathrm{~b}) & 95.0-95.3- & 1 \mathrm{frg} \text {. (cf.) }\end{array}$

\section{Description.}

Protoconch. One to $1 \frac{1}{4}$ initial, slightly sinistral whorls with granulated spirals. About $23 / 4$ medial whorls with curved, collabral riblets crossed by spiral threads on the upper and prosocline threads on the lower part of the whorl. The threads crossing the riblets converge anteriorly at about the upper (adapical) one third of the whorl. Terminal section of about $1 / 4$ whorl with stronger collabral riblets, crossed by about seven spiral riblets, 'Sinusigera' projection short, with shallow sinuses on both sides. Strong spiral riblet at the periphery of the shell base opposite the sinusigera projection, and sculpture of collabral and converging threads on the terminal whorl base similar to sculpture on the spire, but weaker.

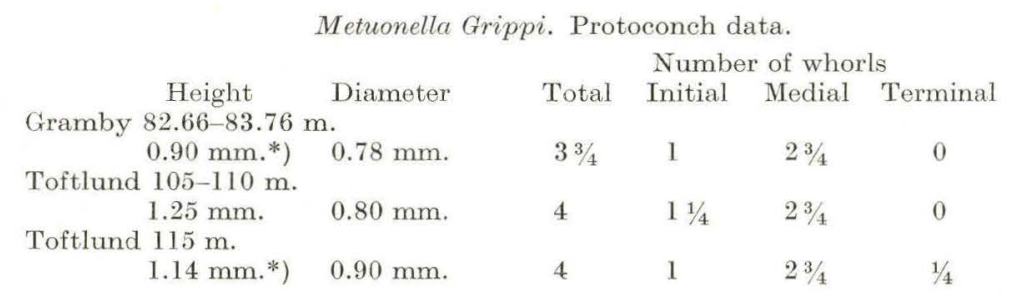

Teleoconch. Turreted spire with 8 to 10 strong, angular collabral ribs per whorl. Initially about 7 spiral ribs with transverse squamules; secondary spirals being very soon intercalated. Sutural spiral more prominent than adjacent spirals. Primary spirals generally somewhat stronger than secondary spirals, especially on the middle part of the whorl corresponding to the angle of the ribs. Spiral ornamentation extends onto the canal which is of intermediate length. The ribs are confined to the whorl proper. Aperture broken. The growth lines suggest a very shallow sinus at about the middle of the collabral ribs or a little above.

Dimensions of specimen from Toftlund $115 \mathrm{~m}$.: Height $5.1 \mathrm{~mm}$., diameter $2.05 \mathrm{~m} ., 4$ protoconch whorls and 3 teleoconch whorls.

Remarks. The particular features which characterize the protoconch of $M$. Grippi, and separate it from other members of the subgeneric group

*) Height of spire only; basal part of terminal whorl not exposed. 
Daphnellinae, have been included in the comments on the new genus. It is, however, also worthwhile to notice the similarities in shell structure between Metuonella and Neoguraleus. The terminal protoconch whorl in the two genera are similar, and the sinus and sculpture of $M$. Grippi and rugose varieties of $N$. tenella are of a similar type.

Distribution.

Miocene: North Sea Basin: Germany: Hemmoor stage. Denmark: Arnum formation.

\section{Genus Oenopota Mörch 1852}

\section{Oenopota sp.}

Plate 64, fig. 213 a-c.

Shell material. Toftlund $110-115 \mathrm{~m} .1$ protoconch; $115 \mathrm{~m} .1$ protoconch. Description.

Both shells consist of the protoconch and a small part of the first teleoconch whorl.

Protoconch. About 1/1/2 depressed, initial whorls with extremely delicate spiral liration; $2 \frac{1}{2}$ medial-terminal whorls with smooth shell surface adjacent to the adapical suture, and irregular, almost orthocline riblets on the whorl periphery. Belt with diverging irregular granular threads opposite the blunt 'Sinusigera' projection, limited abapically by spiral cord on the terminal whorl base. Whorl base smooth below the spiral cord. Short protoconch canal with irregular, granular threads as found on the whorl periphery. Upper sinus adjacent to the suture, very shallow. Projection broad and blunt; lower sinus narrow, moderately deep. Dimensions of shell from 110-115 m. : Height $0.98 \mathrm{~mm}$., diameter $0.69 \mathrm{~mm}$.

Teleoconch. Whorls with round collabral riblets, growth lines indicate absence of apertural sinus; shell surface otherwise smooth.

Remarks. The shells have been referred to Oenopota with some hesitation, since it has not been possible to determine the type of protoconch in Oenopota with certainty. However, absence of an apertural sinus in the teleoconch supports the reference.

The sculpture of the protoconch is rather remarkable, since it might be interpreted as an aberrant Daphnellid sculpture in which the cancellation is reduced to irregular remnants of the collabral threads. The fine liration on the initial whorl is, however, different from the relatively coarse spiral granulation found on the initial whorl of a number of Daphnellinae.

FAMILIA TEREBRIDAE ADAMS (1853)

Genus Terebra Bruguière 1792

\section{Terebra Hörnesi Beyrich}

Plate 65, fig. 214 .

1854. Terebra Hörnesi Beyrich. Die Conchylien etc. p. 115, pl. 6, fig. 13-14.

1907. Terebra Basteroti Nyst. Ravn. Molluskf. Jyll. Tert. p. 341, pl. 7, fig. 2.

1925. Terebra Hörnesi Beyr. Kautsky. D. Mioc. v. Hemmoor u. Basbeck-Osten, p. 194, pl. 12 , fig. 23 . 
1952. Terebra (Terebra) hoernesi Beyrich. GLiBert. Faune mal. du Mioc. de la Begique. 2 , p. 136 , pl. 10 , fig. 6 .

Essential features of original description. Das Gewinde besteht aus einem hohen Embryonalende von etwa 3 Windungen. Die obersten Mittelwindungen haben regelmässige, gerade Längsrippchen, welche sich abwärts zu schwächeren und etwas gebogenen Streifen verändern. Gleichzeitig mit der Biegung bildet sich allmählig eine an der entsprechenden Stelle angeduetete Theilungslinie aus. Die Spindel ist ohne Falten (BEYRICH 1854).

\section{Shell material.}

\begin{tabular}{|c|c|c|c|c|c|c|c|}
\hline \multirow{2}{*}{$\begin{array}{l}\text { Location } \\
\text { Glejbjerg }\end{array}$} & \multicolumn{2}{|c|}{ Depth } & Shells & Location & \multicolumn{2}{|c|}{ Depth } & Shells \\
\hline & 23 & $\mathrm{~m}$. & 2 & Toftlund & $75-100$ & $\mathrm{~m}$. & 146 \\
\hline & 25 & - & 2 & & $100-105$ & - & 38 \\
\hline & 32 & - & 1 & & $105-110$ & - & 139 \\
\hline & 42 & - & 1 & & $110-115$ & - & 41 \\
\hline & 53 & - & 4 & & 115 & - & 17 \\
\hline & 53.5 & - & 7 & Arnum (13) & $28-40$ & - & 3 \\
\hline & 53.75 & - & 8 & & $53-83$ & - & 49 \\
\hline & 55 & - & 3 & & $83-94$ & - & 1 \\
\hline Bramminge & $70-80$ & - & 269 & Arnum (25b) & $62.7-62.9$ & - & 27 \\
\hline Gramby & $82.66-83.76$ & - & 19 & & $95.0-95.3$ & - & 4 \\
\hline & $84.66-87.16$ & - & 5 & & $104.3-107.5$ & - & 2 \\
\hline & $90.42-92.72$ & - & 3 & & & & \\
\hline
\end{tabular}

Description. The shell features are well preserved but hardly any of the specimens have the apertural margin intact as a result of damage during drilling operations.

Protoconch. Spire turreted, cyrtoconoid. Whorls smooth, with faint, curved growth lines corresponding to the sinus for the velum. Number of whorls very variable: $33 / 4$ to $63 / 4$ whorls have been counted. The following table shows the data for a number of shells from Toftlund which have the terminal whorl base exposed:

\begin{tabular}{|c|c|c|c|c|c|c|c|c|c|c|c|}
\hline Location & \multicolumn{7}{|c|}{ Toftlund: $75-100 \mathrm{~m}$. } & \multicolumn{4}{|c|}{$100-105 \mathrm{~m}}$. \\
\hline Number of whorls & $61 / 4$ & $51 / 2$ & 5 & $4 \frac{1}{2}$ & $41 / 2$ & $4 \frac{1}{2}$ & $61 / 2$ & $51 / 2$ & $41 / 2$ & 5 & 5 \\
\hline Height $(\mathrm{h}) \mathrm{mm}$. & 2.74 & 1.68 & 1.41 & 1.37 & 1.56 & 1.47 & 2.74 & 2.15 & 1.29 & 1.60 & 1.6 \\
\hline Diameter (d) $\mathrm{mm}$. & 1.15 & 0.90 & 0.70 & 0.73 & 0.78 & 0.74 & 1.13 & 0.94 & 0.63 & 0.74 & 0.74 \\
\hline $\mathrm{h} / \mathrm{d}$ & 2.38 & 1.87 & 2.00 & 1.87 & 2.00 & 1.97 & 2.41 & 2.29 & 2.06 & 2.16 & 24 \\
\hline Location & Toft & ind & $10-11$ & $\mathrm{~m}$. & & & & & & & \\
\hline Number of whorls & $63 / 4$ & $63 / 4$ & $51 / 2$ & $51 / 4$ & 5 & 5 & 5 & 5 & & & \\
\hline Height (h) mm. & 2.97 & 2.85 & 1.95 & 1.72 & 1.41 & 1.49 & 1.41 & 1.33 & & & \\
\hline Diameter (d) $\mathrm{mm}$. & 1.15 & 1.17 & 0.82 & 0.78 & 0.63 & 0.74 & 0.69 & 0.64 & & & \\
\hline$h / d$ & 2.58 & 2.43 & 2.38 & 2.20 & 2.25 & 2.00 & 2.05 & 2.07 & & & \\
\hline
\end{tabular}

Teleoconch. Spire turreted, whorls flat. Initial whorls with straight, collabral ribs. The ribs are curved on later whorls and a spiral furrow develops gradually about $1 / 3$ of the height of the helicocone below the adapical suture. This furrow is generally only developed in the interspaces between the ribs. The number of collabral ribs varies between 9 and 19 per whorl. The following table relates the number of ribs to whorl no.

\begin{tabular}{c|lrrrrr} 
Number & Whorl no.: & 1 & 2 & 3 & 4 & 5 \\
of & Minimum & 11 & 9 & 10 & 11 & 12 \\
ribs & Maximum & 16 & 14 & 17 & 16 & 17 \\
Average & 12.8 & 12.3 & 13.2 & 13.3 & 14.3 \\
Number of shells & 18 & 18 & 17 & 12 & 7
\end{tabular}


A few shells have spiral furrows on the base of the body whorl, and there are occasionally faint spiral furrows on the whorls of the spire below the strong furrow. The data for the largest shell from Toftlund $(115 \mathrm{~m}$.) are: Height 13.8 mm., diameter $3.31 \mathrm{~mm}$., 5 protoconch whorls, and 91/4 teleoconch whorls.

Remarks. This species seems to be rather variable both in protoconch and teleoconch features. The average type of the South Jutland material is perhaps closer to Beyrich's T. foveolata than to his T. Hörnesi. However, since I am inclined to include $T$. foveolata in $T$. Hörnesi I have not attempted to revive $T$. foveolata which was listed in the synonymy of $T$. Basteroti by von KoEnen.

GLibert has now elected a lectotype for $T$. Basteroti from Nyst's shells, and this is illustrated in his paper (1952 a) pl. 10, fig. 9. According to his statement and illustration T. Basteroti is spirally striated on the spire and is thus clearly different from both T. Hörnesi and T. foveolata. T. foveolata should, therefore, be excluded from the synonymy of T. Basteroti.

Distribution.

Miocene: North Sea Basin: Belgium: Anversien. Germany: Hemmoor stage. Glimmerton (Banke Rasmussen 1956). Denmark: Arnum formation.

\section{Terebra acuminata Borson}

1820. Terebra acuminata Borson. Oritt. Piem. p. 45, pl. 1, fig. 17.

1891. Terebrum acuminatum (Bors.) SACco. I. moll. d. terr. terz. d. Piemonte e d. Liguria. 10, p. 18, pl. 1, fig. 29-39.

1925. Terebra (Subula) fuscata Brocch. Kautsky. D. Mioc. v. Hemmoor u. BasbeckOsten. p. 195, pl. 12, fig. 24.

?1932. Terebra pseudopertusa Peyrot. Conch. Néogén. d. l'Aquit. p. 105, 1931: pl. 10, fig. $27,28,30,32,36,40,43$.

1952. Terebra (Terebra) acuminata Bonson. Glibert. Faune mal. du. Mioc. de la Belgique. 2 , p. 136 , pl. 10 , fig. 7 (a-b).

The original diagnosis cannot be given since Bonson's paper was not available. The paper is quoted from Sacco.

Shell material.

Glejbjerg $53 \mathrm{~m} .1$ fragment; $53.75 \mathrm{~m} .1$ worn shell.

Bramminge $70-80 \mathrm{~m}$. fragments of about 5 individuals.

Description.

The shells are in a rather bad state of preservation. The protoconch is not known.

Teleoconch. The whorls are more or less "imbricated", with deep suture. Collabral ribs curved, prosocline, intersected by a rather conspicuous subsutural furrow, which occurs a little less than $1 /{ }_{3}$ of the height of the helicocone below the suture. Number of collabral ribs about 13 to 17 per whorl. The ribs are obsolete on some shells. Columella with one fold a little above the gutter of the canal. 
Remarks. The morphological relationships between this and allied species can certainly not be solved without statistics. It is believed that several of the species, varieties, mutations, etc., will turn out to be extremes within the natural variation ranges of a minor number of species.

Distribution.

Pliocene: Mediterranean Basin: Italy: Piacenziano, Astiano. Miocene: Aquitanian Basin: (?) Aquitanien, (?)Burdigalien, (?) Helvétien.

North Sea Basin: Belgium: Boldérien, Horizon of Houthaelen, Anversien. Germany: Hemmoor stage. Reinbek stage (Gоттsche 1878). Denmark: Arnum formation. Mediterranean Basin: Italy: Elveziano, Tortoniano.

\section{SUBCLASSIS OPISTHOBRANCHIATA MILNE-EDWARDS 1848.}

Our knowledge on the systematies of the gastropoda has improved remarkably during the last decade by the recognition that the Pyramidellidae actually are Opisthobranchiata. Pyramidella and Odostomia were initially referred to the Opisthobranchiata (Tectibranchia) by MörcH (1865) on the basis of the organisation of the reproductive organs. Later the systematical position of the Pyramidellidae was discussed repetedly, and they were generally referred to the prosobranchs as pointed out by Thorson (1946, p. 200) who revived discussion on the grounds of his own extensive studies on the eggs and larvae of gastropoda. THonson emphasized the significance of similarities in the reproductive organs, the eggs, and the larval shells of the Pyramidellidae and Opisthobranchiata. He assumed, moreover, that these relationships outweight arguments set forth in favour of the prosobranch affinities of the Pyramidellidae.

In 1948 FretTer \& Graham finally concluded after a thorough comparison of the external and internal features of Pyramidellidae with corresponding features in Opistobranchiata and Prosobranchiata, that the Pyramidellidae should be ranged among the Opisthobranchiata. This conclusion was later supported by FranzÉn (1955) who had studied spermiogenesis.

In the following record of Opisthobranchiata from the South Jutland Miocene the Pyramidellidae have been placed after the Acteonidae following the suggestion by Fretter \& Graham (1.c. p. 528). The systematic arrangement, and the concept of species and genera have also benefited from LEMCHE's studies of Opisthobranchiata (1948).

FAMILIA ACTEONIDAE FISCHER 1883

Genus Acteon Montfort 1810

\section{Acteon semistriatus (Basterot)}

Plate 65, fig. 216.

1821. Tornatella semistriata Defrance. Férussac. Tabl. syst. moll. p. 108.

1825. Tornatella semistriata Basterot. Mém. géol. envir. de Bordeaux. p. 25.

1840. Tornatella semistriata Fér. Grateloup. Conch. du bassin de l'Adour. 1, pl. 11, fig. 18. 
1856. Actaeon semistriatus FÉr. Hörnes. D. foss. Moll. d. Tert.-Beckens v. Wien. 1, p. 507, pl. 46 , fig. $22-23$.

1897. Actaeon semistriatus (FÉr.) SAcco. I moll. d. terr. terz. d. Piemonte e d. Liguria. 22 , p. 33 , pl. 3, fig. $21-23$.

? 1907. Actaeon tornatilis L. Ravn. Molluskf. Jyll. Tert. p. 363, pl. 8, fig. 10. pro parte. 1925. Actaeon semistriatus Fér. Kautsky. D. Mioc. v. Hemmoor u. Basbeck-Osten, pl. 201.

1932. Actaeon semistriatus Férussac. Peyrot. Conch. Néogén. d. l'Aquit. p. 154, pl. 11, fig. $36,45.46,58-60$.

1952. Actaeon semistriatus Férússac sp. Glibert. Faune mal. du Mioc. de la Belgique. 2, p. 139, pl. 10, fig. 10 .

Original diagnosis. Testa ovata, semistriata; columella uniplicata (BASTERоT 1825).

Shell material.

\begin{tabular}{|c|c|c|c|c|c|c|c|}
\hline \multirow{2}{*}{$\begin{array}{l}\text { Location } \\
\text { Glejbjerg }\end{array}$} & \multicolumn{2}{|c|}{ Depth } & Shells & \multirow{6}{*}{$\begin{array}{l}\text { Location } \\
\text { Toftlund }\end{array}$} & \multicolumn{2}{|c|}{ Depth } & Shells \\
\hline & 23 & & 1 & & $75-100 \mathrm{n}$ & & 103 \\
\hline & 42 & - & 1 & & $100-105$ & - & 29 \\
\hline & 53 & - & 2 & & $105-110$ & - & 42 \\
\hline & 53.5 & - & 3 & & $110-115$ & - & 32 \\
\hline & 53.75 & - & 2 & & 115 & - & 5 \\
\hline \multirow{5}{*}{$\begin{array}{l}\text { Bramminge } \\
\text { Gramby }\end{array}$} & $70-80$ & - & 52 & \multirow[t]{2}{*}{ Arnum (13) } & $28-40$ & - & 1 \\
\hline & $82.66-83.76$ & - & 16 & & $53-83$ & - & 30 \\
\hline & $84.66-87.16$ & - & 8 & \multirow[t]{3}{*}{ Arnum (2.5b) } & $62.7-62.9$ & - & 8 (cf.) \\
\hline & $90.42-92.72$ & - & 1 & & $95.0-95.3$ & & 4 \\
\hline & $92.72-109.29$ & - & 1 & & $104.3-107.5$ & - & 4 \\
\hline Gramby & $110.86-121.51$ & - & 1 & & & & \\
\hline
\end{tabular}

Description.

A number of shells are excellently preserved.

Protoconch. Only the last sinistral whorl exposed. The protoconch axis forms only a small angle with the teleoconch axis, and the exposed whorl is accordingly almost conformable with the first adult whorl. Shell surface smooth and glossy.

Teleoconch ovoid; surface smooth and glossy with spirals of punctiform impressions and remnants of collabral colouring. Body whorl with one spiral close to the adapical suture, and about 15 to 20 spirals on the lower $2 / 3$ of the whorl. The suture is generally formed between the second and third spiral of the latter group on the preceding whorl. There is thus commonly one spiral at the adapical suture and 2 spirals adjacent to the abapical suture on the whorls of the spire. Aperture drop-shaped with fold on the columella.

Thirty entire shells from Toftlund 75-100 m. were measured for height $(H)$ and diameter $(D)$ and the $H / D$ ratios were calculated. Since the number of shells is insufficient for a safe statistical analysis, the extreme values and means only are listed.

$\begin{array}{lccccc} & \begin{array}{c}\text { Height } \\ (H)\end{array} & \begin{array}{c}\text { Diameter } \\ (D)\end{array} & H / D & \begin{array}{c}\text { Number of: } \\ \text { teleoconch } \\ \text { whorls }\end{array} & \begin{array}{c}\text { spirals on } \\ \text { body whorl }\end{array} \\ & & & & 41 / 2 & 19 \\ \text { Largest shell } & 5.40 \mathrm{~mm} . & 2.69 \mathrm{~mm} . & 2.02 & 18 \\ \text { Smallest shell } & 2.66- & 0.94- & 1.79 & 21 / 2 & 17.7\end{array}$

Remarks. The most variable feature in this species is the convexity of the whorls, as illustrated by the range of the $H / D$ ratio which increases with size of the shell. The number of spirals on the body whorl seems to be relatively 
constant. It must be emphasized, however, that only the third to the fifth teleoconch whorls were examined in the body whorl stage. Concerning differences in relation to $A$. laevigatus, see the description of that species below. RAvn reports his A. tornatitis to have spirals of more or less distinct, punctiform impressions. Some of his shells may therefore belong to $A$. semistriatus.

Distribution:

Pliocene: Mediterranean Basin: Italy: Piacenziano, Astiano.

Miocene: Aquitanian Basin: Aquitanien, Burdigalien, Helvétien. North Sea Basin: Belgium: Anversien. Germany: Hemmoor stage, Reinbek stage (Gоттsche 1878), Glimmerton (Banke Rasmussen 1956). Denmark: Arnum formation.

Mediterranean Basin: Italy: Elveziano, Tortoniano. Vienna Basin: Baden and Vöslau beds.

\section{Acteon laevigatus (Grateloup)}

Plate 65, fig. 217 a-b.

1827. Tornatella lavigata Grateloup. Tabl. Coq. foss. Dax. p. 195, no. 153.

1840. Tornatella lovigata Grateloup. Grateloup. Conch. foss. Bassin de l'Adour. pl. 11, fig. 24 .

1932. Actoon laevigatus Grateloup. Peyrot. Conch. Néogén. d. l'Aquit. p. 161, pl. 11, fig. 50-51.

Diagnosis. Testa ovata, pellucida, lcevigata spira acuta. (GRateloup 1827).

Shell material.

$\begin{array}{lrclrc}\text { Location } & \text { Depth } & \text { Shells } & \text { Location } & \text { Depth } & \text { Shells } \\ \text { Glejbjerg } & 25 \mathrm{~m} . & 1 & \text { Gramby } & 90.42-92.72 \mathrm{~m} . & 3 \\ \text { Bramminge } & 70-80- & 4 & \text { Toftlund } & 75-100- & 19 \\ \text { Gramby } & 84.66-87.16- & 1 & & 100-105- & 1 \text { (cf.) }\end{array}$

Description.

Several shells are excellently preserved, with remnants of original colouring in the shell surface.

Protoconch. Only last protoconch whorl exposed as an oblique coil on top of the teleoconch spire. Shell surface smooth and glossy (if uncorroded, most specimens corroded).

Teleoconch. Spire turreted-ovoid. First adult whorl occasionally with spirals of punctiform impressions over the entire surface, later whorls with one or two spirals adjacent to the adapical suture, but otherwise generally smooth. Body whorl with 10 to 12 spirals on the whorl base and 1 to 3 medial spirals on the middle of the helicocone. The suture is commonly developed along with the upper medial spiral or a little below it. Shell surface with conspicuous, pink, spiral bands in a number of the best preserved shells from Toftlund.

Aperture narrowly drop-shaped, columella with fold. The data for 6 shells from Toftlund $75-100 \mathrm{~m}$. are: 


$\begin{array}{ccccccc}\begin{array}{c}\text { Height }(H) \\ \text { mm. }\end{array} & \begin{array}{c}\text { Diameter }(D) \\ \text { mm. }\end{array} & H / D & \begin{array}{c}\text { Number of spirals on } \\ \text { Number } \\ \text { oconch whorls }\end{array} & \begin{array}{c}\text { basal whorl } \\ \text { medial }\end{array} & \text { sutural } \\ 3.90 & 2.21 & 2.22 & 41 / 2 & 12 & 0 & 1 \\ 3.68 & 1.63 & 2.26 & 4 & 10 & 3 & 2 \\ 3.27 & 1.47 & 2.18 & 33 / 4 & 10 & 2 & 1 \\ 3.00 & 1.58 & 2.07 & 3 \frac{1}{3} & 12 & 2 & 1 \\ 2.05 & 1.39 & 2.16 & 31 / 2 & 10 & 0 & 1 \\ & 1.11 & 1.86 & 21 / 2 & 10 & 3 & 1\end{array}$

Remarks. These shells are in agreement with A. laevigatus (Grateloup) in all general features except the $H / D$ ratio calculated on the basis of PEYrot's figures. However, since the $H / D$ ratios of the shells illustrated by PEYRoT are not very different from the $H / D$ ratios of the present shells the disagreement is probably less important.

The main differences observed between the shells referred to A. semistriatus and A. laevigatus are:

\section{A. semistriatus.}

1. Last protoconch whorl almost conformable with first teleoconch whorl.

2. Teleoconch ovoid, $H / D$ ratio mostly below 2 .

3. Spirals conspicuous on lower $2 / 3$ of body whorl.

4. Remnants of collabral colouring.

\section{A. laevigatus.}

1. Last protoconch whorl obliquely deviated in relation to first teleoconch whorl.

2. Teleoconch turreted-ovoid, $H / D$ ratio mostly above 2 .

3. Spirals conspicuous on lower $1 / 3$ of body whorl.

4. Remnants of spiral colouring.

Distribution.

Miocene: Aquitanian Basin: Aquitanien, Burdigalien.

North Sea Basin: Denmark: Arnum formation.

\section{Acteon cf. pinguis d'Orbigny}

1840. Tornatella sulcata Grateloup. Conch. foss. Bassin de l'Adour. pl. 11, fig. 16.

1852. Acteon pinguis D'Orbigny. Prodrome. 3, p. 36, no. 521.

1856. Actaeon pinguis D'Orbigny. Hörnes. D. foss. Moll. d. Tert.-Beckens v. Wien. 1, p. 506, pl. 46, fig. 21 .

1907. Actaeon pinguis D'Orbigny. Ravn. Molluskf. Jyll. Tert. p. 364.

?1925. Actaeon inflatus Bons. Kautsky. D. Mioc. v. Hemmoor u. Basbeck-Osten. p. 201. 1932. Actaeon pinguis d'Orbigny. Peyrot. Conch. Néogén. d. l'Aquit. p. 157, pl. 11, fig. $55-57$, pl. 14, fig. 12 .

Diagnosis. D'Orbigny has not given any description or diagnosis of this species, but refers to Grateloup's T. sulcata. The first diagnosis of A. pinguis is due to Hörnes (1856, p. 506).

Shell material.

$\begin{array}{lrclcc}\text { Location } & \text { Depth } & \text { Shells } & \text { Location } & \text { Depth } & \text { Shells } \\ \text { Glejbjerg } & 53.5 \mathrm{~m} . & 1 & \text { Gramby } & 109.29-110.86 \mathrm{~m} . & 1 \\ \text { Gramby } & 82.66-83.76- & 2 & \text { Toftlund } & 115- & 2\end{array}$

Description.

The material is rather poor, it consists of juvenile and more or less broken or worn adult shells.

Protoconch. The last smooth sinistral whorl exposed. 
Teleoconch globular-ovoid; entire shell surface covered with spirals of punctiform or dashed impressions. About 20 spirals on the body whorl, and 4 to 6 spirals on the whorls of the spire. Aperture of intermediate width, columella with relatively strong fold. The data of the best preserved shell from Toftlund are: height $2.74 \mathrm{~mm}$., diameter $1.64 \mathrm{~mm} ., 21 / 2$ adult whorls.

Remarks. This is another case in which a species suggested but not described by D'ORBIGNY ought to be seriously questioned. The whole synonymy of $A$. pinguis is furthermore extremely confusing as appears from PEYROT's discussion. KaUtSKY's attempt to establish discriminating criteria between $A$. pinguis and $A$. inflatus does not make the situation less obscure, since his criteria are founded on more or less subjective judgements of variable morphologic features.

The distribution is not given because of the uncertainty of the species.

\section{Acteon arnumensis nov. sp.}

Plate 76, fig. 219.

Diagnosis. Acteon of small size with 14 to 18 relatively coarse spirals of punctiform impressions on the body whorl, and the suture developed at about the 5th to " th spiral of the preceding whorl. Height of aperture related to height of shell, about 5 to 9 and height/diameter ratio about 2 in shells with 2 to 3 teleoconch whorls.

Holotype: Geological Survey of Denmark. File no. 150.25 b. Arnum 62.5$62.7 \mathrm{~m}$. Data of holotype: height $1.65 \mathrm{~mm}$. diameter $0.81 \mathrm{~mm}$., $23 / 4$ teleoconch whorls, 18 spirals on body whorl, and 5-6 spirals on whorls of the spire.

Derivatio nominis: arnumensis-from Arnum.

Shell material.

$\begin{array}{lrc}\text { Location } & \text { Depth } & \text { Shells } \\ \text { Toftlund } & 100-105 \mathrm{~m} . & 1 \\ \text { Arnum (13) } & 53-83- & 3 \\ \text { Arnum } & 62.7-62.9- & 45\end{array}$

Description.

Protoconch. Last sinistral whorl exposed, obliquely mounted on top of spire. The protoconch axis forms a relatively large angle with the teleoconch axis. Shell surface smooth and glossy.

Teleoconch turreted-ovoid, whorls with deep suture, otherwise only slightly convex. Aperture rather narrow, columella with distinct fold. Test relatively strong.

Remarks. This species is a typical Acteon which is remarkable for the small size of the shell. The features are somewhat similar to A. pinguis described above, which, however, is much more ovoid and has weaker spiral impressions than A. arnumensis.

A. arnumensis is obviously closely related to A.levidensis Wood (1848, p. 171, pl. 19, fig. 4) which, however, has 12 to 14 imbricated spiral ribs on the body whorl.

Distribution:

Miocene: North Sea Basin: Denmark: Arnum formation. 


\section{Acteon tornatilis (Linné)}

Plate 66, fig. 220 a-c.

Recent:

1766. Voluta tornatilis Linné. Syst. Nat. Edit. Duod. p. 1187.

1853. Tornatella fasciata Linn aus. Forbes \& Hanley. Brit. Moll. 3. p. 523, pl. 114, fig. 3.

1867. Actcon tornatilis Linné. Jeffreys. Brit. Conch. 4, p. 433, 5, pl. 95, fig. 2.

1868. Actooon tornatilis Linné. Weinkauff. Conch. d. Mittelmeeres. 2, p. 202.

1886. Actoeon tornatilis Linné. Bucquoy, Dautzenberg \& Dollfus. Moll. mar. du Roussillon 1, p. 510, pl. 66, fig. $15-19$.

1888. Actoeon tornatilis Linné. Petersen. De skalb. Moll. etc. p. 78.

Fossil:

1848. Actaon tornatilis Linné. Wood. Monogr. Crag Moll. 1, p. 170, pl. 19, fig. 5.

1856. Actoeon tornatilis Linné. Höknes. D. foss. Moll. d. Tert.-Beckens v. Wien. 1, p. 508, pl. 46, fig. 24.

1897. Actceon tornatilis (L.) Sacco. I moll. d. terr. terz. d. Piemonte e d. Liguria. 22, p. 31, pl. 3, fig. 3-6.

(?)1907. Actceon tornatilis Linnḱ sp. RAvn. Molluskf. Jyll. Tert. p. 363, pl. 8, fig. 10. pro parte.

1910. Actooon tornatilis Linné sp. Cerulli-Ireitr. Fauna mal. mariana. p. 31, pl. 3, fig. $51-56$.

1932. Actoon tornatitis Linné. Peyrot. Conch. Néogén. d. l'Aquit. p. 152, pl. 11, fig. $32-35,38,39$.

Original diagnosis. Testa coarctata ovata substriata, spira elevata acutiuscula, columella uniplicata (LINNÉ 1766).

Shell material. One well preserved juvenile shell from Toftlund 75$100 \mathrm{~m}$.

Description.

Protoconch. Only the last sinistral whorl exposed, it projects only a little above the first teleoconch whorl, surface smooth.

Teleoconch globular ovoid. Body whorl with 16 faint spiral furrows on lower $3 / 4$ of the whorl, and 3 spiral furrows on the shoulder at the adapical suture. Suture deep, formed at the second spiral a little above the middle of the preceding whorl. Aperture wide, columella with distinct fold, narrow umbilical fissure.

Remarks. This shell differs from the preceding species by the continuous furrows and its greater size. It agrees fairly well with $A$. tornatilis in its general features, if reservation is made for the juvenile stage. See also A. semistriatus above.

Distribution.

Recent: North Atlantic Ocean from Lofoten to and including the Mediterranean.

Pliocene: North Sea Basin: England: Coralline Crag and Red Crag.

Mediterranean Basin: Italy: Piacenziano, Astiano, upper Miocene of Monte Mario.

Miocene: Aquitanian Basin: Burdigalien, Helvétien.

North Sea Basin: Denmark: Arnum formation.

Vienna Basin: Grund, Steinabrunn. 


\section{Acteon sp.}

Plate 66, fig. 221 a-b.

1916. Actaeon sp. aff. reticosa v. Koen. sp. Norregandd. M.-mioc. Blokke fra Esbjerg, p. 35 , pl. 3, fig. 13 .

Shell material. One broken shell from Toftlund $75-100 \mathrm{~m}$.

Description.

Protoconch. The last, sinistral, whorl exposed. Whorl large and depressed, surface smooth.

Teleoconch globular. Surface irregularly cancellated by relatively strong spiral ribs and somewhat irregular collabral riblets. Body whorl with about 24 spiral ribs. Suture deep, at the 8 th spiral below the suture of the preceding whorl. Aperture broken.

Remarks. This is the same species as reported by NørRegaArd. There is some morphological relationship with A.reticosa (voN KoEneN) which, however, seems to be less globular and to have stronger spiral ribs. The general impression is that the differences observed in NøRREGAaRD's and the present shells compared with $A$. reticosa are sufficiently significant to suggest a new species. I have, however, desisted from coining a new name on account of the fragmentary shell which would be a very poor holotype.

Distribution.

Miocene: North Sea Basin: Denmark: Arnum formation.

Oligocene: North Sea Basin: Germany (1)?

\section{Genus Actroonidea Gabb 1873}

Shell material.

\section{Actæonidea sp.}

$\begin{array}{lrl}\text { Location } & \text { Depth } & \text { Shells } \\ \text { Gramby } & 82.66-83.76 \mathrm{~m} . & 1 \mathrm{frg} . \\ \text { Toftlund } & 75-100- & 3- \\ & 115- & 1-\end{array}$

Description.

The fragments consist of 1 body whorl (Gramby) and 4 spire fragments.

Protoconch. Axis almost horizontal, about one half of the protoconch exposed, it consists of about two smooth helicoid whorls.

Teleoconch. Spire turreted. Whorls slightly convex, with very delicate spiral striation on adapical part, developing into distinct spiral furrows on lower part of the body whorl. Number of spiral furrows on the body whorl about 30. Aperture narrow. Fold on columella hardly recognizable.

\section{FAMILIA PYRAMIDELLIDAE GRAY 1847 \\ Genus Chrysallida Carpenter 1857}

This genus has been subdivided into various sections mainly on the basis of the sculpture (see for instance THiELe 1931, p. 232). The presence or absence of spiral ribs or striae, and the position of the spiral ornamentation on the 
whorl is in general employed in the subdivision. However, clear definitions of the subgeneric taxonomic units have not been given.

There are species which vary considerably with respect to the spiral ornamentation. Chrysallida cf. cimbrica, for instance, has spiral ribs on the first adult whorls while later whorls may be almost smooth. Under such conditions the application of the subgeneric names established has been considered useless, in spite of the fact that the genus seems to embrace several different types of species.

In the following description of species of the genus Chrysallida those with an apertural sinus have been grouped together. Apart from the apertural sinus these forms have other features in common, such as, for instance, protoconch features, shape of the spire and the aperture, etc. The only representative of non-sinuous Chrysallidae found is C. pygmaea.

A study of the apertural features would no doubt prove useful in any revision of the subgeneric units of Chrysallida.

\section{Chrysallida cf. cimbrica (Kautsky)}

Plate 66, fig. 223 a-b.

1925. Pyrgulina cimbrica Kautsky. D. Mioc. v. Hemmoor u. Basbeck-Osten, p. 73, pl. 6, fig. $27-28$.

Essential features of original description. Sehr schlanke Form. Zahlreiche, ziemlich flache Längsrippchen. Diese Längsrippchen laufen über sehr schwache und feine Spiralen, die auch bei starker Vergrösserung kaum sichtbar sind. Bei zwei Exemplaren ist diese Skulptur nur auf die beiden ersten Mittelwindungen beschränkt. Die letzten Umgänge erscheinen dann glatt und nur mit feinen Zuwachsstreifen bedeckt. Die hinten etwas verdickte Innenlippe trägt eine Falte. Der Nabel ist nicht sichtbar. (KaUtsky 1925).

Shell material.

$\begin{array}{lrllrc}\text { Location } & \text { Depth } & \text { Shells } & \text { Location } & \text { Depth } & \text { Shells } \\ \text { Glejbjerg } & 38 \mathrm{~m} & 1 & \text { Arnum(25b) } & 62.7-62.9 \mathrm{~m} . & 55 \\ \text { Bramminge } & 70-80- & 1 & \text { Toftlund } & 75-100- & 6 \\ \text { Gramby } & 82.66-83.76- & 2 & & 100-105- & 1 \\ & 84.66-87.16- & 2 & & 105-110- & 8 \\ \text { Arnum (13) } & 28-40- & 1 & & 110-115- & 1\end{array}$

Description. Only a few of the shells are well preserved. The aperture is more or less broken in the bulk of the shells.

Protoconch heterostrophe smooth; one whorl visible.

Teleoconch. Initial whorl with about 30 curved collabral ribs; second and third whorl with about 20 ribs. The collabral ribs generally disappear from about the third or fourth whorl. Later whorls are almost smooth. One to two spiral ribs are found on the lower third of the whorl above the suture to the next whorl. The body whorl has a smooth base even in the ribbed juvenile shells. The collabral ribs terminate a little below the lowermost spiral rib, and the suture develops practically where the ribs end.

The aperture is ovoid. Outer lip with relatively deep sinus adjacent to the suture; weak fold on the columella. No umbilicus. Dimensions of one of the 
largest shells from Toftlund $(105-110 \mathrm{~m}$.): height $2.35 \mathrm{~mm}$., diameter $0.78 \mathrm{~mm}$., number of whorls 5 .

Variability. The strength and number of the collabral ribs as well as the number of sculptured whorls seem to be rather variable. The spiral ribs may be weak in some shells.

Remarks. The shells from South Jutland agree fairly well with KaUtsky's description and illustrations except for the spiral ribs. It is believed that KAUTSKY's specimens may belong to a weakly sculptured variety of the species or that the spirals may be covered by the suture. A significant feature which KAUTSKY's shells and the present shells have in common is the fold on the columella by which the shells differ from $P$. nodifera described below.

Distribution.

Miocene: North Sea Basin: Germany: Hemmoor stage.

Denmark: Arnum formation.

\section{Chrysallida nodifera nov. sp.}

Plate 66 and 67, fig. 224.

Diagnosis. Chrysallida with a projecting, narrow, shelf-shaped keel with relatively strong knobs adjacent to the upper suture. A perture round with rather deep sinus opposite the keel. No fold on the columella and no umbilicus.

Derivatio nominis: nodifera - with knobs. Holotype: Geological Survey of Denmark. D.G.U. Toftlund file no. 150. 9. b. (75-100 m.).

\begin{tabular}{lrc}
\multicolumn{2}{c}{ Shell material. } \\
Location & Depth & Shells \\
Glejbjerg & $23 \mathrm{~m}$. & 3 \\
& $25-$ & 4 \\
Bramminge & $53-$ & 2 \\
Gramby & $70-80-$ & 6 \\
& $82.66-83.76-$ & 25 \\
& $84.16-87.16-$ & 5 \\
& $90.42-92.72-$ & 1
\end{tabular}

$\begin{array}{lrc}\text { Location } & \text { Depth } & \text { Shells } \\ \text { Toftlund } & 75-100 \mathrm{~m} . & 26 \\ & 100-105- & 8 \\ & 105-110- & 1 \\ & 110-115- & 5 \\ \text { Arnum (13) } & 53-83- & 54 \\ \text { Arnum (25b) } & 62.7-62.9- & 50 \\ & 95.0-95.3- & 1 \\ & 107.5- & 1\end{array}$

Description. Only a very few of the shells are undamaged since the outer lip of the aperture is mostly broken.

Protoconch heterostrophe, smooth; one whorl visible.

Teleoconch. The whorls have a narrow, shelf-shaped keel adjacent to the upper suture. The first 2 to 3 whorls have curved ribs which form rather strong knobs on the keel. The number of ribs increases with growth from 20 to 25 ribs on the first whorl to 30 to 35 ribs on the third whorl. Beyond about the third whorl there are no ribs but only knobs on the whorls, and in some shells the ribs are very weakly developed even on the first whorls. The knobs may get weaker and almost disappear leaving only a round keel in full-grown shells. Delicate spiral striae have occasionally been recognized under the microscope.

Body whorl smooth at its base; no umbilicus. Aperture round with sharp outer lip which has a rather deep sinus near the suture. No fold on the columella.

Dimensions of one of the largest shells from Toftlund $(75-100 \mathrm{~m}$.$) : height$ $2.7 \mathrm{~mm}$., diameter $1.02 \mathrm{~mm}$.; number of whorls: $41 / 2$. 
Variability. The sculpture varies considerably. The keel seems to be the most constant feature by which the species may be distinguished.

Remarks. It may occasionally be difficult to distinguish shells of $C$. cimbrica with weak sculpture from shells of $C$. nodifera. In such cases the spiral ribs and the fold on the columella clearly indicate $C$. cimbrica.

Distribution.

Miocene: North Sea Basin: Denmark: Arnum formation.

\section{Chrysallida toftlundensis nov. sp.}

Plate 67, fig. 225.

Diagnosis. Chrysallida with curved collabral ribs. A knob on each rib at the suture. Four to six rather delicate spiral striae on the lower half of the whorl. A perture sinuous at the suture. Columella with fold. Derivatio nominis: toftlundensis - from Toftlund. Holotype: Geological Survey of Denmark. File no. 150. 9. b. $75-100 \mathrm{~m}$.

Shell material. One shell from Toftlund $(75-100 \mathrm{~m}$.$) .$

Description.

Protoconch heterostrophe, smooth; one whorl exposed.

Teleoconch. $23 / 4$ whorls. Height $1.28 \mathrm{~mm}$., diameter $0.56 \mathrm{~mm}$. Each whorl has 23-24 distinct curved collabral ribs, which are strongest near the upper suture where a knob is found on each rib. On the lower part of the whorl there are 4 to 6 rather distinct, delicate spiral striae. Such striae are also found on the basal wall of the body whorl. No umbilicus.

The aperture is broken, but the growth lines show that the aperture has a shallow sinus near the suture. There is a fold on the columella.

Remarks. This shell is fundamentally different from the shells of the two preceding species. It is similar to $C$. cimbrica regarding the fold on the columella, but differs from it by the absence of the relatively strong spiral ribs. If it is compared with $C$. nodifera the knobs on the ribs may at first sight give the impression that it belongs to that species. However, the fold on the columella and the spiral striae are sufficient criteria for separating it also from $C$. nodifera.

Distribution.

Miocene: North Sea Basin: Denmark: Arnum formation.

\section{Chrysallida acuticostata nov. sp.}

Plate 67, fig. 226 a-b.

Diagnosis. Chrysallida with sharp collabral ribs and 4 to 6 spiral ribs on the middle part of the body whorl. Base of the body whorl smooth or with faint spiral striae. No umbilicus. Fold on the columella.

Derivatio nominis: acuticostata - with sharp ribs. Holotype: Geological Survey of Denmark. File no. 150. 25. b. Arnum (25 b) 62.7-62.9 m.

Shell material.

$\begin{array}{lrc}\text { Location } & \text { Depth } & \text { Shells } \\ \text { Toftlund } & 75-100 \mathrm{~m} . & 2 \\ & 105-110- & 1 \\ \text { Arnum(25b) } & 62.7-62.9- & 5\end{array}$


Description.

Protoconch heterostrophe, smooth. One whorl seen.

Teleoconch. First whorl with 22 to 27 sharp collabral ribs and 1 to 2 spiral ribs near the lower suture. Whorls rather convex. Body whorl with 4 to 6 spiral ribs which form a decussate sculpture with the collabral ribs on the middle part of the whorl. Base of body whorl almost smooth or with slight indications of emerging spirals below the spirals of the lateral wall. Aperture not preserved. The growth lines indicate that there is a shallow sinus at the upper edge of the aperture. The suture develops about the middle of the spiral ribs. Columella with fold. Dimensions of largest shell from Arnum (25 b): height $2.1 \mathrm{~mm}$, diameter $1.0 \mathrm{~mm}$., number of whorls $3 \frac{3}{4}$.

Variation. The number of collabral ribs is obviously relatively great on the first whorl. There is a minimum number of ribs on the second whorl, and thereafter the number increases by 1 to 5 ribs per whorl in the present material.

Remarks. This species is somewhat similar to $C$. pygmaea, but the absence of the spiral furrows which cover the entire shell in $C$. pygmaea proves the sculpture of the two species to be basically diferent.

Distribution.

Miocene: North Sea Basin: Denmark: Arnum formation

\section{Chrysallida semireticulata nov. sp.}

Plate 67, fig. 227 a-b.

Diagnosis. Chrysallida with 16 to 20 oblique collabral ribs on about the first 3 whorls. Basal and lateral part of the body whorl with strong spiral ribs which form a reticulate sculpture with the collabral ribs. A perture with sinus, and columella with fold.

Derivatio nominis: semireticulata - half reticulated. Holotype: Geological Survey of Denmark: File no. 150. 25 b. Arnum (25b) 62.7-62.9 m.

Shell material: Two shells from Arnum (25 b) 62.7-62.9 m.

Description.

Protoconch heterostrophe, smooth with one whorl exposed.

Teleoconch. Whorls with 16 to 20 oblique collabral ribs on the first 3 whorls (the shells have only reached that size). Body whorl with 6 to 8 strong spiral ribs on the lower half, including the base. Aperture not preserved, but from the course of the growth lines it may be concluded that the aperture has a deep sinus at the suture. The suture is developed below the first or second spiral rib. The collabral ribs form a relatively coarse reticulate pattern with the spirals, but they fade before they reach the columella.

On the holotype there is a weak spiral on top of the initial whorl. It forms low knobs at the intersections with the collabral ribs. It disappears on later whorls. Data of the largest shell : height $1.5 \mathrm{~mm}$. diameter $0.7 \mathrm{~mm}$., whorls: $31 / 2$.

Remarks. These two shells were first believed to belong either to $C$. acuticostata or C. pygmaea. Analysis of the shell features revealed, however, fundamental differences in sculpture which are particularly well illustrated by the strong reticulate sculpture of the lower half of the body whorl. This feature was, therefore, chosen as the specific attribute.

Distribution.

Miocene: North Sea Basin: Denmark: Arnum formation. 


\section{Ghrysallida modesta nov. sp.}

Plate 67, fig. 228a-b.

Diagnosis. Turreted Chrysallida of small size. Shell surface rather glossy, with curved growth lines and microscopic spiral striae. Outer lip with sinus. Fold on the columella.

Derivatio nominis: modesta - modest. Holotype: Geological Survey of Denmark. File no. 150. 25. b. Arnum (25b) 62.7-62.9 m.

Shell material.

$\begin{array}{lrc}\text { Location } & \text { Depth } & \text { Shells } \\ \text { Toftlund } & 105-110 \mathrm{~m} . & 1 \\ \text { Arnum (13) } & 53-83- & 2 \\ \text { Arnum (25 b) } & 62.7-62.9- & 10\end{array}$

Description. Aperture broken on most shells.

Protoconch heterostrophe smooth. One whorl exposed.

Teleoconch. Smooth, more or less convex whorls with curved growth lines. The growth lines tend to form indistinct ribs near the upper suture in a few shells. Minute, somewhat irregularly scattered spiral stria occur all over the whorls. Aperture oval to ovoid; outer lip with sinus at the suture; fold on the columella, but no umbilicus. The dimensions of a few shells are as follows:

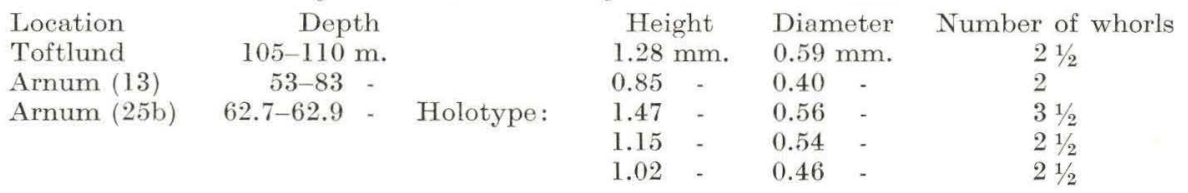

Remarks. This very simple species is in various respects similar to the preceding 5 species in spite of the absence of conspicuous sculptural elements. The whorls are similar, the protoconchs are almost identical, they all have an apertural sinus, etc. These species may, therefore, belong to a distinct group within the Chrysallidae.

Distribution.

Miocene: North Sea Basin: Denmark: Arnum formation.

\section{Chrysallida pygmaea (Grateloup)}

Plate 68, fig. 229.

1840. Acteon pygmea Grateloup. Conch. foss. des Terr. Tert. du Bassin de l'Adour. pl. 11, fig. 77 .

1856. Turbonilla pygmaea Grateloup. Hörnes. D. foss. Moll. d. Tert.-Beckens v. Wien. 1, p. 502, pl. 43 , fig. 32 .

1892. Pyrgulina pygmaea var. postica SACco. I moll. d. terr. terz. d. Piemonte e d. Liguria. 11, p. 651, pl. 1, fig. 113 .

?1892. Pyrgulina pygmaea var. subtypica. Ibid. p. 651.

1918. Chrysallida pygmaea (Grat.). Cossmann \& Peyrot. Conch. Néogén. d. l'Aquit. p. 134, pl. 9, fig. 61-63.

1925. Pyrgulina pygmaea Grat. Kadtsky. D. Mioc. v. Hemmoor u. Basbeck-Osten. p. 73, pl. 6, fig. 26 .

?1952. Chrysallida cf. pygmoea (Grateloup). Glibert. Faune mal. du Mioc. de la Belgique. 2 , p. 53 , pl. 4 , fig. 6 . 
Original diagnosis. Testa parvula cylindrica subturrita, longitudinaliter costata, transversim striata; apertura ovato-elongata (GRATELOUP 1840).

Shell material.

\begin{tabular}{|c|c|c|c|c|c|}
\hline Location & Depth & Shells & Location & Depth & Shells \\
\hline Glejbjerg & $53.75 \mathrm{~m}$. & 1 & Toftlund & $105-110 \mathrm{~m}$. & 1 \\
\hline Bramminge & $70-80-$ & 3 & & 115 & 2 \\
\hline & & & Arnum (13) & $53-83-$ & 2 \\
\hline
\end{tabular}

Description.

Protoconch smooth, heterostrophe, only last whorl exposed.

Teleoconch. Whorls with about 14 to 18 collabral straight or very slightly curved ribs. The ribs are very strong and relatively sharp. Spiral ribs are found in the interspaces; they are equally spaced except for the uppermost spiral which is separated from the one below by a wider interspace. In some shells the uppermost spiral is stronger than the others.

Spiral ribs are found all over the body whorl, where their number varies from 15 to 20 depending on size of the shell. The aperture is more or less broken on all shells. There is obviously no sinus at the suture. Columella with fold. The suture develops at about the middle spiral rib. Concerning dimensions and number of whorls the following should be stated:

Specimen from Bramminge (largest shell): height $3.1 \mathrm{~mm}$., diameter $1.3 \mathrm{~mm}$., number of whorls 4 . Shell from Toftlund 105-110 m.: height $2 \mathrm{~mm}$., diameter $0.95 \mathrm{~mm}$., number of whorls 3 .

Remarks. Grateloup's diagnosis and illustrations are insufficient for a safe determination, while Cossmann \& PEYrot's figures and description are of higher quality. The determination of the shells from South Jutland are therefore founded on the authority of these authors who knew Grateloup's collections. In the case of the shell described by GLIBERT it is believed that the differences mentioned are within the variation range of the species.

Distribution.

Pliocene: Mediterranean Basin: Italy: Astiano, Piacenziano.

Miocene: Aquitanian Basin: Burdigalien.

North Sea Basin: Belgium: Anversien (?) Germany:

Hemmoor stage, Glimmerton (Banke Rasmussen 1956).

Denmark: Arnum formation.

Mediterranean Basin: Italy: Tortoniano (?).

Vienna Basin: Baden clay, Steinabrunn beds.

Genus Kleinella A. Adams 1860

Subgenus Leucotina A. Adams 1860

\section{Kleinella (Leucotina) Nordmanni nov. sp.}

Plate 68, fig. 230 a-c.

Diagnosis. Kleinella with small, rather short shell. Protoconch smooth, with about $1 \frac{1}{2}$ whorls. Initial adult whorl covered with spiral ribs. The spiral ribs generally disappear on the upper part of the succeeding whorls corresponding to the belt of the sinus of the growth lines which then is smooth and glossy. The ribs on the basal part of the body whorl become obsolete. 
A pertural sinus; weak fold on columella; narrow umbilicus.

Holotype: Geological Survey of Denmark. File no. 150. 9. b. Toftlund 75$100 \mathrm{~m}$. Derivatio nominis: named in honour of V. Nordmann Ph. D. former State Geologist and Malacologist of the Geological Survey of Denmark.

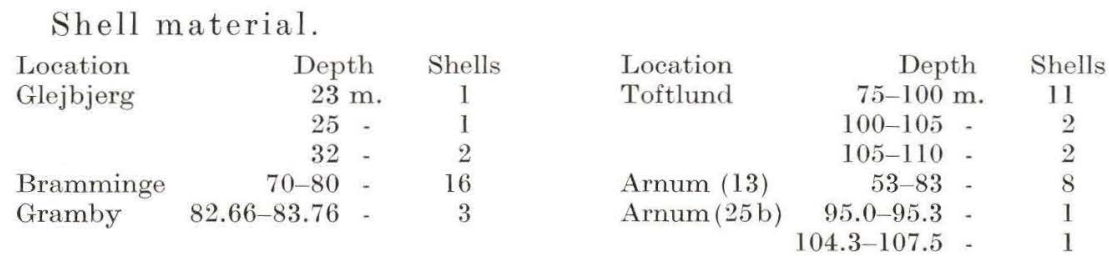

Description.

Protoconch heterostrophe, with open umbilicus. About 11/2 smooth and glossy whorls, occasionally with delicate spiral furrow on upper edge of whorl.

Teleoconch. Initial whorl with about 10 spiral ribs and furrows. Faint growth lines are seen in the interspaces between the ribs. The upper 4 ribs, corresponding to the area of the whorl where the sinus of the growth lines is found, disappear on the succeding whorls. This area is then almost flat, smooth and glossy. Below the sinus belt there are about 6 to 7 spiral ribs the strength of which generally increases with whorl number.

The body whorl has 15 to 20 spiral ribs below the sinus belt. The lower 8 to 10 ribs on the basal part of the whorl occasionally become rather obsolete. In a few shells the spiral ribs divide beyond conspicuous growth lines indicating cessation of growth. The number of spiral ribs deviates in these shells on a major seale from the normal number stated. The spiral ribs on the lateral part of the wall are always stronger than those on the basal part of the wall.

The aperture is broken on all shells, but it may be deduced from the growth lines that the outer lip has a shallow sinus at the suture. The margin bends forward in its lateral part and then back to the columella in the basal part. Columella with more less distinct fold opposite the narrow umbilicus. Aperture oval. Suture relatively deep.

The dimensions of a few relatively well preserved shells are listed in the following table:

\begin{tabular}{|c|c|c|c|c|c|}
\hline Location & Depth & Height & Diameter & $\begin{array}{c}\text { Number of } \\
\text { whorls }\end{array}$ & Remarks \\
\hline Glejbjerg & $32 \mathrm{~m}$. & $2.42 \mathrm{~mm}$. & $1.22 \mathrm{~mm}$. & $31 / 4$ & \multirow{4}{*}{ Holotype } \\
\hline Toftlund & $75-100$ & 3.0 & 1.33 & $31 / 2$ & \\
\hline & & $2.54 \quad$ & 1.16 & $31 / 2$ & \\
\hline Arnum (13) & $53-83-$ & $1.09-$ & 0.76 & $11 / 2$ & \\
\hline
\end{tabular}

Remarks. Typical features of this species are the apertural sinus and the smooth sinus area of the shell surface.

The number and strength of spiral ribs seem to be rather variable.

Distribution.

Miocene: North Sea Basin: Denmark: Arnum formation. 


\section{Genus Odostomia Fleming 1817}

The shells from South Jutland referred to this genus are some of the most difficult to group into specific categories. This is mainly due to the relatively wide variation of a small number of inconspicuous morphological features.

The shape of the spire and the presence or absence of a distinct edge on the body whorl have been suggested as characters of specific value. However, it appears that these features are very inconsistent in Odostomia.

After accurate examination and comparison it would seem that features of the protoconch and the apertural margin are useful in the subdivision of the genus. However, also these features are subject to remarkable variation, and therefore much careful judgement had to be exercised before satisfactorily uniform, specific shell populations were obtained.

\section{Odostomia conoidea (Brocchi)}

Plate 70, fig. 231 a-c.

Recent:

1853. Odostomia conoidea Brocchi. Forbes \& Hantex. Brit. Moll. 3, p. 260, pl. 95, fig. 4.

1867. Odostomia conoidea Brocchi. JefFreys. Brit. Conch. 4, p. 127, pl. 73, fig. 6.

1868. Odontostomia conoidea Brocchi. Weinkauff. Conch. d. Mittelmeeres p. 218.

1883. Odostomia conoidea Brocchi. Bucquoy, Dautzenberg \& Dolleus. Moll. mar. du Roussillon 1, p. 159, pl. 21, fig. 1-3.

1892. Ptychostomon conoideum Brocchi. Locard. Coq. mar. d. côtes d. France. p. 149.

1931. Odostomia conoidea (BRocchr). Plymouth Marine Fauna p. 260.

1932. Odostomia conoidea (BrocchI). Nobre. Moluscos mar. de Portugal. p. 202, pl. 38, fig. 18.

Fossil:

1814. Turbo conoideus Brocchi. Conchiol. Foss. Subapennina. 2, p. 660, pl. 16, fig. 2.

?1856. Odontostoma plicaium Mont. Hörnes. D. foss. Moll. d. Tert.-Beckens v. Wien. 1, p. 496 , pl. 43 , fig. 26 .

1892. Odontostomia conoidea (Brocchi) et var. SAcco. I moll. d. terr. terz. d. Piemonte e d. Liguria. 11, p. 615, pl. 1, fig. 66-70.

1907. Odostomia conoidea Brocchi sp. Ravn. Molluskf. Jyll. Tert. p. 299, pl. 3, fig. 19.

1918. Odontostomia polysarcula Cossmann \& Peyrot. Conch. Néogén. d. l'Aquit. p. 116, pl. 10, fig. 57-58.

1920. Odostomia conoidea (Brocchi). Harmer. Plioc. Moll. p. 599, pl. 50, fig. 33.

1925. Odontostomia conoidea Br. Kautsky. D. Mioc. v. Hemmoor u. Basbeck-Osten, p. 73.

1952. Odostomia (Megastomia) conoidea Brocchi sp. Glibert. Faune mal. du Mioc. de la Belgique 2, p. 55, pl. 4, fig. 10 .

1956. Odostomia (Odostomia) conoidea (Brocchi). Banke Rasmussen. Upper Mioc. South Jutland. p. 99, pl. 10, fig. 5 .

Original diagnosis. Testa conica, glabra, anfractubus planiusculis, infimo subcarinato, apertura ovali, columella uniplicata. (BRoccHI 1814).

Shell material.

$\begin{array}{lrllrr}\text { Location } & \text { Depth } & \text { Shells } & \text { Location } & \text { Depth } & \text { Shells } \\ \text { Glejbjerg } & 53.5 \mathrm{~m} . & 1 \text { (ef.) } & \text { Toftlund } & 110-115 \mathrm{~m} . & 31 \\ & 55- & 2 & & 115- & 6 \\ \text { Bramminge } & 70-80- & 17 & \text { Arnum (13) } & 53-83- & 3 \\ \text { Gramby } & 82.66-83.76- & 12 & \text { Arnum }(25 \mathrm{~b}) & 62.7-62.9- & 2 \\ & 90.42-92.72- & 1 & & 95.0-95.3- & 6 \\ \text { Toftlund } & 75-100- & 18 & 101.0-104.3- & 1 \text { (cf.) } \\ & 100-105- & 22 & 104.3-107.5- & 2 \text { - } \\ & 105-110- & 45 & & 107.5- & 1\end{array}$


Description.

Protoconch heterostrophe; depressed in the first adult whorl and partly concealed. A part of the last protoconch whorl is exposed; it is smooth and apparently glossy. Hardly perceptible punctiform impressions are, however, seen on the shell surface under the microscope.

Teleoconch. The body whorl is flat sided in its upper part in typical developed specimens. A more or less distinct angular keel is often found at about the middle of the whorl, below which the basal wall is evenly convex. The entire shell surface is commonly smooth and glossy, but one or two microscopical spiral furrows have been observed on the upper, flat sided part of the whorl in some shells. The aperture varies from ovoid to rhomboid, depending on the absence or presence of the angular keel. The outer lip bends slightly backwards from the suture and returns in an even curve to the columellar region. The interior may occasionally be striated. The outer lip continues into the columellar lip with which it forms a rather sharp angle at the suture. There is one distinct fold on the columella opposite the narrow umbilicus. The umbilicus may be absent or covered by the columellar lip.

The suture is formed at about the keel of the preceding whorl.

Variability. The shape of the spire is subject to rather wide variation. This is mainly due to the shifting position of the suture. Flat sided, conical shells are formed if the suture is developed along the angular keel. Short, wide shells develop when the whorls are offset adapically and protrude above the keel. The suture is then deep, and the outline of the spire shows steps.

If the whorls are offset downwards it gives rise to slender turreted shells. Provided this is combined with the smoothing out of the keel it is hardly possible to accept the shells concerned as belonging to the same taxonomic unit as the short, clumsy shells in which the whorls are offset in the opposite direction. It is however a fact that numerous transitional forms are found, and the only reasonable inference is that all the shells must be referred to one species.

\begin{tabular}{|c|c|c|c|c|c|}
\hline \multirow[b]{2}{*}{ Location } & \multicolumn{4}{|c|}{ Odostomia conoidea. Dimensions of shells. } & \multirow[b]{2}{*}{ Type } \\
\hline & Depth & Height & Diameter & $\begin{array}{c}\text { Number of } \\
\text { whorls }\end{array}$ & \\
\hline \multirow[t]{2}{*}{ Glejbjerg } & $55 \mathrm{~m}$. & $3.13 \mathrm{~mm}$. & $1.62 \mathrm{~mm}$. & $43 / 4$ & conical \\
\hline & & $2.97-$ & 1.35 & $41 / 2$ & - \\
\hline \multirow[t]{5}{*}{ Toftlund } & $100-105$ & $3.23-$ & $1.56-$ & 5 & turreted \\
\hline & $105-110=$ & 2.07 & 1.09 & $31 / 2$ & short \\
\hline & & 2.07 & 1.14 & $33 / 4$ & - \\
\hline & & 1.88 & 1.02 & 3 & . \\
\hline & & 1.95 & 1.09 & 3 & - \\
\hline \multirow[t]{2}{*}{ Arnum $(25 \mathrm{~b})$} & $95.0-95.3-$ & 2.9 & 1.41 & $41 / 2$ & turreted \\
\hline & & 2.05 & 1.0 & $31 / 2$ & - \\
\hline
\end{tabular}

Remarks. Shape of the spire, the body whorl and the aperture of Odostomia have largely been regarded as of specific significance by earlier authors. The variability of these "specific" features experienced in O. conoidea and the Odostomiae mentioned below shows that these morphologic features are much less definite than was formerly believed. It may consequently be inferred that a considerable number of Odostomia species names are actually synonyms established on the basis of insufficient morphologic evidence. A solution of the taxonomic problems involved may be achieved through the study of variates and a critical revision of the specific significance of morphologic features. It is believed 
that the combination of selected features both in the protoconch and the teleoconch will prove useful in the re-definition of specific shell characters in the genus Odostomia.

\section{Distribution.}

Recent: North Atlantic coasts of Europe from the British Isles and the North Sea area to and including the Mediterranean.

Pliocene: North Sea Basin: England: Coralline Crag. Belgium: Scaldisien.

Mediterranean Basin: Italy: Piacenziano, Astiano.

Miocene: Aquitanian Basin: Helvétien.

North Sea Basin: Belgium: Horizon of Houthaelen, Anversien. Germany: Hemmoor stage, Glimmerton (BANke Rasmussen 1956). Denmark: Arnum and Gram formations.

Mediterranean Basin: Italy: Tortoniano.

Vienna Basin: (?)Baden, (?)Steinabrunn.

\section{Odostomia subintermedia (Cossmann \& Peyrot)}

Plate 70, fig. 232.

1918. Odontostomia subintermedia Cossmann \& Peyrot. Conch. Néogén. d. l'Aquit. p. 123, pl. 10, fig. $55-56$.

Essential features of original description. Test subturriculée, spire à galbe légèrement conö̈dal vers le sommet; protoconque immergée. La base imperforée: labre rectiligne et vertical, mince, non sillonné à l'intérieur. Columelle munie d'un pli assez saillant. (Cossmann \& PeYrot 1918).

Shell material and dimensions of some shells from Arnum (25b) 62.7$62.9 \mathrm{~m}$.

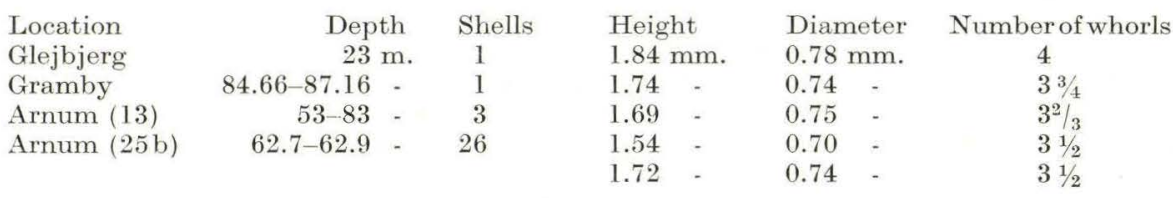

Description.

Protoconch heterostrophe, axis oblique in relation to teleoconch axis. Spire concealed in first adult whorl. The exposed part of the last protoconch whorl is smooth and glossy.

Teleoconch. Spire turreted, with slightly convex smooth whorls. Inverted S-shaped growth lines and microscopical spiral striae are seen on the shell surface under strong magnification. Body whorl with an indistinct keel or uniformly convex. Aperture drop-shaped, pointed at the suture. Outer lip with a shallow sinus adjacent to the suture from where it bends a little forward. The inner lip is only represented by a very thin callosity. There is practically no umbilicus. A low columellar fold is found opposite the center of the growth lines. The suture develops a little beneath the keel or on the corresponding part of the whorl in shells with an evenly rounded whorl outline. 
Remarks. Cossman \& Peyrot have reported the outer lip to be straight and vertical while the shells described here have a slightly curved lip. There are, however, shells in the present material with almost straight apertural margins. Cossmann \& Peyrot could obviously not study the entire variation range of the species since they only had 3 shells at their disposal.

Distribution.

Miocene: Aquitanian Basin: Burdigalien.

North Sea Basin: Denmark: Arnum formation.

\section{Odostomia sallespissensis (Cossmann \& Peyrot)}

Plate 68, fig. 233 a-b.

1918. Odontostoma sallespissensis Cossmann \& Peyrot. Conch. Néogén. d. l'Aquit.p.124, pl. 10, fig. 59-60.

Essential features of original description. Forme turriculée, conique; protoconque petite, formée d'un bouton un peu dévié et renversé sur le sommet de la spire. Tours plans, lisses, subanguleux à la périphérie de la base, qui est tres étroitement perforée au centre. Labre mince, vertical. (Cossmann \& Peyrot $1918)$.

Shell material.

$\begin{array}{lrclrr}\text { Location } & \text { Depth } & \text { Shells } & \text { Location } & \text { Depth } & \text { Shells } \\ \text { Bramminge } & 70-80 \mathrm{~m} . & 3 & \text { Toftlund } & 105-110 \mathrm{~m} . & 1 \\ \text { Gramby } & 82.66-83.76- & 1 & & 110-115- & 2 \\ & 84.66-87.16- & 1 & \text { Arnum }(13) & 53-83- & 12 \\ \text { Toftlund } & 75-100- & 6 & \text { Arnum }(25 \mathrm{~b}) & 62.7-62.9- & 3\end{array}$

\section{Description.}

Protoconch heterostrophe; concealed by the first adult whorl except for the last whorl which is smooth and glossy.

Teleoconch more or less conical with slightly convex or flat sided whorls. Shell surface with faintly curved, inverted S-shaped growth lines erossed by very fine microscopical spiral striae. The surface is otherwise smooth. The body whorl is subangular or smoothly rounded. Aperture oval, bluntly pointed at the suture. Outer lip with a shallow sinus at the suture. Inner lip distinct. Collumellar fold opposite the narrow umbilicus. Occasional striae on the inside of the outer lip.

\begin{tabular}{lcccc}
\multicolumn{5}{c}{ Odostomia sallespissensis. Dimensions of shells. } \\
Location & Depth & Height & Diameter & $\begin{array}{c}\text { Number of } \\
\text { whorls }\end{array}$ \\
Gramby & $82.66-83.76 \mathrm{~m}$. & $1.88 \mathrm{~mm}$. & $0.94 \mathrm{~mm}$. & 3 \\
Toftlund & $75-100-$ & $3.24-$ & $1.52-$ & $41 / 2$ \\
& & $4.03-$ & $1.66-$ & $51 / 2$ \\
& & $2.50-$ & $1.08-$ & 4
\end{tabular}

Remarks. This species is very similar to O. subintermedia, the main difference being the greater apical angle and the correspondingly less turreted shape of the spire. The height/diameter ratio of the shell measured by Cossmans \& 
Peyrot is greater than the corresponding ratio in the shells listed above. This may mainly be explained by the smaller size of the shells from South Jutland. There is a strong indication that the ratio increases with growth.

Distribution.

Miocene: Aquitanian Basin. Helvétien.

North Sea Basin: Denmark: Arnum formation.

\section{Odostomia pallidaeformis (Sacco)}

Plate 68, fig. 234 a-e..

1892. Odontostomia pallidaeformis SAcco. I moll. d. terr. terz. d. Piemonte e d. Liguria. 11, p. 617 , pl. 1, fig. 70 .

1918. Odontostomia pallidaeformis Sacco. Cossmann \& Peyrot. Conch. Néogén. d. l'Aquit. p. 121, pl. 9, fig. 47-48.

1949. Odostomia $(s, s$.$) pallidaeformis Sacco. GLIBERT. Gastr. du mioc. moy. du bassin d.$ 1. Loire 1, p. 185, pl. 12, fig. 5.

Original diagnosis. Testa ovato-fusiformis, ventrosa. Anfractus laeviter convexuli, ultimus permagnus, convexus. A pertura ovulata, obliqua. Peristoma integrum. Labium externum intus plurisulcatum. Labium columellare unidentatum; dens acutus, prominens, in regione ventrali media situs. (SACCO 1892).

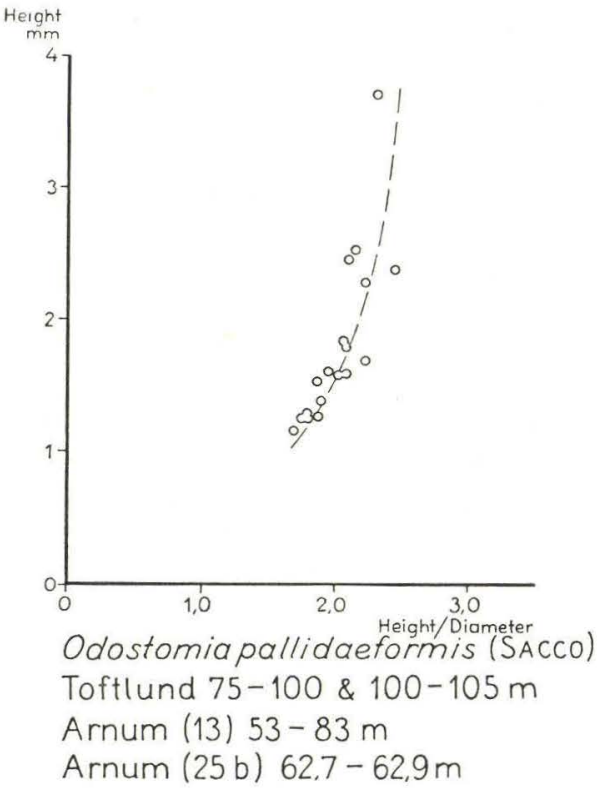

Fig. 18.
Shell material.

$\begin{array}{lrc}\text { Location } & \text { Depth } & \text { Shells } \\ \text { Gramby } & 81.86-82.16 \mathrm{~m} . & 1 \\ & 82.66-83.76- & 2 \\ & 84.66-87.16- & 1 \\ \text { Toftlund } & 75-100- & 6 \\ & 100-105- & 2 \\ & 105-110- & 8 \\ & 110-115- & 2 \\ \text { Arnum (13) } & 53-83- & 14 \\ \text { Arnum(25b) } & 62.7-62.9- & 35 \text { (cf.) } \\ & 107.5- & 1 \text { - }\end{array}$

Description.

Protoconch heterostrophe. The angle between the protoconch axis and the teleoconch axis varies from $90^{\circ}$ to $70^{\circ}$. The smooth and glossy protoconch consists of the nucleus and one whorl. The lower half of the protoconch is generally covered by the first adult whorl.

Teleoconch. The body whorl in most shells has a distinct angular keel about the middle of the whorl. In some shells the keel is further demarcated by a fine spiral furrow immediately above it. The aperture is rhomboid to oval drop-shaped, depending on whether the angular keel is more or less pronounced. Outer lip sharp, vertical; inner lip occasionally very thin; distinct columellar fold opposite the center of growth lines. Five to 7 spiral ribs on the inside of the outer lip in many shells. 
The suture is formed at or a little below the keel. The shell surface is smooth and glossy, the only ornamental feature being the very flat S-shaped almost vertical growth lines. The growth lines do not form a typical sinus adjacent to the suture, as for instance in O. subintermedia.

Variability. The figured specimens illustrate the typically keeled and the uniformly convex types of shell between which transitional forms are found. The protoconch may be more or less covered by the first adult whorl, as is also illustrated by the figures. The shape of the adult shell as shown by the height/ diameter ratio in the following table and fig. 18 varies rather much, as in most other Odostomiae.

\begin{tabular}{|c|c|c|c|c|c|c|c|c|}
\hline \multirow{2}{*}{$\begin{array}{l}\text { Location } \\
\text { Toftlund }\end{array}$} & \multicolumn{2}{|l|}{ Depth } & \multicolumn{2}{|c|}{$\begin{array}{l}\text { Height } \\
(h)\end{array}$} & \multicolumn{2}{|c|}{$\begin{array}{l}\text { Diameter } \\
(d)\end{array}$} & $h / d$ & Number of whorls \\
\hline & $75-100$ & & 3.7 & $\mathrm{~nm}$. & 1.60 & $\mathrm{am}$. & 2.30 & $51 / 2$ \\
\hline & & & 1.27 & - & 0.70 & - & 1.80 & $21 / 2$ \\
\hline & & & 2.38 & - & 0.98 & - & 2.45 & $43 / 4$ \\
\hline & & & 1.54 & - & 0.82 & - & 1.88 & $31 / 4$ \\
\hline & 100-105 & - & 2.45 & - & 1.17 & - & 2.1 & 4 \\
\hline & $105-110$ & - & 2.70 & - & 1.09 & - & 2.46 & $51 / 2$ \\
\hline & & & 2.35 & - & 0.96 & - & 2.44 & 5 \\
\hline & & & 1.94 & - & 0.86 & - & 2.25 & $41 / 2$ \\
\hline & & & 1.88 & - & 0.82 & - & 2.28 & 4 \\
\hline & & & 1.70 & - & 0.78 & - & 2.18 & $3^{4} / 5$ \\
\hline & & & 1.39 & - & 0.65 & - & 2.11 & $3^{1 / 3} / 3$ \\
\hline Arnum (13) & $53-83$ & - & 2.53 & - & 1.17 & - & 2.15 & 5 \\
\hline & & & 2.26 & - & 1.02 & - & 2.22 & $41 / 2$ \\
\hline & & & 1.25 & - & 0.70 & - & 1.78 & 3 \\
\hline Arnum $(25 b)$ & $62.7-62.9$ & - & 1.84 & - & 0.90 & - & 2.06 & 4 \\
\hline & & & 1.60 & - & 0.82 & - & 1.95 & $31 / 2$ \\
\hline & & & 1.79 & - & 0.86 & - & 2.09 & 4 \\
\hline & & & 1.27 & - & 0.72 & - & 1.76 & 3 \\
\hline & & & 1.15 & - & 0.66 & - & 1.74 & $23 / 4$ \\
\hline & & & 1.37 & - & 0.72 & - & 1.90 & 3 \\
\hline & & & 1.68 & - & 0.75 & - & 2.22 & $33 / 4$ \\
\hline & & & 1.57 & - & 0.77 & - & 2.03 & $3^{2} / 3$ \\
\hline & & & 1.58 & - & 0.76 & - & 2.07 & $31 / 2$ \\
\hline & & & 1.25 & - & 0.66 & - & 1.88 & $31 / 4$ \\
\hline
\end{tabular}

Remarks. This species may easily be distinguished from the forgoing by the protoconch features and the absence of a sinus on the growth lines. It is more turreted than $O$. mutinensis described below.

\section{Distribution.}

Miocene: Aquitanian Basin: Helvétien.

Mediterranean Basin: Italy: Elveziano.

North Sea Basin: Denmark: Arnum formation.

\section{Odostomia mutinensis (Sacco)}

Plate 69, fig. 235 a-b, plate 70, fig. 235.

1892. Cyclodostomia mutinensis SACCO. I moll. d. terr. terz. d. Piemonte e d. Liguria 11, p. 628 , pl. 1, fig. 102 .

Original diagnosis. Testa parva, conica. Anfractus 5-6 circiter, complanati, suturis sat profundis disjuncti; prope suturam superam interdum crasso et elato 
cingulo muniti; prope suturam inferam angulato-subcingulati. A pertura subrhomboidalis. Columella uniplicata. Umbilicus nullus. (SACCo 1892).

$\begin{array}{crcc}\begin{array}{c}\text { Shell material. } \\ \text { Location }\end{array} & \text { Depth } & \begin{array}{c}\text { Number of shells } \\ \text { type } a \text { with } \\ \text { sutural shoulder }\end{array} & \begin{array}{c}\text { type } b \\ \text { smooth }\end{array} \\ \text { Glejbjerg } & 42 \mathrm{~m} . & 3 & 1 \\ \text { Gramby } & 54- & 2 & 1 \\ \text { Toftlund } & 82.66-83.76- & 1 \text { (cf.) } & 4 \\ & 90.42-92.72- & 6 & 25 \\ & 100-100-105- & 4 & 7 \\ & 105-110- & 8 & 2 \\ \text { Arnum (13) } & 110-115- & 1 \text { (frg.) } & 2 \\ \text { Arnum (25b) } & 115- & & \end{array}$

\section{Description.}

Protoconch smooth, heterostrophe, about 2 whorls which are smooth and glossy. The upper half of the protoconch is generally exposed. The proto-

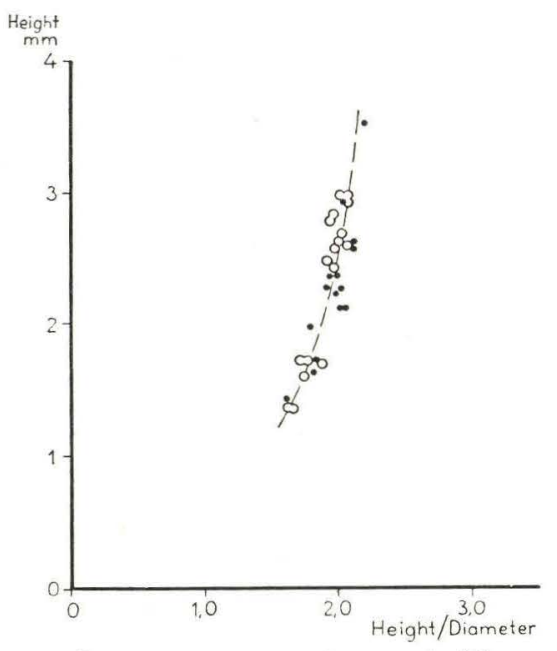

Odostomia mutinensis (SACCO)

- Shells w/sutural shoulder, Toftlund $75-100,105-110 \& 110-115 m$

- Smooth shells, Toftlund 75-100 $105-110$ \& $110-115 m$

Fig. 19. conch axis forms an angle of about $80^{\circ}$ to $90^{\circ}$ with the teleoconch axis.

Teleoconch. Two types of shells are included in this species: $a$. shells with a sutural shoulder adjacent to the upper suture and $b$. smooth shells with same height/diameter ratio as the shells with shoulder. Transitional types between type $a$ and $b$ occur. Type $a$ will be described in the following.

Body whorl with angular shoulder adjacent to upper suture. The upper part of the wall below the sutural shoulder is slightly concave, but thereafter it is almost flat until the middle of the whorl, where it is sub-angular to angular. There are microscopical spiral striae on this part of the shell surface. The growth lines are slightly sinuous immediately below the shoulder; they are most advanced at about the median keel below which they are somewhat recurrent on the basal part of the whorl. Fine spiral striae are occasionally seen on the base of the whorl. Aperture rhomboid, outer lip sharp; shallow sinus below the sutural shoulder. Inner lip distinct, with one fold on the columella opposite the center of growth lines. More or less open umbilicus. The suture is generally formed a little below the middle of the whorl. 
The sutural shoulder is generally absent on the first adult whorl. The spire is conical.

Variability. The sutural shoulder is a rather inconstant feature. It disappeared in some shells with growth, while it is quite absent in a great number of shells as shown in the above table of the material. These shells otherwise display the features of the species e.g. the morphology of the protoconch, the shape of the growth lines and the aperture, as well as the same height/diameter ratio. Intermediate types are found, and it must be accepted that the different looking shells have to be included in one species.

The graph fig. 19 shows that the height/diameter ratio increases somewhat with size of the shell.

There is an umbilicus in most shells, but it is often very narrow.

The table below is a record of measurements etc., of the wellpreserved shells. Transition forms between types $a$ and $b$ have subjectively been put into the category which was assumed to be the best approximation.

Remarks. SACCo has reported that his shells are devoid of an umbilicus. The umbilicus has, however, been demonstrated as a rather variable feature in the present material. The divergence among the shells here described has therefore been considered within the variation range of the species.

\section{Distribution.}

Miocene: Mediterranean Basin: Italy: Tortoniano.

North Sea Basin: Denmark: Arnum formation.

Table 3. Odostomia mutinensis.

Dimensions and other variable features.

\begin{tabular}{|c|c|c|c|c|c|c|c|}
\hline Location & Depth & $\begin{array}{l}\text { Height }(h) \\
\text { mm. }\end{array}$ & $\begin{array}{l}\text { Diameter }(d) \\
\mathrm{mm} .\end{array}$ & $h / d$ & $\begin{array}{l}\text { Type } \\
a b\end{array}$ & $\begin{array}{l}\text { Number } \\
\text { of whorls }\end{array}$ & Umbilicus*) \\
\hline \multirow[t]{19}{*}{ Toftlund } & $75-100 \mathrm{~m}$. & 2.91 & 1.41 & 2.07 & $\mathrm{x}$ & 5 & + \\
\hline & & 2.91 & 1.39 & 2.10 & $\mathrm{x}$ & $43 / 4$ & + \\
\hline & & 2.62 & 1.23 & 2.13 & $\mathrm{x}$ & 4 & $(+)$ \\
\hline & & 2.27 & 1.11 & 2.04 & $\mathrm{x}$ & 4 & - \\
\hline & $105-110 \mathrm{~m}$. & 3.52 & 1.60 & 2.20 & $\mathrm{x}$ & 5 & + \\
\hline & & 2.58 & 1.22 & 2.12 & $\mathrm{x}$ & $4 \frac{1}{4}$ & + \\
\hline & & 2.35 & 1.18 & 1.99 & $\mathrm{x}$ & 4 & + \\
\hline & & 2.31 & 1.17 & 1.97 & $\mathrm{x}$ & 4 & $(+)$ \\
\hline & & 2.23 & 1.11 & 2.00 & $\mathrm{x}$ & 4 & + \\
\hline & & 1.72 & 0.94 & 1.83 & $\mathrm{x}$ & $31 / 4$ & + \\
\hline & & 1.43 & 0.88 & 1.62 & $\mathrm{x}$ & 3 & - \\
\hline & & 2.97 & 1.47 & 2.03 & $\mathrm{x}$ & 5 & t. \\
\hline & & 2.97 & 1.43 & 2.08 & $x$ & 5 & - \\
\hline & & 2.82 & 1.43 & 1.97 & $\mathrm{x}$ & $4^{3 / 4}$ & + \\
\hline & & 2.78 & 1.43 & 1.95 & $\mathrm{x}$ & 5 & $(+)$ \\
\hline & & 2.66 & 1.31 & 2.03 & $\mathrm{x}$ & $4 \frac{1 / 2}{2}$ & $(+)$ \\
\hline & & 2.62 & 1.30 & 2.01 & $\mathrm{x}$ & $41 / 2$ & $(+)$ \\
\hline & & 2.58 & 1.23 & 2.10 & $\mathrm{x}$ & $4^{1 / 2}$ & - \\
\hline & & 2.56 & 1.29 & 1.99 & $\mathrm{x}$ & $41 / 2$ & $(+)$ \\
\hline
\end{tabular}

*) + umbilicus present, (+) "narrow umbilicus", (-) "very narrow umbilicus", - imperforate shell base. 


\begin{tabular}{|c|c|c|c|c|c|c|c|}
\hline Location & Depth & $\begin{array}{l}\text { Height }(h) \\
\text { mm. }\end{array}$ & $\begin{array}{c}\text { Diameter }(d) \\
\mathrm{mm} .\end{array}$ & $h / d$ & $\begin{array}{l}\text { Type } \\
a b\end{array}$ & $\begin{array}{l}\text { Number } \\
\text { of whorls }\end{array}$ & Umbilicus \\
\hline \multirow{13}{*}{ Toftlund } & $105-110 \mathrm{~m}$. & 2.42 & 1.23 & 1.97 & $\mathrm{x}$ & 4 & - \\
\hline & & 1.72 & 1.00 & 1.72 & $\mathrm{x}$ & 3 & - \\
\hline & & 1.72 & 0.98 & 1.76 & $\mathrm{x}$ & 3 & - \\
\hline & & 1.70 & 0.90 & 1.89 & $\mathrm{x}$ & 3 & - \\
\hline & & 1.35 & 0.80 & 1.68 & $\mathrm{x}$ & $23 / 4$ & 一 \\
\hline & $110-115 \mathrm{~m}$ & 2.27 & 1.18 & 1.92 & $\mathrm{x}$ & 4 & + \\
\hline & & 2.11 & 1.03 & 2.05 & $\mathrm{x}$ & 4 & - \\
\hline & & 2.11 & 1.04 & 2.03 & $\mathrm{x}$ & 4 & $(\div)$ \\
\hline & & 1.99 & 1.11 & 1.79 & $\mathrm{x}$ & $33 / 4$ & - \\
\hline & & 1.64 & 0.90 & 1.83 & $\mathrm{x}$ & 3 & $(-1)$ \\
\hline & & 2.47 & 1.17 & 1.91 & $\mathrm{x}$ & $4^{3 / 4}$ & $(+)$ \\
\hline & & 1.60 & 0.92 & 1.75 & $\mathrm{x}$ & 3 & - \\
\hline & & 1.37 & 0.84 & 1.63 & $\mathrm{x}$ & $23 / 4$ & - \\
\hline
\end{tabular}

Subgenus Syrnola A. Adams 1860

\title{
236. Odostomia (Syrnola) subumbilicata (Grateloup)
}

\author{
Plate 70, fig. 236.
}

1838. Acteon subumbilicata Grateloup. La Fam. d. Plicacés, p. 276, pl. 6, fig. 51-52. 1840. Acteon subumbilicata Grateloup. Conch. foss. d. terr. tert. du bassin de l'Adour, pl. 11, fig. 51-52.

1918. Syrnola subumbilicata (Grat.) et mut. bearnensis Cossmann \& Peyrot. Conch. Néogén. d. l'Aquit. p. 101, pl. 9, fig. 14-19.

1949. Odostomia (Syrnola) subumbilicata turoniensis GLIBERT. Gastr. du mioc. moy. du bassin de la Loire. 1, p. 186, pl. 12, fig. 9.

Original diagnosis. Testa turrito-cylindrica, aciculata, subumbilicata, nitide lovigata, apice obtusa; apertura oblonga; anfractibus convexiusculis; columella uniplicata (Grateloup 1838).

\section{Shell material.}

\begin{tabular}{|c|c|c|c|c|c|}
\hline \multirow{4}{*}{$\begin{array}{l}\text { Location } \\
\text { Glejbjerg }\end{array}$} & Depth & Shells & Location & Depth & Shells \\
\hline & $25 \mathrm{~m}$ & 1 frg. & Toftlund & $100-105 \mathrm{~m}$. & $2+3$ frg. \\
\hline & $53.5-$ & $1+2$ frg. & & $105-110=$ & \\
\hline & $55-$ & 3 frg. ef. & & $110-115$ & 2 \\
\hline Gra & $.72-109.29$ & 1 & Arnum (13) & $53-83 \quad-$ & $6 \mathrm{cf}$. \\
\hline Toftlund & $75-100-$ & 1 & $\operatorname{Arnum}(25 \mathrm{~b})$ & $62.7-62.9-$ & $3-$ \\
\hline
\end{tabular}

Description. One well preserved shell from Glejbjerg $53.5 \mathrm{~m}$. The other shells listed are all more or less fragmentary. The description is accordingly mainly based on the shell from Glejbjerg.

Protoconch heterostrophe, the axis deviates about $70^{\circ}$ from the teleoconch axis. The shell is button shaped and consists of about 2 smooth whorls.

Tele oc on ch turreted. Whorls almost flat with rather shallow suture. Growth lines about vertical; fine microscopical spiral striae are seen in some shells. No keel on the body whorl. Aperture rhomboid (outer lip broken). Columella with indistinct fold opposite the center of growth lines; no umbilicus. Dimensions: height $4.38 \mathrm{~mm}$., diameter $1.45 \mathrm{~mm}$. 
Remarks. The shell from Glejbjerg reminds very much of the type described by Cossmand \& Peyrot as mut. bearnensis and is accordingly very similar to GLIBERT's shell. It is believed that VAN Voorthuysen's shells (1944, p. 36) include more than one species, and they have therefore not been listed in the synonymy.

Distribution.

Miocene: Aquitanian Basin: Aquitanien, Burdigalien, Helvétien.

North Sea Basin: Denmark: Arnum formation.

\section{Odostomia (Syrnola) dubia (Grateloup)}

Plate 69, fig. 237.

1827. Auricula dubia Grateloup. Tabl. Dax (Bull. Soc. Lin. Bordeaux t. 2, p. 105, no. 74). 1840. Acteon dubia Grateloup. Conch. foss. d. terr. tert. du bassin de l'Adour, pl. 11, fig. 48-49.

1918. Symola dubia (Grateloup). Cossmann \& Peyrot. Conch. Néogén. d. l'Aquit. p. 107, pl. 9, fig. 28-31.

Diagnosis from 1840: Testa turrito-elongata, lavigata, nitida, subumbiticata; apertura subquadrata. (GRATELOup 1840; paper from 1827 not available).

Shell material. One shell from Bramminge 70-80 m.

Description. The shell surface is rather worn.

Protoconch heterostrophe, one whorl exposed.

Teleoconch. The shape is dimorph as described by Cossunann \& Peyrot: about the first two whorls have a wider apical angle than the succeeding whorls which are subcylindrical. Growth lines approximately vertical. Aperture rounded-rhomboid (outer lip broken). Columella with fold. No umbilicus. Dimensions: height $4.78 \mathrm{~mm}$., diameter $1.91 \mathrm{~mm}$.

Distribution:

Miocene: Aquitanian Basin: Aquitanien, Burdigalien.

North Sea Basin: Denmark: Arnum formation.

\section{Genus Eulimella Gray 1847}

\section{Eulimella concinna nov. sp.}

Plate 69, fig. 238 a-b; plate 70, fig. 238.

Diagnosis. Eulimella with relatively much exposed protoconch of a diameter greater than or equal to first adult whorl. Adult whorls flat sided with occasional microscopical, spiral striae. Outer lip straight and almost perpendicular to suture. Columellar lip oblique. Derivatio nominis: concinna - harmonious. Holotype: Geological Survey of Denmark. File no. 150. 9. b. Toftlund 105-110 m. 
Shell material.

\begin{tabular}{|c|c|c|c|c|c|c|}
\hline Location & Depth & Shells & Location & Dep & & Shells \\
\hline Ribe & $113-114 \mathrm{~m}$ & 1 & Toftlund & 115 & $\mathrm{~m}$. & 1 (cf.) \\
\hline \multirow[t]{2}{*}{ Gramby } & $82.66-83.76-$ & $1 \mathrm{frg}$. & Arnum (13) & $53-83$ & - & 1 \\
\hline & $84.66-87.16$ - & 1 & & $83-94$ & - & I frg. \\
\hline \multirow[t]{4}{*}{ Toftlund } & $75-100-$ & $6(+11$ frg. $)$ & Arnum (25b) & $62.7-62.9$ & - & 3 \\
\hline & $100-105-$ & 3 & & $95.0-95.3$ & - & 2 \\
\hline & $105-110-$ & 27 & & $104.3-107.5$ & - & 2 \\
\hline & $110-115=$ & 11 & & & & \\
\hline
\end{tabular}

\section{Description.}

Protoconch depressed globular; heterostrophe. Protoconch and teleoconch axis form an angle of about $80-90^{\circ}$. About 2 smooth and glossy whorls. Base of last whorl completely exposed. Diameter of last whorl about $0.32-0.34 \mathrm{~mm}$.

Teleoconch turreted; whorls smooth with occasional very faint, microscopical striae and growth lines. No distinct keel at the periphery of the body whorl, base of the whorl round. Aperture trapezoidal; outer lip and columellar lip are not parallel, but diverging abapically; columellar lip oblique, with no fold on the columella. Outer lip almost vertical at right angle to upper suture. The dimensions of a few well preserved shells were:

$\begin{array}{lcllc}\text { Location } & \text { Depth } & \text { Height } & \text { Diameter } & \text { Number of whorls } \\ \text { Toftlund } & 75-100 \mathrm{~m} . & 6.25 \mathrm{~mm} . & 1.52 \mathrm{~mm} . & 10 \\ & 105-110- & 4.45- & 1.09- & 91 / 4 \text { (holotype) } \\ & & 3.44- & 0.92- & 71 / 2 \\ & & 3.42- & 0.90- & 71 / 2\end{array}$

Remarks. The shells remind very much of the shell described by von Koenen (1882, p. 262) as Turbonilla Grateloupii and of the shell described by Cossmann \& Peyrot (1918, p. 104) under the same species name. However, the fold on the columella refers these shells to Syrnola.

Differences in the shell morphology of Eulimellae are often of such a capricious nature that the descriptions and illustrations in the literature are in most cases quite insufficient for identification. In the case of the present shells it is, therefore, very likely that they belong to some species already established, but impossible to detect in the records. Although it is an unsatisfactory solution to erect a new species under these conditions, it was preferred to offering a badly verified known species name.

Distribution.

Miocene: North Sea Basin: Denmark: Arnum formation.

\section{Eulimella Scillae (Scacchi)}

Recent:

$$
\text { Plate 69, fig. } 239 \text { a-c. }
$$

*)1836. Melania Scillae Scacchr. Notizie intorno alle conchiglie etc. p. 51, pl. 2. fig. 2. 1844. Eulima Scillae Scacchi. Philtppi. Enum. Moll. Sic. 2, p. 135, pl. 24, fig. 6.

1853. Eulimella Scillae Scacchi. Forbes \& Hanley. Brit. Moll. 3, p. 309, pl. 98, fig. 5-6. 1867. Odostomia Scillae Scacchr. Jeffreys. Brit. Conch. 4, p. 169; 5, pl. 76, fig. 5 .

*) Original paper unavailable. 
1868. Eutimella Scillae Philippi. Weinkauff. Conch. d. Mittelmeeres, p. 224.

1878. Eulimella Scillae SCACCHI. Sars. Moll. Reg. Arct. Norvegiae. p. 208, pl. 11, fig. 17.

1888. Eulimella Scillae Scacchr. Petersen. De skalb. Moll. etc. p. 73.

1932. Eulimella Scillae Scacchi. Nobre. Moluscos mar. de Portugal, p. 210, pl. 29, fig. $48-51$.

Fossil:

1882. Eulimella Scillae Scaccht. von Koenen. D. Nord. Mioc. u. s. Moll. f. p. 242.

1892. Eulimella Scillae ScACchi et var. SAcco. I moll. d. terr. terz. d. Piemonte e d. Liguria 11, p. 632, pl. 1, fig. 1-7.

1914. Eutimella Scillae Scacchi. Cerulli-Irelli. Fauna mal. mariana p. 256, pl. 22, fig. $46-50$.

1946. Eulimella (Eulimella) Scillae Scacchr. Beets. Plioc. \& Pleistoc. gastr. p. 52, pl. 3, fig. 10.

1956. Eutimella (Eulimella) Scillae Scacchr. Banke Rasmussen. Upper Mioc. South Jutland. p. 100, pl. 10, fig. 2 .

Diagnosis (according to PHILIPPI). Testa subulato-turrita; anfractibus laevissimis, planis, sutura profunda disjunctis; apertura tetragona; columella perpendiculari (1844).

Shell material.

\begin{tabular}{|c|c|c|c|c|c|c|}
\hline Location & Depth & Shells & Protoconch & Teleo & conch & Number of \\
\hline & & & Diameter & Height & Diameter & whorls \\
\hline oftlund & $105-110 \mathrm{~m}$. & $2 *)$ & $0.35 \mathrm{~mm}$. & $3.25 \mathrm{~mm}$. & $0.98 \mathrm{~mm}$. & $6 \frac{1}{4}$ \\
\hline & & & 0.33 & 1.88 & 0.78 & 4 \\
\hline rnum $(25 \mathrm{~b})$ & $95.0-95.3 \quad-$ & 1 & 0.29 & 3.02 & 0.95 & $6^{4} / 5$ \\
\hline
\end{tabular}

Description. All three shells are very well preserved except for the aperture of the shells from Toftlund.

Protoconch globular. Angle of $70-80^{\circ}$ between protoconch axis and teleoconch axis. About 2 smooth and glossy whorls. For diameter of last whorl see table above.

Teleoconch. The shell from Arnum is the more typical of the three specimens; and the following description refers, therefore, to that shell.

Spire conical, apical angle $15^{\circ}$. Smooth, flat sided whorls with inverted s-shaped growth lines and extremely delicate microscopical spiral striae.

Body whorl subangular at the periphery, convex at the base. Aperture rhomboid, outer wall and columellar portion of the aperture almost parallel. The outer lip is curved with a shallow sinuosity adjacent to the suture, and maximum projection at about the periphery of the shell, resulting in the growth lines having an inverted s-shaped appearance, as stated above.

No umbilicus, but thin callosity at the base of the vertical columella. Suture developed along the subangular periphery.

Variability. One shell from Toftlund is less angular at the periphery than the shell from Arnum. Furthermore: the individual whorls are not flat sided but slightly flexuous with a shallow depression below the upper suture and low convexity further down, and the height of the whorls is comparatively greater.

The other shell from Toftlund shows a slightly patologic development, but is obviously of the type with flat sided whorls.

Remarks. The above shells have a smaller apical angle than the typical E.Scillae the apical angle of which is about $20^{\circ}$. This difference and the other

*) Aperture slightly broken on both shells. 
deviations from the normal in the first-named shell from Toftlund arouse considerable doubt as to whether this shell really belongs to this species. It was however considered that the species has apparently a rather wide range of variation, and that the differences observed are probably of a subordinate character. All three shells were finally included in E. Scillae. Both SAcco and Cerulli-Irelli have pictured shells of similar aspect under E. Scillae.

\section{Distribution.}

Recent: North Atlantic Ocean from Lofoten to Madeira and the Canaries.

Mediterranean.

Pliocene: North Sea Basin: Holland.

Mediterranean Basin: Italy: Piacenziano, Astiano, upper Pliocene of Monte Mario.

Miocene: North Sea Basin: Germany: (m. ?), Glimmerton (BANke Rasmussen 1956). Denmark: Arnum and Gram formations.

Mediterranean Basin: Italy: Tortoniano.

\section{Eulimella acicula (Philippi)}

Recent:

1836. Melania acicula Philippr. Enum. Moll. Siciliae. 1, p. 158, pl. 9, fig. 6.

1853. Eulimella acicula Philippi. ? Forbes \& Hanley. Brit. Moll. 3, p. 311, pl. 98, fig. 9-10.

1867. Odostomia acicula Philippt. Jeffreys Brit. Conch 4, p. 170; 5, pl. 76, fig. 6-7.

1868. Eulimella acicula Phimippr. Weinkauff. Conch. d. Mittelmeeres, 2, p. 224.

1883. Eulimella acicula Phitrppi sp. Bucquoy, Dautzenberg \& Dollfus. Moll. mar. du Roussillon 1, p. 187, pl. 20, fig. 17-18.

1888. Eulimella acicula PhintPpi. Petersen. De skalb. Moll. etc. p. 73.

1932. Eulimella acicula Phinrppr. Nobre. Moluscos mar. de Portugal p. 208.

Fossil:

1882. Eulimella acicula Philippi. von Koenen D. Nordd. Mioc. u. s. Moll. f. 2, p. 243, pl. 6, fig. 8.

1952. Eulimella acicula Philippi sp. Glibert. Faune mal. du Mioc. de la Belgique 2, p. 56, pl. 4, fig. 11 .

Original diagnosis. Testa minima, cylindraceo-subulata, laevissima, nitida, anfractibus convexiusculis, apice obtusiusculo, apertura ovata (PHILIPPI 1836).

Shell material. Arnum (13) 53-83 m. 1 shell, Arnum (25b) 62.7-62.9 m. 1 shell.

Description. State of preservation relatively good but last whorl broken on both shells.

Protoconch heterostrophe, globular. Angle of about $60-70^{\circ}$ between protoconch and teleoconch axes. About two smooth and glossy whorls. Diameter of exposed part of last whorl 0.25 and $0.28 \mathrm{~mm}$.

Teleoconch with convex whorls and distinct sutures. Whorls almost smooth. Microscopic spiral striae on the shell from Arnum (13) 53-83 m. Growth lines concave to slightly inverted s-shaped. Body whorl round. Aperture not preserved. No columellar fold nor umbilicus. 


$\begin{array}{lrllc}\text { Dimensions: } & & \text { Height } & \text { Diameter } & \begin{array}{c}\text { Number of } \\ \text { whorls }\end{array} \\ \text { Arnum (13) } & 53-83 \mathrm{~m} . & 1.85 \mathrm{~mm} . & 0.68 \mathrm{~mm} . & 4 \frac{1}{2} \\ \text { Arnum }(25 \mathrm{~b}) & 62.7-62.9- & 1.85- & 0.74- & 4 \frac{1}{2}\end{array}$

Remarks. The shells are similar to that described as var. ventricosa by JEFFREYS.

\section{Distribution.}

Recent: North Atlantic Ocean from the North Sea area to and including the Mediterranean.

Miocene: North Sea Basin: Belgium: Anversien. Germany: Reinbek-Dingden stage. Denmark: Arnum formation.

\section{Eulimella crassitesta nov. sp.}

Plate 69, fig. 241 a-b, plate 70, fig. 241.

Diagnosis. Eulimella with apical angle of about 20 to $30^{\circ}$. Angle between protoconch axis and teleoconch axis about $40^{\circ}$. Only part of last protoconch whorl exposed. Teleoconch with strong test. Surface with indistinct, microscopic spiral striae, and growth lines almost at right angles to the deep suture. Aperture dropshaped; margin smooth and continuous with callosity on columellar division. No umbilicus. Holotype: Geological Survey of Denmark. File no. 141. 28. Gramby 82.66-83.76 m. Derivatio nominis: crassitesta - thick test.

Shell material. Bramminge 70-80 $\mathrm{m}$. one somewhat damaged and corroded shell; Gramby $82.66-83.76$ m. one well preserved shell.

\section{Description.}

To the diagnosis and the illustrations may be added that the protoconch is smooth, and that the apical angle of the teleoconch is obviously not very constant. The dimensions and number of whorls of the two shells are:

$\begin{array}{lllc} & \text { Height } & \text { Diameter } & \text { Number of whorls } \\ \text { Bramminge } & 3.67 \mathrm{~mm} . & 1.19 \mathrm{~mm} . & 51 / 2 \\ \text { Gramby } & 2.52- & 0.98- & 41 / 2\end{array}$

Remarks. At first sight the shells look very similar to E. hydrobiopsis (CossMANn \& Peyrot 1918, p. 178, pl. 10, fig. 81-83), but this species has no spiral ornamentation, and the aperture is discontinuous, as stated by its authors.

Distribution.

Miocene: North Sea Basin: Denmark: Arnum formation.

\section{Genus Turbonilla (Leach) Risso 1826}

\section{Turbonilla costellata (Grateloup)}

Plate 70, fig. 242.

*)1827. Auricula costellata Grateloup. Tabl. Dax. Bull. Soc. Linn. Bordeaux 2, p. 107. 1840. Acteon costellata Grateloup. Conch. foss. du bassin de l'Adour, p. 280, pl. 11, fig. $69-70$.

*) Original paper not available. 
1882. Turbonilla costellata Grateloup. von Koenen. D. Nordd. Mioc. u. s. Moll. f. p. 250, pl. 6, fig. 9.

1907. Turbonilla costellata Grateloup. Ravs. Molluskf. Jyll. Tert. p. 297, pl. 3, fig. 12.

1918. Turbonilla costellata Grateloup. Cossmann \& Peyrot. Conch. Néogén. d. l'Aquit. p. 145 , pl. 9 , fig. $68-70 \& 79-81$.

Diagnosis. Testa turrita, cylindrico-elongata, longitudinaliter costellata; apertura sub-ovata; labro dextro intus substriato; costellis elevatis, aliquando duplicatis. (Grateloup 1838).

Shell material.

$\begin{array}{lrclrc}\text { Location } & \text { Depth } & \text { Shells } & \text { Location } & \text { Depth } & \text { Shells } \\ \text { Bramminge } & 70-80 \mathrm{~m} . & 2 & \text { Arnum }(13) & 53-83 \mathrm{~m} . & 1 \\ \text { Gramby } & 82.66-83.76- & 1 & \text { Arnum(25b) } & 62.7-62.9- & 2 \\ \text { Toftlund } & 75-100- & 1 & & & \end{array}$

Description.

Protoconch smooth and glossy, about $2 \frac{1}{2}$ whorls. Protoconch axis and teleoconch axis form an angle of about 80 to $75^{\circ}$.

Teleoconch. Whorls rather flat with 12 to 16 relatively strong collabral ribs per whorl. The ribs are relatively sharp. Both ribs and interspaces are smooth. The ribs terminate at the periphery of the body whorl, and the base is thus devoid of seulpture except for the growth lines. fold.

Aperture broken on all specimens. Columella obviously straight and without

Remarks. The number of ribs per whorl varies rather much even from one whorl to another in the same shell. The following table shows this variation together with the dimensions of the shells concerned.

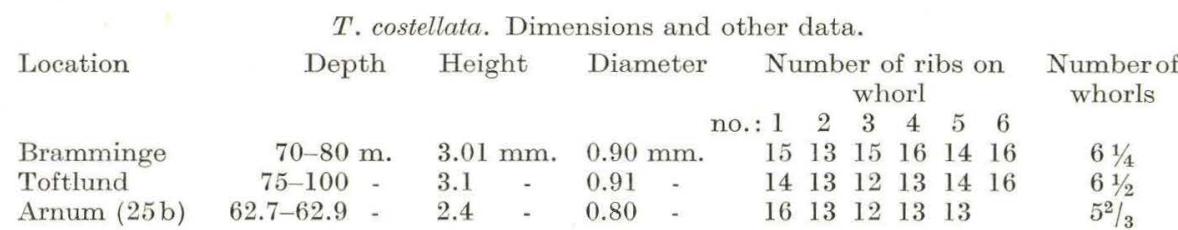

Distribution.

Miocene: Aquitanian Basin: Burdigalien, Helvétien?

North Sea Basin: Germany: middle and upper ? Miocene. Denmark: Arnum formation.

\section{Turbonilla lactea (Linné)}

Recent:

Plate 71, fig. 243.

1758. Turbo lacteus Linné. Syst. Nat. Ed. Dec. p. 765.

1853. Chemnitzia elegantissima Montagu. Forbes \& Hanley. Brit. Moll. 3, p. 242, pl. 93, fig. 1-2.

1867. Odostomia lactea Linné. JefFreys. Brit. Conch. 4, p. 164; 5, pl. 76, fig. 3 .

1868. Turbonilla elegantissima Montagu. Weinkauff. Conch. d. Mittelmeeres. 2, p. 207.

1883. Turbonilla lactea Linné, sp. Bucquox, Dautzenberg \& Dollfus. Moll. mar. du Roussillon. 1, p. 178, pl. 21, fig. 6-7. 
1888. Chemnitzia lactea L. Petersen. De skalb. Moll. etc. p. 74.

Fossil:

?1882. Turbonilla Gastaldii Semper. von Koenen. D. Nordd. Mioc. u. s. Moll. f. p. 254.

1882. Turbonilla denseplicata. v. Koenen. ibid. p. 259, pl. 6, fig. 11.

1892. Turbonilla lactea (LrvN.) et var. SACco. I moll. d. terr. terz. d. Piemonte e d. Liguria 11, p. 654. pl. 2, fig. 44-57.

?1907. Turbonilla denseplicata v. Koenew. Ravn. Molluskf. Jyll. Tert. p. 297, pl. 3, fig. 17.

1914. Turbonilla lactea L. sp. Ceruldi-Iredir. Fauna mal. mariana. p. 267, pl. 23, fig. 2029 , var. $30-31$.

1925. Turbonilla lactea Linné var. Gastaldi Semp. Kautsky. D. Mioc. v. Hemmoor u. Basbeck-Osten. p. 75 , pl. 6, fig. 31 .

1949. Turbonilla elegantissima gastaldi Semper. Glibert. Gastr. du Mioc. moy. du bassin d. 1. Loire p. 188, pl. 11, fig. 16 .

1952. Turbonilla elegantissima f. gastaldi Semper. GLibert. Faune mal. du Mioc. de la Belgique. 2, p. 59, pl. 4, fig. 14 .

Original diagnosis: Testa cancellata turrita: striis longitudinalibus elevatis confertis. (LINNÉ 1758).

Shell material.

$\begin{array}{lrrlrc}\text { Location } & \text { Depth } & \text { Shells } & \text { Location } & \text { Depth } & \text { Shells } \\ \text { Bramminge } & 70-80 \mathrm{~m} . & 1 & \text { Toftlund } & 115 \mathrm{~m} . & 1 \text { (frg.) } \\ \text { Gramby } & 82.66-83.76- & 1 & \text { Arnum (13) } & 28-40- & 1 \\ & 92.42-92.72- & 1 & & 53-83- & 2 \\ \text { Toftlund } & 75-100- & 2 & \text { Arnum }(25 \mathrm{~b}) & 62.7-62.9- & 12 \\ & 100-105- & 2 & & 95.0-95.3- & 3 \\ & 105-110- & 17 & & 104.3-107.5- & 1\end{array}$

Description. Most shells have more or less broken apertures, but the state of preservation is otherwise excellent.

Protoconch. About 21/2 smooth whorls of which the major part is exposed. Protoconch axis forms an angle of about $75^{\circ}$ to $80^{\circ}$ with the teleoconch axis. Diameter of protoconch 0.29 to $0.34 \mathrm{~mm}$.; mean of 7 shells: $0.31 \mathrm{~mm}$.

Teleoconch turreted, apical angle generally about $10^{\circ}$; it may, however, be about $15^{\circ}$ in extremely developed shells. Whorls commonly with 16 to 22 straight or slightly curved, oblique collabral ribs. The number of ribs varies from whorl to whorl and from shell to shell as shown in the table below. Very fine spiral striae are seen, with strong magnification in the interspaces between the ribs. Aperture round to rhomboid, outer lip practically conform with the collabral ribs, inner lip straight. No umbilicus. Base of the body whorl smooth with growth lines. The suture is formed at the lower termination of the collabral ribs.

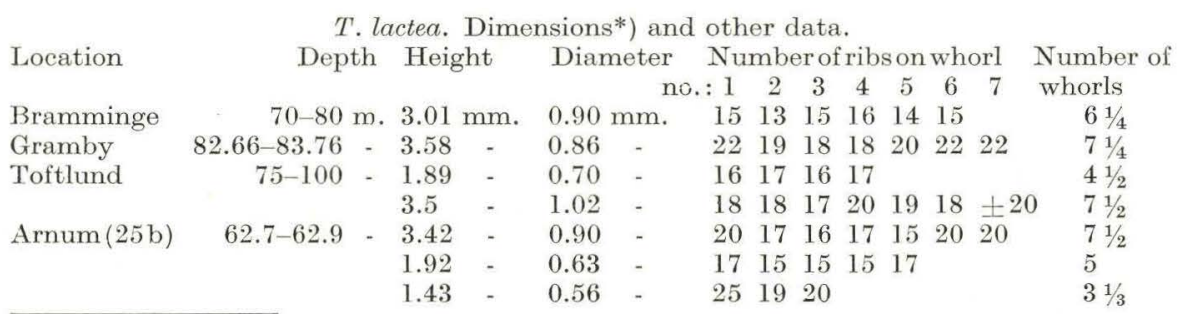

*) Dimensions of the best preserved shells have been measured. They are, however, approximate because the aperture is damaged a little in most shells. 
Variation. The table illustrates a tendency of more ribs being present on the initial whorl than on the two to four succeding whorls. From then on the number may increase slightly with size. A single broken shell shows 25 ribs on the fourth whorl. It displays otherwise the features of the species. The number of ribs is thus not constant.

The variability of number of ribs in T. costellata, T. lacta, and T. rufa shows that species of Turbonilla which are characterized by rib number only may not necessarily be valid.

Remarks. It is rather difficult to decide whether T. lactea is present in the fauna of the Aquitanian Basin. The writer is inclined to believe this in spite of the fact that Cossmann \& PEYRoT have referred their Turbonillae to other species. Turbonilla Falloti, T. multicostata and T. Saccoi (Conch. Néogén d. l'Aquit. 1918, pp. 143, 151, and 152) may be within the variation range of $T$. lactea. The presence of $T$. lactea in the Loire Basin supports the conjecture.

Distribution.

Recent: North Atlantic Ocean from Western Finmark to the Canaries.

Mediterranean.

Pliocene: Mediterranean Basin: Piacenziano, Astiano, upper Pliocene of Monte Mario.

Miocene: North Sea Basin: Belgium: Horizon of Houthaelen, Anversien. Germany: Hemmoor stage. Denmark: Arnum formation.

Loire Basin: middle Miocene.

\section{Turbonilla rufa (Philippi)}

Recent:

Plate 72, fig. 244 a-c.

1836. Melania rufa PHiLiper. Enum. Moll. Sic. 1, p. 156, pl. 9, fig. 7.

1853. Chemnitzia rufa Philmppi. Forbes \& Hanley. Brit. Moll. 3, p. 245, pl. 93, fig. 3-4.

1867. Odostomia rufa Philtppi. Jeftereys. Brit. Conch. 4, p. 162, 5, pl. 76, fig. 1.

1868. Turbonilla rufa Philippi. Weinkauff. Conch. d. Mittelmeeres. p. 211.

1878. Turbonilla rufa PHilippi. Sars. Moll. Reg. Arct. Norvegiae. p. 199, pl. 11, fig. 1.

1883. Turbonilla rufa Philippi sp. Bucquoy. Dautzenberg \& Dollfus. Moll. mar. du Roussillon. 1, p. 183, pl. 20, fig. 15.

1888. Chemnitzia rufa Mtg. Petersen. De skalb. Moll. etc. p. 74.

1932. Turbonilla rufa PhilipPi. Nobre. Moluscos mar. de Portugal, p. 210, pl. 38, fig. 23.

Fossil:

1848. Chemnitzia rufa PhiL. Woon. Monogr. Crag Moll. 1, p. 79, pl. 10, fig. 2.

1914. Turbonilla (Pyrgostelis) rufa Phil. sp. Ceruldi-Irelli. Fauna mal. mariana. p. 271 , pl. 23 , fig. $44-50$.

Original diagnosis. Testa aciculata, rufa, nitidissima, anfractibus explanatis, longitudinaliter plicatis, plicis rectis, interstitiis transversim striatis, labro columellari verticali. (PHILIPPI 1836).

Shell material.

$\begin{array}{lrllrc}\text { Location } & \text { Depth } & \text { Shells } & \text { Location } & \text { Depth } & \text { Shells } \\ \text { Bramminge } & 70-80 \mathrm{~m} . & 1 \mathrm{frg} . & \text { Toftlund } & 100-105 \mathrm{~m} . & 1 \\ \text { Gramby } & 82.66-83.76- & 2- & & 110-115- & 1 \mathrm{frg} . \\ & 84.66-87.16- & 1- & \text { Arnum }(13) & 53-83- & 3 \\ \text { Toftlund } & 75-100- & 3 & \text { Arnum }(25 \mathrm{~b}) & 62.7-62.9- & 2\end{array}$


Description.

Protoconch smooth, about 2 whorls, the greatest part of which is exposed. Protoconch axis and teleoconch axis meet at an angle of about $75^{\circ}$. Diameter of protoconch from 0.26 to $0.31 \mathrm{~mm}$.

Teleoconch turreted, apical angle 14 to $16^{\circ}$. Whorls with a varying number of straight, collabral ribs (from 16 to 32 per whorl as listed in the table below). Spiral ribs, 8 to 16 in number are seen in the collabral rib interspaces. The body whorl is slightly subangular at the periphery. The collabral ribs terminate at the periphery, while spiral ribs are more or less distinctly developed also on the base of the body whorl. Aperture not completely preserved in the shells available. The outer lip is obviously almost straight and conformable with the collabral ribs. Collumella straight. No umbilicus. Suture formed where the collabral ribs terminate on the preceding whorl.

T. rufa. Dimensions*) and other data.

\begin{tabular}{|c|c|c|c|c|c|c|c|c|c|}
\hline \multirow[t]{2}{*}{ Location } & \multirow[t]{2}{*}{ Depth } & \multirow[t]{2}{*}{ Height } & Diameter & \multicolumn{2}{|c|}{ Number } & \multicolumn{3}{|c|}{ of ribs on whorl } & \multirow{2}{*}{$\begin{array}{c}\text { Number of } \\
\text { whorls }\end{array}$} \\
\hline & & & & $: 1$ & 2 & 3 & 4 & 5 & \\
\hline Toftlund & $75-100 \mathrm{~m}$. & & & 32 & 27 & 27 & 28 & & 5 \\
\hline & $100-105$ & & & 18 & 16 & 19 & 20 & & $4^{1 / 2}$ \\
\hline 13) & $53-83-$ & $\begin{array}{l}2.12 \mathrm{~mm} \text {. } \\
1.68\end{array}$ & $\begin{array}{l}0.69 \mathrm{~mm} \text {. } \\
0.59\end{array}$ & $\begin{array}{l}25 \\
22\end{array}$ & $\begin{array}{l}23 \\
21\end{array}$ & $\begin{array}{l}22 \\
19\end{array}$ & $\begin{array}{l}23 \\
19\end{array}$ & 26 & $\begin{array}{ll}5 & 1 / 4 \\
4 & 1 \%\end{array}$ \\
\hline
\end{tabular}

Variation. There is obviously a marked variation in this species concerning the number of collabral ribs and spiral striae. It would be of considerable interest also to have recent shells investigated with regard to rib variation.

Remarks. Recent shells are generally reported to have fewer spiral ribs than the fossils here described. However, since this morphologic element is undoubtedly subject to considerable quantitative variation there seems to be no sound basis at present for referring the fossils to a different species.

Distribution.

Recent: North Atlantic Ocean from the Lofoten islands to Madeira and the Canaries. Mediterranean.

Pliocene: North Sea Basin: England: Coralline Crag.

Mediterranean Basin: Upper Pliocene of Monte Mario.

Miocene: North Sea Basin: Denmark: Arnum formation.

\section{Turbonilla pseudoterebralis (Sacco)}

Plate 72 , fig. 245 a-c.

1856. Turbonilla plicatula Brocc. Hörnes. D. foss. Moll. d. Tert.-Beckens v. Wien. 1, p. 503 , pl. 43 , fig. 33 .

1882. Turbonilla plicatula Brocc. von Koenen. D. Nordd. Mioc. u. s. Moll. f. p. 256, pl. 6, fig. 6.

1892. Pyrgolampros pseudoterebralis SAcco. I moll. terr. terz. d. Piemonte e d. Liguria. 11, p. 670 , pl. 2, fig. 94 .

(?)1918. Turbonilla (Pyrgolampros) pseudo-auricula (Grateloup). Cossmann \& Peyrot. Conch. Néogén. d. l'Aquit. p. 162, pl. 9, fig. 98-100.

1925. Turbonilla (Pyrgolampros) pseudoterebralis Sacco. KaUtsky. D. Mioc. v. Hemmoor u. Basbeck-Osten. p. 76, pl. 6, fig. 32 .

1944. Turbonilla (Pyrgolampros) $c f$. pseudo-auricula (Grateloup). Van Voorthuysen. Mioz. Gastr. a. d. Peelgebiet. p. 37, pro parte, pl. 13, fig. 9, 12.

*) Dimensions approximate due to the more or less broken apertures. The most incomplete shells were not measured. 
1945. Turbonilla (Pyrgolampros) pseudoterebralis SAcco. Glibert. Faune mal. du Mioe. de la Belgique 2, p. 60 , pl. 4, fig. 15 .

Original diagnosis. Testa turrita, subcrassa, albida, subnitens, interdum laeviter subscalarata. Anfractus subplani, ad suturam superam laeviter subinflati, subcingulati, suturis sat profundis disjuncti, longitudinaliter costulati. Costulae longitudinales, rotundatae, laeviter flexuosae, appropinquatae, numerosae, in anfractu ultimo 23-25 circiter, basim versus gradatim evanescentes. Apertura ovato-quadrangula. Labium externum simplex, intus profunde plurisulcatum; labium columellare intus uniplicatum. (SACCO 1892).

Shell material.

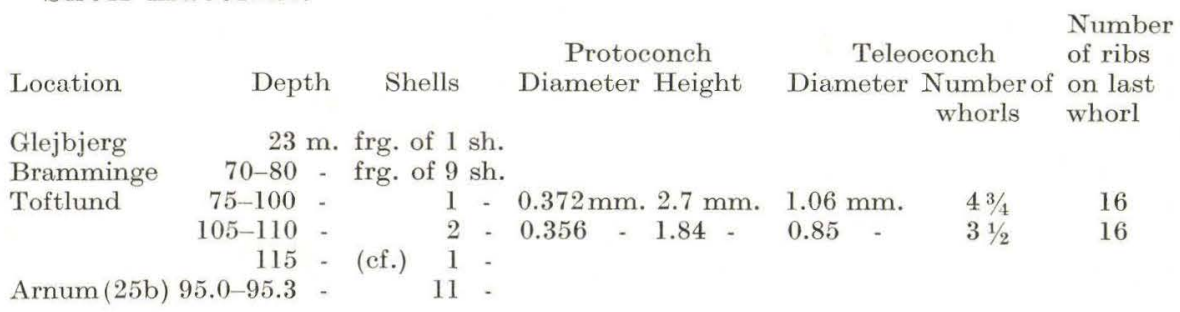

Description. Most of the shells are more or less broken or corroded. It is accordingly not possible to obtain measurements of true dimensions in these specimens. The largest of all the shells (Arnum) is only a little broken at the aperture; it may have been about $7.3 \mathrm{~mm}$. long and about $1.9 \mathrm{~mm}$. in diameter, and consists of $9^{1 / 3}$ adult whorls. The protoconch is corroded.

Protocon ch globular; nucleus relatively low, about $13 \frac{1}{4}$ to 2 smooth whorls. Teleoconch and protoconch axis form an angle of $60^{\circ}$ to $70^{\circ}$. Diameter about $0.36 \mathrm{~mm}$. Greater part of the shell exposed.

Teleoconch. Whorls flat sided to slightly concave a little above their middle part, where the rib interspaces occasionally exhibit a characteristic depression. Sculpture of more or less distinct collabral ribs developed by the wavy structure of the test. The ribs are rather irregular both concerning distinctness and place of occurrence on the different parts of the shell. Irregular spiral striae are occasionally found in the depression of the rib interspaces, or in the corresponding areas of the non-ribbed parts of the shells. Body whorl with subangular to round periphery and smooth base. Aperture oval rhomboid. Outer lip obviously sharp, columella slightly oblique with more or less pronounced fold at its junction with the shell base. No umbilicus.

Variability. The shells seem to be rather inconstant as to their sculptural elements, fold on columella etc. The shell material at hand does not, however, suggest more than one species since transitional forms and variation from whorl to whorl clearly indicate the wide variation range.

Remarks. Shells of this variable species have undoubtedly been referred to various specific categories. The synonymy includes the instances that are mostly obvious to the writer. The illustration of $T$. pseudo-auricula in CossmanN \& PeYrot's paper is unfortunately not sufficiently clear to warrant a final decision, while VAN VoorthuYSEN's photographs are excellent in this respect. (See also the following species).

Distribution.

Miocene: Aquitanian Basin: (?)Aquitanien, (?)Burdigalien. North Sea Basin: Belgium: Anversien. Holland (m.). 
Germany: Hemmoor and Dingden stages, Glimmerton (Banke Rasmussen 1956). Denmark: Arnum formation. Mediterranean Basin: Italy: Tortoniano.

Vienna Basin: Baden and Steinabrunn beds.

\title{
246. Turbonilla sp.
}

\author{
Plate 71, fig. 246.
}

1925. Turbonilla (Pyrgolampros) undulata von Koenen. KAUtsky. D. Mioc. v. Hemmoor u. Basbeck-Osten, p. 77, pl. 6, fig. 33 .

Shell material.

$\begin{array}{lrc}\text { Location } & \text { Depth } & \text { Shells } \\ \text { Bramminge } & 70-80 \mathrm{~m} . & 1 \mathrm{frg} . \\ \text { Gramby } & 82.66-83.76- & 1 \text { - } \\ \text { Toftlund } & 110-115- & 1\end{array}$

Description. The features of the shell surface are well preserved in the shells from Toftlund and Gramby, and the protoconch is preserved in the specimen from the latter locality.

Protoconch smooth, globular with flat nucleus. About 1 1/2 whorl, diameter : $0.372 \mathrm{~mm}$. Angle of about $65^{\circ}$ between protoconch and teleoconch axes.

Teleoconch turreted, apical angle about $15^{\circ}$. Spire almost smooth; suture rather shallow and distinct. There are occasional collabral undulations in the shell surface which in some cases have attained rib stage. A few irregular, delicate, spiral furrows are seen with strong magnification on the shell surface. Body whorl round-subangular at its periphery, base smooth. Apertural features unknown in detail. Columella with fold.

Remarks. Kautsky's shells and the present shells belong undoubtedly to the same species. It should be stated, however, that the morphologic features of the shells are sufficiently vague to make the determination of the species very difficult. The shells remind much of $T$. pseudoterebralis with respect to protoconch, columellar fold, and spiral furrows on the shell surface. The most remarkable difference is the absence of strong collabral ribs in the present shells.

It should be pointed out in this connection that VAN VOORTHUYSEN (1944) has reported variation from ribbed to almost smoot shells in his T. cf. pseudo-auricula, part of which has been referred to $T$. pseudoterebralis above. It is possible, therefore, that the present shells ought to be referred to T. pseudoterebralis which then has a wide, morphological variation range comparable with, for instance, the variation of Odostomia mutinensis discussed on page 319. T. undulata as described by Von Koenen (1882, p. 260, pl. 6, fig. 5) and by VAN VOORTHUYSEN (1944, p. 36, pl. 13, fig. 6-8) is probably not identical with $T$. undulata, described by KAUTSKY, and with the present shells.

Distribution.

Miocene: North Sea Basin: Germany: Hemmoor stage. Denmark: Arnum formation. 


\title{
Genus Pyramidella Lamarck 1799
}

\section{Pyramidella plicosa Bronn}

\author{
Plate 72, fig. 247.
}

1838. Pyramidella plicosa Bronn. Lethaea geogn. 2, p. 1026, pl. 90, fig. 24.

?1848. Pyramidella lovinuscula S. Wood. Monogr. Crag. Moll. 1, p. 77, pl. 9, fig. 2.

1856. Pyramidella plicosa Bronn. Hörnes. D. foss. Moll. d. Tert.-Beckens v. Wien. 1, p. 492 , pl. 46 , fig. 20 .

1892. Pyramidella plicosa Bronn. Sacco. I moll. d. terr. terz. d. Piemonte e d. Liguria. 11, p. 609 , pl. 1, fig. 53 .

1907. Pyramidella plicosa Bronn. Ravn. Molluskf. Jyll. Tert. p. 300, pl. 3, fig. 22.

1918. Pyramidella plicosa Bronn. Cossmann \& Peyrot. Conch. Néogén. d. l'Aquit. p. 95, pl. 9, fig. $8-10$.

1925. Pyramidella plicosa Bronn. Kautsky. D. Mioc. v. Hemmoor u. Basbeck-Osten. p. 72. 1940. Pyramidella plicosa Bronn. Sorgenfrer. Mar. Nedre-Mioc. i Klintinghoved p.Als p. 33.

1944. Pyramidella (Pyramidella) plicosa Bronn. Van Voorthuysen. Mioz. Gastr. a. d. Peelgebiet. p. 39, pl. 13, fig. 18-20.

1949. Pyramidella plicosa Bronn. Glibert. Gastr. du Mioc. moy, du bassin d. 1. Loire. 1, p. 197, pl. 12, fig. 11.

1952. Pyramidella (Pyramidella) plicosa Bronn. Glibert. Faune Mal, du Mioc. de la Belgique. 2 , p. 62, pl. 4, fig. 17 .

1956. Pyramidella (Pyramidella) plicosa Bronn. Banke Rasmussen. Upper Mioc. South Jutland p. 102, pl. 10, fig. 6 .

Essential features of original description. "Schale verlängert thurmförmig, glänzend glatt. Umgänge zahlreich, schmal, flach, durch eine wenig vertiefte Naht getrennt. Die äussre Lippe innen längsstreifig und gezähnt. (BRonN 1838).

Shell material.

$\begin{array}{lrrlrr}\text { Location } & \text { Depth } & \text { Shells } & \text { Location } & \text { Depth } & \text { Shells } \\ \text { Glejbjerg } & 53.50 \mathrm{~m} & 2 & \text { Toftlund } & 75-100 \mathrm{~m} . & 26 \\ & 53.75- & 3 & & 100-105- & 6 \\ \text { Bramminge } & 55- & 2 & & 105-110- & 18 \\ \text { Gramby } & 70-80- & 15 & & 110-115- & 5 \\ & 82.66-83.76- & 7 & & 115- & 12 \\ & 94.66-87.16- & 2 & \text { Arnum (13) } & 53-83- & 14 \\ & 90.42-92.72- & 1 & \text { Arnum (25 b) } & 62.7-62.9- & 4 \\ & 92.72-109.29- & 1 & & & \\ \end{array}$

Description.

Protoconch. Spire partly covered by first adult whorl. The protoconch is depressed, globular, with but little projecting nucleus. Shell surface smooth. About 1 to $1 \frac{1}{2}$ whorls. Protoconch diameter from 0.28 to $0.30 \mathrm{~mm}$. (see table below). Angle between protoconch and teleoconch axes about $45^{\circ}$ to $60^{\circ}$.

Teleocon ch. The shells from South Jutland display the generally accepted characteristics of the species, as illustrated by the figured specimen. Very fine spiral striae are found on the best preserved shells, visible under the microscope. Spiral striae of this kind have also been noticed in the shells from the Peel region by VAN VoORTHUYSEN (1944, p. 39). The internal striae or ribs on the outer lip mentioned by BRoNN and others have only been observed in a few shells. A peculiar feature is the breaking off of a narrow rim of the shell immediately beneath the suture. This is observed in most of the shells including the figured specimen; it appears to be a patologic phenomenon.

Variation. There is undoubtedly some variation in the submergence of the 
protoconch in the first adult whorl, the nucleus being completely covered in some shells and almost exposed in others. The degree of submergence depends of course in part on the angle between the teleoconch axis and the protoconch axis.

The internal ribs of the outer lip are certainly a very variable feature which should not be considered of decisive specific significance.

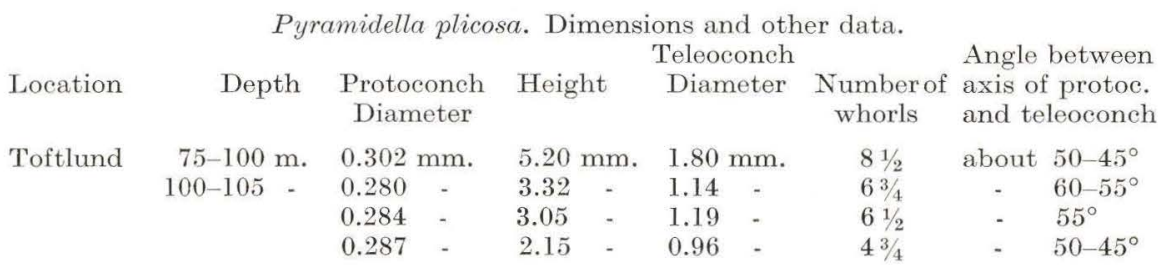

Distribution.

Pliocene: North Sea Basin: England: Coralline Crag.

Mediterranean Basin: Italy: Piacenziano, Astiano.

Miocene: Aquitanian Basin: Burdigalien, Helvétien.

North Sea Basin: Belgium: Anversien. Holland (m.).

Germany: Hemmoor stage, Glimmerton (Banke RasmusSEN 1956). Denmark: Klintinghoved clay, Arnum formation, Gram formation.

Mediterranean Basin: Italy: Elveziano, Tortoniano, Vienna Basin: Steinabrunn beds.

FAMILIA RINGICULIDAE FISCHER 1883

Genus Ringicula Deshayes 1838

248. Ringicula ventricosa (Sowerby)

Plate 72, fig. 248 a-b.

1825. Auricula ventricosa Sowerby. Min. Conch. 5, p. 99, pl. 465, fig. 1.

1848. Ringicula ventricosa J. Sow. Wood. Monogr. Crag. Moll. p. 22, pl. 4, fig. 1.

?1892. Ringicula auriculata var. ventricosa (Sow.). SAcco. I moll. d. terr. terz. d. Piemonte e d. Liguria 12, p. 25. pro parte (?).

?1925. Ringicula (Ringiculella) auriculata Men. var. ventricosa Sow. KaUtsky. D. Mioc. v. Hemmoor u. Basbeck-Osten. p. 197. pro parte (?).

1932. Ringicula (Ringiculella) major Grateloup. Peyrot. Conch. Néogén. d. l'Aquit. p. 138, pl. 11, fig. 1-3, 8, 10 .

1952. Ringicula (Ringiculina) ventricosa Sowerby sp. Glibert. Faune mal. du Mioc. de la Belgique. 2, p. 142, pl. 10, fig. 14.

Original diagnosis. Subovate, inflated, transversely striated; spire short pointed, base notched; three sharp plaits upon the columella; left lip callous, a thick border upon the right lip. (SOWERBY 1825).

Shell material.

$\begin{array}{lrc}\text { Location } & \text { Depth } & \text { Shells } \\ \text { Toftlund } & 115 \mathrm{~m} . & 1 \\ \text { Arnum }(25 \mathrm{~b}) & 95.0-95.3- & 2 \mathrm{frg} .\end{array}$


Description.

The shell from Toftlund is very well preserved, but lacks the protoconch.

Teleoconch. Shell globular, whorls convex. Eight to 9 distinct spiral linear furrows on the whorls of the spire and 20 spiral furrows on the body whorl. Aperture with very much thickened outer lip in which the lamination of the shell is clearly visible. Columella callous with two strong projecting folds, and parietal part of aperture with a third minor fold. Round notch at the junction between the outer lip and the columella.

Remarks. A characteristic feature of this species is the lamination on the outside of the outer lip by which the species is easily distinguished from strong specimens of R. buccinea. SACCO's and KAUTSKY's descriptions are not accompanied by illustrations and are accordingly less reliable references than the others cited.

\section{Distribution.}

Pliocene: North Sea Basin: England: Coralline Crag and Red Crag.

Mediterranean Basin: Italy: Piacenziano (?), Astiano (?).

Miocene: Aquitanian Basin: Burdigalien.

North Sea Basin: Belgium: Anversien. Germany: Hemmoor stage (?). Denmark: Arnum formation.

Mediterranean Basin: Italy: Elveziano (?), Tortoniano (?).

\section{Ringicula buccinea (Brocchi)}

Recent:

Plate 73, fig. 249 a-1.

1868. Ringicula buccinea Renieri. Weinkauff. Conch. d. Mittelmeeres 2. p. 204.

1892. Ringicula buccinea Brocchr. LocARD. Coq. mar. d. côtes d. France. p. 32.

1932. Ringicula buccinea (BRосснг). NoвRe. Moluscos mar. d. Portugal. p. 62, pl. 26, fig. 11.

Fossil:

1814. Voluta buccinea Brocchi. Conchiol. Foss. Subapennina. 2, p. 319, pl. 4, fig. 9.

1848. Ringicula buccinea J. Sow. Woon. Monogr. Crag. Moll. 1, p. 22, pl. 4, fig. 2.

1856. Ringicula buccinea Desh. Hörnes. D. foss. Moll. d. Tert.-Beckens v. Wien. 1. p. 86 , pl. 9, fig. $3-4$.

1892. Ringicula auriculata var. buccinea (BR.). SAcco. I moll. d. terr. terz. d. Piemonte e d. Liguria. 12, p. 20, pl. 1, fig. 7.

1907. Ringicula striata Philippi. Ravn. Molluskf. Jyll. Tert. p. 365, pl. 8, fig. 11.

1907. Ringicula auriculata MÉnard sp. Ravn. Ibid. p. 365.

1925. Ringicula (Ringiculella) auriculata Men. var. ventricosa Sow. Kautsky. D. Mioc. v. Hemmoor u. Basbeck-Osten, p. 197. pro parte (?).

1932. Ringicula (Ringiculella) buccinea Brocchi. Peyrot. Conch. Néogén. d. l'Aquit. p. 142, pl. 11, fig. $9 ; 14-15$.

1952. Ringicula (Ringiculina) buccinea Broccht sp. GutBert. Faune mal. du Mioe. de la Belgique. 2, p. 141, pl. 10, fig. 13.

Original diagnosis. Testa minuta, subovata, inflata, spira breviacuta, basi emarginata, columella plicis tribus acutis, labio sinistro expanso adnato, altero marginato (BRocchI 1814). 
Shell material.

\begin{tabular}{|c|c|c|c|c|c|c|c|}
\hline \multirow{2}{*}{$\begin{array}{l}\text { Location } \\
\text { Glejbjerg }\end{array}$} & \multicolumn{2}{|c|}{ Depth } & Shells & Location & \multicolumn{2}{|c|}{ Depth } & Shells \\
\hline & 23 & & 19 & Gramby & $90.42-92.72$ & $\mathrm{~m}$. & 9 \\
\hline & 25 & - & 17 & & $92.72-109.29$ & - & 9 \\
\hline & 32 & - & 1 (frg.) & & $110.86-121.51$ & - & 2 \\
\hline & 42 & - & 1 & Toftlund & $75-100$ & - & 1566 \\
\hline & 52 & - & 1 & & $100-105$ & - & 72 \\
\hline & 53 & - & 1 & & $105-110$ & - & 48 \\
\hline & 53.5 & - & 41 & & $110-115$ & - & 23 \\
\hline & 53.75 & - & 20 & & 115 & - & 20 \\
\hline & 54 & - & 1 & Arnum (13) & $28-40$ & - & 9 \\
\hline & 55 & - & 12 & & $53-83$ & - & 137 \\
\hline Bramminge & $70-80$ & - & 1641 & Arnum (25b) & $62.7-62.9$ & - & 64 \\
\hline Ribe & $113-114$ & - & 2 (frg.) & & $95.0-95.3$ & - & 12 \\
\hline Gramby & $82.16-82.66$ & - & $1-$ & & $101.4-104.3$ & - & 1 \\
\hline & $82.66-83.76$ & - & 25 & & $104.3-107.5$ & - & 9 \\
\hline & $84.66-87.16$ & - & 52 & & & & \\
\hline
\end{tabular}

\section{Description.}

Protoconch. About 1 1/2 smooth whorls, initial whorl almost wholly exposed, sinistral coil hardly developed.

Teleoconch. Spire ovoid globular. The whorl preceding the body whorl appears slightly gibbous in apertural aspect. Whorls with a greatly varying number of spiral furrows, late whorls occasionally almost smooth. From 6 to 17 spiral furrows on the body whorl. Indication of weak collabral folds or colour bands in a few specimens. Aperture auriculate with more or less thickened outer lip, and callous inner lip and columella. Two strong folds on the columella, and one less strong fold on the parietal lip. Anterior notch developed in shells with callous apertural margins.

Variation. This species varies considerably with respect to shape of shell, number of spiral furrows, and shape of the aperture.

546 specimens from Toftlund $(75-100 \mathrm{~m}$.) have been thoroughly examined regarding height of the shell $(H)$, diameter at the aperture $(D)$, height of aperture, thickness of outer lip $(l)$, number of spiral furrows on the individual whorls, collabral ornamentation, etc.

The $H / D$ ratios were calculated and related to shell height. However, since $D$ includes the variably thickened outer lip of the aperture it does not give a true figure for the diameter of the shell, which is more adequately expressed by $D-\frac{1}{2} l$, and the ratio $\frac{H}{D-\frac{1}{2} l}$ is accordingly a better indication of the shape of the shell than $\frac{H}{D}$. The following table gives the mean values of the two ratios for different size groups of shells from Toftlund $75-100 \mathrm{~m}$.

\begin{tabular}{|c|c|c|c|c|c|c|}
\hline Group & $\begin{array}{l}\text { Height } \\
\text { mm. }\end{array}$ & $\begin{array}{c}\text { Number of } \\
\text { shells }\end{array}$ & $\frac{H}{D}$ mean valu & & $\frac{H}{D-\frac{1}{2} l}$ mean valu & \\
\hline A & $2.50-2.99$ & 52 & $1.4662 \mp 0.0198$ & $\begin{array}{l}1.4464 \\
1.4860\end{array}$ & $1.598 \mp 0.02196$ & $\begin{array}{l}1.5760 \\
1.6200\end{array}$ \\
\hline B & $3.00-3.49$ & 177 & $1.4638 \mp 0.01071$ & $\begin{array}{l}1.4531 \\
1.4745\end{array}$ & $1.6136 \mp 0.01255$ & $\begin{array}{l}1.6010 \\
1.6262\end{array}$ \\
\hline $\mathrm{C}$ & $3.50-3.99$ & 253 & $1.4724 \mp 0.00975$ & $\begin{array}{l}1.4627 \\
1.4822\end{array}$ & $1.6389 \mp 0.01189$ & $\begin{array}{l}1.6270 \\
1.6508\end{array}$ \\
\hline $\mathrm{D}$ & $4.00-4.49$ & 59 & $1.4864 \mp 0.0195$ & $\begin{array}{l}1.4669 \\
1.5059\end{array}$ & $1.6573 \mp 0.0226$ & $\begin{array}{l}1.6347 \\
1.6799\end{array}$ \\
\hline
\end{tabular}




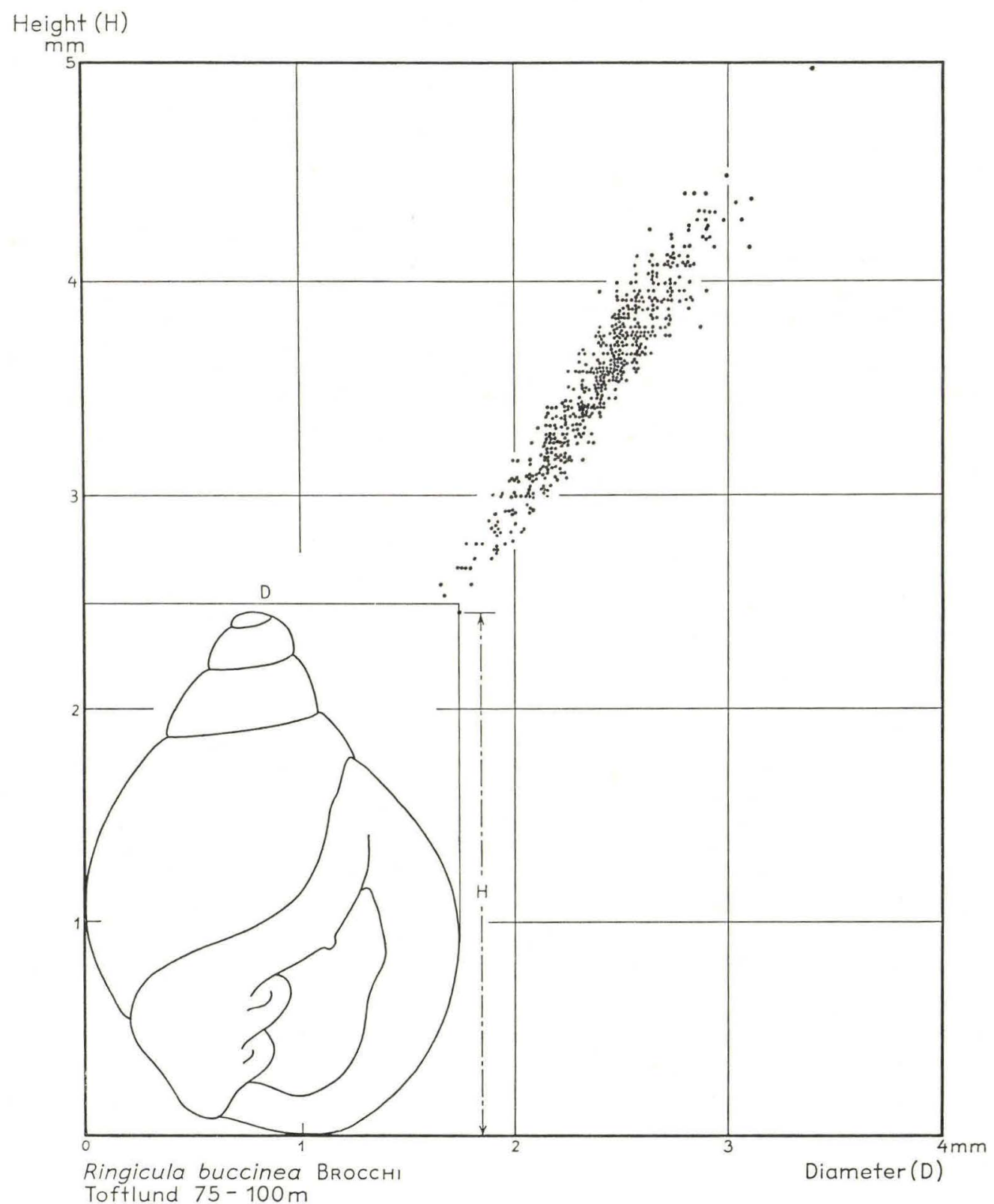

Fig. 20. 


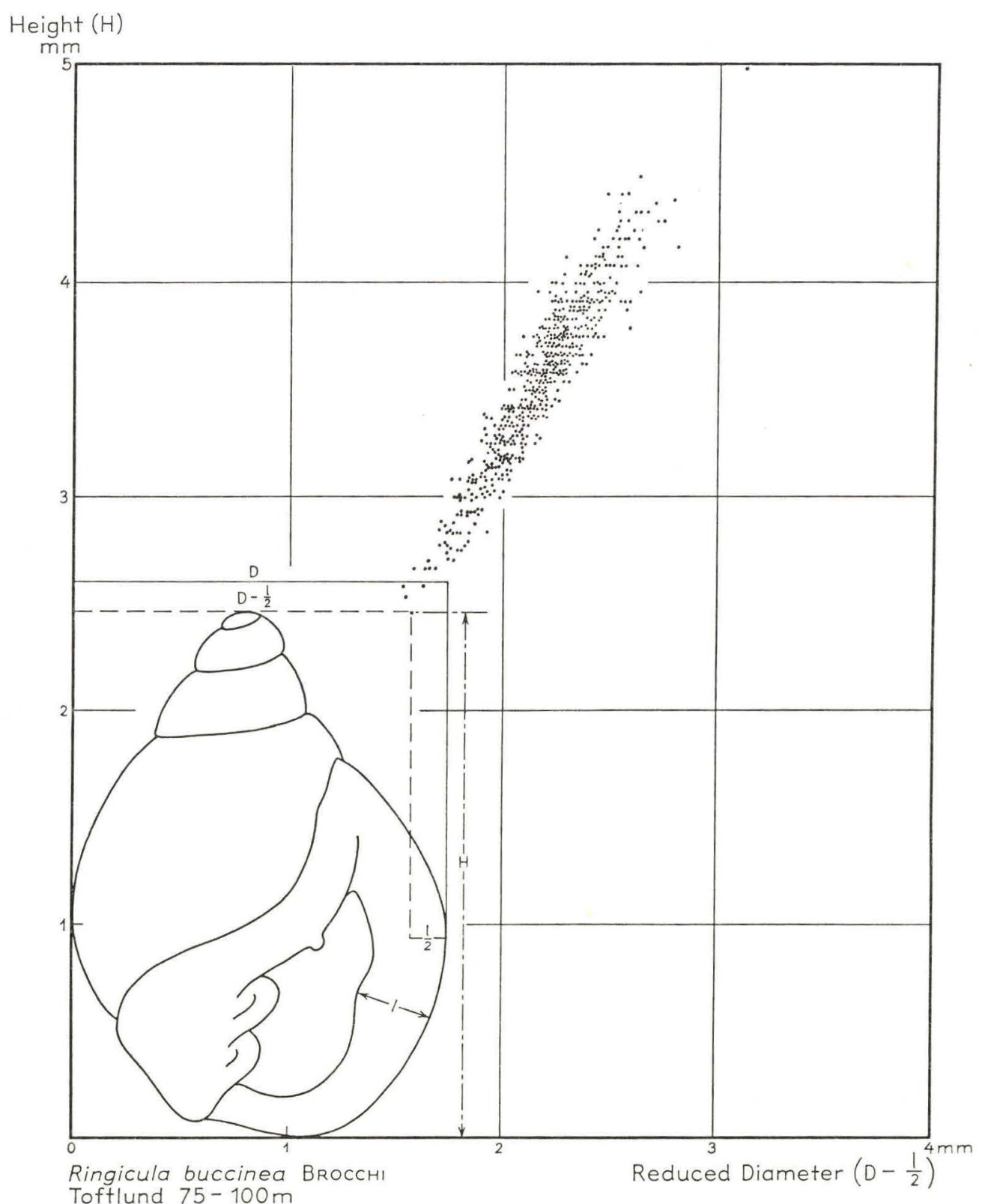

Fig. 21. 


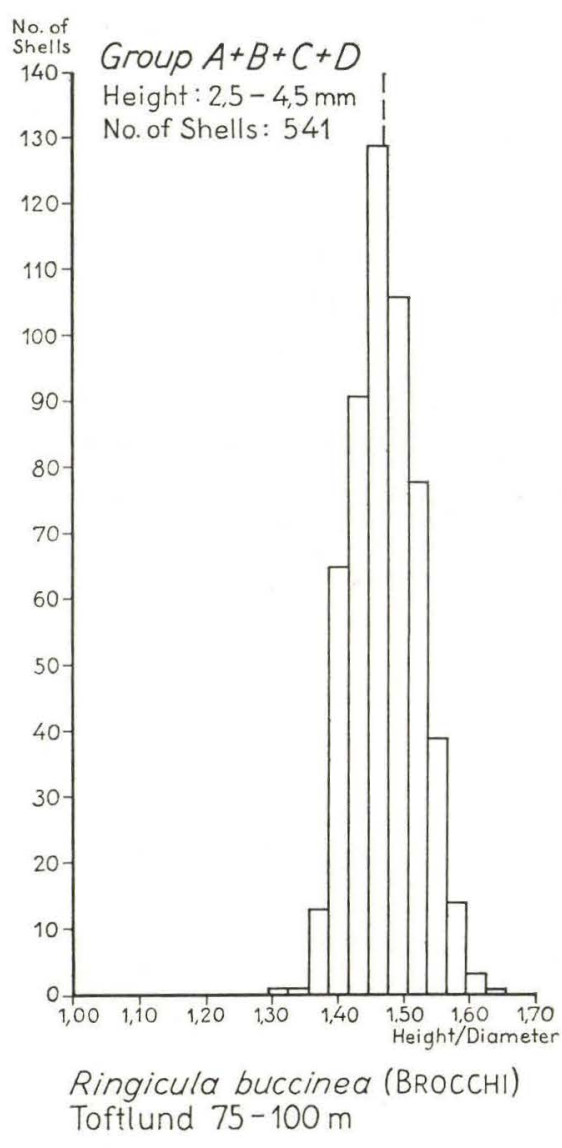

Fig. 22.

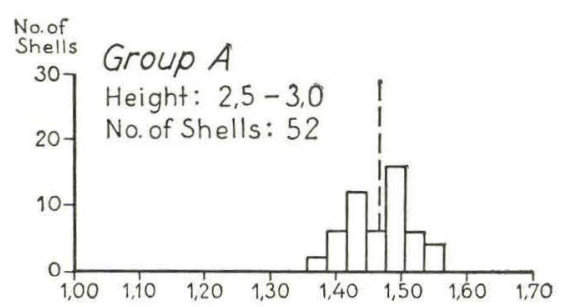

707 Group B

Height: $3,0-3,5 \mathrm{~mm}$

No. of Shells: 177

$60-$

$50-$

$40-$
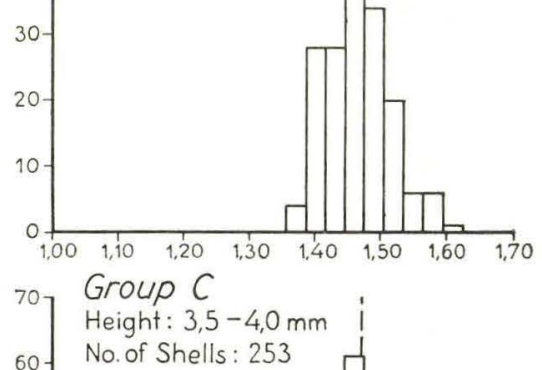

60- No. of Shells : 253
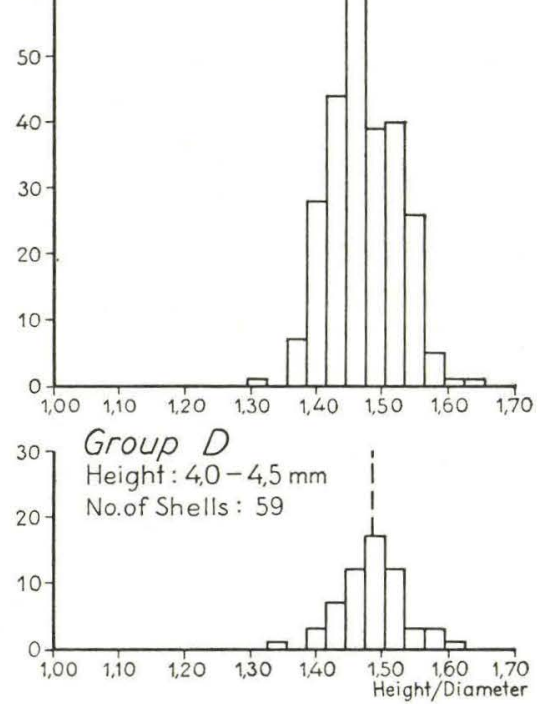

Ringicula buccinea (BRocCHI) Toftlund 75-100 m 


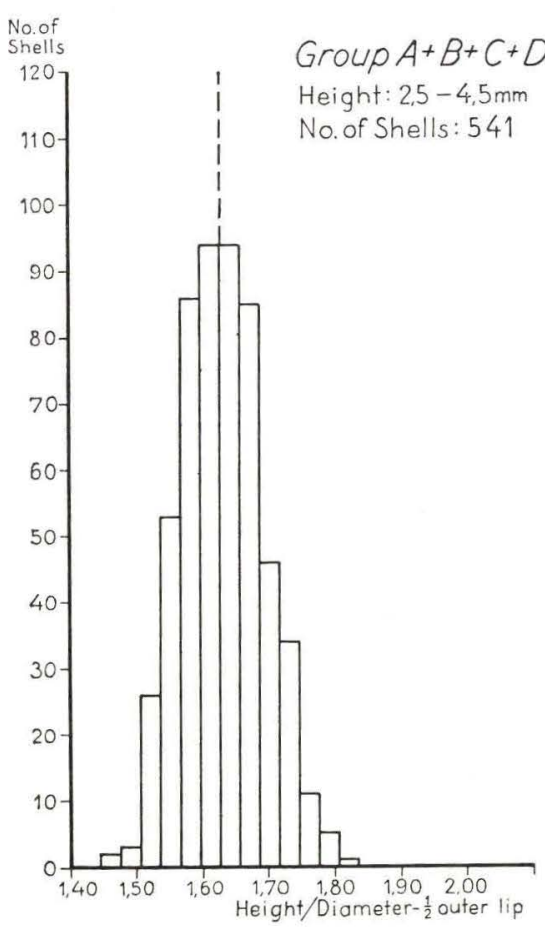

Ringicula buccinea (BROCCHI) Toftlund 75-100m
No.of
Shells
40

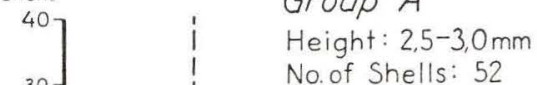

No. of Shells: 52

Fig. 23.
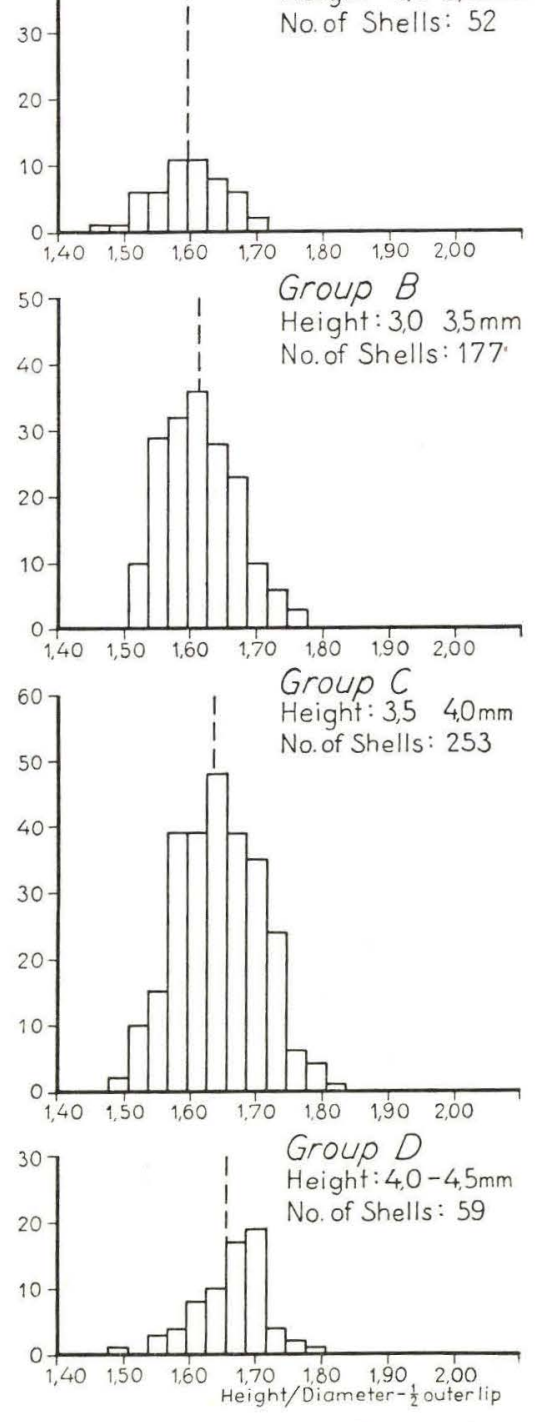

Ringicula buccinea (BRocCHI) Toftlund $75-100 \mathrm{~m}$ 
The table shows that $\frac{H}{D-\frac{1}{2} l}$ increases slightly with growth of the shell while $\frac{H}{D}$ is practically constant. This means that the slight increase of the shell height during growth is accompanied by simultaneous thickening of the outer lip.

The graphs fig. 20-23 illustrate the variation of the entire measured shell material.

It appears from the examination of the shells that it is impossible to differentiate more than one species. However, the collabrally sculptured specimens, and some other extreme types would undoubtedly have been separated as independant species by some workers if only a smaller number of specimens were available, and transitional types consequently were lacking.

The number of spiral furrows shows no apparent correlation with the size or shape of the shell, or with the number of whorls. Similarly the height of the aperture did not permit any significant deduction. Plate 73, fig. $249 \mathrm{a}-\mathrm{m}$ show some of the main shell types; it is evident from them that imponderable shell features contribute to a much wider variation range than could be demonstrated by the measured dimensions.

Remarks. It is rather difficult to define specific shell features which are sufficiently constant to serve as discriminating criteria in this species. The globular shape of the shell, and the slight gibbousity of the penultimate whorl seem to be of some significance.

Distribution.

Recent: North Atlantic Ocean: from the Bay of Biscay to Madeira and the Canaries. The Mediterranean.

Pliocene: North Sea Basin: England: Coralline Crag and Red Crag.

Mediterranean Basin: Italy: Piacenziano, Astiano.

Miocene: Aquitanian Basin: Helvétien.

North Sea Basin: Belgium: Boldérien, Anversien. Germany: Hemmoor stage (?), Reinbek stage (R. auriculata GotTsche 1878), Glimmerton (R. auriculata BANKE Rasmussen 1956). Denmark: Arnum formation.

Mediterranean Basin: Italy: Elveziano(?), Tortoniano.

Vienna Basin: Grund, Baden.

250. Ringicula Ravni nov. sp.

Plate 73, fig. 250 a-c.

Diagnosis. Small Ringicula with regular, turreted-ovoid spire. Sculpture of about 10 spiral furrows on the exposed part of the initial teleoconch whorl. Furrows number 2 or 3 to number 5 or 6 from the adapical suture become generally obsolete on succeeding whorls leaving a smooth belt on upper part of the whorl. The body whorl has 8 to 13 furrows below the smooth belt. Aperture moderately callous, height of aperture about ${ }^{4} / 7$ of entire shell height.

Holotype: Geological Survey of Denmark. File no. 150.9. b. Toftlund 
110-115 m. (Plate 73, fig. 250 a-c). Dimensions of Holotype: height $2.76 \mathrm{~mm}$., diameter $1.64 \mathrm{~mm}$., $1 \frac{1}{2}$ protoconch whorls and 3 teleoconch whorls.

Derivatio nominis. The species is dedicated to the late J.P.J.RAvN who was the leading paleontologist in Denmark for half a century, and contributed valuable papers on the Tertiary of Denmark and its fauna.

Shell material.

$\begin{array}{lrrlrc}\text { Location } & \text { Depth } & \text { Shells } & \text { Loeation } & \text { Depth } & \text { Shells } \\ \text { Toftlund } & 105-110 \mathrm{~m} . & 142 & \text { Arnum }(13) & 83-94 \mathrm{~m} . & 1 \\ & 110-115- & 58 & \text { Arnum }(25 \mathrm{~b}) & 101-104.3- & 2 \\ & 115- & 13 & & 104.3-107.5- & 5\end{array}$

Description. Most shells are fragmentary but otherwise well preserved.

Protoconch. About 1 1/2 smooth, helicoid whorls. Hardly any indication of initial sinistral coil.

Teleoconch. To the diagnosis may be added: Suture occasionally relatively deep, developed at about the 4th to 5th spiral furrow below the smooth belt of the preceding whorl. Body whorl often completely smooth in adult shells (from a size of about 4 to 5 teleoconch whorls). Aperture with two strong columellar folds, one weaker parietal fold, and moderate abapical notch. The following table gives dimensions and sculptural features of a few well preserved specimens.

Ringicula Ravni nov. sp. Dimensions and other data.

\begin{tabular}{|c|c|c|c|c|}
\hline $\begin{array}{l}\text { Height } \\
(H) \mathrm{mm} .\end{array}$ & $\begin{array}{l}\text { Diameter } \\
\text { (D) } \mathrm{mm} \text {. }\end{array}$ & $H / D$ & Number of whorls & $\begin{array}{c}\text { Spirals on body } \\
\text { whorl } \\
\text { at suture }+ \text { below } \\
\text { smooth belt }\end{array}$ \\
\hline 2.21 & 1.37 & 1.62 & $23 / 4$ & $3+12$ \\
\hline 2.56 & 1.56 & 1.64 & 3 & $1+13$ \\
\hline 2.66 & 1.58 & 1.68 & 3 & 13 \\
\hline 2.67 & 1.62 & 1.65 & $31 / 4$ & $2+11$ \\
\hline 2.87 & 1.61 & 1.78 & $31 / 4$ & $2+11$ \\
\hline 2.79 & 1.65 & 1.69 & $31 / 4$ & $1+10$ \\
\hline 2.86 & 1.76 & 1.62 & $31 / 2$ & $2+10$ \\
\hline 3.44 & 2.04 & 1.69 & $33 / 4$ & $1+11$ \\
\hline 3.69 & 2.10 & 1.75 & $33 / 4$ & corroded \\
\hline 3.91 & 2.28 & 1.72 & $3^{3 / 4}$ & $1+11$ \\
\hline 3.99 & 2.50 & 1.62 & 4 & $1+11$ \\
\hline 3.87 & 2.15 & 1.80 & $41 / 4$ & 2 \\
\hline 3.81 & 2.32 & 1.64 & 4 & smooth \\
\hline 4.15 & 2.44 & 1.80 & $43 / 4$ & - \\
\hline 5.15 & 3.17 & 1.62 & $41 / 2$ & $0+8$ \\
\hline
\end{tabular}

Remarks. This species is distinct from $R$. buccinea on account of its more slender spire, as illustrated by the $H / D$ ratios of the two species, and its sculpture. The spire is not at all gibbous in $R$. Ravni, and a very characteristic feature is the smooth belt below the suture. $R$. Ravni is possibly related to $R$. acutior MonLet and R. Tournoueri MonLet which both have a rather turreted spire. $R$. acutior is, however, reported to be smooth, and the spiral ornamentation in $R$. Tournoueri is somewhat different from that of $R$. Ravni since the characteristic smooth belt has not been mentioned by PEYRoT in his description of R. Tournoueri (see PEYrot 1932, Conch. Néogén. ete. p. 141, pl. 11, fig. 16-17 and p. 143, pl. 11, fig. 7, 11-13, 18-25, 37, 54, 61).

Distribution.

Miocene: North Sea Basin: Denmark: Arnum formation. 


\title{
Genus Cylichna Lovén 1847
}

\section{Cylichna cf. cylindracea (Pennant)}

Recent:

\author{
Plate 74, fig. 251 a-c.
}

1777. Bulla cylindracea Pennant. British Zoology. 4, p. 117, pl. 70, fig. 85.

1863. Cylichna cylindracea Pennant. Forbes \& Hanley. Brit. Moll. 3, p. 508, pl. 114 B, fig. 6 .

1867. Cylichna cylindracea Pennant. Jeffreys. Brit. Conch. 4, p. 415, pl. 93, fig. 4.

1868. Cylichna cylindracea Pennant. Weinkauff. Conch. d. Mittelmeeres. 2, p. 194.

1878. Cylichna cylindracea Penn. Sars. Moll. Reg. Aret. Norvegiae. p. 283, pl. 17, fig. 12.

1886. Cylichna cylindracea Pennant $s p$. Bucquoy, Dautzenberg \& Dollfus. Moll. mar. du Roussillon. 1, p. 521, pl. 64, fig. 1-3.

1888. Cylichna cylindracea Penn. Petersen. De skalb. Moll. etc. p. 78.

1892. Cylichna cylindracea Pennant. Locard. Coq. mar. d. côtes d. France. p. 25, fig. 12.

1932. Cylichna cylindracea (Pennant). Nobre. Moluscos mar. de Portugal. p. 56, pl. 26, fig. 6 .

Fossil:

?1848. Bulla cylindracea Penn. Wood. Monogr. Crag. Moll. 1, p. 175, pl. 21, p. 1.

1856. Bulla convoluta Broc. Hörnes. D. foss. Moll. d. Tert. Beckens v. Wien. p. 623, pl. 50 , fig. 7 .

1897. Bulla cylindracea Pennant var. convoluta Sacco. I moll. d. terr. terz. d. Piemonte e d. Liguria. 22, p. 49, pl. 4, fig. 8-10.

1907. Cylichna cylindracea Pennant sp. Ravn. Molluskf. Jyll. Tert. p. 367, pl. 8, fig. 15 .

1910. Bullinella cylindracea Pennt. sp. Ceruldi-Ireldi. Fauna mal. mariana. p. 37, pl. 4, fig. 11-13.

1914. Cylichna cylindracea Penn. sp. Grips. Über eine u. mioz. Moll. f. v. Itzehoe. p. 36.

1925. Bullinella cylindracea Penn. Kautsky. D. Mioc. v. Hemmoor u. Basbeck-Osten. p. 198, pro parte.

1940. Bullinella cylindracea Penn. Sorgenfrer. Mar. Nedre-Mioc. i Klintinghoved p. Als. p. 58 , pl. 6 , fig. 20 .

1952. Cylichna (Cylichna) cylindracea Pennant sp. Glibert. Faune mal. du Mioc. de la Belgique. 2, p. 145, pl. 10, fig. 15.

1956. Cylichna (Cylichna) cylindracea (Pennant 1777) Banke Rasmussen. Upper Mioc. South Jutland. p. 104, pl. 10, fig. 4.

Original diagnosis. White, cylindric, a little umbilicated at the end, about twice the size of a grain of wheat (PENNANT 1777).

Shell material.

$\begin{array}{lrc}\text { Location } & \text { Depth } & \text { Shells } \\ \text { Toftlund } & 110-115 \mathrm{~m} . & 2 \\ \text { Arnum (13) } & 53-83- & 1 \\ \text { Arnum(25b) } & 62.7-62.9- & 11\end{array}$

Description.

All shells are small juvenile specimens. The teleoconch is cylindrical with a relatively strong test. The shell surface is glossy with growth lines, and very delicate spiral striae are found particularly adjacent to the two ends. Narrow umbilicus at the apex. Aperture narrow, apical part of the outer lip projecting above the preceding whorl. Columella short, slightly thickened.

The largest shell from Arnum (25 b) 62.7-62.9 m. is $2.07 \mathrm{~mm}$. high and $0.96 \mathrm{~mm}$. in diameter.

Remarks. The shells are referred to $C$. cylindracea with some hesitation, mainly because of the juvenile stage of the shells. The shells display otherwise very close resemblence with recent shells of $C$. cylindracea from the Kattegat.

It seems rather probable that the shells referred to $C$. cylindracea by different 
authors are not a homogenous group. This assumption is based on a study of literature and the great variation range of recent species of the genus Cylichna (Lemche 1948), p. 41 etc.). The paleobiological and paleoecological evidence of C. cylindracea is accordingly rather poor.

Distribution. (The following record based on the papers in the list of synonymy is probably not fully reliable, see remarks above).

Recent: North Atlantic Ocean from Lofoten to Madeira, the Canaries and the Azores, and Mediterranean.

Pliocene: North Sea Basin: England: Coralline Crag and Red Crag.

Mediterranean Basin: Italy: Piacenziano, Astiano, Upper Pliocene of Monte Mario.

Miocene: North Sea Basin: Belgium: Horizon of Houthaelen, Anversien. Germany: Vierlande stage, Hemmoor stage, Reinbek stage (GotTsche 1878), Glimmerton (BANKE Rasmussen 1956). Denmark: Klintinghoved clay, and Arnum and Gram formations.

Mediterranean Basin: Italy: Elveziano, Tortoniano. Vienna Basin: Steinabrunn beds.

\section{Gylichna Bellardii (von Koenen)}

1882. Bulla Bellardii von Koenen. D. Nordd. Mioc. u. s. Moll. f. 2, p. 346, pl. 7, fig. 10. 1925. Acera Bellardi v. Koen. Kautsky. D. Mioc. v. Hemmoor u. Basbeck-Osten. p. 198, pl. 12, fig. $26-27$.

Essential features of original description. Nur die zwei letzten Windungen sind sichtbar. Die Innenlippe ist oben und noch mehr unten verdickt. Die Spindel ist stark gedreht und trägt, abgesehen von dem recht scharf abgesetzten vorderen Rande, noch eine rundliche Falte. Die Schale ist bedeckt von zahlreichen, feinen, flachen Spiralen, welche durch die Anwachsstreifen gezackt erscheinen und auf dem unteren Drittel der Schale und auch dicht unter der Kante deutlicher hervortreten, aber gleich unter dieser Stelle bis zur stärksten Wölbung ganz undeutlich werden (VON KOENEN 1882).

Shell material.

$\begin{array}{lrc}\text { Location } & \text { Depth } & \text { Shells } \\ \text { Bramminge } & 70-80 \mathrm{~m} . & 2 \\ \text { Ribe } & 113-114- & 1 \text { (frg.) } \\ \text { Toftlund } & 115- & 2\end{array}$

Description.

Teleoconch cylindrical with strong test. Convex apex with narrow perforation representing the apical umbilicus. Spire entirely concealed, only last whorl exposed. Sculpture of delicate collabral threads crossed by closely spaced spiral riblets which are absent on a belt somewhat below the apical end. Collabral threads particularly conspicuous in the interspaces of the spiral riblets. The two sculptural elements may occasionally form a reticulate pattern. Apical 
corner of the aperture, and the columella, callous. Columella with two folds. The specimens available are fragmentary. The best preserved shell from Bramminge may originally have been $4.6 \mathrm{~mm}$. high and $2.5 \mathrm{~mm}$. wide.

Remarks. Pseudavene tauroglandula (SACCO 1897, p. 39, pl. 3, fig. 66-69) might be related to $C$. Bellardi. The poor illustrations offer, however, no possibility of a final judgment in this connection.

Distribution.

Miocene: North Sea Basin: Germany: Hemmoor stage. Denmark: Arnum formation.

\section{Genus Rhizorus Montfort 1810}

\section{Rhizorus acuminatus (Bruguiére)}

Recent:

Plate 74, fig. 253 a-c.

1792. Bulla acuminata Brugutére. Hist. Nat. d. Vers. 6, p. 376.

1853. Ovula ? acuminata Brugutére. Forbes \& Hanley. Brit. Moll. 3, p. 500, pl. 114 B, fig. 3 .

1867. Cylichna acuminata Bruguit́re. Jeffreys. Brit. Conch. 4, p. 411; 5, pl. 93, fig. 1.

1868. Volvula acuminata Bruguí́re. Weinkauff. Conch. d. Mittelmeeres. 2, p. 202.

1886. Volvula acuminata Bruguíre sp. Bucquoy, Dautzenberg \& Doltifus. Moll. mar. du Roussillon. 1, p. 534, pl. 64, fig. 4-5.

1888. Volvula acuminata Brug. Petersen. De skalb. Moll. etc. p. 79.

1892. Volvula acuminata Brug. Locard. Coq. mar. d. côtes d. France. p. 30.

Fossil:

1848. Bulla acuminata Brug. Wood. Monogr. Crag. Moll. 1, p. 174, pl. 21 fig. 7.

1897. Volvula acuminata Brug. SAcco. I moll. d. terr. terz. d. Piemonte e d. Liguria. 22, p. 42, pl. 3, fig. 91-93.

1907. Volvula acuminata Bruguitere sp. Ravn. Molluskf. Jyll. Tert. p. 366, pl.8, fig. 12.

1910. Volvula acuminata Brug. sp. Cerdlir-Irelli. Fauna mal. mariana. p. 35, pl. 3, fig. $75-78$.

1925. Volvulella acuminata Brug. Kautsky. D. Mioc. v. Hemmoor u. Basbeck-Osten. p. 200.

1932. Volvulella acuta (Grateloup). Peyrot. Conch. Néogén. d. l'Aquit. p. 211, pl. 18, fig. $43-44$.

1952. Volvula acuminata Bruguière sp. Glibert. Faune mal. du Mioc. de la Belgique. 2, p. 144.

Original diagnosis. Bulla, testa oblonga ovata laevi, apertura superne coarctata, vertice acuminato. (BRUGUIÈRE 1792).

Shell material.

$\begin{array}{lrc}\text { Location } & \text { Depth } & \text { Shells } \\ \text { Glejbjerg } & 23 \mathrm{~m} \text {. } & 4 \\ & 25- & 1 \\ & 32- & 3 \\ & 38- & 1 \\ & 53- & 2 \\ & 53.5- & 7 \\ \text { Bramminge } & 53.75- & 1 \\ \text { Gramby } & 55-80-80- & 1 \\ & 81.86-82.16- & 45 \\ & 82.66-83.76- & 21 \\ \text { Toftlund } & 84.66-87.16- & 5 \\ & 75-100- & 161\end{array}$

$\begin{array}{lrr}\text { Location } & \text { Depth } & \text { Shells } \\ \text { Toftlund } & 100-105 \mathrm{~m} . & 24 \\ & 105-110- & 105 \\ & 110-115- & 28 \\ & 115- & 11 \\ \text { Arnum (13) } & 28-40- & 3 \\ & 53-83- & 27 \\ \text { Arnum (25 b) } & 83-94- & 2 \\ & 62.7-62.9- & 8 \\ & 95.0-95.3- & 10 \\ 101.0-104.3- & 1 \\ & 104.3-107.5- & 1 \\ & 107.5- & 1\end{array}$


Description.

The accompanying illustrations show the typical development of the shell. The only sculptural elements are growth lines and spiral furrows, which are found particularly on the apical and abapical ends of the shell. The range of morphological variation is rather narrow. The largest shell from Toftlund $75-100 \mathrm{~m}$. is $6.16 \mathrm{~mm}$. high and $2.40 \mathrm{~mm}$. in diameter.

Distribution.

Recent: North Atlantic Ocean from Norway to Biscay and the Mediterranean.

Pliocene: North Sea Basin: England. Coralline Crag.

Mediterranean Basin: Italy: Piacenziano, Astiano, upper Pliocene of Monte Mario.

Miocene: Aquitanian Basin: Aquitanien, Burdigalien, Helvétien. North Sea Basin: Belgium: Horizon of Houthaelen, Anversien. Germany: Hemmoor stage, Reinbek stage (Gottsche 1878), Glimmerton (Banke Rasmussen 1956). Denmark: Arnum formation.

\section{Genus Retusa Brown 1827}

\section{Retusa elongata (Eichwald)}

Plate 74, fig. 254 a-c.

1830. Bulla elongata EichwaId. Naturhist. Skizze ete. p. 214.

1853. Bulla elongata Eichwatd. Lethaea Rossica p. 305, pl. 11, fig. 15.

1856. Bulla conulus Desh. Hörnes. D. foss. Moll. d. Tert.-Beckens v. Wien. 1, p. 620, pl. 50, fig. 4.

1897. Cylichnina elongata (EICHW.) SACCo. I moll. d. terr. terz. d. Piemonte e d. Liguria. 22. p. 50, pl. 4, fig. 13-14.

1907. Cylichna elongata EichWaLd sp. Ravn. Molluskf. Jyll. Tert. p. 366.

1925. Bullinella (Cylichnina) elongata Eichw. KaUtsky. D. Mioc. v. Hemmoor u. BasbeckOsten. p. 199.

1932. Bullinella (Cylichnina) elongata Eichwald. Peyrot. Conch. Néogén. d. l'Aquit. p. 190, pl. 13, fig. 52-54.

1952. Retusa (Cylichnina) elongata Eichwats sp. Gtrbert. Faune mal. du Mioc. de la Belgique. 2, p. 143, pl. 10, fig. 18.

1956. Retusa (Cylichnina) elongata (Eichwald 1830). Banke Rasmussen. Upper Mioc. South Jutland. p. 103, pl. 10, fig. 3.

Original diagnosis. Testa elongata, ad aperturam subtus tumida, versus apicem sensim attenuata, laevis, umbilicata, raro 2 lin. longa. (EICHWALd 1830).

Shell material.

$\begin{array}{lrc}\text { Location } & \text { Depth } & \text { Shells } \\ \text { Glejbjerg } & 25 \mathrm{~m} . & 2 \\ & 32- & 1 \\ & 53.5- & 2 \\ 53.75- & 1 \\ \text { Bramminge } & 55- & 1 \\ \text { Gramby } & 70-80- & 8 \\ & 82.66-83.76- & 7 \\ & 84.66-87.16- & 5 \\ & 90.42-92.76- & 2 \\ 109.29-110.86 & - & 1\end{array}$

$\begin{array}{lrc}\text { Location } & \text { Depth } & \text { Shells } \\ \text { Toftlund } & 75-100 \mathrm{~m} . & 20 \\ & 100-105- & 7 \\ & 105-110- & 15 \\ & 110-115- & 16 \\ & 115- & 14 \\ \text { Arnum (13) } & 53-83- & 25 \\ \text { Arnum (25b) } & 62.7-62.9- & 7 \\ & 95.0-95.3- & 8 \\ & 104.3-107.5 & 1\end{array}$


Description.

The shell is more or less conical with a glossy surface on which growth lines and spiral furrows represent the main sculptural features. The spiral furrows may occasionally be absent on the middle part of the shell. Apical end with deep umbilicus which is generally delimited by a relatively sharp edge. Occasionally also deep umbilicus at the abapical end of the shell. The shape of the shell, as well as the number and spacing of the spiral furrows varies somewhat.

The largest shell (Toftlund $75-100 \mathrm{~m}$.) is $3.21 \mathrm{~mm}$. high and $1.56 \mathrm{~mm}$. in diameter.

Remarks. It is sometimes difficult to distinguish smooth forms, without or with only indistinct spiral striae, from $R$. umbilicata. However, a sharp edge at the apical umbilicus, spiral furrows at the ends, or an abapical umbilicus suggest $R$. elongata.

Distribution.

Pliocene: Mediterranean Basin: Italy: Piacenziano, Astiano.

Miocene: Aquitanian Basin: Burdigalien, Helvétien.

North Sea Basin: Belgium: Anversien. Germany: Hemmoor stage, Glimmerton (Banke Rasuussen 1956). Denmark: Arnum and Gram formations.

Mediterranean Basin: Italy: Elveziano, Tortoniano. Vienna Basin: Steinabrunn and Baden beds.

\section{Retusa umbilicata (Montaǵu)}

Recent:

Plate 75, fig. 255 a-c.

1803. Bulla umbilicata Montagu. Testacea Britannica. 1, p. 222. pl. 7, fig. 4.

1853. Cylichna umbilicata Montagu. Forbes \& Hanley. Brit. Moll. 3, p. 519, pl. 114e, fig. 9.

1867. Cylichna umbilicata Montagu. Jeffreys. Brit. Conch. 4, p. 413; 5, pl. 93, fig. 3.

1868. Cylichna umbilicata Montagu. Weinkauff. Conch. d. Mittelmeeres. 2, p. 198.

1878. Utriculus umbilicatus Montagu. Sars. Moll. Reg. Arct. Norvegiae. p. 286, pl. 17, fig. 14.

1886. Cylichna umbilicata Montagu sp. Bucquoy, Dautzenberg \& Dollfus. Moll. mar. du Roussillon. 1, p. 524, pl. 64, fig. 6-8.

1888. Cylichna umbilicata Montagu. Petersen. De skalb. Moll. etc. p. 79.

1892. Cylichna umbilicata Montagu. Locard. Coq. mar. d. côtes d. France. p. 26.

Fossil:

1897. Cylichnina umbilicata Montagu. Sacco. I moll. d. terr. terz. d. Piemonte e d. Liguria. 22 , p. 50, pl. 4 , fig. 12 .

1910. Bullinella (Cylichnina) umbilicata Mtg. sp. Cerulli-Ireldr. Fauna mal. mariana p. 38 , pl. 4, fig. 14-22.

?1925. Bullinella cylindracea Penn. Kautsky. D. Mioc. v. Hemmoor u. Basbeck-Osten. p. 198 (pro parte?)

1932. Bullinella (Cylichnina) subangistoma D’Orbigny. Peyrot. Conch. Néogén. d l'Aquit. p. 189 , pl. 13, fig. $34-35$.

Original diagnosis. B. with an oblong-oval, smooth, white shell: apex rounded, umbilicated: aperture extremely narrow, the whole length of the shell, dilating a little at the base. Length one-eighth of an inch; breadth one half its length. (Montagu 1803). 
Shell material.

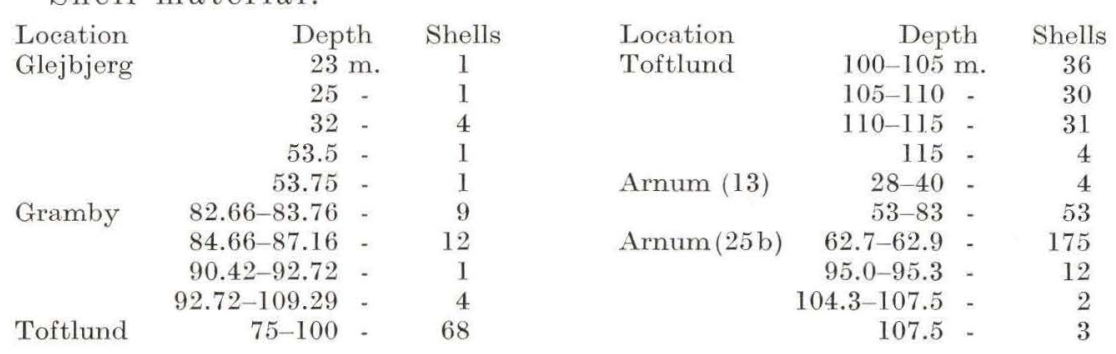

Description. The shells are generally smooth and glossy, the only sculptural feature present being growth lines. A few specimens do, however, have faint spiral striae on the abapical end of the shell. The shape of the teleoconch is commonly slightly conical to ovoid. There is a distinct, deep umbilicus at the apical end, where the whorl edge is occasionally angular. Abapical umbilicus rarely developed. Weak fold on the columella of some shells. The largest shell (Toftlund $75-100 \mathrm{~m}$.) is $5.1 \mathrm{~mm}$. high and $2.5 \mathrm{~mm}$. wide.

Remarks. The shape of the shell is rather variable: some shells are more or less conical and a few are almost cylindrical. It has, however, been impossible to find distinct morphological criteria by which these and other types could be specifically distinguished. The variation of the shell is therefore clearly similar to C. alba (see Lemche 1948, p. 43).

\section{Distribution.}

Recent: North Atlantic Ocean from Lofoten to Gibraltar and the Mediterranean.

Pliocene: Mediterranean Basin: Italy: Piacenziano, upper Pliocene of Monte Mario.

Miocene: Aquitanian Basin: Aquitanien, Burdigalien, Helvétien. North Sea Basin: Germany: Hemmoor stage (?). Denmark: Arnum formation.

\section{Retusa obtusa (Montag̉u)}

Recent:

1803. Bulla obtusa Montagu. Testacea Britannica. 1, p. 223, pl. 7, fig. 3 .

1853. Cylichna obtusa Montagu. Forbes \& Hanley. Brit. Moll. 3, p. 512, pl. 114, fig. 1-3.

1857. Utriculus obtusus Montagu. Jeffreys. Brit. Conch. 4, p. 423; 5, pl. 94, fig. 3.

1892. Cytichna obtusa Montagu. Locard. Coq. mar. d. côtes d. France. p. 27.

Fossil:

1848. Bulla Regulbiensis Adams. Wood. Monogr. Crag Moll. 1, p. 177, pl. 21, fig. 4.

1897. Retusa obtusa? var. plioparva SAcco. I moll. d. terr. terz. d. Piemonte e d. Liguria. 22 , p. 41 , pl. 3, fig. 90.

1910. Tornatina obtusa Mtg. sp. Cerulli-Irelli. Fauna mal. mariana. p. 33, pl. 3, fig. $63-65$.

1921. Utriculus obtusus (Montagu). Harmer. Plioc. Moll. 2, p. 797, pl. 63, fig. 5.

Original diagnosis. B. with a moderately strong, subcylindric, opaque white shell, wrinkled longitudinally: apex convoluted, obtuse; volutions four or five, very little produced: aperture nearly the whole length of the shell, narrow, rather more 
compressed in the middle, dilated at the base: inner lip thickened, smooth, white. (MONTAGU 1803).

Shell material: Toftlund $75-100 \mathrm{~m}$. one juvenile shell; height $2.27 \mathrm{~mm}$., diameter $1.23 \mathrm{~mm}$., about $2 \frac{1}{2}$ teleoconch whorls.

Description.

Test rather strong. Sculpture of conspicuous, low collabral folds, with conformable light and brown bands in the shell surface. The folds are particularly distinct on the shoulders of the whorls. Columella slightly thickened.

Distribution.

Recent: North Atlantic Ocean: from Massachusetts to New England, and from Iceland and Britain to the Bay of Biscay.

Mediterranean (acc. to Harmer 1921 ref. (Arus 1889)).

Pliocene: North Sea Basin: England: Red Crag.

Mediterranean Basin: Italy: Astiano, upper Pliocene of Monte Mario.

Miocene: North Sea Basin: Denmark: Arnum formation.

\section{Genus Acteocina Gray 1847}

Shell material.

\section{Acteocina sp.}

$\begin{array}{lrllrl}\text { Location } & \text { Depth } & \text { Shells } & \text { Location } & \text { Depth } & \text { Shells } \\ \text { Toftlund } & 100-105 \mathrm{~m} . & 1 \mathrm{frg} . & \text { Arnum }(25 \mathrm{~b}) & 62.7-62.9 \mathrm{~m} . & 3 \mathrm{frg} . \\ & 105-110- & 1- & 95.0-95.3- & 3-\text { (cf.) } \\ \text { Arnum (13) } & 53-83- & 2- & 104.3-107.5- & 1-\end{array}$

Description.

The fragments consist of parts of the spire which include the more or less exposed sinistral protoconch. The spire is more elevated than in the following species.

\section{Acteocina Lajonkaireana (Basterot)}

Plate 75 , fig. 258 a-c.

1825. Bullina Lajonkaireana Basterot. Mém. géol. environs de Bordeaux. p. 22, pl. 1, fig. 25 .

1848. Bulla Lajonkaireana Bast. Wood. Monogr. Crag Moll. 1, p. 178, pl. 21, fig. 5.

1856. Bulla Lajonkaireana Bast. Hörnes. D. foss. Moll. d. Tert.-Beckens v. Wien. 1, p. 624 , pl. 50, fig. 9.

1897. Tornatina lajonkaireana (BAST.) SAcco. I moll. d. terr. terz. d. Piemonte e d. Liguria. 22 , p. 38 , pl. 3, fig. 55-57.

1921. Utriculus Lajonkaireanus (BASTERot). Harmer. Plioc. Moll. 2, p. 796, pl. 63, fig. 3.

1925. Tornatina Lajonkaireana Bast. Kautsky. D. Mioc. v. Hemmoor u. Basbeck-Osten. p. 200.

1932. Tornatina Lajonkaireana Basterot. Peyrot. Conch. Néogén. d. l'Aquit. p. 206, pl. 12, fig. 1-2; 8-11.

Original diagnosis. Testa minuta, loevi, olivaeformi, columella tecta; spira brevi (BASTERot 1825). 
Shell material.

$\begin{array}{lrrlrl}\text { Location } & \text { Depth } & \text { Shells } & \text { Location } & \text { Depth } & \text { Shells } \\ \text { Gramby } & 82.66-83.76 \mathrm{~m} . & 1 & \text { Toftlund } & 110-115 \mathrm{~m} . & 7 \\ & 84.66-87.16- & 1 & \text { Arnum (13) } & 53-83- & 2 \\ \text { Toftlund } & 75-100- & 9 & \text { Arnum }(25 \mathrm{~b}) & 62.7-62.9- & 1 \text { (cf.) } \\ & 105-110- & 1 & & 95.0-95.3- & 1\end{array}$

\section{Description.}

Last whorl of protoconch exposed, surface smooth. Spire of teleoconch relatively low. Deep sutural furrow immediately below the suture. Shell surface ornamented only with growth lines. Columella with fold, no umbilicus. Largest shell (Toftlund 75-100 m.): $4.0 \mathrm{~mm}$. high and $1.9 \mathrm{~mm}$. in diameter; number of teleoconch whorls: $3 \frac{1}{2}$.

Distribution.

Pliocene: North Sea Basin: England: Coralline Crag.

Miocene: Aquitanian Basin: Aquitanien, Burdigalien, Helvétien. North Sea Basin: Germany: Hemmoor stage. Denmark: Arnum formation.

Mediterranean Basin: Italy: Elveziano.

Vienna Basin: Brackish beds at Vienna (Cerithienschichten).

\section{Genus Scaphander Montfort 1810}

\section{Scaphander lignarius (Linné)}

Recent:

1758. Bulla lignaria Linné. Syst. Nat. Ed. Dec. p. 727.

1853. Scaphander lignarius Linndeus. Forbes \& Hanley. Brit. Moll. 3, p. 536, pl. 114 F, fig. 3.

1867. Scaphander lignarius Linné. Jeffreys. Brit. Conch. 4, p. 443; 5, pl. 95, fig. 5.

1868. Scaphander lignarius Linné. Weinkauff. Conch. d. Mittelmeeres. 2, p. 192.

1878. Scaphander lignarius Linné. SARs. Moll. Reg. Arct. Norvegiae. p. 292, pl. 18, fig. 7, pl. 26, fig. 4 .

1886. Scaphander lignarius Linné $s p$. Bucquoy, Dautzenberc \& Dollfus. Moll. mar. d. Roussillon. 1, p. 536, pl. 63, fig. 1-3.

1892. Scaphander lignarius Linné. Locard. Coq. mar. d. côtes d. France. p. 21.

1932. Scaphander lignarius Linné. Nobre. Moluscos mar. de Portugal. p. 55. fig. 1.

Fossil:

1848. Bulla lignaria Linn. Wood. Monogr. Crag Moll. 1, p. 173, pl. 21, fig. 8.

1856. Bulla lignaria Linn. Hörnes. D. foss. Moll. d. Tert.-Beckens v. Wien. 1, p. 616, pl. 50 , fig. 1.

1897. Scaphander lignarius (I.). SACco. I moll. d. terr. terz. d. Piemonte e d. Liguria. 22, p. 43 , pl. 3 , fig. $94-112$.

1921. Scaphander lignarius (Linné). Harmer. Plioc. Moll. 2, p. 806, pl. 63, fig. 14-15.

1907. Scaphander lignarius Linné sp. var. Grateloupi Michelottu. Ravn. Molluskf. Jyll. Tert. p. 368 .

1910. Scaphander lignarius L. sp. Ceruldi-Irelli. Fauna mal. mariana. p. 35, pl. 4, fig. 1-7. 1914. Scaphander lignarius var. Grateloupi МICH. GRIPP. Über eine u. mioz. Moll. f. v. Itzehoe. p. 36.

1925. Scaphander lignarius L. var. Grateloupi Mich. KaUtsky. D. Mioe. v. Hemmoor u. Basbeck-Osten. p. 198. 
1932. Scaphander lignarius Linné. mut. Grateloupi Mich. Peyrot. Conch. Néogén. d. 1'Aquit. p. 202, pl. 12, fig. 15, 17-21.

1940. Scaphander lignarius L. var. Grateloupi Mich. Sorgenfrei, Mar. Nedre-Mioc. i Klintinghoved p. Als. p. 57, pl. 6, fig. 19.

1952. Scaphander (Scaphander) grateloupi Michelotri sp. GLibert. Faune mal. du Mioc. de la Belgique. 2, p. 146, pl. 10, fig. 17.

Original diagnosis. Bulla testa obovata oblongiuscula transverse striata, vertice subumbilicato. (LINNÉ 1758).

Shell material.

\begin{tabular}{|c|c|c|c|c|c|c|}
\hline Location & Depth & Shells & Location & Dep & & Shells \\
\hline \multirow{3}{*}{ Glejbjerg } & $53.50 \mathrm{~m}$. & 1 frg. (cf.) & Toftlund & $105-110$ & $\mathrm{~m}$. & 7 \\
\hline & $53.75 \quad-$ & $1-$ & & $110-115$ & - & 2 \\
\hline & $55-$ & $1-$ & & 115 & - & 4 \\
\hline Ribe & $119-120-$ & $1-$ & $\operatorname{Arnum}(25 \mathrm{~b})$ & $95.0-95.3$ & - & 1 \\
\hline \multirow[t]{2}{*}{ Toftlund } & $75-100$ & 1 & & $104.3-107.5$ & - & 1 (= = 5 frg.) \\
\hline & $100-105-$ & 1 & & & & \\
\hline
\end{tabular}

Description.

With a few exceptions the shells are fragmentary. The specimen from Arnum $95.0-95.3 \mathrm{~m}$. is a juvenile shell which shows that the first teleoconch whorl is devoid of spiral sculpture. No comments will be made on other shell features.

Distribution.

Recent: North Atlantic Ocean from Lofoten to Gibraltar and the Mediterranean.

Pliocene: North Sea Basin: England: Coralline Crag, Red Crag. Mediterranean Basin: Italy: Piacenziano, Astiano, upper Pliocene of Monte Mario.

Miocene: Aquitanian Basin: Aquitanien, Burdigalien, Helvétien. North Sea Basin: Belgium: Anversien. Germany: Vierlande and Hemmoor stages, Reinbek stage (GoTTSCHE 1878), Glimmerton (Banke Rasmusser 1956). Denmark: Klintinghoved clay, Arnum formation. Mediterranean Basin: Italy: Elveziano, Tortoniano. Vienna Basin: Grund beds.

\section{Genus Roxania (Leach) Gray 1847}

\section{Roxania utriculus (Brocchi)}

Recent:

Plate 76, fig. $260 \mathrm{a}-\mathrm{b}$.

1867. Bulla utriculus Brocchi. Jeffreys. Brit. Conch. 4, p. 440; 5, pl. 95, fig. 4.

1868. Bulla utriculus Brocchi. Weinkauff. Conch. d. Mittelmeeres. 2, p. 189.

1888. Atys Cranchii Leach. Petersen. De skalb. Moll. etc. p. 80.

1892. Bulla utriculata Brocchi. Locard. Coq. mar. d. côtes d. France. p. 23.

1932. Bulla utriculus (BRocchi). Moluscos mar. de Portugal p. 57, pl. 26, fig. 7.

Fossil:

1814. Bulla utriculus Brocchi. Conchiol. Foss. Subapennina. 2, p. 633, pl. 1, fig. 6. (B. striata BRUG.). 
1856. Bulla utricula Brocc. Hörnes. D. foss. Moll. d. Tert.-Beckens v. Wien. 1, p. 618, pl. 50, fig. 2 .

1870. Bulla utricula Brocc. Speyer. D. Conch. d. Casseler Tert., p. 253, pl. 22, fig. 5-6.

1897. Roxania utriculus (BR.) SAcco. I moll. d. terr. terz. d. Piemonte e d. Liguria. 22, p. 45, pl. 3, fig. 127-134.

1907. Atys utriculus Brocont sp. Ravn. Molluskf. Jyll. Tert., p. 367, pl. 8, fig. 13.

1910. Roxania utriculus Br. sp. Ceruldt-Irelti. Fauna mal. mariana. p. 36, pl. 4, fig. 8-9.

1913. Atys utriculus Brocchi sp. Harder. De olig. Lag etc. v. Aarhus St. p. 103, pl. 9, fig. 26.

1914. Atys utriculus Brocchi. Gripp. Über eine u. mioz. Moll. f. v. Itzehoe. p. 35.

1916. Atys utriculus Brocchi sp. Nørregandd. M.-mioc. Blokke fra Esbjerg. p. 36.

1925. Roxania utriculus Brocchi. Kautsky. D. Mioc. v. Hemmoor u. Basbeck-Osten. p. 200 .

1932. Roxania subutricula d'Orbigny. Peyrot. Conch. Néogén d. l'Aquit. p. 193, pl. 12, fig. $43-48$.

1940. Roxania utriculus Brocohr. Sorgenfrer. Mar. Nedre-Mioc. i Klintinghoved p. Als. p. 58.

1952. Sabatia (Damoniella) utricula Brocchi sp. Glibert. Faune mal. du Mioc. de la Belgique. 2, p. 145, pl. 10, fig. 16.

Original diagnosis. Testa ovata, turgidula, solida, utrinque umbilicata, transversim striata, striis in utraque extremitate profundis, intermediis obsoletis. (BROCCHI 1814).

Shell material.

$\begin{array}{lrrlrc}\text { Location } & \text { Depth } & \text { Shells } & \text { Location } & \text { Depth } & \text { Shells } \\ \text { Glejbjerg } & 23 \mathrm{~m} . & 1 & \text { Toftlund } & 110-115 \mathrm{~m} . & 6 \\ & 32- & 3 & & 115- & 5 \\ & 53.5- & 3 & \text { Arnum }(13) & 53-83- & 15 \\ \text { Bramminge } & 53.75- & 1 & & 83-94- & 1 \\ \text { Gramby } & 70-80- & 15 & \text { Arnum }(25 \mathrm{~b}) & 62.7-62.9- & 9 \\ & 82.66-83.76- & 10 & & 95.0-95.3- & 2 \\ \text { Toftlund } & 84.66-87.16- & 3 & 101.0-104.3- & 1 \\ & 75-100- & 117 & 104.3-107.5- & 3 \\ & 100-105- & 13 & & 107.5- & 1 \text { frg. (cf.) }\end{array}$

\section{Description.}

The shells display the typical features of the species: more or less globular shape and conspicuous, dashed spiral furrows on both ends of the shell. The middle part of the shell is generally devoid of spirals, but there are specimens with spiral furrows over the entire shell surface. Apical umbilicus. Commonly also narrow umbilical fissure at the abapical end. One of the larger shells (Toftlund $115 \mathrm{~m}$.) is $5.45 \mathrm{~mm}$. high and $2.40 \mathrm{~mm}$. in diameter.

Remarks. Since this species obviously varies rather much with respect to the spiral ornamentation and shape, the writer supports PEYrot's suppression of $R$. subutricula D'ORBIGNY which undoubtedly is within the variation range of $R$. utriculus.

\section{Distribution.}

Recent: North Atlantic Ocean: From Norway to the Canary Isles and the Mediterranean.

Pliocene: Mediterranean Basin: Italy: Piacenziano, Astiano, upper Pliocene of Monte Mario.

Miocene: Aquitanian Basin: Burdigalien, Helvétien.

North Sea Basin: Belgium: Horizon of Houthaelen, Anversien. Germany: Vierlande, Hemmoor and Reinbek 
stages (Gottsche 1878), Glimmerton (Banke Rasmussen 1956). Denmark: Klintinghoved clay, Arnum formation. Mediterranean Basin: Italy: Elveziano, Tortoniano.

Vienna Basin: Baden and Steinabrunn beds.

Oligocene: North Sea Basin: Germany (u.) Denmark (u.).

\title{
Genus Philine Ascanius 1772
}

\section{Philine sp. a.}

Shell material: Gramby $84.66-87.16 \mathrm{~m}$. One very poor apical fragment of a Philine sp. The shell surface is smooth.

\section{Philine (?) sp. b.}

Shell material: Toftlund $105-110 \mathrm{~m}$. One apical fragment of a Philine (?) sp. The shell surface is irregularly folded and covered by fine, spiral threads.

\author{
ORDO PTEROPODA CUVIER 1804 \\ FAMILIA SPIRATELLIDAE THIELE 1931
}

Genus Spiratella Blainville 1817

\section{Spiratella atlanta (Mørch)}

1874. Valvatina atlanta Мøвсн. Forst. i Tert. p. 298.

1907. Valvatina atlanta Mørch. Ravn. Molluskf. Jyll. Tert. p. 369, pl. 8, fig. 16.

1916. Valvatina atlanta Mørch. NørRegaARd. M. Mioc. Blokke frá Esbjerg. p. 37.

?1925. Spirialis miorostralis Kautsky. D. Mioc. v. Hemmoor u. Basbeck-Osten. p. 202.

?1952. Spiratella miorostralis Kautsky sp. Glibert. Faune mal. du Mioc. de la Belgique 2 , p. 147.

1956. Spiratella atlanta (Mørch). Banke Rasmussen. Upper Mioc. South Jutland. p. 105, pl. 10 , fig. 7 .

Original diagnosis. Testa forma planorbi albi, lactea nitidissima, spira immersa; margo suturalis anfr. ultimi perpendicularis; peripheria rotundata, apertura dilatata. (Мøвсн 1874).

$\begin{array}{crc}\begin{array}{c}\text { Shell material. } \\ \text { Location }\end{array} & \\ \text { Glejbjerg } & 23 \mathrm{~m} . & 1 \\ \text { Gramby } & 81.86-82.16- & 5 \\ & 82.66-83.76- & 2 \\ & 84.66-87.16- & 9 \\ & 90.42-92.72- & 4 \\ & 92.72-109.29- & 2 \\ & 109.29-110.86- & 27 \\ & 110.86-121.51- & 1 \\ & 75-100- & 5 \\ \text { Toftlund } & 100-105- & 4\end{array}$

$\begin{array}{lrc}\text { Location } & \text { Depth } & \text { Shells } \\ \text { Toftlund } & 105-110 \mathrm{~m} . & 7 \\ & 110-115- & 5 \\ \text { Arnum (13) } & 28-40- & 1 \\ & 53-83- & 102 \\ \text { Arnum (25b) } & 62.7-62.9- & 89 \\ & 95.0-95.3- & 9 \\ 101.0-104.3- & 5 \\ 104.3-107.5- & 5 \\ 107.5- & 1\end{array}$


Description.

Shape planorbid. Shell surface smooth and glossy. The helicocone of the first two whorls descends abapically, thereafter the helicocone widens rapidly and the apex is lowered into the coils of the succeding whorls. Narrow umbilicus.

Remarks. von Koenen's figure of Spiratis atlanta (1882, p. 359, pl. 7, fig. 16) does not agree very well with the description and illustration of $V$. atlanta by RAVN who was able to compare his shells with specimens collected by Mørch. von KoEnen's S. atlanta has therefore been omitted from the above list of synonymy. KaUtSKY's S. miosuturalis has, on the other hand been included in the list since KaUTSKY's and Ravy's descriptions are almost identical. Both KaUtsky's and GLibert's species are, as indicated, accepted with some reservation on account of lack of illustration, and of description and illustration respectively.

Distribution.

Miocene: North Sea Basin: Belgium: Anversien (?) Germany: Hemmoor stage (?), Glimmerton (BANke Rasmussen 1956). Denmark: Arnum and Gram formations.

\section{Spiratella cf. valvatina (Reuss)}

1867. Spirialis valvatina Reuss. D. foss. F. Wieliczka. p. 146, pl. 6, fig. 11.

1882. Spirialis valvatina Reuss. von Koenen. D. Nordd. Mioc. u. s. Moll. f. p. 357.

1914. Spirialis valvatina Reuss. GRIPP. Über eine U. mioz. Moll. f. v. Itzehoe. p. 36.

1925. Spirialis valvatina Reuss. Kautsky. D. Mioc. v. Hemmoor u. Basbeck-Osten. p.203. 1952. Spiratella valvatina Reuss sp. Guibert. Faune mal. du Mioe. de la Belgique 2, p. 147.

Essential features of original description. Das Gewinde erhebt sich in schwacher stumpfer Wölbung nur wenig. Die Windungen sind gerundet. Die Unterseite des Gehäuses ist von einem sehr engen Nabelloch durchbohrt; die Mündung halbrund, nach abwärts etwas ausgezogen. (REuss 1867).

Shell material.

$\begin{array}{lrc}\text { Location } & \text { Depth } & \text { Shells } \\ \text { Gramby } & 84.66-87.16 \mathrm{~m} . & 2 \\ \text { Arnum }(25 \mathrm{~b}) & 95.0-95.3- & 8\end{array}$

Description. Shape helicoid, surface smooth and glossy, spire slightly elevated. Helicocone increases moderately. Aperture approximately semilunar with straighter columellar lip. Narrow umbilicus.

Remarks. The shells differ from Reuss' figure by a lower spire and a more straight columellar lip. Therefore the reference should not be regarded as final.

Distribution.

Miocene: North Sea Basin: Belgium: Anversien. Germany:Vierlande and Hemmoor stages, Glimmerton (BANKe RASMUSSEN 1956). Denmark: Arnum formation. 


\section{FAMILIA CAVOLINIDAE D'ORBIGNY 1837 \\ Genus Clio Linné 1767}

\section{Clio sp.}

1907. Cleodora sp. Ravn. Molluskf. Jyll. Tert. p. 370, pl. 8, fig. 18.

Shell material. Arnum (25b) 62.7-62.9 m. fragments of 4 shells.

Description.

Initial nucleus bulbous, slightly tapering. Constricted at the transition from the nucleus to the teleoconch. Teleoconch with triangular section resulting from relatively flat, ventral side and angularly keeled dorsal side. Shell axis more or less curved with convexity on ventral side. Two marginal riblets on the lateral edges of the shell, which is otherwise smooth and glossy. Slight longitudinal concavities on the ventral side adjacent to the lateral edges.

Remarks. This is probably a new species as already pointed out by RAVN. The reason why no specific name has been suggested is the fragmentary nature of the shell material, which not would be satisfactory as a type reference.

\section{Distribution.}

Miocene: North Sea Basin: Denmark: Arnum formation.

\section{Genus Vaginella Daudin 1800}

\section{Vaginella depressa Daudin}

1800. Vaginella depressa DAUDIN. Nouveau genre etc. p. 145

1856. Vaginella depressa Daudin. Hörnes. D. foss. Moll. d. Tert.-Beckens v. Wien. 1, p. 663 , pl. 50 , fig. 42 .

1904. Vaginella depressa Daudin. SAcco. I moll. d. terr. terz. d. Piemonte e d. Liguria. 30 , p. 15 , pl. 4 , fig. 10 .

1907. Vaginella depressa Daudin. Ravn. Molluskf. Jyll. Tert., p. 369, pl. 8, fig. 17.

1913. Vaginella depressa Daudin. Harder. De olig. Lag ete. v. Aarhus St. p. 103, pl. 9, fig. 28 .

1916. Vaginella depressa Daudin. NørRegandD. M.-mioc. Blokke fra Esbjerg. p. 37.

1925. Vaginella depressa DaUdin var. austriaca Kittu. KaUtsky. D. Mioc. v. Hemmoor u. Basbeck-Osten. p. 203.

1933. Vaginella depressa Daudin. Peyrot. Conch. Néogén. d. l'Aquit. p. 22, 1932: pl. 18, fig. 36-37.

1940. Vaginella depressa Daudin. Sorgenfrer. Mar. Nedre-Mioe. i Klintinghoved p. Als. p. 60 .

1952. Vaginella depressa Daudin. Glibert. Faune mal. du Mioc. de la Belgique. 2, p. 148.

Original diagnosis. Longueur de trois lignes, largeur d'une ligne. Tube lisse en dehors et en dedans; un peu déprimé, d'un blanc quelquefois luisant et un peu transparent, avex l'ouverture large et étroite. (DAUDIN 1800). 
Shell material.

\begin{tabular}{|c|c|c|c|c|c|c|c|}
\hline \multirow{2}{*}{$\begin{array}{l}\text { Location } \\
\text { Glejbjerg }\end{array}$} & \multicolumn{2}{|c|}{ Depth } & \multirow{2}{*}{$\begin{array}{c}\text { Shells } \\
3\end{array}$} & Location & \multicolumn{2}{|c|}{ Depth } & \multirow{2}{*}{$\begin{array}{c}\text { Shells } \\
2\end{array}$} \\
\hline & 23 I & & & Gramby & $110.86-121.51$ r & $\mathrm{m}$. & \\
\hline & 25 & - & 3 & Toftlund & $75-100$ & - & 400 \\
\hline & 42 & - & 7 & & $100-105$ & - & 74 \\
\hline & 52 & - & 1 & & $105-110$ & - & 10 \\
\hline & 53.5 & - & 1 & & $110-115$ & - & 12 \\
\hline & 53.75 & - & 1 & & 115 & - & 9 \\
\hline & 54 & - & 1 & Arnum (13) & $28-40$ & - & 2 \\
\hline Bramminge & $70-80$ & - & 32 & & $53-83$ & - & 40 \\
\hline Ribe & $115-116$ & - & 1 & & $83-94$ & - & 4 \\
\hline Gramby & $81.86-82.16$ & - & 2 & $\operatorname{Arnum}(25 \mathrm{~b})$ & $62.7-62.9$ & - & 17 \\
\hline & $82.66-83.76$ & - & 44 & & $95.0-95.3$ & - & 4 \\
\hline & $84.66-87.16$ & - & 26 & & $101.0-104.3$ & - & 5 \\
\hline & $90.42-92.72$ & - & 9 & & $104.3-107.5$ & - & 20 \\
\hline & $92.72-109.29$ & - & 6 & & 107.5 & - & 1 \\
\hline & $109.29-110.86$ & - & 3 & & & & \\
\hline
\end{tabular}

Shell material more or less fragmentary. No intact initial nucleus, but shell features otherwise well preserved.

The first one half of the shell is almost conical while later it is dorsoventrally flattened. There is a fine thread on each side extending from the proximal end to about the middle of the shell.

Remarks. It is difficult to get a precise impression of the morphological variation on account of the fragmentary nature of the material. However, it would appear that both narrow and wide specimens are present, but that they undoubtedly belong to one species.

Distribution.

Miocene: Aquitanian Basin: Burdigalien, Helvétien.

North Sea Basin: Belgium: Anversien. Germany:

Hemmoor stage. Reinbek stage (Gotтsche 1878). Denmark: Klintinghoved clay, Arnum formation.

Mediterranean Basin: Italy: Elveziano.

Vienna Basin: Baden beds.

Oligocene: North Sea Basin: Denmark (u.).

\section{CLASSIS CEPHALOPODA CUVIER 1798 \\ Genus Aturia Bronn 1838}

\section{Aturia(?) sp.}

Shell material. Gramby $82.66-83.76 \mathrm{~m} .1 \mathrm{frg}$.

Description.

The small fragment consists of the umbilical wall of a smooth nautiloid shell with about 10 septa in the last whorl. 
FR, BAGGES KGL, HOFBOGTRYKKERI KøBENHAYN

Pris bd. I-II 70 kr. 